\title{
RFI/RI Work Plan for the Road A Chemical Basin 904-111G
}

by

T. F. Kmetz

Westinghouse Savannah River Company

Savannah River Site

Aiken, South Carolina 29808

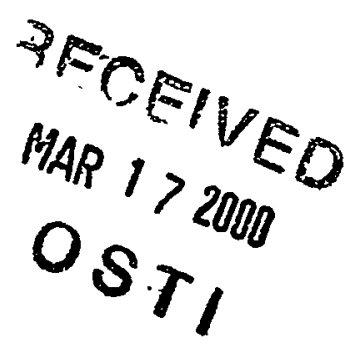

R. Vanpelt

T. McAdams

This paper was prepared in connection with work done under the above contract number with the U.S.

Department of Energy. By acceptance of this paper, the publisher and/or recipient acknowledges the U.S.

Government's right to retain a nonexclusive, royalty-free license in and to any copyright covering this paper, along with the right to reproduce and to authorize others to reproduce all or part of the copyrighted paper. 


\section{United States Department of Energy}

Savannah River Site

\section{RFI/RI Work Plan for the \\ Road A Chemical Basin \\ 904-111G (U)}

WSRC-RP-98-4032

Revision 1.1

October 1999

Prepared by:

Westinghouse Savannah River Company

Savannah River Site

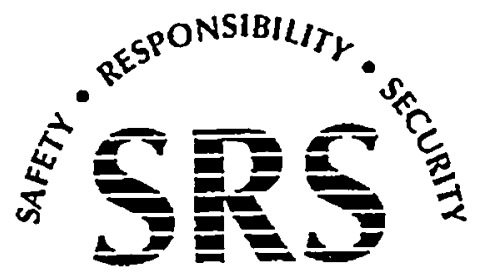

Aiken, SC 29808

SAVANNAH RIVER SITE

Prepared for U.S. Department of Energy Under

Contract No. DE-AC09-96SR18500 


\section{DISCLAIMER}

This report was prepared as an account of work sponsored by an agency of the United States Government. Neither the United States Government nor any agency thereof, nor any of their employees, makes any warranty, express or implied, or assumes any legal liability or responsibility for the accuracy, completeness, or usefulness of any information, apparatus, product or process disclosed, or represents that its use would not infringe privately owned rights. Reference herein to any specific commercial product, process or service by trade name, trademark, manufacturer, or otherwise does not necessarily constitute or imply its endorsement, recommendation, or favoring by the United States Government or any agency thereof. The views and opinions of authors expressed herein do not necessarily state or reflect those of the United States Government or any agency thereof.

This report has been reproduced directly from the best available copy.

Available for sale to the public, in paper, from: U.S. Department of Commerce, National Technical Information Service, 5285 Port Royal Road, Springfield, VA 22161, phone: (800) 553-6847

fax: (703) 605-6900

email: orders@ntis.fedworld.gov

online ordering: http://www.ntis.gov/ordering.htm

Available electronically at http://www.doe.gov/bridge

Available for a processing fee to U.S. Department of Energy and its contractors, in paper, from: U.S. Department of Energy, Office of Scientific and Technical Information, P.O. Box 62, Oak Ridge, TN 37831-0062, phone: (865) 576-8401

fax: (865) 576-5728

email: reports@adonis.osti.gov

Printed in the United States of America

Prepared for the

U.S. Department of Energy

and

Westinghouse Savannah River Company 


\section{DISCLAIMER}

Portions of this document may be illegible in electronic image products. Images are produced from the best available original document. 


\section{CERTIFICATION}

Clean Version of the

RCRA Facility Investigation/Remedial Investigation (RFI/RI)

Work Plan for the

Road A Chemical Basin (904-111G)

\section{Revision.1.1, WSRC-RP-98-4032}

"I certify under the penalty of law that this document and all attachments were prepared under my direction or supervision in accordance with a system designed to assure that qualified personnel properly gather and evaluate the information submitted. Based on my inquiry of the person or persons who manage the system, the information submitted is, to the best of my knowledge and belief, true, accurate, and complete. I am aware that there are significant penalties for submitting false information, including the possibility of fines and imprisonment for knowing violations."

Date: $11 / 4 / 99$

Date: $11 / 5 / 99$
Signature:

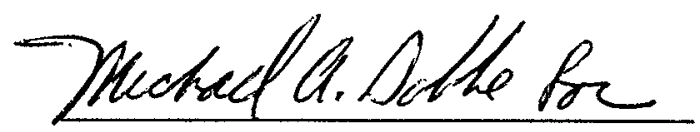

Richard R. Harbert

Vice President \& General Manager

Environmental Restoration Division Westinghouse Savannah River Company

Co-operzor for the U.S. Dept. of Exprgy

Savamah River Operations

Signature:
Cyhthia V. Anderson

Ditector

Environmental Restoration Division

U.S. Department of Energy

Savannah River Field Office

Owner and Co-operator 


\section{EXECUTIVE SUMMARY}

The Road A Chemical Basin (904-111G) Operable Unit (RdACB OU) is located in the southwestern section of the Savannah River Site (SRS), approximately 0.8 kilometer $(\mathrm{km})(0.5$ mile [mi]) southwest of the intersection of SRS Road A (South Carolina Route 125) and SRS Road 6. The unit is approximately $3 \mathrm{~km}(1.9 \mathrm{mi})$ southeast of the D-Area Powerhouse and approximately $6.4 \mathrm{~km}$ ( $4 \mathrm{mi}$ ) from the nearest plant boundary.

The RdACB OU is an inactive liquid waste disposal basin, which received unknown quantities of hazardous and radioactive materials. The exact operation period of the unit is not known, but it is expected that the basin existed as early as 1954. In 1973, the basin was backfilled with native soil. No wastes have been deposited since this time. The area surrounding the basin was regraded between 1973 and 1987. The exact nature of hazardous and, potentially, radioactive wastes disposed at the RdACB OU is not known because an inventory of disposal was not logged for this basin.

The RdACB OU is irregular in shape, with average dimensions of approximately 30 meters (m) ( $98 \mathrm{feet}[\mathrm{ft}$ ) wide by $53 \mathrm{~m}$ (174 ft) long. The unit is located in a cleared area adjacent to wooded lands in an area of moderate relief. The perimeter of the unit is protected by a $2.4 \mathrm{~m}(8.0 \mathrm{ft})$ high chain-link fence to prevent unauthorized access. A locked gate is located on the south side of the unit.

The RdACB OU is located in the Savannah River Floodplain Swamp Watershed. The dominant vegetative cover in the vicinity of the RdACB OU consists of loblolly, longleaf pine, slash pine, various hardwoods and scrub/shrub species. No endangered species have been identified in the vicinity of the RdACB OU. Surface soils at the RdACB OU are classified as Udorthents, friable substratum. Previous subsurface investigations revealed that the Tobacco Road and Dry Branch Formations of the Barnwell Group underlie the RdACB OU. These formations are generally comprised of sands, clayey sands, and clays.

Previous investigations at the RdACB OU included collecting soil samples in 1989, monitoring groundwater at five Water Table Aquifer wells from 1984 through 1997, performing a soil gas survey in 1992, and performing a radiological survey of surface soils in 1997. The historical soil analytical results from sampling in 1989 indicate soil contamination from volatile organic compounds (VOCs), semi-volatile organic compounds (SVOCs), and metals. Radionuclide soil screening provided inconclusive results. Groundwater quality data collected from five 
monitoring wells are also inconclusive. These results provide insufficient data to determine whether primary and secondary release mechanisms have impacted or continue to impact groundwater. Evaluation of data, however, from the previous investigations of the RdACB OU and the current physical state of the unit suggests that contamination from the unit does not currently pose a threat to human health or the environment.

Based upon review of the Conceptual Site Model (CSM) and the results of the preliminary unit evaluation, the following data needs for the RdACB OU have been identified:

- Data to support a Resource Conservation and Recovery Act (RCRA) Facility Investigation (RFI)/Remedial Investigation (RI)/Baseline Risk Assessment (BRA) and to form the basis for a risk management decision

- Data to support selection and implementation of remedial actions

Specifically, the identified data needs for the RdACB OU are as follows:

- Define the location and lateral and vertical extent of the original basin

- Characterize the lithology beneath and adjacent to the basin

- Identify the geotechnical properties of the confining unit between the water table aquifer and the uppermost confined aquifer

- Characterize the nature and extent of contamination in surface, subsurface, and deep soils beneath and adjacent to the basin

- Identify surface water and seep locations between the OU and the Savannah River, if any

- Determine the $2 \mathrm{X}$ average background soil screening concentrations

- Determine the nature and extent of groundwater contamination in the Water Table Aquifer

- Determine the aquifer characteristics and the nature and extent of groundwater contamination in the Gordon Aquifer (uppermost confined aquifer), if any.

To fulfill these data needs, a focused Sampling and Analysis Plan has been developed. Geophysical surveys will be performed to determine vertical and horizontal boundaries of the basin and subsequently to define soil sampling intervals. The Sampling and Analysis Plan 
presents the proposed soil sampling locations within, beneath, and adjacent to the basin designed to characterize secondary sources. Background soil sampling locations are proposed at locations hydraulically and topographically upgradient of the $\mathrm{RdACB}$ OU to determine $2 \mathrm{X}$ average background soil concentrations for identifying unit-specific constituents. Downslope surface soil sampling will be conducted to determine if contaminants were transported downgradient by deposition, erosion, or sheet flow.

The proposed groundwater characterization includes installing one background and two hydraulically downgradient monitoring wells in the Water Table Aquifer. It also includes installing one background, one side-gradient, and one hydraulically downgradient monitoring well in the Gordon Aquifer, a confined aquifer that underlies the Water Table Aquifer. The Gordon monitoring wells will be installed to determine the local vertical and lateral hydraulic gradient and groundwater quality in the Gordon Aquifer. The new monitoring wells will be sampled in conjunction with the five existing wells. The existing monitoring wells will be refitted with new dedicated pumps and will be redeveloped.

The data obtained under this Work Plan will be integrated with data from previous investigations to support an RFI/RI/BRA, contaminant fate and transport analysis, and selection of remedial options for the RdACB OU. 
This page intentionally left blank. 


\section{Table of Contents}

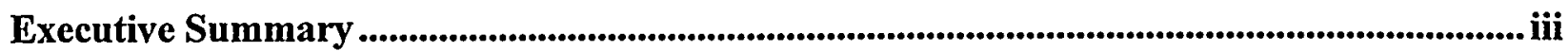

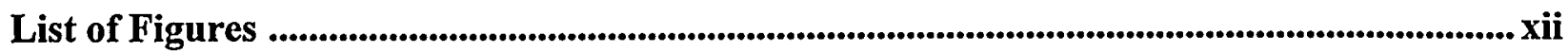

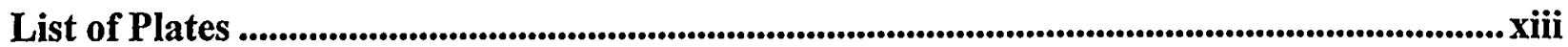

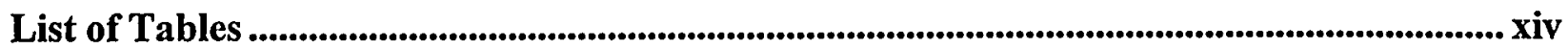

List of Acronyms and Abbreviations ........................................................................................ Xv

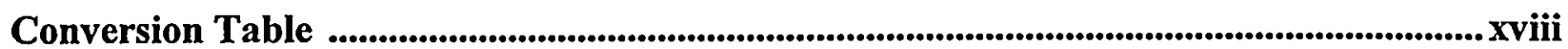

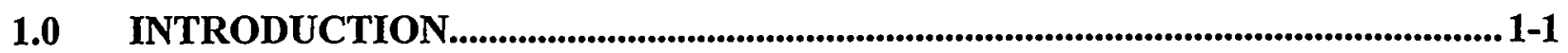

1.1 RFI/RI Work Plan Organization............................................................................ 1-2

1.2 Regulatory Background .......................................................................................... 1-2

1.2.1 RCRA Facility Investigation (RFI) Program ........................................ 1-2

1.2.2 CERCLA Remedial Investigation Program ............................................... 1-3

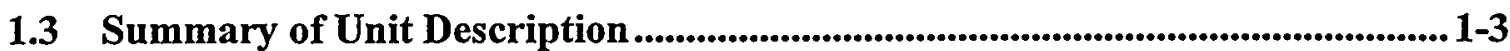

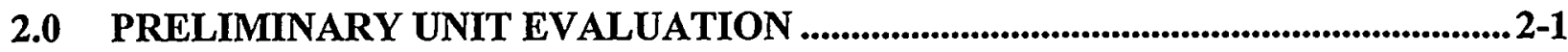

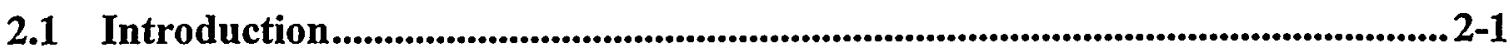

2.2 Unit Characteristics .............................................................................................

2.2.1 Unit History and Waste Composition ..................................................... 2-1

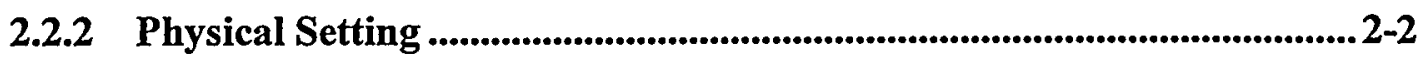

2.2.3 Demography and Land Use .................................................................... 2-3

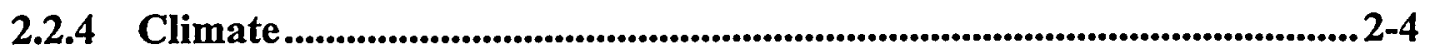

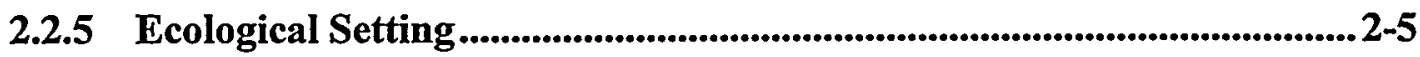

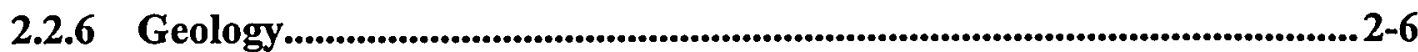

2.2.6.1 Regional Geology ..........................................................................2-6

2.2.6.2 Unit Geology ................................................................................2 2-9

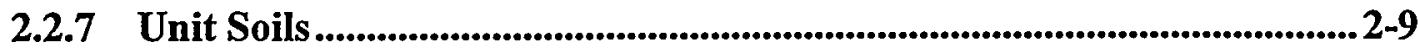

2.2.8 Hydrogeology......................................................................................2-10

2.2.8.1 Regional Hydrogeology ........................................................ 2-10 
2.2.8.2 Unit Hydrogeology .................................................................... 2-12

2.3 Existing/Previous Investigations...........................................................................2-13

2.3.1 Groundwater Monitoring..............................................................................2-13

2.3.2 Groundwater Sampling and Analysis ..................................................... 2-14

2.3.3 Soil Sampling........................................................................................................2-15

2.3.4 Soil Gas Survey ................................................................................................2-16

2.3.5 Radiological Survey ........................................................................................2-17

2.4 Unit Evaluation Conclusions...................................................................................2-18

2.5 Operable Unit Strategy..........................................................................................2-19

2.6 Potential Applicable or Relevant and Appropriate Requirements (ARARs) and "To-Be-Considered" (TBC) Criteria ...........................................................2-20

2.7 Potential Corrective Measures Study/Feasibility Study (CMS/FS) Options ................................................................................................................................. 2-20

2.7.1 Standard Remedial Technologies ............................................................2-20

2.7.2 Innovative Remedial Technologies................................................................ 2-21

2.8 Potential Early and/or Interim Remedial Actions ............................................... 2-21

2.8.1 Early Action Strategy ................................................................................2-21

3.0 DATA QUALITY OBJECTIVES …...................................................................................3-1

3.1 DQO Evaluation.....................................................................................................3-2

3.1.1 Conceptual Site Model.........................................................................3-2

3.1.1.1 Primary Sources of Contamination............................................... 3-2

3.1.1.2 Primary Release Mechanisms..........................................................3-2

3.1.1.3 Secondary Sources of Contamination ........................................3-3

3.1.1.4 Secondary Release Mechanisms ......................................................3-3

3.1.1.5 Exposure Pathways (Media) .............................................................. 3-4

3.1.1.6 Exposure Routes..........................................................................................3-4

3.1.1.7 Receptors .....................................................................................................3-4

3.1.2 State the Problem ......................................................................................3-5 
3.1.3 Identify the Decisions..................................................................................................3-5

3.1.4 Identify the Inputs to the Decisions.................................................................... 3-7

3.1.5 Define the Boundaries of the Study ................................................................... 3-8

3.1.6 Develop Decision Rules.............................................................................................3-9

3.1.7 Specify Tolerable Limits on Decision Errors ..............................................3-11

3.1.8 Optimize the Design for Obtaining Data .......................................................3-11

3.2 Summary of DQO Evaluation .................................................................................3-12

4.0 UNIT ASSESSMENT .................................................................................................................4 4-1

4.1 Objectives.................................................................................................................................. 4-2

4.2 Primary Source Characterization .................................................................................. 4-3

4.3 Secondary Source Characterization.............................................................................4-3

4.3.1 Soil Sampling at the RdACB OU................................................................. 4-4

4.3.2 Background Soil, Sediment, and Surface Water Characterization ..... 4-5

4.4 Exposure Media Characterization ..................................................................................... 4-6

4.4.1 Downslope Soil, Sediment, and Surface Water ........................................... 4-6

4.4.2 Groundwater ............................................................................................................. 4-7

4.5 Physical Characteristics ................................................................................................... 4-8

4.5.1 Geophysical Survey............................................................................................. 4-8

4.5.1.1 Ground Penetrating Radar ............................................................. 4-8

4.5.1.2 Electromagnetic Survey........................................................................... 4-9

4.5.2 Lithologic Characterization .............................................................................. 4-9

4.5.3 Geotechnical Characterization ......................................................................4-9

4.5.4 Field Permeability Testing ............................................................................. 4-10

4.5.4.1 Summary of Test Method................................................................. 4-10

4.5.4.2 Test Procedure ................................................................................... 4-11

4.5.4.3 Presentation and Interpretation of Results ............................... 4-11

4.6 Investigation-Derived Waste Identification, Generation, and Management.................................................................................................................... 4-12 
5.0 SCHEDULE ......................................................................................................................... 5-1

6.0 SAFETY, HEALTH, AND EMERGENCY RESPONSE PLAN ............................. 6-1

7.0 QUALITY ASSURANCE/QUALITY CONTROL PLAN ........................................... 7-1

8.0 DATA MANAGEMENT PLAN ................................................................................

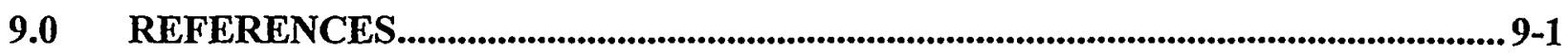




\section{APPENDICES}

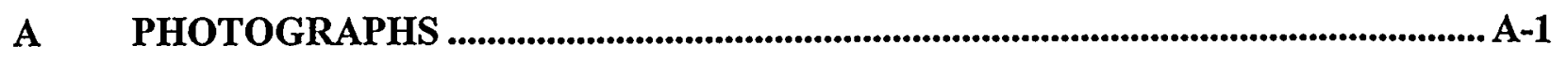

B SOIL BORING LOG ................................................................................................. B-1

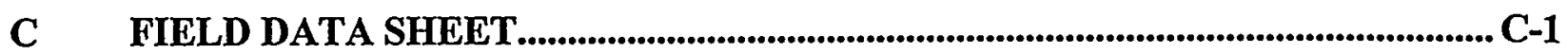

D SOIL BORING ANALYSES ............................................................................ D-1

E SOIL GAS INVESTIGATIONS AT THE ROAD A CHEMICAL BASIN ........... E-1

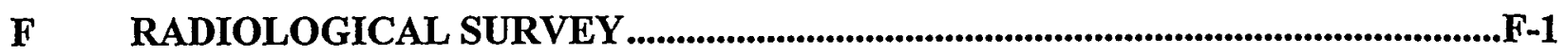




\section{List of Figures}

Figure

Page

1-1. Location of the Road A Chemical Basin (904-111G) on the Savannah River Site 1-7

1-2. Location of the Road A Chemical Basin (904-111G) and Local Landmarks 1-9

2-1. Road A Chemical Basin Groundwater Monitoring Well Locations. 2-25

2-2. Borehole Locations at the Road A Chemical Basin (904-111G) 2-27

2-3. Locations of Soil Gas Survey Points 2-29

2-4. Location of the Road A Chemical Basin and Watersheds at the Savannah River Site 2-31

2-5. Soil Map of the RdACB OU and Vicinity 2-33

2-6. Proposed Future Land Use for the Savannah River Site. 2-35

2-7. Savannah River Site Lithostratigraphy and Hydrostratigraphy . 2-37

2-8. Road A Chemical Basin Lithologic Cross Section A-A' 2-39

2-9. Road A Chemical Basin Lithologic Cross Section B-B' $2-41$

2-10. Water Table Surface at the Road A Chemical Basin (904-111G).

2-11. Hydraulic Head Relationships at the P-23 Well Cluster

2-12. Hydraulic Head Relationships at the P-26 Well Cluster

2-13. Hydrographs for Monitoring Wells at the Road A Chemical Basin (Based on Available Average Annual Water Levels)

3-1. Conceptual Site Model for the Road A Chemical Basin

4-1. Proposed Soil Sample Locations Within and Adjacent to the Road A Chemical Basin 4-15

4-2. Proposed Background Soil Sample Locations at the Road A Chemical Basin........ 4-17

4-3. Groundwater Monitoring Well and Piezometer Locations in the Vicinity of the Road A Chemical Basin.

4-4. Proposed GPR and EM Survey Transect Locations at the Road A Chemical Basin

4-5. Road A Chemical Basin Proposed Soil Sample Intervals....................................... 4-23

5-1. Road A Chemical Basin Implementation Schedule . 


\section{List of Plates}

Plate

$\underline{\text { Page }}$

1. Savannah River Site Environmental Restoration RI/FS Early Action Strategy ..... 2-51 
Table

\section{List of Tables}

2-1. Road A Chemical Basin Well Construction Summary $.2-55$

2-2. Statistical Summary from Available 1984-1997 Groundwater Elevations Measured in Monitoring Wells at the RdACB

2-3. Analytes Detected in Monitoring Wells at the RdACB 1988 to 1996 2-57

2-4. Analytes Detected in Groundwater above the Maximum Contaminant Level (MCL) or the Risk-Based Concentration (RBC) at the RdACB.

2-5. Sampling Depths and Analyses for Soil Collected at the RdACB 2-60

2-6. Potential ARARs and TBC Criteria for the RdACB 2-61

2-7. Potential Effective Remedial Technologies for the RdACB 2-62

3-1. Data Quality Objectives Worksheet 3-21

4-1. Summary of Characterization Activities at the RdACB OU 4-27

4-2. Analytical Parameters for Groundwater and Soil Samples 4-29

4-3. Summary of Proposed Sampling at the Road A Chemical Basin 4-36

4-4. Summary of the Groundwater Samples and Constituents to be Analyzed at the RdACB OU 


\section{List of Acronyms and Abbreviations}

\begin{tabular}{|c|c|}
\hline ARAR & applicable or relevant and appropriate requirement \\
\hline ASTM & American Society for Testing and Materials \\
\hline bls & below land surface \\
\hline BRA & Baseline Risk Assessment \\
\hline BTEX & benzene, toluene, ethylbenzene, and xylene \\
\hline $\mathbf{C}$ & Celsius \\
\hline $\begin{array}{l}\text { CERCLA } \\
\mathrm{cm}\end{array}$ & $\begin{array}{l}\text { Comprehensive Environmental Response, Compensation, and Liability Act } \\
\text { centimeter }\end{array}$ \\
\hline CMS & Corrective Measures Study \\
\hline CPP & Corrugated Polyethylene Pipe \\
\hline CSM & Conceptual Site Model \\
\hline DOE & U.S. Department of Energy \\
\hline DPT & direct push technology \\
\hline DQO & Data Quality Objective \\
\hline $\mathbf{E M}$ & electromagnetic \\
\hline EPA & U.S. Environmental Protection Agency \\
\hline ESC & Expedited Site Characterization \\
\hline $\mathbf{F}$ & Fahrenheit \\
\hline FFA & Federal Facility Agreement \\
\hline & Feasibility Study \\
\hline$f$ & foot \\
\hline $\mathbf{g}$ & gram \\
\hline GPR & Ground Penetrating Radar \\
\hline hr & hour \\
\hline HSWA & Hazardous and Solid Waste Amendments \\
\hline WW & investigation-derived waste \\
\hline & inch \\
\hline & kilogram \\
\hline & kilometer \\
\hline
\end{tabular}




\begin{tabular}{ll} 
LLTSM & Low Level Threat Source Material \\
m & meter \\
MCL & Maximum Contaminant Level \\
$\mu \mathrm{g}$ & microgram \\
mg & milligram \\
mi & mile \\
$\mu$ rem & microrem \\
msl & mean sea level \\
PCB & polychlorinated biphenol \\
PCE & tetrachloroethylene \\
pCi & picocurie \\
PHA & pulse height analysis \\
ppmv & parts per million per volume \\
PTSM & principal threat source material \\
QA & Quality Assurance \\
QC & Quality Control \\
RBA & Risk-Based Activity \\
RBC & Risk-Based Concentration \\
RCRA & Resource Conservation and Recovery Act \\
RdACB OU & Road A Chemical Basin Operable Unit \\
RFI & RCRA Facility Investigation \\
RI & Remedial Investigation \\
SAFER & Streamlined Approach for Environmental Restoration \\
SAP & Sampling and Analysis Plan \\
SCDHEC & South Carolina Department of Health and Environmental Control \\
SRS & Savannah River Site \\
SVOC & semi-volatile organic compound \\
TAL & target analyte list \\
TBC & to be considered \\
TCE & trichloroethylene \\
TCL & target compound list \\
\hline
\end{tabular}


USC

unit-specific constituent

VOC volatile organic compound

WSRC Westinghouse Savannah River Company 


\section{Conversion Table}

\begin{tabular}{|c|c|c|}
\hline Metric Unit & English Unit & Conversion Factor \\
\hline Celsius (C) & Fahrenheit $(\mathrm{F})$ & $1.8^{*}$ \\
\hline Centimeters $(\mathrm{cm})$ & Inches (in.) & 0.394 \\
\hline Kilometers $(\mathrm{km})$ & Miles (mi) & 0.621 \\
\hline Meters (m) & Feet (ft) & 3.28 \\
\hline Square meters $\left(\mathrm{m}^{2}\right)$ & Square feet $\left(\mathrm{ft}^{2}\right)$ & 10.76 \\
\hline
\end{tabular}

Note: To convert the Metric Unit to English Unit, multiply by the conversion factor provided

* To convert Celsius to Fahrenheit multiply by 1.8 then add 32 to the product 


\subsection{INTRODUCTION}

This Resource Conservation and Recovery Act (RCRA) Facility Investigation (RFI)/Remedial Investigation (RI) Work Plan has been prepared for the Road A Chemical Basin Operable Unit (RdACB OU) (904-111G). This unit is subject to the requirements of both RCRA and the Comprehensive Environmental Response, Compensation, and Liability Act (CERCLA). This Work Plan presents the initial evaluation of existing unit data, applicable background data, the regulatory framework for the unit investigation, and the evaluations and decisions made during the determination of the scope and objectives of the planned Remedial Investigation/Feasibility Study (RI/FS) activities.

The development of this Work Plan is based upon the Streamlined Approach for Environmental Restoration (SAFER) and Expedited Site Characterization (ESC). These environmental management approaches produce cost-effective results consistent with standard engineering practice. They provide the framework for rapid waste unit characterization and regulatory document development and approval. These management approaches are described in the following paragraphs.

SAFER is an iterative or phased approach to guide the process from preliminary investigation to remediation. Through the development of a Conceptual Site Model (CSM) and Data Quality Objectives (DQOs), SAFER ensures that data of sufficient quality and quantity are collected. As a result, decisions can be proven technically valid and legally defensible.

ESC incorporates SAFER to optimize field activities to produce a product that is both cost- and time-effective. It identifies the minimum data required to produce unit characterization results that are acceptable to the public. ESC uses a technical team, which maximizes the use of existing data to identify unit-specific constituents (USCs). The technical team continually reviews and modifies the Sampling and Analysis Plan (SAP) based on real-time data acquired during sampling.

This Work Plan presents an investigation designed to determine the nature and extent of contamination originating from the RdACB OU and to prepare for a human health and ecological Baseline Risk Assessment (BRA). 


\subsection{RFI/RI Work Plan Organization}

This Work Plan is organized into nine sections, corresponding to the format described in Regulatory Document Formats (U) (WSRC 1996b). All figures and tables are located at the end of the section in which they are first referenced. Section 1, "Introduction," outlines the regulatory framework guiding the Work Plan and presents an overview of the location, history, and environmental setting of the RdACB OU. Section 2, "Preliminary Unit Evaluation," details the unit history and waste composition, physical setting, demography and land use, climate, ecological setting, regional and unit-specific geology, and hydrogeology. It also presents previous investigations conducted at the RdACB OU. Section 3, "Data Quality Objectives," discusses the DQOs associated with the unit, outlines contaminant transport and receptor mechanisms in the CSM, identifies the preliminary remedial alternatives, and establishes the data needs to support the CSM and preliminary remedial alternatives. Section 4, "Unit Assessment," outlines the environmental sampling needed to fill identified data gaps and confirm existing data. Section 5, "Schedule," addresses Savannah River Site (SRS) schedule deadlines for field activities, milestones, and deliverables. Sections 6, 7, and 8 provide information on the Safety, Health, and Emergency Response Plan; Quality Assurance/Quality Control Plan; and Data Management Plan, respectively. Section 9 lists references used to prepare the document. Appendices provide detailed supporting information.

\section{$1.2 \quad$ Regulatory Background}

\subsubsection{RCRA Facility Investigation (RFI) Program}

The United States Department of Energy (DOE) Savannah River Operations Office manages waste materials that are regulated under RCRA, a comprehensive law that requires the stringent management of hazardous waste. In 1984, the original RCRA requirements were augmented by the Hazardous and Solid Waste Amendments (HSWA).

Certain activities require operation or post-closure permits issued in accordance with RCRA and HSWA. SRS has received a RCRA permit from the South Carolina Department of Health and Environmental Control (SCDHEC). The permit mandates that SRS establish and implement an RFI program to fulfill the requirements of RCRA Section 3004(u). Solid Waste Management Units were identified by the United States Environmental Protection Agency (EPA) Region IV through the RCRA Facility Assessment process and are therefore subject to the RFI process. 


\subsubsection{CERCLA Remedial Investigation Program}

SRS was included on the National Priorities List on December 21, 1989, and is subject to the provisions of CERCLA. In accordance with Section 120 of CERCLA, DOE negotiated a threeparty Federal Facility Agreement (FFA) with the EPA and SCDHEC to develop a single comprehensive cleanup strategy at SRS.

Public participation requirements are listed in Sections 113 and 117 of CERCLA. These requirements include establishing an Administrative Record File that permits the public to be informed about the selection of cleanup alternatives. Additionally, this file provides a medium through which the public can review and comment on the selected cleanup alternatives.

This unit-specific Work Plan will become part of the Administrative Record File. Repositories containing information from these files have been established at DOE's Public Reading Room, located at the University of South Carolina in Aiken, South Carolina; the Thomas Cooper Library in Columbia, South Carolina; the Reese Library in Augusta, Georgia; and the Asa H. Gordon Library in Savannah, Georgia.

\subsection{Summary of Unit Description}

The RdACB OU is located in the southwestern section of SRS, approximately 0.8 kilometers (km) (0.5 miles [mi]) southwest of the intersection of SRS Road A (South Carolina Route 125) and SRS Road 6 (Figure 1-1). The unit is approximately $3 \mathrm{~km}(1.9 \mathrm{mi})$ southeast of the D-Area Powerhouse and approximately $6.4 \mathrm{~km}(4 \mathrm{mi})$ from the nearest plant boundary. The RdACB OU is an inactive liquid waste disposal basin, which received unknown quantities of hazardous and radioactive materials (Figure 1-2). The exact operation period of the unit is not known, but it is expected that the basin existed as early as 1954. In 1973, the basin was backfilled with native soil. No wastes have been deposited since this time. The area surrounding the basin was regraded between 1973 and 1987. The exact nature of hazardous and, potentially, radioactive wastes disposed at the RdACB OU is not known because an inventory of disposal was not logged for this basin. Additional details concerning the history of the RdACB OU are presented in Section 2.2.1.

The RdACB OU is irregular in shape, with average dimensions of approximately 30 meters (m) (98 feet [ft]) wide by $53 \mathrm{~m}$ (174 ft) long (Figure 1-2). The unit is located in a cleared area adjacent to wooded lands in an area of moderate relief. Previous subsurface investigations revealed that the Tobacco Road and Dry Branch Formations of the Barnwell Group underlie the 
RdACB OU. Soils at the RdACB OU are classified as Udorthents, friable substratum. Unit geology and unit soils are discussed in detail in Sections 2.2.6.2 and 2.2.7, respectively. Groundwater beneath the unit is approximately $10.7 \mathrm{~m}$ (35 ft) below land surface (bls) and is identified as the Upper Three Runs Aquifer Unit. Unit hydrogeology is discussed in Section 2.2.8.2. 


\section{FIGURES}


This page intentionally left blank. 


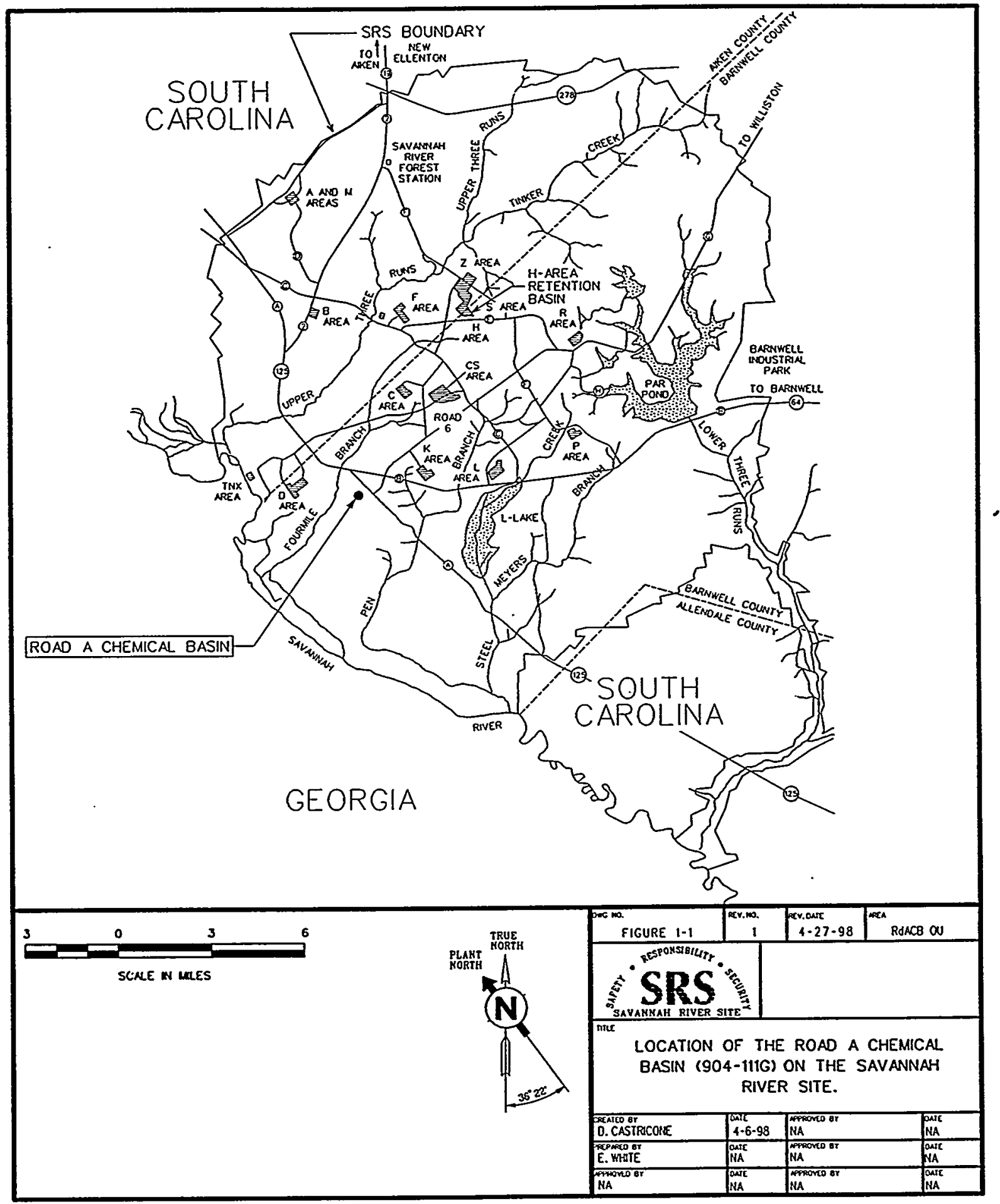

Figure 1-1. Location of the Road A Chemical Basin (904-111G) on the Savannah River Site 
This page intentionally left blank. 


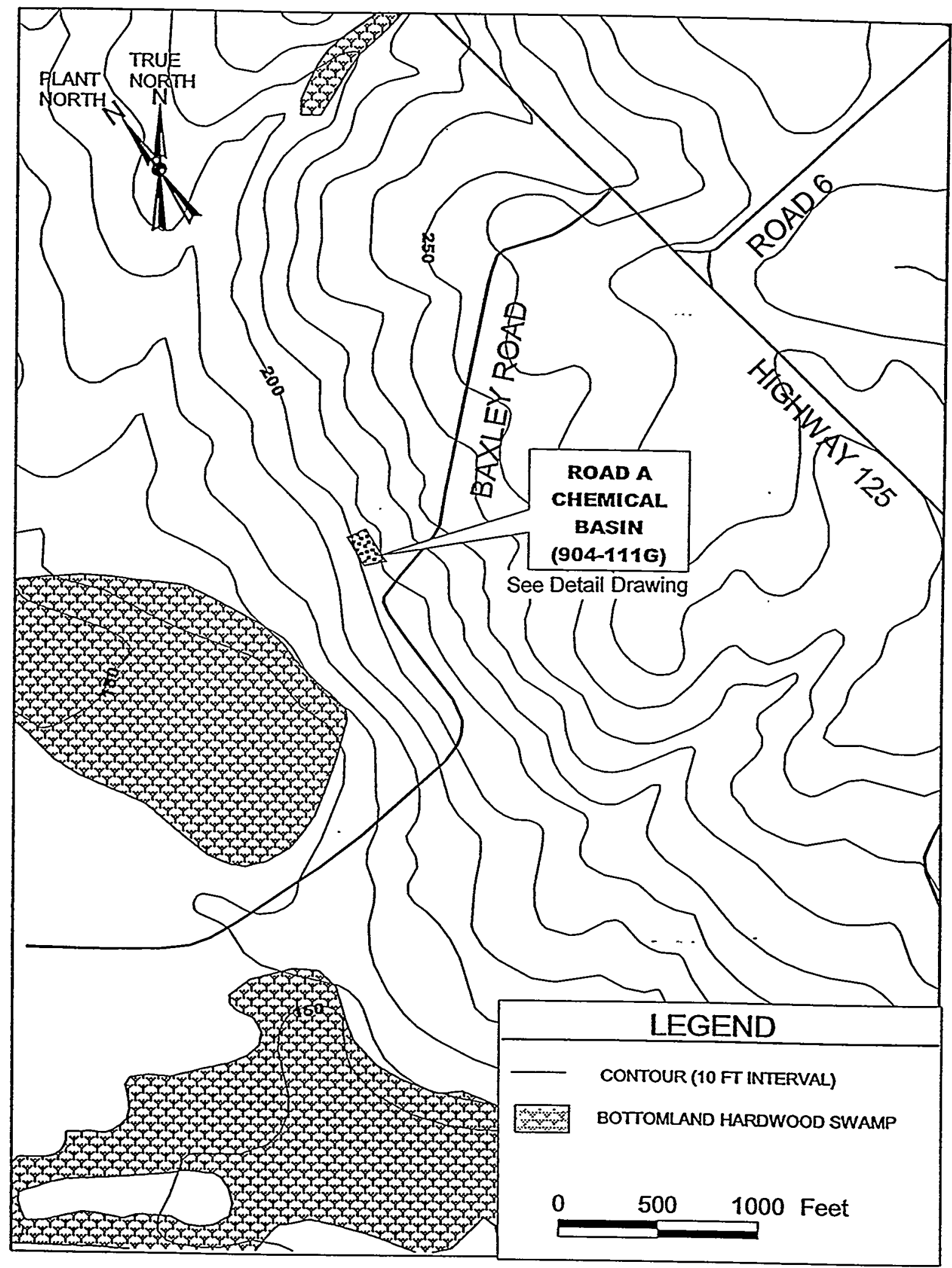

Figure 1-2. Location of the Road A Chemica 
WSRC-RP-98-4032

October 1999

Rev. 1.1

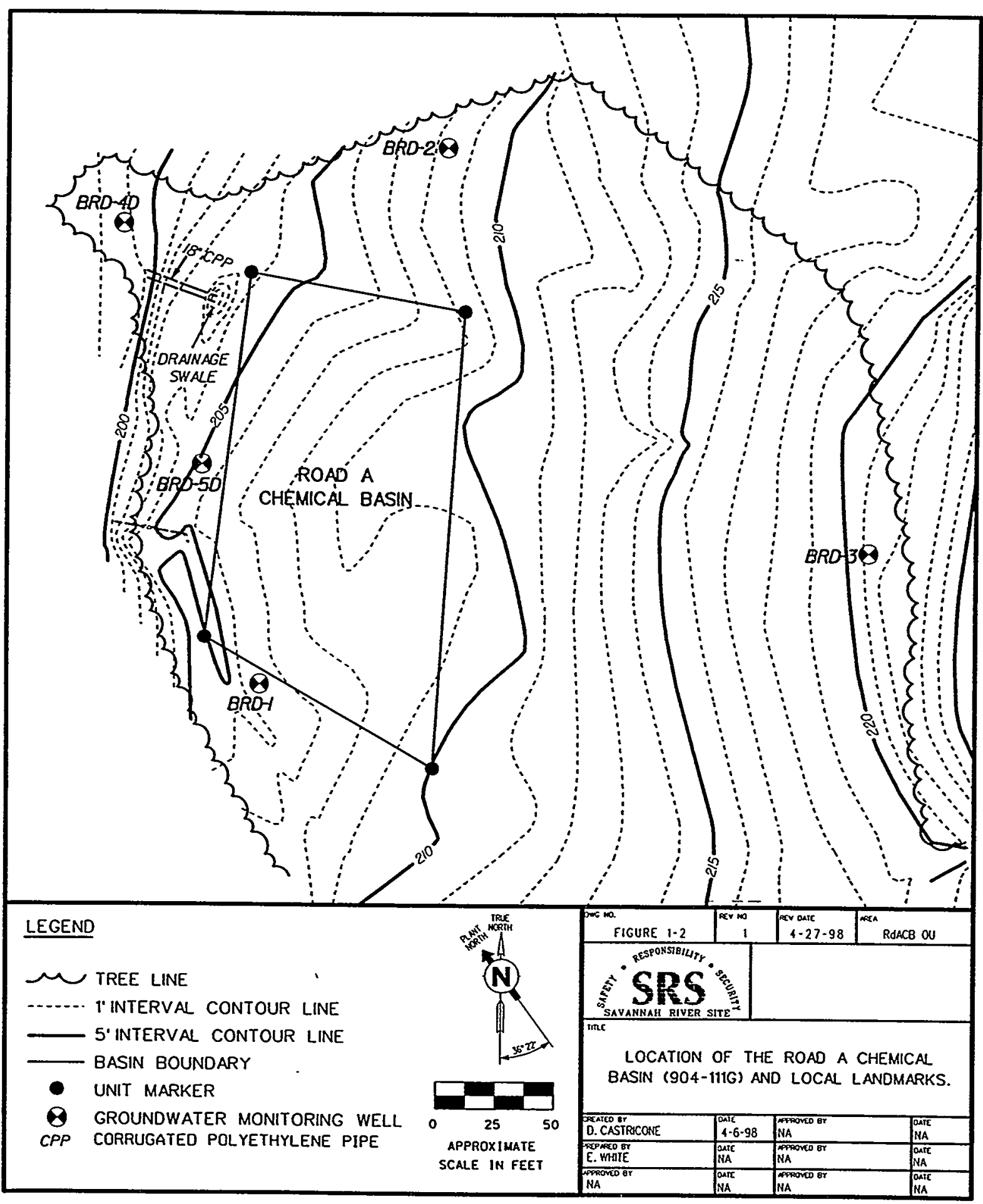

Basin (904-111G) on the Savannah River Site 
This page intentionally left blank. 


\subsection{PRELIMINARY UNIT EVALUATION}

\section{$2.1 \quad$ Introduction}

This section describes the preliminary unit evaluation of the RFI/RI for the RdACB OU. This preliminary evaluation is based on the Environmental Information Document for the Road A Chemical Basin (Pickett et al. 1987), the draft Preliminary Characterization Summary/Preliminary Risk Assessment Report for the Road A Chemical Basin $\left(\mathrm{CH}_{2} \mathrm{M}\right.$ Hill 1990), and the Predecisional, Revision 0, Phase II, RCRA Facility Investigation Work Plan for the Road A Chemical Basin (U) (WSRC 1992). In addition, the unit evaluation presents the results of a unit reconnaissance, a soil gas survey, and groundwater well monitoring and sampling data.

Using the concept of the SAFER, the available information for the RAACB OU was reviewed and evaluated to determine the nature of contaminants potentially placed in the RdACB OU, as well as the probability of secondary source contamination. Based upon this review, a preliminary list of applicable or relevant and appropriate requirements (ARARs) and "to be considered" (TBC) factors was developed to establish preliminary objectives.

\subsection{Unit Characteristics}

The following sections present known unit characteristics, including unit history and waste composition, physical setting, demography and land use, climate, ecological setting, regional and unit-specific geology, and hydrogeology.

\subsubsection{Unit History and Waste Composition}

Little information is available on the operational history of the RdACB OU. The disposal history of wastes in the RdACB OU, including the exact dates of operation and the quantities of materials disposed in the unit, was not recorded, however, evidence suggests that the basin was in operation as early as 1954 . The RdACB OU received uranium process liquids, primarily caustics from the 300-M Area from an unknown time until 1974 (Pirkle and Masdea 1993). An Environmental Information Document and the draft Preliminary Characterization Summary/Preliminary Risk Assessment Report indicate that the contents of the basin included miscellaneous radioactive waste and chemical aqueous wastes (Pickett et al. 1987; $\mathrm{CH}_{2} \mathrm{M}$ Hill 1990). The RdACB OU consists of an inactive waste disposal basin, which received unknown 
quantities of hazardous and radioactive materials (Figure 1-2). In 1973, the basin was backfilled with native soil. No wastes have been disposed in the unit since this time. Photographs taken in 1973, shortly before the unit closure, show a surface depression containing standing water (Pickett et al. 1987). These photographs are included in Appendix A. The photographs also show signs labeled "Keep Out-Dangerous Chemicals" at each end of the unit. However, these warning signs were removed after the unit was backfilled. Figures A-1 and A-2 in Appendix A show standing water contained within the RdACB OU prior to closure and backfilling in 1973. No information is available concerning closure and backfilling of the RdACB, or disposition of standing surface water contained within the basin at the time of closure. Surface soils surrounding the basin could have been impacted during backfilling operations due to displacement of potentially contaminated surface water. Some time after 1973, but before 1987, an area approximately ten times the area of the original basin was regraded and vegetated with vetch (Pickett et al. 1987).

The history of investigation activities at the RdACB OU includes the installation of four groundwater monitoring wells in 1983 and 1984, installation of a fifth groundwater monitoring well in 1989 (Figure 2-1), nine boreholes drilled in 1989 (Figure 2-2), and a soil gas survey conducted in 1992 (Figure 2-3).

\subsubsection{Physical Setting}

The RdACB OU is located on the Aiken Plateau at a ground surface elevation of approximately $62.5 \mathrm{~m}$ (205 ft) above mean sea level (msl). Topographically, the basin is close to the

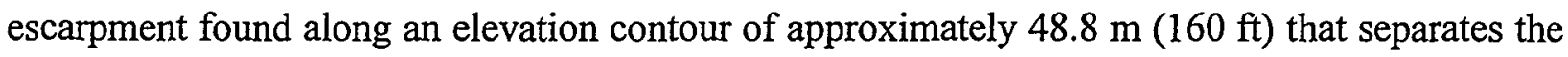
Aiken Plateau from the Ellenton Plain. The Ellenton Plain is the highest of three step-like surfaces between the Savannah River and the Aiken Plateau (Pickett et al. 1987).

The ground surface slopes moderately from the basin at a rate of approximately 4 to 5 percent to the wetlands (Figure 1-2). These wetlands are approximately $243.8 \mathrm{~m}$ (800 ft) southwest of the RdACB OU. Fourmile Creek, a major tributary of the Savannah River, drains these wetlands between 1,676 and 1,829 $\mathrm{m}(5,500$ and $6,000 \mathrm{ft})$ west of the RdACB OU. The unit is located in the Savannah River Floodplain Swamp Watershed. Figure 2-4 shows the location of the RdACB OU, in the Savannah River Floodplain Swamp Watershed, and its relation to the other watersheds at SRS. 
The RdACB OU is situated within a cleared area adjacent to wooded lands in an area of moderate relief. The cleared area, approximately $569 \mathrm{~m}^{2}\left(6,125 \mathrm{ft}^{2}\right)$, is surrounded by pines and hardwoods, with a stand of bottomland hardwood approximately $200 \mathrm{~m}(656 \mathrm{ft}$ ) to the southwest. Five groundwater monitoring wells are located in the immediate vicinity of the RdACB OU. These wells are BRD-1, BRD-2, BRD-3, BRD-4D, and BRD-5D. Access to the RdACB OU is via a gravel road (Baxley Road) off of South Carolina Route 125 (Figure 1-1). Route 125 traverses through the SRS boundary and is open to the general public. Access to the unit is prevented by a $2.4 \mathrm{~m}(8 \mathrm{ft}$ ) locked chain-link fence that surrounds the basin. Orange Health Protection RFI/RI unit marker balls, which indicate a RCRA/CERCLA unit, are located at the corners of the RdACB OU.

Surface soils at the RdACB OU belong to the Udorthents soil series. Udorthents are soils that occur as spoil from excavated or disturbed areas of friable soil material. Udorthents soils generally are friable but can be firm in areas that have been compacted by heavy equipment. The Udorthents generally have a very low content of organic matter and are strongly to extremely. acidic (Rodgers 1990). Figure 2-5 identifies the soil classifications at the unit and surrounding area.

The depth to groundwater beneath the RdACB OU is approximately $10.7 \mathrm{~m}(35 \mathrm{ft}) \mathrm{bls}$ at an

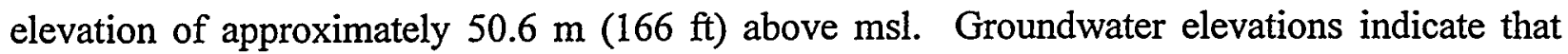
groundwater flow is to the southwest. Natural discharge of the Water Table Aquifer is toward the bottomland wetlands, which are about $243.8 \mathrm{~m}(800 \mathrm{ft})$ to the southwest (Figure 1-2). The groundwater from the Water Table Aquifer likely crops out in that area and then discharges to Fourmile Creek.

\subsubsection{Demography and Land Use}

SRS is located approximately $32 \mathrm{~km}$ (20 mi) south of Aiken, South Carolina, and approximately $40 \mathrm{~km}(25 \mathrm{mi})$ southeast of Augusta, Georgia. According to 1990 census data, the average population densities (people per square mile) for the surrounding South Carolina counties are 111 for Aiken County, 36 for Barnwell County, and 28 for Allendale County. For the surrounding Georgia counties, the densities are 228 for Columbia County, 524 for Richmond County, 25 for Burke County, and 21 for Screven County. The average population density in the counties surrounding SRS is 85 people per square mile. Based on 1990 U.S. Census Bureau data, the population within a $80.5 \mathrm{~km}$ (50 mi) radius of SRS is 620,100 (WSRC 1995c). The estimated population for the area in the year 2000 is projected to be 852,000 . This estimate was 
calculated utilizing the 1970 to 1980 growth rate of each county within a $80.5 \mathrm{~km}$ (50 mi) radius, assuming the same growth rate for the period between the years 1990 and 2000. The calculation assumed that the population would remain constant for counties that experienced a negative population growth between 1970 and 1980. Additional details on demography can be found in the "Site Characteristics" chapter of the Generic Safety Analysis Report for SRS (WSRC 1995c).

Most of the urbanized development in the SRS area has occurred in and around the cities of Augusta, Georgia, and Aiken, South Carolina. Agriculture accounts for 24 percent of the total land use; forest, wetlands, water bodies, and unclassified land that is predominantly rural accounts for about 70 percent of the total land use. A projected 2 percent increase in the development of urban land surrounding SRS is expected by the year 2000. Within SRS, less than 5 percent of the total area is urbanized and/or developed. All of the facilities engaged in the production of special nuclear materials are located within a fraction of this area. Reservoirs and ponds comprise approximately $12.9 \mathrm{~km}^{2}\left(5 \mathrm{mi}^{2}\right)$ of SRS. The remainder of the more than 776 $\mathrm{km}^{2}\left(300 \mathrm{mi}^{2}\right)$ is comprised of natural vegetation and pine plantations. The Savannah River Site Future Use Project Report (DOE 1996) presents SRS stakeholder-preferred future use recommendations. The preferred future land use for the area where the RdACB OU is located is designated as residential (DOE 1996). Figure 2-6 illustrates proposed future land use for SRS.

\subsubsection{Climate}

The average regional annual temperature is $18.3^{\circ} \mathrm{Celsius} \mathrm{(C)}\left(65^{\circ} \mathrm{Fahrenheit}\right.$ [F]) at SRS. In general, the SRS region has a temperate climate with relatively short, mild winters and long, hot, and humid summers. Summer average low and high temperatures are approximately $21.1^{\circ} \mathrm{C}$ $\left(70^{\circ} \mathrm{F}\right)$ and $33.3^{\circ} \mathrm{C}\left(92^{\circ} \mathrm{F}\right)$, respectively, while average winter low and high temperatures are approximately $2.2^{\circ} \mathrm{C}\left(36^{\circ} \mathrm{F}\right)$ and $15^{\circ} \mathrm{C}\left(59^{\circ} \mathrm{F}\right)$, respectively. The SRS region is subject to continental influences but is protected from relatively severe winters by the Appalachian Mountains to the north and northwest. Often influenced by warm, moist, maritime air masses throughout the year, less than one-third of the winter days have a minimum temperature below freezing.

Rainfall at the site tends to be evenly distributed throughout the year. The average annual precipitation at SRS is 122 centimeters (cm) (48 inches [in.]), and the greatest observed rainfall for a 24-hour ( $\mathrm{hr}$ ) period was approximately $50 \mathrm{~cm}$ (19.6 in.) in October 1990. The evaporation rate is approximately $76.2 \mathrm{~cm}$ (30 in.) per year. The most severe weather is limited to frequent 
thunderstorms and infrequent tornadoes and hurricanes. There are approximately 54 thunderstorm days per year. Most of these thunderstorm days occur during the summer.

In general, seasonal prevailing winds are as follows: winter, northwest to southeast; spring, west to east; summer, southwest to northeast; and autumn, toward the southwest and southeast. Additional details concerning the climatology and meteorology of SRS can be found in the "Site Characteristics" chapter of the Generic Safety Analysis Report for SRS (WSRC 1995c).

\subsubsection{Ecological Setting}

The RdACB OU is located in the Savannah River Floodplain Swamp Watershed (Figure 2-4). Seven major vegetation communities are reported from within the floodplain. These include the "Pine," "Nonforested," "Bottomland Hardwood," "Pine/Hardwood," "Upland Hardwood," "Swamp," and "Water" classes, providing a habitat for a wide range of terrestrial and aquatic animals (Workman and McLeod 1990). These community habitat types support about 54 species of mammals, 216 species of birds, 43 species of amphibians, and 58 species of reptiles throughout SRS (Wike et al. 1994).

In the immediate vicinity (within a 1,000 ft radius) of the RdACB OU, "Nonforested," "Pine," and "Pine/Hardwood" habitat types are mainly present. The dominant vegetative cover in the vicinity of the RdACB OU consists of loblolly pine (Pinus taeda), longleaf pine (Pinus palustris), slash pine (Pinus elliottii), various hardwoods and scrub/shrub species. Loblolly pine is widely planted at SRS from the uplands to bottomland terraces. Loblolly stands commonly contain sweetgum (Liquidambar styraciflua), red maple (Acer rubrum), water oak (Quercus nigra) and persimmon seedlings (Diospyros virginiana), with southern red oak (Quercus falcata) and sand hickory (Carya pallida) occasionally present. The understory infrequently contains broomsedge (Andropogon virginicus), dog fennel (Eupatorium capillifolium) and Japanese honeysuckle (Lonicera japonica) (Workman and McLeod 1990).

Federally protected species occurring at SRS include the wood stork, red-cockaded woodpecker, bald eagle, peregrine falcon, and Kirkland's warbler. All are permanent residents at SRS, except the bald eagle, which migrates from July to September, and the peregrine falcon and Kirkland's warbler, which are rare visitors. No federally listed amphibians, reptiles, or mammals are known to occur on SRS. No threatened, endangered, or sensitive bird species are known to occur at the RdACB. 


\subsubsection{Geology}

\subsubsection{Regional Geology}

Three distinct geologic and hydrogeologic systems occur in the subsurface beneath SRS: (1) Paleozoic metamorphic and igneous rocks; (2) Triassic mudstones, sandstones, and conglomerates; and (3) Late Cretaceous to Tertiary unconsolidated and semi-consolidated Coastal Plain sediments (Figure 2-7). The Coastal Plain sequence is essentially an undeformed wedge of sediments consisting of marine and fluvial clay, limestone, sand, and gravel. In South Carolina, the Coastal Plain sediments thicken southeastward from the Fall Line near Augusta, Georgia, to the coast where their thickness exceeds $1,097 \mathrm{~m}(3,600 \mathrm{ft})$. In the vicinity of SRS, these sediments are approximately $320 \mathrm{~m}(1,050 \mathrm{ft})$ thick and range in age from Late Cretaceous to Holocene.

The upper part of the Coastal Plain sequence at SRS consists of the Barnwell Group. The Barnwell Group includes (from oldest to youngest) the Clinchfield Formation, the Dry Branch Formation, the Tobacco Road Formation, and the Altamaha Formation. The group is about $21.3 \mathrm{~m}(70 \mathrm{ft})$ thick near the northwestern boundary of SRS and $51.8 \mathrm{~m}(170 \mathrm{ft})$ thick near the southeastern boundary (Aadland et al. 1995).

The uppermost aquifer beneath the RdACB OU consists of sediments representing the Barnwell Group (Figure 2-7). These sediments are described below. The nomenclature follows Fallaw and Price (1995); the source for these descriptions is Aadland et al. (1995) and references therein.

\subsection{Clinchfield Formation}

The basal late Eocene Clinchfield Formation consists of light-colored quartz sand and glauconitic, biomoldic limestone, calcareous sand, and clay. Sand beds of the formation constitute the Riggins Mill member of the Clinchfield Formation and are composed of medium to coarse, poorly to well-sorted, loose and slightly indurated, tan, gray, and green quartz. The sand is difficult to identify unless it occurs between the carbonate layers of the Griffins Landing member of the overlying Dry Branch Formation and the carbonate layers of the underlying

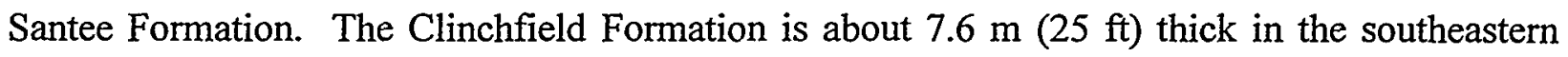
part of SRS and pinches out or becomes unrecognizable at the center of the site. Sand probably was deposited as the Barnwell Sea transgressed over the eroded Santee Formation. 
The carbonate sequence of the Clinchfield Formation constitutes the Utley Limestone member of the Clinchfield Formation. It is composed of sandy, glauconitic limestone and calcareous sand, with an indurated, biomoldic facies developed in places. In lithologic cores, the sediments are tan and white and slightly to well indurated.

\subsection{Dry Branch Formation}

The Jacksonian (late Eocene) Dry Branch Formation is divided into the Griffins Landing member, the Twigs Clay member, and the Irwinton Sand member. The unit is about $18.3 \mathrm{~m}$ $(60 \mathrm{ft})$ thick at SRS. The top of the Dry Branch Formation has been identified from geophysical logs, where a low gamma ray count in the relatively clean Dry Branch sand increases sharply in the more argillaceous sediments of the overlying Tobacco Road Formation. The Dry Branch Formation contains a tan, light gray, and brown discontinuous clay up to $3.6 \mathrm{~m}$ (12 ft) thick.

The Griffins Landing member is composed mostly of tan or green, slightly to well-indurated, quartzose, calcareous micrite and sparite, calcareous quartz sand, and slightly calcareous clay. Local oyster beds are common in the Griffins Landing member. The unit is widespread in the southeastern part of SRS, where it is about $15 \mathrm{~m}$ (50 ft) thick, but becomes sporadic in the center of SRS where it pinches out. Carbonate content is highly variable. In places, the unit lies unconformably on the Utley Limestone member, which contains much more indurated, moldic limestone. In other areas at SRS, the unit lies on the noncalcareous quartz sand of the Clinchfield Formation. Updip, the Clinchfield Formation is difficult to identify or is missing, and the Griffins Landing member may lie unconformably on the sand and clay facies of the Santee Formation. The Griffins Landing member appears to have formed in shallow marine to lagoonal environments.

The Twiggs Clay member is composed of tan, light gray, and brown clay. The Twiggs Clay member is as thick as $3.6 \mathrm{~m}$ (12 ft) but is not continuous over long distances.

The Irwinton Sand member is composed of tan, yellow and orange, moderately sorted, quartz sand, with interlaminated and locally abundant interbedded clay. Pebbly layers and clay clast-rich zones are common. Discontinuous clay beds are tan, light gray, and brown and can be several feet thick in places. These are the "tan clay" beds stated in various SRS reports. Irwinton sand beds have the characteristics of a shallow marine deposit, and the clay may have formed in a lagoonal or marsh environment. The thickness of the Irwinton Sand member varies from 12.2 to $21.3 \mathrm{~m}$ ( 40 to $70 \mathrm{ft}$ ). 


\subsection{Tobacco Road Formation}

The late Jacksonian (Late Eocene) Tobacco Road Formation consists of moderately to poorly sorted, red, brown, tan, purple, and orange, fine to coarse, clayey quartz sand. Pebble layers are common, as are clay laminae and beds; burrows are abundant in parts of the formation. The top of the Tobacco Road Formation is identified where comparatively well-sorted sand is overlain by more poorly sorted sand, pebbly sand, and clay of the Altamaha Formation. Contact between the units is difficult to identify on geophysical logs because the upper surface of the unit is irregular due to fluvial incision that accompanied deposition of the overlying Altamaha Formation.

\subsection{Altamaha Formation}

Deposits of poorly sorted, silty, clayey sand, pebbly sand, and conglomerate of the Altamaha Formation (formerly "Upland Unit") cap many of the hills at higher elevations over much of SRS. Weathered feldspar is abundant in places. The color is variable, and facies changes are abrupt. These materials have previously been assigned to the Hawthorn Formation and may be Miocene in age. According to Siple (1967), a significant characteristic of the Hawthorn Formation that distinguishes it from underlying units is the presence of numerous clastic dikes. These features, according to Siple, do not occur in the Eocene (Jacksonian) sediments, at least to the degree that they do in the overlying Altamaha Formation. The environment of deposition for the Altamaha Formation appears to be fluvial, and the thickness changes abruptly, owing to channeling of the underlying Tobacco Road Formation during Altamaha deposition and subsequent erosion of the Altamaha Formation itself. Thicknesses up to $18.3 \mathrm{~m}(60 \mathrm{ft})$ have been documented.

The Altamaha Formation, Tobacco Road Formation, and Dry Branch Formation are similar in texture and composition, indicating that they might have a similar provenance (i.e., that they are part of the same transgressive/regressive depositional cycle, with the Altamaha Formation being the most continental lithofacies and the Dry Branch Formation being the most marine lithofacies). Thus, the Altamaha Formation represents a major regressive pulse that closed out deposition of the Barnwell Group depositional cycle. The Altamaha Formation may be correlative with the Chandler Bridge Formation downdip in South Carolina and Georgia. This hypothesis is significant because it implies that there was no major hiatus between the Altamaha Formation and the underlying Tobacco Road Formation and Dry Branch Formation. However, 
the existence of a hiatus between the units has been reported by numerous researchers of the South Carolina Coastal Plain.

\subsection{Quaternary Deposits}

Quaternary alluvium comprises the floodplains and constructional terraces of the Savannah River and its major tributaries. The deposits are poorly sorted sands, clays, and gravels, which vary in thickness from a fraction of an inch in the higher elevations of the subsequent streams to over $9 \mathrm{~m}$ (30 ft) thick in the Savannah River floodplain. Within the boundaries of SRS, the Quaternary terraces are generally thin and discontinuous.

\subsubsection{Unit Geology}

In 1989 , a preliminary investigation was conducted at the RdACB OU. This preliminary investigation included drilling nine boreholes within and adjacent to the unit. Five of these boreholes were drilled to a depth of $3.0 \mathrm{~m}(10 \mathrm{ft})$ and four were drilled to a depth of $10.7 \mathrm{~m}$ (35 ft) (Figure 2-2). The lithologic logs from these boreholes and geologic data collected during groundwater monitoring well installation provide unit-specific lithologic data about the shallow geology beneath the RdACB OU. Appendix B contains the lithologic logs for the nine boreholes and groundwater monitoring well BRD-5D. Cross-sections were generated using the data obtained from the nine boreholes (Figures 2-8 and 2-9).

Based on the boreholes to $10.7 \mathrm{~m}$ ( $35 \mathrm{ft}$ ) deep and the lithologic log from monitoring well BRD-5D, which was installed to $18.9 \mathrm{~m}$ (62 ft) deep, the Tobacco Road and Dry Branch Formations of the Barnwell Group underlie the RdACB OU. Both of these formations are predominantly sandy, with the Tobacco Road Formation showing more orange color and the Dry Branch Formation showing more tan to yellow color. The lithologic logs from the nine boreholes installed at the RdACB OU indicate that most of the soil profile is predominantly sands and silty sands with minor amounts of clayey sand and cobbles. Cobbles are common near the surface and are present in an eroded area adjacent to the RdACB OU.

\subsubsection{Unit Soils}

The soils at the RdACB OU are predominantly sandy, varying primarily by their slope and degree of drainage. Soils series within and adjacent to the RdACB OU are Udorthents, Blanton sands, Wagram sands, and Pickney sands (Figure 2-5). 
In the immediate RdACB OU area, the soils are classified as Udorthents, friable substratum. This classification is reserved for areas that have been graded, or otherwise disturbed, by human activities.

The Blanton sand is the predominant soil series present immediately beyond the disturbed area of the RdACB OU. These soils are generally excessively drained, low in organic matter and available water, and found on slopes of 0 to 6 percent. These soils are predominantly sand to a depth of $122 \mathrm{~cm}$ (48 in.). At this depth, the soil grades to a sandy loam (Rogers 1990).

Soils of the Wagram sand are adjacent to the Blanton sand series. These soils are very similar to Blanton sands with regards to the soil profile, composition, and other classification parameters. The primary difference is that the Wagram sand is found on slopes of 2 to 6 percent (Rogers 1990).

Along the perennial streams and floodplains in this area, the soils are predominantly classified as Pickney sand, frequently flooded. These soils are predominantly sandy with abundant organic matter near the surface, and less organic matter with increasing depth. This soil is typified by a high water table and is frequently flooded during the winter and spring (Rogers 1990).

\subsubsection{Hydrogeology}

\subsubsection{Regional Hydrogeology}

In the immediate area of the RdACB OU, hydrogeologic details are poorly defined compared to other areas of SRS. No Baseline Hydrogeologic Investigation Observation Well Clusters (P-well series) are in the immediate vicinity of the RdACB OU. The closest well cluster of this series

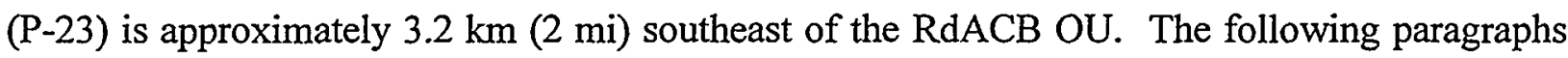
describe the hydrogeology at the unit starting with the uppermost aquifer. This information has been summarized from Hydrogeologic Framework of West-Central South Carolina (Aadland et al. 1995).

The vadose zone contains sediments of the Barnwell Group. The thickness of the vadose zone is approximately $10.7 \mathrm{~m}$ ( $35 \mathrm{ft}$ ) beneath the RdACB OU. The unconfined aquifer, known as the Upper Three Runs Aquifer, belongs to the Floridan Aquifer System (Figure 2-7). The aquifer occurs between the water table and the Gordon Confining Unit. The aquifer is composed of Tertiary deposits of the Orangeburg Group and all of the overlying Barnwell Group. It consists mainly of unconsolidated, moderately sorted, subangular, lower coarse- to medium-grained, 
slightly gravelly, immature yellow and tan quartz sand and clayey sand of the Santee Formation; poorly to well-sorted sand and interbedded tan or gray clay of the Dry Branch Formation; and moderately to poorly sorted, fine- to coarse-grained sand, pebbly sand, and minor clay of the Tobacco Road Formation.

The Upper Three Runs Aquifer consists of the water-bearing sediment from the water table to the top of the Gordon Confining Unit. The aquifer is $18.3 \mathrm{~m}$ (60 ft) thick at the P-23 well cluster. The Upper Three Runs Aquifer generally demonstrates lower transmissivity values than the underlying Gordon Aquifer.

Hydrostratigraphic head generally decreases from the water table to the Gordon Aquifer, indicating downward migration of groundwater. However, vertical flow is impeded by the Gordon Confining Unit, where leakage is calculated to be approximately $5.3 \mathrm{E}-05 \mathrm{ft} / \mathrm{day} / \mathrm{ft}$ (Aadland et al. 1995). In addition to impeded flow, the presence of clay minerals in the confining unit may retard migration of some contaminants, especially metals and metallic radionuclides.

The Gordon Confining Unit separates the Upper Three Runs Aquifer from the Gordon Aquifer across much of SRS. The Gordon Confining Unit consists of an interval of clayey sand and clay. Boundaries between the Upper Three Runs and Gordon Aquifers are defined by the vertical extent of the confining units. A confining unit is differentiated from an aquifer by a relative increase in silt and clay content that is consistent over a large area. The hydrogeologic changes do not always correspond with boundaries between stratigraphic units. Geologic formations therefore remain implicit in the hydrostratigraphy.

The Gordon Confining Unit is $2.1 \mathrm{~m}$ (7-ft) thick at the P-23 well cluster; it thickens to $26 \mathrm{~m}$ $(85 \mathrm{ft}$ ) in the southeastern portion of SRS. It is composed of fine-grained, glauconitic, clayey sand and clay of the Warley Hill Formation, and clayey, micritic limestone of the Blue Bluff member of the Santee Formation. The Gordon Aquifer underlies the Gordon Confining Unit and comprises the lowermost element of the Floridan Aquifer System. Deeper hydrostratigraphic units include the Crouch Branch Confining Unit of the Meyers Branch Confining System; Crouch Branch Aquifer, McQueen Branch Confining Unit, and McQueen Branch Aquifer of the Dublin-Midville Aquifer System; and undifferentiated units of the Appleton Confining System. 


\subsubsection{Unit Hydrogeology}

The unit hydrogeology is defined from data collected during the preliminary characterization borehole sampling and the five existing BRD series wells. Lithologic descriptions from the nine boreholes indicate that sands and silty sands underlie the RdACB OU. No continuous, lowpermeability layers are present locally in the vadose zone. Therefore, there are no local barriers to prevent infiltration of precipitation to the Water Table Aquifer, based on the data provided by the nine boreholes.

The BRD series wells are all screened in the Upper Three Runs Aquifer. The top of the Upper Three Runs Aquifer, as recorded by the BRD well series, is approximately $11.3 \mathrm{~m}(37 \mathrm{ft}) \mathrm{bls}$. Groundwater elevations beneath the RdACB OU range between 51.2 and $52.1 \mathrm{~m}$ (168 and $171 \mathrm{ft}$ ) above msl. As shown on Figure 2-10, groundwater flow is to the west-southwest at a gradient of approximately $0.006 \mathrm{~m} / \mathrm{m}(0.006 \mathrm{ft} / \mathrm{ft})$.

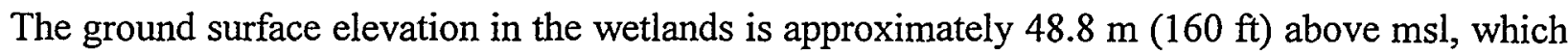
is approximately $1.5 \mathrm{~m}(5 \mathrm{ft})$ below the water table elevation at the RdACB OU. Groundwater discharges along the seepage line are likely from the Water Table Aquifer (Upper Three Runs Aquifer). The drop in elevation results in an approximate 0.6 percent gradient, which is consistent with the expected range in this region.

The existing groundwater monitoring wells do not penetrate the deep aquifers in the vicinity of the RdACB OU. Therefore, the properties of these aquifers have not been tested. The approximate elevation of the potentiometric surface in the Gordon Aquifer beneath the RdACB OU is about $39.6 \mathrm{~m}$ (130 ft) above msl (Pickett et al. 1987). This lower elevation suggests possible downward flow from the Water Table Aquifer to the Gordon Aquifer. At the same time, the potentiometric surface of the Crouch Branch Aquifer is believed to be approximately $50.0 \mathrm{~m}(164 \mathrm{ft})$ above msl. This higher potentiometric surface suggests groundwater flow from the Crouch Branch Aquifer to the Gordon Aquifer (Bledsoe 1987). Potentiometric head relationships in the P-23 well cluster support this hypothesis. The P-23 well cluster, located

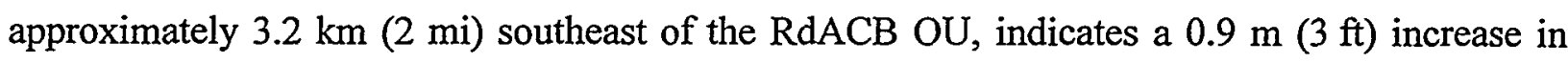
hydraulic head from the Water Table Aquifer to the Gordon Aquifer (Figure 2-11) (Aadland et al. 1995). The P-26 well cluster also shows head reversal from the Gordon Aquifer to the Water Table Aquifer (Figure 2-12) (Aadland et al. 1995). The groundwater elevation of the deeper Crouch Branch Aquifer is $5 \mathrm{~m}$ (17 ft) higher than the groundwater elevation in the overlying 
Gordon Aquifer at well cluster P-26, indicating potential upward flow across the Crouch Branch Confining Unit.

\subsection{Existing/Previous Investigations}

Previous investigations conducted at the $\mathrm{RdACB} O U$ include installation and sampling of groundwater monitoring wells, soil samples collected from nine boreholes, a soil gas survey, and a radiological survey. The results of these previous investigations are presented in the following sections.

\subsubsection{Groundwater Monitoring}

Based on review of the WSRC Environmental Protection Department's Well Inventory, and the unit reconnaissance presented in Appendix C, five groundwater monitoring wells are located in the vicinity of the RdACB OU (Figure 2-1). These wells are BRD-1, BRD-2, BRD-3, BRD-4D, and BRD-5D (WSRC 1996a). Wells BRD-1, BRD-2, BRD-3, and BRD-4D were installed in 1983 and 1984; well BRD-5D was installed in 1989. Well construction details are presented in Table 2-1. Monitoring well construction details for wells BRD-4D and BRD-5D are presented in Appendix B. Screened intervals range from 39.3 to $57.5 \mathrm{~m}$ (129.1 to $188.5 \mathrm{ft}$ ) above msl, and total depths range from 17.4 to $21.3 \mathrm{~m}$ (57 to $70 \mathrm{ft}$ ) deep. From 1984 to 1992 , the groundwater elevations were measured quarterly in all five wells. Due to an observed drop in groundwater elevation, the upgradient well (BRD-3) went dry in 1987. However, groundwater was observed in this well again in 1992. After 1993, groundwater elevations were measured in the first, second, and third quarters of 1994; in the first quarters of 1995 and 1996; and in second quarter of 1997. Hydrographs for all five wells are presented in Figure 2-13. These hydrographs indicate a general decrease in the water table elevation from 1985 to 1989 . The water table elevation increased from 1989 to 1991 and has remained relatively stable since 1991. Overall, the average groundwater elevations range from 49.9 to $51.7 \mathrm{~m}(163.7$ to $169.5 \mathrm{ft})$ above msl. A statistical summary of the water level elevation data is presented in Table 2-2.

The water table surface map (Figure 2-10) was generated from first quarter 1996 groundwater elevations measured in all five BRD series wells. Groundwater flow is to the west-southwest. Based on this water table surface map, well BRD-3 is upgradient of the RdACB OU. Well BRD-2 is side-gradient, and wells $B R D-1, B R D-4 D$, and $B R D-5 D$ are downgradient of the RdACB OU. 
Based on groundwater velocities calculated in the area, the groundwater travel time from the RdACB OU to the wetlands seep line, which is approximately $243.8 \mathrm{~m}$ (800 ft) away, was estimated to range from 75 to 150 years $\left(\mathrm{CH}_{2} \mathrm{M}\right.$ Hill 1990).

\subsubsection{Groundwater Sampling and Analysis}

From 1988 to 1996, all five wells were sampled and analyzed for volatile organic compounds (VOCs), semi-volatile organic compounds (SVOCs), metals, dioxins/furans, pesticides, gross alpha, nonvolatile beta, and tritium. Groundwater is potentially contaminated through the leaching of contaminants from the deep soil. The discussion of the CSM in Section 3 presents this information in further detail.

Table 2-3 summarizes the groundwater analytical data collected and analyzed from 1988 to 1996 and presents all analytes detected in monitoring wells at the RdACB OU. Table 2-3 also provides the total number of samples collected, the number of times each analyte was detected, the maximum observed concentration, the Safe Drinking Water Act Maximum Contaminant Level (MCL), and the EPA Risk-Based Concentration (RBC). Both the MCL and RBC are used in the preliminary evaluation of groundwater quality. $\mathrm{RBC}$ values used in this evaluation are published by EPA Region III (EPA 1999).

Sixty analytes have been detected in samples collected from the monitoring wells. Of the 60 analytes detected in samples from the five BRD series wells, eight analytes exceeded MCLs and nine exceeded RBCs. Table 2-4 presents only the analytes that exceeded MCLs and/or RBCs. One indicator parameter (nitrate as nitrogen) was detected at concentrations that exceed the RBC value. Three VOCs (dichloromethane [methylene chloride], tetrachloroethylene [PCE], and trichloroethylene [TCE]) were detected at concentrations greater than their respective MCL and RBC values. Bis (2-ethylhexyl) phthalate was the only SVOC detected above its MCL and RBC values. Three pesticides (dieldrin, heptachlor, and heptachlor epoxide) were detected at concentrations greater than their respective RBC values. Radium was the only radionuclide detected above its MCL and risk-based activity (RBA) values. Two metals (lead and mercury) were detected at concentrations greater than their respective MCL values. Iron was detected at concentrations exceeding its $\mathrm{RBC}$ value. Detected concentrations of metals may be due to excess turbidity, and the high lead concentration may be due to the age of the pumps in the wells. The existing wells will be redeveloped with new pumps prior to re-sampling when the new wells are installed. 


\subsubsection{Soil Sampling}

Surface soils and subsurface soils are potentially contaminated through deposition and bioturbation. Deep soils may be contaminated due to infiltration/percolation of rainwater through the waste mass and into the underling soil. The discussion of the CSM in Section 3 presents this information in further detail.

In 1989, nine boreholes (SB-1 through SB-9) were drilled and sampled with hollow-stem augers at the RdACB OU (Figure 2-2). Five boreholes were drilled to $3.0 \mathrm{~m}(10 \mathrm{ft}$ ) deep, and four were drilled to $10.6 \mathrm{~m}(35 \mathrm{ft})$ deep. Cross-sections generated from these boreholes are presented in Figures 2-8 and 2-9. Lithologic logs for each of these boreholes are presented in Appendix B. Continuous split-spoon samples were collected for lithologic description and laboratory analysis. Field screening for VOCs was performed on split-spoon samples with a photoionization detector. Field screening showed elevated levels of VOCs.

Soil samples consisted of fine to coarse sand and silty sand. Pebbles and/or cobbles were encountered in several boreholes in the 1.2 to $1.8 \mathrm{~m} \mathrm{(4} \mathrm{to} 6 \mathrm{ft}$ ) depth interval. Minor clay and sandy clay lenses also were encountered. However, these clay lenses are discontinuous throughout the site.

Soil samples were collected from boreholes SB-6, SB-8, and SB-9 for laboratory analysis. Table 2-5 summarizes the soil sample intervals and parameters analyzed at these three borehole locations. Soil analytical results for boreholes SB-6, SB-8, and SB-9 are summarized in Appendix D. At each borehole, two samples were collected and analyzed for VOCs and metals. In addition, one sample was collected at each borehole and analyzed for base/neutral and acid extractable compounds, pesticides and polychlorinated biphenols (PCBs), radionuclide indicators, and total radium. No samples were collected for radiological analysis from the approximate basin bottom (57.9 $\mathrm{m}$ [190 ft] above $\mathrm{msl})$.

No unit-specific background soil samples were collected during this investigation. Therefore, no comparisons can be made between the concentrations detected in soils at the RAACB OU and background concentrations. Other than anthropogenic contaminants (e.g., VOCs, SVOCs), it is not possible to determine the impact of contaminants on soil associated with the waste disposal activities at the RdACB OU.

Three VOCs (chlorobenzene, methylene chloride, and acetone) were detected in soil samples collected from boreholes SB-6, SB-8, and SB-9. Chlorobenzene was detected at a maximum 
concentration of 26 micrograms per kilogram $(\mu \mathrm{g} / \mathrm{kg}$ ) at a depth of 1.8 to $2.4 \mathrm{~m}(6$ to $8 \mathrm{ft}$ ) in borehole SB-6. At this borehole location, chlorobenzene concentrations increased with depth to $2.4 \mathrm{~m}(8 \mathrm{ft})$, then decreased below this depth. Methylene chloride and acetone also were detected in Quality Assurance/Quality Control (QA/QC) blank samples associated with these samples. Methylene chloride and acetone are common laboratory contaminants; thus, the presence of these contaminants in soil samples is suspect. The concentrations detected in each soil sample, except SB-9-05, were less than ten times the concentration detected in the associated blanks. Therefore, the presence of methylene chloride and acetone is likely due to laboratory contamination and the results are eliminated from the data set. No other VOCs were detected in soil samples.

Seven metals were detected in soil samples collected from boreholes SB-6, SB-8, and SB-9. These metals are aluminum, arsenic, barium, chromium, lead, lithium, and mercury. The highest detected metal concentration was for aluminum, at 17,750 milligrams per kilogram (mg/kg). Aluminum is ubiquitous in SRS soils, therefore, it is likely that this concentration falls within the background soils range in the RdACB OU area. Arsenic was detected at a maximum concentration of $8.2 \mathrm{mg} / \mathrm{kg}$. Barium and cadmium were detected in borehole SB-6 at maximum concentrations of 321.5 and $60.3 \mathrm{mg} / \mathrm{kg}$, respectively. Lead was detected at a maximum concentration of $15.7 \mathrm{mg} / \mathrm{kg}$ in borehole SB-8. Mercury was detected in one sample collected from borehole SB-8 at a maximum concentration of $0.14 \mathrm{mg} / \mathrm{kg}$. Lithium was detected in borehole SB-8 at a maximum concentration of $2.4 \mathrm{mg} / \mathrm{kg}$.

Gross alpha activity was detected at borehole SB-6 from 0.6 to $1.2 \mathrm{~m} \mathrm{(2} \mathrm{to} 4 \mathrm{ft}$ ) deep, and at borehole SB-9 from 1.8 to $2.4 \mathrm{~m}$ ( 6 to $8 \mathrm{ft}$ ) deep. Gross alpha activity was only analyzed in these two soil samples. The maximum gross alpha activity detected in these two soil samples was 16 picocuries per gram (pCi/g) in SB-6. The maximum nonvolatile beta activity was detected in SB- 6 at 15 pCi/g. These maximum gross alpha and nonvolatile beta activities fall within the natural background ranges and are below the SRS radiological screening criteria of $20 \mathrm{pCi} / \mathrm{g}$ and $50 \mathrm{pCi} / \mathrm{g}$, respectively. Total radium was detected at a maximum activity of $8 \mathrm{pCi} / \mathrm{g}$ in borehole SB-6.

\subsubsection{Soil Gas Survey}

Volatilization from surface, subsurface, and deep soils contaminated with VOCs can affect air quality at the unit. As a result, this volatilization can present potential risk to either human or ecological receptors. The CSM in Section 3 discusses this information in further detail. 
In September 1992, a soil gas survey was performed at the RdACB OU. The objective of the soil gas survey was to determine the presence and lateral extent of VOCs in soil gas at the unit. A total of 36 soil gas sampling locations were selected. Eleven were located directly above the approximate boundaries of the RdACB OU (Figure 2-3). The soil gas samples were analyzed for light hydrocarbons $\left(\mathrm{C}_{1}-\mathrm{C}_{4}\right)$; gasoline range normal paraffins $\left(\mathrm{C}_{5}-\mathrm{C}_{10}\right)$; gasoline range aromatic hydrocarbons; chlorinated organics; and benzene, toluene, ethylbenzene, and xylene (BTEX). All analyses for the $\mathrm{C}_{1}-\mathrm{C}_{4}$ hydrocarbons were performed by an onsite laboratory. All VOC analyses were performed by Microseeps' laboratory in Pittsburgh, Pennsylvania. During the 1989 soil investigation, chlorobenzene was the only detected VOC other than common laboratory contaminants (acetone and methylene chloride). Chlorobenzene was included in the chlorinated organics analysis. Soil gas samples were analyzed on an instrument calibrated for chlorobenzene. However, none of the soil gas sample chromatograms indicated the presence of chlorobenzene. The results of these analyses are presented in Appendix E.

In general, VOC concentrations detected in this soil gas survey are very low. The most commonly observed VOCs at the RdACB OU were pentane and hexane. Pentane was detected in 24 of the 36 locations at a maximum concentration of 0.42 parts per million per volume (ppmv). Hexane was detected at six locations at a maximum concentration of $0.14 \mathrm{ppmv}$. The locations where pentane and hexane were detected are correlative with the location of the RdACB OU. Benzene, toluene, octane, and xylenes were detected at one location, and chloroform was detected at two locations.

\subsubsection{Radiological Survey}

In 1997, a radiological survey was performed at the RdACB OU. This survey included exposure rate measurements, direct alpha and beta/gamma contamination surveys, and collection and analysis of 20 surface soil samples. Exposure rate measurements were 10 microrem per hour ( $\mu \mathrm{rem} / \mathrm{hr}$ ) at the RdACB OU. This exposure rate is equivalent to background in the area. Direct alpha and beta/gamma contamination surveys showed no detectable contamination of surface soil covering the RdACB OU. The maximum gross alpha activity detected in the soil samples was $90 \mathrm{pCi} / \mathrm{g}$. The maximum nonvolatile beta activity detected in soil samples was $27 \mathrm{pCi} / \mathrm{g}$. The results of the radiological survey are presented in Appendix F. 


\subsection{Unit Evaluation Conclusions}

Based on quarterly groundwater monitoring data, soil and groundwater analytical data, and the results of the 1992 soil gas survey, potential environmental contamination exists at the RdACB OU. However, the nature and extent of environmental contamination at the RdACB OU are currently unknown for primary and secondary sources. It is also unknown if release mechanisms have impacted the groundwater media. Based upon the evaluation of the existing data, which have been determined to be insufficient, and the operational history of the RdACB OU, a unit characterization should be performed.

Fourteen years of groundwater monitoring and sampling data provides a baseline for groundwater quality at the RdACB OU. Additional groundwater quality data are needed; therefore, quarterly monitoring and sampling should continue at each of the five wells. Historical groundwater data collected from 1988 to 1996, and the soil analytical results collected from the nine boreholes, indicate potential soil contamination from VOCs, SVOCs, and metals. Insufficient data are available to determine if unit soils have been impacted by radionuclides. The results of the 1992 soil gas survey indicated low VOC concentrations. Pentane and hexane were detected in several soil gas samples. The locations where pentane and hexane were detected are correlative with the location of the RdACB OU.

Additional soil sampling should be conducted to establish unit-specific background concentrations at the RdACB OU. Additional soil sampling should be conducted within the RdACB OU and in adjacent areas. Additional soil sampling should be performed at locations adjacent to the basin based on surface water drainage pathways to assess the impact to soil downslope of the unit. The suite of analyses for soil samples should include VOCs, SVOCs, inorganics and metals, pesticides/PCBs, and radionuclide indicators (gross alpha and nonvolatile beta). Isotopic analysis of radionuclides will be performed if the indicator analyses exceed 20 $\mathrm{pCi} / \mathrm{g}$ gross alpha or $50 \mathrm{pCi} / \mathrm{g}$ nonvolatile beta.

Lead was detected in monitoring well BRD-3, which is upgradient of the RdACB OU. A new background well should be installed and sampled at the RdACB OU to provide unit-specific background data. The suite of analyses for groundwater samples should include VOCs, SVOCs, metals, pesticides, and radionuclide indicators. 


\subsection{Operable Unit Strategy}

The proposed operable unit strategy for the RdACB OU is based upon the assumption that the recommended final land use will be residential (DOE 1996). The strategy consists of the following steps:

- Develop the RFI/RI Work Plan to adequately characterize the nature of contaminants and the vertical and horizontal extent of contamination in all media

- Perform site characterization under the RFI/RI Work Plan to include surface and subsurface soil sampling within the waste unit boundaries; surface and subsurface soil sampling of the areas on the perimeter of the waste unit; soil sampling of the drainage swale adjacent to the waste unit; and groundwater characterization

- Evaluate all characterization data

- Develop an RFI/RI/BRA for the RdACB OU, including quantifying the nature and vertical/horizontal extent of contamination, determining contaminant migration, and quantifying human health and ecological risk

- Develop a Corrective Measures Study/Feasibility Study (CMS/FS) with remedial action objectives, including remedial alternatives screened against the nine CERCLA evaluation criteria

- Prepare a Proposed Plan and Final Record of Decision for the selected alternative

- Conduct a remedial action (if required)

At this time, the nature and quantity of the primary source are unknown. Also, there are no data concerning the impact to secondary sources or migration of contaminants to groundwater. As such, it is not possible to forecast remedial options until data of sufficient quality and quantity have been collected and evaluated. Evaluation of the characterization data will lead to a revised CSM, the development of protective remedial action objectives, and screening of remedial alternatives. Potential remedial options for soils must include the following: no action, institutional controls, excavation and removal, containment/stabilization, and/or natural soil cover/capping. Groundwater remedial options might include the following: no action, institutional controls, or mixing zone application. Because meaningful groundwater data have not been collected, an assessment to determine appropriate strategies, beyond those mentioned above, is limited (DOE 1996). 
2.6 Potential Applicable or Relevant and Appropriate Requirements (ARARs) and "To-Be-Considered" (TBC) Criteria

A preliminary list of potential ARARs and TBC criteria for the RdACB OU is presented in Table 2-6. Development of ARARs and TBC criteria is an iterative process performed throughout the assessment and corrective action of the unit. This list of potential ARARs is expected to be modified and refined as more data are obtained. ARARs may be location-, chemical-, or actionspecific.

Because groundwater monitoring data indicate possible impact to groundwater from the RdACB OU, the EPA and South Carolina Drinking Water Regulations and the South Carolina Water Standards are potential ARARs. The Atomic Energy Act is likely to be applicable, since radioactive materials are thought to be associated with disposal activities at the RdACB OU. Certain other requirements may be applicable, depending on specific remedial actions implemented at the unit. RCRA and South Carolina Hazardous Waste Management Regulations may be considered ARARs if removal of waste material from the unit is conducted. If groundwater extraction wells or monitoring wells are required for remedial action, then the South Carolina Well Standards would be considered an action-specific ARAR.

Certain potential ARARs can be identified as inappropriate based on existing information available about the RdACB OU. No critical habitats for endangered species have been identified in the immediate vicinity of the unit; therefore, the Endangered Species Act is not applicable.

There are no archeological or historic sites located at or near the RdACB OU; therefore, the National Archeological and Historical Preservation Act is not included as an ARAR.

\subsection{Potential Corrective Measures Study/Feasibility Study (CMS/FS) Options}

\subsubsection{Standard Remedial Technologies}

Based upon previous investigations, $\mathrm{RdACB}$ OU soils and groundwater may require remediation. Institutional controls, such as access controls, monitoring, and land use restrictions, are likely to be potential actions at the RdACB OU. Other remedial options for unit soils include "No Further Action," as required by the EPA, and excavation and disposal.

Historical groundwater monitoring data indicate that groundwater may also require remediation. Based on available data, the potential remediation techniques include use of alternate 
concentration limits, mixing zone concentration limits, and "No Further Action." Potential remedial alternatives for the RdACB OU are presented in Table 2-7.

\subsubsection{Innovative Remedial Technologies}

Available information indicates that innovative remedial technologies need not be considered for the RdACB OU. Standard remedial technologies and process options should provide appropriate protection to human health and the environment.

\subsection{Potential Early and/or Interim Remedial Actions}

An evaluation of data from the previous investigations of the RdACB OU indicates that there is no immediate human health or ecological risk associated with the RdACB OU. Additionally, historical groundwater analytical data do not indicate an immediate risk from groundwater contamination. Therefore, no early or interim remedial action will be necessary for the source material, soil, or groundwater. An interim remedial action, such as institutional controls, will be considered if an immediate threat is identified.

\subsubsection{Early Action Strategy}

The feasibility of an early action for the entire waste unit, or a portion, cannot be assessed at this time. Because of the lack of sufficient information about the primary source, location of the primary source, contamination of secondary sources, and the extent of contamination in groundwater (if any), it is not appropriate to propose an early action. This conclusion is consistent with the early action decision-making process presented in Plate 1. 
This page intentionally left blank. 


\section{FIGURES}


This page intentionally left blank. 


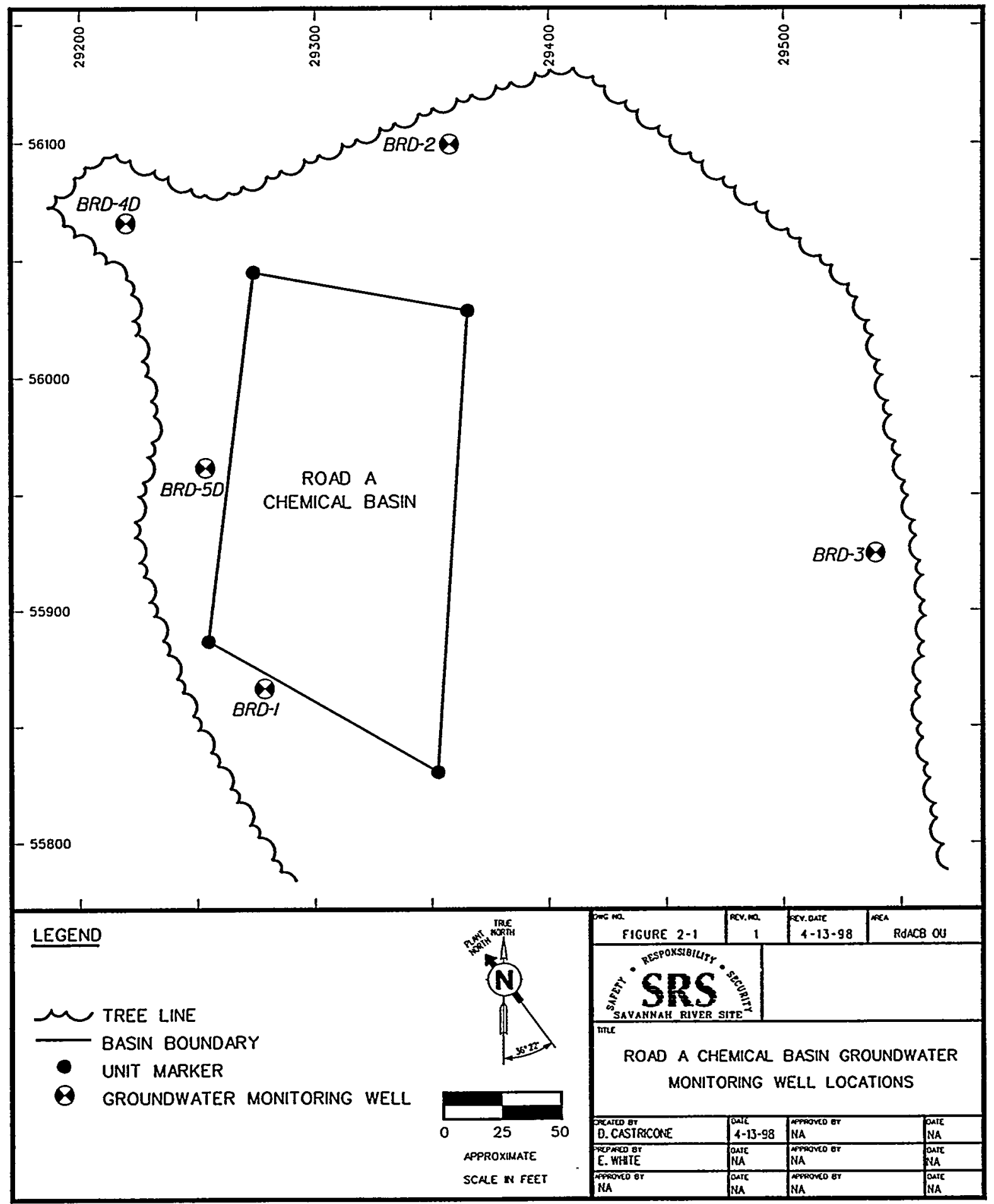

Figure 2-1. Road A Chemical Basin Groundwater Monitoring Well Locations 
This page intentionally left blank. 


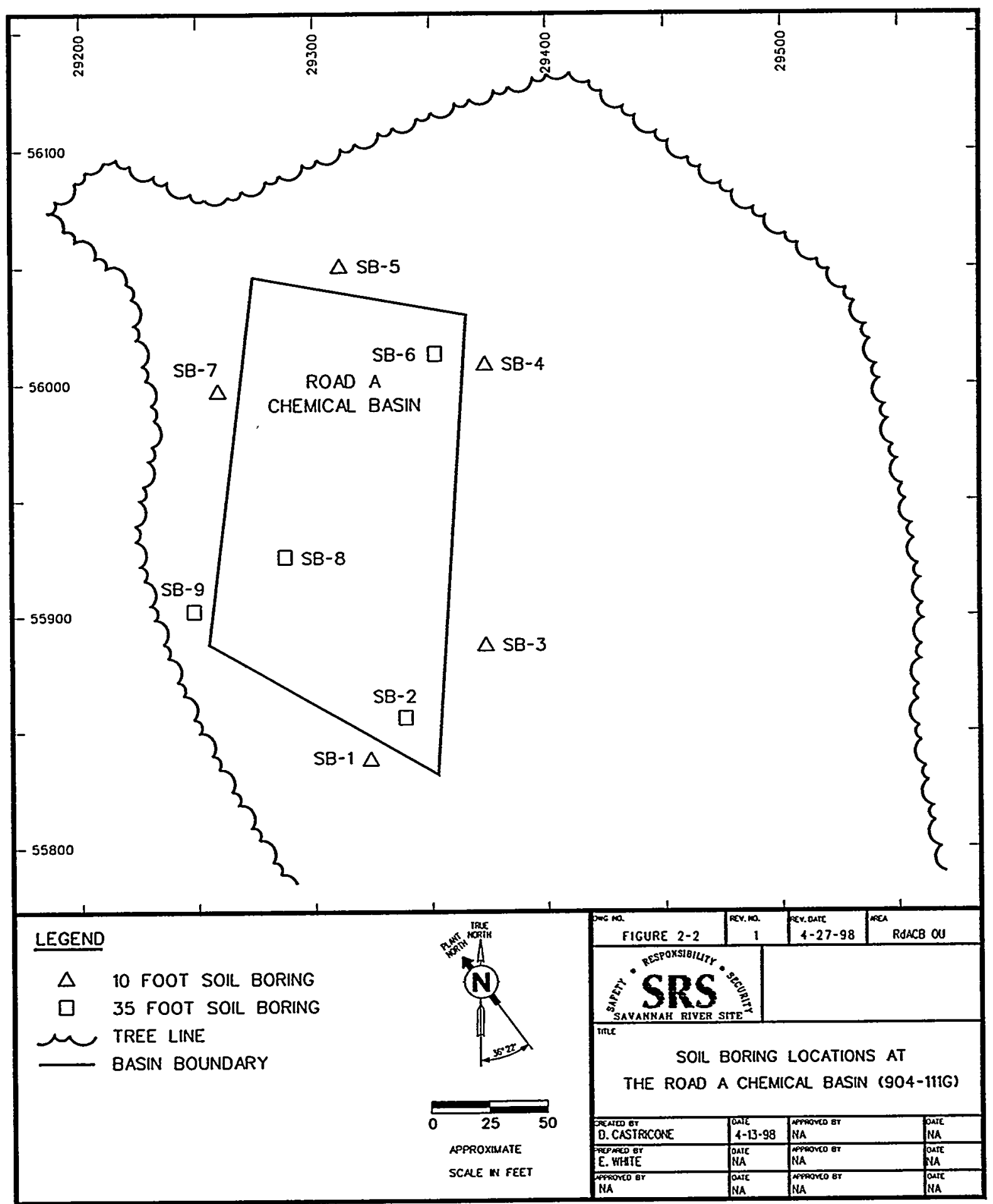

Figure 2-2. Borehole Locations at the Road A Chemical Basin (904-111G) 
This page intentionally left blank. 


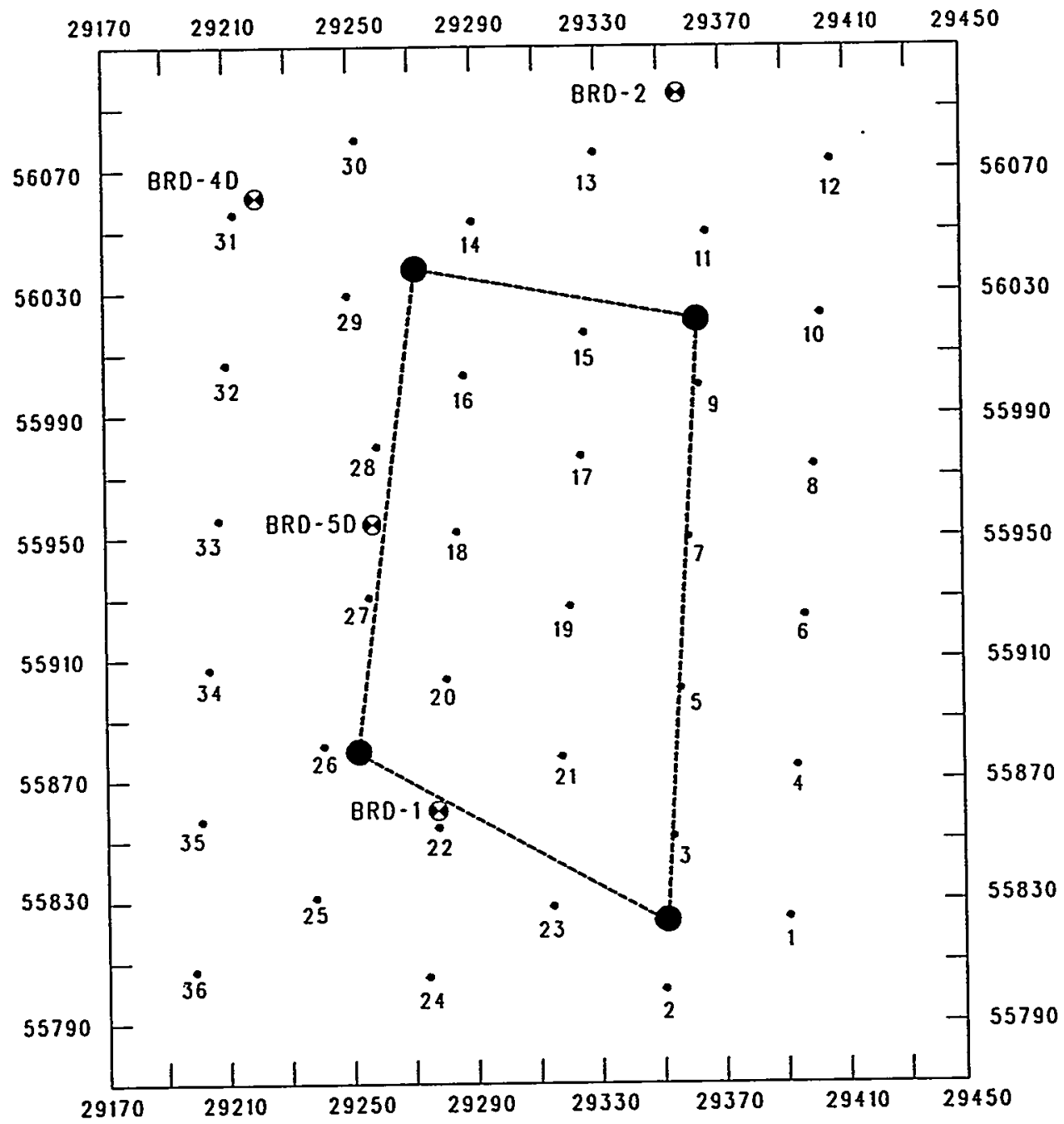

LEGEND

BASIN BOUNDARY

UNIT MARKER

8 GROUNDWATER MONITORING WELL

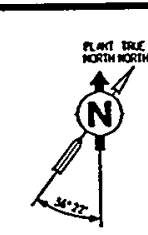

- soll gas survey point
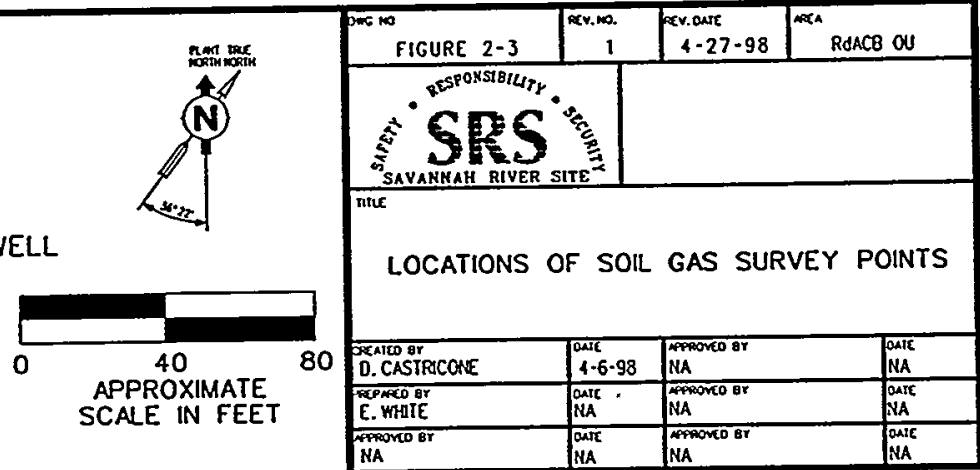

Figure 2-3. Locations of Soil Gas Survey Points 
This page intentionally left blank. 


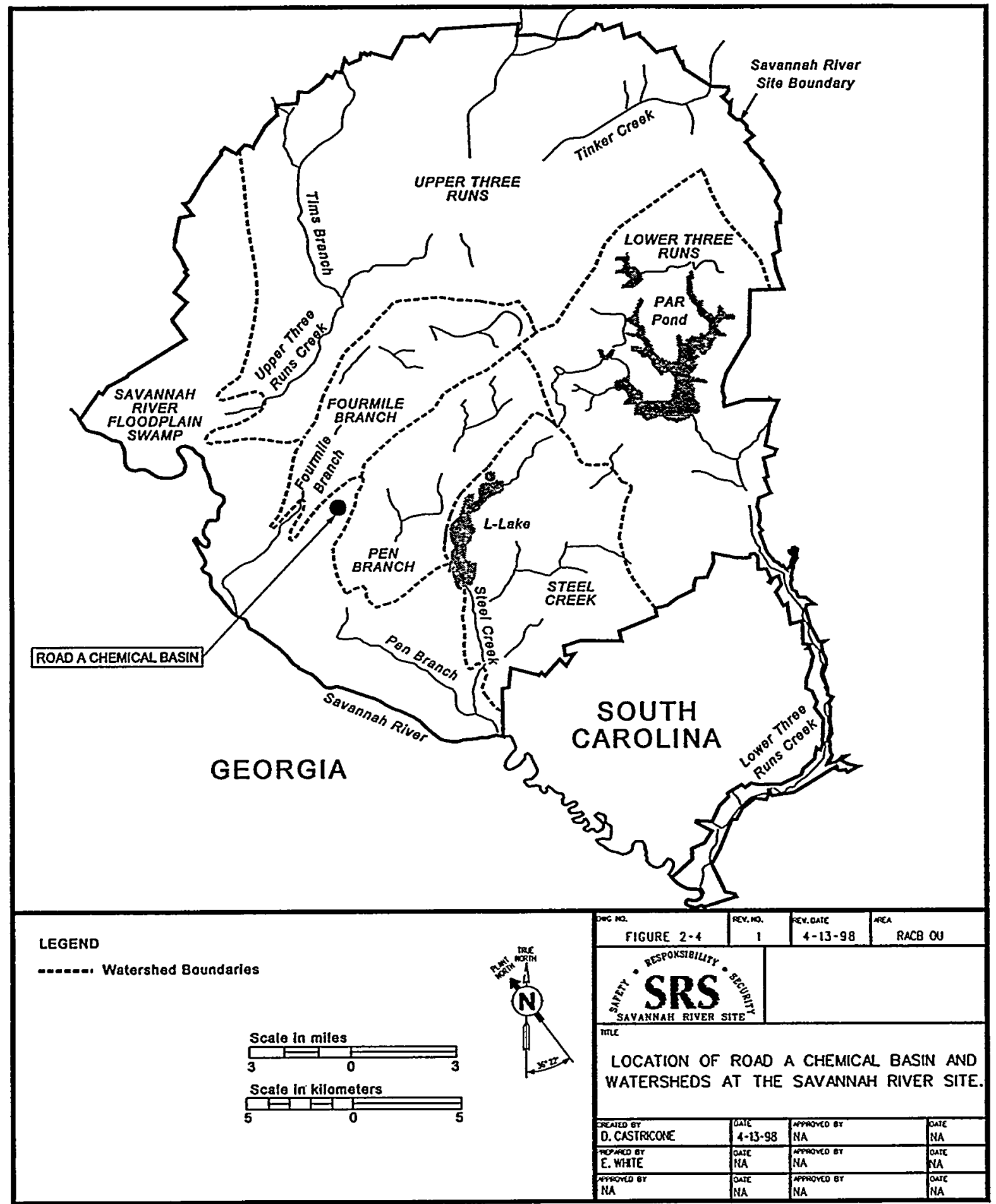

Figure 2-4. Location of the Road A Chemical Basin and Watersheds at the Savannah River Site 
This page intentionally left blank. 


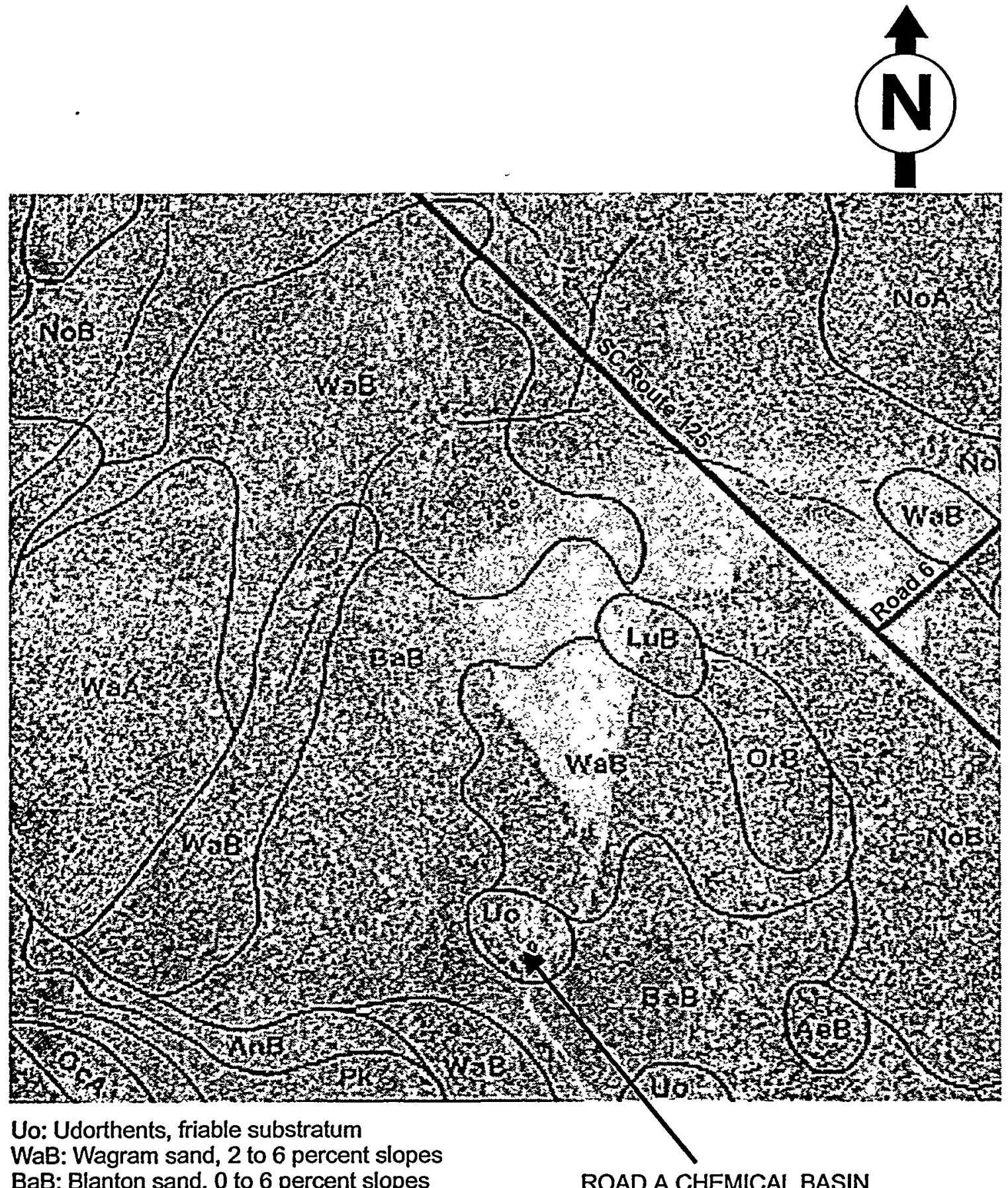

ROAD A CHEMICAL BASIN

LuB: Lucy sand, 2 to 6 percent slopes

OrB: Orangeburg loamy sand, 2 to 6 percent slopes

AnB: Abany loamy sand, 0 to 6 percent slopes

OcA: Ocilla loamy sand, 0 to 2 percent slopes

NoA: Norfolk loamy sand, 0 to 2 percent slopes

Pk: Pickney sand, 0 to 2 percent slopes

Figure 2-5. Soil Map of the RdACB OU and Vicinity 
This page intentionally left blank. 


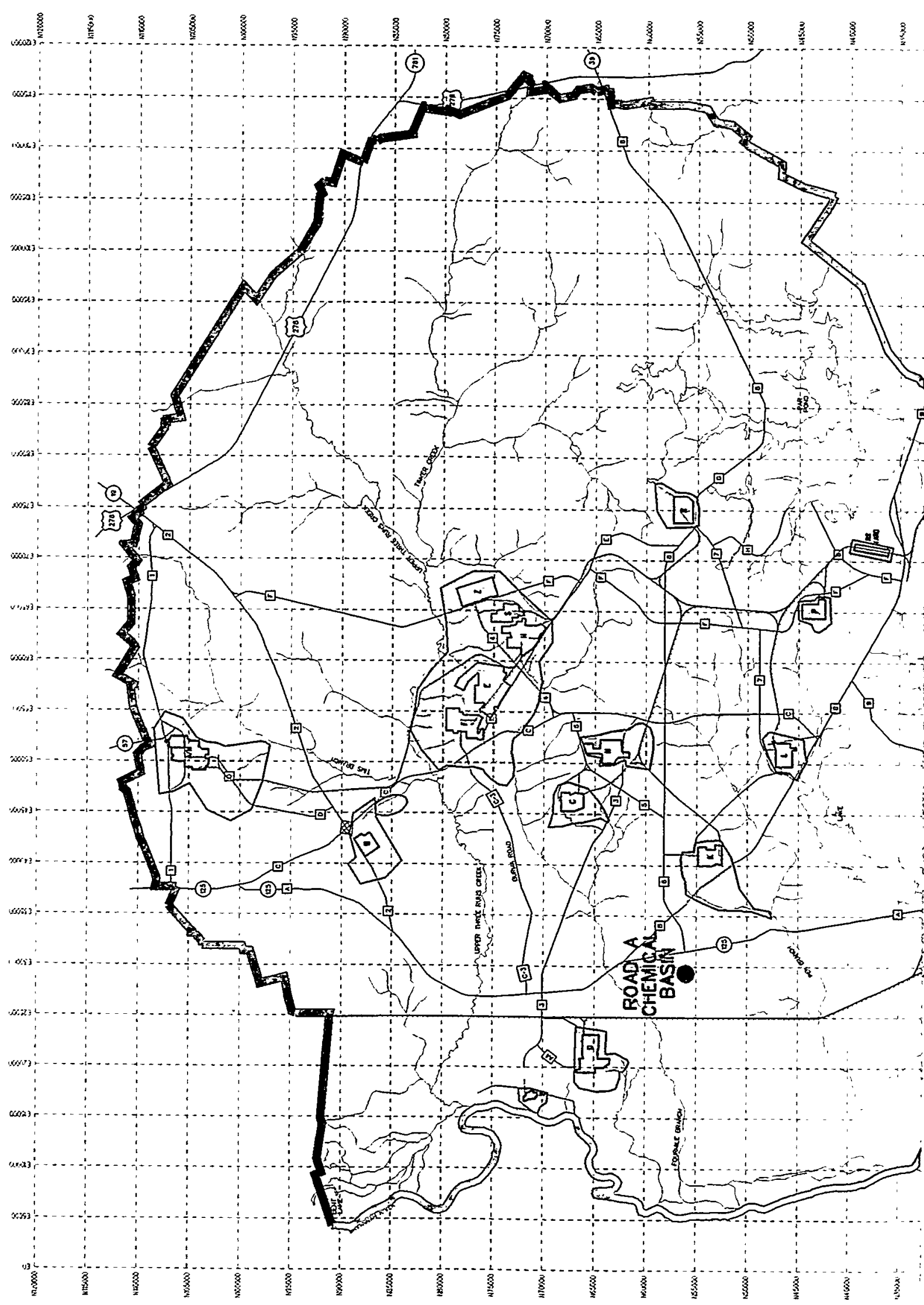


WSRC-RP-98-4032

October 1999

Rev. 1.1
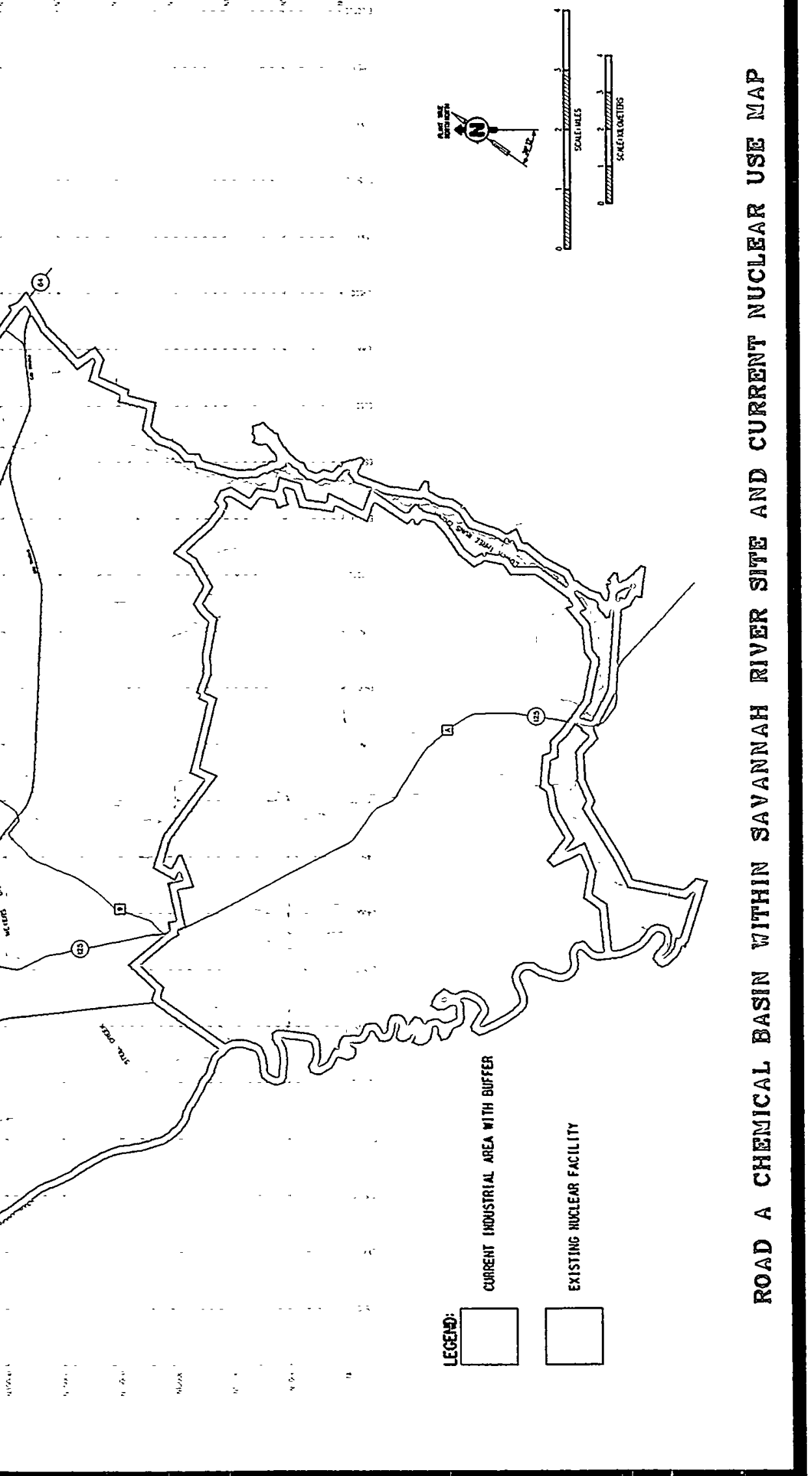
This page intentionally left blank. 


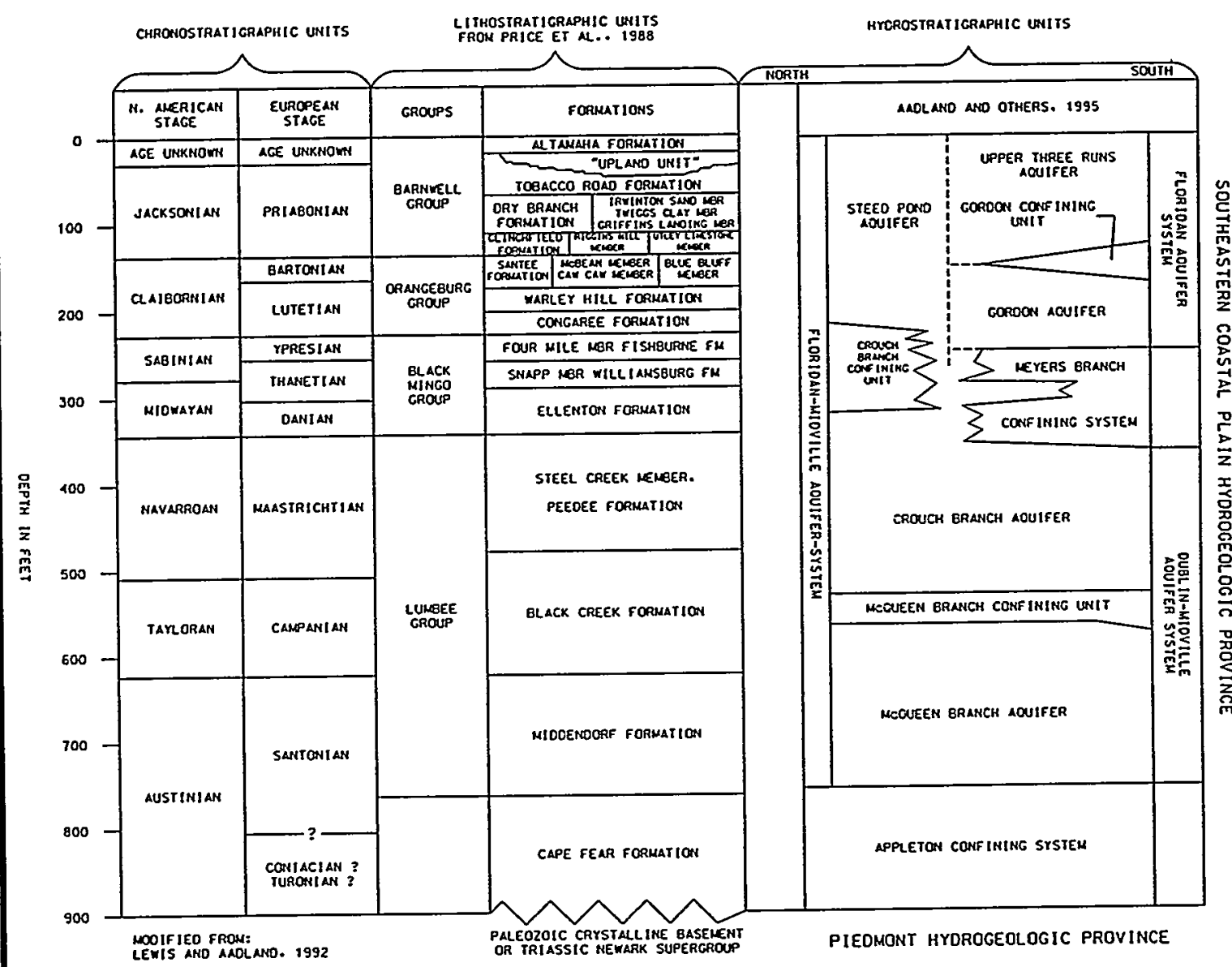

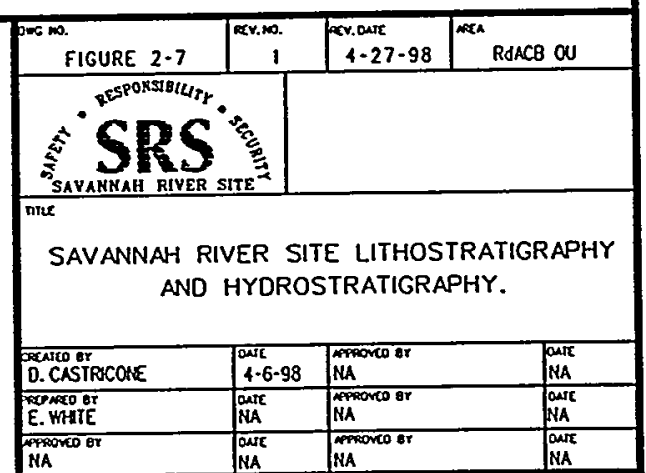

Figure 2-7. Savannah River Site Lithostratigraphy and Hydrostratigraphy 
This page intentionally left blank. 


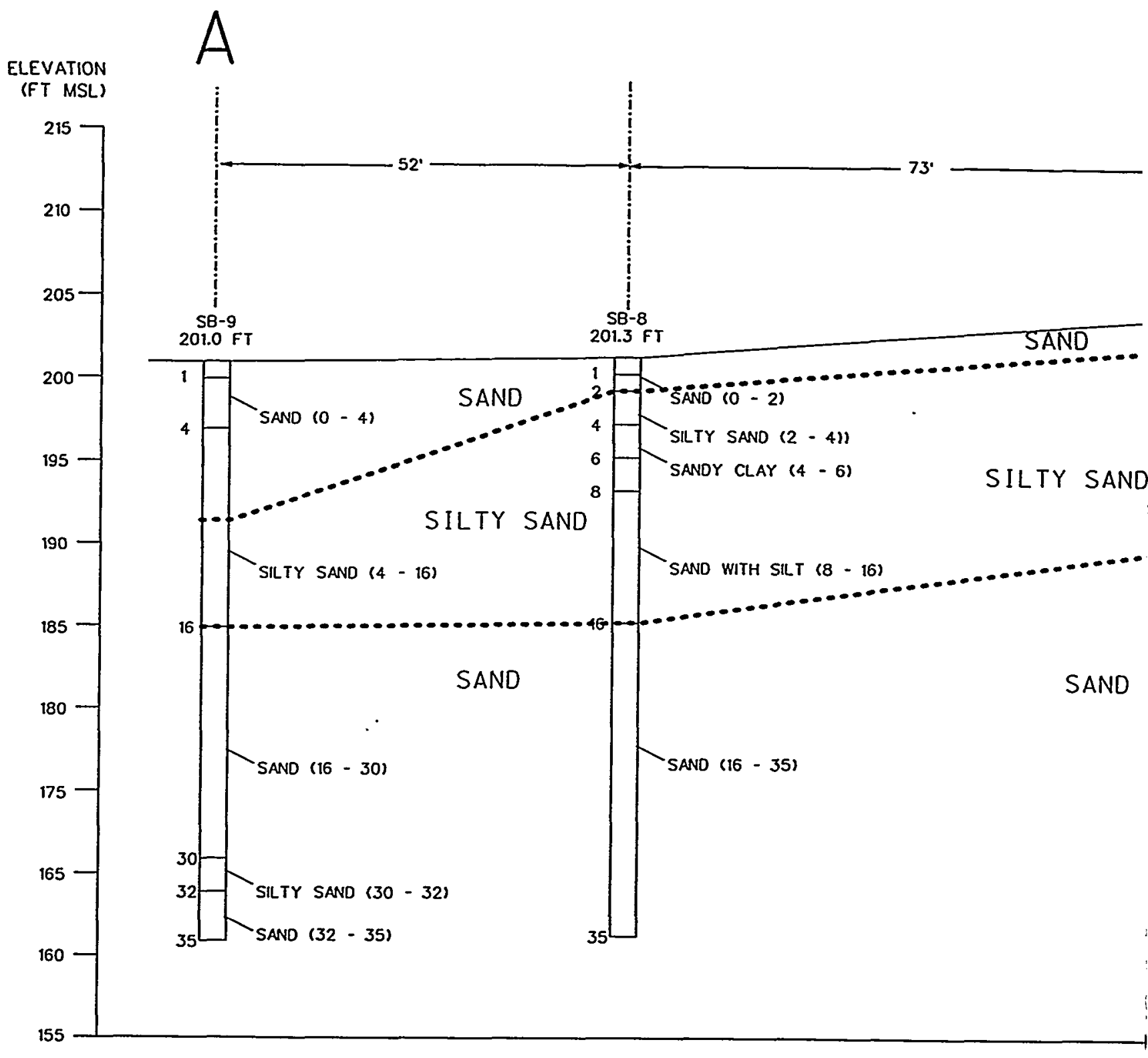

Figure 2-8. Road A Chemical Ba 


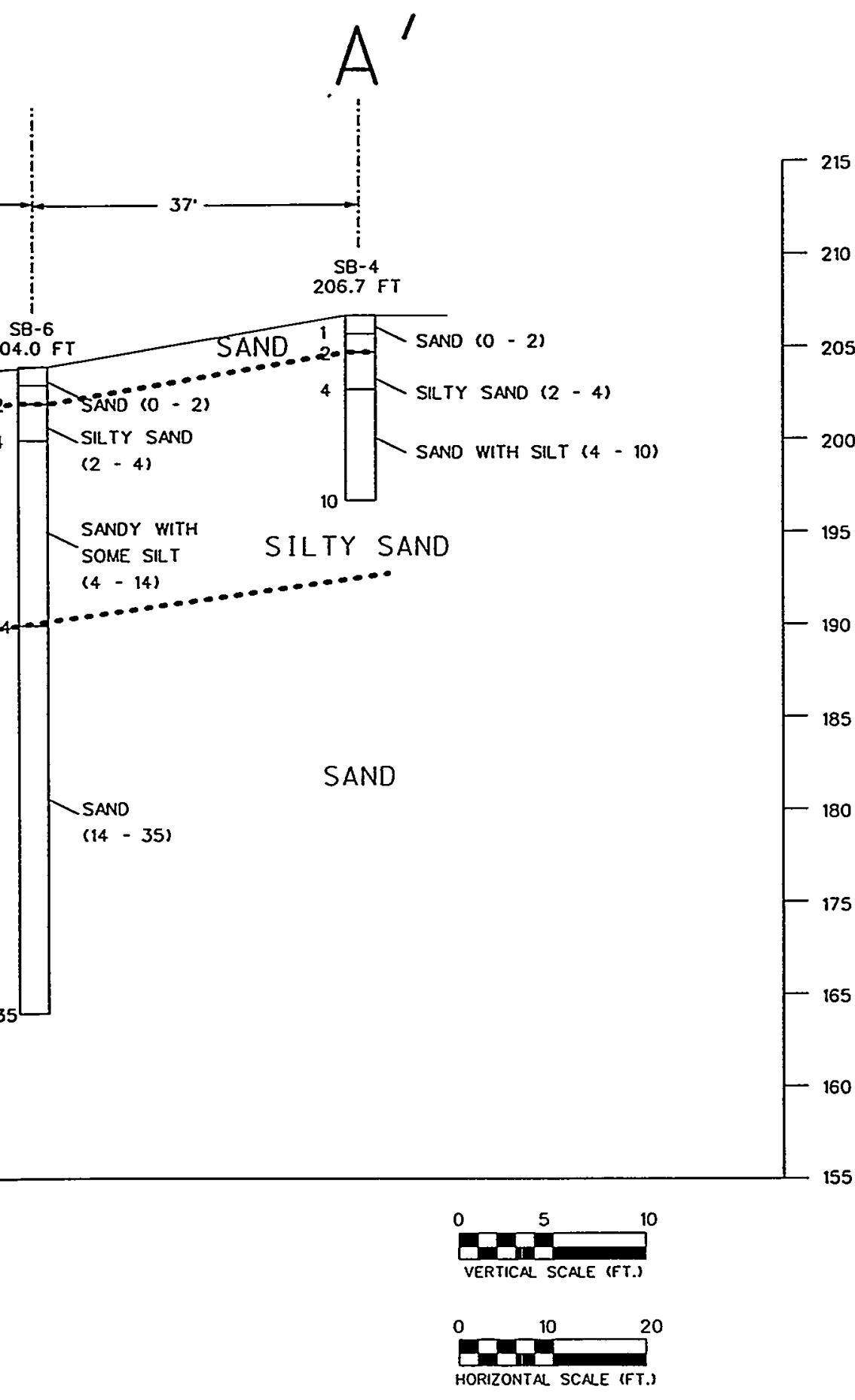

\section{LEGEND}

CROUND ELEVATION

$\mathrm{XXX}-\mathrm{XXX}$ BORINC NUMBER $X X X . X X \multimap$ ELEVATION (FT MSL) SANPLED INTERVAL BORING DEPTH

- groung surface

- LITHOLOGIC BOUNDARY

$\triangle 10$ FOOT SOLL BORING

$\square \quad 35$ FOOT SOIL BORING

L LINE OF CROSS-SECTION

- basin BOUNDaRY

AREA BOUNDARY

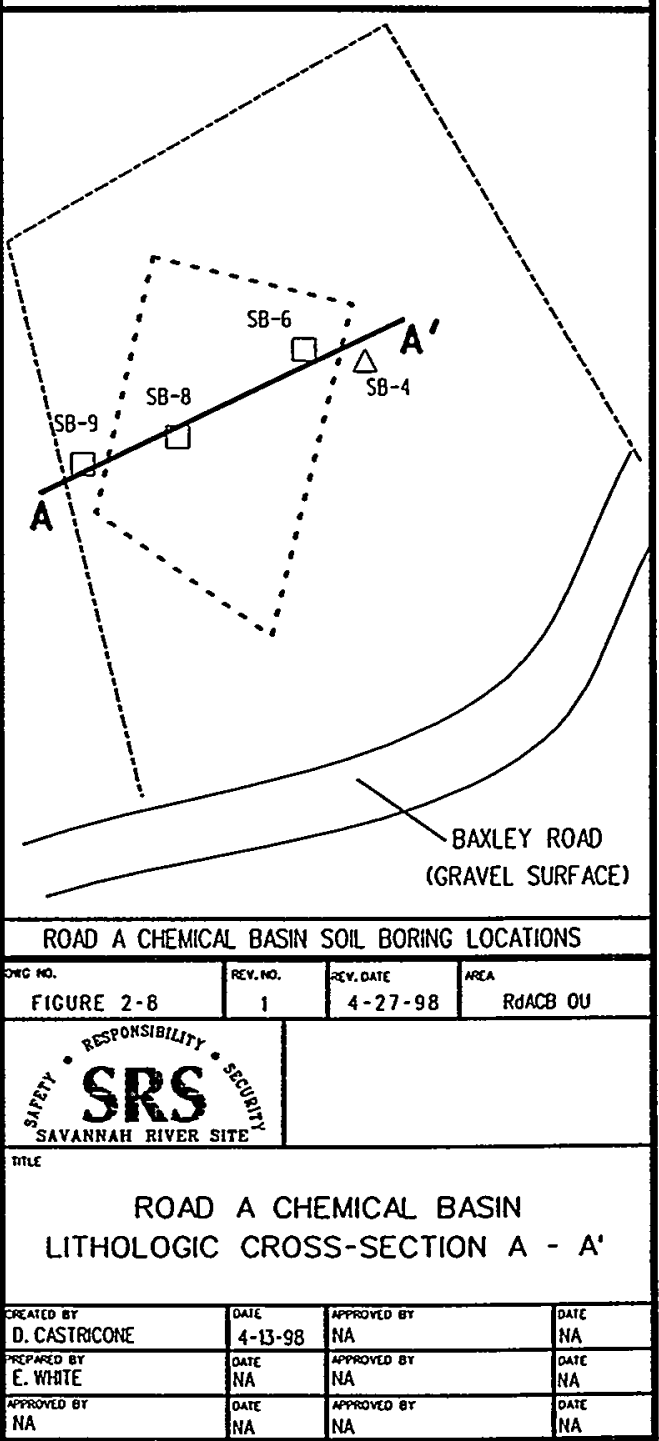

n Lithologic Cross Section A-A' 
This page intentionally left blank. 


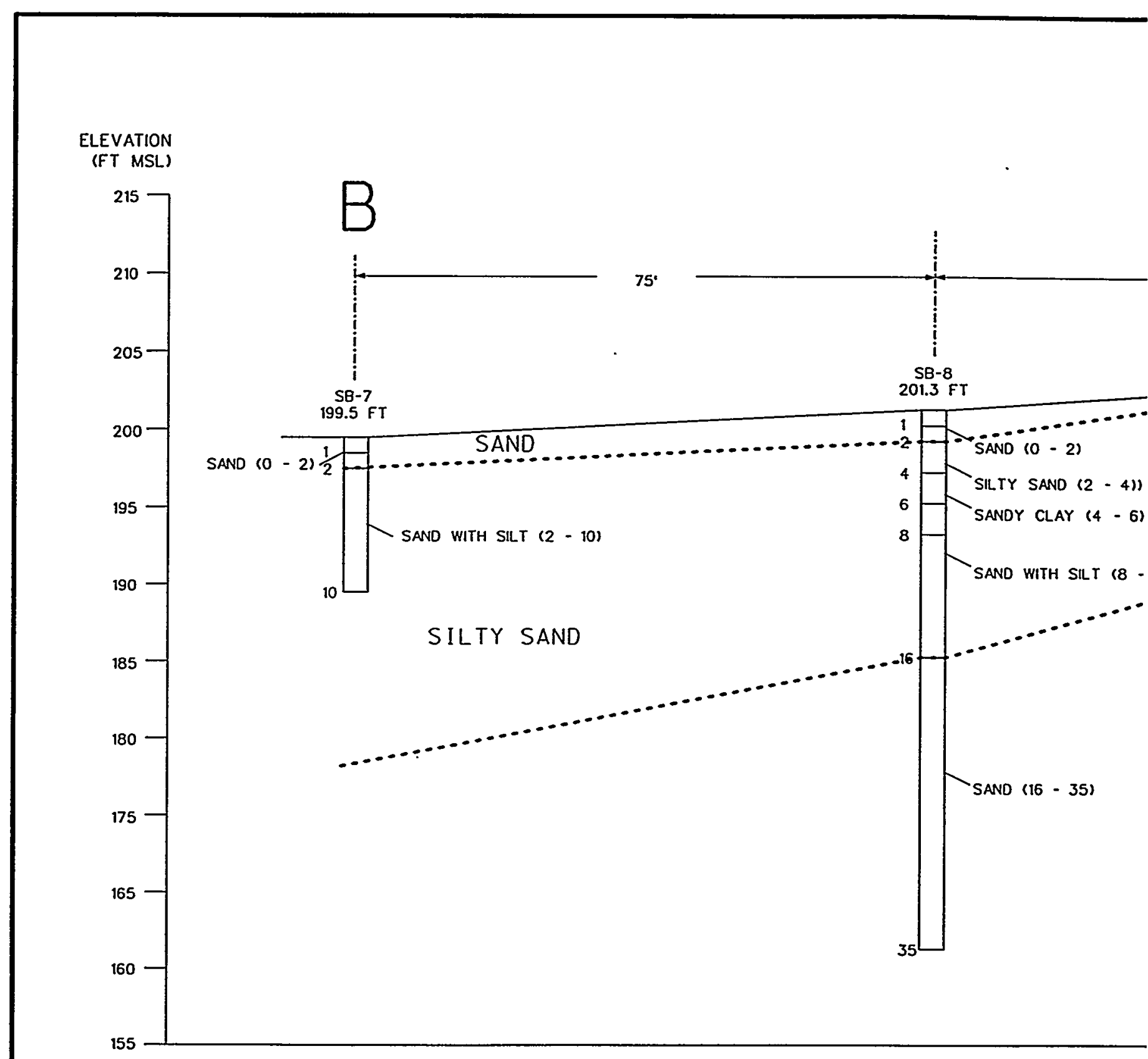

Figure 2-9. Road A Chemical B 
This page intentionally left blank. 


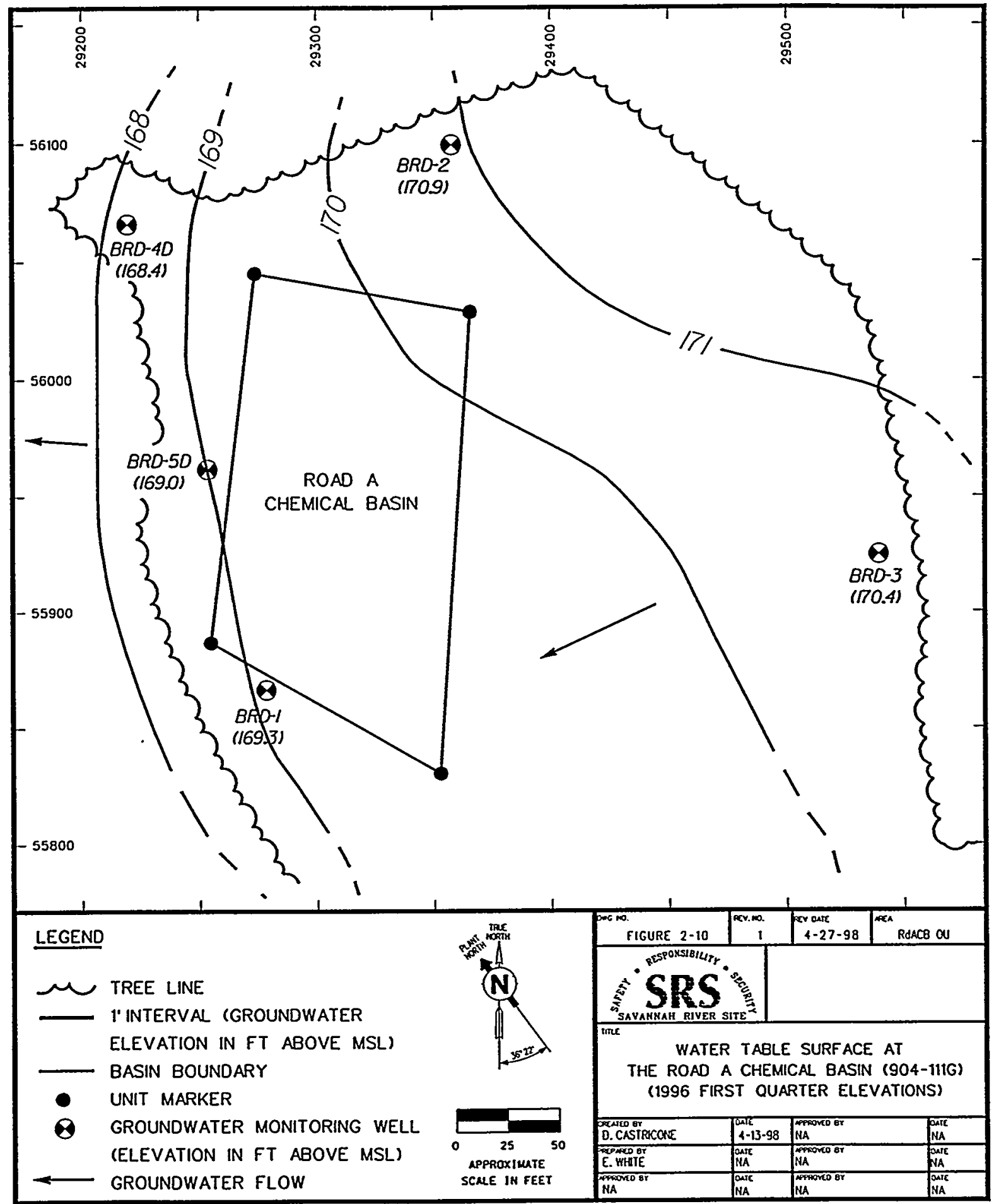

Figure 2-10. Water Table Surface at the Road A Chemical Basin (904-111G) 
This page intentionally left blank. 


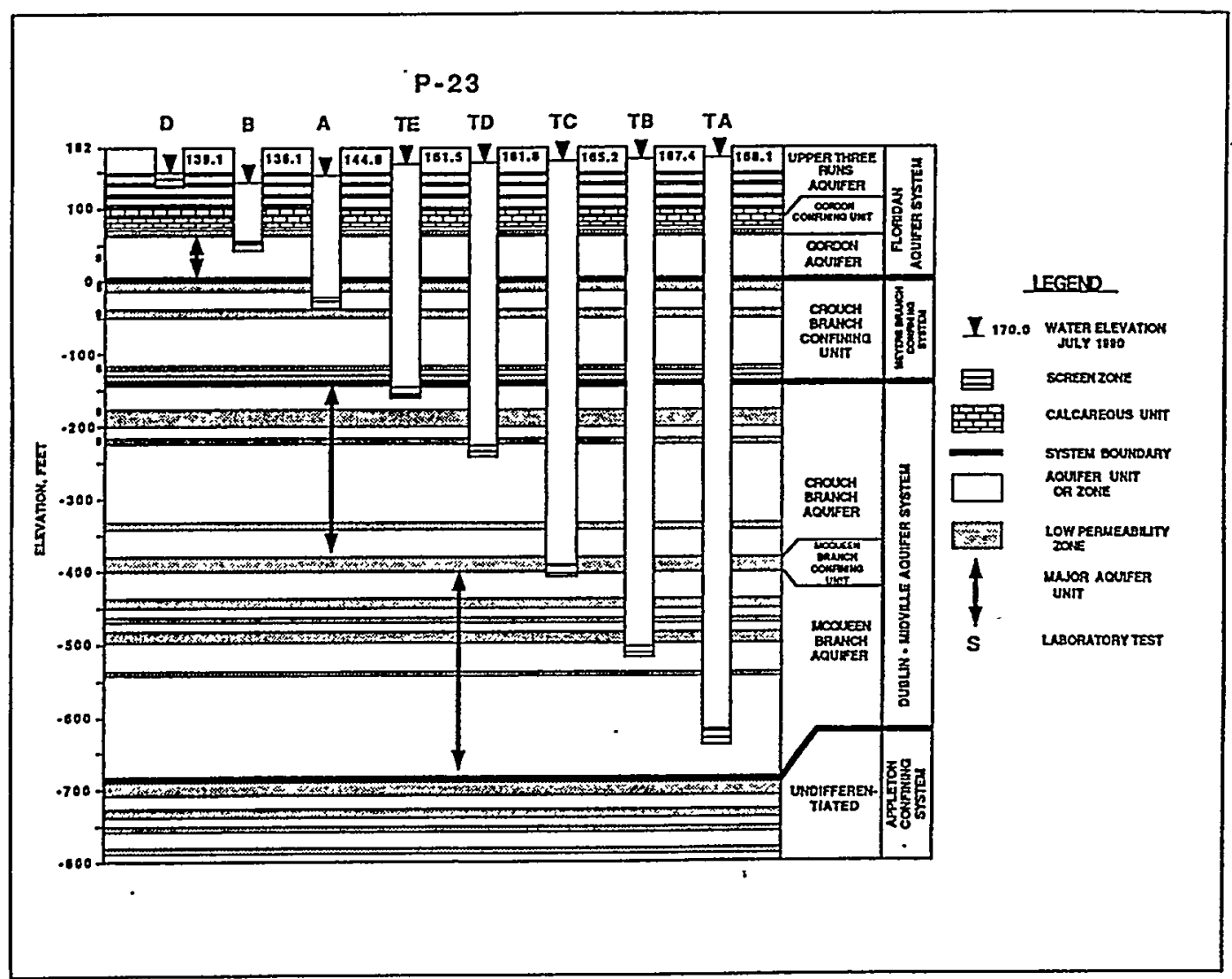

Figure 2-11. Hydraulic Head Relationships at the P-23 Well Cluster 
This page intentionally left blank. 


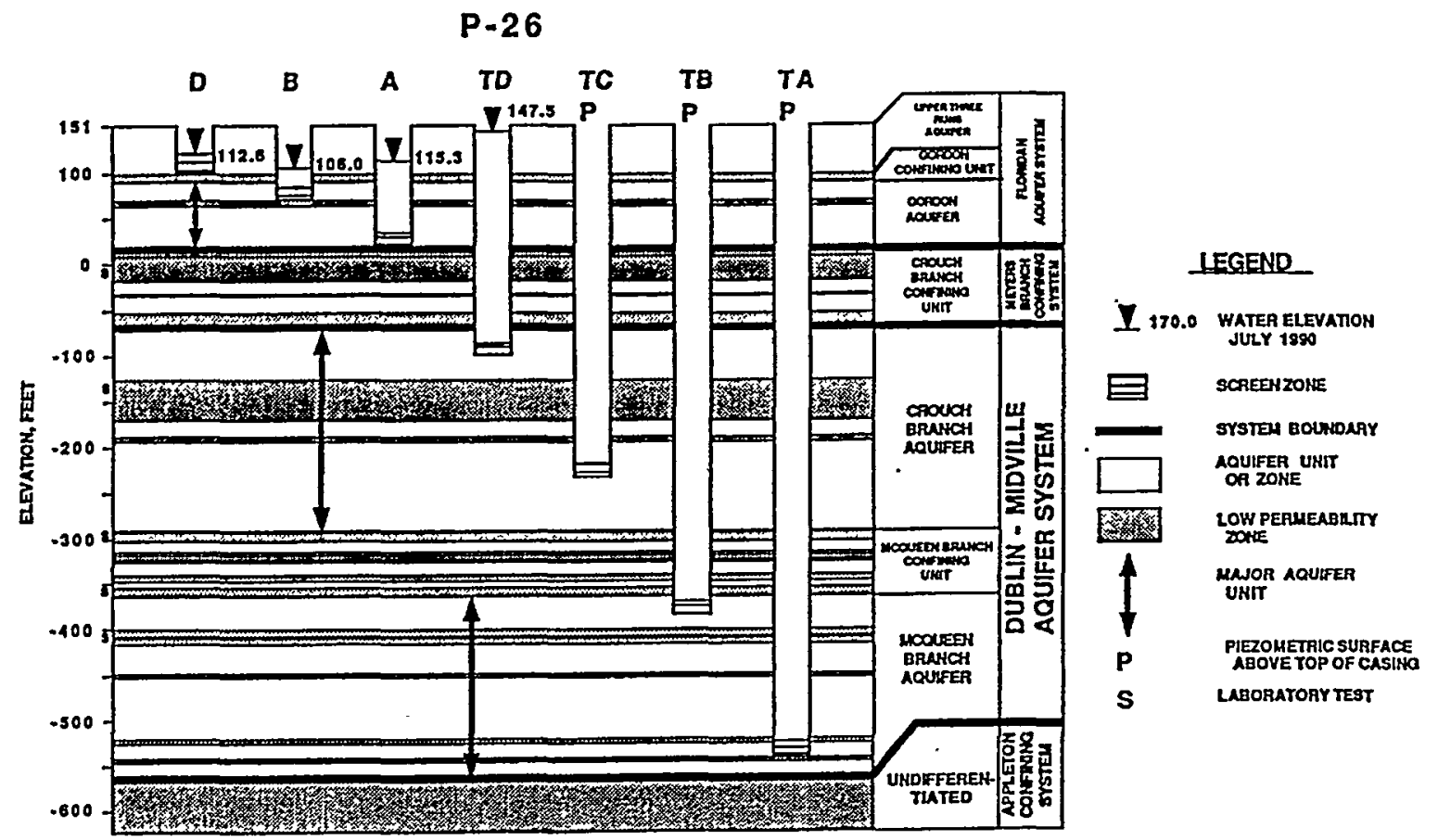

Figure 2-12. Hydraulic Head Relationships at the P-26 Well Cluster 
This page intentionally left blank. 


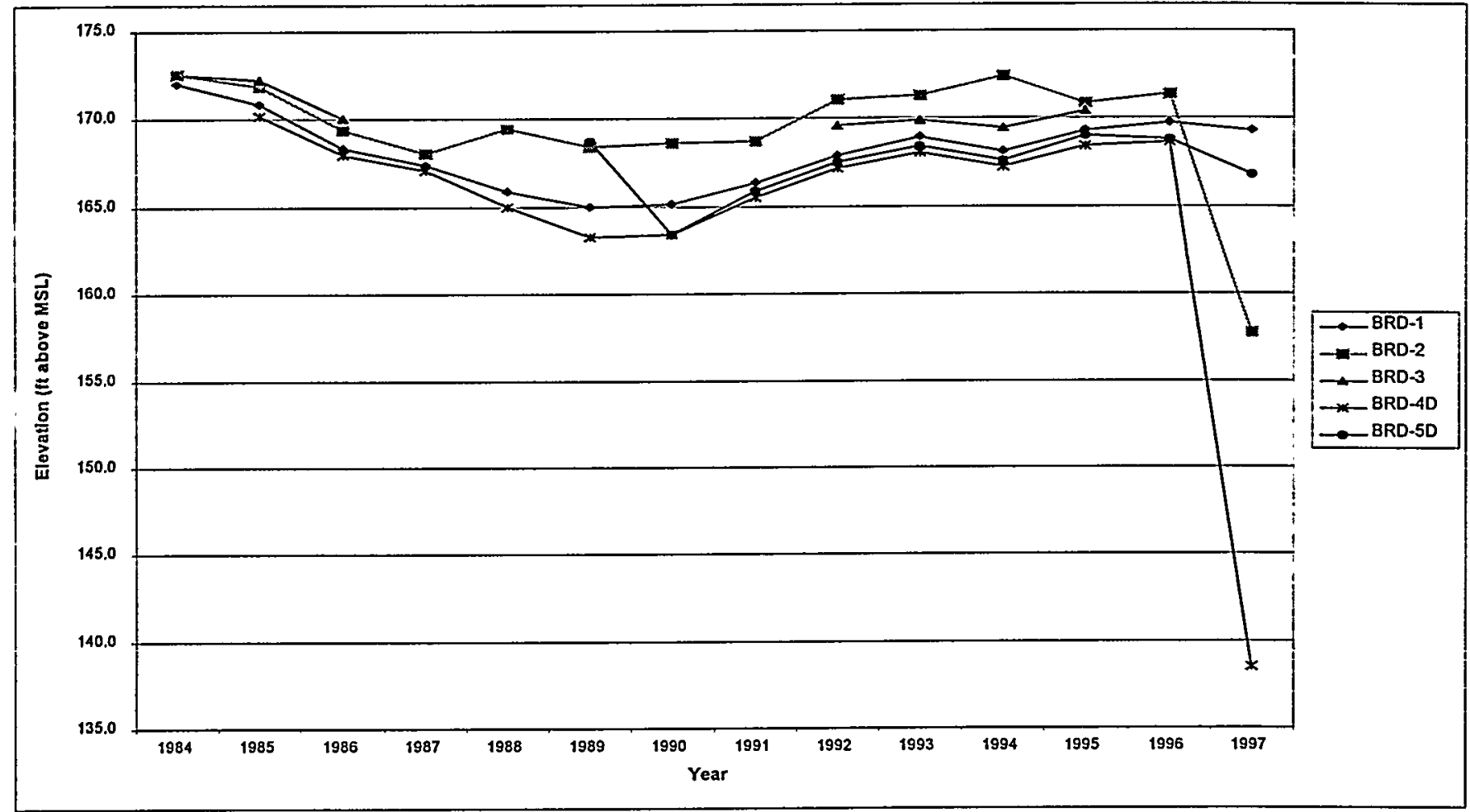

Figure 2-13. Hydrographs for Monitoring Wells at the Road A Chemical Basin (Based on Available Average Annual Water Levels) 
This page intentionally left blank. 


\section{Plate 1.}

\section{Savannah River Site}

Environmental Restoration RI/FS Early Action Strategy 
This page intentionally left blank. 


\section{Notice}

Page(s) size did not permit electronic reproduction. Information may be purchased by the general public from the National Technical Information Service, U.S. Department of Commerce, Springfield, VA 22161 (1800-553-6847). DOE and DOE contractors may purchase information by contacting DOE's Office of Scientific and Technical Information, P.O. Box 62, Oak Ridge, TN 37831-0062, Attn: Information Services (1865-576-8401). 


\section{TABLES}


This page intentionally left blank. 


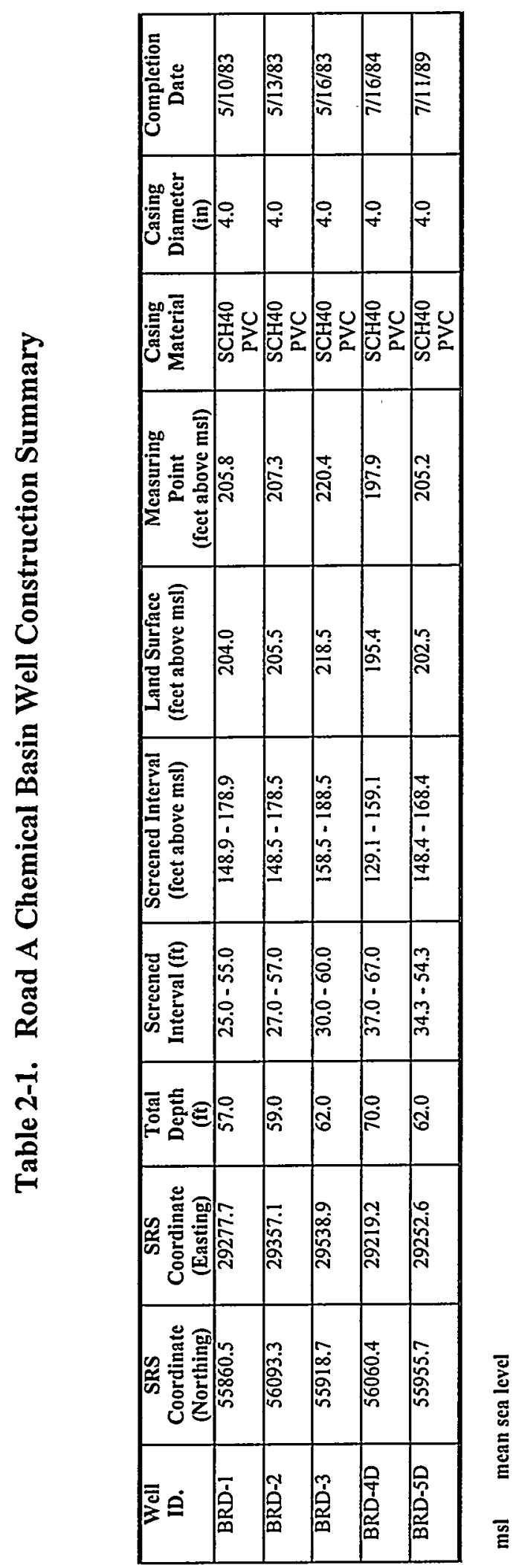


Table 2-2. Statistical Summary from Available 1984-1997 Groundwater Elevations Measured in Monitoring Wells at the RdACB

\begin{tabular}{|c|c|c|c|c|}
\hline \hline Well Number & $\begin{array}{c}\text { Maximum } \\
\text { Elevation } \\
\text { ft-msl }\end{array}$ & $\begin{array}{c}\text { Minimum } \\
\text { Elevation } \\
\text { ft-msl }\end{array}$ & $\begin{array}{c}\text { Average } \\
\text { Elevation } \\
\text { ft-msl }\end{array}$ & $\begin{array}{c}\text { Standard } \\
\text { Deviation } \\
\text { ft-msl }\end{array}$ \\
\hline BRD-1 & 172.0 & 164.2 & 167.1 & 2.2 \\
\hline BRD-2 & 172.5 & 155.9 & 168.3 & 4.0 \\
\hline BRD-3 & 172.5 & 168.8 & 169.5 & 2.1 \\
\hline BRD-4D & 170.2 & 164.0 & 163.7 & 8.3 \\
\hline BRD-5D & 168.7 & 161.4 & 165.2 & 2.1 \\
\hline
\end{tabular}

msl mean sea level 
Table 2-3. Analytes Detected in Monitoring Wells at the RdACB from 1988 to 1996

\begin{tabular}{|c|c|c|c|c|c|c|}
\hline ANALYTE NAME & No. of Samples & $\begin{array}{c}\text { No. of } \\
\text { Detections }\end{array}$ & $\begin{array}{c}\text { Maximum } \\
\text { Concentration } \\
\text { Detected }\end{array}$ & - Ūnits & $\overline{\mathrm{MCL}}$ & $\mathbf{R B C}^{\mathbf{I}}$ \\
\hline INDICATOR PARAMETERS & & & & & & 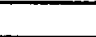 \\
\hline Fluoride & 46 & 1 & 0.355 & $\mathrm{mg} / \mathrm{L}$ & NA & 2.2 \\
\hline Nitrate as nitrogen & 45 & 45 & 5.9 & $\mathrm{mg} / \mathrm{L}$ & 10 & 5.8 \\
\hline Nitrate-nitrite as nitrogen & 22 & 22 & 2.2 & $\mathrm{mg} / \mathrm{L}$ & 10 & 5.8 \\
\hline Sulfate & 47 & 16 & 2.25 & $\mathrm{mg} / \mathrm{L}$ & 500 & NA \\
\hline Total dissolved solids & 65 & 64 & 113 & $\mathrm{mg} / \mathrm{L}$ & NA & NA \\
\hline Total organic carbon & 47 & 6 & 2.0 & $\mathrm{mg} / \mathrm{L}$ & NA & NA \\
\hline Total organic halogens & 79 & 23 & 0.282 & $\mathrm{mg} / \mathrm{L}$ & NA & NA \\
\hline Total phosphates (as P) & 47 & 10 & 0.21 & $\mathrm{mg} / \mathrm{L}$ & $\overline{N A}$ & NA \\
\hline METALS & & & & - & & \\
\hline Aluminum, dissolved & 14 & 6 & 0.045 & $\mathrm{mg} / \mathrm{L}$ & NA & 37 \\
\hline Aluminum, total recoverable & 45 & 34 & 1.08 & $\mathrm{mg} / \mathrm{L}$ & NA & 37 \\
\hline Antimony, dissolved _ - & 17 & 2 & 0.004 & $\mathrm{mg} / \mathrm{L}$ & 0.006 & 0.015 \\
\hline Barium, dissolved & 52 & 48 & 0.016 & $\mathrm{mg} / \mathrm{L}$ & 2 & 2.6 \\
\hline Barium, total recoverable & 7 & 7 & 0.066 & $\mathrm{mg} / \mathrm{L}$ & 2 & 2.6 \\
\hline Beryllium, dissolved & 17 & 1 & 0.00047 & $\mathrm{mg} / \mathrm{L}$ & 0.004 & 0.0073 \\
\hline Cadmium, dissolved & 47 & 3 & 0.004 & $\overline{\mathrm{mg} / \mathrm{L}}$ & 0.005 & 0.018 \\
\hline Calcium, dissolved & $5 I$ & 51 & 3.626 & $\mathrm{mg} / \mathrm{L}$ & $\overline{N A}$ & NA \\
\hline Calcium, total recoverable & 8 & 8 & 1.83 & $\mathrm{mg} / \mathrm{L}$ & NA & NA \\
\hline Chloride & 62 & 61 & 9.0 & $\mathrm{mg} / \mathrm{L}$ & NA & NA \\
\hline Chromium, dissolved & 45 & 6 & 0.01 & $\mathrm{mg} / \mathrm{L}$ & 0.10 & 0.11 \\
\hline Chromium, total recoverable & 7 & 2 & 0.006 & $\mathrm{mg} / \mathrm{L}$ & 0.10 & 0.11 \\
\hline Cobalt, dissolved & 18 & 3 & 0.002 & $\mathrm{mg} / \mathrm{L}$ & NA & 2.2 \\
\hline Copper, dissolved & 21 & 15 & 0.916 & $\mathrm{mg} / \mathrm{L}$ & 1.3 & 1.5 \\
\hline Iron, dissolved & 52 & 46 & 0.170 & $\mathrm{mg} / \mathrm{L}$ & NA & 1.1 \\
\hline Iron, total recoverable & 42 & 38 & 1.51 & $\mathrm{mg} / \mathrm{L}$ & $\overline{\text { NA }}$ & 1.1 \\
\hline Lead, dissolved & 74 & 53 & 0.66 & $\mathrm{mg} / \mathrm{L}$ & 0.015 & NA \\
\hline Lead, total recoverable & 56 & 39 & 0.06 & $\mathrm{mg} / \mathrm{L}$ & 0.015 & NA \\
\hline Lithium, dissolved & 47 & 1 & 0.008 & $\mathrm{mg} / \mathrm{L}$ & $\overline{\mathrm{NA}}$ & 0.73 \\
\hline Magnesium, dissolved & 52 & 52 & 0.598 & $\mathrm{mg} / \mathrm{L}$ & NA & NA \\
\hline Magnesium, total recoverable & 8 & $\overline{8}$ & 0.871 & $\mathrm{mg} / \mathrm{L}$ & $\overline{N A}$ & NA \\
\hline Manganese, dissolved & 68 & 68 & 0.057 & $\mathrm{mg} / \mathrm{L}$ & NA & 0.73 \\
\hline Manganese, total recoverable & 38 & 38 & 0.358 & $\mathrm{mg} / \mathrm{L}$ & NA & 0.73 \\
\hline Mercury, dissolved & 40 & 10 & 0.003 & $\mathrm{mg} / \mathrm{L}$ & 0.002 & 0.011 \\
\hline Mercury, total recoverable & 28 & 1 & 0.000304 & $\mathrm{mg} / \mathrm{L}$ & 0.002 & 0.011 \\
\hline Nickel, dissolved & 49 & 24 & 0.013 & $\mathrm{mg} / \mathrm{L}$ & 0.100 & 0.73 \\
\hline Nickel, total recoverable & 5 & 3 & 0.006 & $\mathrm{mg} / \mathrm{L}$ & 0.100 & 0.73 \\
\hline Potassium, dissolved & 46 & 16 & 1.13 & $\mathrm{mg} / \mathrm{L}$ & NA & $\overline{\text { NA }}$ \\
\hline
\end{tabular}


Table 2-3. Analytes Detected in Monitoring Wells at the RdACB from 1988 to 1996 (Continued)

\begin{tabular}{|c|c|c|c|c|c|c|}
\hline ANALYTE NAME & $\begin{array}{l}\text { No. of } \\
\text { Samples }\end{array}$ & $\begin{array}{c}\text { No. of } \\
\text { Detections }\end{array}$ & $\begin{array}{c}\text { Maximum } \\
\text { Concentration } \\
\text { Detected }\end{array}$ & Units & $\overline{\mathrm{MCL}}$ & $\overline{\mathrm{RBC}}$ \\
\hline METALS (continued) & \multicolumn{6}{|c|}{ 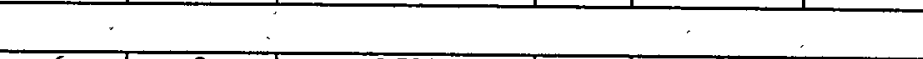 } \\
\hline Potassium, total recoverable & 6 & 2 & 0.784 & $\mathrm{mg} / \mathrm{L}$ & NA & NA \\
\hline Sodium, dissolved & 46 & 46 & 3.948 & $\mathrm{mg} / \mathrm{L}$ & NA & $\overline{\mathrm{NA}}$ \\
\hline Sodium, total recoverable & 8 & 8 & 2.68 & $\mathrm{mg} / \mathrm{L}$ & NA & NÁ \\
\hline Vanadium, dissolved & 18 & 2 & 0.002 & $\mathrm{mg} / \mathrm{L}$ & 0.002 & 0.260 \\
\hline Zinc, dissolved & 22 & 21 & 0.181 & $\overline{\mathrm{mg} / \mathrm{L}}$ & NA & 11 \\
\hline \multicolumn{7}{|l|}{ PESTICIDES / PCBS } \\
\hline Dieldrin & 17 & 1 & $0 . \overline{033}$ & $\mu \mathrm{g} / \mathrm{L}$ & NA & 0.0042 \\
\hline Heptachlor & 16 & 2 & 0.144 & $\mu \mathrm{g} / \mathrm{L}$ & 0.4 & 0.015 \\
\hline Heptachlor epoxide & 17 & 1 & 0.022 & $\mu \mathrm{g} / \mathrm{L}$ & 0.2 & 0.0074 \\
\hline \multicolumn{7}{|l|}{ RADIONÜCLIDES } \\
\hline Gross alpha & 77 & 30 & 9 & $\mathrm{pCi} / \mathrm{L}$ & NA & NA \\
\hline Nonvolatile beta & 65 & 27 & 9 & $\mathrm{pCi} / \mathrm{L}$ & $\overline{N A}$ & $\overline{N A}$ \\
\hline Radium, total alpha-emitting & 85 & 49 & 6 & $\mathrm{pCi} / \mathrm{L}$ & 5 & 0.16 \\
\hline Radium-226 & 12 & 10 & 1 & $\mathrm{pCi} / \mathrm{L}$ & 5 & NA \\
\hline Radium-228 & 11 & 8 & 3 & $\mathrm{pCi} / \mathrm{L}$ & 5 & $\overline{\text { NA }}$ \\
\hline Tritium & 74 & 51 & 0.004 & $\mathrm{pCi} / \mathrm{L}$ & 20 & $\overline{\mathrm{NA}}$ \\
\hline $\begin{array}{c}\text { SEMIVOLATILE ORGANIC } \\
\text { COMPOUNDS }\end{array}$ & \multicolumn{6}{|c|}{ (2) } \\
\hline Bis(2-ethylhexyl) phthalate & 17 & 1 & 24 & $\mu \mathrm{g} / \mathrm{L}$ & 6 & 4.8 \\
\hline Phenol & 24 & 2 & 9 & $\mu \mathrm{g} / \mathrm{L}$ & NA & 22000 \\
\hline Phenols & 46 & 3 & 85 & $\mu \mathrm{g} / \mathrm{L}$ & NA & 22000 \\
\hline VOLATILE ORGANIC COMPOUNDS & \multicolumn{6}{|c|}{. } \\
\hline 2,4-Dichlorophenoxyacetic acid & 45 & 1 & 0.35 & $\mu \mathrm{g} / \mathrm{L}$ & NA & 61 \\
\hline Acetone & 19 & 3 & 37 & $\mu \mathrm{g} / \mathrm{L}$ & $\overline{\mathrm{NA}}$ & 61 \\
\hline Dichloromethane (Methylene chloride) & 55 & 25 & 8 & $\mu \mathrm{g} / \mathrm{L}$ & 5 & 4.1 \\
\hline Tetrachloroethylene & 52 & 4 & 55 & $\mu \mathrm{g} / \mathrm{L}$ & 5 & 1.1 \\
\hline Toluene & 50 & 1 & 1 & $\mu \mathrm{g} / \mathrm{L}$ & 1000 & 750 \\
\hline Trichloroethylene & 51 & 3 & 6 & $\mu g / L$ & 5 & 1.6 \\
\hline Trichlorofluoromethane & 50 & 2 & 2 & $\mu g / L$ & NA & 1300 \\
\hline
\end{tabular}

NA - Not Applicable

${ }^{1}$ - RBC values from EPA Region III Risk-Based Concentrations Table, April 1999 update. 
Table 2-4. Analytes Detected in Groundwater above the Maximum Contaminant Level (MCL) or the Risk-Based Concentration (RBC) at the RdACB

\begin{tabular}{|c|c|c|c|c|c|c|}
\hline ANALYTE NAME & No. of Samples & $\begin{array}{c}\text { No. of } \\
\text { Detections }\end{array}$ & $\begin{array}{l}\text { Maximum } \\
\text { Concentration } \\
\text { Detected }\end{array}$ & Units & MCL & $\overline{\mathbf{R B C}}^{\mathbf{T}}$ \\
\hline \multicolumn{7}{|c|}{ INDICATOR PARAMETERS } \\
\hline Nitrate as $\mathrm{N}$ & 45 & 45 & 5.9 & $\mathrm{mg} / \mathrm{L}$ & 10 & 5.8 \\
\hline METALS & \multicolumn{6}{|l|}{. } \\
\hline Iron, total recoverable & 42 & 38 & 1.51 & $\mathrm{mg} / \mathrm{L}$ & NA & 1.1 \\
\hline Lead, dissolved & 74 & 53 & 0.066 & $\mathrm{mg} / \mathrm{L}$ & 0.015 & NA \\
\hline Lead, total recoverable & 56 & 39 & 0.060 & $\mathrm{mg} / \mathrm{L}$ & 0.015 & NA \\
\hline Mercury, dissolved ${ }^{2}$ & 40 & 10 & 0.003 & $\mathrm{mg} / \mathrm{L}$ & 0.002 & 0.011 \\
\hline PESTICIDES/PCBs & \\
\hline Dieldrin & 17 & 1 & 0.033 & $\mu g / L$ & NA & $\overline{0.0042}$ \\
\hline Heptachlor & 16 & 2 & 0.144 & $\mu \mathrm{g} / \mathrm{L}$ & 0.4 & 0.015 \\
\hline Heptachlor epoxide & 17 & 1 & 0.022 & $\mu \mathrm{g} / \mathrm{L}$ & 0.2 & 0.0074 \\
\hline \multicolumn{7}{|l|}{ RADIONUCLIDES } \\
\hline Radium, total alpha-emitting & 85 & 49 & 6 & $\mathrm{pCi} / \mathrm{L}$ & 5 & 0.16 \\
\hline \multicolumn{7}{|c|}{$\begin{array}{c}\text { SEMIVOLATILE ORGANIC } \\
\text { COMPOUNDS } \\
\end{array}$} \\
\hline Bis(2-ethylhexyl) phthalate & 17 & 1 & 24 & $\mu g / L$ & 6 & 4.8 \\
\hline \multicolumn{7}{|l|}{$\begin{array}{l}\text { VOLATILE ORGANIC } \\
\text { COMPOUNDS }\end{array}$} \\
\hline $\begin{array}{l}\text { Dichloromethane (Methylene } \\
\text { chloride) }\end{array}$ & 55 & 25 & 8 & $\mu g / L$ & 5 & 4.1 \\
\hline Tetrachloroethylene & 52 & 4 & 55 & $\mu g / L$ & 5 & 1.1 \\
\hline Trichloroethylene & 51 & 3 & 6 & $\mu g / L$ & 5 & 1.6 \\
\hline
\end{tabular}

NA - Not Applicable

${ }^{1} \mathrm{RBC}$ set at 1.0E-6 cancer risk and $0.1 \mathrm{HQ}$ for non-cancer hazard.

${ }^{2}$ Mercuric chloride RBC used.

${ }^{3}$ RBA for Ra-226 + daughter products used. 
Table 2-5. Sampling Depths and Analyses for Soil Collected at the RdACB

\begin{tabular}{|c|c|c|c|}
\hline Sample Interval & \multicolumn{3}{|c|}{ Analytical Parameter } \\
\hline$m(\mathrm{ft})$ & Soil Boring-6 & Soil Boring-8 & Soil Boring-9 \\
\hline $0-0.6(0-2)$ & (i) & 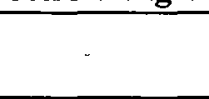 & $-1+-10$ \\
\hline $0.6-1.2(2-4)$ & $(1)(2)(3)(4)$ & $(1)(2)(4)$ & \\
\hline $1.2-1.8(4-6)$ & & (1) & \\
\hline $1.8-2.4(6-8)$ & $\dot{0}$ & (1) & (2) $(3)(4)$ \\
\hline $2.4-3.0(8-10)$ & $\therefore$ & (1) & 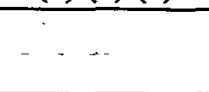 \\
\hline $3.0-3.7(10-12)$ & $\dot{\bullet}$ & & \\
\hline $3.7-4.3(12-14)$ & & & \\
\hline $4.3-4.9(14-16)$ & $\dot{\bullet}$ & (1) & \\
\hline $4.9-5.5(16-18)$ & & & \\
\hline $5.5-6.1(18-20)$ & $\dot{\bullet}$ & & \\
\hline $6.1-6.7(20-22)$ & & $\dot{\bullet}$ & \\
\hline $6.7-7.3(22-24)$ & & & \\
\hline $7.3-7.9(24-26)$ & $\dot{\bullet}$ & & $\ddot{(1)}(3)$ \\
\hline $7.9-8.5(26-28)$ & & & \\
\hline $8.5-9.1(28-30)$ & & & (1) (3) \\
\hline $9.1-9.8(30-32)$ & (1) (3) (4) & & \\
\hline $10.1-10.7(33-35)$ & & & $\stackrel{\bullet}{(1)(3)}$ \\
\hline $10.4-11.0(34-36)$ & $(1)(3)$ & & \\
\hline
\end{tabular}

(1) VOCs and Metals

(2) Radionuclides

(3) Pesticides and PBCs

(4) Base/Neutral and Acid Extractable Compounds

- Indicates Sample Collection Point 
Table 2-6. Potential ARARs and TBC Criteria for the RdACB

\begin{tabular}{|c|c|l|}
\hline \multicolumn{1}{|c|}{ Federal } & \multicolumn{1}{|c|}{ Type } & \multicolumn{1}{|c|}{ Applicability } \\
\hline Atomic Energy Act & Action/Chemical specific & Radioactive waste \\
\hline $\begin{array}{c}\text { Resource Conservation and } \\
\text { Recovery Act }\end{array}$ & Action/Chemical specific & $\begin{array}{l}\text { Treatment, storage and disposal } \\
\text { of hazardous waste }\end{array}$ \\
\hline Clean Air Act & Action/Chemical specific & $\begin{array}{l}\text { Potential releases to air from } \\
\text { units }\end{array}$ \\
\hline Safe Drinking Water Act & Chemical specific & MCL and MCL Goals \\
\hline Clean Water Act & Action/Chemical specific & Discharge Limitations \\
\hline Toxic Substances Control Act & Action/Chemical specific & $\begin{array}{l}\text { Potentially applicable if specific } \\
\text { constituents determined to be } \\
\text { present }\end{array}$ \\
\hline $\begin{array}{c}\text { Federal Insecticide, Fungicide, } \\
\text { and Rodenticide Control Act }\end{array}$ & Chemical specific & $\begin{array}{l}\text { Potentially applicable if } \\
\text { pesticides determined to be } \\
\text { present }\end{array}$ \\
\hline DOE Orders & $\begin{array}{l}\text { Treatment, Storage and Disposal } \\
\text { of hazardous and radioactive } \\
\text { wastes }\end{array}$ \\
\hline
\end{tabular}

\begin{tabular}{|c|c|l|}
\hline \multicolumn{1}{|c|}{ State } & \multicolumn{1}{c|}{ Type } & \multicolumn{1}{c|}{ Applicability } \\
\hline S.C. Pollution Control Act & Action specific & $\begin{array}{l}\text { Potential releases to surface } \\
\text { water, groundwater, air, or soil }\end{array}$ \\
\hline S.C. Wastewater Regulations & Chemical specific & Discharge limitations \\
\hline S.C. Drinking Water Regulations & Chemical specific & MCLs and MCL Goals \\
\hline $\begin{array}{c}\text { S.C. Hazardous Waste } \\
\text { Management Regulations }\end{array}$ & Action specific & $\begin{array}{l}\text { Treatment, Storage and Disposal } \\
\text { of hazardous and radioactive } \\
\text { wastes }\end{array}$ \\
\hline $\begin{array}{c}\text { S.C. Water Air Pollution Control } \\
\text { Regulations }\end{array}$ & Action specific & Potential releases to air \\
\hline $\begin{array}{c}\text { S.C. Water Classification } \\
\text { Standards }\end{array}$ & Chemical/location specific & $\begin{array}{l}\text { Surface water and groundwater } \\
\text { classification }\end{array}$ \\
\hline S.C. Well Standards Regulations & Action specific & Well construction requirements \\
\hline
\end{tabular}


Table 2-7. Potential Effective Remedial Technologies for the RdACB

\begin{tabular}{|l|l|}
\hline \multicolumn{1}{|c|}{ Response } & \multicolumn{1}{|c|}{ Technology } \\
\hline Removal & Excavation \\
\hline \multirow{4}{*}{ Treatment } & Soil Flushing/Washing (Contaminated Soils) \\
\cline { 2 - 2 } & Air Stripping (Contaminated Water) \\
\cline { 2 - 2 } & Carbon Adsorption (Contaminated Water) \\
\cline { 2 - 2 } & $\begin{array}{l}\text { Solidification: In-situ or Excavate and process } \\
\text { (Contaminated Soils) }\end{array}$ \\
\cline { 2 - 2 } & Vitrification (Contaminated Soils) \\
\hline Containment/Migration Control & Capping \\
\hline
\end{tabular}




\subsection{DATA QUALITY OBJECTIVES}

SAFER and ESC incorporate the DQO process developed by the EPA as guidance for data collection activities (EPA 1994). The DQOs are developed using an interactive and iterative approach to decision making based on seven steps outlined by EPA guidance.

DQOs are useful in identifying data gaps and in developing SAPs that describe the procedures for collecting sufficient data of known and defensible quality. These data are used to define the nature, magnitude, and extent of contamination and to define human-health and ecological risks. In turn, these findings will facilitate the derivation of sound decisions concerning remedial response activities. DQOs also assist in determining appropriate detection limits, analytical methods, and sampling and handling procedures/requirements.

The focus of the DQO development process is efficient planning for data collection. This process is participatory, encouraging input and consensus from all data users, thus facilitating the understanding and acceptance of project goals. The DQO process applies to the entire planning team, including management, regulators, and technical personnel. The DQO process is a series of planning steps based on the scientific methods (Sections 3.1.2 through 3.1.8 of this document) that are detailed in Guidance for the Data Quality Objectives Process (EPA 1994). This process provides a systematic, flexible approach to decision making. Although the steps are described sequentially, the DQO process is iterative. The results of the DQO process are a set of data specifications and an efficient, cost-effective SAP. This plan is designed to meet those specifications.

The major benefits of the $\mathrm{DQO}$ process are as follows:

- Promotes efficient, cost-effective, and timely data collection

- Provides a thorough, systematic approach to relate data collection specifications to the end needs of the data users

- Involves the decision makers and the assessment technical team in establishing a definitive plan with objective criteria

- Aids in communicating and understanding the levels of risk and the basis for decisions 
- Encourages critical thinking about data gathering and interpretation

\subsection{DQO Evaluation}

\subsubsection{Conceptual Site Model}

EPA guidance for both RCRA RFI and CERCLA RI investigations stresses the need and utility of a conceptual representation of the unit under consideration. Such a representation provides an objective framework around which existing information can be organized and synthesized, data gaps can be identified, and sampling programs can be designed to address critical data needs identified in the DQO process. The CSM addresses EPA guidance for this conceptual representation. It presents the preliminary understanding of the unit and focuses on the identification of potential contaminant migration from the sources to various potential receptors.

The CSM for the RdACB OU is presented in Figure 3-1. It identifies the potential sources of contamination, release mechanisms, media of concern, exposure routes, and potential receptors. Each of these components is described in the following sections. The CSM is considered iterative and will be revised as more information is known about the unit from the planned characterization activities.

\subsubsection{Primary Sources of Contamination}

The primary sources of contamination are miscellaneous aqueous radioactive and chemical wastes disposed at the RdACB OU. The exact nature and quantities of materials disposed are not known, although an environmental information document for the RdACB OU identifies them as miscellaneous aqueous radioactive and chemical wastes (Pickett et al. 1987). Since the basin was backfilled in 1973, it is not likely that any primary source material remains in the basin.

\subsubsection{Primary Release Mechanisms}

Contaminants may have been released from the primary sources by three primary release mechanisms: (1) deposition of contaminants on the surface soil and soils adjacent to the basin during waste disposal and during closure and backfilling operations, (2) infiltration and percolation of waste constituents into underlying soil, and (3) infiltration of precipitation through 
the primary source material and leaching of contamination from the waste into underlying soils and groundwater. Deposition of contaminants includes water that may have drained directly into the basin during disposal activities. Infiltration includes ponded water in the basin prior to backfilling that may have subsequently infiltrated into the subsurface.

\subsubsection{Secondary Sources of Contamination}

Environmental media impacted by the release of contamination from the primary sources become secondary sources. Secondary sources of contamination at the RdACB OU include sludge, surface soil ( 0 to $0.3 \mathrm{~m}$ [0 to $1 \mathrm{ft}$ ]), subsurface soil ( 0.3 to $1.2 \mathrm{~m}$ [1 to $4 \mathrm{ft}]$ ), and deep soil $(>1.2 \mathrm{~m} \mathrm{[}>4 \mathrm{ft}])$ derived from the basin bottom, sidewalls, berm, and potentially from the drainage area at the basin outlet. Currently, sufficient data do not exist to perform a screeninglevel ecological risk assessment to determine if there is a complete ecological pathway at the RdACB. Therefore, a screening-level ecological risk assessment will not be performed as part of this Work Plan. However, as the characterization data are collected, they will be evaluated in the ecological risk assessment in the RI/BRA.

\subsubsection{Secondary Release Mechanisms}

The secondary sources may release contamination to other media through a variety of secondary release mechanisms, including the following:

- Release of volatile constituents from the soil (volatilization)

- Generation of contaminated fugitive dust by wind or other surface soil disturbance

- Biotic uptake

- Direct contact

- Leaching of contaminants from subsurface and deep soils to groundwater

- Transport of contaminants via stormwater runoff and erosion

The most significant secondary release mechanism affecting the RdACB OU is expected to be the leaching of contaminants into the deep soils because the primary source material (basin sludge) was not removed during closure. Near-surface mechanisms, such as volatilization, 
fugitive dust generation, biotic uptake, direct contact, and stormwater runoff and erosion, are not likely to be significant secondary release mechanisms because the unit was backfilled. The backfill is believed to have retarded or prohibited the release and dispersion of contaminants by surficial processes, such as stormwater runoff and water and wind erosion. In addition, because the basin bottom was below grade while the basin was in operation and waste material was not likely to have been deposited above grade, the dispersion of contaminants by surficial processes would be unlikely. Post-depositional erosion of the fill covering the basin has generally been limited by vegetation.

\subsubsection{Exposure Pathways (Media)}

Contact with contaminated environmental media creates pathways for both human and ecological receptors. The exposure pathways at the RdACB OU include air (vapor and particulates), biota, surface and subsurface soils, and groundwater.

\subsubsection{Exposure Routes}

The final element of the CSM linking the primary and secondary sources to potential receptors is the exposure route. Exposure routes for human and ecological receptors may include inhalation of volatile emissions and airborne dust, ingestion of contaminated media (soils, groundwater, surface water, and/or vegetation), dermal contact with contaminated media, and human showering (which takes into account inhalation of volatiles from the shower spray and dermal contact with the water). Showering and ingestion of produce pertain only to the scenario of a hypothetical on-unit resident. External radiation pathways include surface soil, subsurface soil, and groundwater.

\subsubsection{Receptors}

Contamination from the RdACB OU may reach either human or ecological receptors. Human receptors include known on-unit workers, hypothetical industrial workers, and hypothetical adult and child residents. The most likely human receptors are known on-unit workers who frequent the area while collecting samples from the groundwater monitoring wells and other phases of ongoing RFI/RIs. Because the RdACB OU is located within SRS's controlled boundaries, the general public is not considered to be a potential receptor; the large distances and access 
restrictions make all pathways to the general public incomplete. In terms of future industrial use, potential human receptors are most likely industrial workers. In the event that future land use is converted from industrial to residential, future human receptors could include on-unit residents.

Potential ecological receptors include terrestrial and aquatic organisms. Terrestrial ecological receptors, such as vegetation, invertebrates, birds, reptiles, and small and large mammals, likely inhabit the wooded and grassy areas near the basin. Aquatic ecological receptors, such as aquatic plants, aquatic reptiles, or amphibians, likely inhabit the bottomland hardwood swamp located several hundred feet downgradient of the basin. Terrestrial and aquatic receptors will be evaluated either qualitatively or quantitatively based on area ecological reconnaissance results.

\subsubsection{State the Problem}

The initial step in the DQO process is to define the problem so that the focus of the investigation will be clear and disciplined. To do this, existing data from previous investigations are summarized and evaluated (Section 2). From there, a CSM is developed (Section 3.1.1), and potential exposure pathways are identified.

The unit history indicates a potential for contamination at the RdACB OU. Secondary sources of contamination may also exist. The existing data are not adequate to identify the nature or extent of contaminants in soil and groundwater. Data needs begin with identifying the actual dimensions and location of the original basin. Currently, the unit-specific stratigraphy and hydrostratigraphy in the vicinity of the RdACB OU are not adequately defined and additional data are needed. These data will be necessary to support any future remedial actions.

Additional information must be collected to characterize surface, subsurface, and deep soils in the basin, adjacent to the basin, and downslope of the unit. In addition, groundwater quality at the unit must be characterized.

\subsubsection{Identify the Decisions}

The purpose of this DQO step is to identify the decisions that must be supported with the collected data to address the problem. This step helps define the objectives of the field investigation. 
Unit process history and screening data indicate that the RdACB OU is a potential source of contamination. The following are decisions that need to be addressed under this Work Plan:

- Determine the dimensions and location of the original basin in order to accurately estimate the volume of the primary (if any) and secondary sources

- Collect data for lithologic characterization of soil beneath and adjacent to the basin

- Define the unit-specific stratigraphy and hydrostratigraphy

- Determine if principal threat source material (PTSM) or low level threat source material is present at the RdACB OU

- Determine the nature of contamination from the primary and secondary sources at the RdACB OU

- Determine the location(s), if any, of seeps and/or surface water between the OU and the Savannah River

- Determine whether any contaminant residual within basin soils will migrate to the groundwater in concentrations exceeding MCLs

- Determine the nature and concentrations of naturally occurring and anthropogenic analytes in the soil background

- Determine the nature and concentrations of naturally occurring and anthropogenic analytes in the groundwater background

- Determine whether surface, subsurface, and deep soils have been impacted by previous operations, within the unit boundaries, adjacent to the basin, and downslope of the unit

- Determine whether sediment and surface water have been impacted by previous operations in the bottomland hardwood swamp

- Determine whether groundwater has been impacted by operations at the RdACB $\mathrm{OU}$; if so, determine the risk the impact poses and the appropriate response to that level of risk

Unit screening data will be compiled and evaluated as part of this investigation in accordance with EPA guidance (EPA 1994). In conjunction with existing data, the new data will be used to 
address the decisions listed above and to determine whether the contaminants at the RdACB OU exceed ARAR criteria (discussed in Section 2.6), ecological criteria, 1E-06 Risk-Based Concentrations/Risk-Based Activities (RBCs/RBAs), or background concentrations. Both human health and ecological risk assessments will be performed. The determination of the basin dimensions and unit-specific stratigraphy and hydrostratigraphy will support the design and implementation of remedial actions. Potential remedial alternatives are discussed in Section 2.7.

\subsubsection{Identify the Inputs to the Decisions}

The purpose of this step is to identify the information needed to support the decisions presented in Section 3.1.3 and to specify which inputs require new environmental measurements. Existing data that support the decisions are also addressed. Each of the following inputs requires new environmental measurements:

- Ground Penetrating Radar (GPR) survey data to identify the location and dimensions of the basin (to be confirmed by lithologic data)

- Soil descriptions from boreholes to define actual basin dimensions

- Site/area reconnaissance to identify the location(s) of seeps and surface water

- Geotechnical parameters to accurately develop a unit-specific vadose zone transport model to assess contaminant migration to groundwater

- Definitive analytical data for soil within, beneath, and adjacent to the basin to be used in contaminant fate and transport analyses and to supplement secondary source characterization

- Definitive analytical data for surface, subsurface, and deep soil adjacent to and downslope of the basin to determine the nature and extent of contamination in the soils

- Definitive analytical data for sediment and surface water from the bottomland hardwood swamp to determine impact from RdACB OU operations

- Definitive analytical data for soil hydraulically upgradient of the basin to establish unit-specific background

- Definitive analytical data for sediment and surface water from the bottomland hardwood swamp to establish unit-specific background 
- Definitive analytical data for surface and subsurface soil and groundwater media to quantify human health and ecological risk in the BRA

- Constraints on the hydrostratigraphy and groundwater hydrology to identify the extent of a plume, if present, for input into contaminant fate and transport analyses and the BRA

- Screening-level VOC and radionuclide indicator data for input into the nature and extent of groundwater contamination and contaminant fate and transport analysis

- Definitive groundwater quality data from the Water Table Aquifer both sidegradient and downgradient of the basin to determine the nature of the plume, if present, for ecological and human health risk assessments and contaminant fate and transport analysis

- Definitive groundwater quality data from the Water Table and Gordon Aquifers to establish unit-specific background

\subsubsection{Define the Boundaries of the Study}

The purpose of this step is to identify the spatial limits of the affected media and to determine the discrete area affected by the decisions. This step also identifies the human health and ecological populations at risk and investigates the impact of present and future land use on these populations. Another goal of this step is to determine if the time of the sample collection will affect the quality of the characterization data.

The primary goal of this RFI/RI Work Plan is to determine the nature and extent of contamination resulting from RdACB OU operations. Characterization activities under this Work Plan will include soil sampling within the RdACB OU boundaries, as well as soil sampling adjacent to, and downslope, of the RdACB OU. Sediment and surface water samples will be collected from the bottomland hardwood swamp. In addition, unit groundwater quality and hydrogeology will be evaluated. This information will establish impacted surface, subsurface, deep, and adjacent soil and groundwater plume boundaries. These boundaries will determine the populations at risk and will affect the selection of the preferred remedial alternative. A preliminary evaluation of the potential populations at risk is provided in Section 3.1.1.7. Section 4, which discusses the unit assessment, provides specific details of the methodology to determine the nature and extent of contamination. 
This methodology is designed to consider potential seasonal variations in groundwater flow direction, elevations, contaminant concentration, and other aquifer characteristics. Field observations indicate relative consistent groundwater flow direction. However, during field activities, groundwater monitoring will continue monthly. In general, sampling procedures will remain relatively unaffected by temporal variations.

\subsubsection{Develop Decision Rules}

The purpose of this step is to integrate output from the previous steps of the DQO process into a statement that defines the conditions that would cause the decision maker to choose among alternative actions. These actions encompass the entire RCRA/CERCLA process. The decisions will use the ESC concept, which requires frequent team review and possible modifications of field activities based on real-time data obtained during sampling. The decision rules are as follows:

- If media concentrations exceed unit-specific soil screening levels, then a contaminant fate and transport analysis will be performed to determine whether there is a potential impact to groundwater. If the media concentrations are less than soil screening levels, then the RdACB OU will not be considered a continuing source to groundwater.

- If media concentrations exceed risk criteria, then remedial goal objectives will be developed for the appropriate constituents. This item will be addressed in a BRA. If no concentrations exceed risk criteria, then it will be documented in the BRA that no further action will be required.

- If uncertainty exists for media concentrations that exceed risk criteria, then an uncertainty analysis will be conducted to clarify this issue. This item will be included in the BRA.

- Soils from 0.0 to $0.3 \mathrm{~m}$ ( 0 to $1 \mathrm{ft}$ ), 0.3 to $1.2 \mathrm{~m}$ ( 1 to $4 \mathrm{ft}$ ), 2.1 to $3.0 \mathrm{~m}$ ( 7 to $10 \mathrm{ft}$ ), and 3.0 to $4.0 \mathrm{~m}$ (10 to $13 \mathrm{ft}$ ) have required definitive analyses at an offsite certified laboratory for target compound list/target analyte list (TCL/TAL) and specific radionuclide analysis. Contingent soil samples from the basin will be sent to an offsite certified laboratory for definitive analysis if (1) field screening with a photoionization detector/flame ionization detector indicates greater than 1 ppm VOCs, or (2) onsite laboratory screening for radioactivity indicates greater 
than $20 \mathrm{pCi} / \mathrm{g}$ gross alpha or $50 \mathrm{pCi} / \mathrm{g}$ nonvolatile beta-gamma. All of the offsite laboratory samples will be analyzed for TCL/TAL parameters, gross alpha, nonvolatile beta-gamma, and gamma spectroscopy. If gross alpha triggers are exceeded, the sample will receive additional alpha spectroscopy analyses. Similarly, if nonvolatile beta-gamma triggers are exceeded, gamma pulse height analysis (PHA) will be performed.

- At a given borehole, sampling will be terminated when two consecutive sample intervals screen "clean", tool refusal is met three times, perched water is encountered, or a maximum depth is obtained with the sample tool. "Clean" is defined as less than $1 \mathrm{ppm}$ VOC (using field instrumentation), less than or equal to $20 \mathrm{pCi} / \mathrm{g}$ gross alpha, and/or less than or equal to $50 \mathrm{pCi} / \mathrm{g}$ nonvolatile betagamma.

- If a new borehole proposed in this Work Plan is located near a borehole performed during the 1989 soil investigation, and the results of the sampling and analysis for that particular location indicate potential contamination at depth, the new borehole will be sampled to the water table surface (approximately $10.7 \mathrm{~m}$ [35 ft] bgs), regardless of the screening results.

- For surface and subsurface soil samples collected below the surface water drainage culvert, if the screening gross alpha result for a sample exceeds the $20-\mathrm{pCi} / \mathrm{g}$ trigger, or if the screening nonvolatile beta-gamma result for a sample exceeds the 50-pCi/g trigger, a stepout surface soil sampling location will be located $3.5 \mathrm{~m}(10 \mathrm{ft})$ downslope of the initial location. Alpha spectroscopy and/or ,gamma PHA will be performed on all samples collected from this stepout location. Stepouts will continue to be collected until two clean stepout locations are encountered. Additionally, sediment and surface water samples will be collected in the bottomland hardwood swamp at the intersection of the drainage path and the swamp.

- If groundwater sampling from monitoring wells indicates VOC contamination, sampling will proceed downgradient, using direct push technology (DPT) sampling methods. The extent of contamination will be determined by obtaining screening-level VOC data. A sample will be considered contaminated if a VOC is detected above the MCL, or in the case an MCL is not available, above the RBC. 
DPT sampling will continue downgradient until a sample does not indicate potential groundwater contamination that exceeds an MCL or RBC.

- If groundwater sampling from monitoring wells indicates contamination other than VOC contamination, additional monitoring wells will be installed further downgradient of the basin until the extent of groundwater contamination is defined.

\subsubsection{Specify Tolerable Limits on Decision Errors}

This section presents guidelines for the decision maker's acceptable limits on decision errors, which are used to establish performance goals for limiting uncertainty in the data. Due to inherent uncertainty introduced by heterogeneity and error in sampling, storing, transporting, and analyzing environmental media, it is important to specify the acceptable decision error rates. Potential errors resulting from field sampling modifications implemented under the ESC program will be minimized by using the decision rules outlined in Section 3.1.6. Establishing a sample protocol and using definitive analyses will also minimize potential errors introduced during field operations. During the field investigation, acceptable levels of uncertainty will be identified jointly between SRS and regulatory personnel using the procedures outlined in Guidance for Data Usability in Risk Assessment - Parts A and B (EPA 1992).

\subsubsection{Optimize the Design for Obtaining Data}

The final step in the DQO process is to develop a sampling plan that takes into account the problems, key issues, environmental variables, and process for identifying spatial and temporal boundaries of the contamination and populations at risk. The approaches will be used to optimize the design of the RFI/RI and SAFER and ESC. SAFER is being applied throughout the development of the CSM and DQOs. These tools are helpful in establishing site uncertainties and in determining data needs and are important factors in the development of a comprehensive SAP. ESC is applied by reviewing all existing data by performing a limited (Phase I) precharacterization and by obtaining analytical data in a time frame that allows for timely decisions to streamline the investigation process. An integral part of the ESC process is a dynamic work plan that is viewed as a guide subject to modification, rather than an absolute, unchangeable document. As such, decisions will be made throughout the characterization to optimize field activities for obtaining data. 


\subsection{Summary of DQO Evaluation}

This section discusses the unit characterization objectives as they address the CSM and meet the DQO process needs. The data needs developed under the DQO process are summarized in Table 3-1; the CSM is discussed in Section 3.1.1 and is presented as Figure 3-1.

The primary sources of contamination are miscellaneous aqueous radioactive and chemical wastes disposed at the RdACB OU. If unusual material, liquids, or visibly impacted soils are identified, samples of these materials will be obtained for characterization. A list of USCs has not been established based on validated analytical Phase I data. Limited additional sampling of the primary sources and the determination of the base of the basin are necessary to perform contaminant fate and transport analyses and to supplement primary source characterization.

Secondary source materials may have become contaminated by infiltration/percolation of the primary sources and/or deposition of contaminants on the surface soil during waste disposal activities. Leaching from the primary source material to deep soil may have contaminated the groundwater pathway. Geochemical data obtained from the Water Table Aquifer will be used to determine the nature of the primary and secondary sources' contribution to groundwater contamination, if any, and to refine the remedial design. If a plume does exist, its lateral and vertical extent will be delineated by collecting samples by DPT (if a VOC plume exists) to guide in the placement of new monitoring wells. Additional monitoring wells will be installed if a contaminant plume other than VOCs exists. Hydrostratigraphic and hydraulic properties of the affected aquifers will also be determined for site-specific contaminant fate and transport analyses.

Soils in and adjacent to the basin may have been contaminated by direct contact. To evaluate this pathway, surface and subsurface soil samples will be collected adjacent to the boundaries of the RdACB OU. Likewise, surface and subsurface soils downgradient of the RdACB OU may have been contaminated by surface water runoff. To evaluate this pathway, surface and subsurface soil samples will be collected. In addition, sediment and surface water samples will also be collected from the bottomland hardwood swamp to evaluate this pathway.

At present, human health and ecological risk assessments cannot be performed with existing data. Therefore, RCRA/CERCLA characterization objectives have not been satisfied. To resolve this issue, four areas of possible contamination require characterization: secondary 
source material; surface, subsurface, and deep soils at the RdACB OU; soils adjacent to the basin; and groundwater in the Water Table and Gordon Aquifers. Characterization of these areas will establish whether secondary sources exist and whether pathways to potential receptors are complete. 
This page intentionally left blank. 
This page intentionally left blank. 

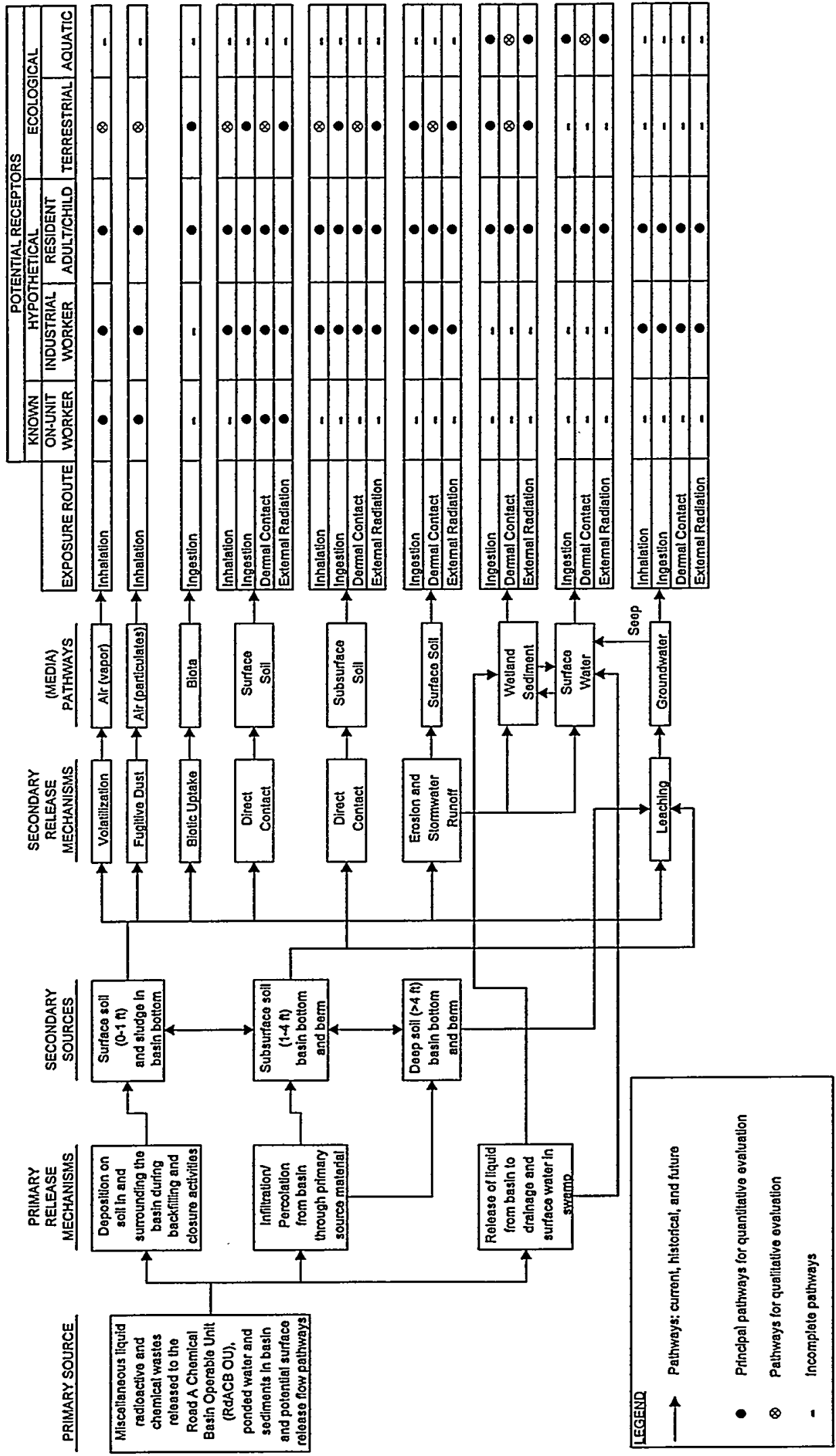

Figure 3-1. Conceptual Site Model for the Road A Chemical Basin 
This page intentionally left blank. 
This page intentionally left blank. 


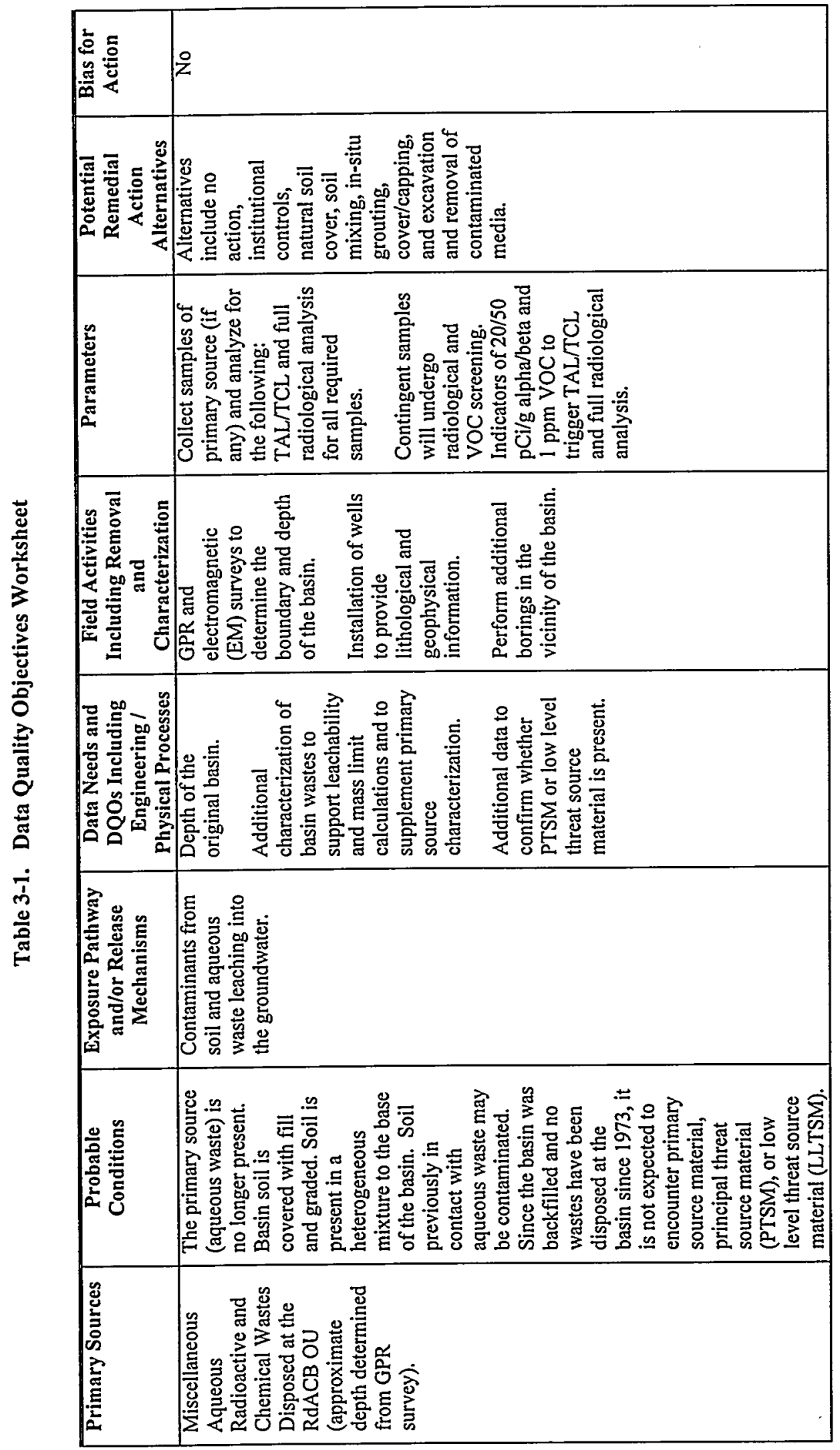




\begin{tabular}{|c|c|c|}
\hline 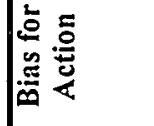 & \multicolumn{2}{|l|}{ z } \\
\hline 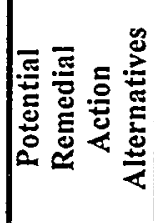 & 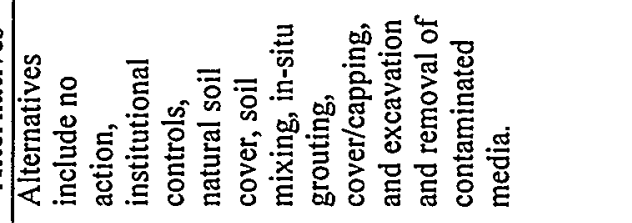 & \\
\hline 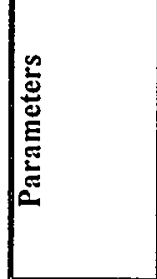 & 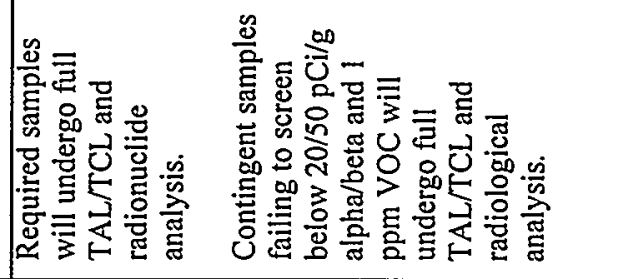 & \\
\hline 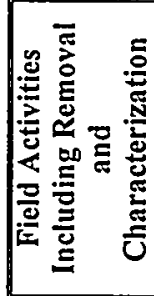 & 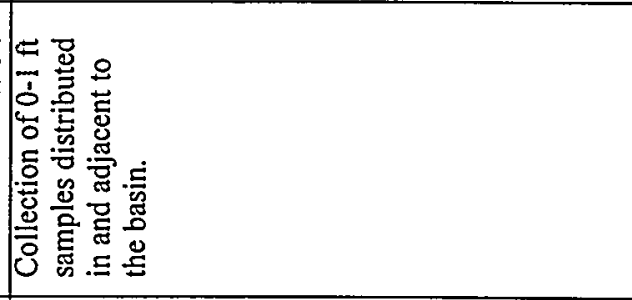 & \\
\hline 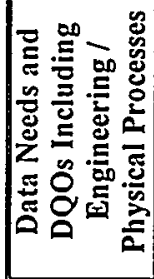 & 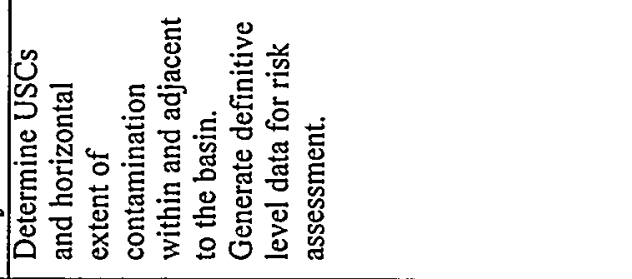 & \\
\hline 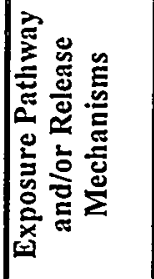 & 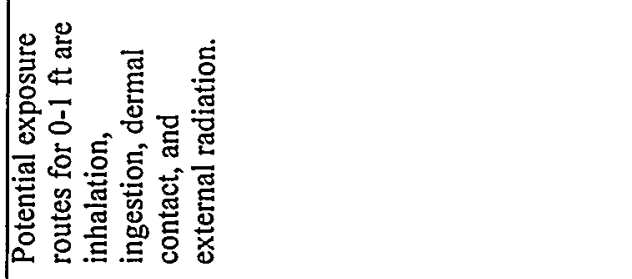 & \\
\hline 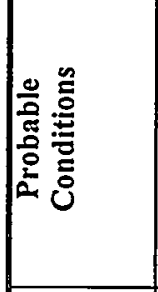 & 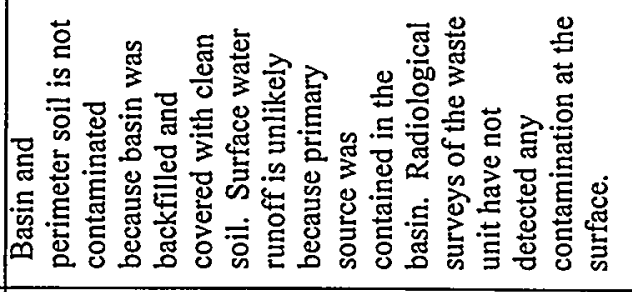 & 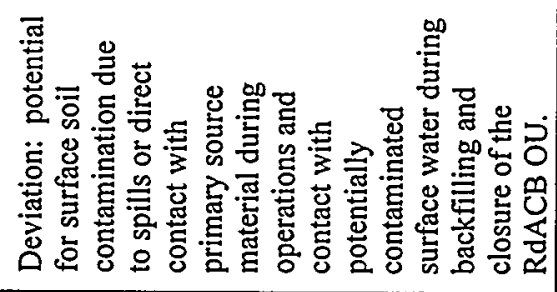 \\
\hline 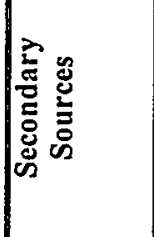 & 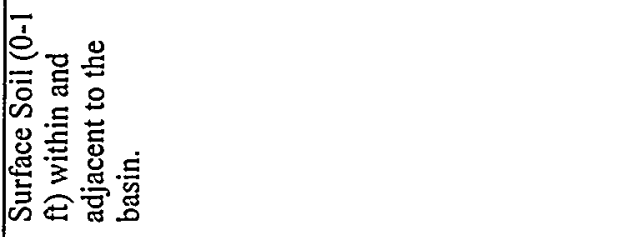 & \\
\hline
\end{tabular}


Table 3-1. Data Quality Objectives Worksheet (continued)

\begin{tabular}{|c|c|c|c|c|c|c|c|}
\hline $\begin{array}{l}\text { Secondary } \\
\text { Sources }\end{array}$ & $\begin{array}{l}\text { Probable } \\
\text { Conditions }\end{array}$ & $\begin{array}{c}\text { Exposure } \\
\text { Pathway and/or } \\
\text { Release } \\
\text { Mechanisms }\end{array}$ & $\begin{array}{c}\text { Data Needs and } \\
\text { DQOs Including } \\
\text { Engineering / } \\
\text { Physical Processes }\end{array}$ & $\begin{array}{c}\text { Field Activities } \\
\text { Including Removal } \\
\text { and } \\
\text { Characterization }\end{array}$ & Parameters & $\begin{array}{c}\text { Potential } \\
\text { Remedial } \\
\text { Action } \\
\text { Alternatives } \\
\end{array}$ & $\begin{array}{l}\text { Bias for } \\
\text { Action }\end{array}$ \\
\hline $\begin{array}{l}\text { Subsurface soil } \\
(1-4 \mathrm{ft}) \text { within and } \\
\text { adjacent to the } \\
\text { basin. }\end{array}$ & $\begin{array}{l}\text { Basin and perimeter } \\
\text { subsurface soil is not } \\
\text { contaminated } \\
\text { because the basin } \\
\text { was backfilled and } \\
\text { covered with clean } \\
\text { soil. The basin } \\
\text { bottom was deeper } \\
\text { than } 4 \mathrm{ft} \text {; therefore, } \\
\text { the backfill should be } \\
\text { clean. Historical soil } \\
\text { sampling did not } \\
\text { detect radiological } \\
\text { indicators above } \\
\text { background levels in } \\
\text { subsurface soils. } \\
\text { Deviation: potential } \\
\text { for subsurface soil } \\
\text { contamination due to } \\
\text { spills or direct } \\
\text { contact with primary } \\
\text { source material } \\
\text { during operations. }\end{array}$ & $\begin{array}{l}\text { Potential exposure } \\
\text { routes are } \\
\text { inhalation, } \\
\text { ingestion, dermal } \\
\text { contact, and } \\
\text { external radiation. }\end{array}$ & $\begin{array}{l}\text { Determine USCs } \\
\text { and horizontal } \\
\text { extent of } \\
\text { contamination } \\
\text { within and adjacent } \\
\text { to the basin. } \\
\text { Assess impact on } \\
\text { soils adjacent to the } \\
\text { basin, and } \\
\text { supplement risk } \\
\text { assessment data. }\end{array}$ & $\begin{array}{l}\text { Initial borings } \\
\text { located within and } \\
\text { no more than } 10 \mathrm{ft} \\
\text { from basin edges. } \\
1-4 \mathrm{ft} \text { around } \\
\text { perimeter of the } \\
\text { original basin. }\end{array}$ & $\begin{array}{l}\text { Required samples } \\
\text { will undergo full } \\
\text { TAL/TCL and } \\
\text { radionuclide } \\
\text { analysis. } \\
\text { Contingent samples } \\
\text { failing to screen } \\
\text { below } 20 / 50 \mathrm{pCi} / \mathrm{g} \\
\text { alpha/beta and } 1 \\
\text { ppm VOC will } \\
\text { undergo full } \\
\text { TAL/TCL and } \\
\text { radiological } \\
\text { analysis. }\end{array}$ & $\begin{array}{l}\text { Alternatives } \\
\text { include no } \\
\text { action, } \\
\text { institutional } \\
\text { controls, } \\
\text { natural soil } \\
\text { cover, soil } \\
\text { mixing, in-situ } \\
\text { grouting, } \\
\text { cover/capping, } \\
\text { and excavation } \\
\text { and removal of } \\
\text { contaminated } \\
\text { media. }\end{array}$ & No \\
\hline
\end{tabular}




\begin{tabular}{|c|c|c|}
\hline 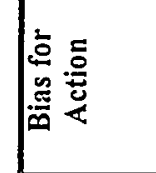 & z & | \\
\hline 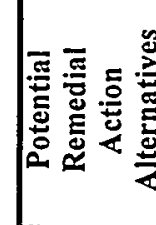 & 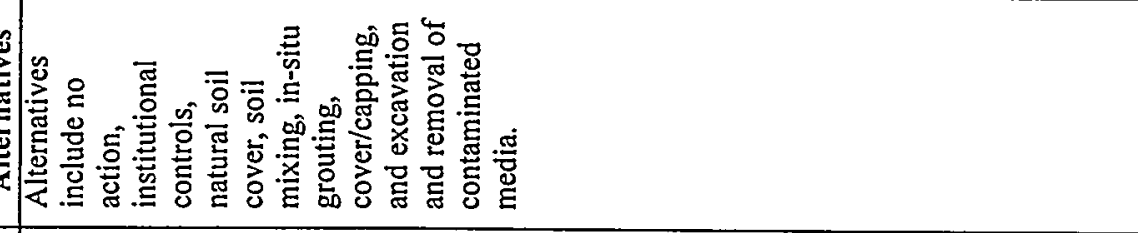 & 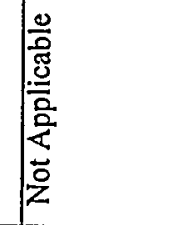 \\
\hline 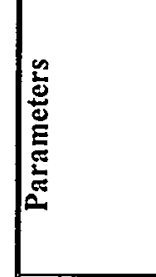 & 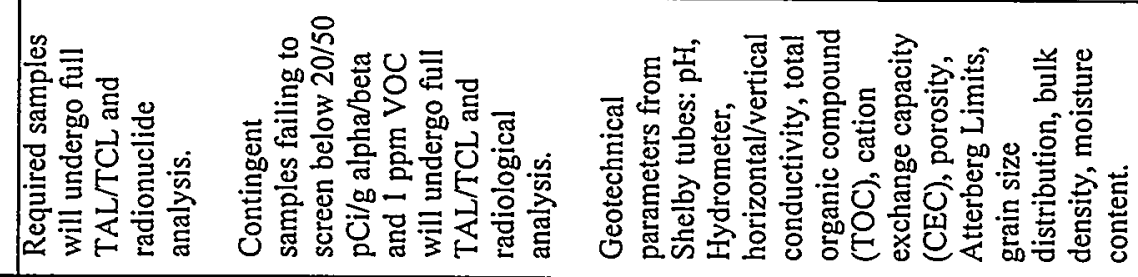 & 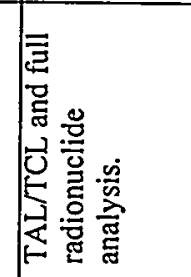 \\
\hline 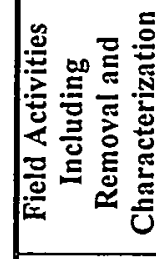 & 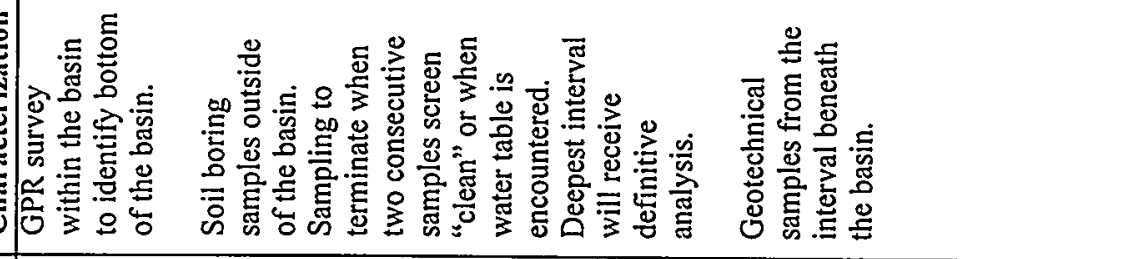 & 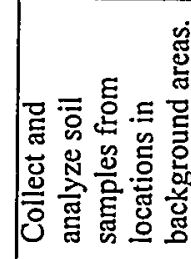 \\
\hline 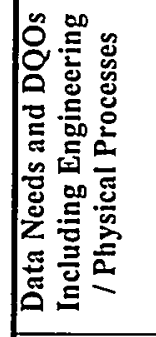 & 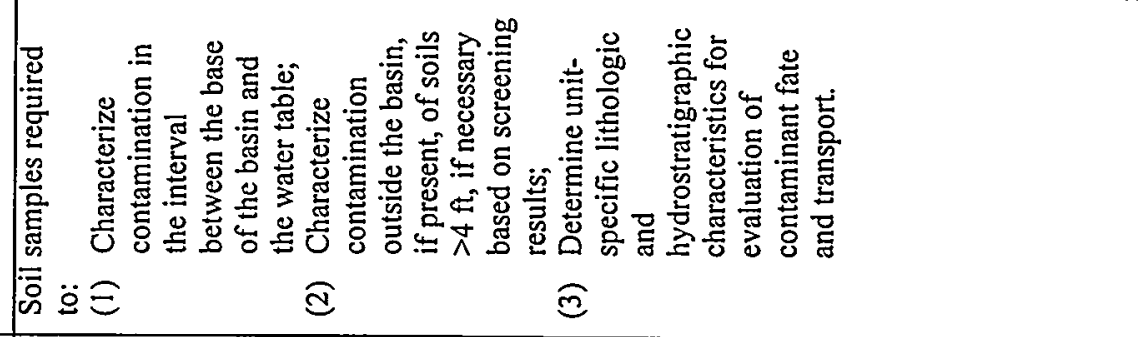 & 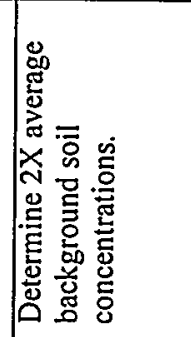 \\
\hline 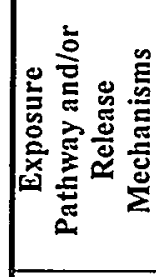 & 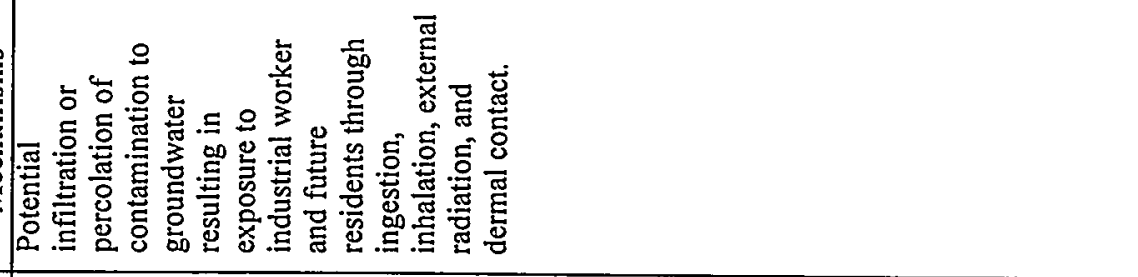 & 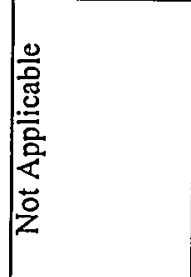 \\
\hline 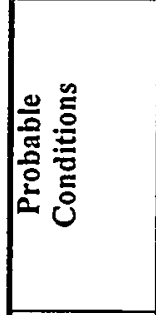 & 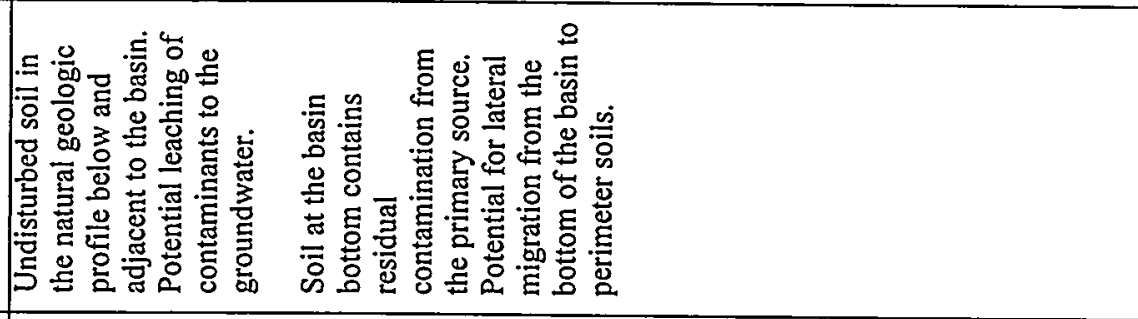 & 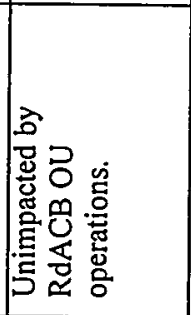 \\
\hline 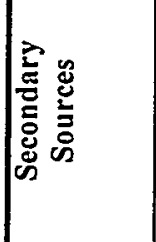 & 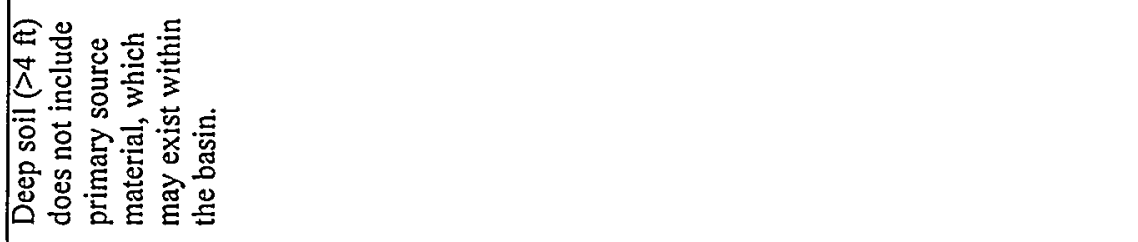 & 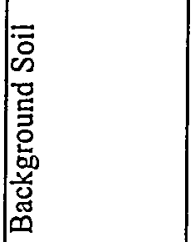 \\
\hline
\end{tabular}




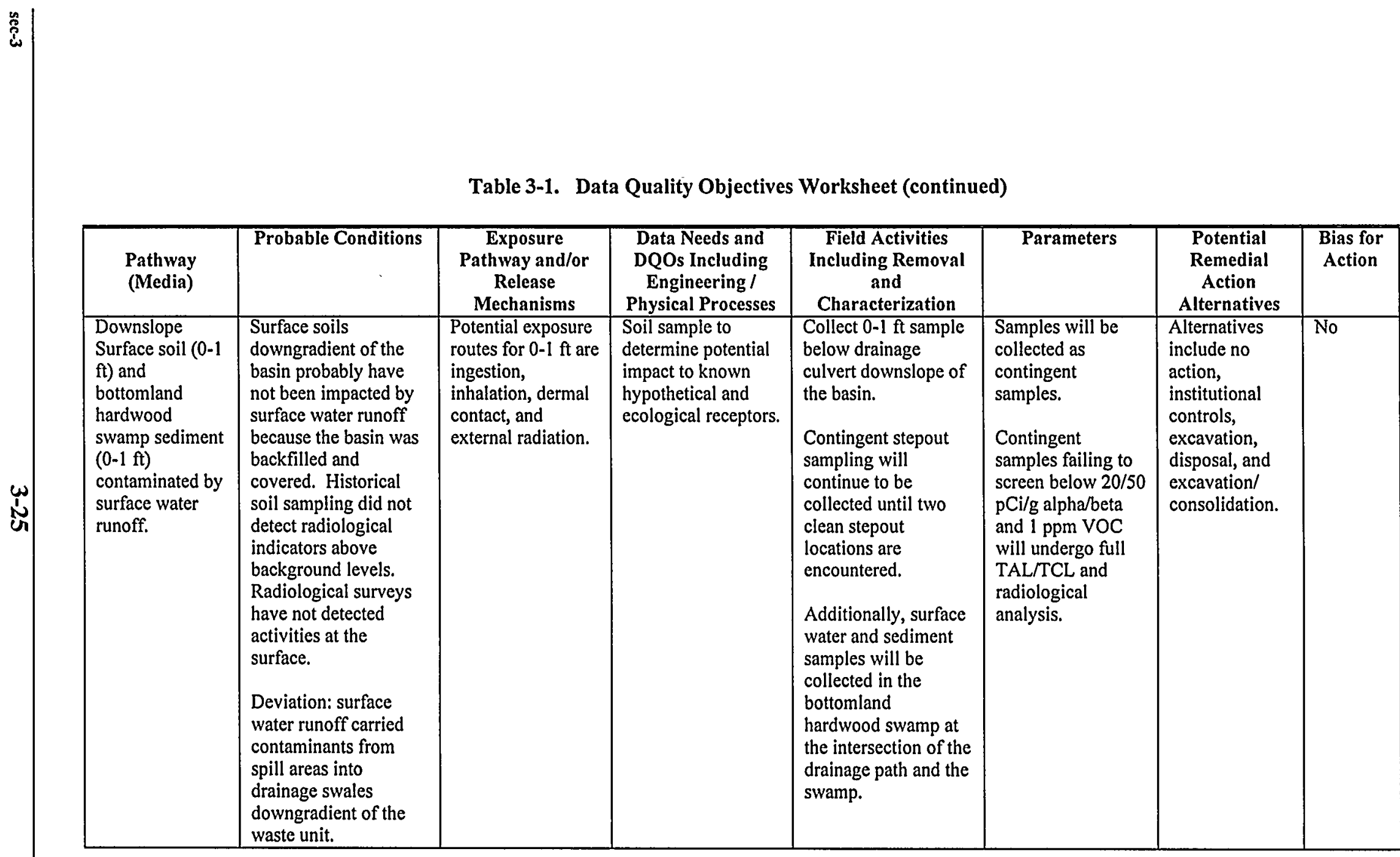




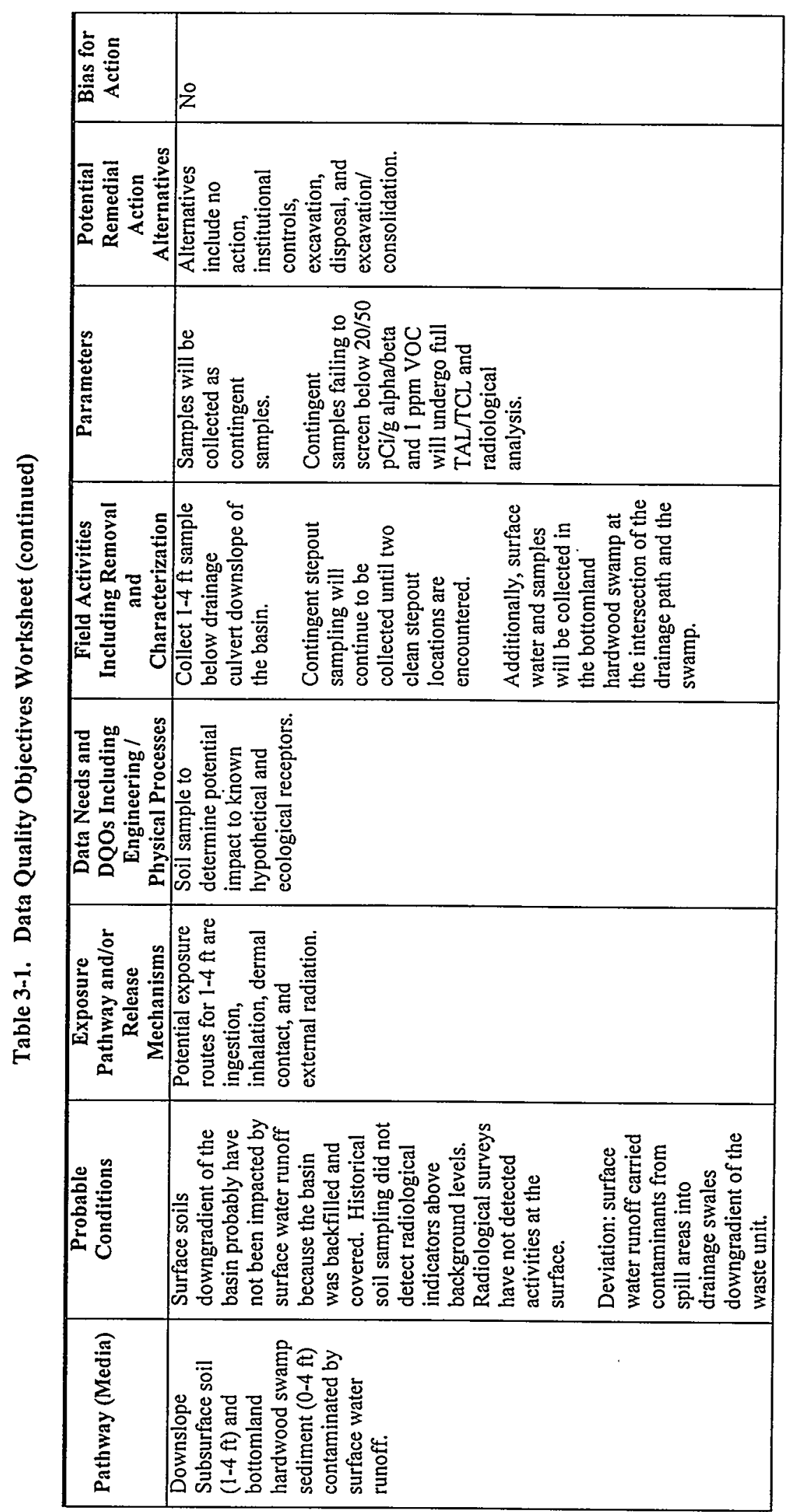




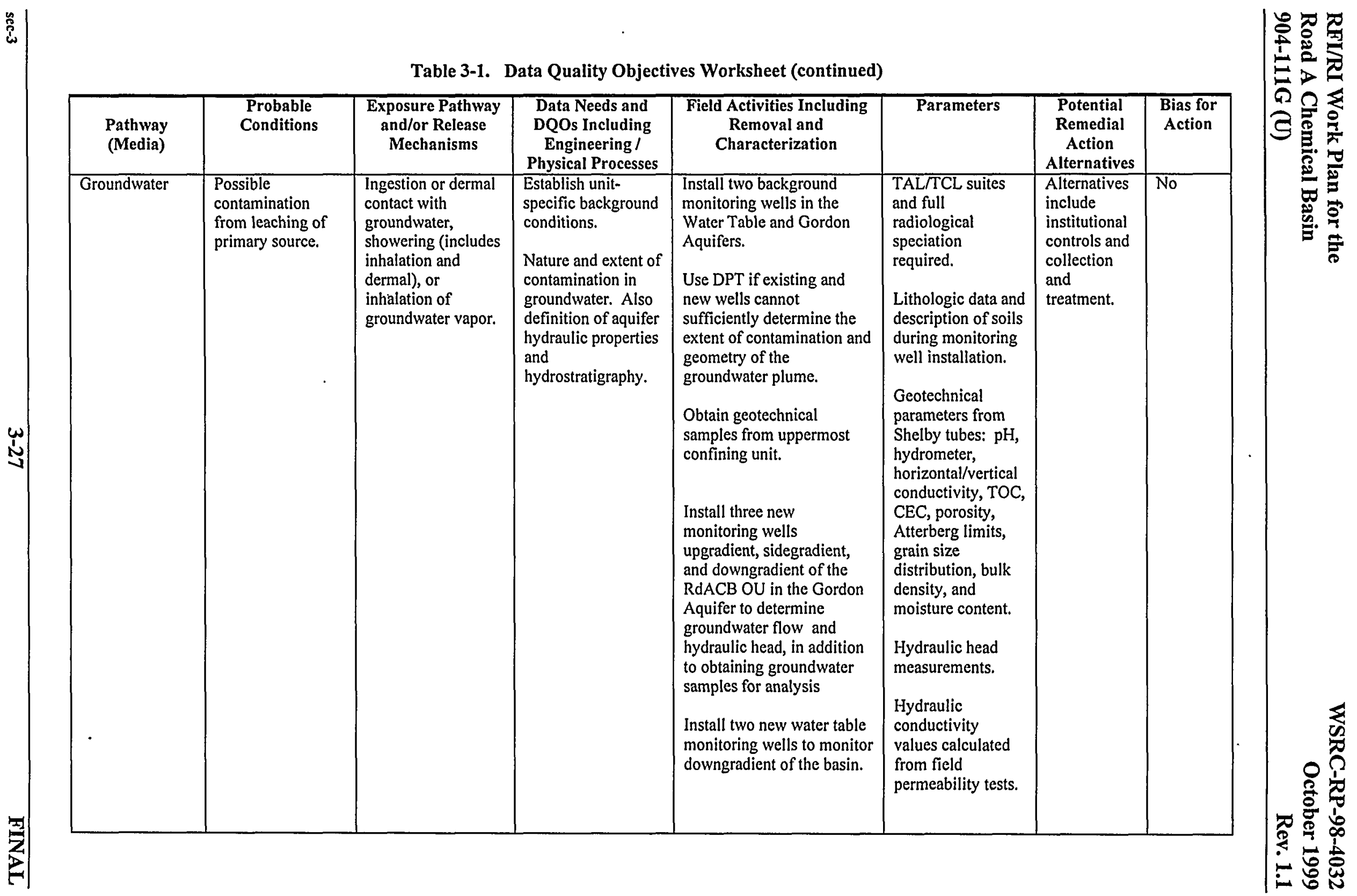




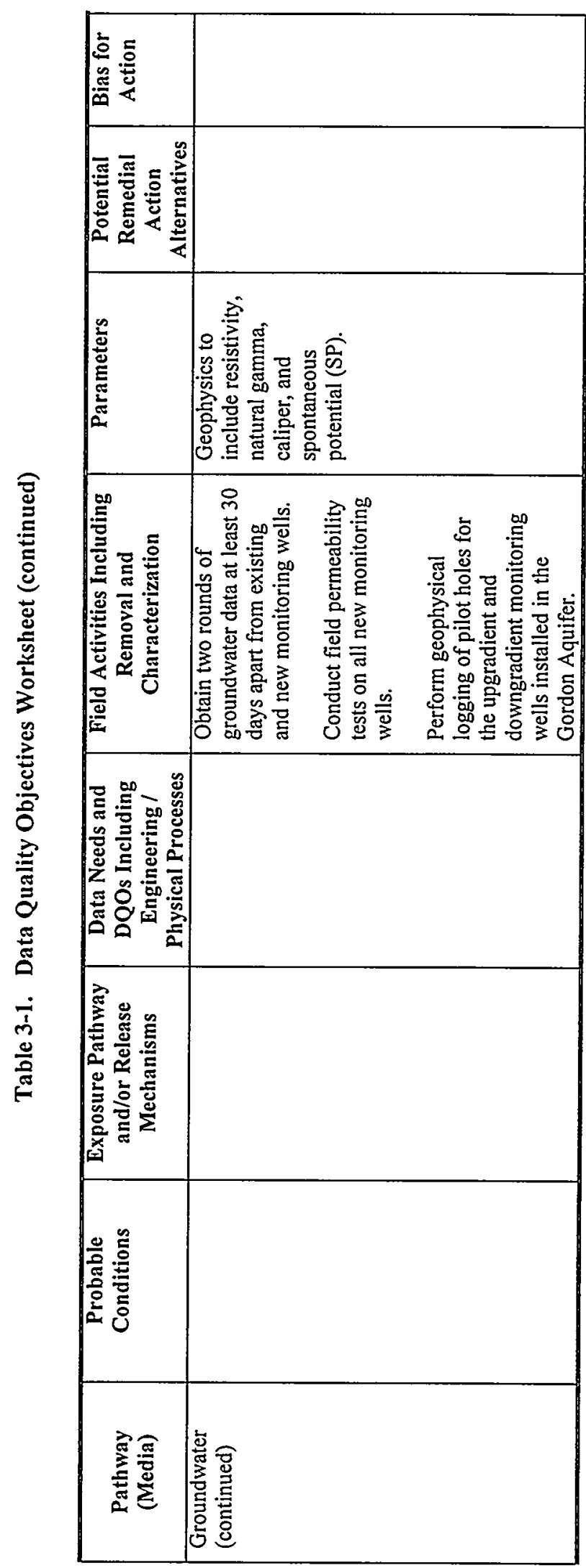




\subsection{UNIT ASSESSMENT}

The unit assessment for the RdACB OU is designed to supplement and expand the pre-existing data set developed from historical data, soil gas surveys, soil boreholes, and groundwater monitoring. These data have been used to streamline characterization efforts, eliminate unnecessary sampling, and provide sufficient data required to help make decisions at various points in the environmental assessment process. The combined data will be used to support contaminant fate and transport analyses, determine the nature and extent of contamination, evaluate remedial action objectives, and support human health and ecological risk assessments to satisfy RCRA and CERCLA requirements for the RdACB OU.

This section discusses the unit objectives as they address the CSM and meet the DQO process needs. Based on the DQOs developed in Section 3, the following data needs have been identified:

- Define the location and lateral and vertical extent of the original basin

- Characterize the lithology beneath and adjacent to the basin

- Identify the geotechnical properties of the upper confining unit

- Characterize the nature and extent of contamination in surface, subsurface, and deep soils beneath and adjacent to the basin

- Identify surface water and seep locations between the OU and the Savannah River, if any

- Characterize deep soil in the interval between the bottom of the basin and the water table

- Determine the $2 X$ average background soil screening concentrations

- Determine the nature and extent of groundwater contamination in the Water Table Aquifer

- Determine the nature and extent of groundwater contamination and groundwater flow direction in the Gordon Aquifer

- Characterize the nature and extent of the surface runoff pathway from the basin to the bottomland hardwood swamp and within the swamp. 
All soil and groundwater samples will be analyzed by EPA-certified laboratories using SW-846 methods. Physical and hydrological parameters will be determined using American Society for Testing and Materials (ASTM) or other standard methods. Water samples collected by DPT will be screened for VOCs by an onsite laboratory with a 24-hour turnaround schedule to allow the project team to adjust the sampling strategy, as necessary, based on analytical data.

\subsection{Objectives}

The field investigation will be conducted in compliance with WSRC Manual 3Q5 (WSRC 1997) and Manual 3Q1-7 (WSRC 1995b). The characterization activities are summarized in Table 4-1. Proposed soil sample locations are presented in Figures 4-1 and 4-2. Figure 4-3 shows the locations of the proposed piezometer and groundwater monitoring wells. GPR and EM survey transect locations are presented in Figure 4-4. All sample locations from previous investigations are presented in Section 2.

In general, samples collected during this investigation will be analyzed for TCL VOCs, TCL SVOCs, TCL pesticides/PCBs, and TAL inorganics. Samples also will be analyzed for radioisotopes. The constituents, analytical methods, and detection limits for each parameter are presented in Tables 4-2 and 4-3. Upon review, the analyte list from previous investigations was inadequate (see Section 2) and results were considered inconclusive. Therefore, for this investigation, samples will be analyzed for full analyte suites as discussed in the following sections.

In accordance with $\mathrm{QA} / \mathrm{QC}$ requirements, during the unit assessment, field $\mathrm{QC}$ samples consisting of duplicates, splits, rinsate blanks, field blanks, and trip blanks will be collected for samples requiring definitive analytical data. Duplicates and splits will be analyzed for the same analytical parameters as the associated sample. Duplicates will be collected at a rate of one per 20 definitive samples per matrix (soil or water). Splits will also be collected at a rate of one per 20 definitive samples per matrix. Duplicates are independent samples collected from the same source and analyzed independently by the same laboratory. Duplicates are useful in evaluating the precision of the sampling process. A split is also an independent sample collected from the same source and analyzed independently by two different laboratories. Split samples are used to evaluate interlaboratory precision. Rinsate blanks, field blanks, and trip blanks will be analyzed for only TCL VOCs and TAL inorganics. If contamination from either of these two suites is 
detected in the rinsate blanks, field blanks, or trip blanks, then contamination of the associated samples for all analyte suites will be suspected.

Field blanks will be collected at the rate of one per 20 definitive samples per matrix, except where the sample is not exposed to potential external contamination from handling during the sample event. Thus, field blanks are not required when the sample is pumped directly from its natural condition into the sample bottle.

Rinsate blanks will also be collected at a rate of one per 20 definitive samples per matrix, except where the sample is collected with a dedicated sampling tool. Dedicated sampling tools effectively eliminate the risk of cross-contamination. Trip blanks will be analyzed for TCL VOCs only. They will be collected and shipped at the rate of one per cooler containing a VOC sample.

\subsection{Primary Source Characterization}

The primary sources (miscellaneous aqueous radioactive and chemical wastes disposed at the RdACB OU) may have been released by deposition or infiltration/percolation to deep soil. The primary sources were not characterized during the previous investigations. Since the basin was backfilled in 1973 and no wastes have been disposed at the RdACB OU since that time, it is unlikely that primary source material will be encountered. However, if unusual materials are encountered, additional samples will be collected. Sampling of the primary sources is contingent upon identifying material during the soil sampling and is described in Section 4.3.

\subsection{Secondary Source Characterization}

To characterize secondary sources identified in the CSM, surface, subsurface, and deep soils at the basin will be sampléd. There are three secondary sources identified in the CSM: surface soil ( 0 to $0.3 \mathrm{~m}$ [0 to $1 \mathrm{ft}] \mathrm{bls}$ ), subsurface soil ( 0.3 to $1.2 \mathrm{~m}$ [1 to $4 \mathrm{ft}]$ bls), and deep soil ( $>1.2 \mathrm{~m} \mathrm{[>4}$ $\mathrm{ft}$ bls). Table 4-2 lists the analytical parameters for groundwater and soil samples, and Table 4-3 summarizes secondary source sampling, locations, and suites of analytes. 


\subsubsection{Soil Sampling at the RdACB OU}

To determine the nature and extent of contamination beneath the RdACB OU, soil samples will be collected at six borehole locations (RAC-01 through RAC-06) within the basin footprint. In addition, the lithology of the soil samples collected from each borehole will be described and used to define the original depth of the basin. The proposed borehole locations are shown in Figure 4-1. Prior to soil sampling, GPR and EM surveys will be conducted to better define the lateral and vertical extent of the basin. The proposed borehole locations may be changed based on the results of the GPR and EM surveys. The GPR survey is described in greater detail in Section 4.5.1. To determine if contaminants from the RdACB OU have laterally migrated from the basin or overflowed from the basin to the perimeter surface soil/vadose zone soils, ten borehole locations (RAC-07 through RAC-16) around the perimeter of the basin footprint will be sampled (Figure 4-1). The perimeter boreholes will characterize potential surface releases from the displacement of standing water or waste observed during backfill operations. Boreholes RAC-07, RAC-11, and RAC-12 are located topographically downgradient of the basin.

If the perimeter samples fail to screen "clean," one stepout borehole will be sampled proximate to the suspect location. The stepout boring will be located $3 \mathrm{~m}(10 \mathrm{ft})$ from the suspect borehole and perpendicular to the basin boundary. Stepout sampling will begin at the elevation where contamination was first detected.

Samples will be collected beneath the RdACB OU and at the perimeter of the basin with a splitspoon sampler using DPT at the following intervals (Figure 4-5):

- 0 to $0.3 \mathrm{~m}(0$ to $1 \mathrm{ft}) \mathrm{bls}$

- 0.3 to $1.2 \mathrm{~m}(1$ to $4 \mathrm{ft}) \mathrm{bls}$

- 1.2 to $2.1 \mathrm{~m}(4$ to $7 \mathrm{ft}$ ) bls (contingent based on 0.3 to $1.2 \mathrm{~m}$ [1 to $4 \mathrm{ft}$ ] screening results)

- 2.1 to $3.0 \mathrm{~m}(7$ to $10 \mathrm{ft}) \mathrm{bls}$

- 3.0 to $3.9 \mathrm{~m}(10$ to $13 \mathrm{ft}) \mathrm{bls}$

The locations and intervals of these borings may be adjusted based on the results of the GPR and EM survey. Each sample will be screened for both radioactivity and VOCs. Soil samples collected deeper than $3.9 \mathrm{~m}$ (13 ft) bls (depending upon the elevation of the basin bottom) will be 
screened for radioactivity and VOCs. A sample will be considered "clean" if radioactivity is below $20 \mathrm{pCi} / \mathrm{g}$ for gross alpha, or below $50 \mathrm{pCi} / \mathrm{g}$ for nonvolatile beta-gamma, and if VOCs are less than $1 \mathrm{ppm}$ above background. If the deepest required soil sample interval (estimated at approximately $3.9 \mathrm{~m}[13 \mathrm{ft}]$ bls) does not screen "clean," then samples will be collected

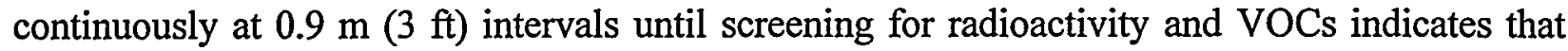
two consecutive soil samples screen clean. If soil sampling is terminated because two consecutive samples screen "clean" for radioactivity and VOCs, the last sample interval will be sent to the offsite laboratory for detailed analyses. The results of the offsite analyses will be used to confirm the accuracy of the screening results and to define the vertical extent of contamination.

All samples will be sent to an offsite laboratory for analysis and will be analyzed for the following:

- TCL VOCs

- TCL SVOCs

- TCL pesticides/PCBs

- TAL inorganics

- Full radiological analysis

\subsubsection{Background Soil, Sediment, and Surface Water Characterization}

Site-specific background samples will be collected and analyzed to quantify concentrations of naturally occurring or non-unit related constituents. These data will be used to establish the $2 \mathrm{X}$ average background screening values, which in turn will be used to screen against the unitspecific sample results to determine the magnitude of contamination associated with waste unit operations. Background surface, subsurface, and deep soil samples will be collected from six locations (RAC-19 through RAC-24) indicated in Figure 4-2. The background locations will be hydraulically upgradient of the RdACB OU in an area expected to be un-impacted by former RdACB OU operations.

Background soil sampling will occur after the soil samples beneath the basin have been collected. The borehole depths and sampling intervals at the background locations will be consistent with the borehole depths and sampling intervals of the basin and perimeter borings. 
Soil samples will be collected with a split-spoon sampler using DPT, and all samples will be sent to an offsite laboratory for analysis and will be analyzed for the same suites of analyses as for the basin (Section 4.3.1).

Site-specific background sediment and surface water samples will be collected and analyzed to quantify concentrations of naturally occurring or non-unit related constituents. These data will be used to establish $2 \mathrm{X}$ average background screening values.

Background sediment and surface water samples will be collected from three locations (RAC-25 through RAC-27) in the bottomland hardwood swamp south of the RdACB OU. Background sediment and surface water samples will be collected with a stainless steel scoop, and all samples will be sent to an offsite laboratory for analysis. Background sediment and surface water samples will be analyzed for the same suites of analyses as unit-specific samples.

\subsection{Exposure Media Characterization}

To evaluate exposure media pathways identified in the CSM, surface soils downslope of the basin and groundwater will be characterized to support risk assessment and contaminant fate and transport analyses. Air and biota were also identified as exposure media in the CSM. However, these media will not be evaluated because they are not considered significant pathways for exposure. Table 4-3 provides a summary of exposure source sampling, locations, and suites of analytes.

\subsubsection{Downslope Soil, Sediment, and Surface Water}

Two site-specific boreholes (RAC-17 and RAC-18) will be sampled to determine if contaminants from the unit were discharged through an overflow culvert downslope in the drainage ditch. The boreholes will be located immediately below the surface water drainage culvert, downslope of the RdACB OU (Figure 4-1). The boreholes will be advanced with a hand auger from 0 to $0.3 \mathrm{~m}$ $(0$ to $1 \mathrm{ft}$ ) and 0.3 to $1.2 \mathrm{~m}$ ( 1 to $4 \mathrm{ft}$ ) bls. Contingent stepout sampling (RAC-28 through RAC34) will continue to be collected until two clean stepout locations are encountered. Additionally, surface water and sediment samples will be collected from four locations (RAC-35 through RAC-38) in the bottomland hardwood swamp at the intersection of the drainage path and the swamp. These samples will be analyzed for the following constituents: 
- TCL VOCs

- TCL SVOCs

- TCL pesticides/PCBs

- TAL inorganics

- Full radiological analysis

If any soil samples fail to screen "clean," two additional boreholes will be drilled downslope of the previous borings. This process will continue until two consecutive samples are screened "clean."

\subsubsection{Groundwater}

Three Water Table Aquifer monitoring wells (BRD-6D, BRD-7D, and BRD-8D) and three Gordon Aquifer monitoring wells (BRD-2C, BRD-6C, and BRD-7C) are proposed for installation for this investigation. The three monitoring wells installed in the Gordon Aquifer (below the Gordon Confining Unit) will be used to determine the vertical hydraulic gradient between the Water Table Aquifer and the Gordon Aquifer, as well as groundwater flow direction and groundwater quality in the Gordon Aquifer. The monitoring well locations were determined based upon characteristics and direction of local groundwater flow (Figure 4-3). Tables 4-2 and 4-4 summarize groundwater samples and constituents to be analyzed. Wells BRD-6D and BRD6C will serve as unit background wells. Wells BRD-7D, BRD-7C, and BRD-8D will be located downgradient of the basin. Well BRD-2C will be located within $3 \mathrm{~m}(10 \mathrm{ft})$ of existing monitoring well BRD-2, located side-gradient of the basin. Lithologic and geotechnical data will be collected during the installation of these wells as described in Sections 4.5.2 and 4.5.3, respectively. The data needs to be addressed by the groundwater investigation are as follows:

- Determining USCs and ARAR COCs

- Generating definitive data for risk assessment

- Defining the nature and extent of contamination in the Water Table and Gordon Aquifers (if present)

The existing and proposed wells will be sampled 30 days apart following groundwater sampling procedures presented in WSRC Manual 3Q5 (WSRC 1997). The 30-day period between the two 
sampling events will allow for adequate aquifer recovery and timely collection and analysis of the groundwater quality data. The five existing wells will be redeveloped and new dedicated pumps will be installed prior to sampling. Samples will be analyzed for the constituents listed in Table 4-2. These data will indicate whether contaminants have migrated from the basin through the vadose zone and into the groundwater, and will be used in contaminant fate and transport modeling and risk analyses. In addition, field parameters, such as temperature, $\mathrm{pH}$, specific conductance, and turbidity, will be recorded at each monitoring well. These parameters are used to indicate when formation water is being pumped from the well. Once the parameters stabilize, the groundwater sample is collected. In addition, these parameters provide an indication of water quality and may be useful in evaluating data anomalies.

If the existing and newly installed wells cannot sufficiently determine the extent of contamination and geometry of the groundwater plume (if present), groundwater samples will be collected downgradient of the basin with DPT. After an evaluation of the DPT groundwater data, additional groundwater monitoring wells will be installed in areas required to define the horizontal and vertical extent of groundwater contamination. Prior to performing DPT and monitoring well installation activities, an addendum to this Work Plan will be submitted to the appropriate regulatory agencies for approval.

\subsection{Physical Characteristics}

Physical/analytical parameters of the RdACB OU will be obtained to evaluate the CSM and to explain the lithologic, hydrogeologic, and geotechnical characteristics of the basin to perform contaminant fate and transport analysis.

\subsubsection{Geophysical Survey}

\subsubsection{Ground Penetrating Radar}

Prior to soil sampling, a GPR survey will be conducted to better define the lateral and vertical extent of the basin. The GPR survey results will be used to help determine the depth to the bottom of the original basin. This information will be used to determine the proper soil sample locations and interval depths required to characterize the basin soils. Four GPR transects will be run parallel to the long axis of the basin, and seven GPR transects will be run transverse to the long axis of the basin. The proposed transect locations are shown in Figure 4-4. 
The depth of penetration of GPR is dependent on the lithology and amount of moisture in the

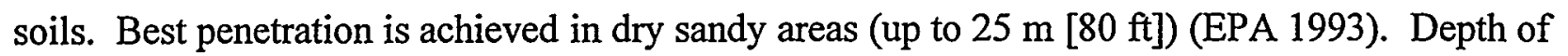
penetration is typically 1 to $15 \mathrm{~m}$ ( 3 to $50 \mathrm{ft}$ ) and is further reduced in moist and/or clayey soils.

\subsubsection{Electromagnetic Survey}

In addition to a GPR survey, an EM survey also will be conducted. The EM survey can be used to help locate buried bulk wastes with and without metal (to depths up to $6 \mathrm{~m}$ [20 ft]) (EPA 1993) that may potentially be buried beneath the basin. The EM survey, however, is susceptible to interference due to the presence of metal on the surface (in this case, the chain-link fence that surrounds the perimeter of the site). Because of this limitation, transects will be located only in the interior portions of the basin footprint. The transect locations will be identical to those of the GPR survey, excluding the outermost transects. The proposed transect locations are shown in Figure 4-4.

\subsubsection{Lithologic Characterization}

All lithologic samples will be described during the soil sampling and monitoring well installation activities following the procedures in WSRC Manual 3Q5 (WSRC 1997).

Continuous core logging will be conducted during installation of the background monitoring well and at one of the downgradient monitoring wells. Soil samples will be described and classified in accordance with Manual 3Q5. At each pilot borehole, the following geophysical logs will be run:

- Caliper

- Natural gamma

- Resistivity

- Spontaneous potential

\subsubsection{Geotechnical Characterization}

The geotechnical data will be used to determine the integrity of the Gordon Confining Unit in preventing vertical migration of potentially contaminated groundwater. Undisturbed soil samples will be collected from the first confining layer (Gordon Confining Unit) encountered for 
geotechnical characterization of the RdACB OU. The undisturbed soil samples will be collected from each of the pilot boreholes drilled for each monitoring well installed in the Gordon Aquifer. One sample will be collected using Shelby tubes at each location.

The samples will be analyzed for the following geotechnical properties:

- $\mathrm{pH}$

- Horizontal and vertical hydraulic conductivity

- TOC

- $\mathrm{CEC}$

- Total soil porosity

- Atterberg limits

- Grain size distribution

- Bulk density

- Moisture content

\subsubsection{Field Permeability Testing}

Field hydraulic permeability tests (slug tests) will be performed on all monitoring wells to further define the hydraulic conductivity of the Water Table Aquifer. Rising head tests will be performed on each well, and the data will be analyzed using the Bouwer and Rice Method (Bouwer and Rice 1976).

\subsubsection{Summary of Test Method}

This test method describes the field procedures involved in conducting an instantaneous head (slug) test. The slug test method involves causing a sudden change in head in a test well and measuring the water level response within that well. Head change may be induced by removing a known quantity or "slug" of water from the well, rapidly removing a mechanical "slug" from below the water level, or decreasing the air pressure in the well casing. The water level response in the well is a function of the mass of water in the well and the transmissivity and coefficient of storage of the aquifer. 
The slug test provides an advantage over pumping tests in that it does not require the disposal of large quantities of water that may be produced. This advantage is of special importance when testing a potentially contaminated aquifer. However, slug tests reflect conditions near the well and are influenced by near-well conditions, such as gravel pack, poor well development, and skin effects.

\subsubsection{2 $\quad$ Test Procedure}

A pressure transducer linked to a data logger will be used to measure head change with time. Prior to each test, the water level in the test well will be measured for a period of about the duration of the test to determine the pre-test water level fluctuations and to determine a reference static water level.

At each test well location, the test will be performed first either by injecting a slug of water or by emplacing a mechanical slug below the water level. After the water level has recovered to static, a rising head test will be conducted by removing either a slug of water or the mechanical slug. There is no fixed requirement for the magnitude of the change in water level. Similar results can be achieved with a wide range of induced head change. Generally a head change of 0.3 to $0.9 \mathrm{~m}$ ( 1 to $3 \mathrm{ft}$ ) is adequate.

\subsubsection{Presentation and Interpretation of Results}

The water level tables of data collected during each test and the data plots used in analysis of the data will be presented in an EXCEL spreadsheet. The data plots and the straight-line matches and corresponding parameters at match points will be shown graphically in EXCEL.

The test reports will include the following:

- Date, time, and well identification

- Method of slug injection or withdrawal, as well as whether the test is a falling head or rising head test

- Inside diameter of the well screen and well casing above the screen

- Volume of slug (although this information is not necessary to do a Bouwer and Rice analysis) 
- Depth of well, and length and depth of screen

- Pre-testing water-level trend

Water levels measured during the test will include information on date, clock time, and time since the test started, along with the data logger and pressure transducer used.

\subsection{Investigation-Derived Waste Identification, Generation, and Management}

Sampling activities associated with the RdACB OU may generate both aqueous and non-aqueous investigation-derived waste (IDW). These materials will be managed in accordance with the IDW Management Plan (WSRC 1994b). Aqueous IDW may consist of decontamination rinsates and purge water from monitoring wells, and drilling fluids. Non-aqueous IDW may consist of material from drilling mud, personal protective equipment, and excess soil from drilling within the unit. It is anticipated that decontamination rinsates and purge water from monitoring wells will generate three 55-gallon drums of aqueous IDW per monitoring well. All DPT boreholes will generate no more than one 55-gallon drum of combined excess soil. Each pilot borehole drilled during monitoring well installation will generate almost three 55-gallon drums of excess soil and two 55-gallon drums of drilling fluids. Personal protective equipment will be decontaminated and reused, where possible. Additional IDW-specific information will be documented in an IDW Management Strategy, which will be maintained in the project file. 


\section{FIGURES}


This page intentionally left blank. 


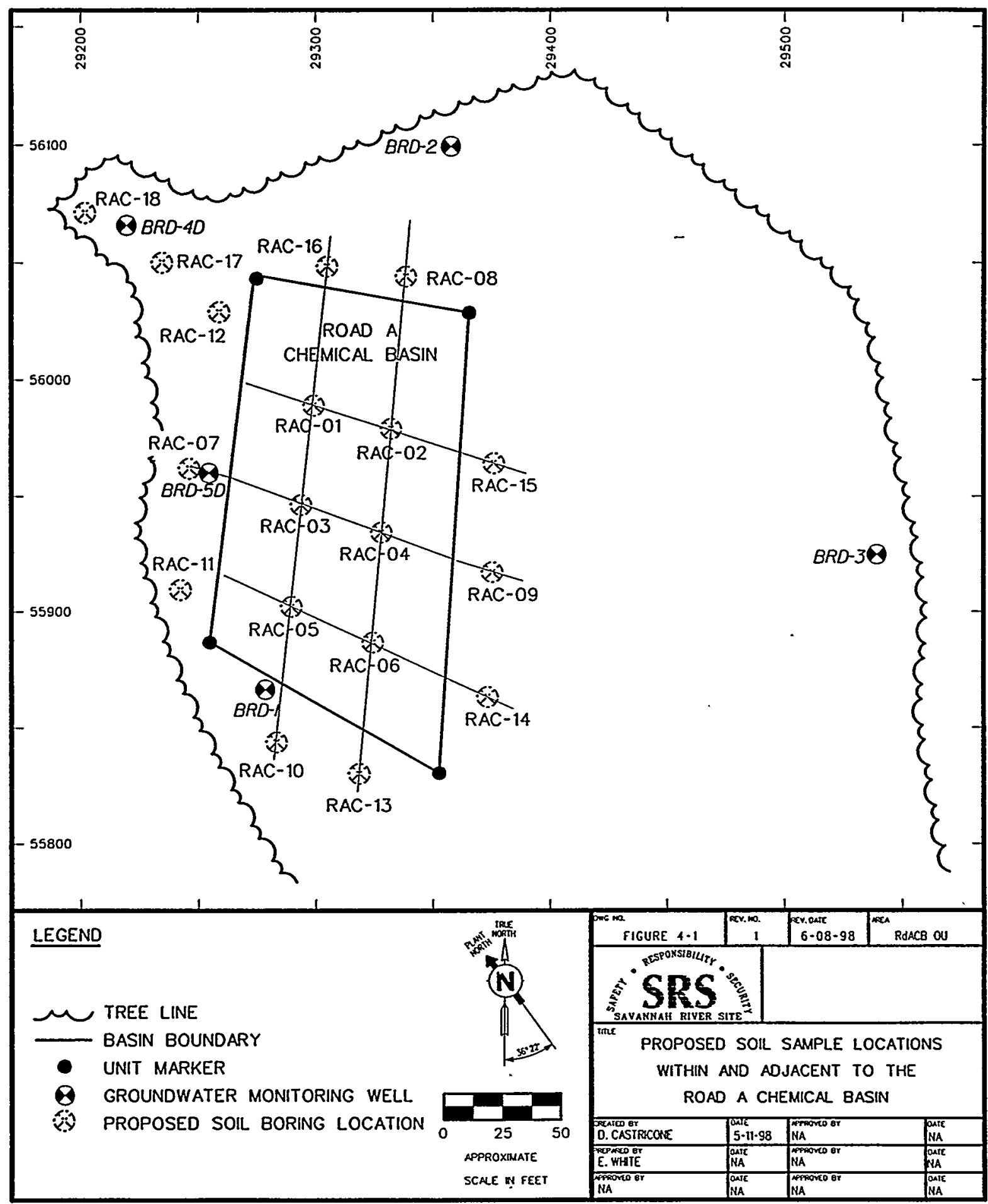

Figure 4-1. Proposed Soil Sample Locations Within and Adjacent to the Road A Chemical Basin 
This page intentionally left blank. 


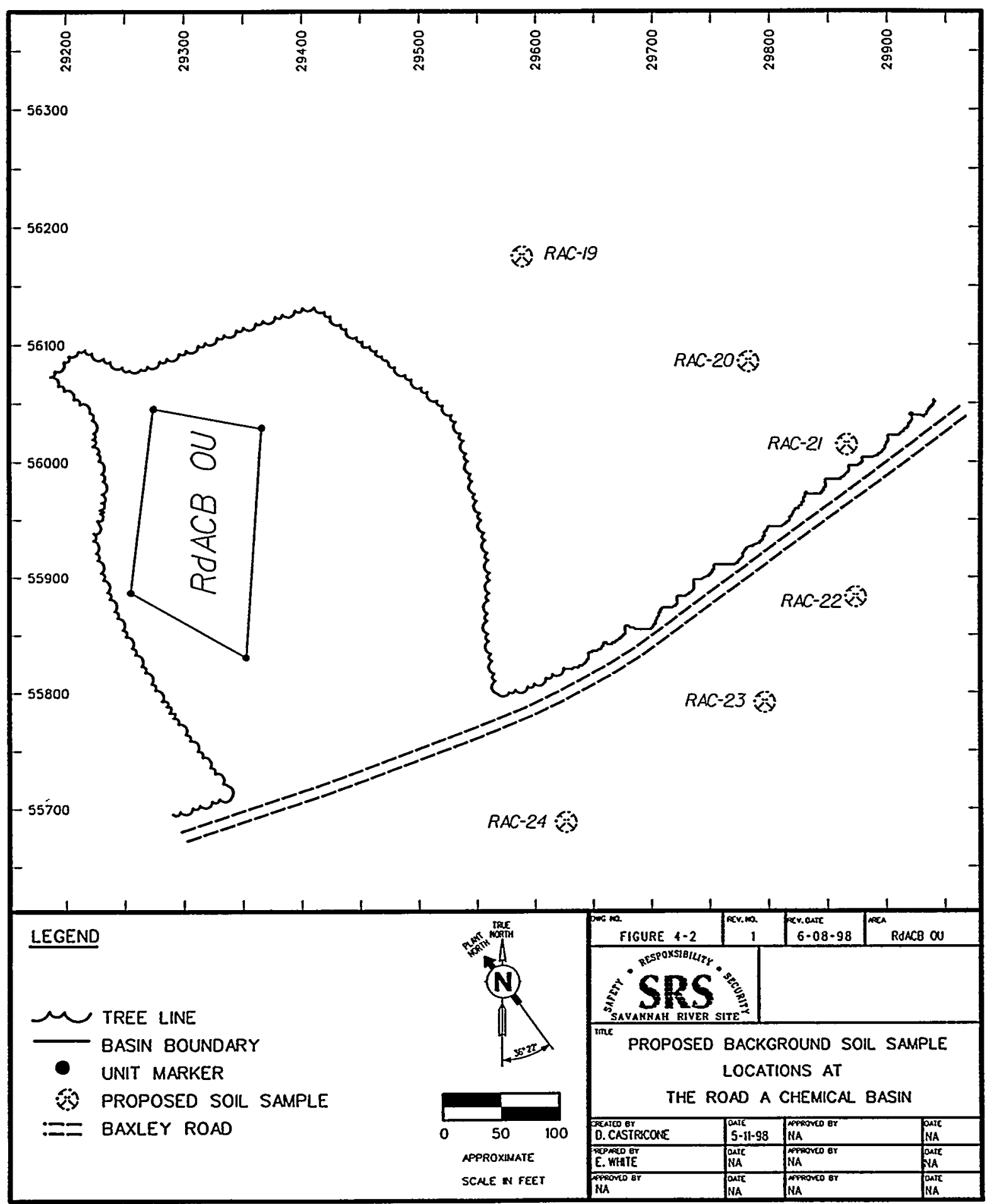

Figure 4-2. Proposed Background Soil Sample Locations at the Road A Chemical Basin 
This page intentionally left blank. 


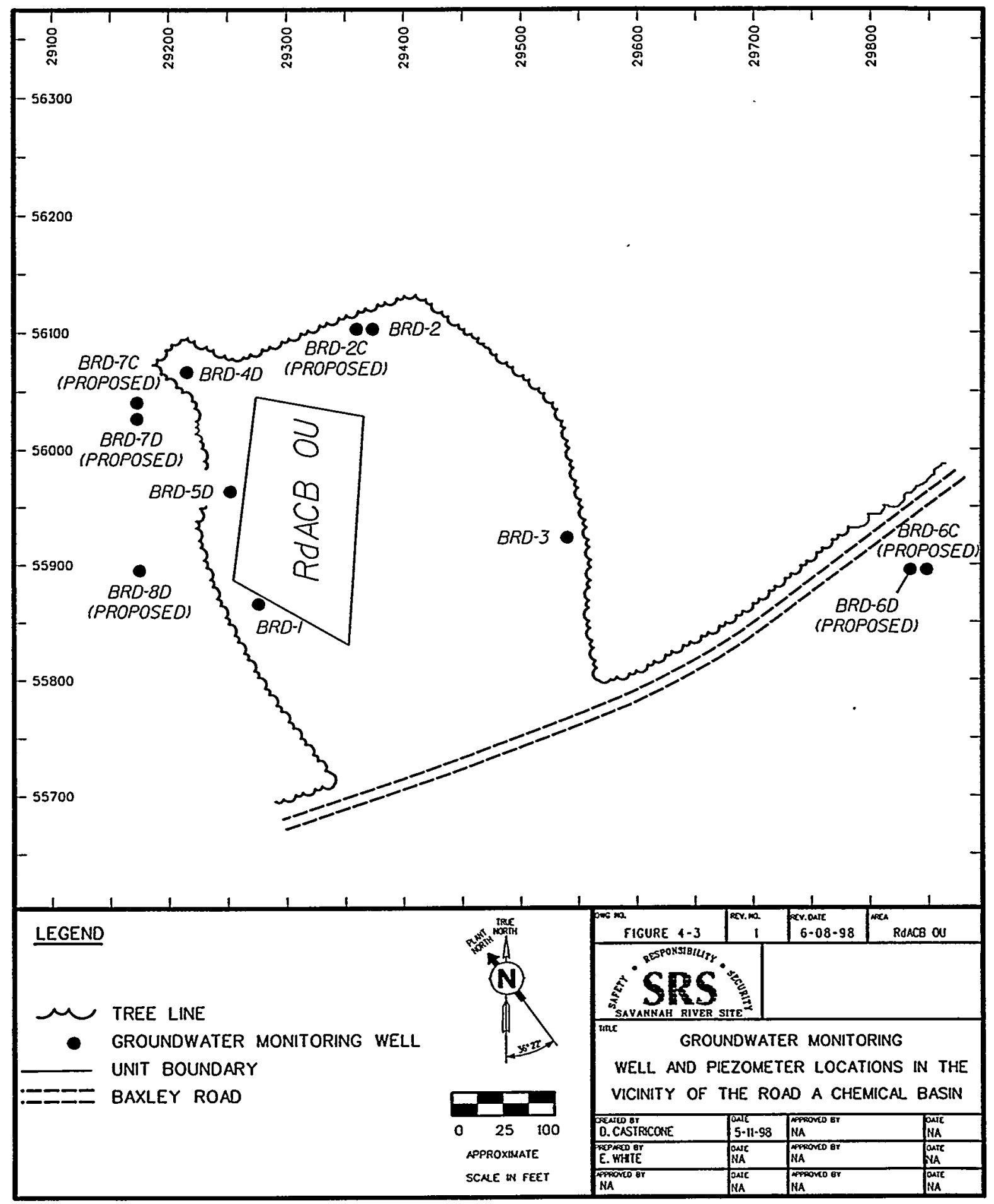

Figure 4-3. Groundwater Monitoring Well and Piezometer Locations in the Vicinity of the Road A Chemical Basin 
This page intentionally left blank. 


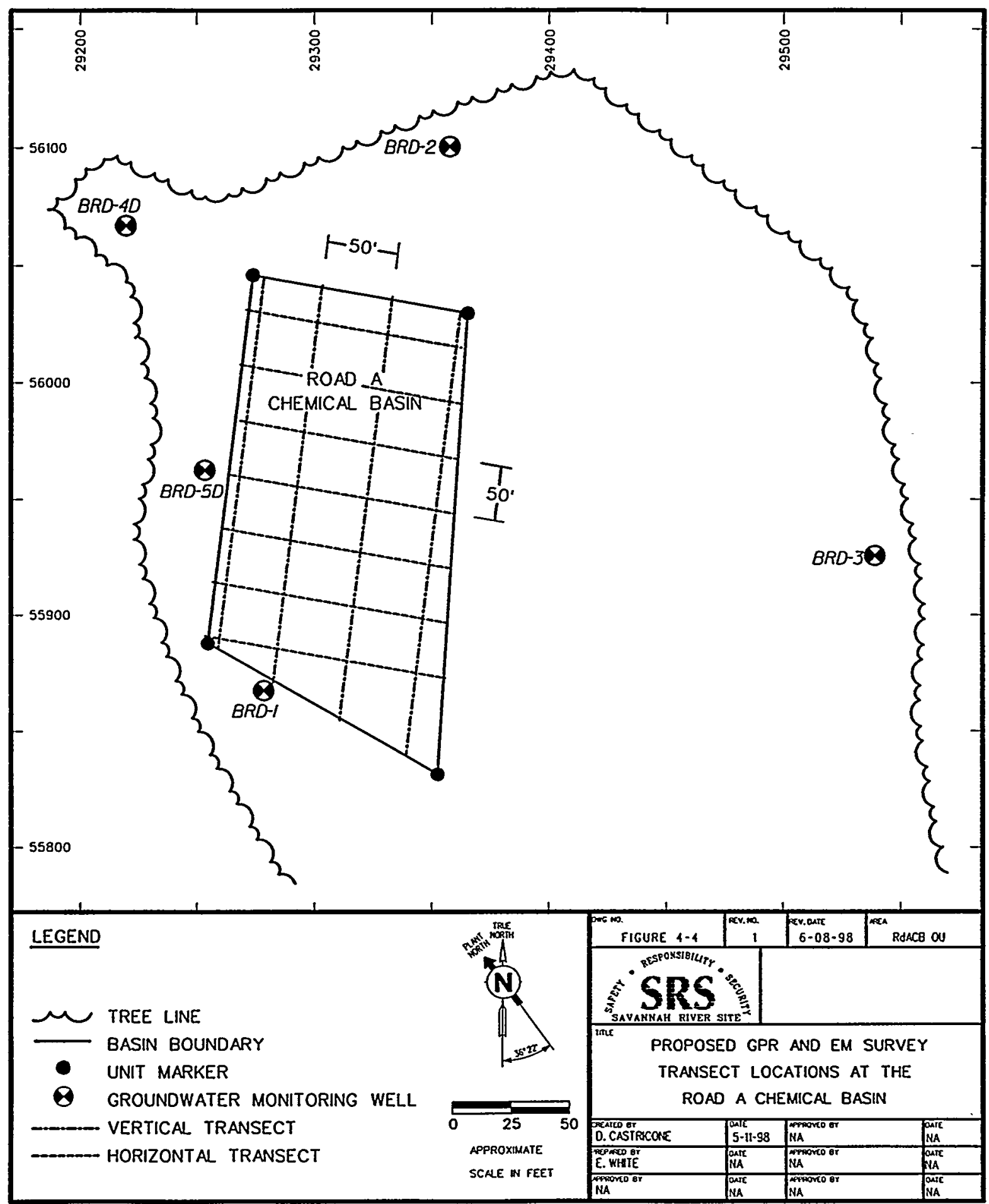

Figure 4-4. Proposed GPR and EM Survey Transect Locations at the Road A Chemical Basin 
This page intentionally left blank. 


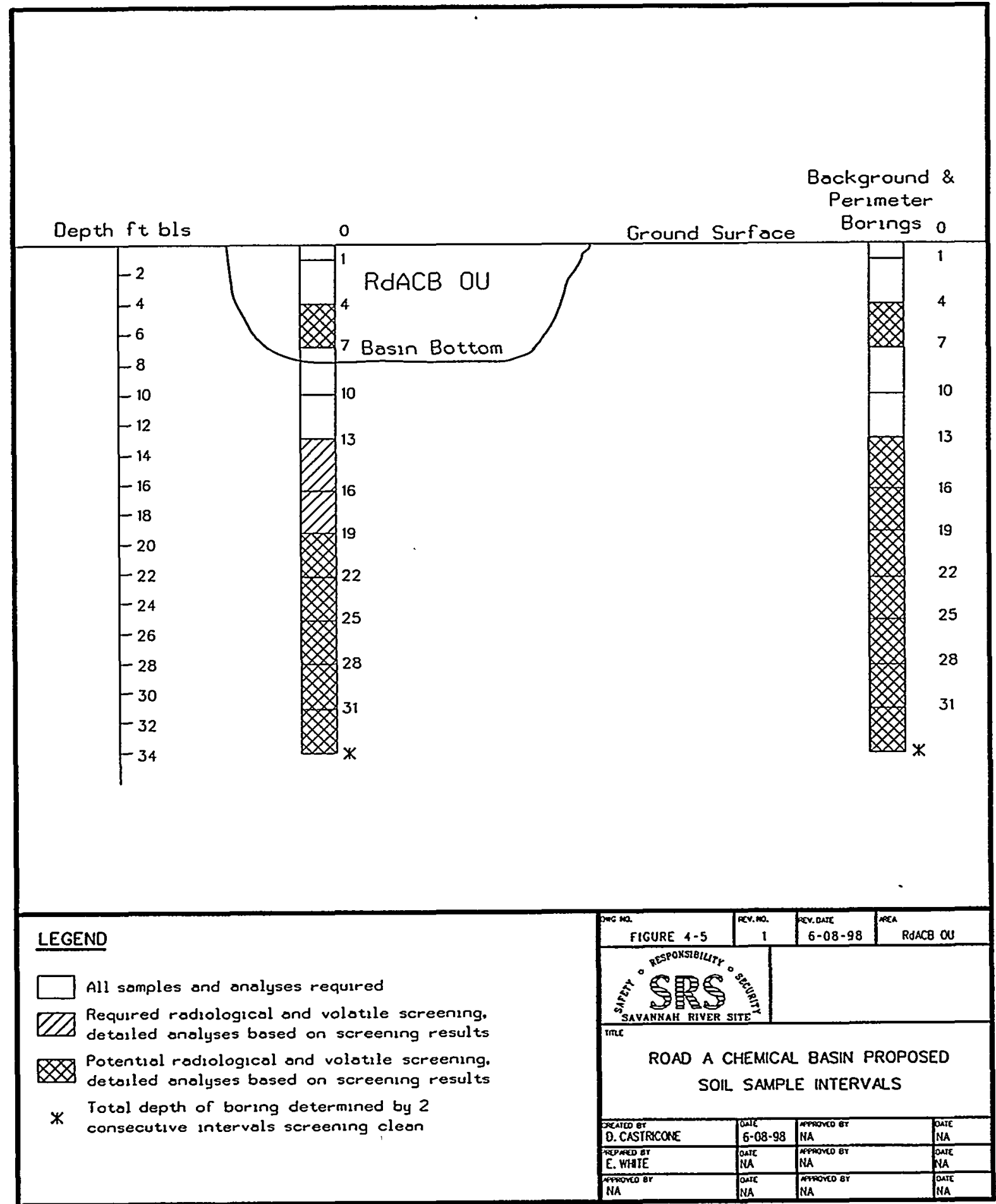

Figure 4-5. Road A Chemical Basin Proposed Soil Sample Intervals 
This page intentionally left blank. 


\section{TABLES}


This page intentionally left blank. 


\section{Table 4-1. Summary of Characterization Activities at the RdACB OU}

\begin{tabular}{|c|c|c|c|}
\hline Unit Component & Data Needs & $\begin{array}{c}\text { Characterization } \\
\text { Activity }\end{array}$ & Parameters \\
\hline $\begin{array}{l}\text { RdACB } \\
\text { Lithology/Hydrogeology }\end{array}$ & $\begin{array}{l}\text { Determine unit-specific } \\
\text { lithologic and hydrogeologic } \\
\text { characteristics. Generate unit- } \\
\text { specific geotechnical data for } \\
\text { contaminant fate and transport } \\
\text { analysis and FS. }\end{array}$ & $\begin{array}{l}\text { Install three Water Table } \\
\text { Aquifer monitoring wells } \\
\text { Install three monitoring wells } \\
\text { in the Gordon Aquifer. } \\
\text { Geophysically log two wells } \\
\text { installed in the Gordon Aquifer } \\
\text { Perform slug tests on new } \\
\text { wells. } \\
\text { Collect water level data in } \\
\text { existing and proposed } \\
\text { monitoring wells } \\
\text { Collect geotechnical data from } \\
\text { the three new monitoring wells } \\
\text { installed in the Gordon Aquifer }\end{array}$ & $\begin{array}{l}\text { Resistivity, gamma, caliper, SP } \\
\text { Slug tests to calculate hydraulic } \\
\text { conductivity } \\
\text { Hydraulic head to determine head } \\
\text { reversal } \\
\text { Shelby tubes: pH, Hydrometer, } \\
\text { horizontal/vertical conductivity, TOC, } \\
\text { CEC, porosity, Atterberg Limits, grain } \\
\text { size distribution, bulk density, moisture } \\
\text { content. }\end{array}$ \\
\hline Background Soil Quality & $\begin{array}{l}\text { Determine } 2 X \text { average } \\
\text { background soil concentrations. }\end{array}$ & $\begin{array}{l}\text { Collect soil samples with a } \\
\text { split-spoon sampler using DPT } \\
\text { at the same sample intervals for } \\
\text { the boreholes located in the } \\
\text { basin. }\end{array}$ & $\begin{array}{l}\text { TAL/TCL and full radiological analysis } \\
\text { for all samples. }\end{array}$ \\
\hline $\begin{array}{l}\text { Background Sediment and } \\
\text { Surface Water Quality }\end{array}$ & $\begin{array}{l}\text { Determine } 2 X \text { average } \\
\text { background sediment and } \\
\text { surface water concentrations }\end{array}$ & $\begin{array}{l}\text { Collect sediment samples from } \\
\text { the } 0.0-1.0 \mathrm{ft} \text { interval with a } \\
\text { stainless steel scoop. Surface } \\
\text { water samples will also be } \\
\text { collected with a stainless steel } \\
\text { scoop. }\end{array}$ & $\begin{array}{l}\text { TALTCL and full radiological analysis } \\
\text { for all samples. }\end{array}$ \\
\hline Basin Surface Soils $(0.0-1.0 \mathrm{ft})$ & $\begin{array}{l}\text { Determine USCs and } \\
\text { vertical/horizontal extent of } \\
\text { contamination within basin and } \\
\text { generate definitive level data } \\
\text { for risk assessment. }\end{array}$ & $\begin{array}{l}\text { Collect and analyze soil } \\
\text { samples from } 0.0-1.0 \mathrm{ft} \text { interval } \\
\text { from six grid sample locations. }\end{array}$ & $\begin{array}{l}\text { VOC and gross alpha and nonvolatile } \\
\text { beta field screening to be performed on } \\
\text { all samples. TAL TCL and full } \\
\text { radiological analysis for all samples. }\end{array}$ \\
\hline $\begin{array}{l}\text { Basin Subsurface Soils (1.0- } \\
4.0 \mathrm{ft})\end{array}$ & $\begin{array}{l}\text { Determine USCs and } \\
\text { vertical/horizontal extent of } \\
\text { contamination within basin and } \\
\text { generate definitive level data } \\
\text { for risk assessment. }\end{array}$ & $\begin{array}{l}\text { Collect and analyze soil } \\
\text { samples from } 1.0-4.0 \mathrm{ft} \text { interval } \\
\text { from six grid sample locations. }\end{array}$ & $\begin{array}{l}\text { VOC and gross alpha and nonvolatile } \\
\text { beta field screening to be performed on } \\
\text { all samples. TALTCL and full } \\
\text { radiological analysis for all samples. }\end{array}$ \\
\hline Basin Deep Soils (>4.0 ft) & $\begin{array}{l}\text { Determine USCs and } \\
\text { vertical/horizontal extent } \\
\text { of contamination within } \\
\text { basin and generate } \\
\text { definitive level data for } \\
\text { contaminant fate and } \\
\text { transport analysis. } \\
\text { Continue deep soil borings } \\
\text { to determine vertical extent } \\
\text { of contamination. }\end{array}$ & $\begin{array}{l}\text { Collect and analyze soil } \\
\text { samples from basin soils }>4.0 \mathrm{ft} \\
\text { interval from six grid sample } \\
\text { locations. } \\
\text { Sample } 4.0-7.0 \mathrm{ft} \text { interval } \\
\text { contingent as VOC and } \\
\text { radiological screening } \\
\text { indicates. }\end{array}$ & $\begin{array}{l}\text { VOC and gross alpha and nonvolatile } \\
\text { beta field screening to be performed on } \\
\text { all samples. TAL TCL and full } \\
\text { radiological analysis for all required } \\
\text { sample locations (non-contingent). }\end{array}$ \\
\hline
\end{tabular}




\section{Table 4-1. Summary of Characterization Activities at the RdACB OU (continued)}

\begin{tabular}{|c|c|c|c|}
\hline Unit Component & Data Needs & $\begin{array}{c}\text { Characterization } \\
\text { Activity }\end{array}$ & Parameters \\
\hline $\begin{array}{l}\text { Basin Deep Soils }(>4.0 \mathrm{ft}) \\
\text { (continued) }\end{array}$ & & $\begin{array}{l}\text { Sampling of } 7.0-10.0 \text { and } 10.0- \\
13.0 \mathrm{ft} \text { intervals is required for } \\
\text { the full TAL } / \mathrm{TCL} \text { and } \\
\text { speciated radiological suites. } \\
\text { Contingency sampling based } \\
\text { on VOC and radiological } \\
\text { screening for soil samples }>13.0 \\
\text { ft. }\end{array}$ & \\
\hline Basin Perimeter Soils & $\begin{array}{l}\text { Determine if contaminants } \\
\text { from RdACB OU have } \\
\text { laterally migrated from } \\
\text { basin bottoms or } \\
\text { overflowed from basin to } \\
\text { perimeter surface/vadose } \\
\text { zone soils. }\end{array}$ & $\begin{array}{l}\text { Collect and analyze soil } \\
\text { samples from } 0.0-1.0,1.0-4.0 \text {, } \\
7.0-10.0,10.0-13.0 \mathrm{ft} \text { intervals. } \\
\text { All other samples and analyses } \\
\text { contingent as VOC and } \\
\text { radiological screening } \\
\text { indicates. } \\
\text { Step-out } 10 \mathrm{ft} \text { if lateral } \\
\text { contamination of media is } \\
\text { detected. Step-out sampling } \\
\text { begins at elevation where } \\
\text { contamination was detected. }\end{array}$ & $\begin{array}{l}\text { VOC and gross alpha and nonvolatile } \\
\text { beta-gamma field screening to be } \\
\text { performed on all samples. TAL/TCL } \\
\text { and full radiological analysis for all } \\
\text { required sample locations. } \\
\text { All other analyses contingent as VOC } \\
\text { and radiological screening indicates. }\end{array}$ \\
\hline $\begin{array}{l}\text { Downslope Surface and } \\
\text { Subsurface Soil }\end{array}$ & $\begin{array}{l}\text { Determine if contaminants } \\
\text { from RdACB OU were } \\
\text { carried downgradient in } \\
\text { drainage ditch by erosion } \\
\text { or sheet flow. }\end{array}$ & $\begin{array}{l}\text { Sample locations } 0.0-1.0 \mathrm{ft} \text { and } \\
1.0-4.0 \mathrm{ft} \text { at the outlet pipe } \\
\text { discharge point. }\end{array}$ & $\begin{array}{l}\text { VOC and gross alpha and nonvolatile } \\
\text { beta-gamma field screening to be } \\
\text { performed on all samples. TAL/TCL } \\
\text { and full radiological analysis for all } \\
\text { required sample locations. } \\
\text { All other analyses contingent as VOC } \\
\text { and radiological screening indicates. }\end{array}$ \\
\hline $\begin{array}{l}\text { Swamp Sediment and } \\
\text { Surface Water }\end{array}$ & $\begin{array}{l}\text { Determine if contaminants } \\
\text { were carried downgradient } \\
\text { to the swamp. }\end{array}$ & $\begin{array}{l}\text { Collect sediment sample from } \\
\text { the } 0.0-1.0 \mathrm{ft} \text { interval with a } \\
\text { stainless steel scoop. Surface } \\
\text { water samples will also be } \\
\text { collected with a stainless steel } \\
\text { scoop. }\end{array}$ & $\begin{array}{l}\text { TALTCL and full radiological analysis } \\
\text { for all samples. }\end{array}$ \\
\hline Groundwater & $\begin{array}{l}\text { Determine USCs and } \\
\text { ARAR COCs. Generate } \\
\text { definitive level data from } \\
\text { risk assessment. }\end{array}$ & $\begin{array}{l}\text { Collect groundwater samples } \\
\text { from existing and new } \\
\text { monitoring wells for two } \\
\text { episodes } 30 \text { days apart. }\end{array}$ & $\begin{array}{l}\text { TAL/TCL suites and full radiological } \\
\text { speciation required. }\end{array}$ \\
\hline $\begin{array}{l}\text { Groundwater Phase II (if } \\
\text { required) }\end{array}$ & $\begin{array}{l}\text { Determine extent of } \\
\text { contamination and plume } \\
\text { geometry. }\end{array}$ & $\begin{array}{l}\text { Collect groundwater samples } \\
\text { downgradient of the basin with } \\
\text { geoprobe or CPT if possible. } \\
\text { Otherwise install monitoring } \\
\text { wells. }\end{array}$ & $\begin{array}{l}\text { To be determined after evaluation of } \\
\text { groundwater data. }\end{array}$ \\
\hline
\end{tabular}


Table 4-2. Analytical Parameters for Groundwater and Soil Samples

TARGET COMPOUND LIST (TCL)

\begin{tabular}{|c|c|c|c|}
\hline & \multicolumn{2}{|c|}{ Quantitation Limits ${ }^{2}$} & \multirow[b]{2}{*}{ Analytical Method ${ }^{\mathrm{ce}}$} \\
\hline Compound & $\begin{array}{c}\text { Groundwater } \\
(\mu \mathrm{g} / \mathrm{L})\end{array}$ & $\begin{array}{c}\text { Soil }^{b} \\
(\mu \mathrm{g} / \mathrm{kg})\end{array}$ & \\
\hline Volatile Organic Compounds: & & $\cdots$ & \\
\hline Chloromethane & 10 & 10 & $8240 / 8260 \mathrm{~B} / 5035$ \\
\hline Bromomethane & 10 & 10 & $8240 / 8260 \mathrm{~B} / 5035$ \\
\hline Vinyl Chloride & 10 & 10 & $8240 / 8260 \mathrm{~B} / 5035$ \\
\hline Chloroethane & 10 & 10 & $8240 / 8260 \mathrm{~B} / 5035$ \\
\hline Methylene Chloride & 5 & 5 & $8240 / 8260 \mathrm{~B} / 5035$ \\
\hline Acetone & 10 & 10 & $8240 / 8260 \mathrm{~B} / 5035$ \\
\hline Carbon Disulfide & 5 & 5 & $8240 / 8260 \mathrm{~B} / 5035$ \\
\hline 1,1-Dichloroethylene & 5 & 5 & $8240 / 8260 \mathrm{~B} / 5035$ \\
\hline 1,1-Dichloroethane & 5 & 5 & $8240 / 8260 \mathrm{~B} / 5035$ \\
\hline 1,2-Dichloroethylene (total) & 5 & 5 & $8240 / 8260 \mathrm{~B} / 5035$ \\
\hline Chloroform & 5 & 5 & $8240 / 8260 \mathrm{~B} / 5035$ \\
\hline 1,2-Dichloroethane & 5 & 5 & $8240 / 8260 \mathrm{~B} / 5035$ \\
\hline 2-Butanone & 10 & 10 & $8240 / 8260 \mathrm{~B} / 5035$ \\
\hline $1,1,1-$ Trichloroethane & 5 & 5 & $8240 / 8260 \mathrm{~B} / 5035$ \\
\hline Carbon Tetrachloride & 5 & 5 & $8240 / 8260 \mathrm{~B} / 5035$ \\
\hline Vinyl Acetate & 10 & 10 & $8240 / 8260 \mathrm{~B} / 5035$ \\
\hline Bromodichloromethane & 5 & 5 & $8240 / 8260 \mathrm{~B} / 5035$ \\
\hline 1,1,2,2-Tetrachloroethane & 5 & 5 & $8240 / 8260 \mathrm{~B} / 5035$ \\
\hline 1,2-Dichloropropane & 5 & 5 & $8240 / 8260 \mathrm{~B} / 5035$ \\
\hline trans-1,3-Dichloropropene & 5 & 5 & $8240 / 8260 \mathrm{~B} / 5035$ \\
\hline Trichloroethylene & 5 & 5 & $8240 / 8260 \mathrm{~B} / 5035$ \\
\hline Dibromochloromethane & 5 & 5 & $8240 / 8260 \mathrm{~B} / 5035$ \\
\hline 1,1,2-Trichloroethane & 5 & 5 & $8240 / 8260 \mathrm{~B} / 5035$ \\
\hline Benzene & 5 & 5 & $8240 / 8260 \mathrm{~B} / 5035$ \\
\hline cis-1,3-Dichloropropene & 5 & 5 & $8240 / 8260 \mathrm{~B} / 5035$ \\
\hline Bromoform & 5 & 5 & $8240 / 8260 \mathrm{~B} / 5035$ \\
\hline 4-Methyl-2-Pentanone & 10 & 10 & $8240 / 8260 \mathrm{~B} / 5035$ \\
\hline 2-Hexanone & 10 & 10 & $8240 / 8260 \mathrm{~B} / 5035$ \\
\hline Tetrachloroethylene & 5 & 5 & $8240 / 8260 \mathrm{~B} / 5035$ \\
\hline Toluene & 5 & 5 & $8240 / 8260 \mathrm{~B} / 5035$ \\
\hline Chlorobenzene & 5 & 5 & $8240 / 8260 \mathrm{~B} / 5035$ \\
\hline Ethylbenzene & 5 & 5 & $8240 / 8260 \mathrm{~B} / 5035$ \\
\hline Styrene & 51 & 5 & $8240 / 8260 \mathrm{~B} / 5035$ \\
\hline Xylene (total) & 51 & 5 & $8240 / 8260 \mathrm{~B} / 5035$ \\
\hline
\end{tabular}


Table 4-2. Analytical Parameters for Groundwater and Soil Samples (continued)

TARGET COMPOUND LIST (TCL)

\begin{tabular}{|c|c|c|c|}
\hline & \multicolumn{2}{|c|}{ Quantitation Limits $^{\mathrm{a}}$} & \multirow[b]{2}{*}{ Analytical Method ${ }^{\mathrm{ce}}$} \\
\hline Compound & $\begin{array}{c}\text { Groundwater } \\
(\mu \mathrm{g} / \mathrm{L})\end{array}$ & $\begin{array}{c}\text { Soil }{ }^{\mathrm{b}} \\
(\mu \mathrm{g} / \mathrm{kg})\end{array}$ & \\
\hline Semi-Volatile Organic Compounds: & 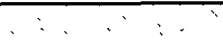 & $\because$ & \\
\hline Phenol & 10 & 330 & $8270 \mathrm{G}$ \\
\hline Benzidine & 10 & 330 & $8270 \mathrm{G}$ \\
\hline bis(2-chloroethyl)ether & 10 & 330 & $8270 \mathrm{G}$ \\
\hline 2-Chlorophenol & 10 & 330 & $8270 \mathrm{G}$ \\
\hline 1,3-Dichlorobenzene & 10 & 330 & $8270 \mathrm{G}$ \\
\hline 1,4-Dichlorobenzene & 10 & 330 & $8270 \mathrm{G}$ \\
\hline Benzyl alcohol & 10 & 330 & $8270 G$ \\
\hline 1,2-Dichlorobenzene & 10 & 330 & $8270 \mathrm{G}$ \\
\hline 2-Methylphenol & 10 & 330 & $8270 \mathrm{G}$ \\
\hline bis(2-chloroisopropyl)ether & 10 & 330 & $8270 \mathrm{G}$ \\
\hline 4-Methylphenol & 10 & 330 & $8270 \mathrm{G}$ \\
\hline N-Nitroso-di-n-propylamine & 10 & 330 & $8270 \mathrm{G}$ \\
\hline Hexachloroethane & 10 & 330 & $8270 \mathrm{G}$ \\
\hline Nitrobenzene & 10 & 330 & $8270 \mathrm{G}$ \\
\hline Isophorone & 10 & 330 & $8270 \mathrm{G}$ \\
\hline 2-Nitrophenol & 10 & 330 & $8270 \mathrm{G}$ \\
\hline 2,4-Dimethylphenol & 10 & 330 & $8270 \mathrm{G}$ \\
\hline Benzoic acid & 50 & 1,600 & $8270 \mathrm{G}$ \\
\hline bis(2-chloroethoxy) methane & 10 & 330 & $8270 G$ \\
\hline 2,4-Dichlorophenol & 10 & 330 & $8270 \mathrm{G}$ \\
\hline 1,2,4-Trichlorobenzene & 10 & 330 & $8270 \mathrm{G}$ \\
\hline Naphthalene & 10 & 330 & $8270 \mathrm{G}$ \\
\hline 4-Chloroaniline & 10 & 330 & $8270 \mathrm{G}$ \\
\hline Hexachlorobutadiene & 10 & 330 & $8270 \mathrm{G}$ \\
\hline 4-Chloro-3-methylphenol & 10 & 330 & $8270 \mathrm{G}$ \\
\hline 2-Methylnaphthalene & 10 & 330 & $8270 G$ \\
\hline Hexachlorocyclopentadiene & 10 & 330 & $8270 \mathrm{G}$ \\
\hline 2,4,6-Trichlorophenol & 10 & 330 & $8270 \mathrm{G}$ \\
\hline 2,4,5-Trichlorophenol & 50 & 1,600 & $8270 \mathrm{G}$ \\
\hline 2-Chloronaphthalene & 10 & 330 & $8270 \mathrm{G}$ \\
\hline 2-Nitroaniline & 50 & 330 & $8270 \mathrm{G}$ \\
\hline Dimethylphthalate & 10 & 330 & $8270 \mathrm{G}$ \\
\hline Acenaphthylene & 10 & 330 & $8270 \mathrm{G}$ \\
\hline 2,6-Dinitrotoluene & 10 & 330 & $8270 \mathrm{G}$ \\
\hline 3-Nitroaniline & 10 & 330 & $8270 \mathrm{G}$ \\
\hline Acenaphthene & 50 & 1,600 & $8270 \mathrm{G}$ \\
\hline
\end{tabular}




\section{Table 4-2. Analytical Parameters for Groundwater and Soil Samples (continued)}

TARGET COMPOUND LIST (TCL)

\begin{tabular}{|c|c|c|c|}
\hline & \multicolumn{2}{|c|}{ Quantitation Limits $^{\mathrm{a}}$} & \multirow[b]{2}{*}{ Analytical Method ${ }^{\mathrm{Ge}}$} \\
\hline Compound & $\begin{array}{c}\text { Groundwater } \\
(\mu \mathrm{g} / \mathrm{L})\end{array}$ & $\begin{array}{c}\text { Soil }^{b} \\
(\mu \mathrm{g} / \mathrm{kg})\end{array}$ & \\
\hline Semi-Volatile Organic Compounds (continued): & \multicolumn{3}{|l|}{ 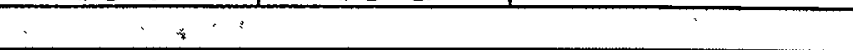 } \\
\hline 2,4-Dinitrophenol & 50 & 1,600 & $8270 \mathrm{G}$ \\
\hline 4-Nitrophenol & 50 & 1,600 & $8270 \mathrm{G}$ \\
\hline Dibenzofuran & 10 & 330 & $8270 \mathrm{G}$ \\
\hline 2,4-Dinitrotoluene & 10 & 330 & $8270 \mathrm{G}$ \\
\hline Diethylphthalate & 10 & 330 & $8270 \mathrm{G}$ \\
\hline 4-Chlorophenyl-phenylether & 10 & 330 & $8270 \mathrm{G}$ \\
\hline Fluorene & 10 & 330 & $8270 \mathrm{G}$ \\
\hline 4-Nitroaniline & 50 & 1,600 & $8270 \mathrm{G}$ \\
\hline 4,6-Dinitro-2-methylphenol & 50 & 1,600 & $8270 \mathrm{G}$ \\
\hline N-Nitrosodiphenylamine $e^{d}$ & 10 & 330 & $8270 \mathrm{G}$ \\
\hline 4-Bromophynyl-phenylether & 10 & 330 & $8270 \mathrm{G}$ \\
\hline Hexachlorobenzene & 10 & 330 & $8270 \mathrm{G}$ \\
\hline Pentachlorophenol & 50 & 1,600 & $8270 G$ \\
\hline Phenanthrene & 10 & 330 & $8270 \mathrm{G}$ \\
\hline Anthracene & 10 & 330 & $8270 \mathrm{G}$ \\
\hline Di-n-butylphthalate & 10 & 330 & $8270 \mathrm{G}$ \\
\hline Fluoranthene & 10 & 330 & $8270 \mathrm{G}$ \\
\hline Pyrene & 10 & 330 & $8270 \mathrm{G}$ \\
\hline Butylbenzylphthalate & 10 & 330 & $8270 \mathrm{G}$ \\
\hline 3,3'-Dichlorobenzidine & 20 & 660 & $8270 \mathrm{G}$ \\
\hline Benzo(a)anthracene & 10 & 330 & $8270 \mathrm{G}$ \\
\hline Chrysene & 10 & 330 & $8270 \mathrm{G}$ \\
\hline bis(2-ethylhexyl)phthalate & 10 & 330 & $8270 \mathrm{G}$ \\
\hline Di-n-octylphthalate & 10 & 330 & $8270 \mathrm{G}$ \\
\hline Benzo(b)fluoranthene & 10 & 330 & $8270 \mathrm{G}$ \\
\hline Benzo(k)fluoranthene & 10 & 330 & $8270 \mathrm{G}$ \\
\hline Benzo(a)pyrene & 10 & 330 & $8270 \mathrm{G}$ \\
\hline Indeno(1,2,3-cd)pyrene & 10 & 330 & $8270 \mathrm{G}$ \\
\hline Dibenz(a,h)anthracene & 10 & 3,301 & $8270 \mathrm{G}$ \\
\hline Benzo(g,h,i)perylene & 10 & 3,301 & $8270 \mathrm{G}$ \\
\hline
\end{tabular}


Table 4-2. Analytical Parameters for Groundwater and Soil Samples (continued)

TARGET COMPOUND LIST (TCL)

\begin{tabular}{|c|c|c|c|}
\hline & \multicolumn{2}{|c|}{ Quantitation Limits $^{\mathrm{a}}$} & \multirow[b]{2}{*}{ Analytical Method ${ }^{\mathrm{ce}}$} \\
\hline Compound & $\begin{array}{c}\text { Groundwater } \\
(\mu \mathrm{g} / \mathrm{L})\end{array}$ & $\begin{array}{c}\text { Soil }^{b} \\
(\mu \mathrm{g} / \mathrm{kg})\end{array}$ & \\
\hline \multicolumn{4}{|c|}{ Polynuclear Aromatic Hydrocarbons: } \\
\hline Acenaphthene & 18.0 & 1.2 & 8310 \\
\hline Acenaphthylene & 23.0 & 1.54 & 8310 \\
\hline Anthracene & 6.6 & 0.44 & 8310 \\
\hline Benzo(a)anthracene & 0.13 & 0.009 & 8310 \\
\hline Benzo(a)pyrene & 0.23 & 0.015 & 8310 \\
\hline Benzo(b)fluoranthene & 0.18 & 0.012 & 8310 \\
\hline Benzo(g,h,i)perylene & 0.76 & 0.05 & 8310 \\
\hline Benzo(k)fluoranthene & 0.17 & 0.011 & 8310 \\
\hline Chrysene & 1.5 & 0.1 & 8310 \\
\hline Dibenzo(a,h)anthracene & 0.3 & 0.02 & 8310 \\
\hline Fluoranthrene & 2.1 & 0.14 & 8310 \\
\hline Fluorene & 2.1 & 0.14 & 8310 \\
\hline Indeno(1,2,3-c,d)pyrene & 0.43 & 0.03 & 8310 \\
\hline Naphthalene & 18.0 & 1.2 & 8310 \\
\hline Phenanthrene & 6.4 & 0.42 & 8310 \\
\hline \multicolumn{4}{|l|}{ Pesticides/PCBs: } \\
\hline alpha-BHC & 0.05 & 8 & 8080 \\
\hline beta-BHC & 0.05 & 8 & 8080 \\
\hline delta-BHC & 0.05 & 8 & 8080 \\
\hline gamma-BHC (Lindane) & 0.05 & 8 & 8080 \\
\hline Heptachlor & 0.05 & 8 & 8080 \\
\hline Aldrin & 0.05 & 8 & 8080 \\
\hline Heptachlor epoxide & 0.05 & 8 & 8080 \\
\hline Endosulfan I & 0.05 & 8 & 8080 \\
\hline Dieldrin & 0.1 & 16 & 8080 \\
\hline 4,4'-DDE & 0.1 & 16 & 8080 \\
\hline Endrin & 0.1 & 16 & 8080 \\
\hline Endosulfan II & 0.1 & 16 & 8080 \\
\hline $4,4^{\prime}-\mathrm{DDD}$ & 0.1 & 16 & 8080 \\
\hline Endosulfan sulfate & 0.1 & 16 & 8080 \\
\hline 4,4'-DDT & 0.1 & 16 & 8080 \\
\hline Methoxychlor & 0.5 & 80 & 8080 \\
\hline Endrin ketone & 0.1 & 16 & 8080 \\
\hline alpha-chlordane & 0.5 & 80 & 8080 \\
\hline gamma-chlordane & 0.5 & 80 & 8080 \\
\hline Toxaphene & 1 & 160 & 8080 \\
\hline Aroclor-1016 & 0.5 & 80 & 8080 \\
\hline Aroclor-1221 & 0.5 & 80 & 8080 \\
\hline Aroclor-1232 & 0.5 & 80 & 8080 \\
\hline Aroclor-1242 & 0.5 & 80 & 8080 \\
\hline Aroclor-1248 & 0.5 & 80 & 8080 \\
\hline Aroclor-1254 & 1 & 1,601 & 8080 \\
\hline Aroclor-1260 & 1 & 1,601 & 8080 \\
\hline
\end{tabular}




\section{Table 4-2. Analytical Parameters for Groundwater and Soil Samples (continued)}

TARGET COMPOUND LIST (TCL)

\begin{tabular}{|c|c|c|c|}
\hline & \multicolumn{2}{|c|}{ Quantitation Limits ${ }^{2}$} & \multirow[b]{2}{*}{ Analytical Method ${ }^{\mathrm{c}, \mathrm{c}}$} \\
\hline Compound & $\begin{array}{c}\text { Groundwater } \\
(\mu \mathrm{g} / \mathrm{L})\end{array}$ & $\begin{array}{c}\text { Soil }^{\mathrm{b}} \\
(\mu \mathrm{g} / \mathrm{kg})\end{array}$ & \\
\hline Metals: & \multicolumn{3}{|c|}{$\therefore$} \\
\hline Aluminum & 200 & 200 & $6010 \mathrm{~B}$ \\
\hline Antimony & 60 & 60 & 7041 \\
\hline Arsenic & 10 & 10 & 7060 \\
\hline Barium & 200 & 200 & $6010 \mathrm{~B}$ \\
\hline Beryllium & 5 & 5 & 6010B \\
\hline Cadmium & 5 & 5 & 7131 \\
\hline Calcium & 5,000 & 5,000 & $6010 \mathrm{~B}$ \\
\hline Chromium & 10 & 10 & $6010 \mathrm{~B}$ \\
\hline Cobalt & 50 & 50 & $6010 \mathrm{~B}$ \\
\hline Copper & 25 & 25 & $6010 \mathrm{~B}$ \\
\hline Iron & 100 & 100 & $6010 \mathrm{~B}$ \\
\hline Lead & 5 & 5 & 7421 \\
\hline Magnesium & 5,000 & 5,000 & $6010 \mathrm{~B}$ \\
\hline Manganese & 15 & 15 & $6010 \mathrm{~B}$ \\
\hline Mercury & 0.2 & 0.2 & 7470 \\
\hline Nickel & 40 & 40 & $6010 \mathrm{~B}$ \\
\hline Potassium & 5,000 & 5,000 & $6010 \mathrm{~B}$ \\
\hline Selenium & 5 & 5 & 7740 \\
\hline Silver & 10 & 10 & $6010 \mathrm{~B}$ \\
\hline Sodium & 5,000 & 5,000 & $6010 \mathrm{~B}$ \\
\hline Thallium & 10 & 10 & 7841 \\
\hline Vanadium & 50 & 50 & $6010 \mathrm{~B}$ \\
\hline Zinc & 20 & 20 & $6010 \mathrm{~B}$ \\
\hline \multicolumn{4}{|l|}{ Common Anions: } \\
\hline Nitrate & 100 & 100 & 9056 \\
\hline Conventionals: & $\because$ & & 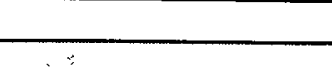 \\
\hline Cyanide & 25 & 500 & 9010 \\
\hline Total Petroleum Hydrocarbons: & $10 \mathrm{mg} / \mathrm{L}$ & $50 \mathrm{mg} / \mathrm{kg}$ & 418.1 \\
\hline RCRA Herbicides: & & & \\
\hline 2,4-Dichlorophenoxyacetic Acid & 1 & 20 & 8150 \\
\hline $2,4,5-\mathrm{TP}$ (Silvex) & 0.5 & 10 & 8150 \\
\hline
\end{tabular}


Table 4-2. Analytical Parameters for Groundwater and Soil Samples (continued)

\section{RADIONUCLIDES}

\begin{tabular}{|c|c|c|c|}
\hline \multirow[b]{2}{*}{ Compound } & \multicolumn{2}{|c|}{ Quantitation Limits ${ }^{\mathbf{a}}$} & \multirow[b]{2}{*}{ Analytical Method $^{\text {se }}$} \\
\hline & $\begin{array}{c}\text { Groundwater } \\
(\mathrm{pCi} / \mathrm{L})\end{array}$ & $\begin{array}{c}\text { Soil }^{\mathrm{b}} \\
\text { (pCi/g) }\end{array}$ & \\
\hline Gross Alpha & 1.5 & 4 & GFPC \\
\hline Nonvolatile Beta & 2 & 10 & GFPC \\
\hline Tritium & 700 & 10 & LS \\
\hline Americium-241 & 1 & 0.6 & $\overline{A S}$ \\
\hline Curium-242 & 1 & 0.6 & $\overline{A S}$ \\
\hline Curium-243 & 1 & 0.6 & AS \\
\hline Curium-244 & 1 & 0.6 & AS \\
\hline Curium-246 & 1 & 0.6 & AS \\
\hline Neptunium-237 & $\mathrm{I}$ & 0.6 & $\overline{\mathrm{AS}}$ \\
\hline Uranium-234 & 1 & 0.6 & $\overline{\mathrm{AS}}$ \\
\hline Uranium-235 & 1 & 0.6 & $\overline{\mathrm{AS}}$ \\
\hline Uranium-238 & 1 & 0.6 & AS \\
\hline Thorium-228 & 1 & 0.1 & AS \\
\hline Thorium-230 & 1 & 0.6 & AS \\
\hline Thorium-232 & 1 & 0.1 & AS \\
\hline Plutonium-238 & 1 & 0.6 & $\overline{\mathrm{AS}}$ \\
\hline Plutonium-239 & 1 & 0.6 & AS \\
\hline Plutonium-240 & 1 & 0.6 & AS \\
\hline Radium-226 & 1 & 0.6 & GS/LC \\
\hline Radium-228 & 1 & 0.8 & GFPC/GS \\
\hline Iodine-129 & 2 & 2 & LEGS \\
\hline Carbon-14 & 200 & 2 & LS \\
\hline Technecium-99 & 300 & 1 & LS \\
\hline Strontium-90 & 2 & 1 & GFPC \\
\hline Sodium-22 & 10 & 0.1 & Gamma SPEC \\
\hline Potassium-40 & 50 & 0.5 & Gamma SPEC \\
\hline Manganese-54 & 10 & 0.6 & Gamma SPEC \\
\hline Cobalt-57 & 10 & 0.1 & Gamma SPEC \\
\hline Cobalt-58 & 10 & 0.1 & Gamma SPEC \\
\hline Cobalt-60 & 10 & 0.1 & Gamma SPEC \\
\hline Zinc-65 & 15 & 0.1 & Gamma SPEC \\
\hline Yttrium-88 & 30 & 0.3 & Gamma SPEC \\
\hline Zirconium-95 & 10 & 0.2 & Gamma SPEC \\
\hline Ruthenium-106 & 60 & 0.5 & Gamma SPEC \\
\hline Tin-113 & 50 & 0.1 & Gamma SPEC \\
\hline Antimony-124 & 10 & 0.1 & Gamma SPEC \\
\hline
\end{tabular}




\section{Table 4-2. Analytical Parameters for Groundwater and Soil Samples (continued)}

\section{RADIONUCLIDES}

\begin{tabular}{|c|c|c|c|}
\hline & \multicolumn{2}{|c|}{ Quantitation Limits ${ }^{a}$} & \\
\hline Compound & $\begin{array}{c}\text { Groundwater } \\
(\mathrm{pCi} / \mathrm{L})\end{array}$ & $\begin{array}{c}\text { Soil }^{6} \\
(\mathrm{pCi} / \mathrm{g})\end{array}$ & Analytical Method ${ }^{\text {ce }}$ \\
\hline Antimony-125 & 20 & 0.2 & Gamma SPEC \\
\hline Cesium-134 & 10 & 0.1 & Gamma SPEC \\
\hline Cesium-137 & 10 & 0.1 & Gamma SPEC \\
\hline Barium-133 & 10 & 0.1 & Gamma SPEC \\
\hline Cerium-144 & 40 & 0.4 & Gamma SPEC \\
\hline Promethium-144 & 10 & 0.1 & Gamma SPEC \\
\hline Promethium-146 & 10 & 0.1 & Gamma SPEC \\
\hline Europium-152 & 40 & 0.6 & Gamma SPEC \\
\hline Europium-154 & 10 & 0.3 & Gamma SPEC \\
\hline Europium-155 & 20 & 0.1 & Gamma SPEC \\
\hline Lead-212 & 15 & 0.5 & Gamma SPEC \\
\hline Thorium-234 & 175 & 5 & Gamma SPEC \\
\hline Actinium-228 & 30 & 0.2 & Gamma SPEC \\
\hline Neptunium-239 & 20 & 0.4 & Gamma SPEC \\
\hline Nickel-59 & 10,001 & 21 & X-Ray SPEC \\
\hline
\end{tabular}

a Specific quantification limits are highly matrix-dependent. The quantification limits listed herein are provided for guidance and may not always be achievable.

b Quantitation limits listed for soil are based on wet weight. The quantification limits calculated by the laboratory for soil, calculated on a dry-weight basis, will be higher.

c Analytical methods may vary between laboratories for the same analysis.
AS
$=$ Alpha Spectroscopy
Gamma SPEC = Previously Gamma PHA
GFPC $=$ Gas Flow Proportional Counting
GS = = Gamma Spectroscopy
LC $\quad=$ Lucas Cell
LEGS = Low Energy Gamma Spectroscopy
LS $\quad=$ Liquid Scintillation
ppt $\quad=$ parts per trillion

d Cannot be separated from Diphenylamine.

c Method 5035 is for soil analysis only. 


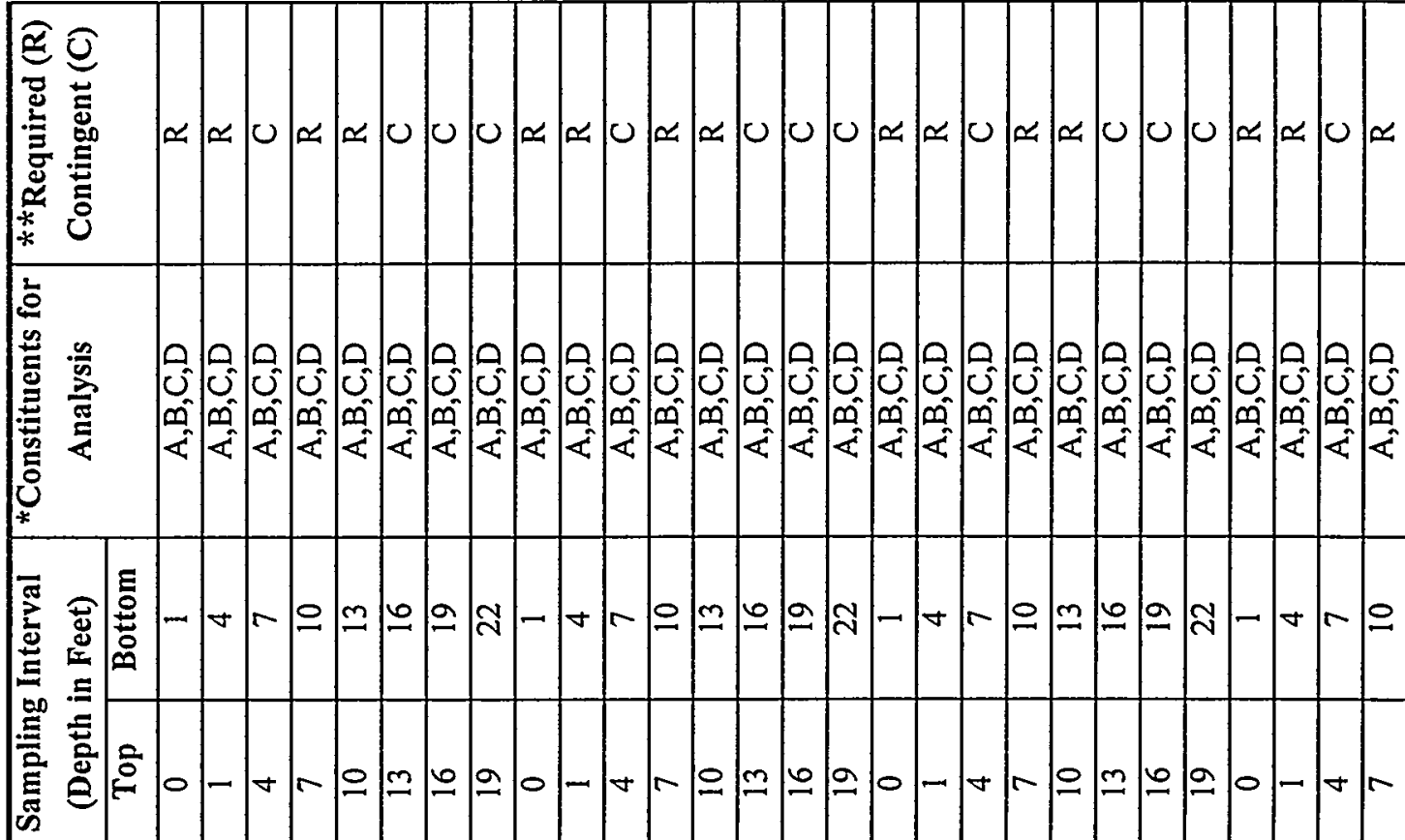

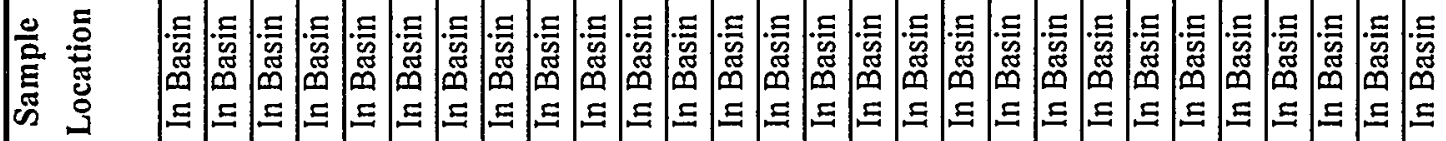

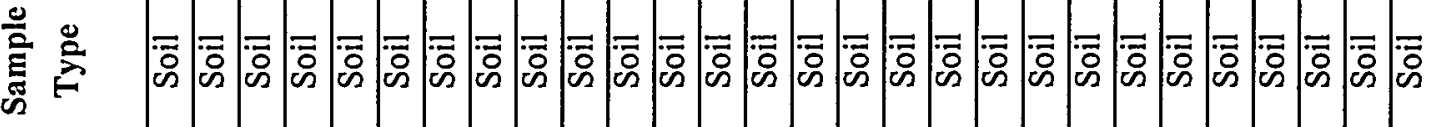

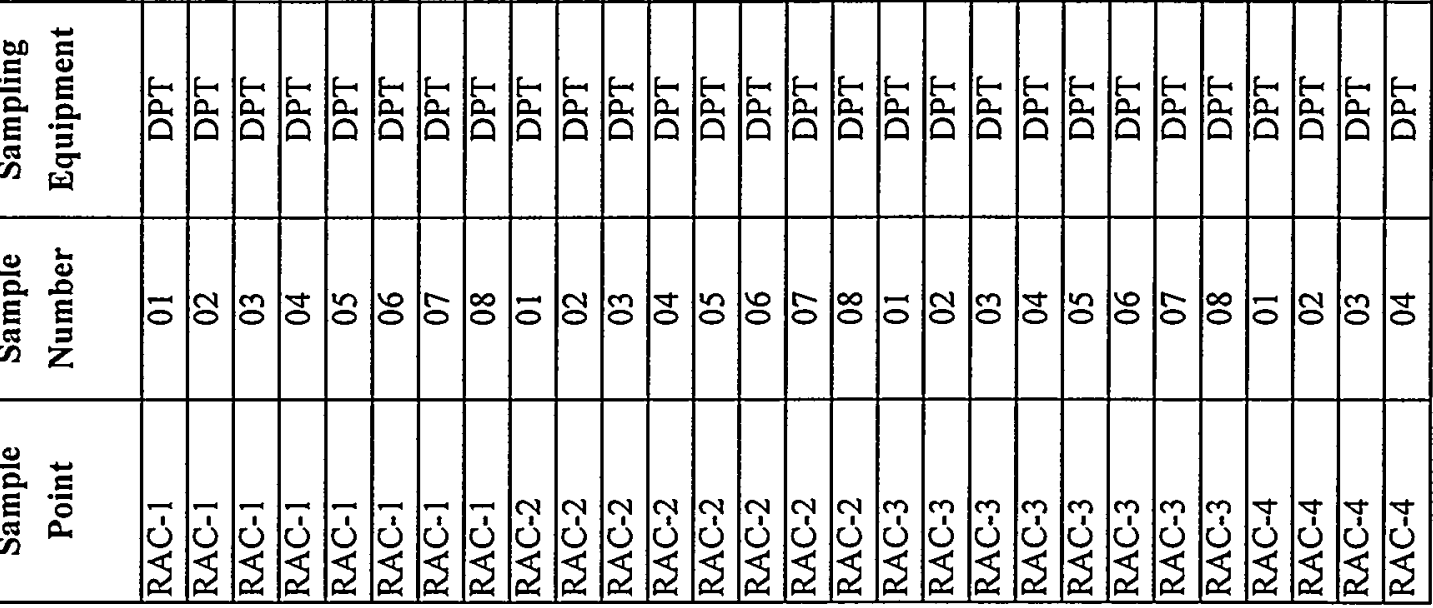




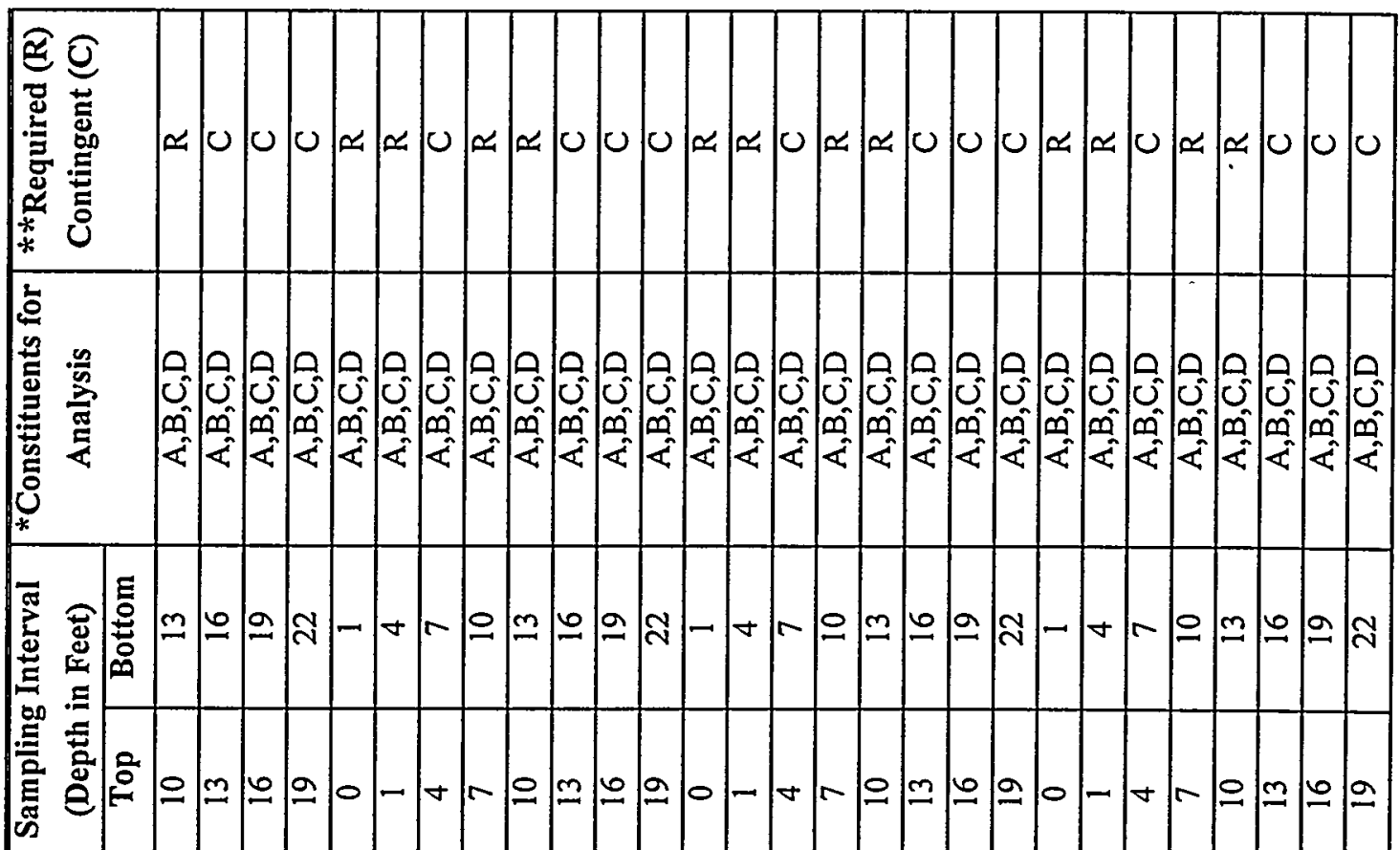

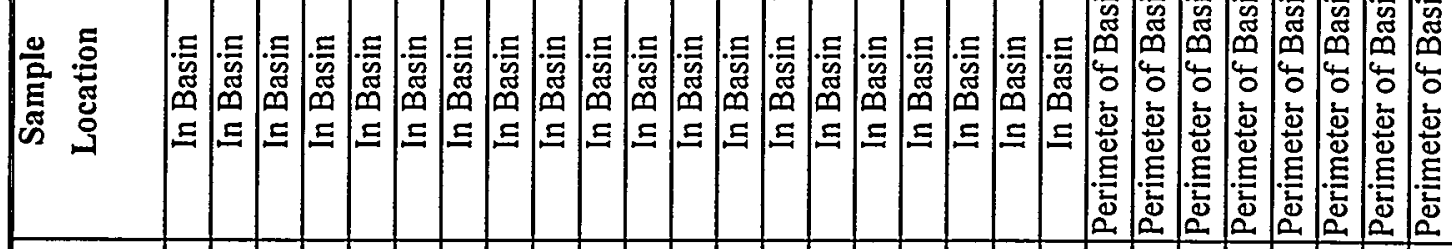

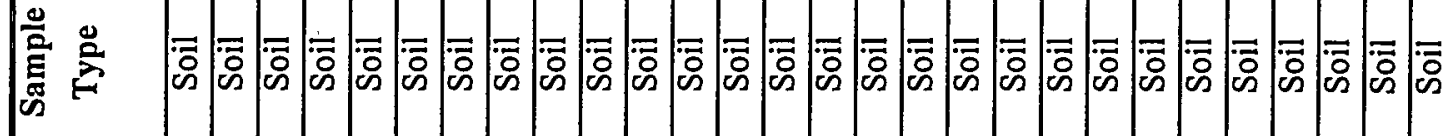

造

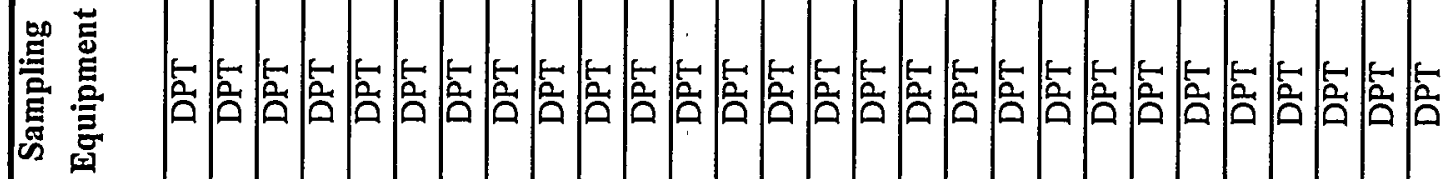

至

要 


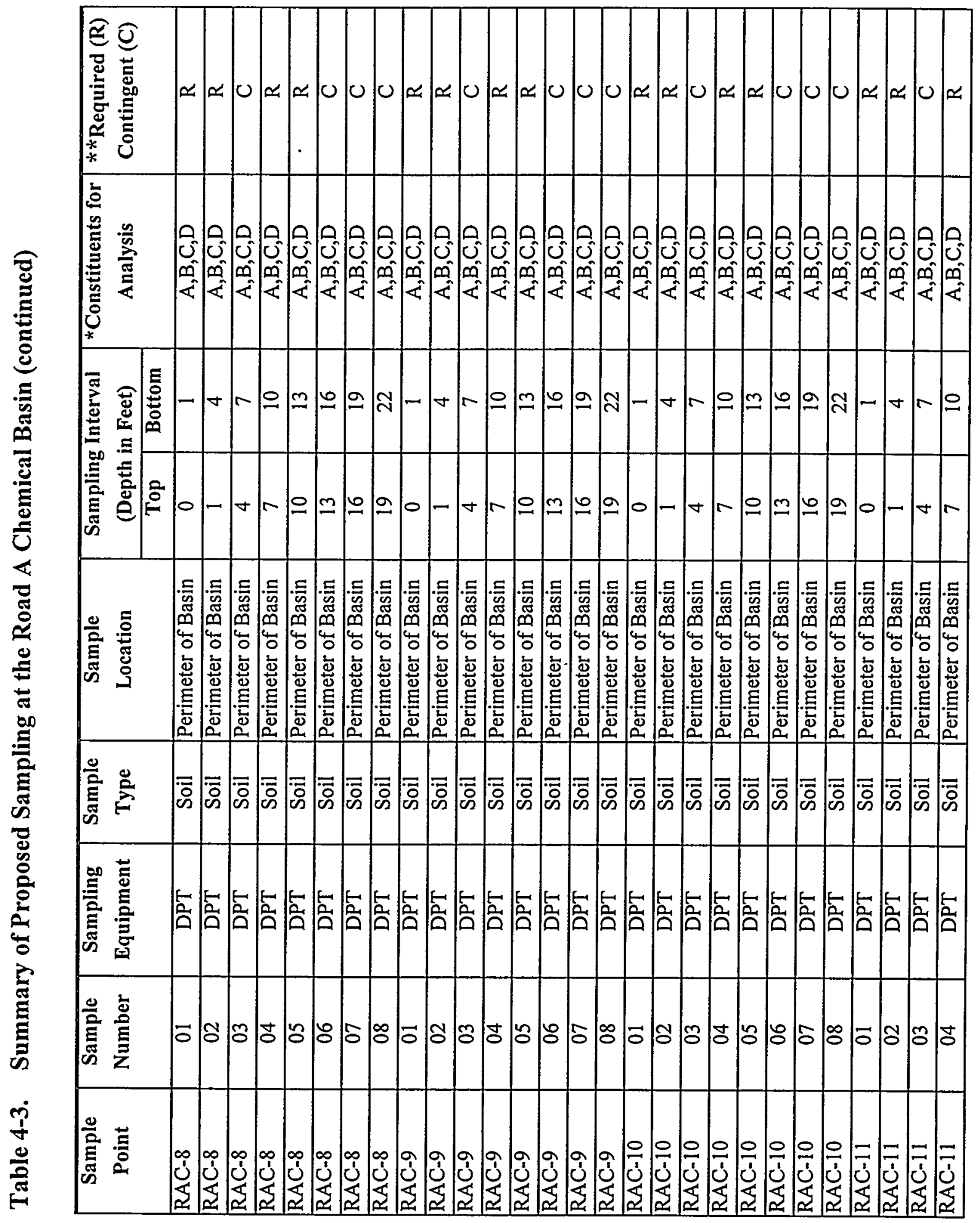




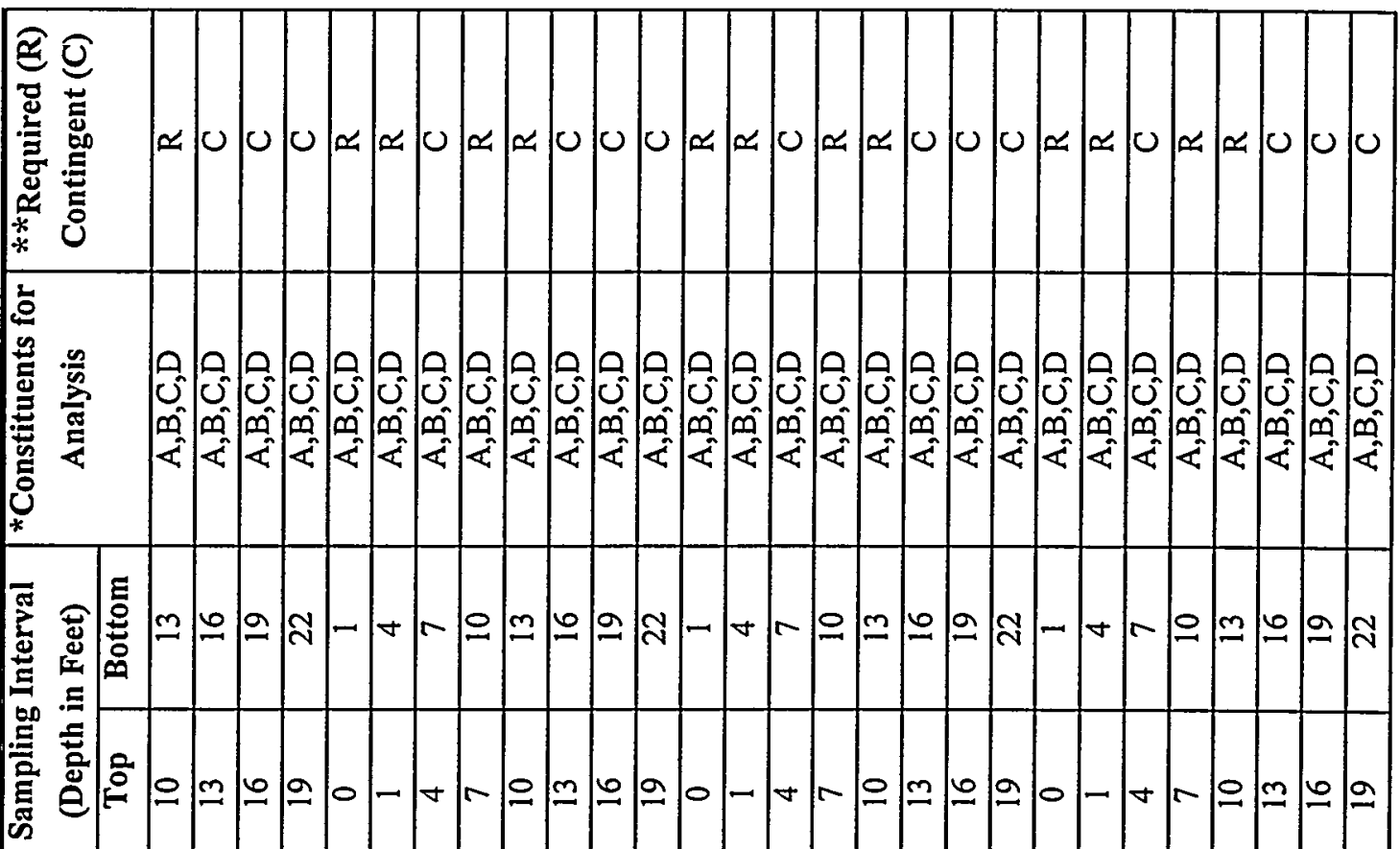

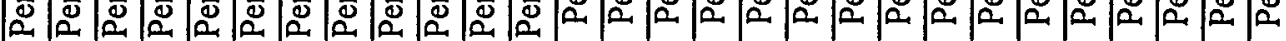

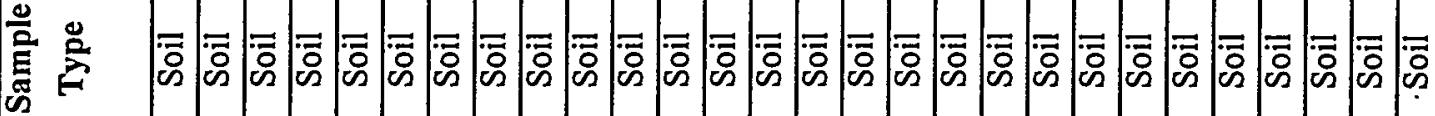
焉 兽 总 ஊ

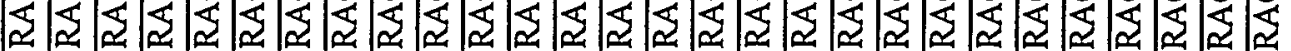




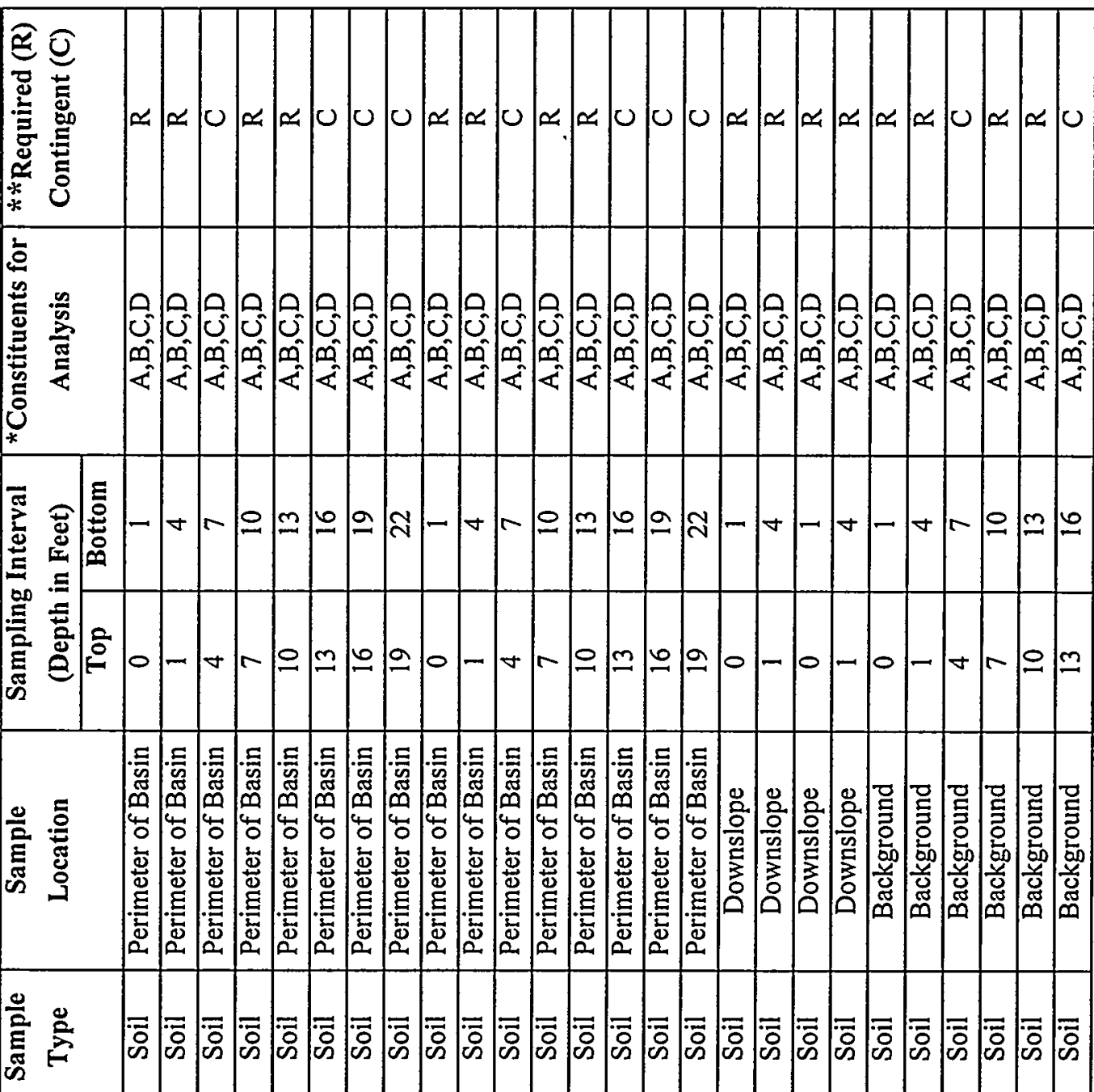

蓄

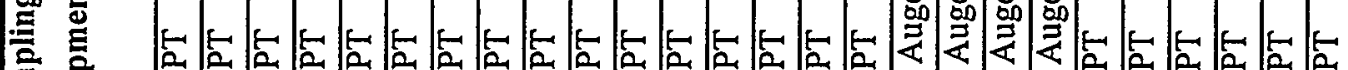

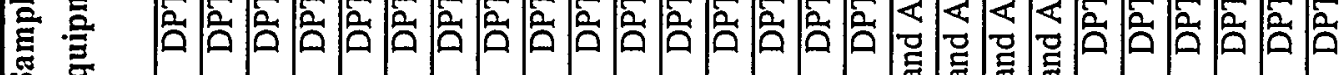

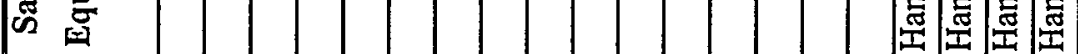

空

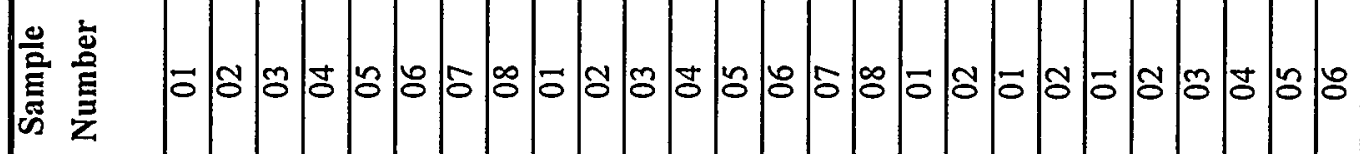

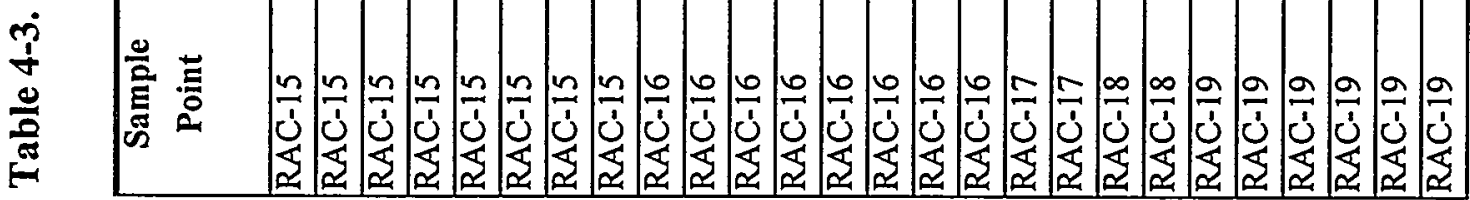




\begin{tabular}{|c|c|c|c|c|c|c|c|c|c|c|c|c|c|c|c|c|c|c|c|c|c|c|c|c|c|}
\hline 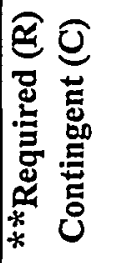 & 0 & 0 & $\alpha$ & $\alpha$ & 0 & $\underline{x}$ & $\infty$ & 0 & 0 & 0 & $\infty$ & $\infty$ & | & $\checkmark \approx$ & 0 & 0 & 0 & $\simeq \mid \infty$ & $=0$ & $\approx$ & $\approx$ & 0 & 0 & $\infty \propto ⿻ 上$ & 0 \\
\hline 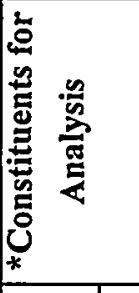 & $\begin{array}{l}0 \\
0 \\
0 \\
\infty \\
<\end{array}$ & $\begin{array}{l}0 \\
0 \\
0 \\
0 \\
<\end{array}$ & $\mid \begin{array}{l}0 \\
0 \\
0 \\
0 \\
<\end{array}$ & $\mid \begin{array}{l}0 \\
0 \\
0 \\
0 \\
\infty \\
4\end{array}$ & $\left|\begin{array}{l}0 \\
0 \\
0 \\
\infty \\
\infty \\
<\end{array}\right|$ & 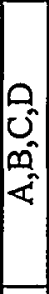 & $\mid \begin{array}{c}0 \\
0 \\
0 \\
\infty \\
< \\
<\end{array}$ & 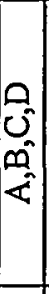 & $\left|\begin{array}{c}0 \\
0 \\
0 \\
n \\
< \\
<\end{array}\right|$ & & $\begin{array}{l}0 \\
0 \\
0 \\
0 \\
0\end{array}$ & & & | & $\mid \begin{array}{l}0 \\
0 \\
0 \\
0 \\
<\end{array}$ & $\mid \begin{array}{l}\Omega \\
0 \\
m \\
-1 \\
\vdots\end{array}$ & $\mid$\begin{tabular}{l|l}
$A$ & 0 \\
0 & 0 \\
$e_{0}^{-}$ & 0 \\
$<$ & 4 \\
$<$ & 4
\end{tabular} & | & : & $\left|\begin{array}{ll}0 & 0 \\
0 \\
0 \\
0 \\
< \\
<\end{array}\right|$ & $\begin{array}{lll}0 & 0 \\
0 & 0 \\
0 & 0 \\
0 & 0 \\
0 & 0\end{array}$ & $\mid \begin{array}{l}a \\
0 \\
0 \\
0 \\
0\end{array}$ & 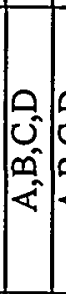 & 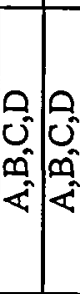 & $\left\{\begin{array}{l}0 \\
0 \\
0 \\
\infty \\
\infty \\
<\end{array}\right.$ \\
\hline 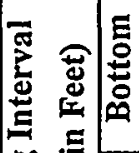 & 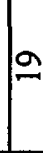 & $\approx$ & - & $\nabla$ & 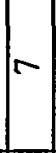 & 응 & $m$ & 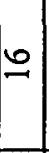 & 2 & 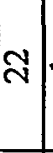 & $\rightarrow$ & $\nabla$ & -10 & $2 m$ & 0 & 2 & สิ & $-\nabla$ & $r$ & 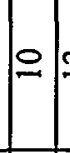 & $\because$ & 20 & $\widehat{N}$ & & r \\
\hline 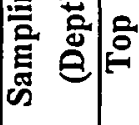 & 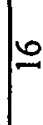 & 2 & 0 & - & $\nabla$ & & 이 & $m$ & $\div$ & $a$ & 0 . & - & $\nabla r$ & -10 & $m$ & $\because$ & $\approx$ & 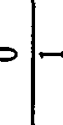 & 10 & $r$ & $\therefore=$ & 10 & 2 & 0 - & | \\
\hline 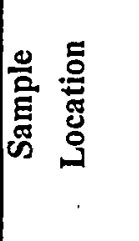 & 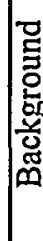 & 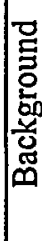 & 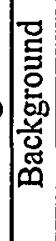 & 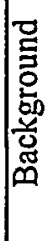 & 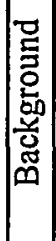 & 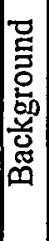 & 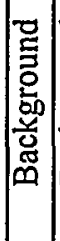 & 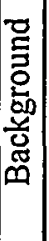 & 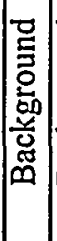 & 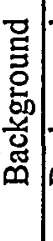 & 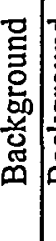 & 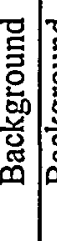 & 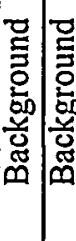 & 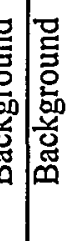 & 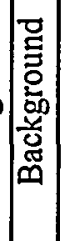 & 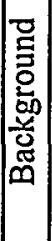 & 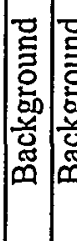 & 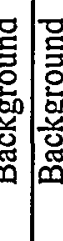 & 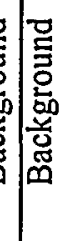 & 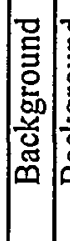 & 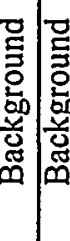 & 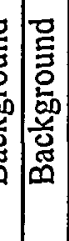 & 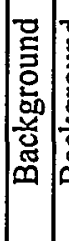 & \begin{tabular}{l|l} 
\\
0
\end{tabular} & 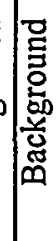 \\
\hline 寜 & $=$ & 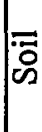 & : & : & $=\overrightarrow{0}$ & $=$ & $=$ & $=$ & $=$ & 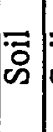 & $=$ & : & : & $\vec{b}$ & $\overrightarrow{\overline{\dot{b}}}$ & $=$ & $=\overline{\bar{D}}$ & $\overline{\bar{c}} \overline{\overline{0}}$ & $=\overline{\bar{\partial}}$ & $\overline{0}$ & $\overrightarrow{\dot{c}}=\overrightarrow{\bar{\partial}}$ & $\vec{b}$ & $\overline{0}$ & $\overline{\dot{\delta}}$ & $\overrightarrow{\bar{D}}$ \\
\hline 哭 & 望 & 占 & 占 & 管 & 客 & 䓃 & 占 & $\mid$ & $\mid$ & 它 & É & 点: & 占占 & 点 & 䒧 & 望 & 䓟点 & 它 & 容 & 售盾 & & 合 & 窝 & 芯芯芯 & 会 \\
\hline 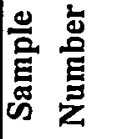 & 5 & & $\sigma$ & 今 & 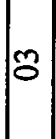 & ठ & 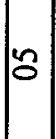 & 8 & & $\infty$ & $\bar{\sigma}$ & $\delta$ & $m \&$ & t & 8 & 5 & 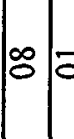 & 5 & 8 & 号 & & 5 & $\%$ & $\sigma \delta$ & 0 \\
\hline 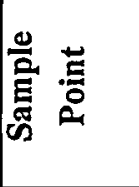 & 告 & & 管 & & 染 & & 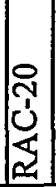 & 告 & 勇 & & 究 & آخ & 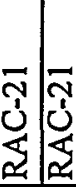 & 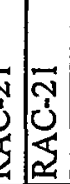 & 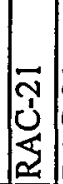 & נָ & 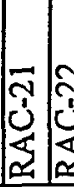 & 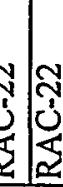 & 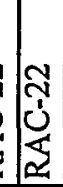 & 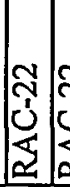 & 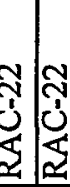 & 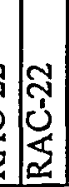 & 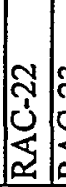 & 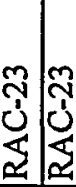 & 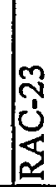 \\
\hline
\end{tabular}


Table 4-3. Summary of Proposed Sampling at the Road A Chemical Basin (continued)

\begin{tabular}{|c|c|c|c|c|c|c|c|c|}
\hline \multirow[t]{2}{*}{$\begin{array}{c}\text { Sample } \\
\text { Point }\end{array}$} & \multirow[t]{2}{*}{$\begin{array}{l}\text { Sample } \\
\text { Number }\end{array}$} & \multirow[t]{2}{*}{$\begin{array}{l}\text { Sampling } \\
\text { Equipment }\end{array}$} & \multirow[t]{2}{*}{$\begin{array}{l}\text { Sample } \\
\text { Type }\end{array}$} & \multirow[t]{2}{*}{$\begin{array}{c}\text { Sample } \\
\text { Location }\end{array}$} & \multicolumn{2}{|c|}{$\begin{array}{l}\text { Sampling Interval } \\
\text { (Depth in Feet) }\end{array}$} & \multirow[t]{2}{*}{$\begin{array}{c}{ }^{*} \text { Constituents for } \\
\text { Analysis }\end{array}$} & \multirow[t]{2}{*}{$\begin{array}{l}* * \text { Required (R) } \\
\text { Contingent (C) }\end{array}$} \\
\hline & & & & & Top & Bottom & & \\
\hline RAC-23 & 04 & $\overline{D P T}$ & Soil & Background & 7 & 10 & $A, B, C, D$ & $\bar{R}$ \\
\hline$\overline{R A C-23}$ & 05 & $\overline{\mathrm{DPT}}$ & Soil & Background & 10 & 13 & $A, B, C, D$ & $\mathrm{R}$ \\
\hline RAC-23 & 06 & $\overline{\mathrm{DPT}}$ & Soil & Background & 13 & 16 & $\mathrm{~A}, \mathrm{~B}, \mathrm{C}, \mathrm{D}$ & $\bar{C}$ \\
\hline RAC-23 & 07 & $\overline{\mathrm{DPT}}$ & Soil & Background & 16 & 19 & $A, B, C, D$ & $\bar{C}$ \\
\hline RAC-23 & 08 & $\overline{\mathrm{DPT}}$ & Soil & Background & 19 & 22 & $A, B, C, D$ & $\mathrm{C}$ \\
\hline RAC-24 & 01 & $\overline{\mathrm{DPT}}$ & Soil & Background & 0 & 1 & $A, B, C, D$ & $\mathrm{R}$ \\
\hline RAC-24 & 02 & DPT & Soil & Background & 1 & 4 & $A, B, C, D$ & $\mathrm{R}$ \\
\hline RAC-24 & 03 & $\overline{\mathrm{DPT}}$ & Soil & Background & 4 & 7 & $A, B, C, D$ & $\bar{C}$ \\
\hline RAC-24 & 04 & DPT & Soil & Background & 7 & 10 & $A, B, C, D$ & $\mathrm{R}$ \\
\hline RAC-24 & 05 & $\overline{\mathrm{DPT}}$ & Soil & Background & 10 & 13 & $A, B, C, D$ & $\bar{R}$ \\
\hline RAC-24 & 06 & $\overline{\mathrm{DPT}}$ & Soil & Background & 13 & 16 & $A, B, C, D$ & $\mathrm{C}$ \\
\hline RAC-24 & 07 & $\overline{\mathrm{DPT}}$ & Soil & Background & 16 & 19 & $\mathrm{~A}, \mathrm{~B}, \mathrm{C}, \mathrm{D}$ & $\mathrm{C}$ \\
\hline RAC-24 & 08 & $\overline{\mathrm{DPT}}$ & Soil & Background & 19 & 22 & $A, B, C, D$ & $\mathrm{C}$ \\
\hline$\overline{R A C-25}$ & 01 & Scoop & Sediment & Background & 0 & 1 & $A, B, C, D$ & $\mathrm{R}$ \\
\hline$\overline{\mathrm{RAC}-25}$ & 02 & Scoop & $\begin{array}{l}\text { Surface } \\
\text { Water }\end{array}$ & Background & 0 & 1 & $A, B, C, D$ & $\bar{R}$ \\
\hline RAC-26 & 01 & Scoop & Sediment & Background & 0 & 1 & $\mathrm{~A}, \mathrm{~B}, \mathrm{C}, \mathrm{D}$ & $\mathrm{R}$ \\
\hline RAC-26 & 02 & Scoop & $\begin{array}{l}\text { Surface } \\
\text { Water }\end{array}$ & Background & 0 & 1 & $\mathrm{~A}, \mathrm{~B}, \mathrm{C}, \mathrm{D}$ & $\bar{R}$ \\
\hline RAC-27 & 01 & Scoop & Sediment & Background & 0 & 1 & $\mathrm{~A}, \mathrm{~B}, \mathrm{C}, \mathrm{D}$ & $\mathrm{R}$ \\
\hline$\overline{R A C-27}$ & 02 & Scoop & $\begin{array}{c}\text { Surface } \\
\text { Water }\end{array}$ & Background & 0 & 1 & $A, B, C, D$ & $\mathrm{R}$ \\
\hline RAC-28 & 01 & Hand Auger & Soil & Downslope & 0 & 1 & $\mathrm{~A}, \mathrm{~B}, \mathrm{C}, \overline{\mathrm{D}}$ & $\bar{C}$ \\
\hline RAC-28 & 02 & Hand Auger & Soil & Downslope & 1 & 4 & $\mathrm{~A}, \mathrm{~B}, \mathrm{C}, \mathrm{D}$ & $\mathrm{C}$ \\
\hline RAC-29 & 01 & Hand Auger & Soil & Downslope & 0 & 1 & $\mathrm{~A}, \mathrm{~B}, \mathrm{C}, \mathrm{D}$ & $\mathrm{C}$ \\
\hline RAC-29 & 02 & Hand Auger & Soil & Downslope & 1 & 4 & $\mathrm{~A}, \mathrm{~B}, \mathrm{C}, \mathrm{D}$ & $\mathrm{C}$ \\
\hline RAC-30 & 01 & Hand Auger & Soil & Downslope & 0 & $\mathrm{~T}$ & $\mathrm{~A}, \mathrm{~B}, \mathrm{C}, \mathrm{D}$ & $\mathrm{C}$ \\
\hline RAC-30 & 02 & Hand Auger & Soil & Downslope & 1 & 4 & $\mathrm{~A}, \mathrm{~B}, \mathrm{C}, \mathrm{D}$ & $\mathrm{C}$ \\
\hline RAC-31 & 01 & Hand Auger & Soil & Downslope & 0 & 1 & $\mathrm{~A}, \mathrm{~B}, \mathrm{C}, \mathrm{D}$ & $\mathrm{C}$ \\
\hline RAC-31 & 02 & Hand Auger & Soil & Downslope & 1 & 4 & $A, B, C, D$ & $\mathrm{C}$ \\
\hline
\end{tabular}



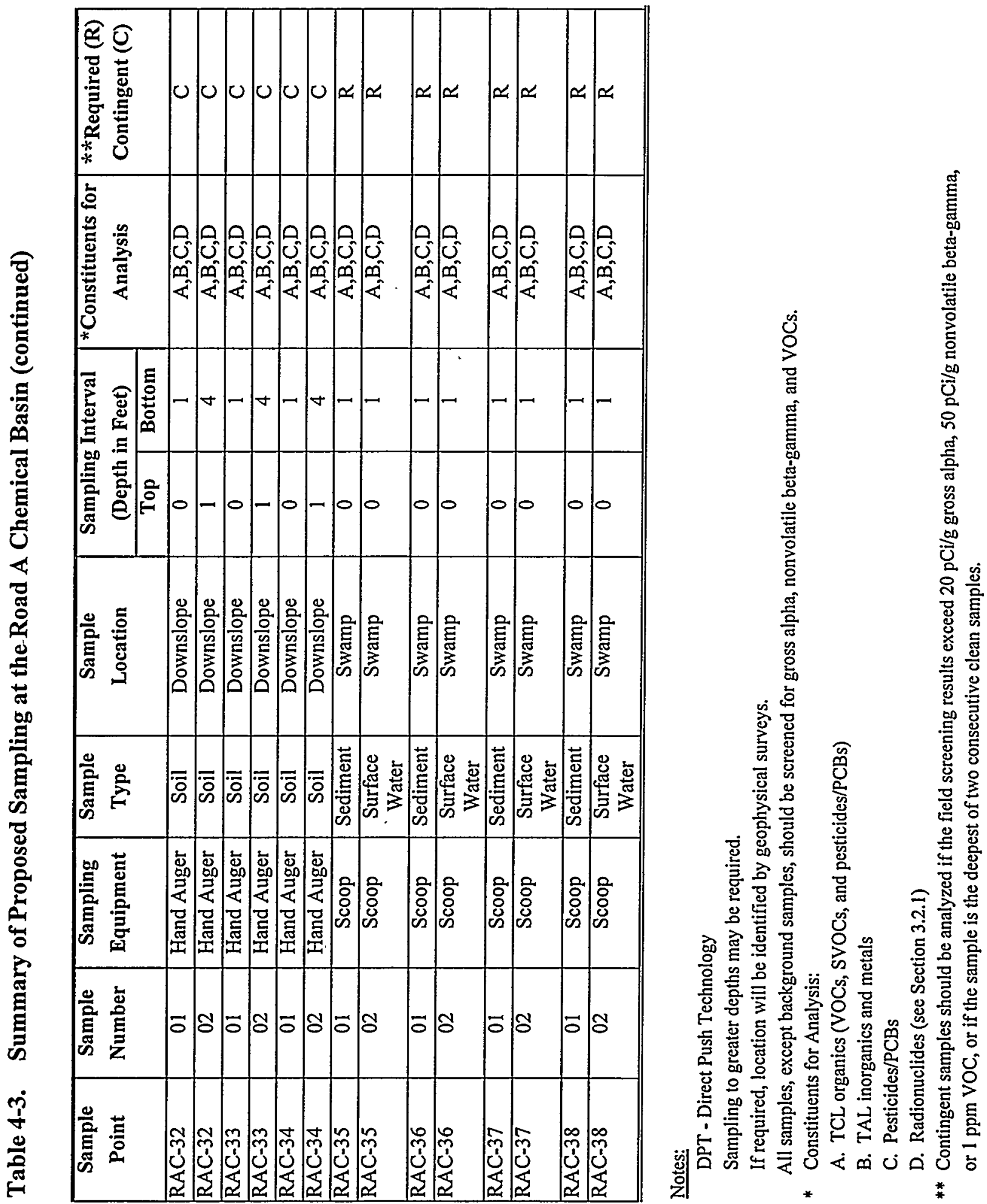
Table 4-4. Summary of Groundwater Samples and Constituents to be Analyzed at the RdACB OU

\begin{tabular}{|c|c|c|c|c|c|}
\hline $\begin{array}{l}\text { Monitoring } \\
\text { Well }\end{array}$ & Well Status & $\begin{array}{l}\text { Sampling } \\
\text { Instrument }\end{array}$ & $\begin{array}{c}\text { Sample } \\
\text { Location }\end{array}$ & $\begin{array}{l}\text { Sampling } \\
\text { Interval }\end{array}$ & $\begin{array}{c}\text { Constituent } \\
\text { for Analysis }\end{array}$ \\
\hline BRD-1 & Existing & Pump & $\begin{array}{l}\text { Side-gradient } \\
\text { to RdACB OU }\end{array}$ & Water Table & $1,2,3$ \\
\hline BRD-2 & Existing & Pump & $\begin{array}{l}\text { Side-gradient } \\
\text { to } \mathrm{RdACB} \text { OU }\end{array}$ & Water Table & $1,2,3$ \\
\hline BRD-2C & Proposed & Pump & $\begin{array}{l}\text { Side-gradient } \\
\text { to } \mathrm{RdACB} \text { OU }\end{array}$ & $\begin{array}{l}\text { Gordon } \\
\text { Aquifer }\end{array}$ & $1,2,3$ \\
\hline BRD-3 & Existing & Pump & $\begin{array}{l}\text { Upgradient to } \\
\text { RdACB OU }\end{array}$ & Water Table & $1,2,3$ \\
\hline BRD-4D & Existing & Pump & $\begin{array}{l}\text { Downgradient } \\
\text { to RdACB OU }\end{array}$ & Water Table & $1,2,3$ \\
\hline BRD-5D & Existing & Pump & $\begin{array}{l}\text { Downgradient } \\
\text { to RdACB OU }\end{array}$ & Water Table & $1,2,3$ \\
\hline BRD-6D & Proposed & Pump & $\begin{array}{l}\text { Upgradient to } \\
\text { RdACB OU }\end{array}$ & Water Table & $1,2,3$ \\
\hline BRD-6C & Proposed & Pump & $\begin{array}{l}\text { Upgradient to } \\
\text { RdACB OU }\end{array}$ & $\begin{array}{l}\text { Gordon } \\
\text { Aquifer }\end{array}$ & $1,2,3$ \\
\hline BRD-7D & Proposed & Pump & $\begin{array}{l}\text { Downgradient } \\
\text { to RdACB OU }\end{array}$ & Water Table & $1,2,3$ \\
\hline BRD-7C & Proposed & Pump & $\begin{array}{l}\text { Downgradient } \\
\text { to RdACB OU }\end{array}$ & $\begin{array}{l}\text { Gordon } \\
\text { Aquifer }\end{array}$ & $1,2,3$ \\
\hline BRD-8D & Proposed & Pump & $\begin{array}{l}\text { Downgradient } \\
\text { to RdACB OU }\end{array}$ & Water Table & $1,2,3$ \\
\hline$\overline{\mathrm{BRD}-\mathrm{XC}}{ }^{\mathrm{a}}$ & & Pump & & $\begin{array}{l}\text { Gordon } \\
\text { Aquifer }\end{array}$ & $1,2,3$ \\
\hline BRD-XD ${ }^{a}$ & & Pump & & Water Table & $1,2,3$ \\
\hline
\end{tabular}

${ }^{a}$ Contingency: Number and location of wells determined by nature and extent of contaminant plume, if present

${ }^{b}$ Analyte Codes:

1 Unit-specific groundwater analyte suite (Table 4-2)

2 Field measurements: $\mathrm{pH}$, specific conductivity, and turbidity

3 Two rounds of sampling at least 30 days apart. QA/QC samples collected in accordance with WSRC

Groundwater Monitoring Program Protocols 


\subsection{SCHEDULE}

This section includes the proposed implementation schedule of field activities and document submittals for the RdACB OU (Figure 5-1). The field start for characterization is scheduled to begin on June 30, 1999. The Revision 0 RFI/RI/BRA Report will be submitted on November 10, 2000. The Revision 0 Corrective Measures Study/Feasibility Study/Statement of Basis/Proposed Plan/draft Record of Decision will be submitted on July 6, 2001. Submittal of the signed Record of Decision is forecasted for June 29, 2002. This schedule will be submitted for approval by EPA and SCDHEC upon approval of this RFI/RI Work Plan. 
RFI/RI Work Plan for the

Road A Chemical Basin

904-111G (U)
WSRC-RP-98-4032

October 1999

Rev. 1.1

This page intentionally left blank. 


\section{FIGURES}


This page intentionally left blank. 


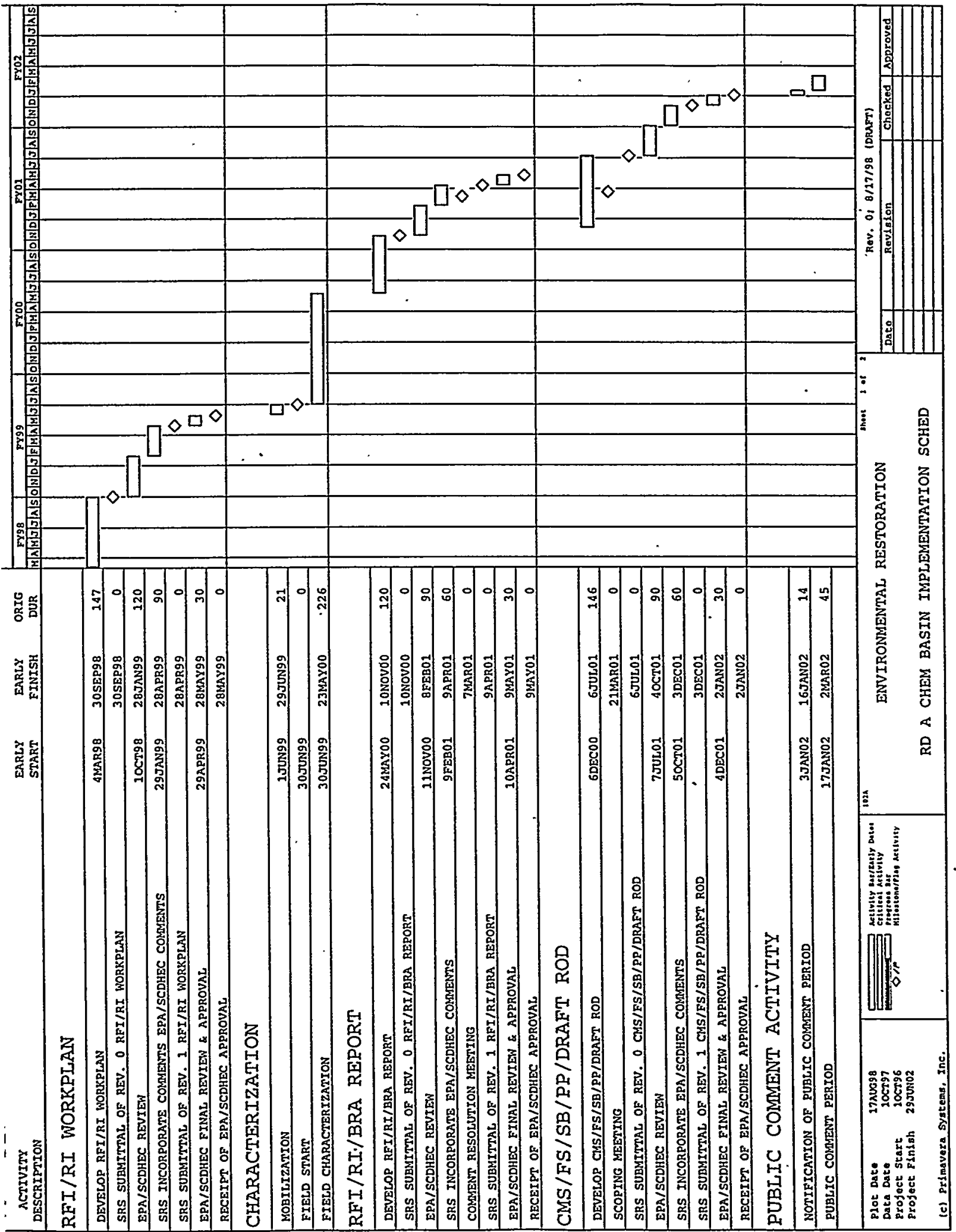

Figure 5-1. Road A Chemical Basin Implementation Schedule 


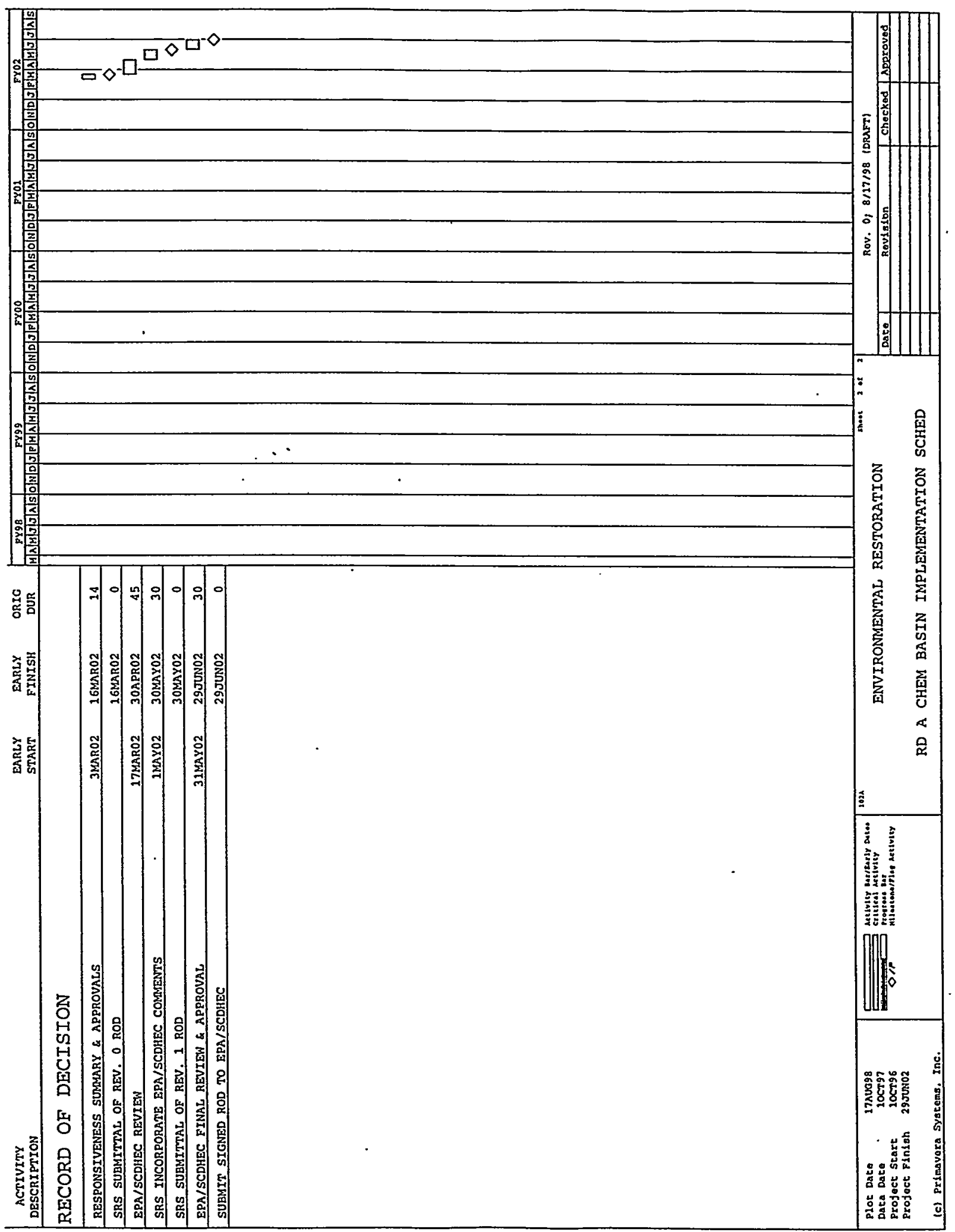

Figure 5-1. Road A Chemical Basin Implementation Schedule (continued) 


\subsection{SAFETY, HEALTH, AND EMERGENCY RESPONSE PLAN}

A Site-Specific Health and Safety Plan will be prepared in accordance with Title 29 Code of Federal Regulations Part 1910.120 and approved prior to starting the field investigation. This plan will meet Occupational Safety and Health Administration requirements. The plan will also fulfill the requirements of SRS RFI/RI Work Plan SHERP, QA/QC and Data Management Requirements, Revision 1 (U) (WSRC 1996c). All personnel involved in the performance of work shall be familiar with the provisions of the Site-Specific Health and Safety Plan. 
This page intentionally left blank. 


\subsection{QUALITY ASSURANCE/QUALITY CONTROL PLAN}

Precision, accuracy, completeness, representativeness, comparability, and documentation of the characterization are specified in the following site-level QA procedures:

- WSRC Manual 1Q, Quality Assurance Manual (U) (WSRC 1994a)

- WSRC Manual 3Q5, Hydrogeologic Data Collection (U) (WSRC 1997)

- ESH-EMS-950076, Environmental Monitoring Section, Environmental Geochemistry Group Program Overview (WSRC 1995a)

- WSRC-RP-96-234, SRS RFI/RI Work Plan SHERP, QA/QC and Data Management Requirements, Revision 1 (U) (WSRC 1996c) 
This page intentionally left blank. 


\subsection{DATA MANAGEMENT PLAN}

Data management will be performed in accordance with the Environmental Monitoring Section, Environmental Geochemistry Group Program Overview (WSRC 1995a). Data management will also fulfill the requirements of SRS RFI/RI Work Plan SHERP, QA/QC and Data Management Requirements, Revision 1 (U) (WSRC 1996c). 
This page intentionally left blank. 


\subsection{REFERENCES}

Aadland, R.K., J.A. Gellici, and P.A. Thayer, 1995. Hydrogeologic Framework of West-Central South Carolina. Report 5, State of South Carolina Department of Natural Resources, Water Resources Division.

Bledsoe, H.W., 1987. SRP Baseline Hydrogeologic Investigations - Phase II, DPST-86-674, E.I. DuPont de Nemours and Company, Aiken, South Carolina.

Bouwer, H. and R.C. Rice, 1976. A Slug Test for Determining Hydraulic Conductivity of Unconfined Aquifers with Completely or Partially Penetrating Wells. Water Resources Research, Vol. 12, No. 3.

$\mathrm{CH}_{2} \mathrm{M}$ Hill, 1990. Preliminary Characterization Summary/Preliminary Risk Assessment Report for the Road A Chemical Basin. WSRC-RP-90-815, Draft.

DOE, 1996. Savannah River Site Future Use Project Report. United States Department of Energy, Savannah River Site, Aiken, South Carolina, January 1996.

EPA, 1992. Guidance for Data Usability in Risk Assessment - Parts A and B. Office of Emergency and Remedial Response. U.S. Environmental Protection Agency, Washington, D.C.

EPA, 1993. Subsurface Characterization and Monitoring Techniques: A Desk Reference Guide, Volume I: Soils and Ground Water Appendices $A$ and B. EPA/625/R-93/003a, Office of Research and Development, U.S. Environmental Protection Agency, Washington, D.C., May 1993.

EPA, 1994. Guidance for the Data Quality Objectives Process. EPA/600/R-96/055, Office of Research and Development, U.S. Environmental Protection Agency, Washington, D.C., September 1994.

EPA, 1999. EPA Region III Risk-Based Concentration Table April 1999 Update. U.S. Environmental Protection Agency, Washington, D.C., April 1999.

Fallaw, W. and V. Price, 1995. Stratigraphy of Savannah River Site and Vicinity. Southeastern Geology, v. 35 , no. 1, p. 21-58. 
Pickett, J.B., et al., 1987. Environmental Information Document for the Road A Chemical Basin. DPST-85-699, Savannah River Laboratory, Aiken, South Carolina, March 1987.

Pirkle, R.J., and D.J. Masdea, 1993. Soil Gas Investigations at the Road A Chemical Basin (904111 G) Draft. Microseeps, Pittsburgh, PA, March 1993.

Rogers, V.A., 1990. Soil Survey of Savannah River Plant Area, Parts of Aiken, Barnwell, and Allendale Counties, South Carolina. Soil Conservation Service, United States Department of Agriculture, June 1990.

Siple, G.E., 1967. Geology and Groundwater of the Savannah River Plant and Vicinity, South Carolina. United States Geological Survey.

Wike, L.D., et al., 1994. SRS Ecology Environmental Information Document. WSRC-TR-93496, Westinghouse Savannah River Company, Savannah River Site, Aiken, South Carolina.

Workman, S.W. and K.W. McLeod, 1990. Vegetation of the Savannah River Site: Major Community Types. SRO-NERP-19, Savannah River Site Ecology Laboratory, Aiken, South Carolina, April 1990.

WSRC, 1992. Predecisional, Revision 0, Phase II, RCRA Facility Investigation Work Plan for the Road A Chemical Basin (U). WSRC-RP-92-374 Rev. 0, Westinghouse Savannah River Company, Savannah River Site, Aiken, South Carolina, June 1992.

WSRC, 1994a. Quality Assurance Manual (U). WSRC Manual 1Q, Westinghouse Savannah River Company, Savannah River Site, Aiken, South Carolina.

WSRC, 1994b. SRS Investigation Derived Waste Management Plan. WSRC-RP-94-1227, Rev. 2, Westinghouse Savannah River Company, Savannah River Site, Aiken, South Carolina.

WSRC, 1995a. Environmental Monitoring Section, Environmental Geochemistry Group Program Overview. ESH-EMS-950076, Westinghouse Savannah River Company, Savannah River Site, Aiken, South Carolina. 
WSRC, 1995b. Environmental Monitoring Section, Environmental Geology Procedures. WSRC Manual 3Q1-7, Westinghouse Savannah Company, Savannah River Site, Aiken, South Carolina.

WSRC, 1995c. Generic Safety Analysis Report for SRS, Chapter 1.0: Site Characteristics. WSRC-SA-19, Rev. 0, Westinghouse Savannah River Company, Savannah River Site, Aiken, South Carolina.

WSRC, 1996a. Environmental Protection Department's Well Inventory (U). ESH-EMS960488, Westinghouse Savannah River Company, Aiken, South Carolina.

WSRC, 1996b. Regulatory Documents Formats (U). ER-AP-136, WSRC Manual C-1 Westinghouse Savannah Company, Savannah River Site, Aiken, South Carolina.

WSRC, 1996c. SRS RFI/RI Work Plan SHERP, QA/QC and Data Management Requirements, Revision 1 (U). WSRC-RP-96-234, Westinghouse Savannah River Company, Savannah River Site, Aiken, South Carolina.

WSRC, 1997. WSRC Hydrogeologic Data Collection, Revision 2 (U). WSRC Manual 3Q5, Westinghouse Savannah Company, Savannah River Site, Aiken, South Carolina. 
This page intentionally left blank. 


\section{Appendix A}

\section{Photographs}


This page intentionally left blank. 


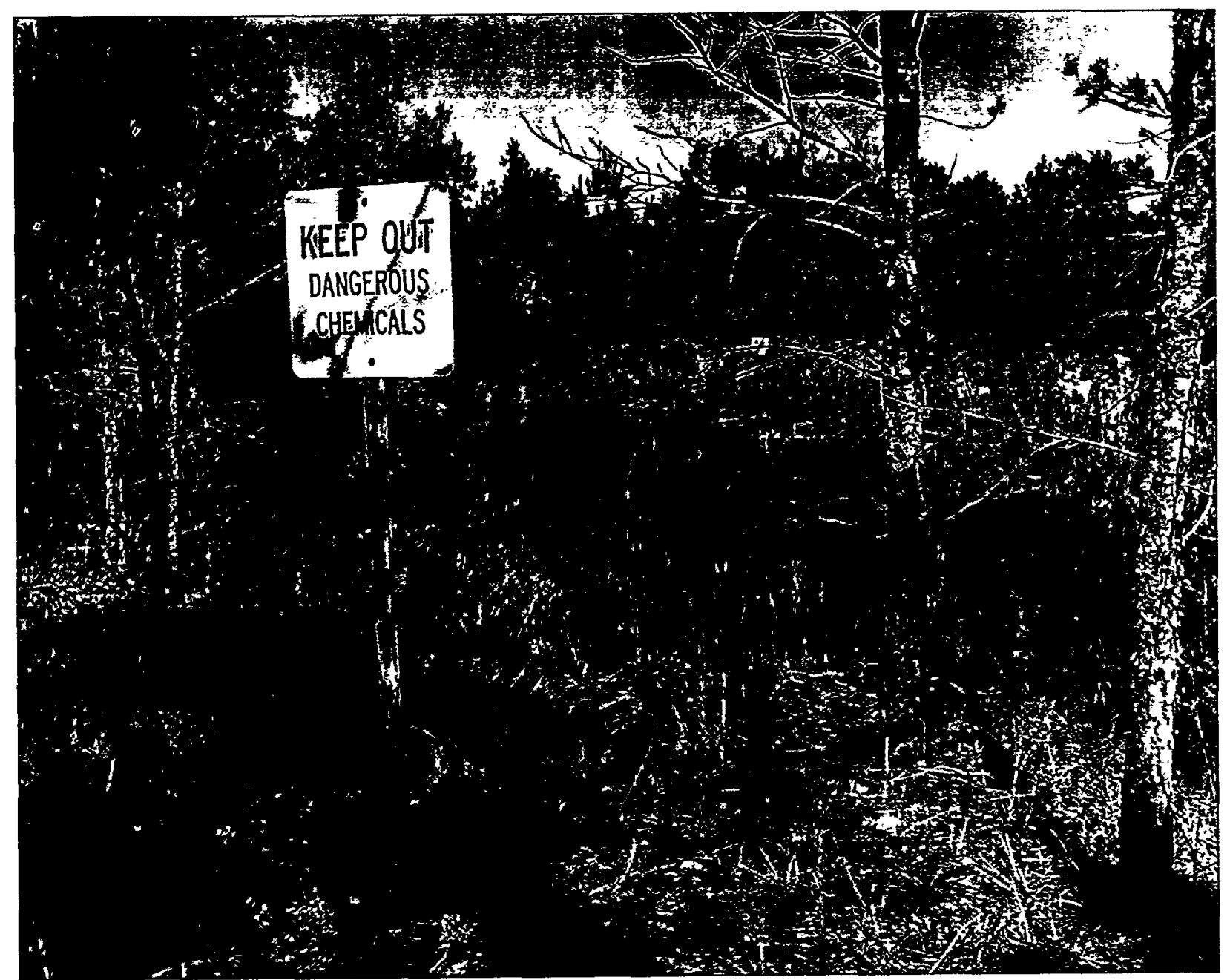

View looking north approximately $4.6 \mathrm{~m}$ (15 ft) from the RdACB OU boundary

Figure A-1. Road A Chemical Basin Prior to Closure and Backfilling 
This page intentionally left blank. 


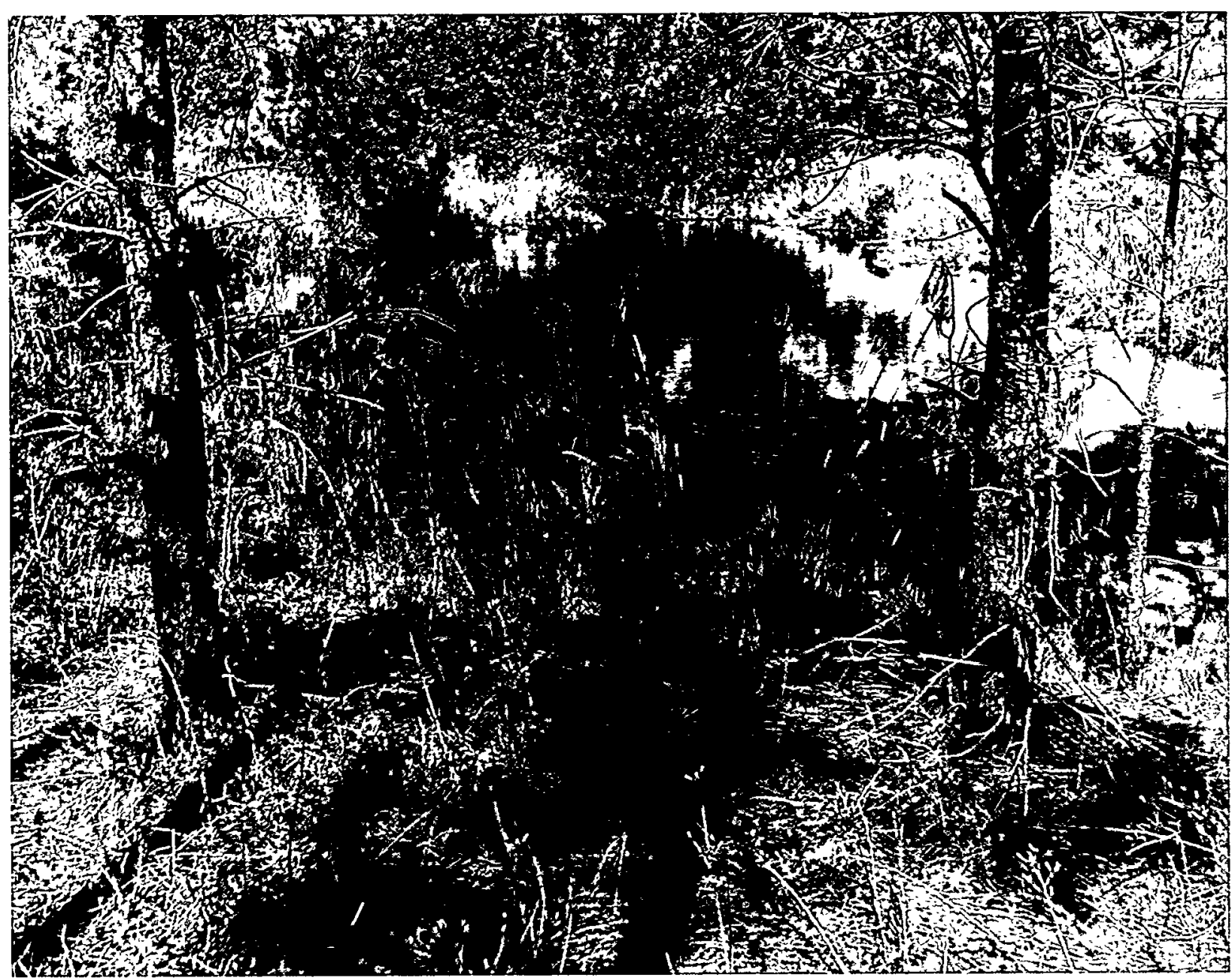

View looking north approximately $3 \mathrm{~m}(10 \mathrm{ft})$ from the RdACB OU boundary

Figure A-2. Road A Chemical Basin Prior to Closure and Backfilling 
This page intentionally left blank. 


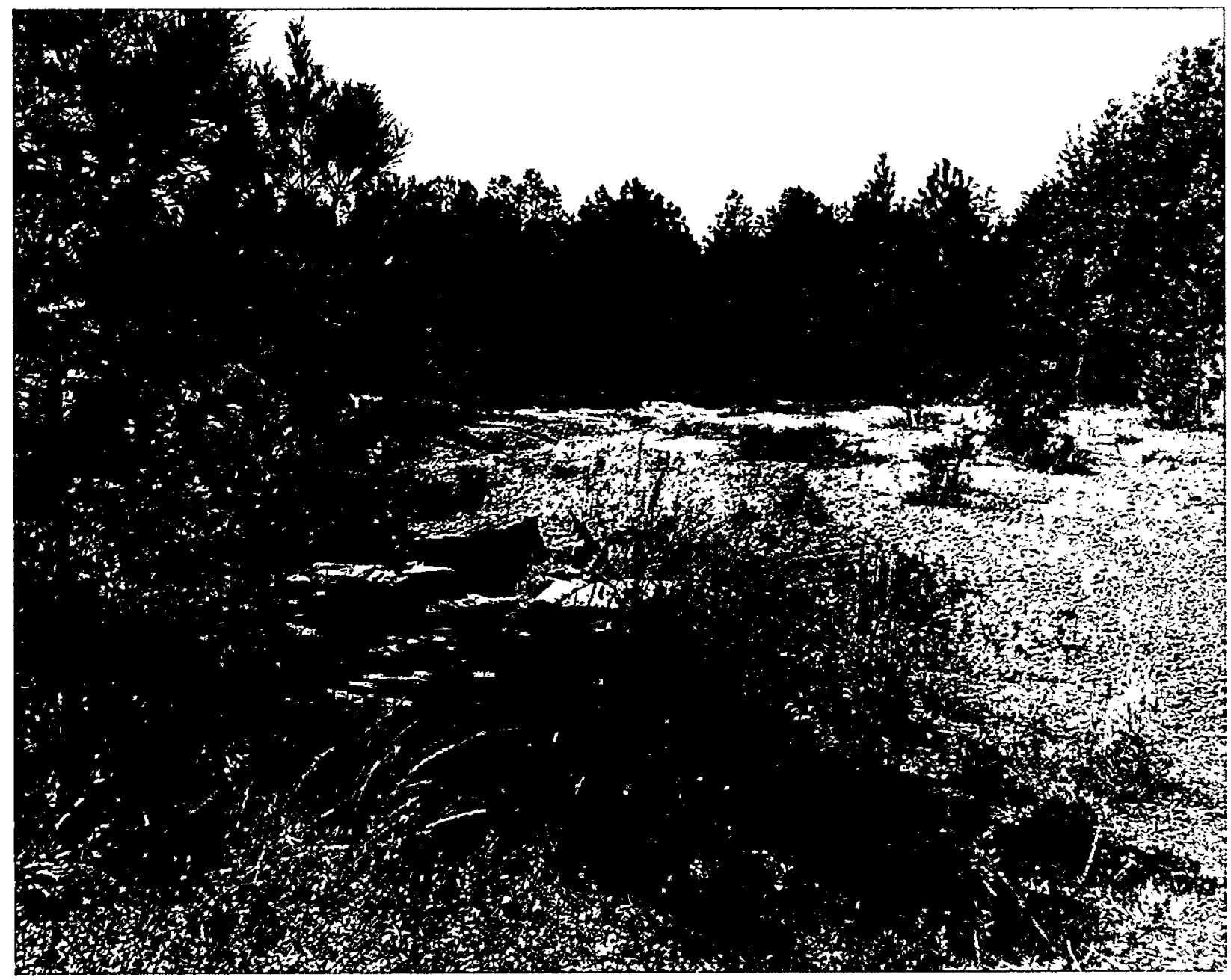

View looking north approximately $61 \mathrm{~m}(200 \mathrm{ft})$ from the RdACB OU boundary

Figure A-3. Road A Chemical Basin Prior to Closure and Backfilling 
This page intentionally left blank. 


\section{Appendix B}

Soil Boring Log 
This page intentionally left blank. 
PROJECT SRP RHET REI

ELEVATION DRILLING CONTRACTOR MTC

DRILLING METHOD ANO EQUIPHENT. Hollöis Stem A4ger Location Baxley Rd. (RACB)

WATER LEVEL AND DATE_ NA sTART $3-20-89$ FINISH 3-20-89 LOGGER H.Reilly

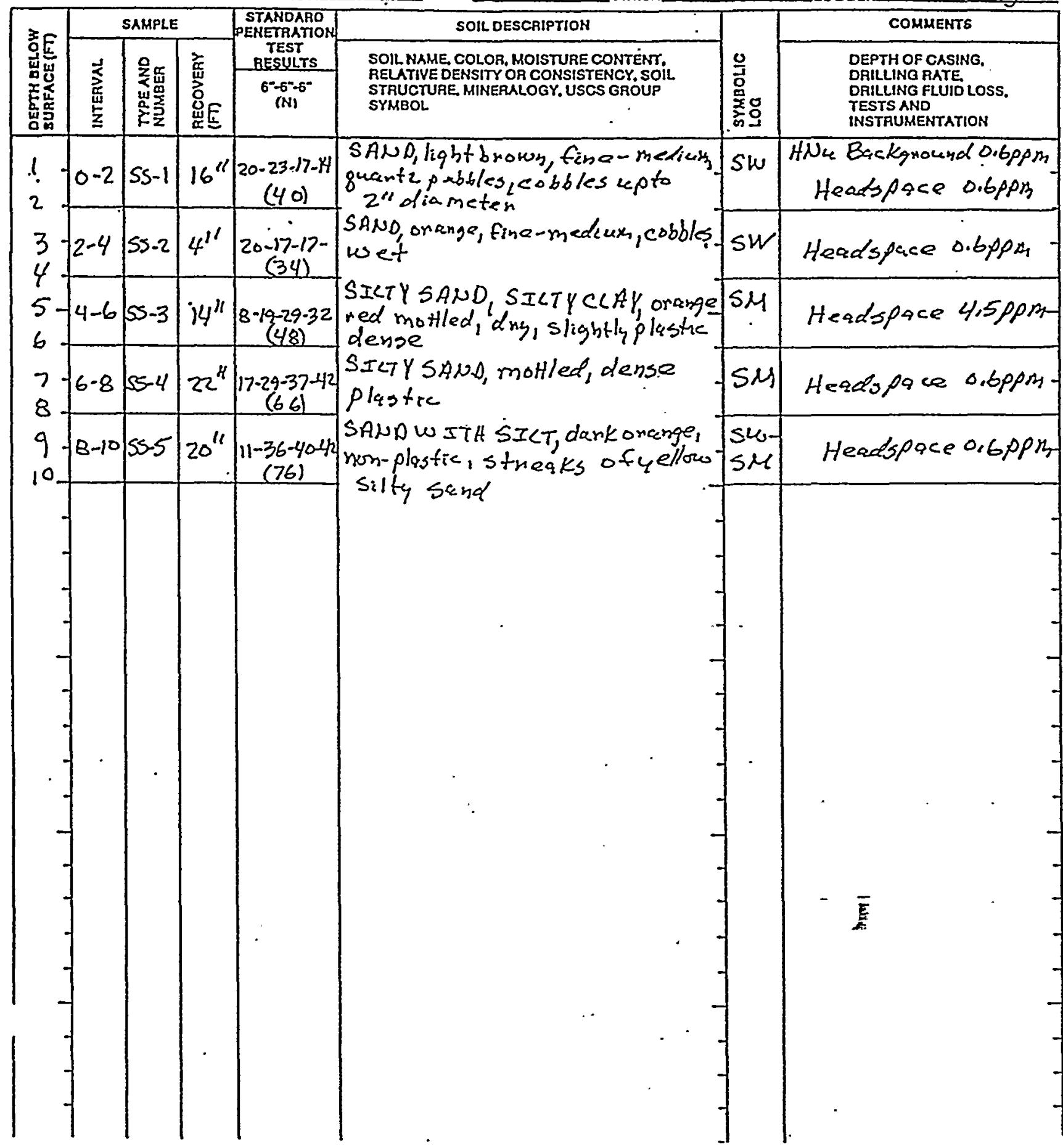


RFIRI Work Plan for the

WSRC-RP-98-4032

Road A Chemical Basin

October 1999

904-111G (U)

Rev. 1.1

\section{aseng}

axion:ex

Cintaln

Exatris:

\begin{tabular}{|l|l|l|}
\hline PAOJECT NUMEER \\
$S A T 22540.16 . R A$ & $\begin{array}{c}\text { BORING NUMAER } \\
B R D-5 B-2\end{array}$ SHEET 1 OF.2 \\
\hline
\end{tabular}

SOIL-BORING LOG

PROJECT SRP RMET RFI

ELEVATION DRILLING CONTAACTOR HTS

orilling Method ano equipMent Hollow StaH Akyen

WATER LEVEL ANO DATE START $4-3 \cdot 89$

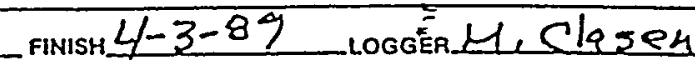

\begin{tabular}{|c|c|c|c|c|c|c|c|}
\hline \multirow[b]{2}{*}{ 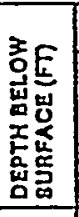 } & \multicolumn{3}{|c|}{ SAHPLE } & \multirow{2}{*}{\begin{tabular}{|c|} 
STANDARO \\
PENETRATION \\
TEST \\
RESULTS. \\
$\begin{array}{c}6--5^{\prime}-5^{-} \\
\text {(N) }\end{array}$ \\
\end{tabular}} & SOIL DESCRIPTION & \multirow[b]{2}{*}{ 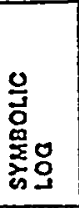 } & COHHENTS \\
\hline & 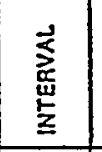 & 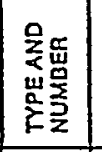 & 总 & & $\begin{array}{l}\text { SOIL NAME, COLOR, MOISTUAE CONTENT, } \\
\text { RELATIVE DENSTY OR CONSISTENCY, SOIL } \\
\text { STRUCTURE, MINERALOGY, USCS GROUP } \\
\text { SYMBOL }\end{array}$ & & $\begin{array}{l}\text { DEPTH OF CASING, } \\
\text { DRILLING RATE } \\
\text { ORILLING FLUIO LOSS, } \\
\text { TESTS ANO } \\
\text { INSTRUMENTATION } \\
\end{array}$ \\
\hline \multirow[t]{2}{*}{0} & $0-2$ & $S s-1$ & $16^{11}$ & $\begin{array}{c}4-7-9 \\
(16)\end{array}$ & $\begin{array}{l}S I L T Y \text { SAND, browh, tine to } \\
\text { medium guentz, some sitt/cky } \\
\text { moist }\end{array}$ & $S M$ & $\begin{array}{l}\text { HNk Backgroure } 0.2 \\
\text { Headspace } 0.4 \text { ppm }\end{array}$ \\
\hline & $2-4$ & $5 S-2 \mid$ & $20^{\prime \prime}$ & $\begin{array}{c}6-10-28-30 \\
(38)\end{array}$ & 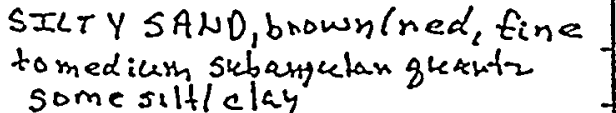 & St & pace $0.4 p 0 m_{1}$ \\
\hline \multirow[t]{3}{*}{$5-$} & $4-6$ & $55-3$ & $22^{\prime \prime}$ & $\begin{array}{c}7-2 l-25-49 \\
(46)\end{array}$ & $\begin{array}{l}\text { SAND wITH SICT, ned fine to } \\
\text { medium, skbangklangwastin } \\
\text { moist, wellgnaded }\end{array}$ & $\begin{array}{l}S 1 \\
-S 1\end{array}$ & sace $0.4 \mathrm{Ppm}^{-}$ \\
\hline & $6-8$ & $55-4$ & $16^{\prime \prime}$ & $\left|\begin{array}{c}9-18-24-24 \\
(42)\end{array}\right|$ & $\begin{array}{l}\text { Squd, ned, fine t } \\
\text { poorly graded, t }\end{array}$ & $S P$ & Headspace 0.4 ppm \\
\hline & $8-10$ & $55-5$ & $22^{\prime \prime}$ & $\begin{array}{c}1324-26-30 \\
(50)\end{array}$ & $\begin{array}{l}\text { SAND, red, fine, sub angular } \\
\text { poorly graded, molst }\end{array}$ & $S P$ & ace. $6.4 \mathrm{ppr}$ \\
\hline \multirow{2}{*}{$10-$} & $10-12$ & $5 s-6$ & $21^{k}$ & $\begin{array}{c}10-12-20-31 \\
(32)\end{array}$ & $\begin{array}{l}\text { SALD, red, fine, subangelargu } \\
\text { poorly graded, morst }\end{array}$ & $S$ & orce $1,6 p p 4$ \\
\hline & $12-14$ & 55.7 & $20^{\prime \prime}$ & $10-22-27.32$ & $\begin{array}{l}\text { SAnd, red, Fine subangularguart } 2 \text {, } \\
\text { poorly gnaded, guartz }\end{array}$ & $5 P$ & cace $3.2 p p m$ \\
\hline \multirow[t]{3}{*}{$15-$} & $|14-16|$ & $55-8$ & $19^{11}$ & $\begin{array}{c}12-20-27-32 \\
(47)\end{array}$ & $\begin{array}{l}\text { SAw } 0_{1} \text { red, fine subargelar gleart } 2 \\
\text { traco black minemals. poorly } \\
\text { gnaded, moist }\end{array}$ & $S P$ & 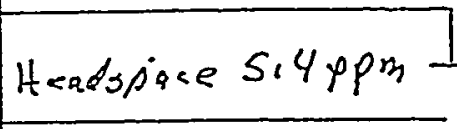 \\
\hline & $16-18$ & SS-9 & $22^{\prime \prime}$ & $\begin{array}{c}9-15-18-25 \\
(33)\end{array}$ & $\begin{array}{l}\text { SAUD, red, opange, fine subanglar } \\
\text { guant } 2 \text { white clab motlling, pooxly } \\
\text { gnuded, moist }\end{array}$ & & Headspece 6,0 \\
\hline & $18-20$ & $55-10$ & $13^{\prime \prime}$ & $\begin{array}{c}7-15-21-27 \\
(36)\end{array}$ & $\begin{array}{l}\text { SAND, onange, fine submoulan } \\
\text { quetitz,joonly graded mast }\end{array}$ & & pace 3,4 \\
\hline \multirow{2}{*}{$20-$} & $20-22$ & $|55-1|$ & $20^{\prime \prime}$ & $\begin{array}{c}6-12-15-22 \\
(27)\end{array}$ & $\begin{array}{l}<\text { subangulas } \\
\text { aded, moist }\end{array}$ & & Headspace 0.4 \\
\hline & $22-24 \mid$ & $55-12$ & $22^{\prime \prime}$ & $\begin{array}{c}12-18-23-30 \\
(41)\end{array}$ & $\begin{array}{l}\text { SAND, onange, fme subargulas } \\
\text { guemt2 }\end{array}$ & & Heacospace, iz \\
\hline \multirow[t]{3}{*}{$25-$} & $24-26$ & $|55-13|$ & $20^{\prime \prime}$ & $\begin{array}{c}0-12-15-20 \\
(27)\end{array}$ & $\begin{array}{l}\text { SAND, orange, tan, pink, red, } \\
\text { moltled, subangulanguartz, } \\
\text { poorl's grader, moist }\end{array}$ & & Headspace 2.2 \\
\hline & 2628 & $55-14 \mid$ & $22^{\prime \prime}$ & $\begin{array}{c}8-12 \cdot 15-24 \\
(27) \\
\end{array}$ & $\begin{array}{l}\text { S FNU, white, pink, find on } \\
\text { poorly graded, moist }\end{array}$ & & Headsproc 1.2 \\
\hline & $28-30$ & $55-15$ & $19^{\prime \prime}$ & $\left|\begin{array}{c}16-13-2014 \\
(33)\end{array}\right|$ & 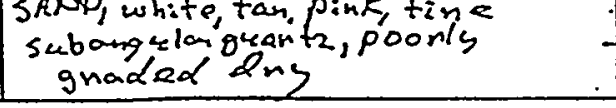 & $5 P$ & Headspare 3.6 \\
\hline
\end{tabular}




\begin{tabular}{|c|c|c|c|}
\hline \multirow{2}{*}{ 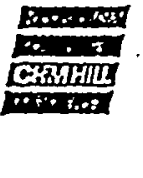 } & $\begin{array}{l}\text { PROJECT NUMBER } \\
\text { SAT } 22540,16, R A\end{array}$ & $\frac{\text { BORING NUMAER }}{B R D-5 B-2}$ & SHEer 2 of 2 \\
\hline & \multicolumn{3}{|c|}{$\begin{array}{c}(\text { RAC B) } \\
\text { SOIL BORING LOG }\end{array}$} \\
\hline
\end{tabular}

PROJECT SRP RHET REI - Location Baxley Ra (RACB)

ELEVATION orilling contractor_ H TC

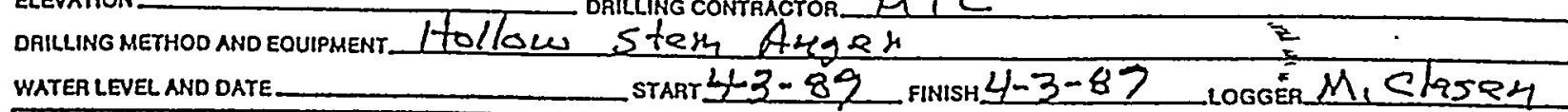

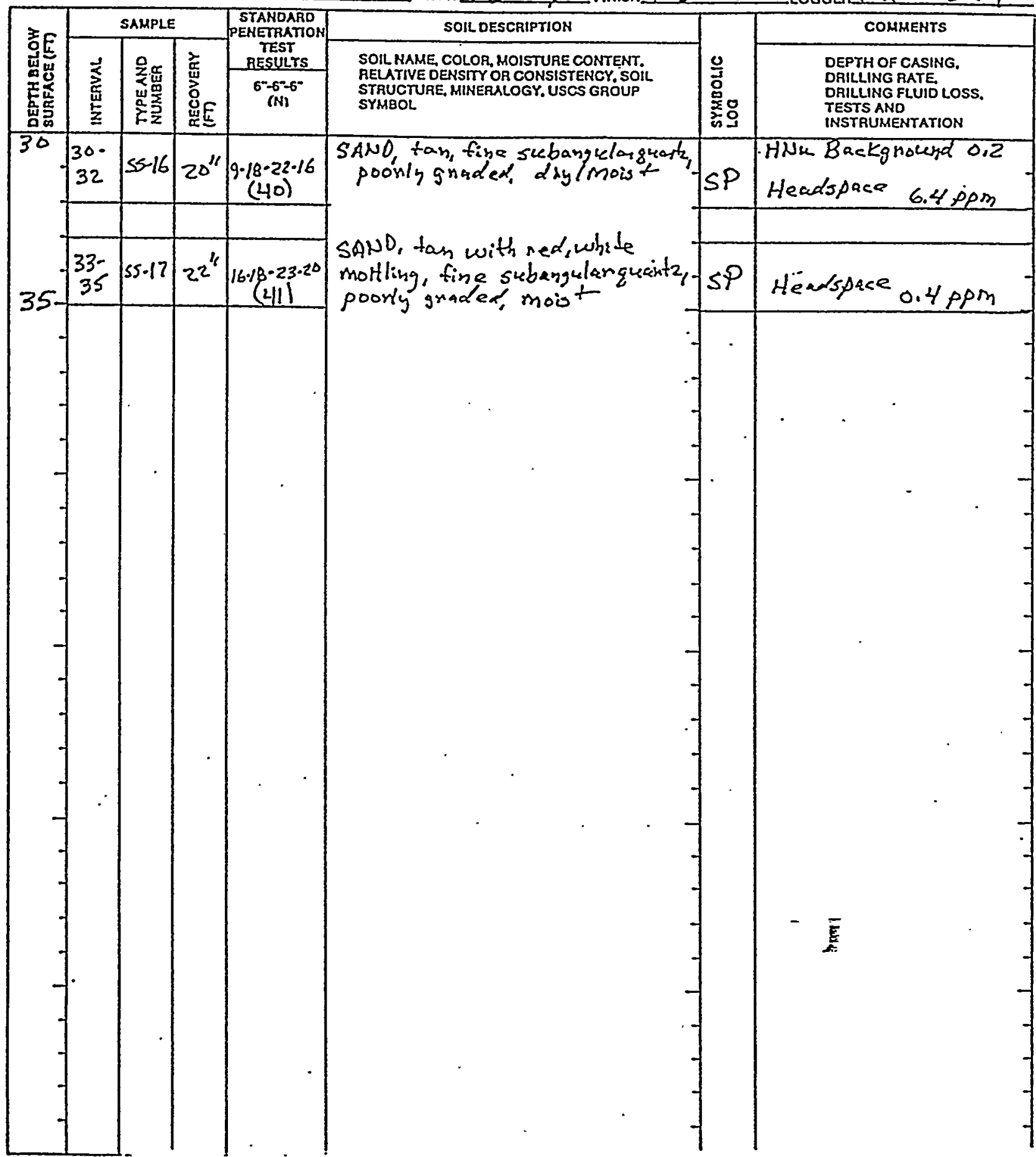




\begin{tabular}{|c|c|c|c|c|}
\hline \multirow{2}{*}{ 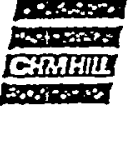 } & PROJECT NUMAER & \multicolumn{3}{|l|}{ BORING NUMBER } \\
\hline & SAT $22540.16 .2 A$ & $B R D-5 B-3$ & SHEET & of $/$ \\
\hline
\end{tabular}

PROJECT SRP RMET RFF Location Baxley Rde (RA=B)

ELEVATION DRILling ContaActor H T $C$

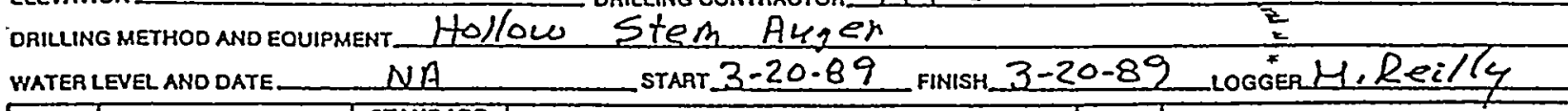
COMMEHTS

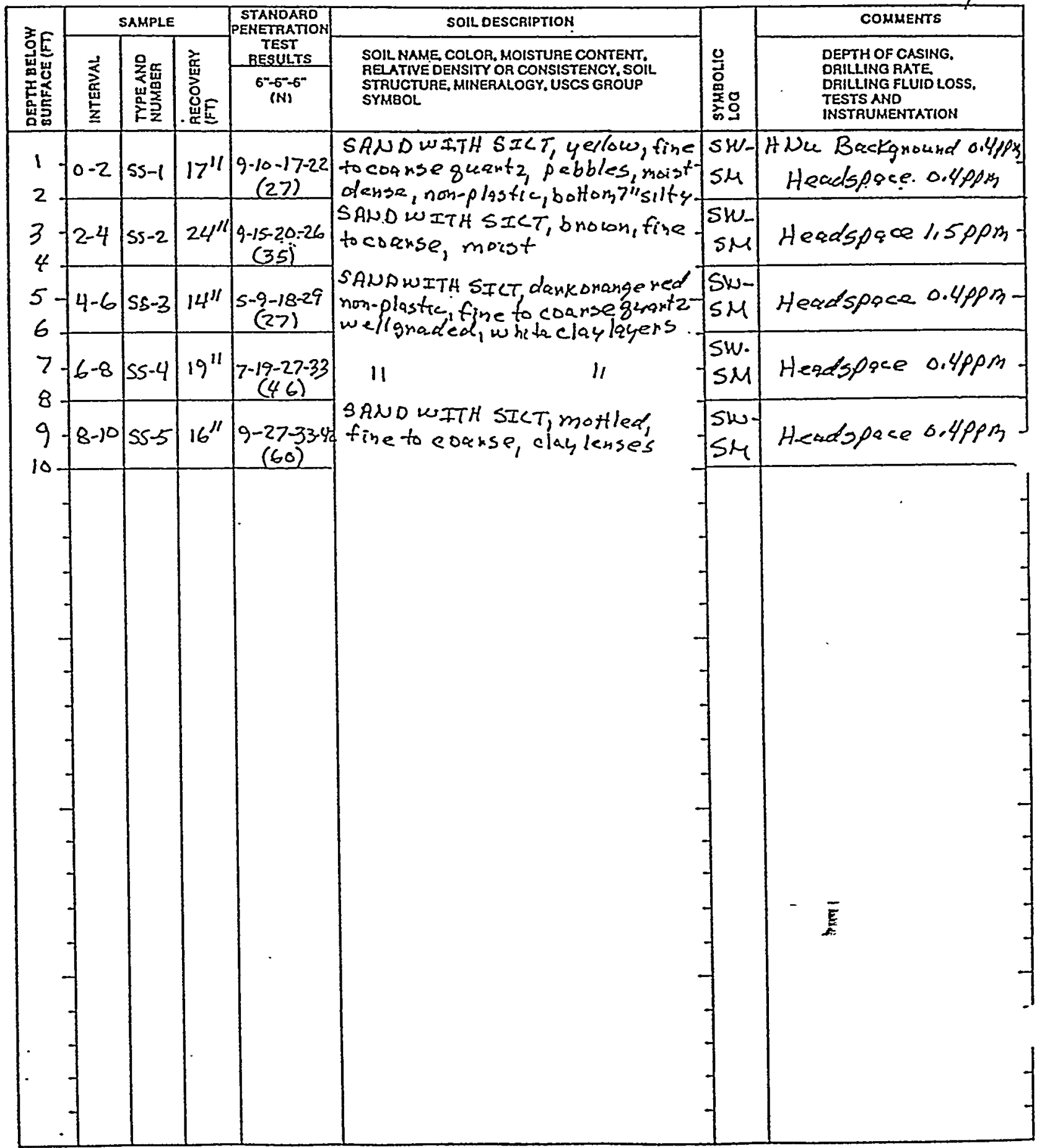




\begin{tabular}{|c|c|c|c|c|}
\hline \multirow{2}{*}{ 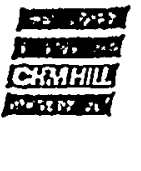 } & $\begin{array}{l}\text { PROJECT NUMBER } \\
\text { SAT } 22540.16,2 A\end{array}$ & $\begin{array}{l}\text { BORIMO AUMAER } \\
B R D \text { SB-4 }\end{array}$ & SHEET & of $/$ \\
\hline & & $\begin{array}{l}(R A C B) \\
\text { IL BORING LOG }\end{array}$ & & \\
\hline
\end{tabular}

PROJECT SRP RHET REI
Location Baxley Rd. $(R A \subset B)$

ELEVATION DRILLING CONTRACTOR $H \mathrm{I} C$

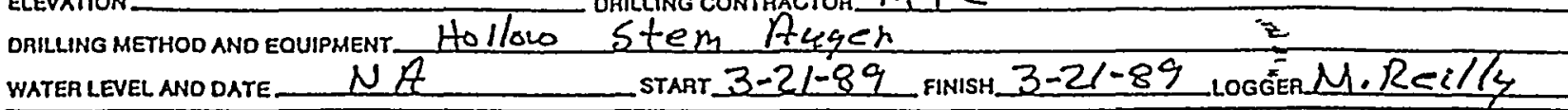

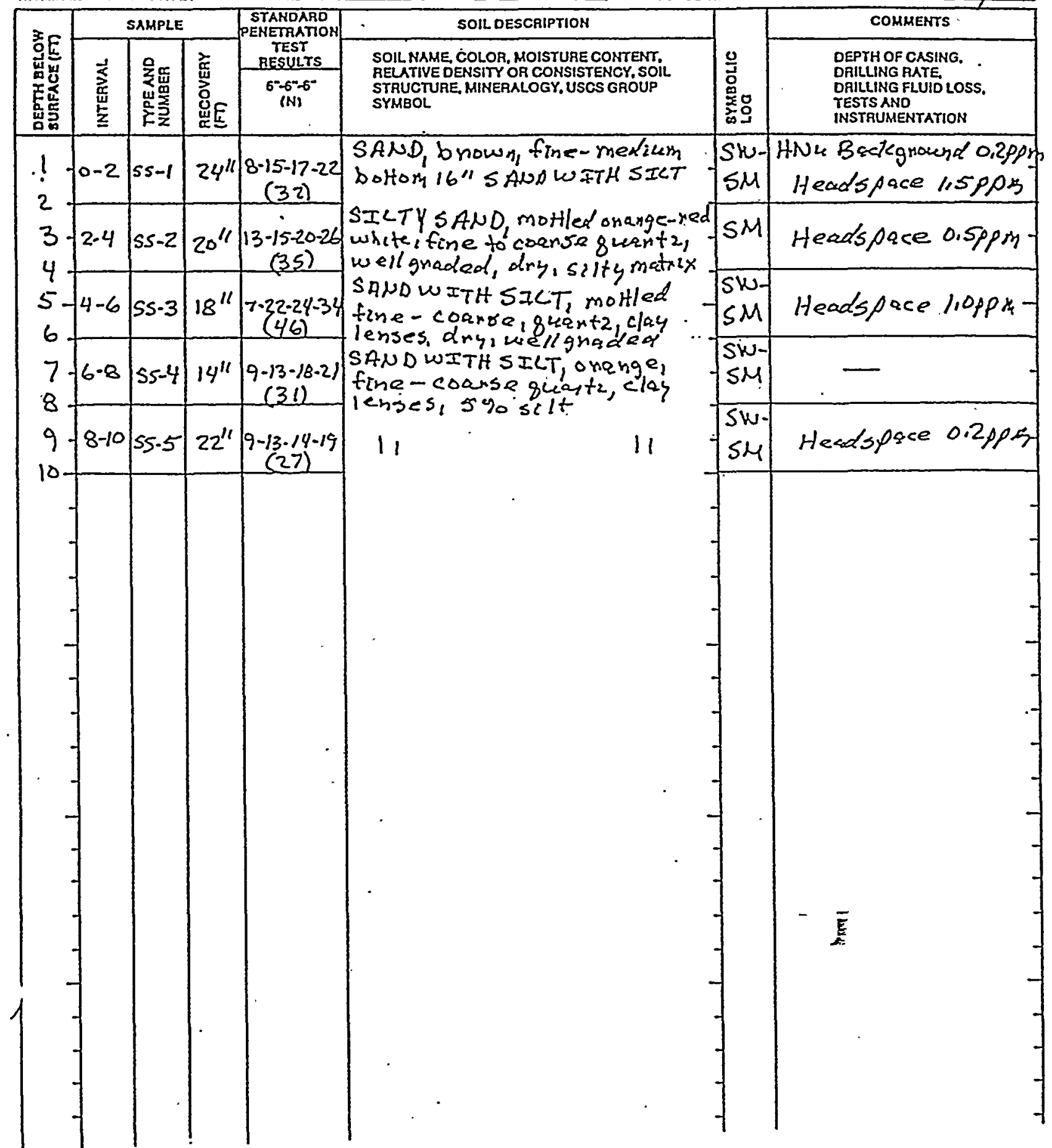




\begin{tabular}{|c|c|c|c|c|}
\hline Fring & $\begin{array}{l}\text { PROJECT NUMBER } \\
\text { SAT } 22540,16, R A\end{array}$ & 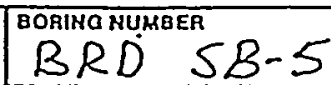 & SHEET & of 1 \\
\hline 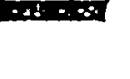 & sc & $\left\{\begin{array}{l}R A \subset B) \\
\text { BORING LOG }\end{array}\right.$ & & \\
\hline
\end{tabular}

PROJECT SRP RMET RFI Location Baxley $R d . \quad(R R \subset B)$

ELEVATION DRILLING CONTAACTOR $M r c$

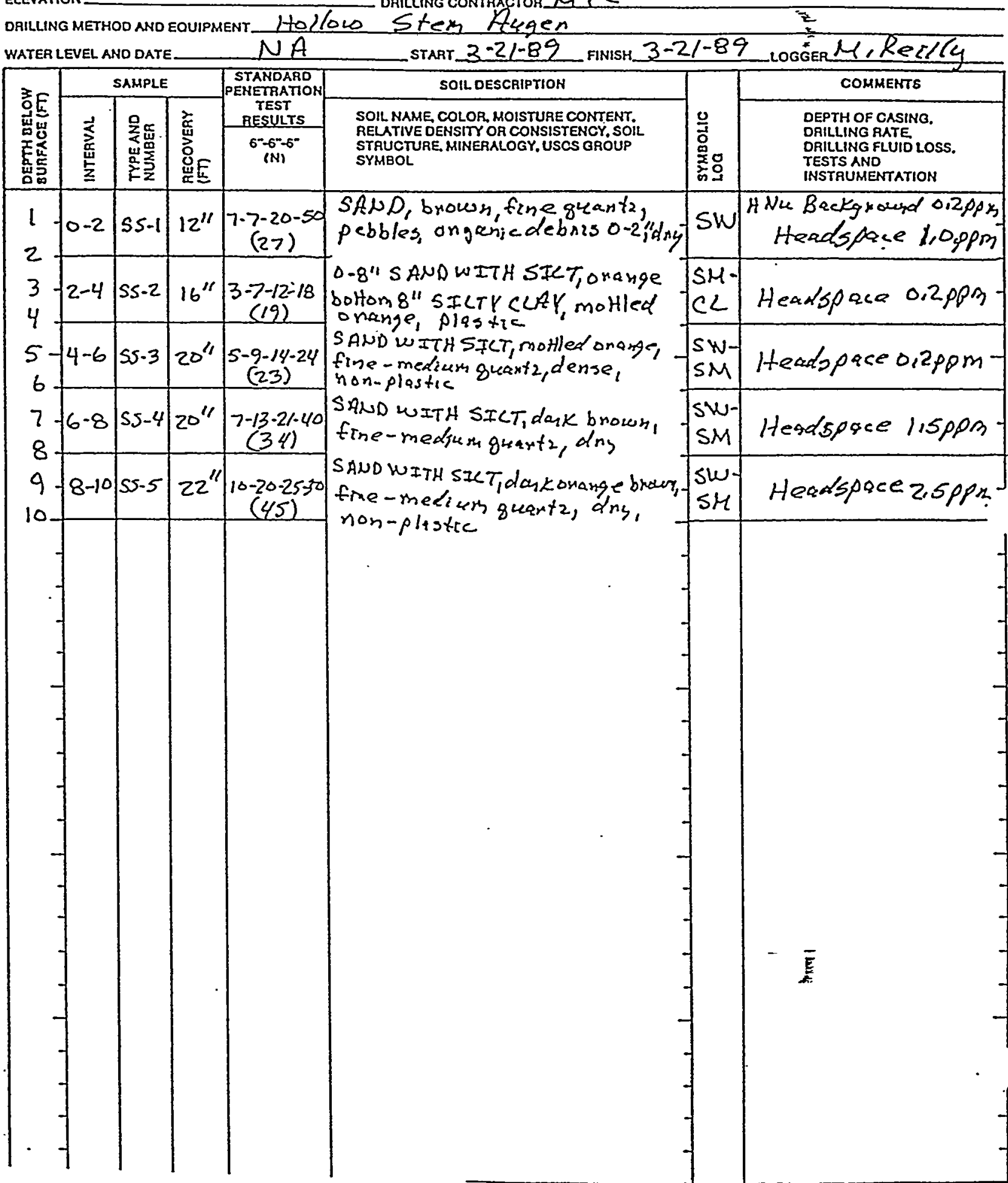


RFI/RI Work Plan for the

WSRC-RP-98-4032

Road A Chemical Basin

October 1999

904-111G (U)

Rev. 1.1

Exomeno

anding

CHRTIII

osicisy

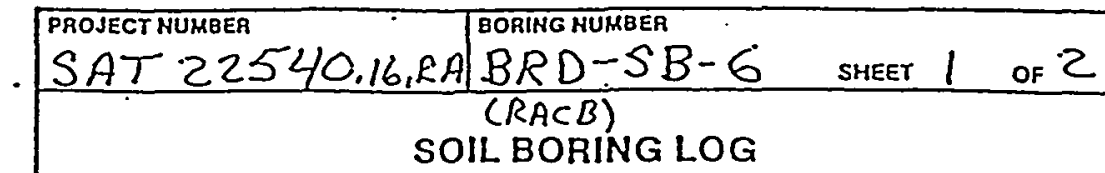

PROJECT SRP RMET REI

ELEVATION DRILLING CONTRACTOR_MTS Location Baxley Rd (RACB) dalluing method ano eouipment Hollew Stem Augen WATER LEVEL ANO DATE. START $3-28-89$ FINISH $3-30-89$ LOGGER M. Clasen

\begin{tabular}{|c|c|c|c|c|c|c|c|}
\hline \multirow[b]{2}{*}{ 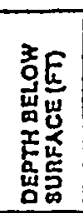 } & \multicolumn{3}{|c|}{ SAMPLE } & \multirow{2}{*}{ 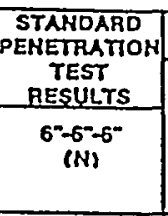 } & \multirow{2}{*}{$\begin{array}{l}\text { SOIL DESCRIPTION } \\
\text { SOIL NAME COLOR, MOISTURE CONTENT, } \\
\text { RELATIVE OENSTY ORR CONSISTENCY. SOIL } \\
\text { STRUCTURE. MINERALOGY. USCS GROUP } \\
\text { SYMBOL }\end{array}$} & \multirow[b]{2}{*}{ 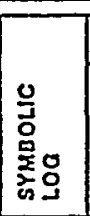 } & \multirow{2}{*}{$\begin{array}{l}\text { COMHENTS } \\
\text { DEPTH OF CASING. } \\
\text { DRILLING RATE. } \\
\text { DRILLING FLUID LOSS. } \\
\text { TESTSAND } \\
\text { INSTRUMENTATION }\end{array}$} \\
\hline & 莣 & 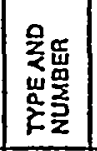 & 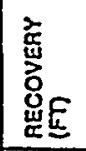 & & & & \\
\hline$i$. & $0-2$ & Ss-il & $15^{16}$ & $\begin{array}{r}21-17-20 \\
-30(37) \\
\end{array}$ & $\begin{array}{l}\text { SAND, brown, fine-medic } \\
\text { gnained guantz, some con } \\
\text { traco sr } 1 t \text {; some fill, }\end{array}$ & SW & $\begin{array}{l}\text { HNu Background } \\
0.2 \rho p m \\
\text { Head space }-0.2 \text { ppa }\end{array}$ \\
\hline $\begin{array}{l}3 . \\
4\end{array}$ & $2-4$ & $|s s-2|$ & $1 \varepsilon^{\prime \prime}$ & $\begin{array}{l}15-16-15- \\
(3) 4\end{array}$ & 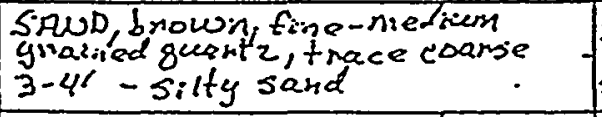 & $\begin{array}{l}S W \\
S M\end{array}$ & Headspace 0.2 ppm \\
\hline 5 & $4-6$ & $5 s-3$ & $18^{\prime \prime}$ & $\left.\mid \begin{array}{r}11-11-14 \\
-21(20)\end{array}\right]$ & $\begin{array}{l}\text { SAND, brown, fine-medicm } \\
\text { ynasned guant', some gravel, } \\
\text { pebbles, some silt . }\end{array}$ & sw & Headspree 0.2 ppm \\
\hline 7 & $6-8$ & $|s s-4|$ & $12^{11}$ & $\begin{array}{c}4-4-5-15 \\
(9)\end{array}$ & $\begin{array}{l}\text { SAND, red, fine-medicm geant? } \\
\text { trace piclt, trace whiteclay } \\
\text { moitling }\end{array}$ & $s p$ & Heatspeceo. 2 \\
\hline 9 & $8-10$ & $|s s-5|$ & $4^{\prime \prime}$ & $\begin{array}{c}5-5-5-10 \\
(10)\end{array}$ & Poor Recovery & $s P$ & Heredspuce 0 \\
\hline 11. & $10-12$ & $5 s-6$ & $16^{k}$ & $\begin{array}{c}5-4-4-10 \\
(8)\end{array}$ & $\begin{array}{l}\text { SAND, red, fine } \\
\text { trace silf }\end{array}$ & $S P$ & Headspace 0 \\
\hline $\begin{array}{l}13 . \\
14 .\end{array}$ & $12 \cdot 14$ & $5 s .7$ & $12^{\prime \prime}$ & $\begin{array}{c}4-6-8-11 \\
(14)\end{array}$ & $\begin{array}{l}\text { SAND, red, fine } \\
\text { trace sit }\end{array}$ & $S P$ & Heartspice 0.1 \\
\hline $15-$ & $14-16$ & $|5 s-8|$ & $16^{\prime \prime}$ & $\begin{array}{c}4-7-10-9 \\
(17)\end{array}$ & $\begin{array}{l}\text { SAwo, red fine grained otz, } \\
\text { some yellow nitifling }\end{array}$ & $S P$ & Iteadspice 0 \\
\hline 17 & $16-18$ & $s 5.9$ & 0 & $\begin{array}{c}4-7-10-20 \\
(17)\end{array}$ & No $R \in C O U \in R Y$ & - & ice 0 \\
\hline 19. & 18.20 & $55-10$ & $18^{\prime \prime}$ & $\begin{array}{c}7-15-13-16 \\
(26)\end{array}$ & $\begin{array}{l}\text { SAND, citange to ned, fine, subergulay } \\
\text { 8ugnty, trace dark minencels, } \\
\text { dry }\end{array}$ & $S P$ & $\begin{array}{l}\text { HNhe backgrakxd }=0.5 p \rho p \\
\text { Headopace }-0.5 \rho p \dot{m} \text {. }\end{array}$ \\
\hline 22 & $20-22$ & $|s s-11|$ & $18^{\prime \prime}$ & $\begin{array}{l}11-12-9)^{-12} \\
(21)^{2}\end{array}$ & $\begin{array}{l}\text { SAND, pink to wide fine } \\
\text { subongular guat? dry }\end{array}$ & $S P$ & Heaslspice $0.5 \mathrm{ppm}$ \\
\hline 23 & $22-24$ & $55-12$ & $18^{\prime \prime}$ & $\begin{array}{r}24-34-36 \\
-36(79 \\
\end{array}$ & $\begin{array}{l}\text { SAxid light brown to oncenge, } \\
\text { fine sublangular ginartz, } \\
\text { trace sziff diny }\end{array}$ & $S P$ & Headspece 2.0ppm - \\
\hline is & $24-26 \mid$ & $55-13$ & $16^{\prime \prime}$ & $\begin{array}{r}14-18-23- \\
25(41)\end{array} \mid$ & 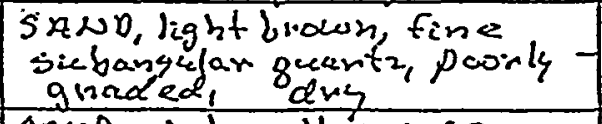 & $S P$ & Herdspuce \\
\hline 27 & $26-28$ & ss 14 & $12^{11}$ & $\begin{array}{c}12-87 \cdot 2 \pi-21 \\
(37)\end{array}$ & 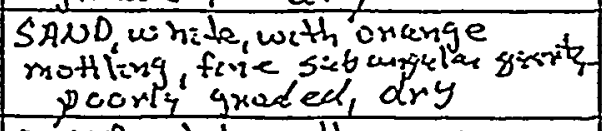 & $S P$ & Headspace \\
\hline & & $|s\rangle-15 \mid$ & $18^{\prime \prime}$ & $\mid 6-12-10-14$ & 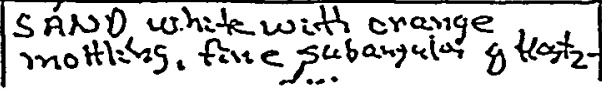 & & Heatspace \\
\hline
\end{tabular}




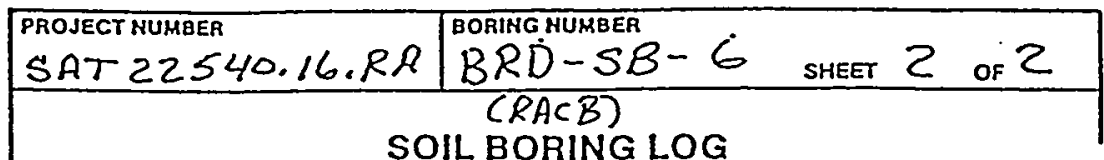

PROJECT SRP RMET RFI ELEVATION DRILLING CONTRACTOR_. MJ

DRILLING method and equipment. Hollow stem Aleger Location Baxley Rde (RACB) WATER LEVEL ANO DATE START $3-28-Q$

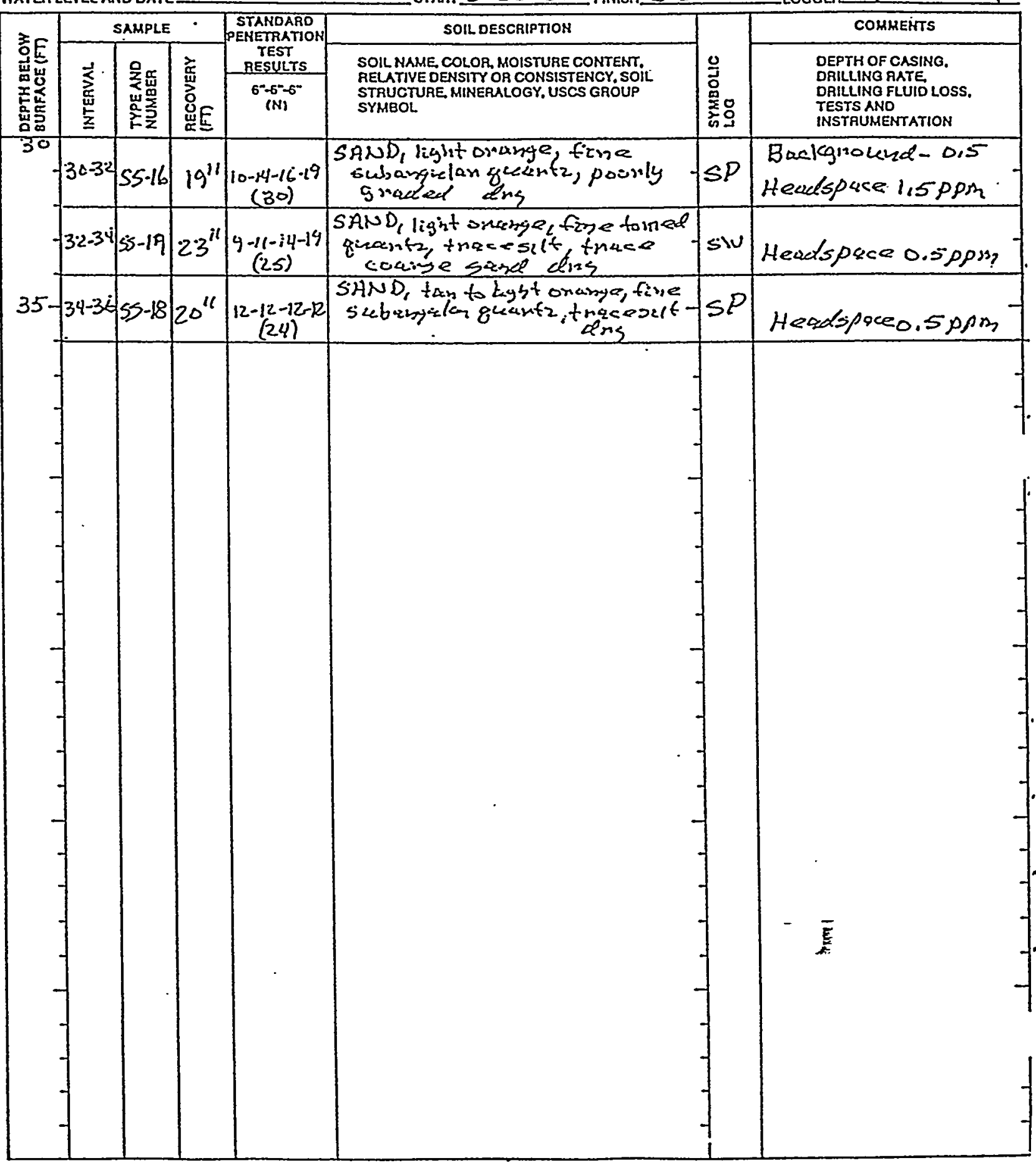




\begin{tabular}{|c|c|c|c|c|}
\hline \multirow{2}{*}{ 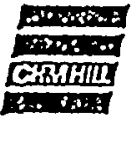 } & $\begin{array}{l}\text { PROJECT NUMBEA } \\
\text { SAT } 22540.16, R A\end{array}$ & $\begin{array}{l}\text { BOAING NUMBEA } \\
\text { BRD } 5 B-7\end{array}$ & SHEET & of 1 \\
\hline & & $\begin{array}{l}(R A C B) \\
\text { IL BORING LOG }\end{array}$ & & \\
\hline
\end{tabular}

PAOJECT SRP RMET REI

\section{ELEVATION} Location Baxley Rd.

$(R A \subset B)$ DAILLING METHOD AND EQUIPMENT HO $/$ /OQ2
WATER LEVEL AND DATE \& A DRILLING CONTRACTOR_HTC Stem Augen

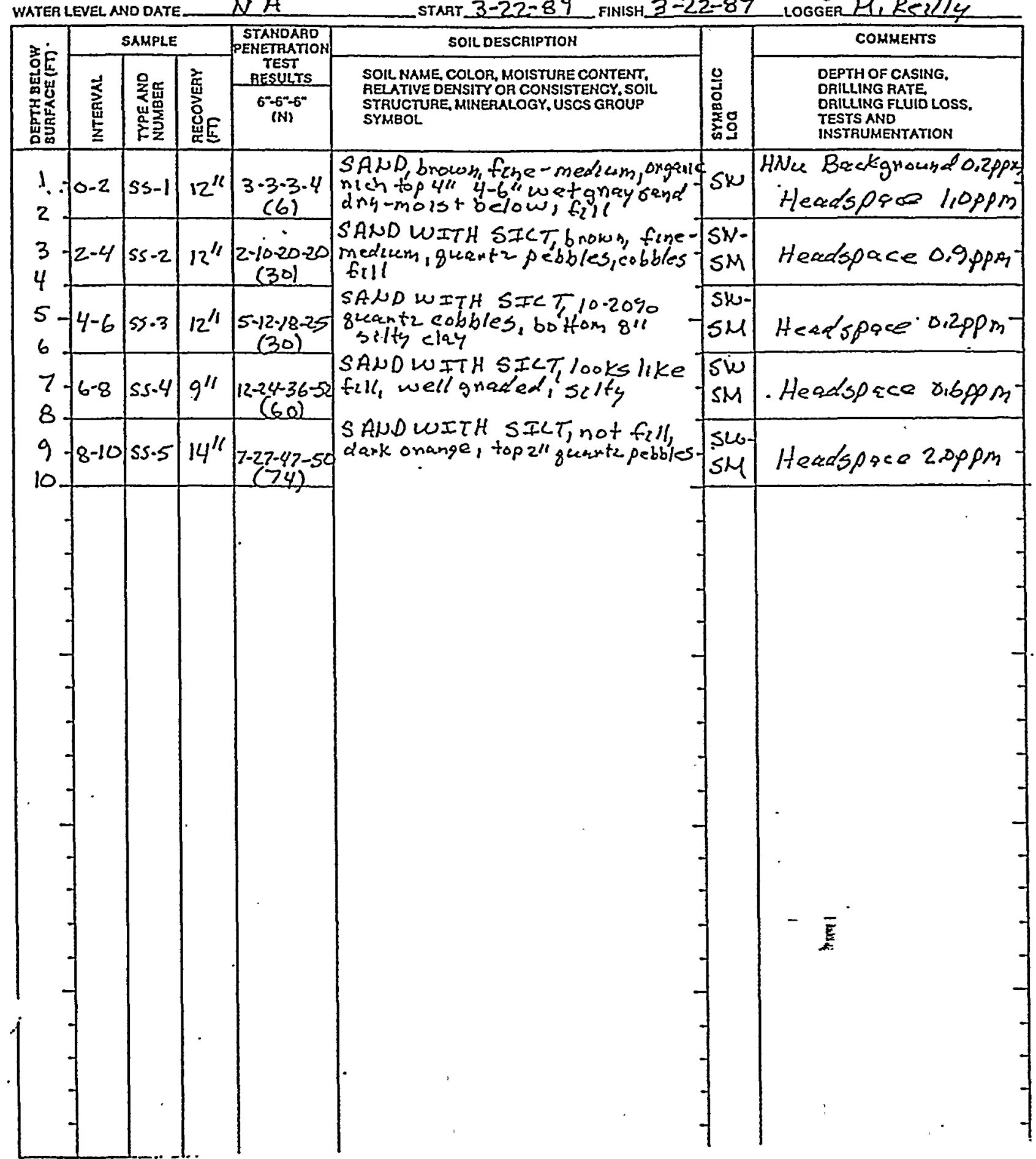


PROJECT_SRP RMET RFI

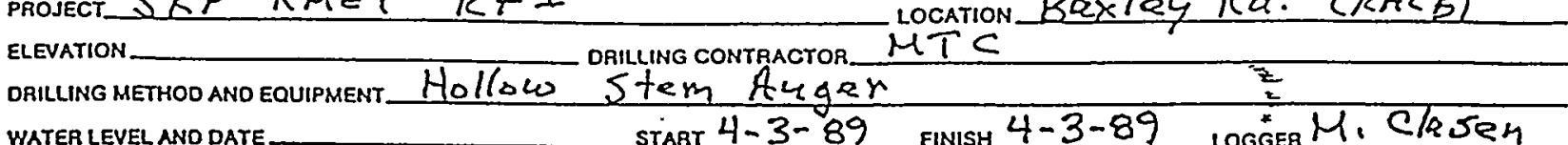

\begin{tabular}{|c|c|c|c|c|c|c|c|}
\hline \multirow[b]{2}{*}{ 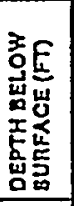 } & \multicolumn{3}{|c|}{ SAMPLEE } & \multirow{2}{*}{$\begin{array}{c}\text { STANDARD } \\
\text { PENERATION } \\
\text { TEST } \\
\text { RESULTS } \\
\begin{array}{c}6^{-}-6^{-}-6^{-} \\
\text {(N) }\end{array} \\
\end{array}$} & \multirow{2}{*}{$\begin{array}{l}\text { SOIL DESCRIPTION } \\
\text { SOIL NAME, COLOR, MOISTURE CONTENT, } \\
\text { RELAIVEENSTYOR CONSISTENGY, SOIL } \\
\text { STRUCTURE, MINERALOGY, USCS GROUP } \\
\text { SYMBOL }\end{array}$} & \multirow[b]{2}{*}{ 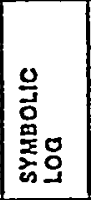 } & \multirow{2}{*}{ 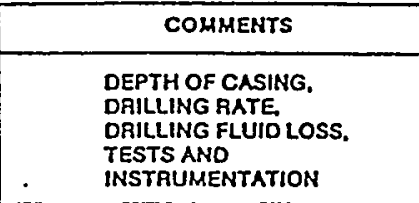 } \\
\hline & 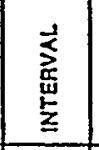 & 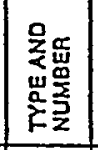 & 焉 & & & & \\
\hline \multirow{5}{*}{$5-$} & 0.2 & $5 s-1 \mid$ & $18^{\prime \prime}$ & $\begin{array}{c}8-9-11-11 \\
(20)\end{array}$ & 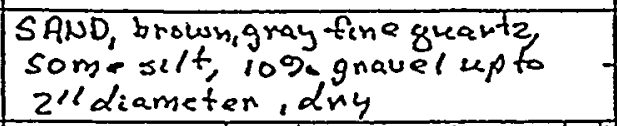 & sw & $\begin{array}{l}\text { HNu Background 0,2ppm } \\
\text { Headspace 0.2ppm }\end{array}$ \\
\hline & $2-4$ & $5 s-2$ & $15^{11}$ & $\begin{array}{c}8-41-62-86 \\
(91)\end{array}$ & $\begin{array}{l}\text { SILTY SAND, gray wat "Iskedget } \\
5090 \text { gray si it, 50\%o gnavel } \\
\text { wet }\end{array}$ & $\operatorname{ses}$ & Headspace $0.4 \mathrm{ppm}$ \\
\hline & $4-6$ & 553 & $16^{\prime \prime}$ & $\begin{array}{c}36-32-14-16 \\
(46)\end{array}$ & $\begin{array}{l}\text { SANDY CLAY brown } \\
\text { plastice soft, clay, } \\
\text { trace gnavel, }\end{array}$ & $C L$ & Heads pace $0.2 \mathrm{ppm}$. \\
\hline & $6-8$ & ss. 4 & $20^{\prime \prime}$ & $\begin{array}{c}18-20-34-50 \\
(54)\end{array}$ & 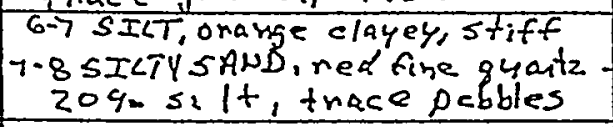 & $M L$ & Hearspace $0.5 p p m$ \\
\hline & $8-10$ & $5 s-5$ & $12^{11}$ & $\begin{array}{c}20-32-4974 \\
(81)\end{array}$ & $\begin{array}{l}\text { SANDWITH SILT, red, fino, subangh } \\
\text { quant2, well graded, mols } t \text {. }\end{array}$ & SW & Headspece 5.0ppm \\
\hline \multirow{5}{*}{$15-$} & $10-12$ & $55-6$ & $23^{11}$ & $\begin{array}{c}24-32-35-30 \\
(67)\end{array}$ & $\begin{array}{l}\text { SAND WITH SICT, } \\
\text { suantz, trace black } \\
\text { poorls gnader }\end{array}$ & $\begin{array}{l}S P \\
S M\end{array}$ & Headspace 4,0ppm \\
\hline & $|12-14|$ & $55-7$ & $22^{\prime \prime}$ & $\begin{array}{c}11-32-52-56 \\
(84)\end{array}$ & $\begin{array}{l}\text { SAND wiTh SICT, red fine, } \\
\text { Subongular quant } 2 \text {, poonly gnaded }\end{array}$ & $\begin{array}{l}S P \\
S M\end{array}$ & Headspace $9.0 p p m$ \\
\hline & $\mid 14-16$ & $5 s-8$ & $14^{\prime \prime}$ & $\begin{array}{c}8-24-35-46 \\
(59)\end{array}$ & $\begin{array}{l}\text { ITH SICT, ne } \\
\text { ilom guart2, } \\
\text { is t }\end{array}$ & \begin{tabular}{|l}
$S P$ \\
$S M$
\end{tabular} & Headspace $7.2 p_{p+4}$. \\
\hline & $\mid 16-18$ & $5 s .9$ & $15^{\prime \prime}$ & $\begin{array}{c}8-15-19-23 \\
(34)\end{array}$ & $\begin{array}{c}\text { SAND, redlorangef } \\
\text { guarti, poorly graded } \\
\text { molst }\end{array}$ & $S P$ & Headspace 3.8ppin \\
\hline & $\mid 18-20$ & $\mid 5 s-10$ & $18^{11}$ & $\begin{array}{c}8-16-18-25 \\
(34)\end{array}$ & $\begin{array}{l}\text { onarge, fine, se } \\
2, \text { poorly grade } \\
\text { K minera!s }\end{array}$ & $S P$ & Headspiace 4,5 \\
\hline \multirow[t]{2}{*}{ - } & $|20-22|$ & $\mid 5 s-11$ & $19^{16}$ & $\mid \begin{array}{ll}11 \cdot 15-23-26 \\
(38)\end{array}$ & $\begin{array}{l}\text { SAND, onange fine skbargular } \\
\text { guati } z_{1} \text { poorly graded, thace }\end{array}$ & $S P$ & Head space 6.6 \\
\hline & 22.24 & $\mid 55 \cdot 12$ & $23^{\prime \prime}$ & $\begin{array}{c}11-21-21-28 \\
(4 \geq !\end{array}$ & $\begin{array}{l}\text { SAND, pink to ned, fine } \\
\text { subangulan guarti, poorly } \\
2 \text { naded. noest }\end{array}$ & $S P$ & $-1+$ exdspace 10.2 \\
\hline \multirow[t]{3}{*}{$25-$} & $=24-26$ & $55-13$ & $22^{\prime \prime}$ & {$\left[\begin{array}{c}8-20-23-28 \\
(931)\end{array}\right.$} & $\begin{array}{l}\text { SAND, whete orange, ned, pink } \\
\text { fine, subuenglas gttant?, poorls } \\
\text { gneded mols t }\end{array}$ & $S P$ & Headspere 20.5 \\
\hline & $-26-28$ & $s s-14$ & $22^{\prime \prime}$ & $\left|\begin{array}{l}10-18-26-30 \\
(4 \leq 4)\end{array}\right|$ & 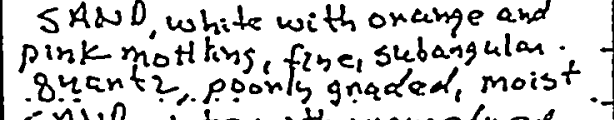 & $S P$ & $\begin{array}{l}\text { Headspace } 0.8 \\
. . . . . .\end{array}$ \\
\hline & $28.3^{\circ}$ & $5 s .15$ & $22^{\prime \prime}$ & $\begin{array}{c}8-13-23-35 \\
(36)\end{array}$ & 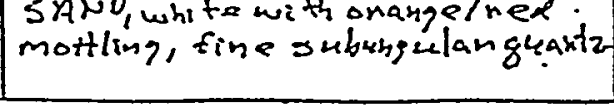 & $S P$ & Heanspoce 0.8 . \\
\hline
\end{tabular}


\begin{tabular}{|l|l}
\hline PROJECT HUMBER & BORING NUMBER \\
\hline
\end{tabular}

\begin{tabular}{|l|l|l|}
\hline$S A T 22540,16, R A$ & $\begin{array}{l}\text { BOAING NUMBER } \\
B R D-5 B-8\end{array}$ SHEET 2 of 2 \\
\hline
\end{tabular}
SOIRCB)

SOIL BORING LOG

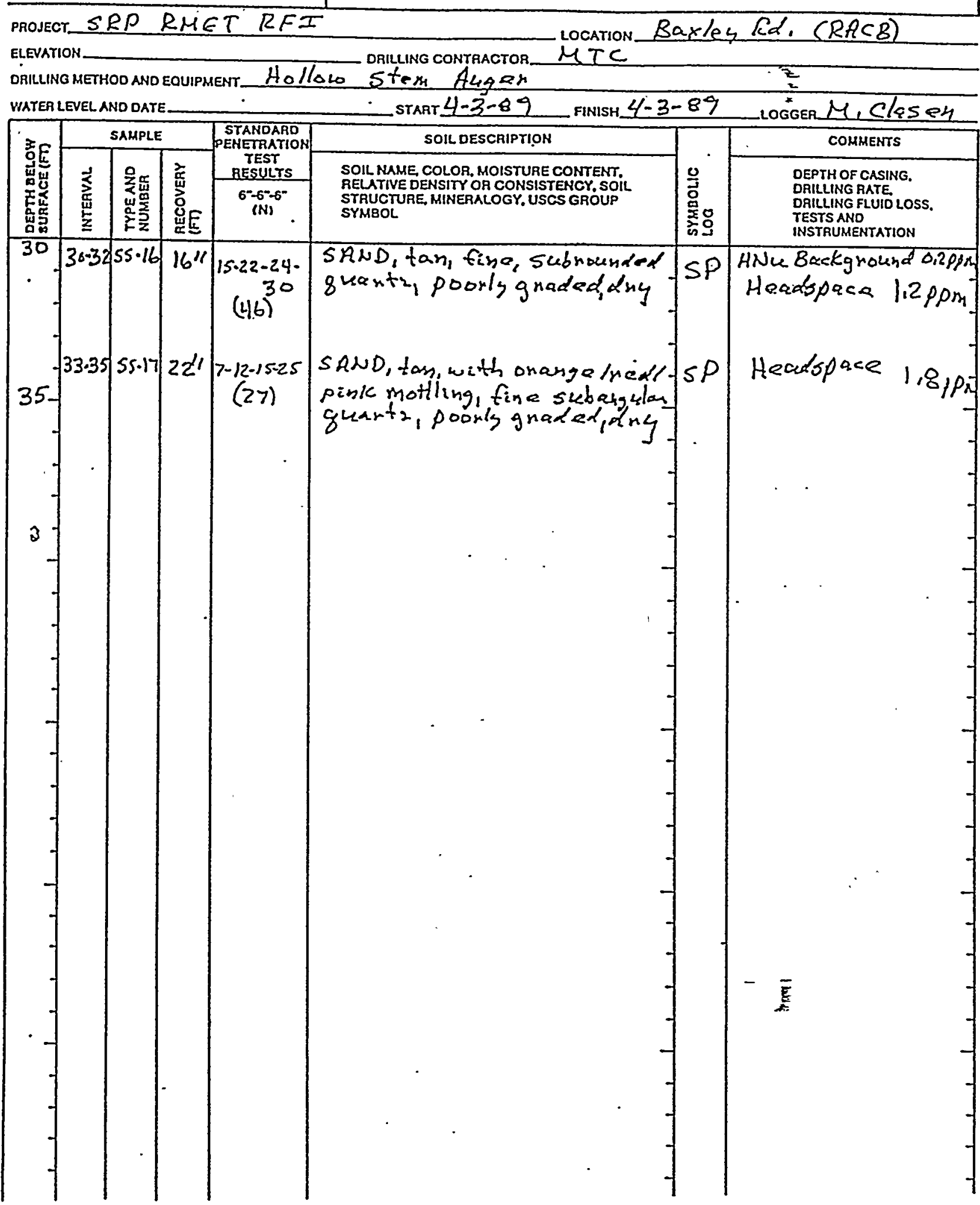




\begin{tabular}{|c|c|c|c|}
\hline $\begin{array}{l}\text { PROJECT NUMBER } \\
\text { SAT } 22540.16 .8 A\end{array}$ & $\begin{array}{l}\text { BORING NUMAEA } \\
\text { BRD-SB-9 }\end{array}$ & SHEET & $=2$ \\
\hline
\end{tabular}

PROJECT SRP RMET RFI ELEVATION DRILLING CONTRACTOR MTC LOCATION Baxley Rd, $(R R \subset B)$ DRILLING METHOO ANO EOUIPMENT Hollow Stem Aygen WATER LEVEL ANO OATE START $3-22-89$ FINISH $3-31-89$ 7

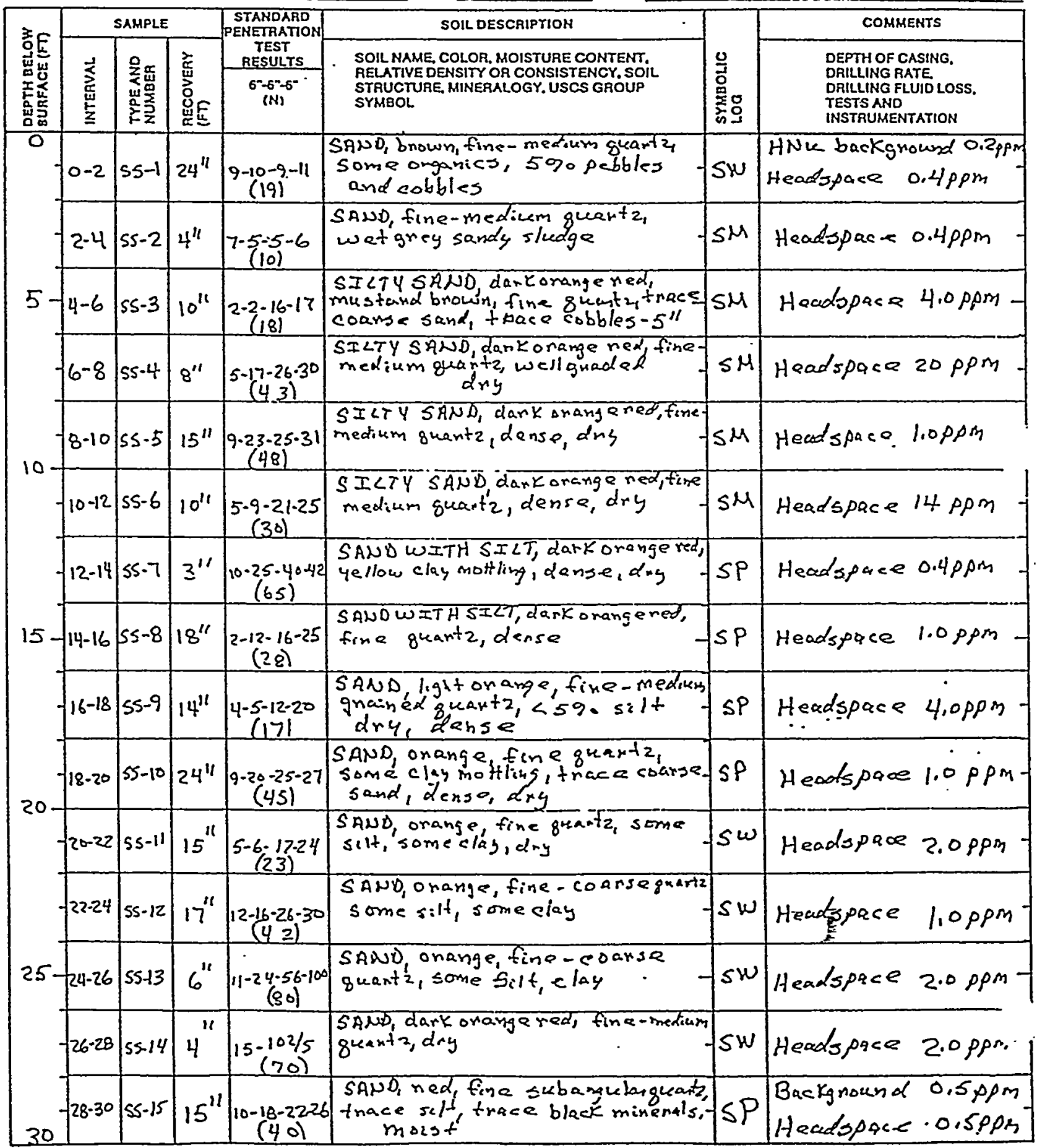




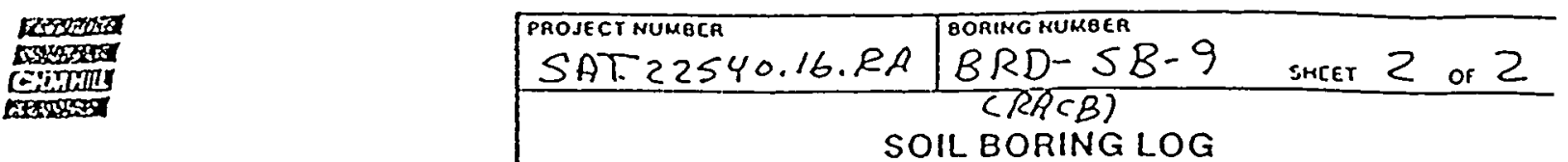

mouecr SRP RMET RFI Locarion Baxley RQ. (RRCB)

ELEVATION ORILLING CONTRACTOR_h TC

ORILLING METHOO aND EOUIPMENT Hollow S tom Ayser WATER LEVEL ANO DATE START 3-22-89 FINISH $3-31-89$ cogger M. Clasef

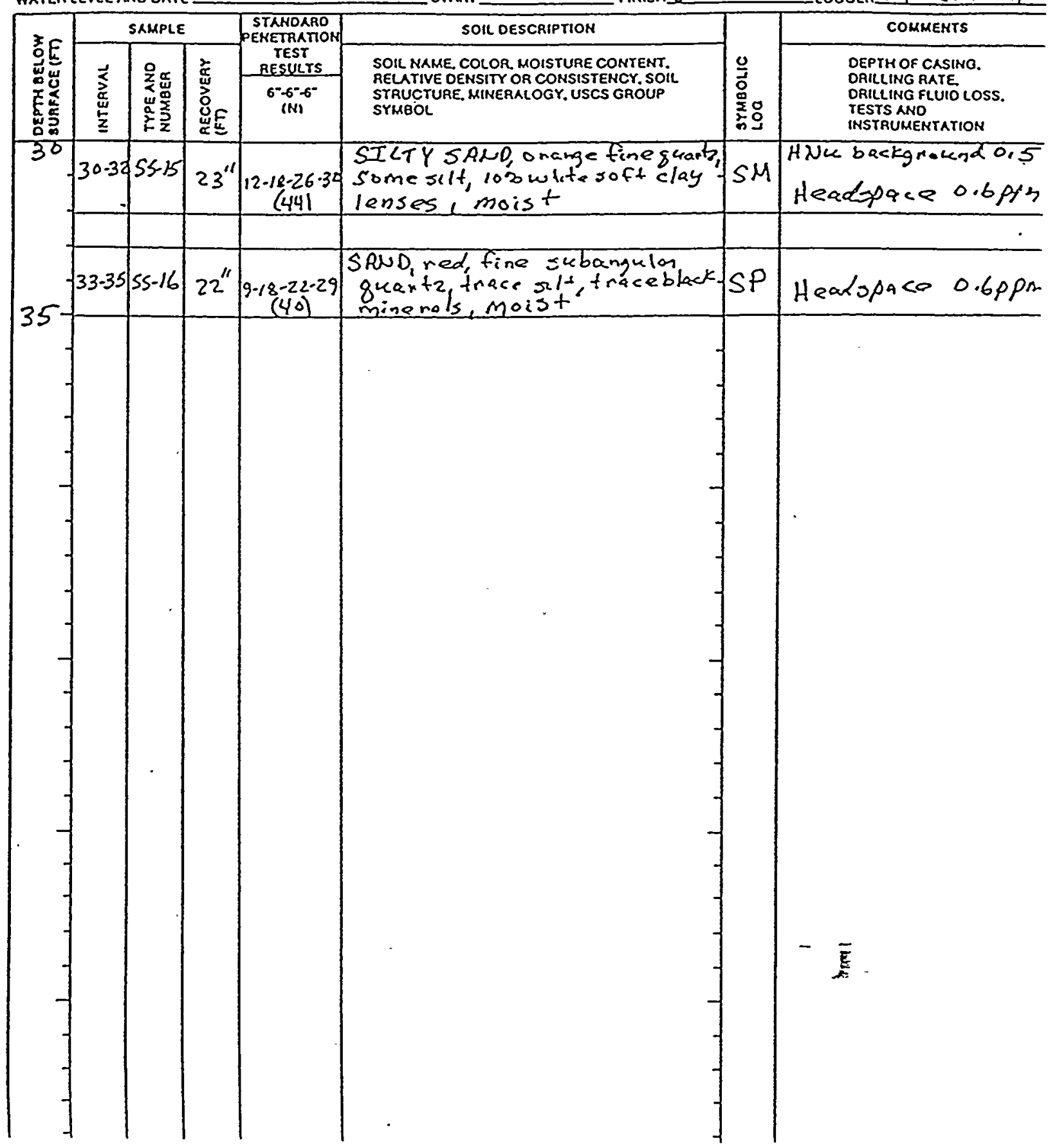




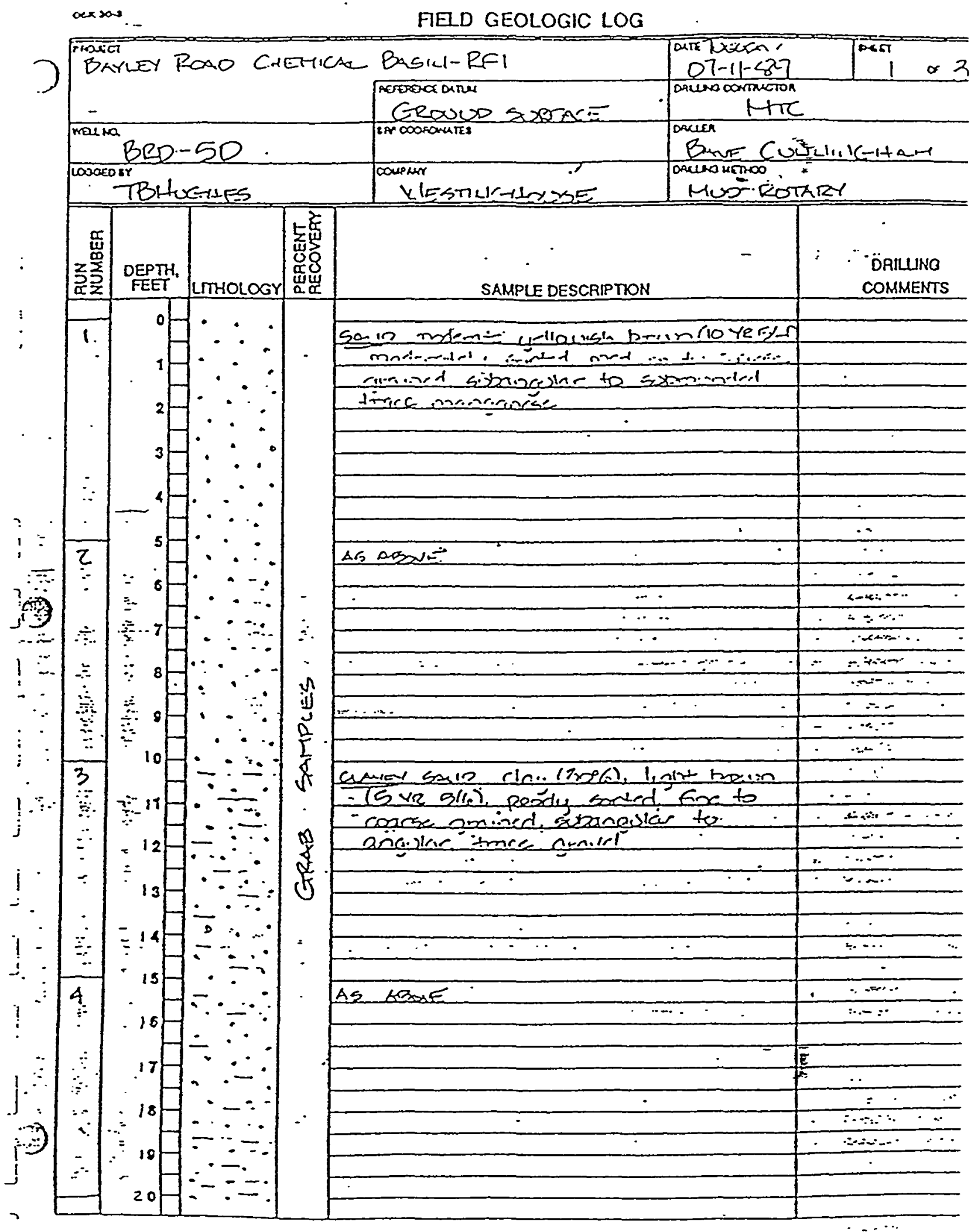




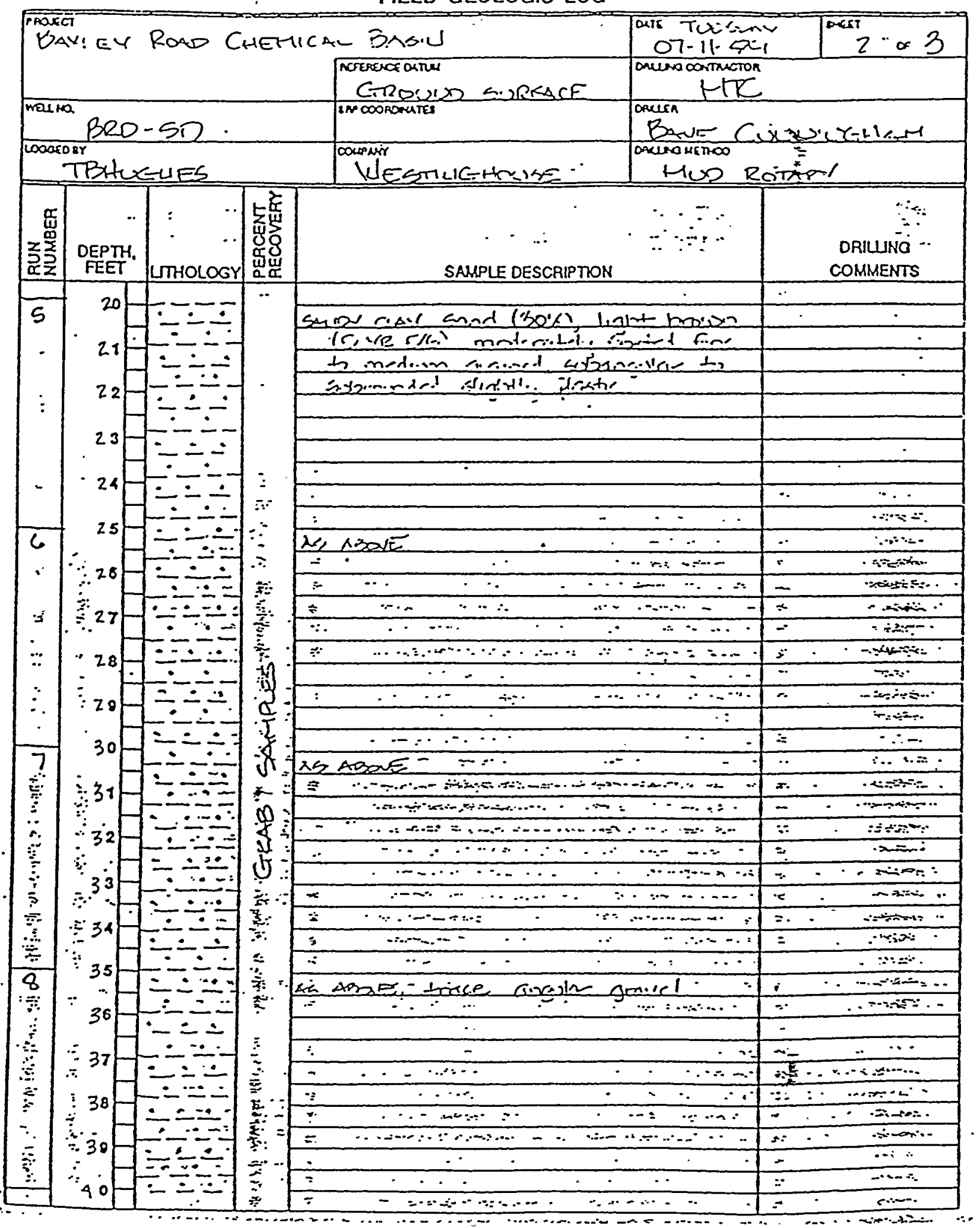


$\infty \times 200$

FIELD GEOLOGIC LOG

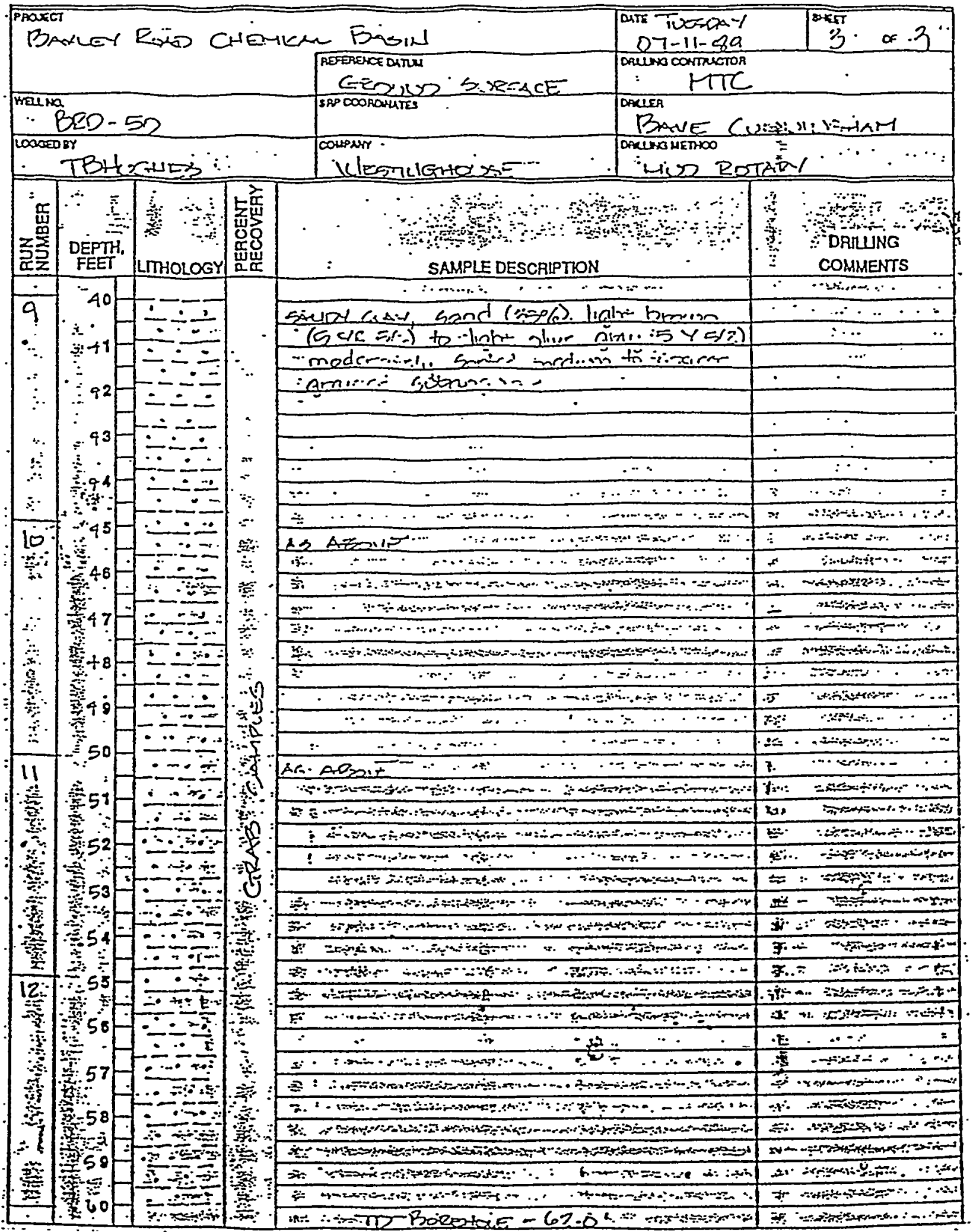




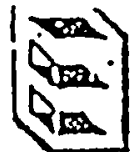

ENMRODYNE: ENGINEERS INC. ste of Instal12ation $7 / 16 ; 34$ phd Surface Elev. .220'

\section{WELL CONSTRUCTION DETAILS} Job No.

Time started 8:00
Boring No. $904-11: 6+4$

The completed $2: 00$

11 depth sensurements of vell detail axe from ground surface unless otherwise indicated.

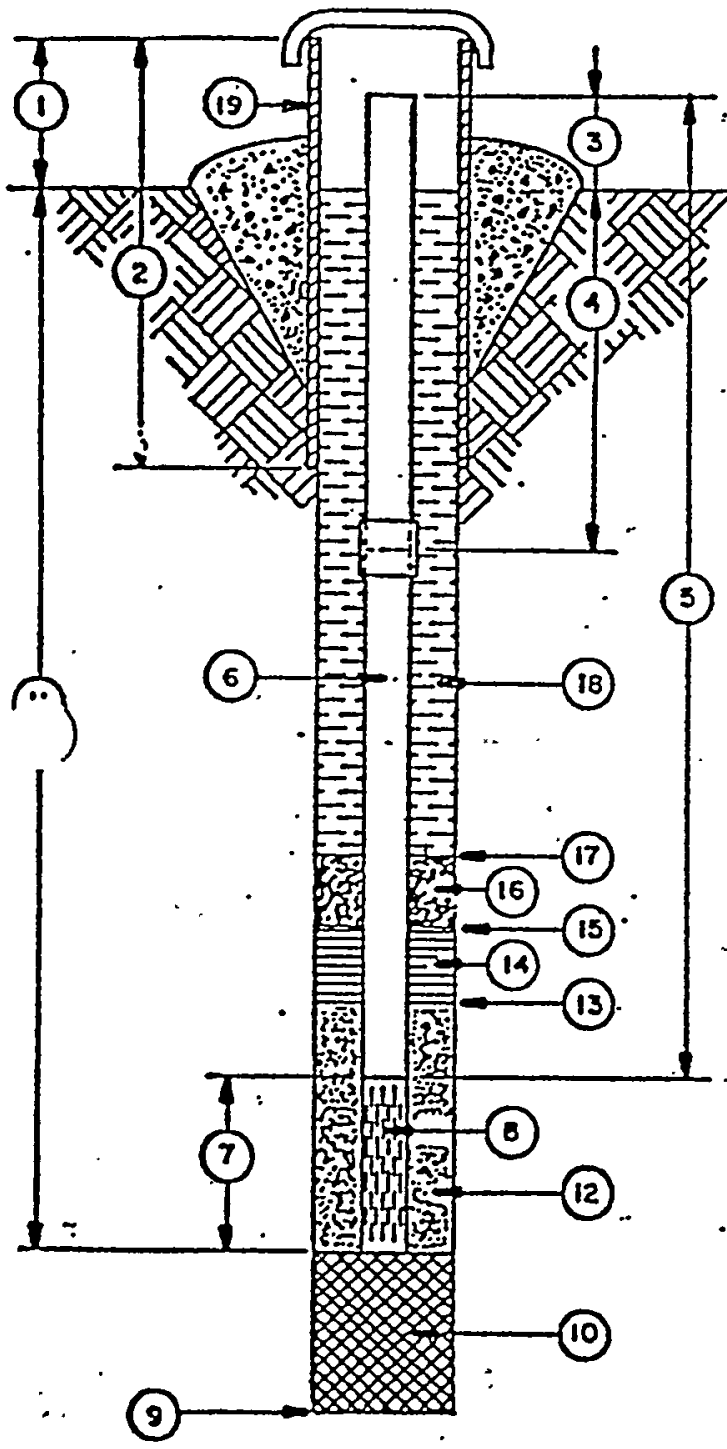

(1) Height of Protective Casing sbove Ground $\mathrm{w} / \mathrm{a}$

(2) Total length of Protective casing via

(3) Reight of Standpipe dbove Ground $\because 2$

(4) Depth to First Coupling $17^{\prime}$ Coupling Interval $20^{\circ} / 20^{\prime} / 10: / 20^{\prime}$

(3) rotai iength of Blank Pipe $37^{\circ}$.

(6) Type of Blark Pipe PVC 4"!

(7) Length of Screen $30^{\prime}$

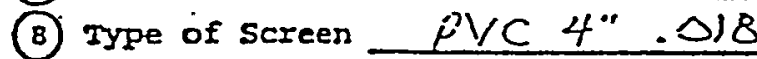

(9) Total Depth of Boring $70^{\prime}$ Hole Diam. $10^{\prime \prime}$

(10). Type of Material Native od $4 \mathrm{cl} y$

(11) Depth tö Botton of screen $67^{\prime}$

(12) Iype of screen Eilter Péa Groud -Quantity used 16 bags $\cdots \cdots$

(13) Depth to rop of Filter $32^{\prime} \cdots \cdots \cdot$

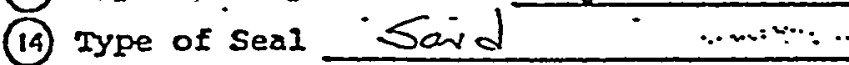

- quantity used 3 bacs

(13) Depth to Top of seal '28'

(16) Type of Seal Weight Nia quantity used $\mathrm{rla}$

(17) Depth to Top of seal Height wla.

(B) Type of Grout iSimet . Grout Mrturo Geneil/oster

(19) Type of protective casing rla

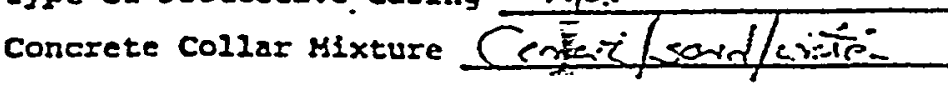


cose 30.8

SRP MONITORING WELL CONSTRUCTION DETAILS -

DRILLING SUBCONTRACTOR MTC

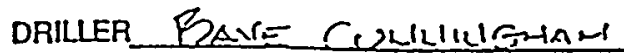

DATE OF INSTALLATION $7-11-89$

TECH. O.SJCO. NAME TEÄrN B. Hexules VlesTuGHOUSE

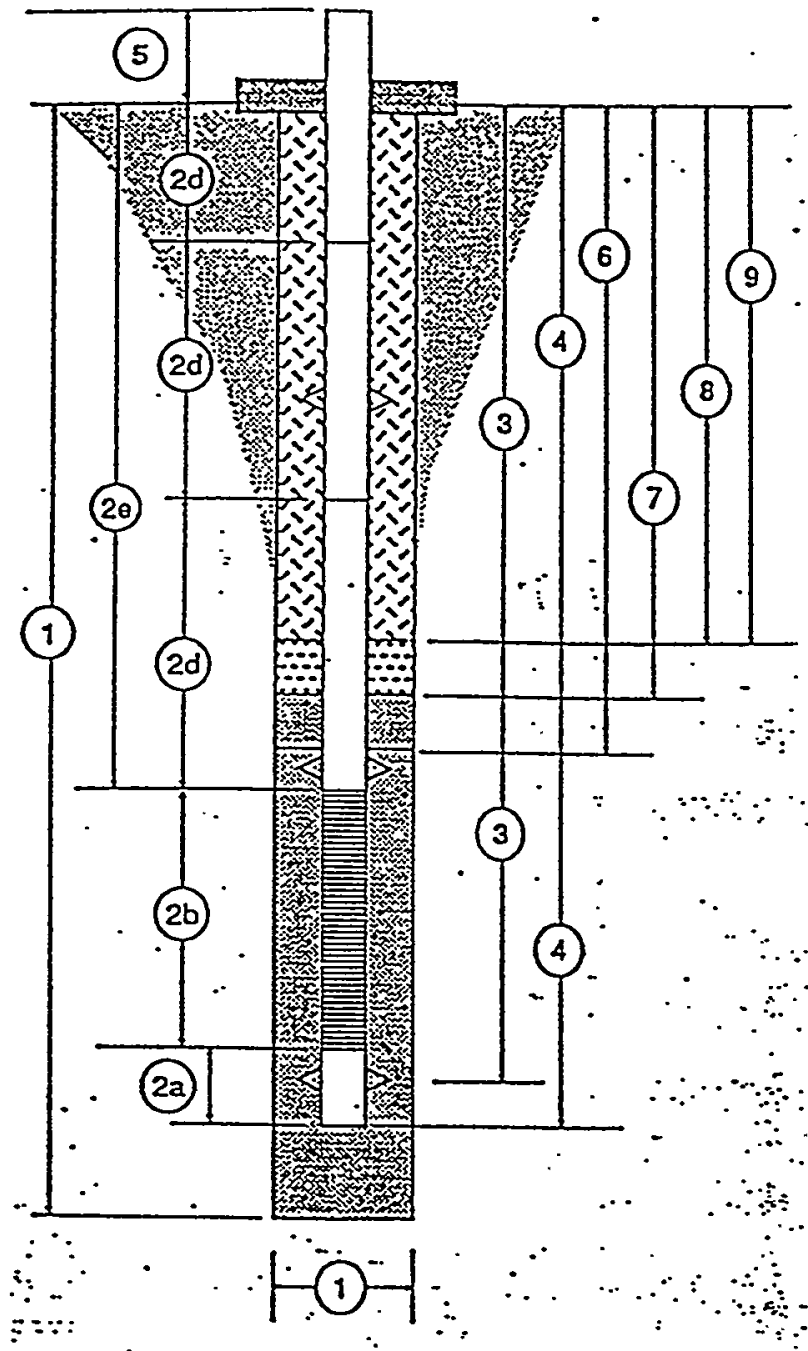

1) Total dialled depthhole diameler $\left(22.0 / 9^{7} / \Omega^{4}\right.$

2) Casing/Screen Tally (Measured to Nearest 0.01 Foot)

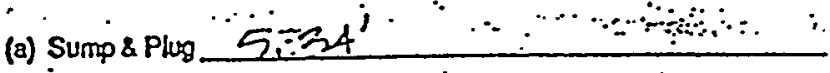

(b) Screen Longth $20.05^{\circ}$

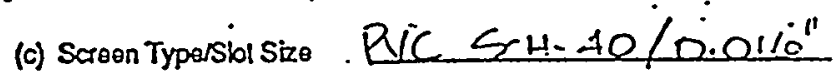

(d) Casing Joinl Lengths (Measured in up 1 (1) 10.02 :(1) $10.01^{\prime}:$ (2) $10.03^{\prime}\left(+1.4 .25^{\circ}\right.$

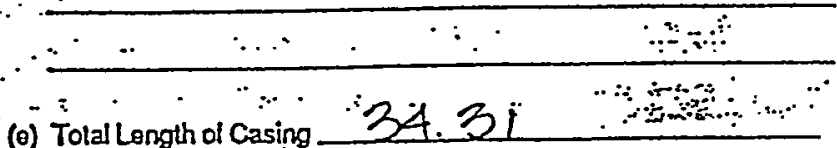

(0) Tolal Longth of Casing $\frac{34.31}{2 \ldots}$

(i) Type of Casing PUC $5 \mathrm{xH}-40$

3) Depths to Contralcers 20.0; $32,2^{i}-54.5$

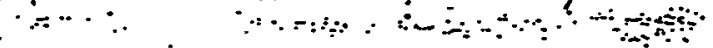

4) Total Depth of hnstalled Woll $59.7^{\prime} \cdots: \because$

5) Casing Stick Up (Standard 25 A.G.s) $7.5^{\prime}$

6) Depth to Top of Futer Pack_ZCe.9 . . A.

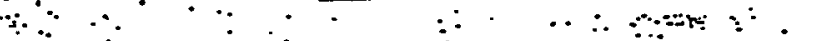
Quandy (Bass) $14 . \quad \because 5 i z 0 . .45-.55 \mathrm{~min}$

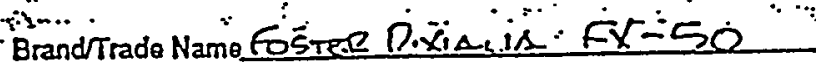

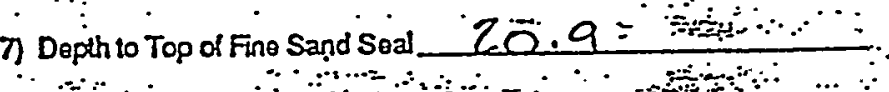
Quantity (Sacks) $\because \because \cdots \cdots$

NOTE: ALL MEASUREMENTS ARE FROM GROUND

$\therefore \quad$ SURFACE AT START

8) Depth to Tóp of Bentonite Seal

$17: 0$

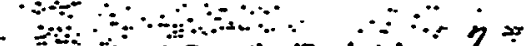
$\because \cdots \quad \therefore \quad \cdots$

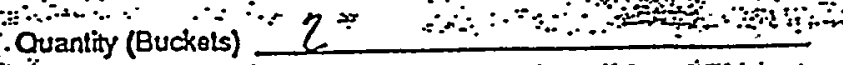
The

9) Thickness of Grout 17.0 $\therefore \because$ Total Grout Quantity (Bags) $\quad C^{-}$ 
Appendix C

Field Data Sheet 
This page intentionally left blank. 


\title{
UNIT RECONNAISSANCE
}

FIELD DATA SHEET

SAVANNAH RIVER SITE, AIKEN SOUTH CAROLINA

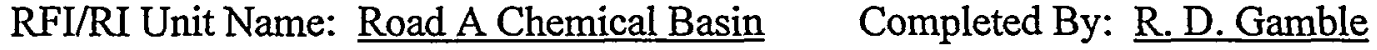 \\ 904-111G
}

RFI/RI Unit Location: $\underline{\text { Road A Chemical Basin } \quad \text { SRS Representative Name: Stephani Fuller }}$

\section{ENVIRONMENTAL SETTING}

Unit Arrival Time: $\underline{1320}$

Health and Safety Recommendation Initiated: No

1. Meteorological Conditions
a. Temperature: $\sim 50^{\circ} \mathrm{F}$ Sky Cover: Sunny
b. Precipitation: N/A
c. Wind Conditions: Negligible

2. Topographical/Biological Description

a. Description of corresponding natural features (hills, valleys, depressions, etc.): The topography at the unit is moderately sloping towards the southwest. The area immediately adjacent to the unit on the southwest side is relatively steep, indicative of a berm. Two depressions (drainage swales) filled with rip-rap are present along the southwest side of the unit. One at the approximately the mid-point of the southwest side and one at the west corner of the unit.

b. Description of surface water bodies (stream, river, lake, leachate): № surface water bodies are located in the immediate vicinity of the unit

c. Description of corresponding vegetation (weeds, grass, underbrush, small/mature trees): The unit is covered primarily with grass. Patches of heavy underbrush and thicket which has recently been cut are present in the center portion of the unit. Two mature pine trees $(\sim 1.0 \mathrm{ft}$. in diameter at their base) are growing within the unit boundaries as well as two smaller pine trees $>2$ inches in diameter. 
d. Description of animal presence/habitat (tracks, nests, dens, etc.): No nests or dens were observed on the unit or in the immediate vicinity. Deer tracks were found in an eroded area approximately $20.0 \mathrm{ft}$. east of the unit.

3. Man-Made-Features

a. Description of corresponding features (buildings, roads, powerlines, wells): An $8.0 \mathrm{ft}$. high chain-link fence surrounds the entire unit. Five groundwater monitoring wells are located in the immediate area, three are located outside the fenced area, two are located within the fenced area. The gravel access road is located approximately 125 feet from the nearest unit boundary marker. An unimproved road is located approximately 50 feet northeast of the unit.

\section{SOURCE CHARACTERIZATION}

\section{Unit Area Characteristics}

a. Description of management activities (landfill, surface impoundment, etc.): Historical photographs indicate the unit was a surface impoundment

b. Estimation of waste management area size: The aerial dimensions of the unit are approximately $90 \mathrm{ft} \times 200 \mathrm{ft} \times 110 \mathrm{ft} \times 160 \mathrm{ft}$.

c. Construction of waste management area (earthen, liners, cement, above grade, etc.): The unit was a earthen basin during its operational period. The unit was filled with native soil and graded in 1973

d. Is the unit in current use/operation: No

2. Waste Characteristics

a. Description of any visible waste: None visible, basin backfilled with native soils in 1973

b. Quantity of waste (number of drums, pile size, etc.):information is not available 


\section{WASTE RELEASE POTENTIAL}

1. To Soil/Groundwater/Surface Water

a. Description of waste run-off/leachate (soil discoloration, dead vegetation or no growth, erosion, etc.): The unit is currently filled with native soil and graded and vegetated to prevent erosion. Surface runoff from the unit is channeled to two drainage swales on the down-slope side of the unit. A culvert in each drainage swale directs surface runoff to the southwest. No leachate, dead or stressed vegetation was observed.

b. Estimate of impacted area (size of area, distance from the source, etc.) No impact to soil or surface water observed

IV. FINAL CHARACTERIZATION

1. Additional comments: The unit perimeter is protected by an $8.0 \mathrm{ft}$ high chain-link fence. The access gate is too small to allow drill rig access on the unit itself. Large rounded pebbles and cobbles are present at the surface east of the unit. If these materials are predominant in the surface and near-surface soil at the unit, this may prevent hand auger sampling methods during the characterization phase.

2. Follow-up questions: Request additional information on groundwater monitoring data and construction details of wells at the unit.

3. Health/Safety concerns: Wildlife in forested area

4. Site Departure Time: $\underline{1430}$

\section{PHOTOGRAPHS}

1. Photographs taken: No

2. Quantity of Photographs Taken: N/A 
This page intentionally left blank. 
Appendix D

Soil Boring Analyses 
This page intentionally left blank. 


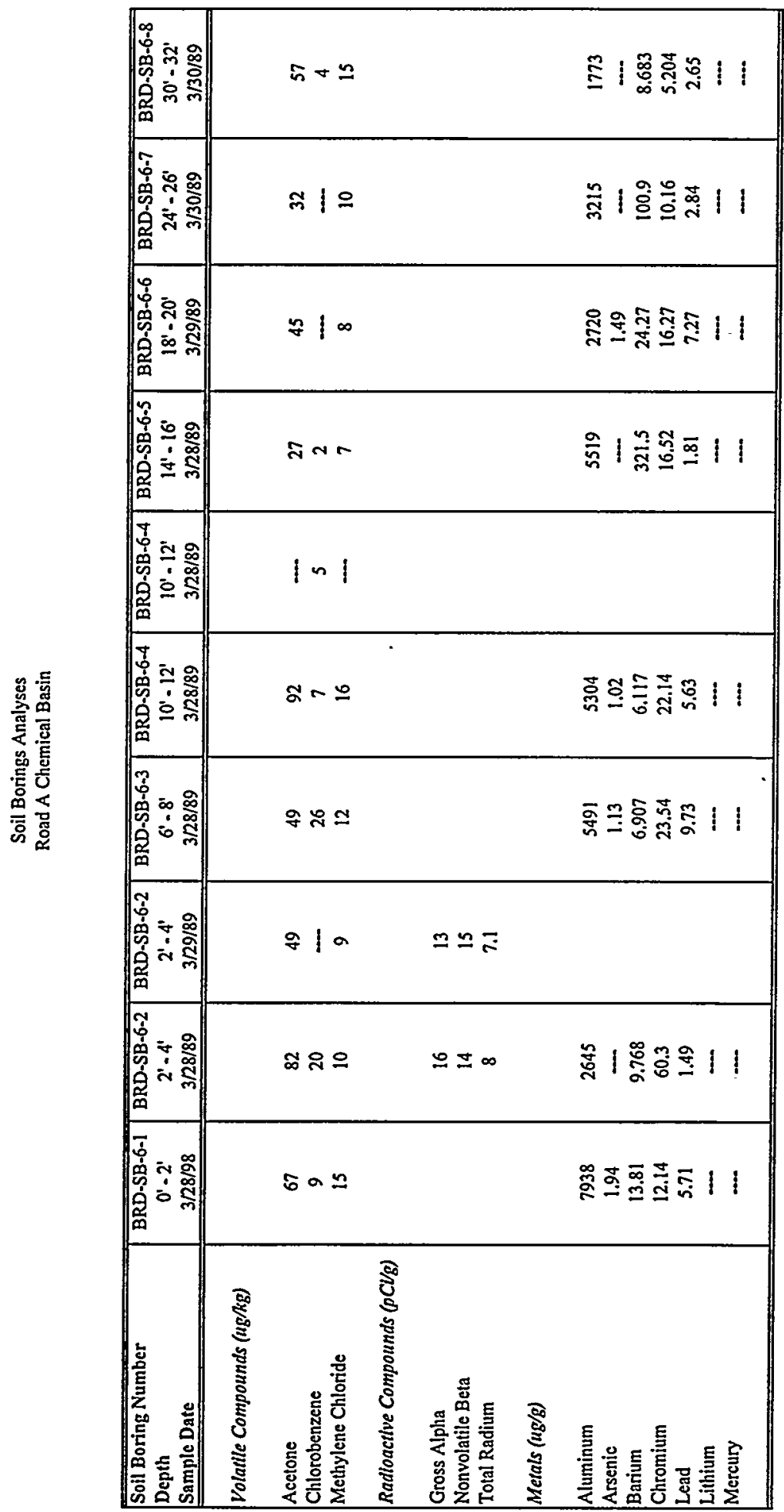




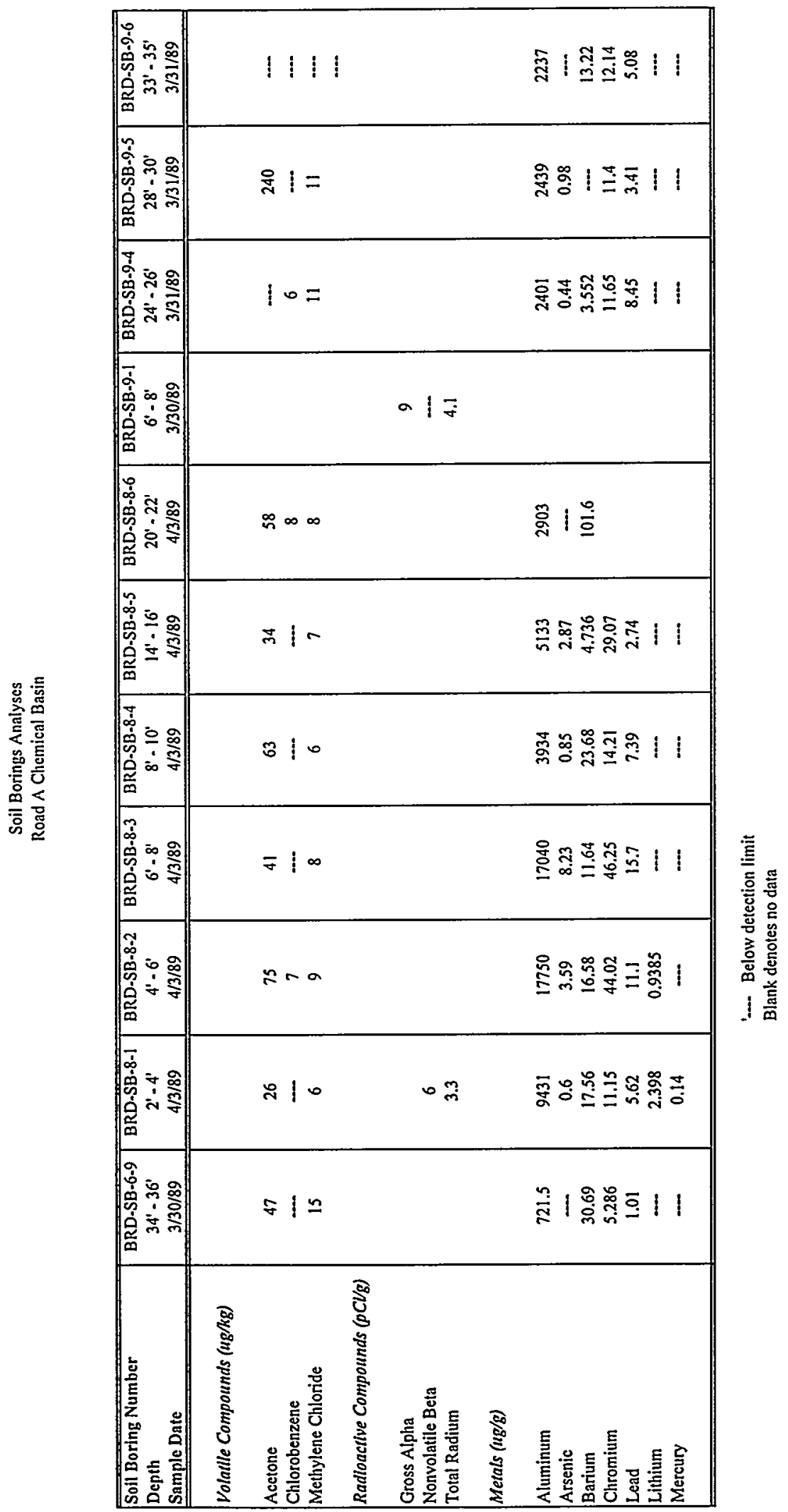


Appendix E

Soil Gas Investigations at the Road A Chemical Basin 
This page intentionally left blank. 


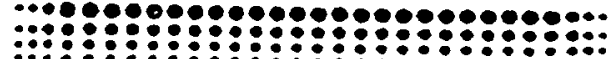

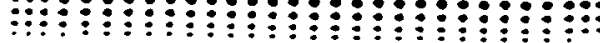

\author{
Draft Report \\ SOIL GAS INVESTIGATIONS \\ at the \\ ROAD A CHEMTCAL BASIN \\ (904-111G)
}

SAVANNAH RIVER SITE

March, 1993

Robert J. Pirkle

David J. Masdea

Task 24.

Subcontract.

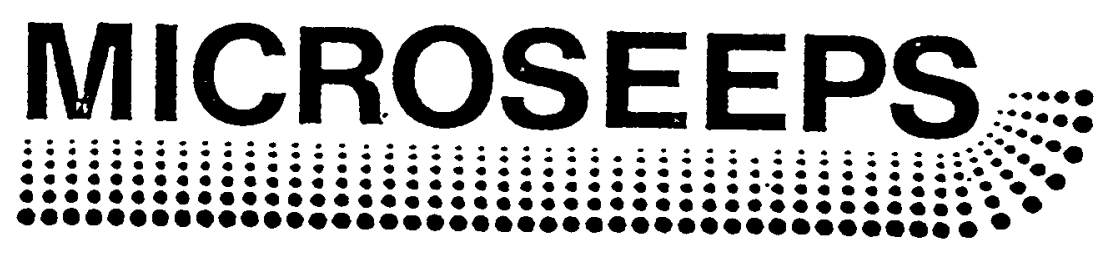

University of Pittsburgh Applied Research Center

220 William Pitt Way

Pittsburgh, PA 15238

(412) 826-5245 


\section{EXECUTIVE SUMMARY}

A soil gas survey was performed at the Road A Chemical Basin (904-i11G) during september, 1992. The survey monitored the presence and distribution of the $C_{1}-C_{4}$ hydrocarbons; the $C_{5}-C_{10}$ normal paraffins; the aromatic hydrocarbons, BTXE; and selected chlorinated hydrocarbons at a total of 36 sample locations.

Levels of volatile organics observed are very low. 'only. occasional, isolated observations of benzene, toluene, the xylenes, and chloroform wiere made. Levels of methane are anomalous at several sites which may be suggestive of active biological processes. 


\section{TABLE OF CONंTENTS}

Executive Summary

List of Figures

List of Tables

I. Introduction

II. Background

III. Quality Assurance

A. Sampling Methods

B. Analytical Methods

C. Accuracy

D. Reliability of Selected Data

E. Precision

F. Minimum Detection Levels

G. Blanks

H. Data on Magnetic Disk

IV. Results

V. Conclusions

VI. Appendix I

Sampling Method SM1

Sampling Method SM4

Analytical Method AM1

Analytical Method AM4

Standard Preparation Method SP3

VII. Appendix II

Soil Gas collection logs

Waste Management Unit Worksheets 


\section{LIST OF FIGURES}

Figure 1. The Road A Chemical Basin (904-111G) Sample Location Map

Figure 2. Gas Chromatogram of Soil Gases at Site 29 from the Flame Ionization Detector

Figure 3. Gas Chromatogram of Soil Gases at site 29 from the Electron Capture Detector

Figure 4. Gas Chromatogram of System Blank \#3 from the FID Detector

Figure 5. Gas Chromatogram of System Blank \# 3 from the ECD Detector

Figure $\sigma_{2}$. Gas Chromatogram of $C_{1}-C_{4}$ standard $M$

Figure $\sigma_{b}$. Gas Chromatogram of $C_{1}-C_{4}$ standard 224

Figure 7. Gas Chromatogram (FID) of Voc standard "K4", Level 3

Figure 8. Gas Chromatogram (ECD) of VoC standard "K4", Level 5

Figure 9. Gas Chromatogram of $\mathrm{C}_{1}-\mathrm{C}_{4}$ Hydrocarbon Standard $\mathrm{M}$ e 200:1 Dilution in $\mathrm{N}_{2}$

Figure 10. Benzene Symbol Map

Figure 11. Benzene (ppbv) Map

Figure 12. Toluene Symbol Map

Figure 13. Toluene (ppbv) Map

Figure 14. o-Xylene Symbol Map

Figure 15. o-XYlene (ppbv) Map

Figure 16. m\&p-xylene Symbol Map

Figure 17. m\&p-Xylene (ppbv) Map

Figure 18. Pentane Symbol Map

Figure 19. Pentane (ppbv) Map

Figure 20. Hexane Symbol Map

Figure 21. Hexane (ppbv) Map 


\section{IIST OF FIGURES}

(continued)

Figure 22. Octane Symbol.Map

Figure 23. Octane (ppbv) Map

Figure 24. Chloroform symbol Map

Figure 25. Chloroform (ppbv) Map

Figure 26. Methane Symbol Map

Figure 27. Methane (ppmv) Map 


\section{LIST OF TÁBLES}

Table 1. Hydrocarbon Soil Gas concentrations and system Blanks at the Road A Chemical Basin (904-111G)

Table 2. Chlorinated Hydrocarbon. Soil Gas Concentrations and System Blanks at the Road A Chemical Basin (904-111G)

Table 3. Light Hydrocarbon soil Gas Concentrations and system Blanks at the Road A Chemical Basin (904-111G)

Table 4. VOC Prepared standard concentrations

Table 5. Hydrocarbon Analyses of Voc Standard "K4" in Data Directory 23

Table 6. Chlorinated Hydrocarbon Analyses of VoC Standard "K4" in Data Directory 23

Table 7. Light Hydrocarbon Analyses of Standards "M" and "224"

Table 8. Minimum Detection Levels

Table 9. System Blanks (FID) for Data Directories "D2I - D25"

Table 10. System Blanks (ECD) for Data Directories "D21 - D25" 


\section{INTRODUCTION}

A soil gas survey was designed and executed at the Road A Chemical Basin (904-11iG) at the Savannah River site in September, 1992. The objective of the soil gas survey was to determine the presence and extent, or absence of contamination in near surface soil gases at the site. A total of 36 sample locations were established, as shown on Figure 1 , and sampled for soil gases in order to accomplish these objectives. Species monitored were the light hydrocarbons, $\left(C_{1}-C_{4}\right)$; gasoline range normal paraffins $\left(C_{5}-C_{10}\right)$; gasoline range aromatic hydrocarbons, (BTXE); and selected chlorinated organics. All analyses for the $C_{1}-C_{4}$ hydrocarbons were carried out in an on-site laboratory staffed and equipped by Microseeps. All VọC analyses were carried out in Microseeps' laboratory in Pittsburgh, PA. The results of these analyses are shown on Tables 1,2 and 3 , and selected data are mapped as shown on Figures $10-27$. 


\section{BACKGROUND}

The 904-111G Road A Chemical Basin received uranium contaminated process liquids, primarily caustics from the 300-M Area from an unknown time until 1974. These wastes were routinely disposed of in a borrow pond and holding pond. The site was closed in 1974. There are no other records of hazardous wastes or hazardous constituents disposed at this site. other data relative to this site $A_{i s}$ documented on page $C-6 /$ of volume $I$ : Waste Management Unit Worksheets, October, 1990; WSRC-RP-90-1046 (which is attached in App̀endix II). 
III. QUALITY ASSURANCE

Mićroseeps quality assurance procedures have been documented in its Quality Assurance Manual and have been audited and approved by the Department of Energy for implementation at the Savannah River site. A copy of this manual in its entirety was submitted at the time of the audit and is on file. Documentation of applicable sampling and analytical methods and associated quality assurance procedures are on file in our laboratory at all times and are included in this report in Appendix I.

\section{A. Sampling Methods}

Methods and quality assurance procedures used.to obtain soil yas samples are documented in Sampling Method SMI in Appendix I. Samples were generally obtained from depths of $36^{\prime \prime}$ to $48^{\prime \prime}$. Actual. sample depths for this survey are recorded in the soil Gas sample Collection Log in Appendix II. Samples for the light hydrocarbon analyses were taken in previously evacuated $125 \mathrm{mI}$ bottles. Samples for volatile organic compound (Voc) analyses were taken in previously evacuated $22 \mathrm{ml}$ bottles. A duplicate sample and a blank was collected for every ten samples. The duplicate samples were taken from a separate location which was approximately 1 ft. from the original site. Logs which document the details of sample. collection are included in Appendix II. 


\section{B. Analytical Methods}

Methods and quality assurance procedures for the analysis of light hydrocarbon soil gas samples are documented in Analytical Method AMI and for VOC soil gas samples in Analytical Method AM4 in Appendix I. Methods AMI and AM4 are modifications of EPA Headspace Method 3810 and Gas Chromatography Method 8000. Representative chromatograms of a sample and a blank from this data set are showi on Figures 2 - 5 .

\section{Accuracy}

Calibration of the $\mathrm{C}_{1}-\mathrm{C}_{4}$ hydrocarbon gas chromatograph was accomplished using a certified commercial standard (Matheson Gas Products Inc.) which is of the order 10 ppm for methane and 1 ppm for the other light hydrocarbons and is called standard "M"; and a second commercial standard (Scotty specialty Gases, Can Mix 224, ICN $\# 35$ ) which contains only the $C_{1}-C_{4}$ straight chain hydrocarbons and is of the order $1000 \mathrm{ppmv}$ for each hydrocarbon. Chromatograms of Standards "M" and "224" are shown on Figure 6.

Calibration of the gas chromatograph used to analyze volatile organics was accomplished using standards prepared as a blend of pure compounds according to the methods documented in standard Preparation Method SP3 which is included in Appendix I. These standards were prepared in methanol (Alarich, HPLC grade. ICN \#30), at six concentration levels as shown on Table 4. Initially two standards from each of levels 1 through 6 were run to set up the calibration table. Thereafter, one standard was run for every 10 
samples. A chromatogram of standard $K 4$, Level 3 for the FID is shown on Figure 7 and Level 5 for the ECD on Figure 8.

Calibration of the gas chromatograph for vinyl chloride was achieved using a commercial standard gas (Scotty Specialty Gases, Can Mix 74, ICN \# 9) e 1000 ppmv.

\section{Reliability of Vinyl Chloride and Methylene Chloride Data}

The reliability of results presented in this report for. vinyl chloride and methylene chloride is adversely affected by compounds which elute closely in time to their retention times. Namely, in the case of vinyl chloride, the presence of two frequently occurring compounds which elute 0.07 minutes before and 0.15 minutes after the vinyl chloride elution time. The earlier peak is probably n-butane and the later peak is presently unknown. In the case of methylene chloride, an impurity thought to be derived from the septum (identity unknown), elutes 0.07 minutes before the methylene chloride elution time. While we can normally distinguish between such retention times, these separations are of the same order as the peak widths.

\section{E. Precision}

The analytical precision was calculated using the repetitive analysis of standards as shown in Tables 5 - 7. In order to derive a meaningful estimate of precision, the calculation was made over all standards in a data directory rather than a single survey. A data directory includes data from the analyses of all samples, 
standards and blanks for a period of 3 to 6 weeks. The 904-111G Basin data reside in data directory \#23. Standards, which were run with the samples and blanks from the Road A Chemical Basin survey, are designated on Tables 5 and 6 as area "904-111G".

For the VOC standards in general, percent standard deviations are less than 10\%. At the 10 ppbv level, percent standard deviations for the chlorinated hydrocarbon standard analyses increase as background concentrations become a significant part of: the overall signal.

For the Iight hydrocarbons, the precision is better than $4 \%$ for all hydrocarbons for analyses of standard " $M$ " and "224" as shown on Table 7 .

\section{F. Minimum Detection Levels}

Minimum detection levels reported in this survey for the light hydrocarbons, $C_{1}-C_{4}$, are 5 ppbv. In practice a 5 ppbv standard (Microseeps standard $M$ diluted 200:1) is reliably determined with signal to noise ratio $(S / N)>2$. A chromatogram of the diluted standard is shown on Figure 9 .

For the VOC standard, where peaks are well separated and the baseline is stable, signals of the order 8 uv may be detected with a $S / N \geq 4$. In a complex mixture of Voc's with many compounds, and overlapping peaks, we have determined that signals of the order 20 uv are the smallest that can be reliably and routinely determined. This corresponds to a concentration of about $70 \mathrm{ppbv}$ for the gasoline range compounds; 5 ppbv for the tri- and tetra- 
halocarbons; and $100 \mathrm{ppb}$ for trans 1,2-dichloroethylene: We have visually checked the integration of each peak for these compounds down to these concentration levels. We have not reported concentration levels for smaller signals, though in some individual. cases they may be valid.

Under ideal conditions where an $8 \mathrm{uv}$ signal can be reliably integrated, minimum detection levels may be considerably lower. Experience has shown that with our system, an 8 uv signal corresponds to approximately 40 area counts. We have used our calibration factors to calculate the amount of each compound corresponding to 40 area counts as shown on Table 8 . In practice, we have set the "area reject" of our system to 40 area counts, which programs the system to reject lesser areas. This minimizes the integration of noise related events.

\section{G. Blanks}

System blanks are collected after normal purging of the probe sampler at each loth sample location. Ambient air is drawn through the probe then dispiaced into evacuated vials. The vials are then given the same consideration as samples and analyzed identically. The purpose of the system blanks is to determine if and when sample-to-sample contamination occurs, and also to help establish background levels throughout the sampling and analytical process.

Results of the analyses of all blank samples run as a part of data directory D23 are shown on Tables 9 and 10. The symbol "ND" means "not detected" and suggests an area of less than 40 area 
counts as discussed above. For calculation of means and standard deviations, the amounts indicated on Table 8 for 40 area counts were used when "ND" is indicated. Results of analyses of blanks for the 904-111G basin data set are. included on Tables 1, 2, and 3, and representative chromatograms are shown on Figures 4 and 5 . Amounts measured in the blanks have not been subtracted from the reported sample concentrations in this report.

\section{H. Data on Magnetic Disk}

All analyticàl data, including samples, duplicates, standards, and blanks are provided (one copy) on magnetic disk. All data are in units of ppmv or ppbv as reported on Tables 1,2, and 3 .

All data are in Lotus 123 (Release 2, 1985) spreadsheet format using DOS (Version 5.0). All analytical data are accumulated and processed via Microseeps gas chromatographic data system. 


\section{RESULTS}

The results of the soil gas survey described above are recorded in Tables 1,2 and 3 and selected data are mapped on Figures $10-27$. In general, levels of yolatile organics detected in this survey are very low. The most commonly observed voc's at this site were pentane and hexane as shown on Table 1 and Figures. 18 - 21, however their concentrations appear to be only slightly higher than levels observed in the sRS Background study (in progress). At site 29, low, but anomalous levels of toluene, oxylene, and m\&p-xylene were observed, as shown on Table 1. As shown on Figures $12-17$, this is an isolated occurrence. At site 30, a low level of chloroform was observed and a similar amount was also observed in the duplicate site $30 \mathrm{~A}$ one foot away as shown on Table 2. This level of chloroform was occasionalily observed in widely scattered samples in the SRS Background study. While to our knowledge, chloroform is not naturally occurring, it is observed with regularity in the SRS area. possibly, since gas chromatography does not physically identify the compound causing the detector response, one might attribute this observation to a naturally occurring compound with the same retention time in our column. Similar speculation can be made with regard to widespread occurrences of o-xylene and its apparent association with the occurrence of pinenes which are natural products in pine resins which are common at SRS. In the case of chloroform, however, the observation is made with the electron capture detector which is reasonably specific for halogenated compounds. It is more 
difficuit to imagine a compound with a response on the electron capture detector which has the identical retention time as chloroform.

Methane concentrations, as shown on Table 3 and Figures 26 and 27, at several sites are anomalously high and are suggestive of biological activity. 
V. CONCLUSIONS

Levels of volatile organics observed in the soil gas survey at the Road A Chemical Basin are very low. Only occasional, isolated observations of benzene, toluene, the xylenes, and chloroform were made. Levels of methane are anomalous at several sites which may. be suggestive of active biological processes. 
$\begin{array}{llllllll}29170 & 29210 & 29250 & 29290 & 29330 & 29370 & 29410 & 29450\end{array}$

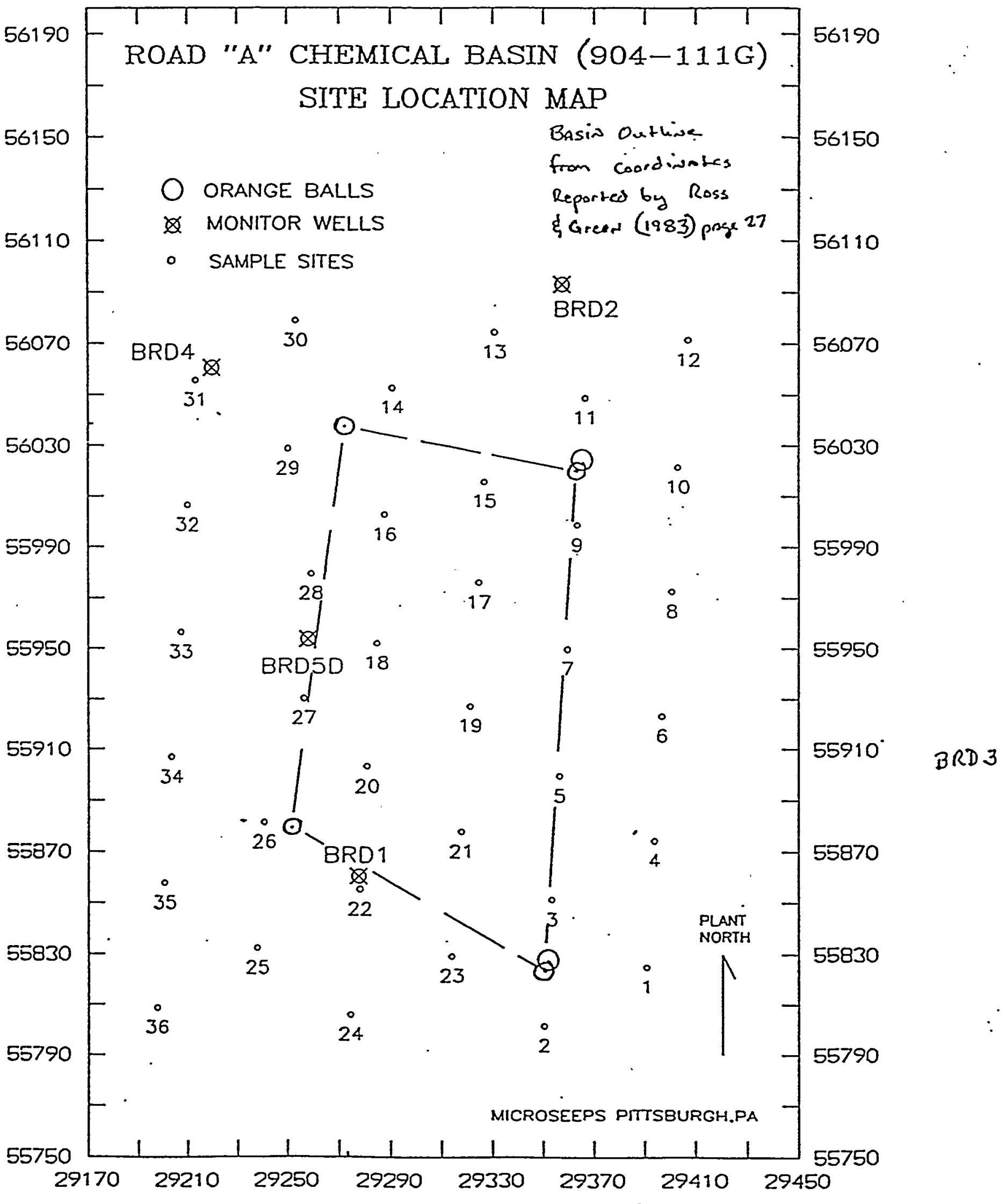

Figure 1. The Road A Chemical Basin (904-i11G) Sample Location Map 


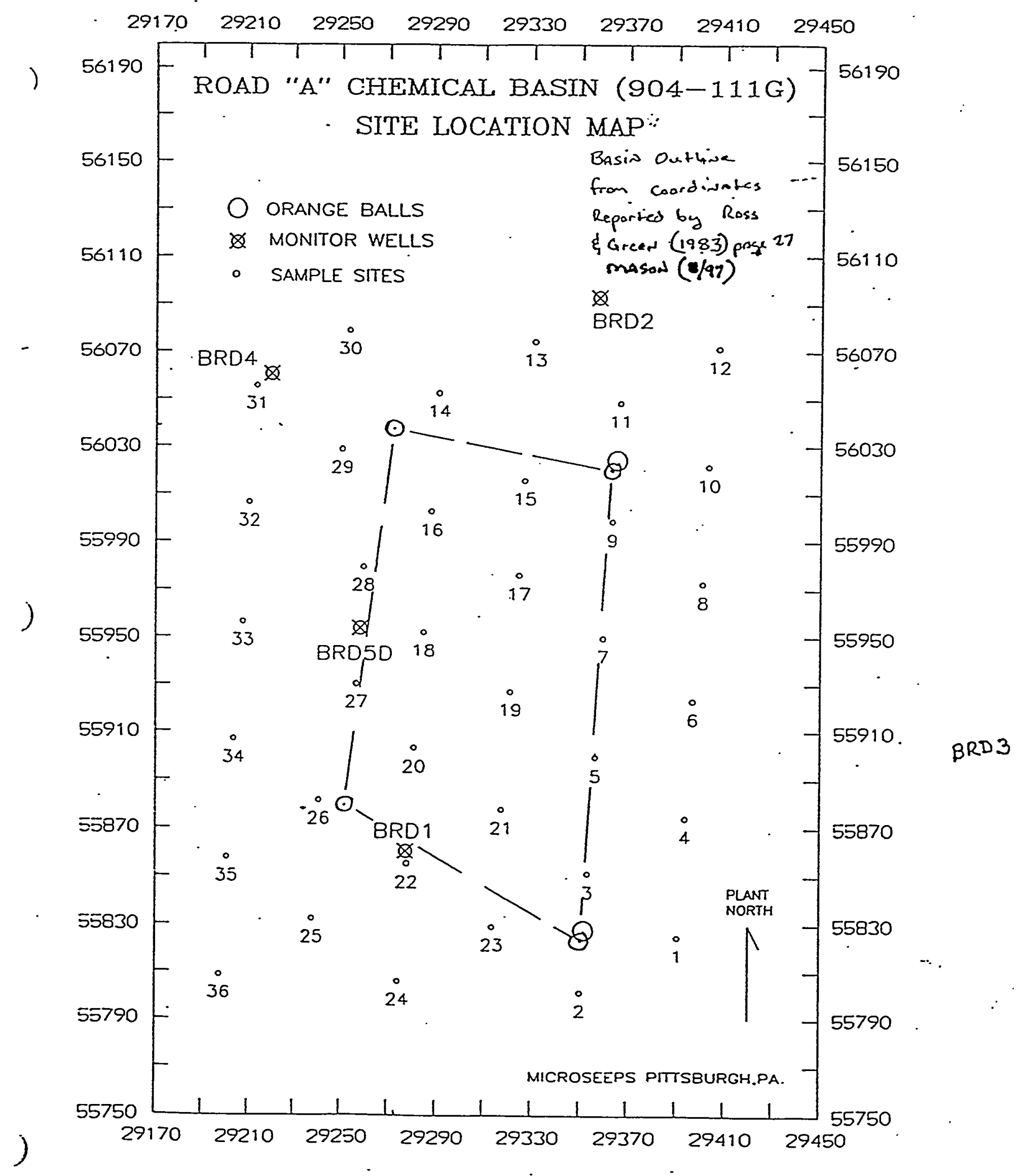

Figure 1: The Road A Chemical Basin (904-i11G) Sample Location Map 


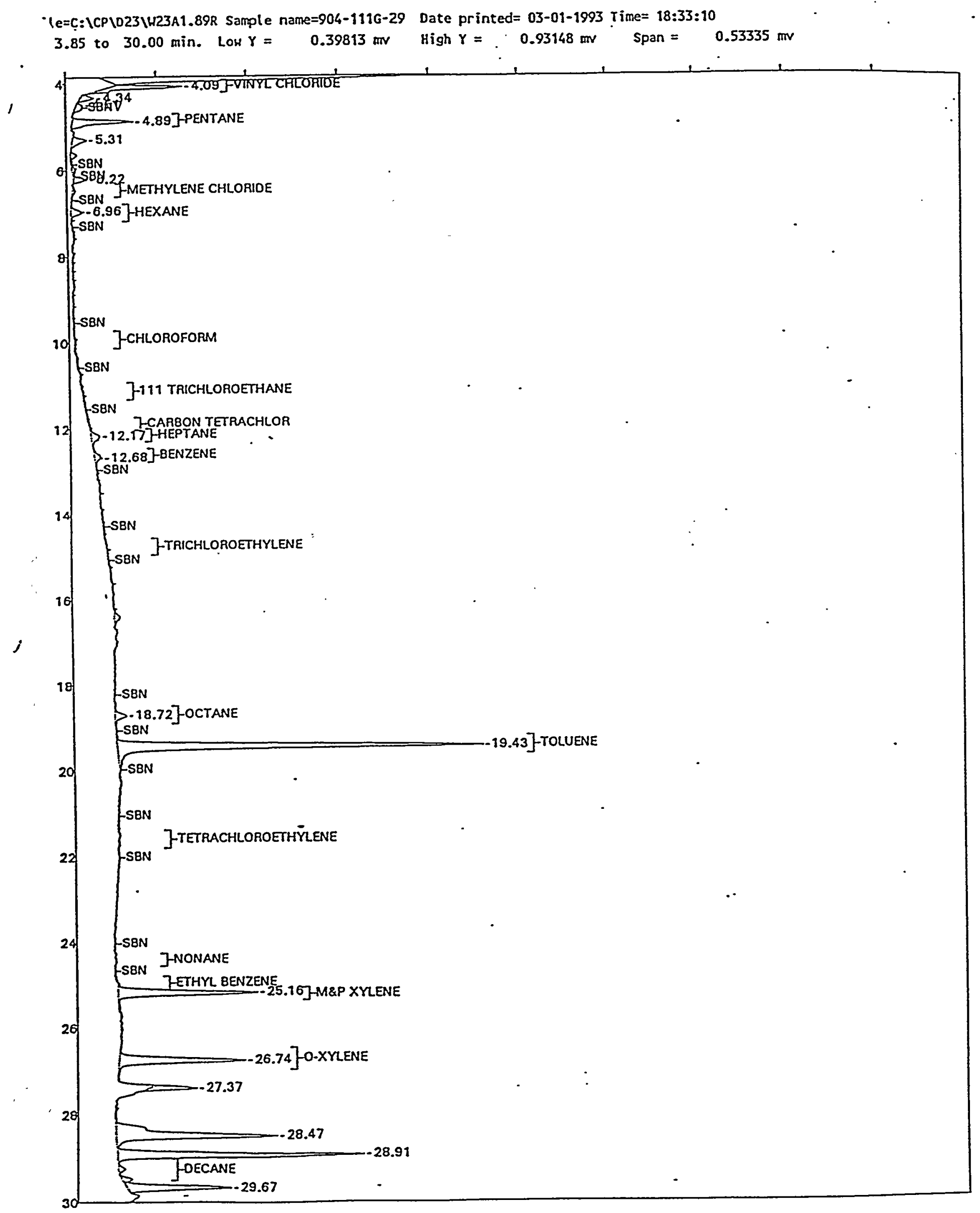

Figure 2. Gas Chromatogram of Soil Gases at Site.29 from 


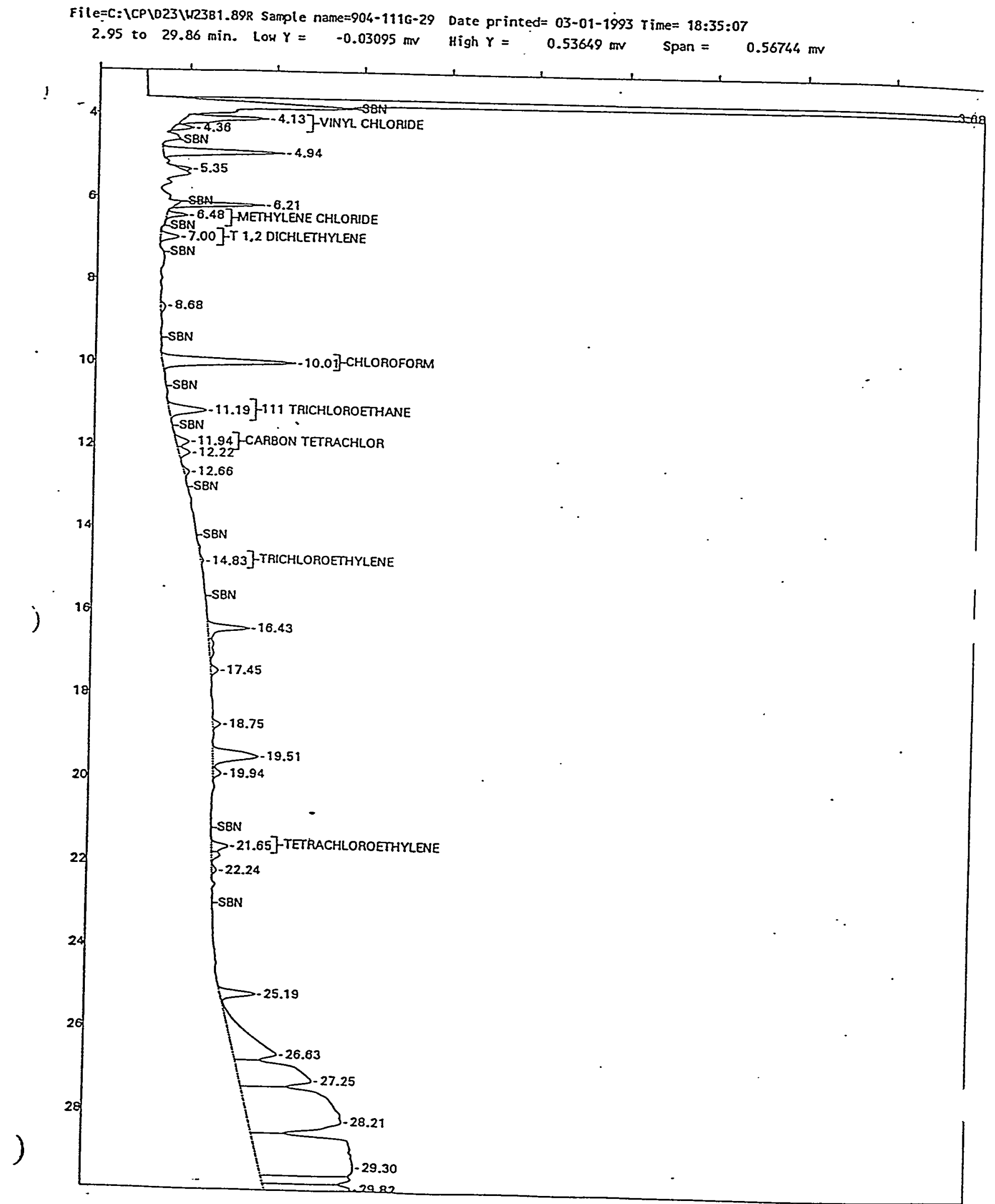

Figure 3. Gas Chromatogram of Soil Gases at site 29 from 
=C: \CP \O23IU23A1.79R Sample name=904-1119*S83 Date printed $=03-01-1993$ Time= 18:04:10

.86 to $29.83 \mathrm{~min}$. LOH $Y=0.37235 \mathrm{mr}$ High $Y=\cdot 0.58355 \mathrm{mr} \quad$ Span $=0.21119 \mathrm{mr}$

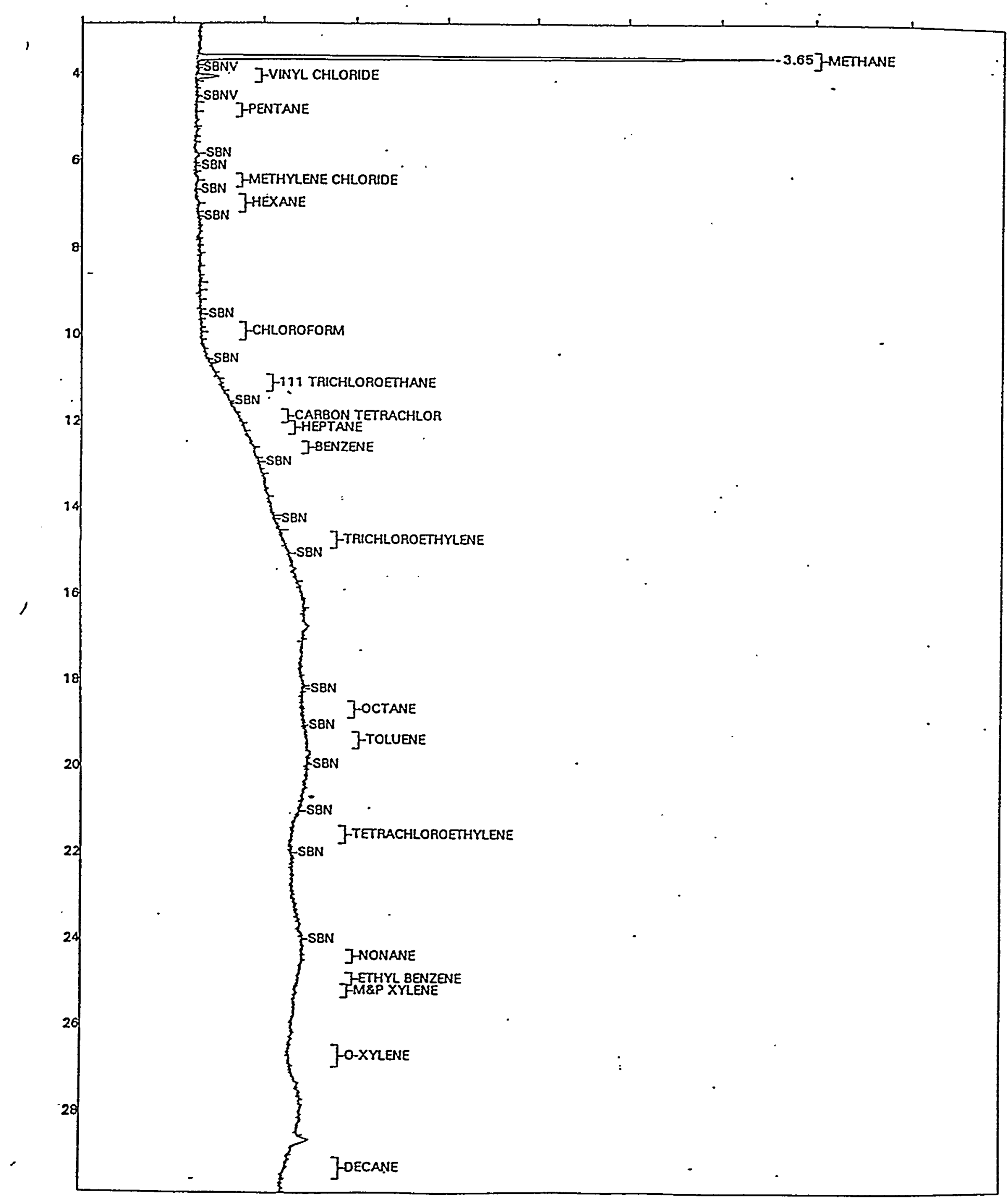

Figure 4. Gas Chromatooram of Svstem Blank $\$ 3$ frim tho fin 


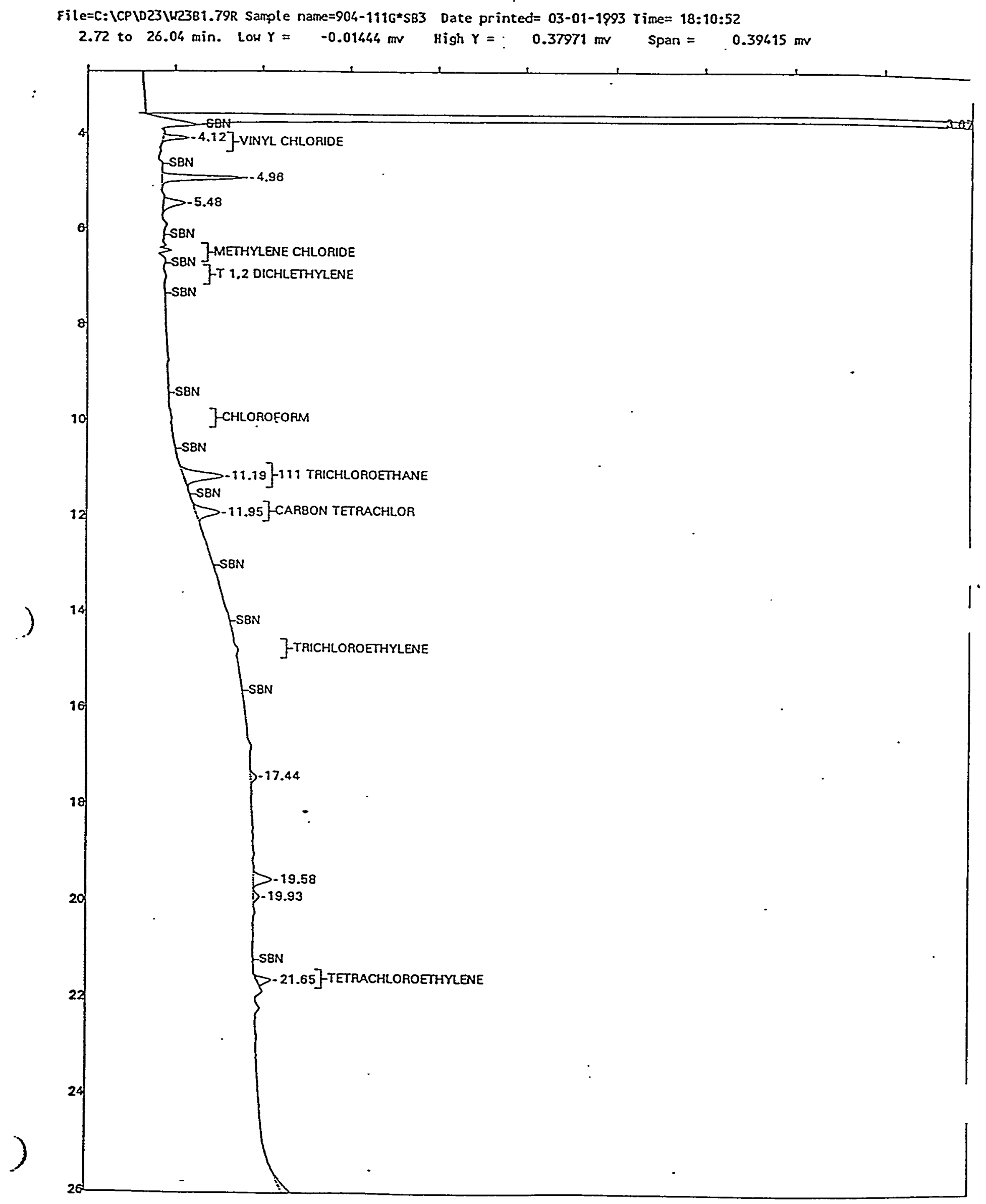

Figure 5. Gas Chromatogram of System Blank
Detector 


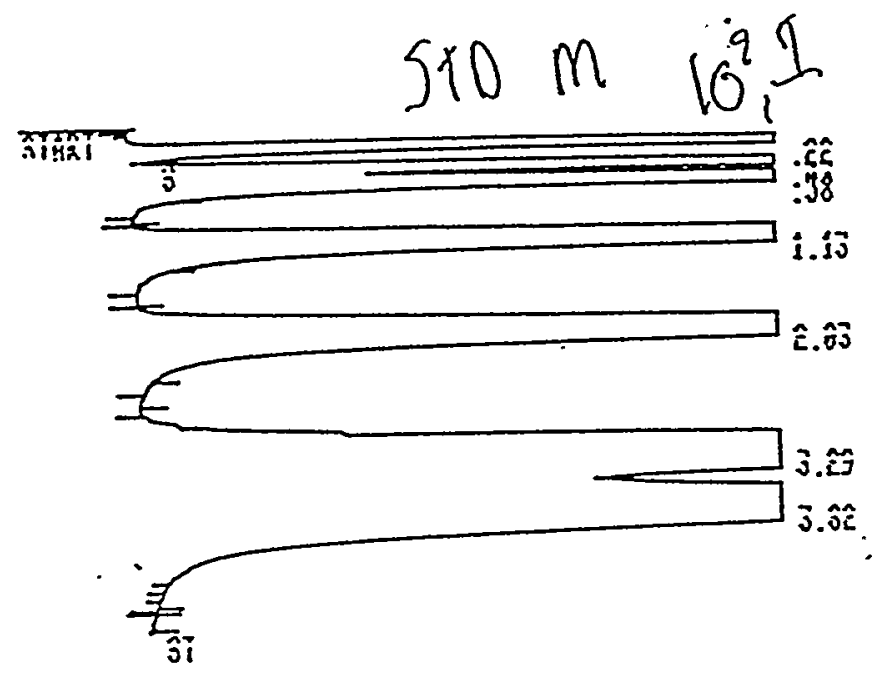

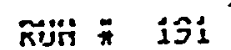

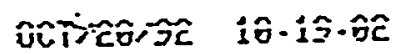

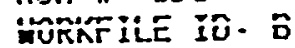

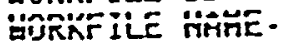

\begin{tabular}{|c|c|c|c|c|}
\hline 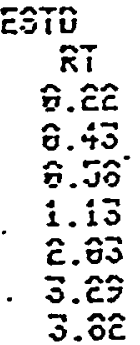 & 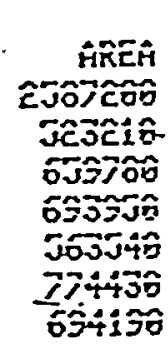 & 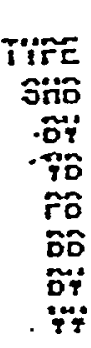 & 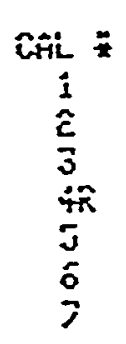 & 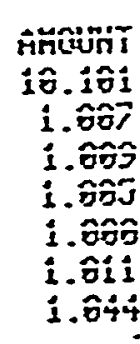 \\
\hline
\end{tabular}

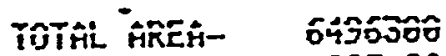

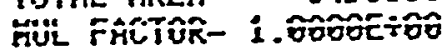

$964) 116-1$

Figure 6.. Gas Chromatogram of $C_{1}-C_{4}$ standard $M$ 


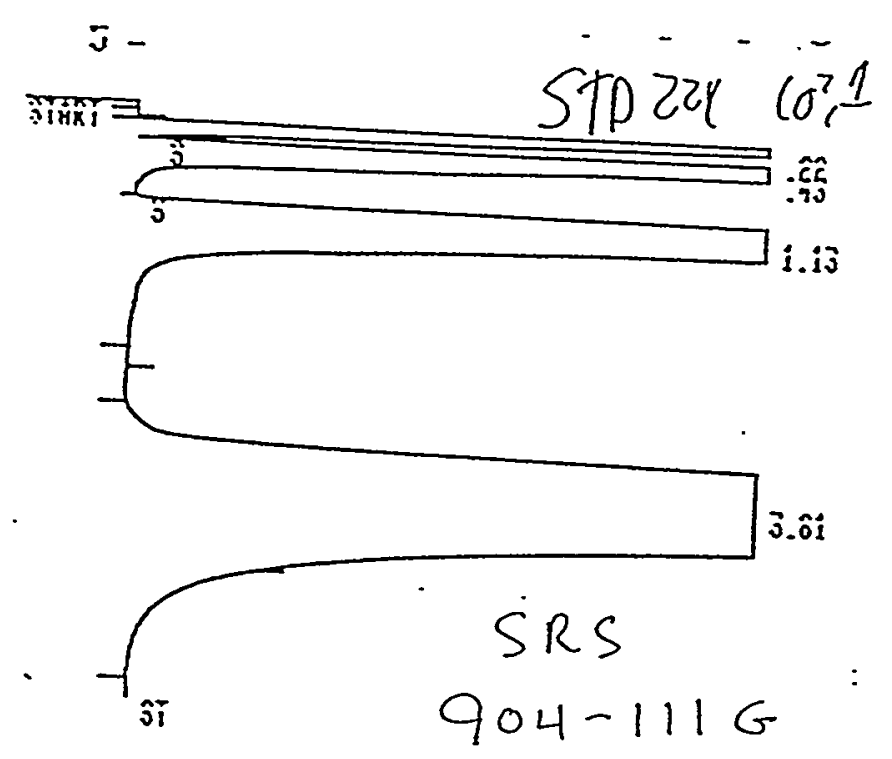

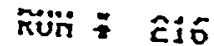

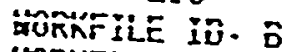

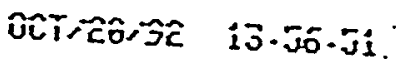

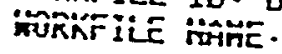

Fริธิ

$\widehat{x} \bar{i}$

$\hat{\mathrm{z} . \hat{c} \hat{\mathbf{E}}}$

0. 40

i. 13

J. $\hat{o} i$

\begin{tabular}{|c|c|c|c|}
\hline 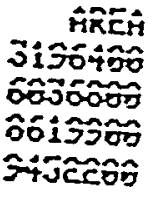 & 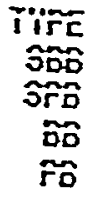 & $\begin{array}{l}\hat{c+i i} \\
\hat{i} \\
\hat{c} \\
j \pi \\
\dot{i}\end{array}$ & 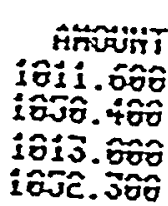 \\
\hline
\end{tabular}

Tิ์

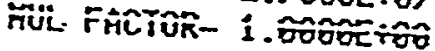

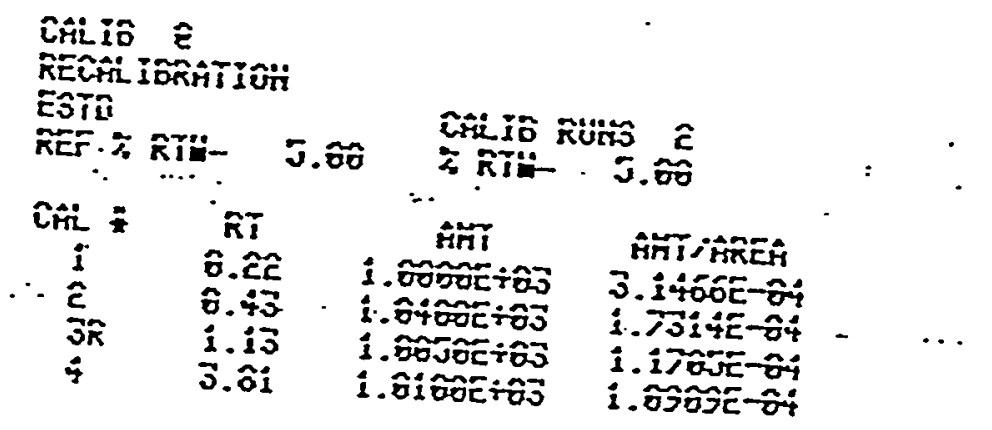

)

Figure $\sigma_{b}$. Gas Chromatogram of $c_{1}-C_{4}$ standard 224. 


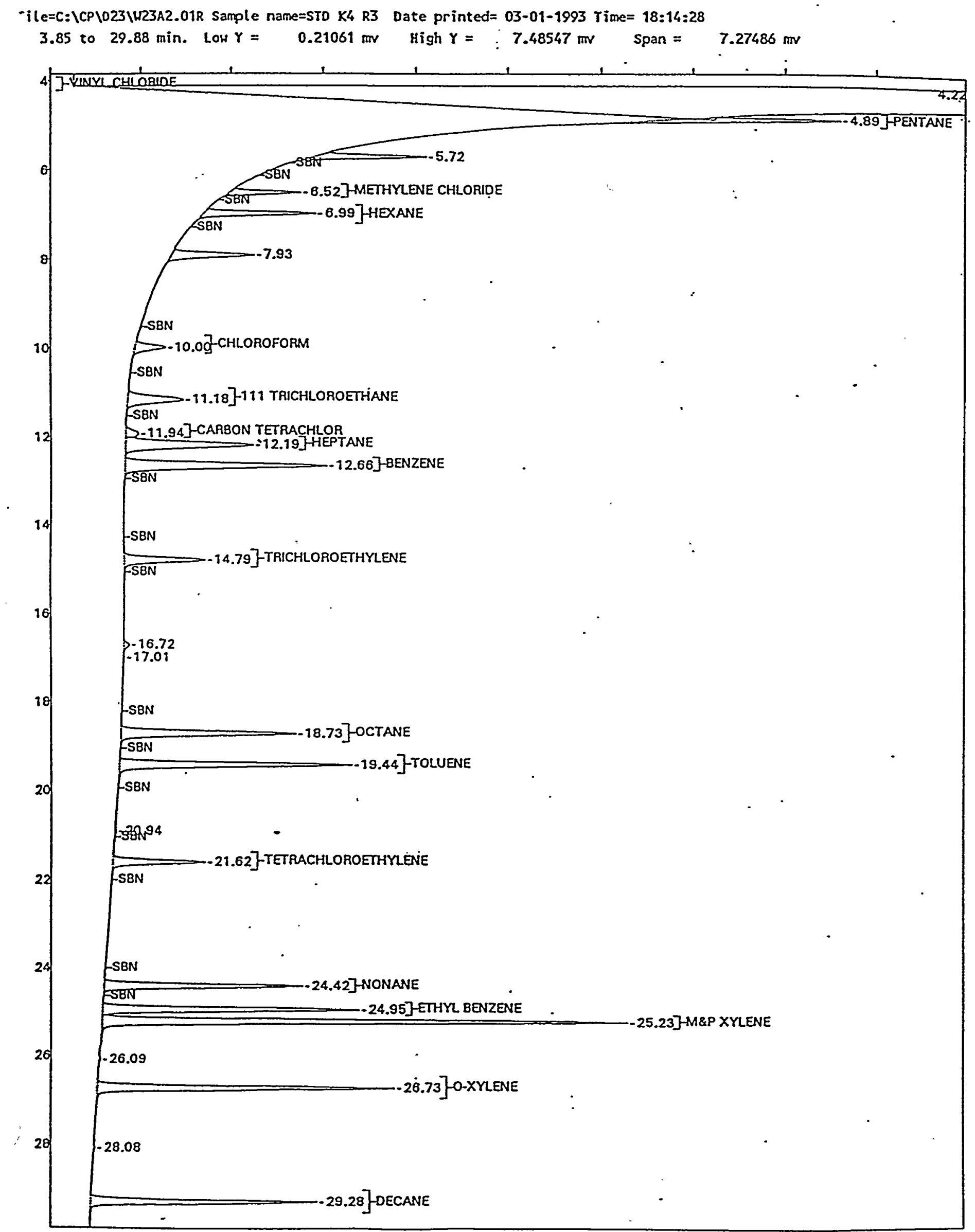

Fiqure 7. Gas chromatammom

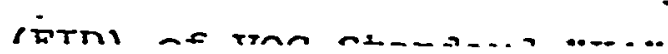

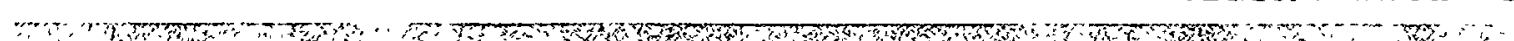




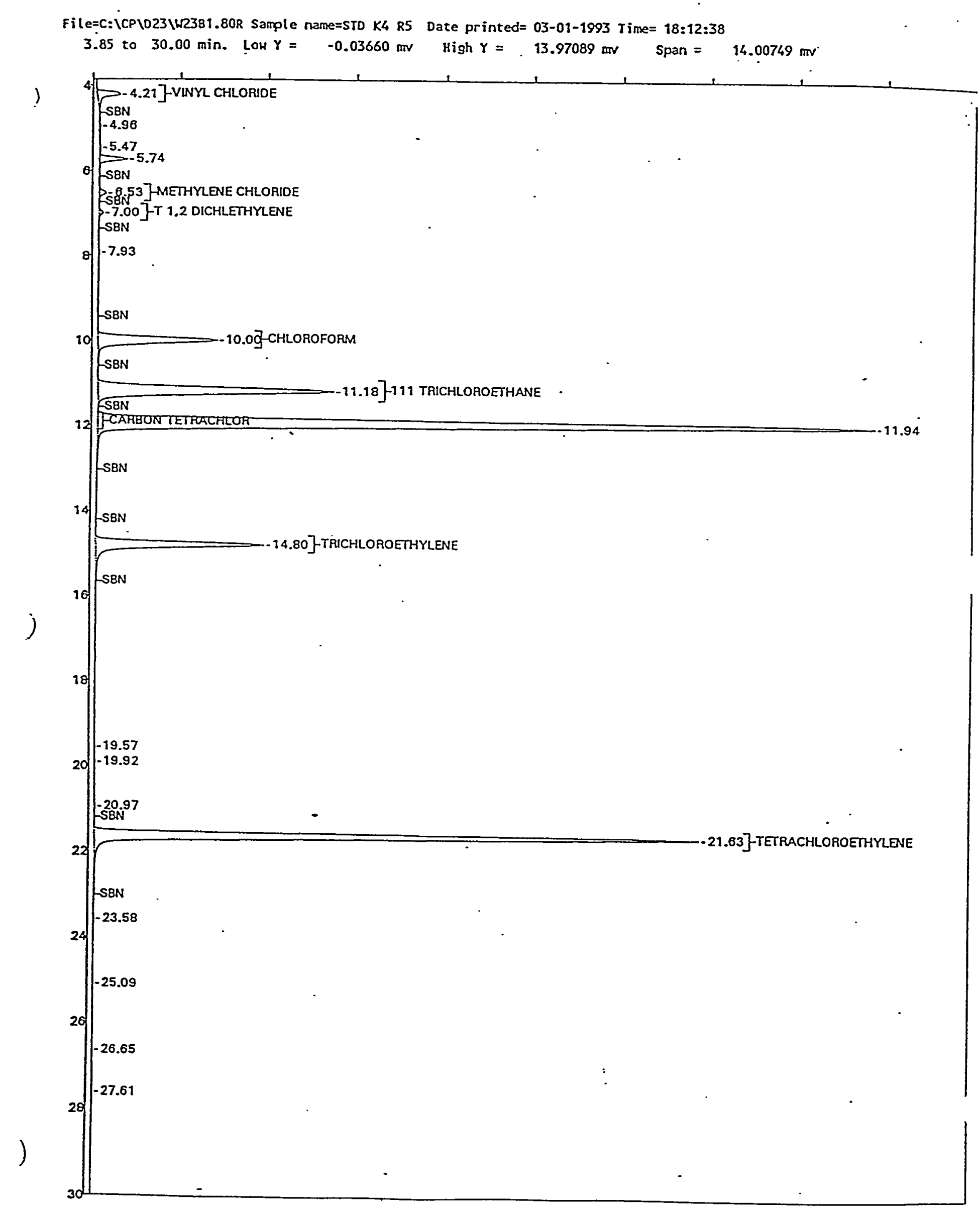

Figure 8. Gas Chromatogram (ECD) of VOC standard "K4", Level 5 


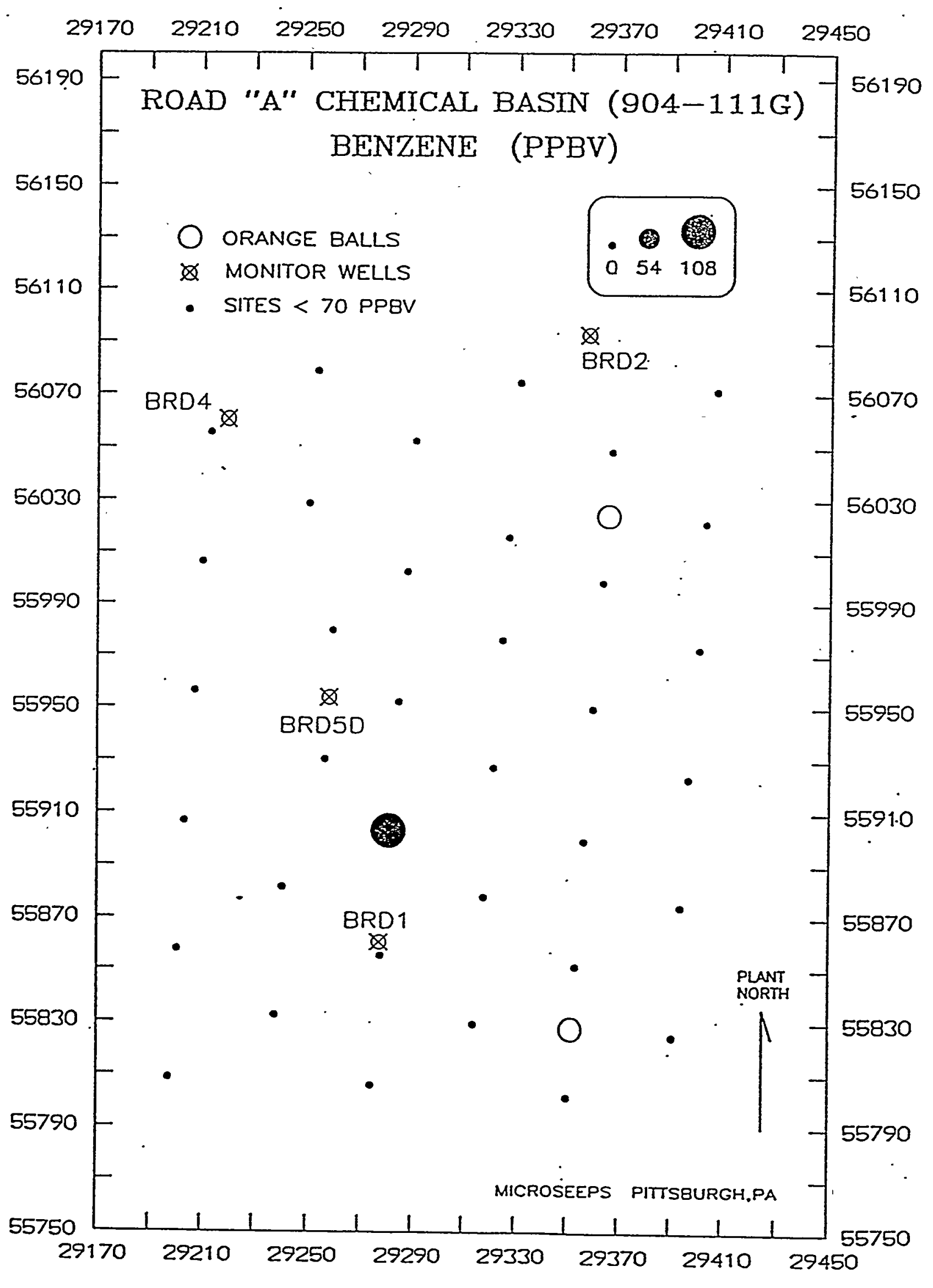




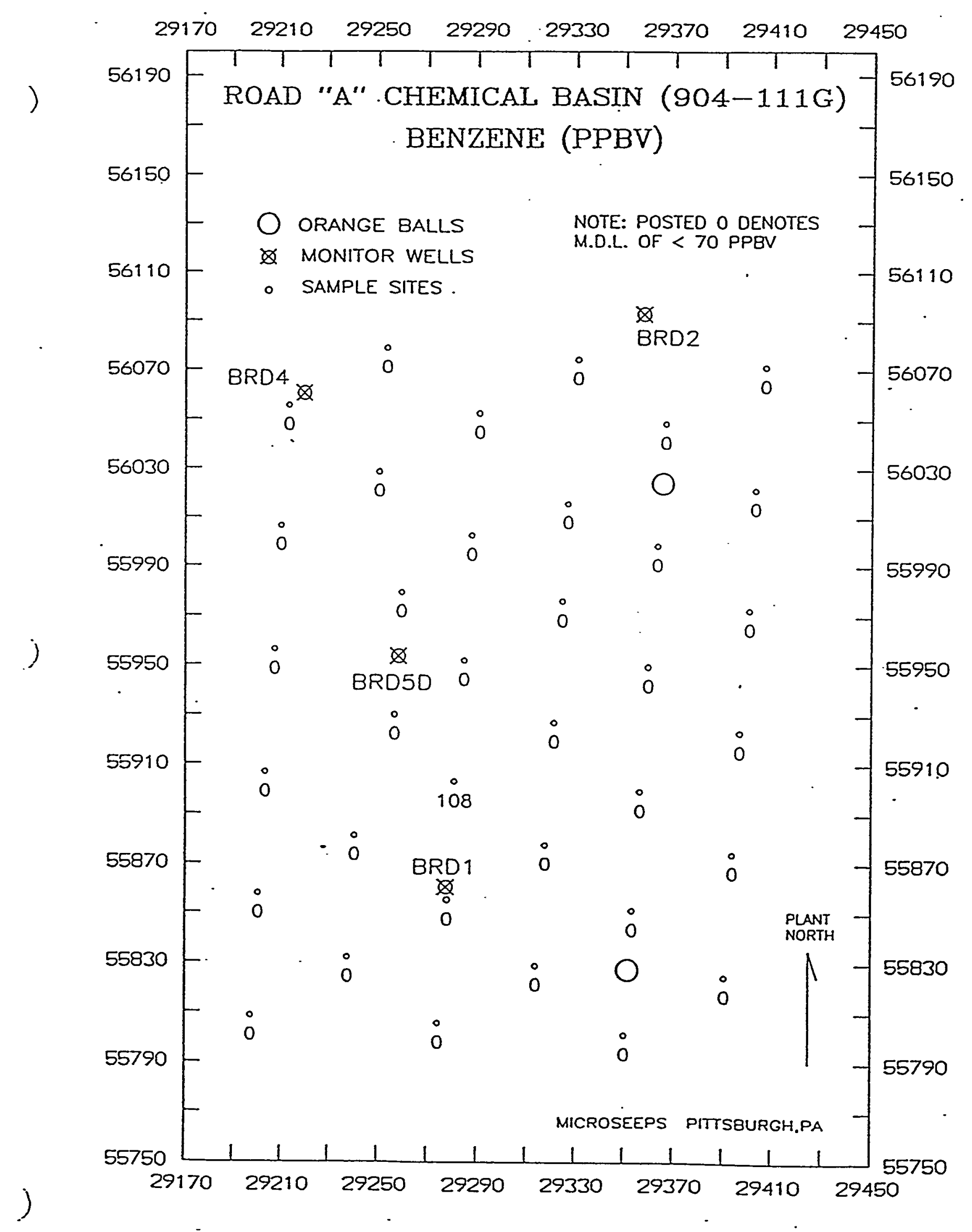

Figure 11. Benzene (ppbv) Map 


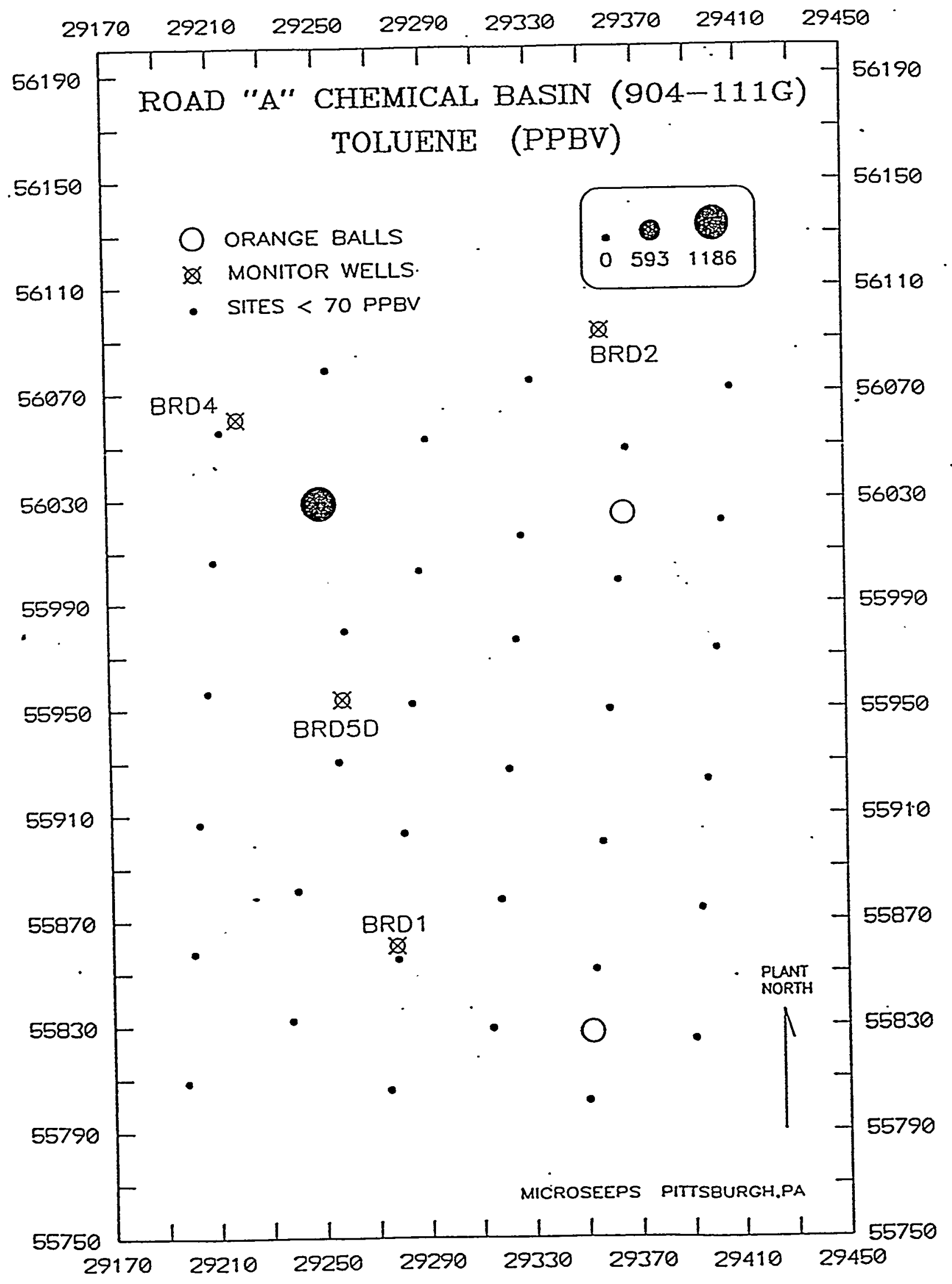

Figure 12. Toluene symbol Map 


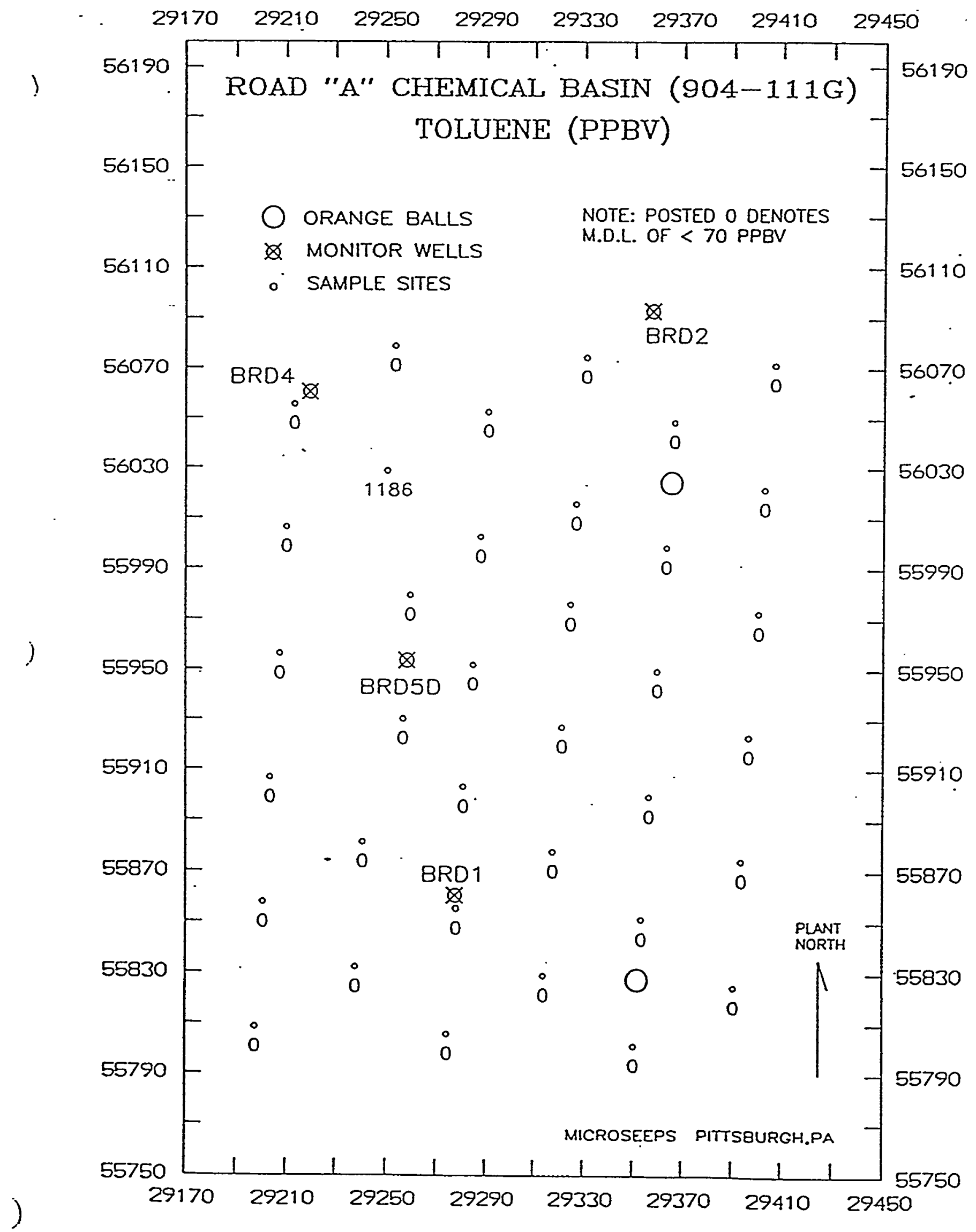

Figure 13. Toluene (ppbv) Map 


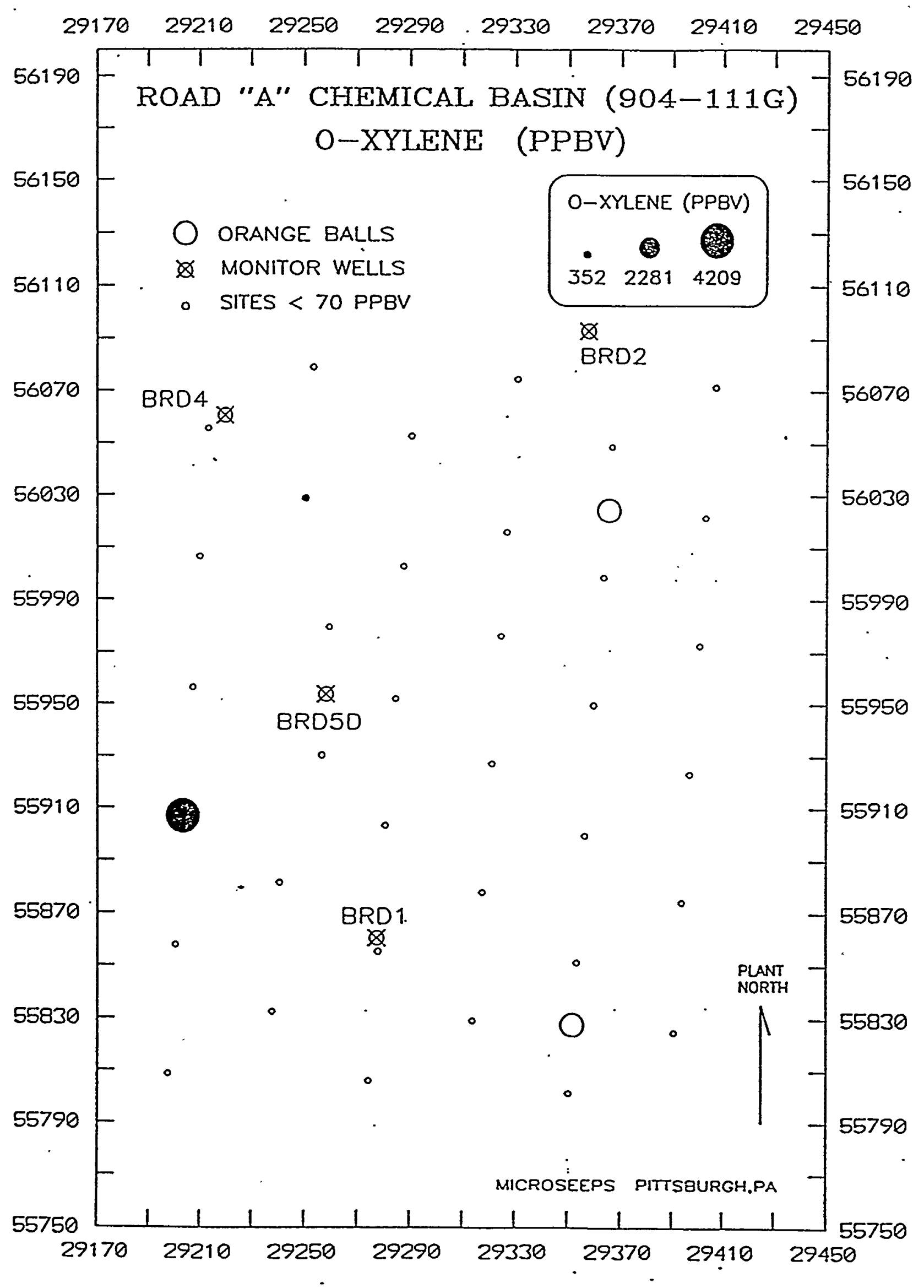

Figure 14. o-Xylene Symbol Man 


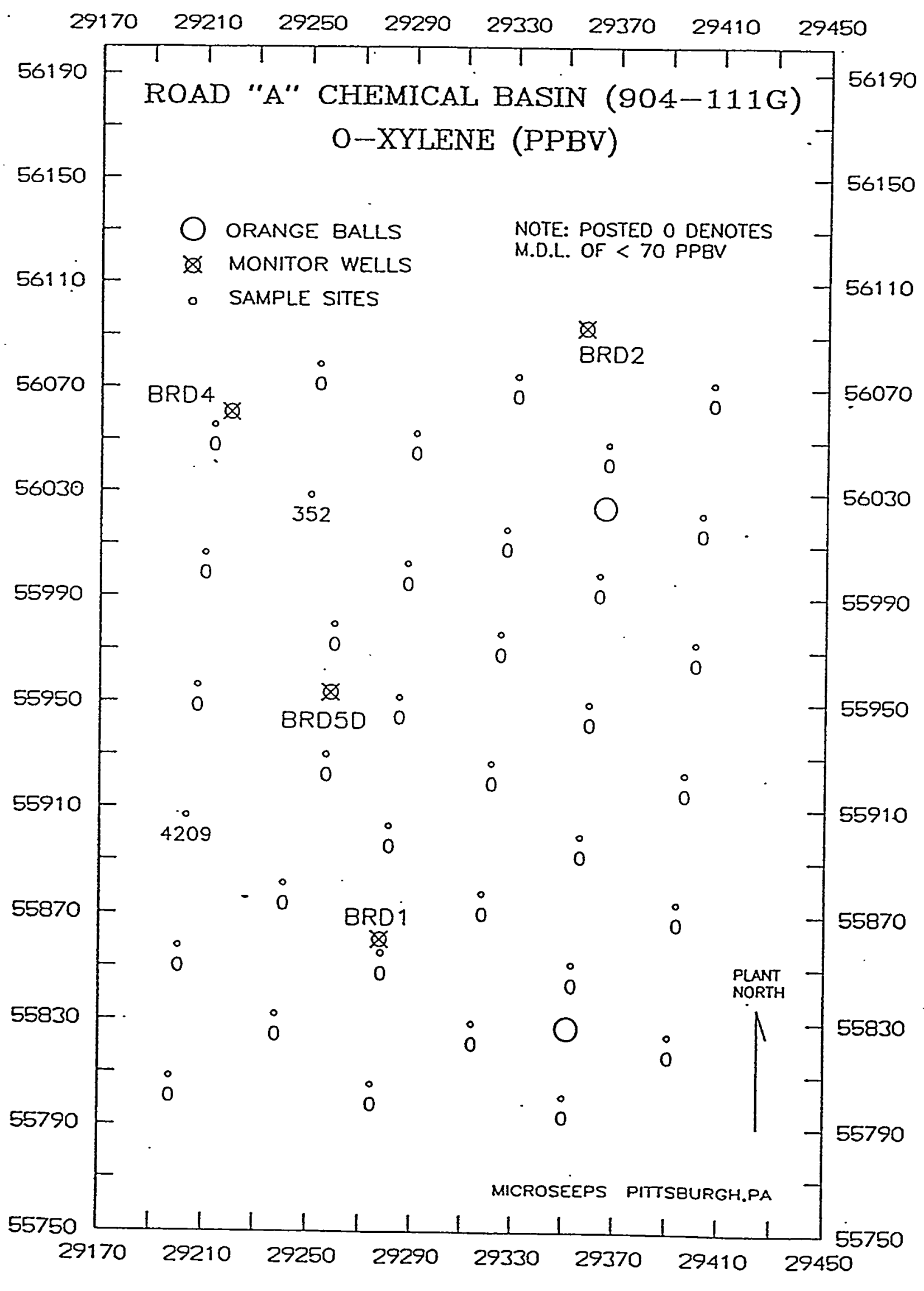

Figure 15. o-Xylene (ppbv) Map 


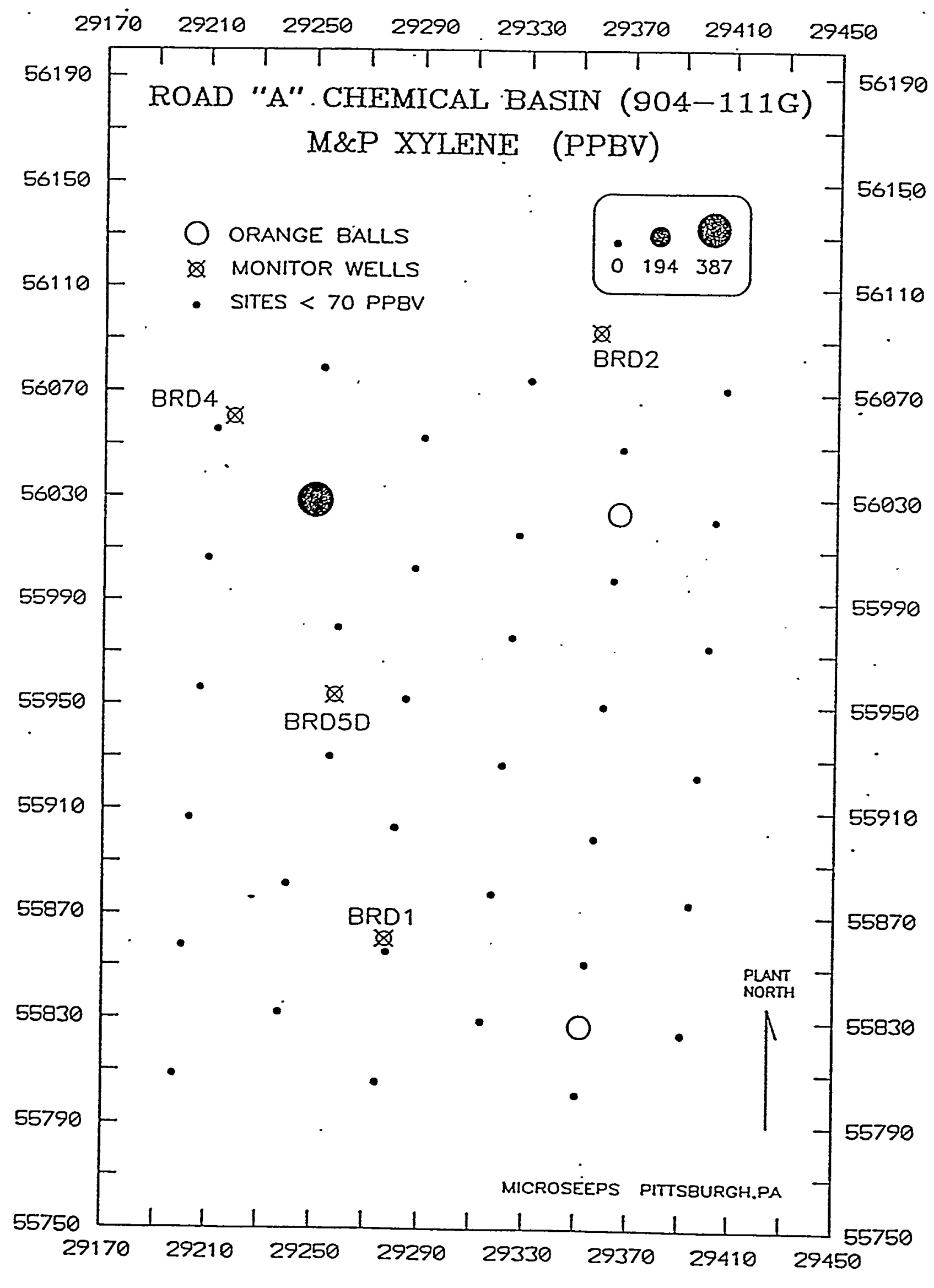

Fiqure 16. Min-Xvions Simmal ar-m 


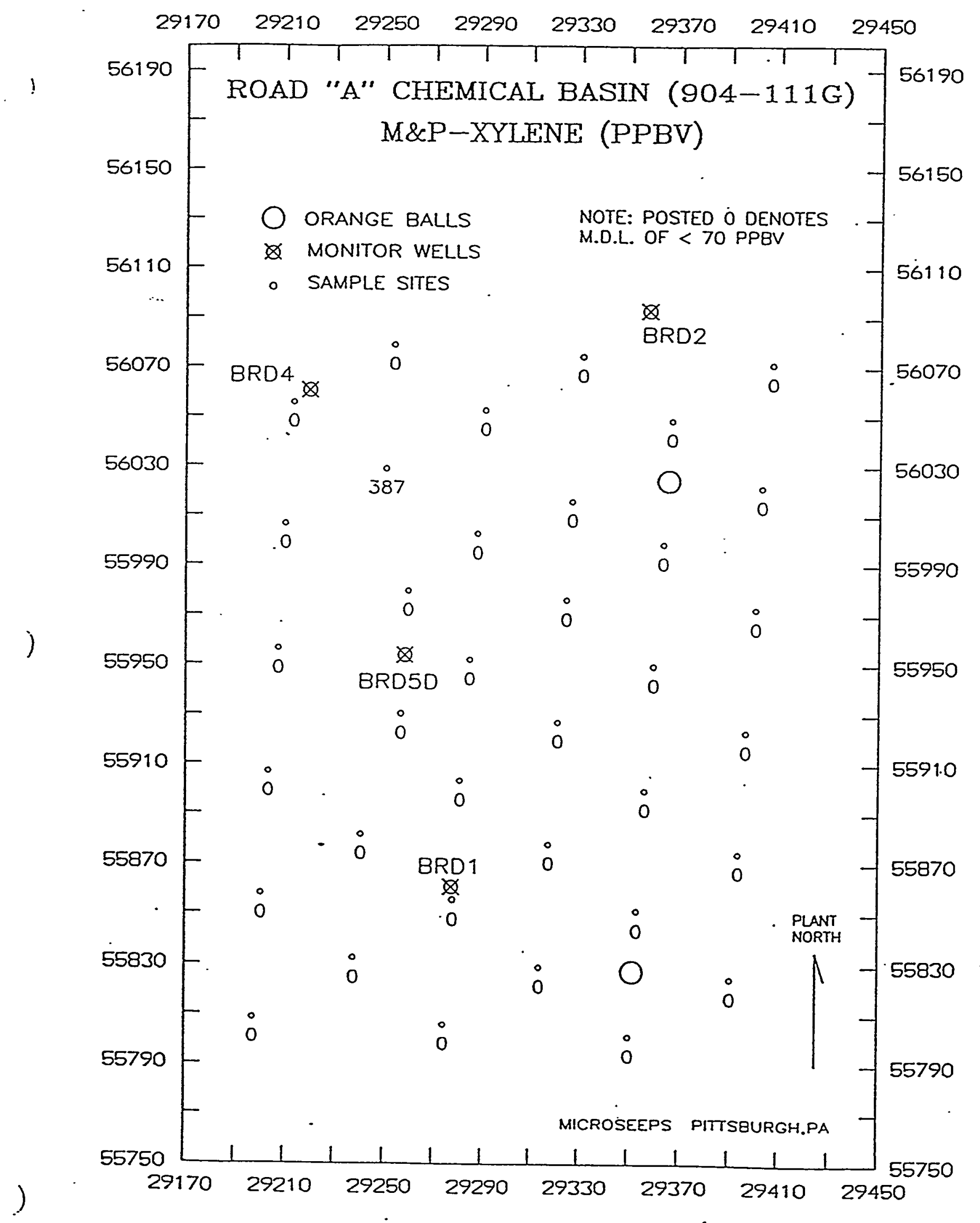

Figure 17. m\&p-Xylene (ppbv) Map 


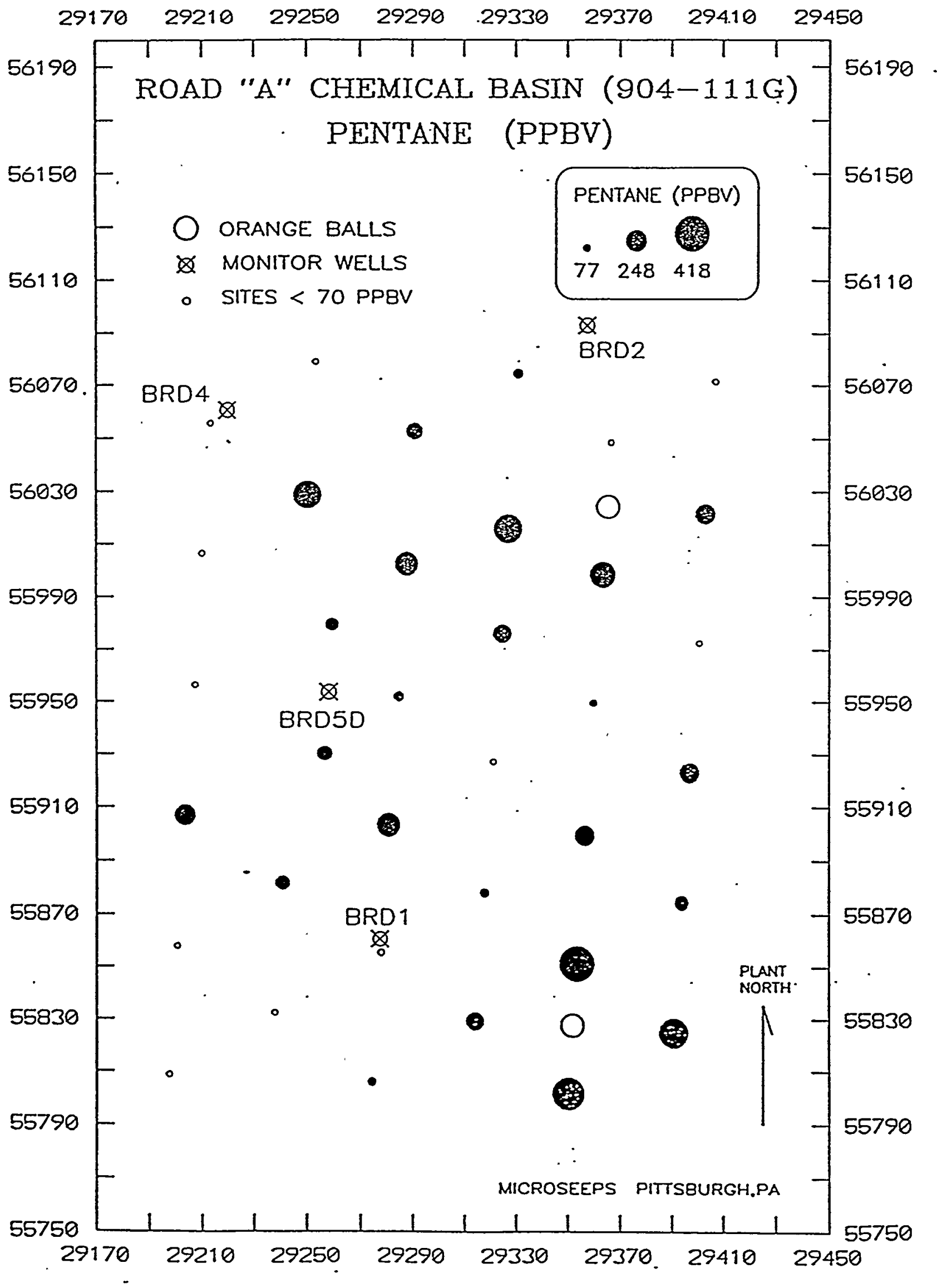

Figure 18. Pentane Symbol Map 


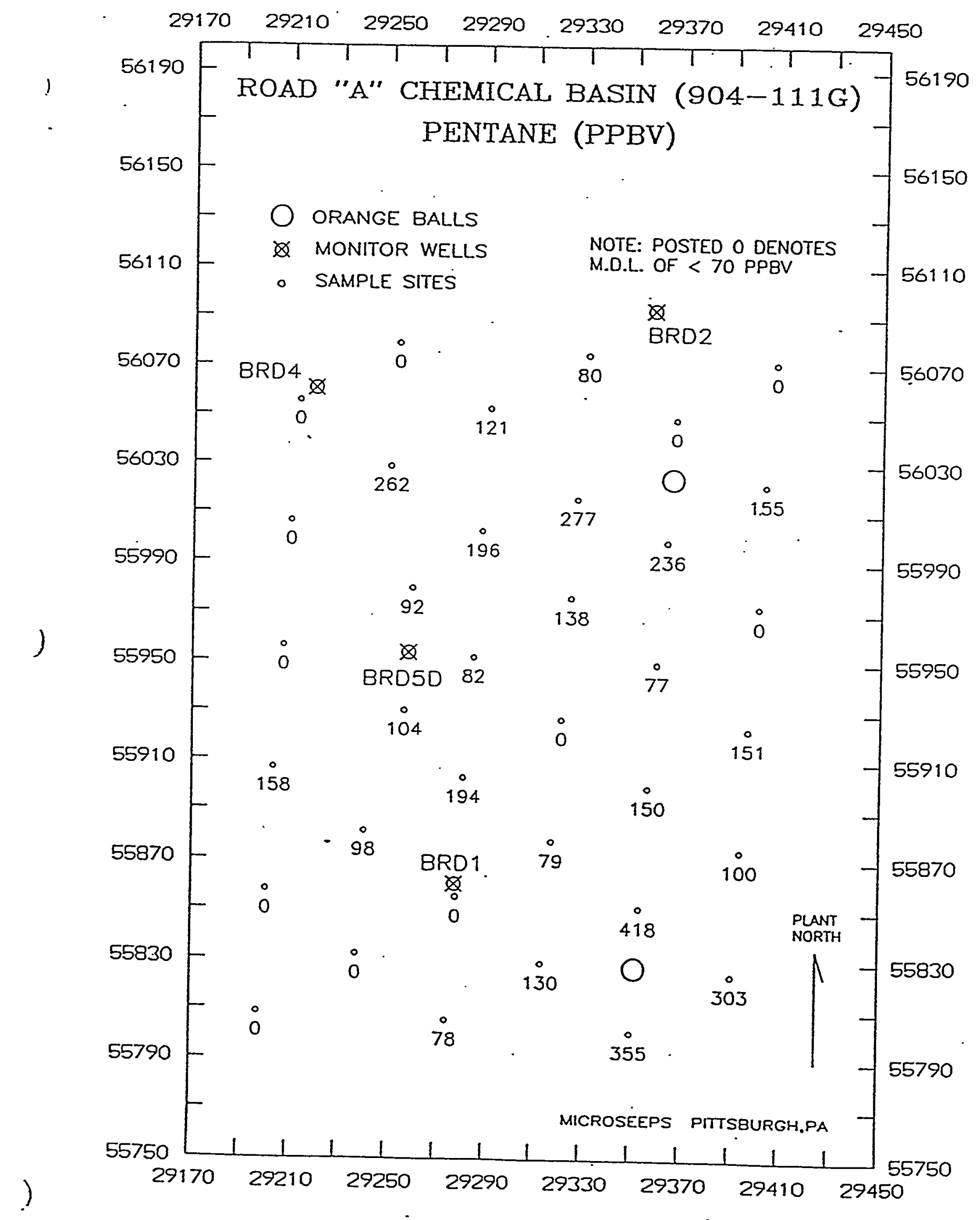

Figure 19. Pentane (ppbv) Map 


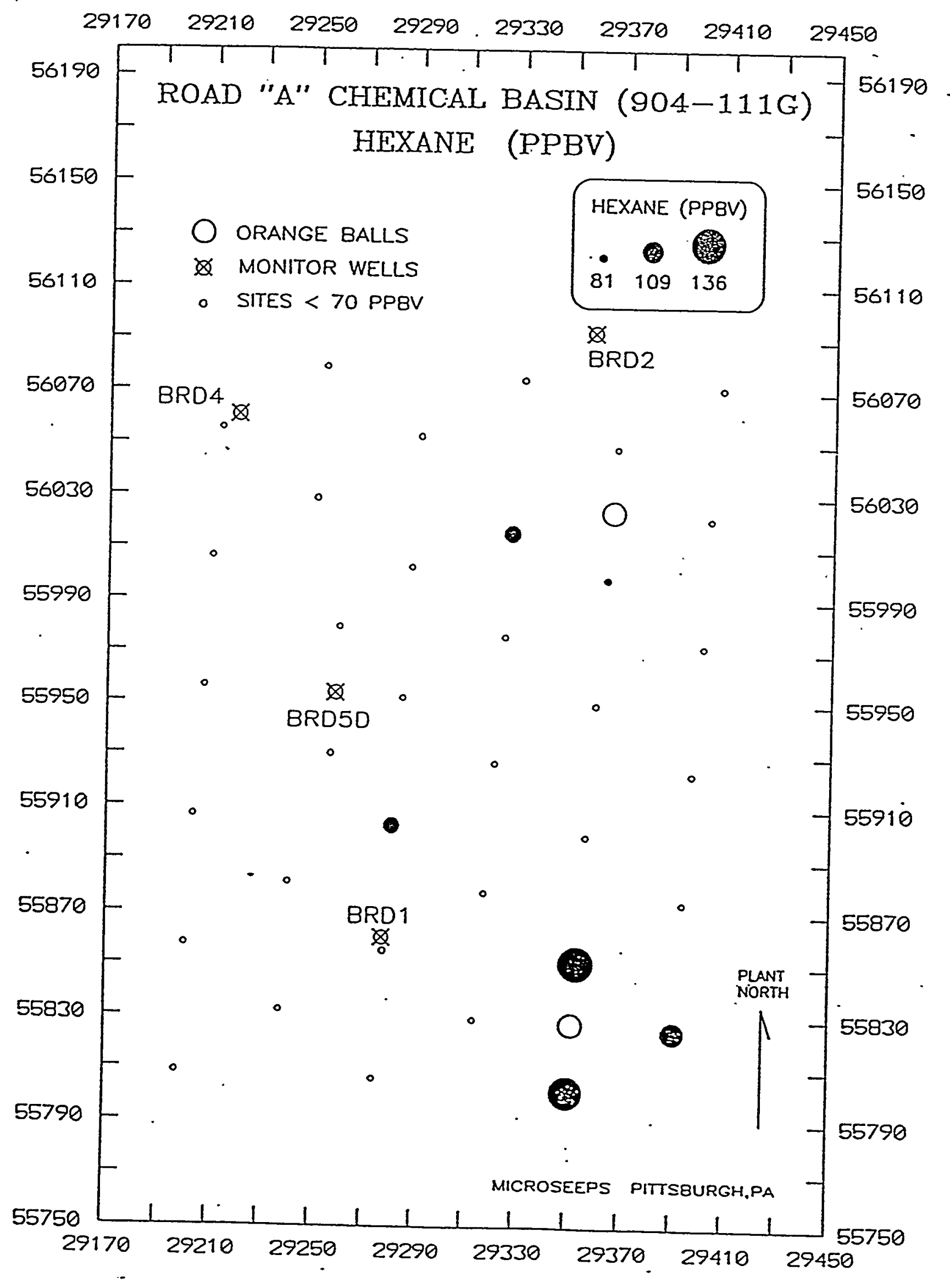




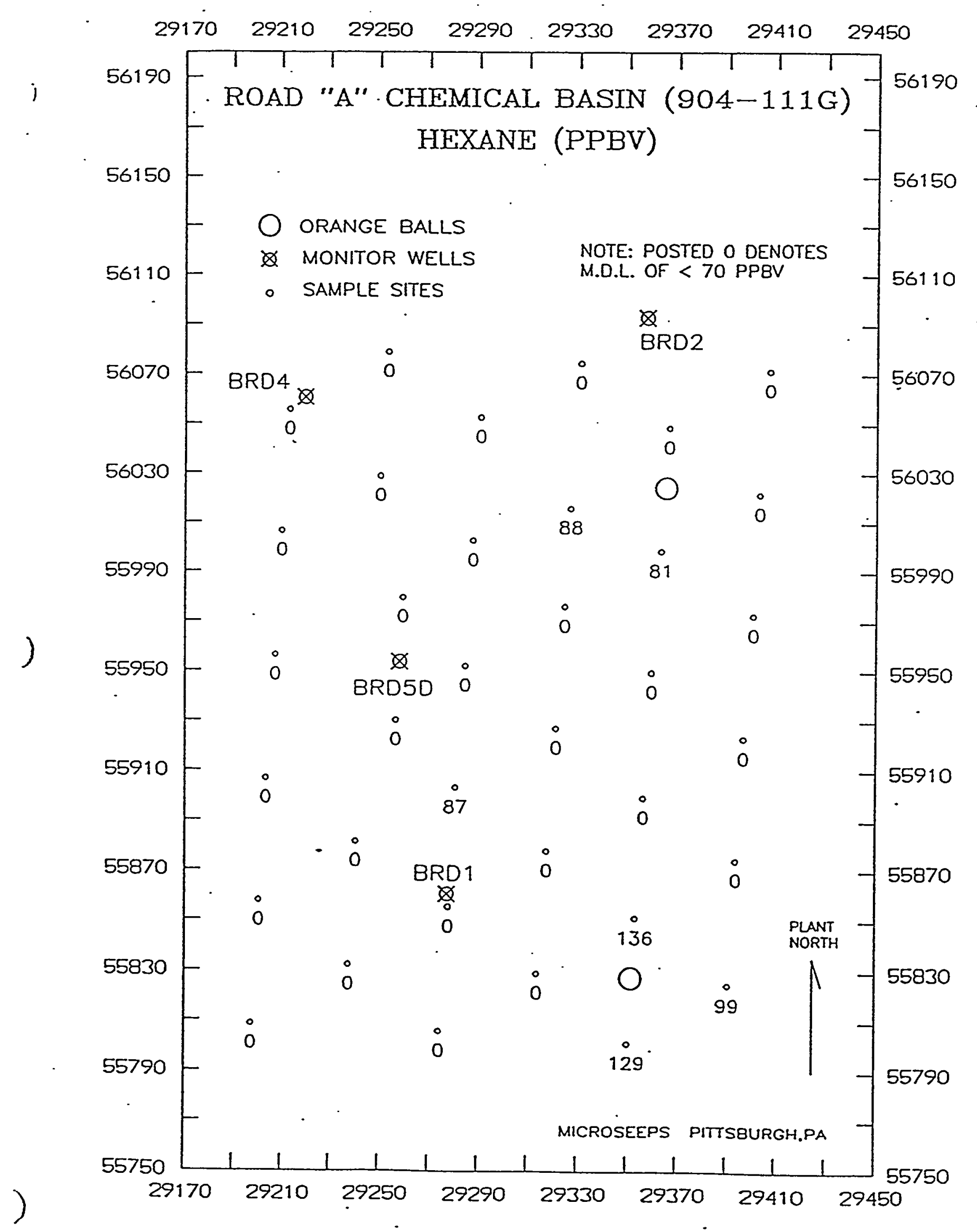

Figure 21. Hexane (ppbv) Map 


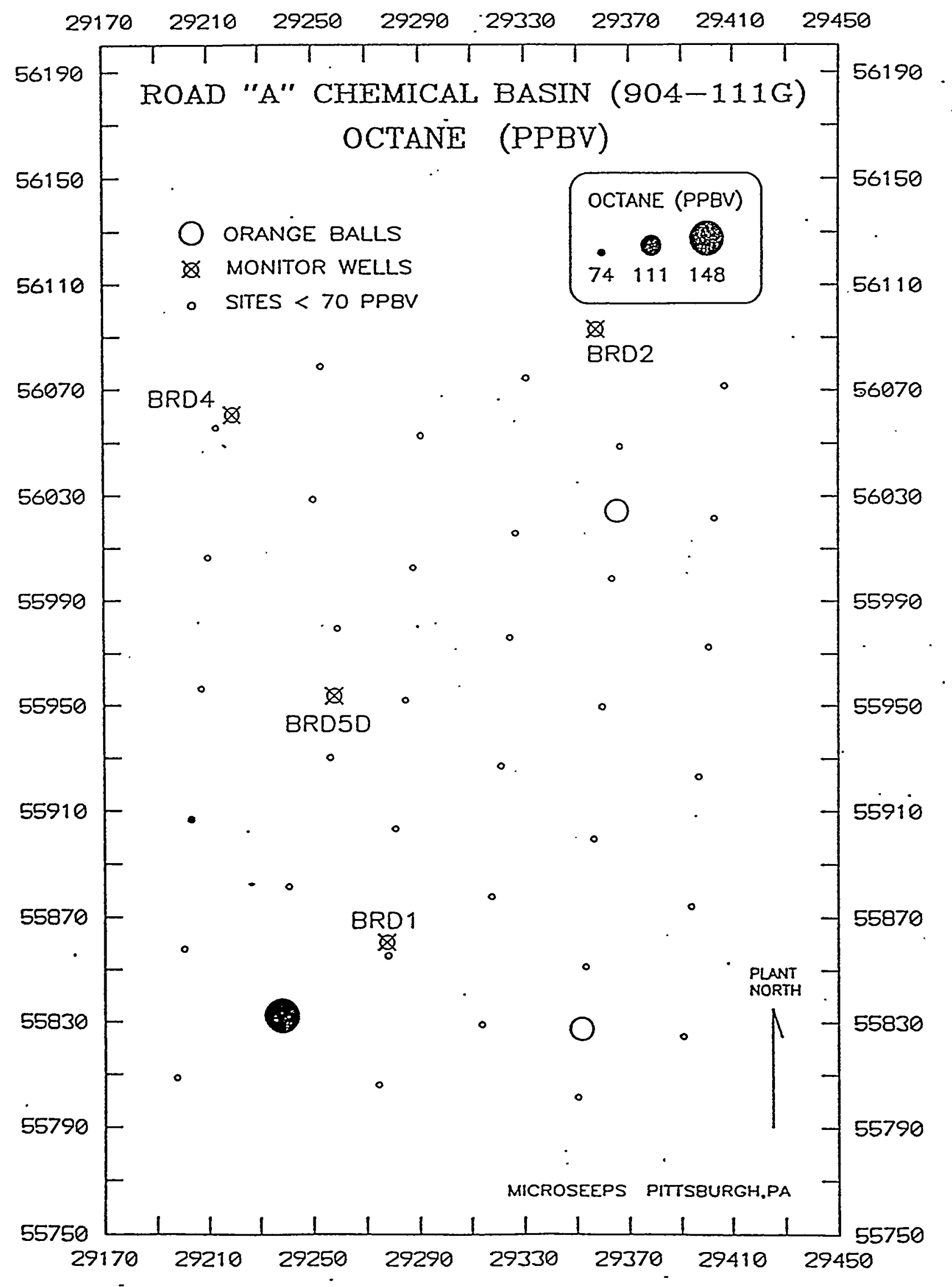




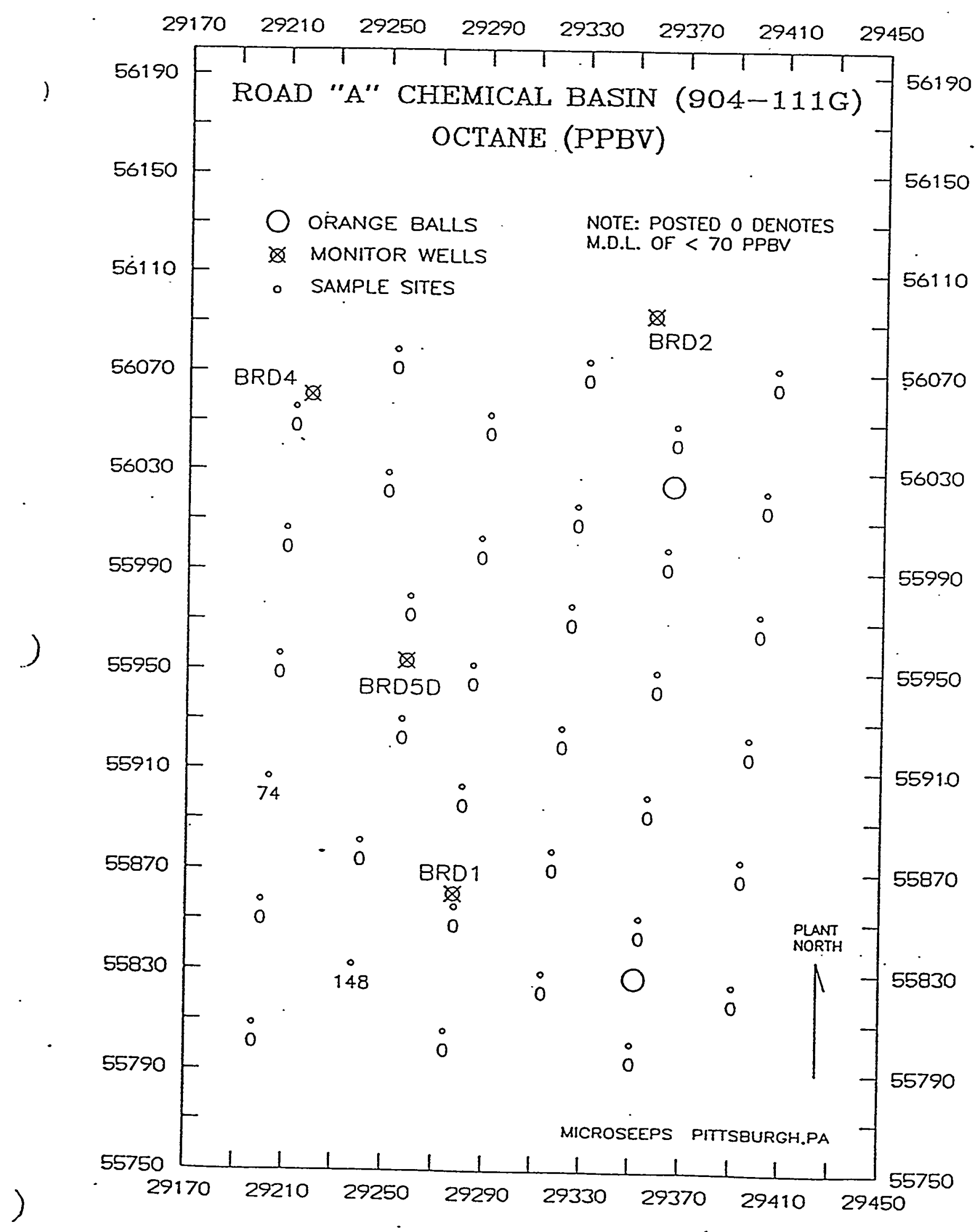

Figure 23. Octane (ppbv) Map 


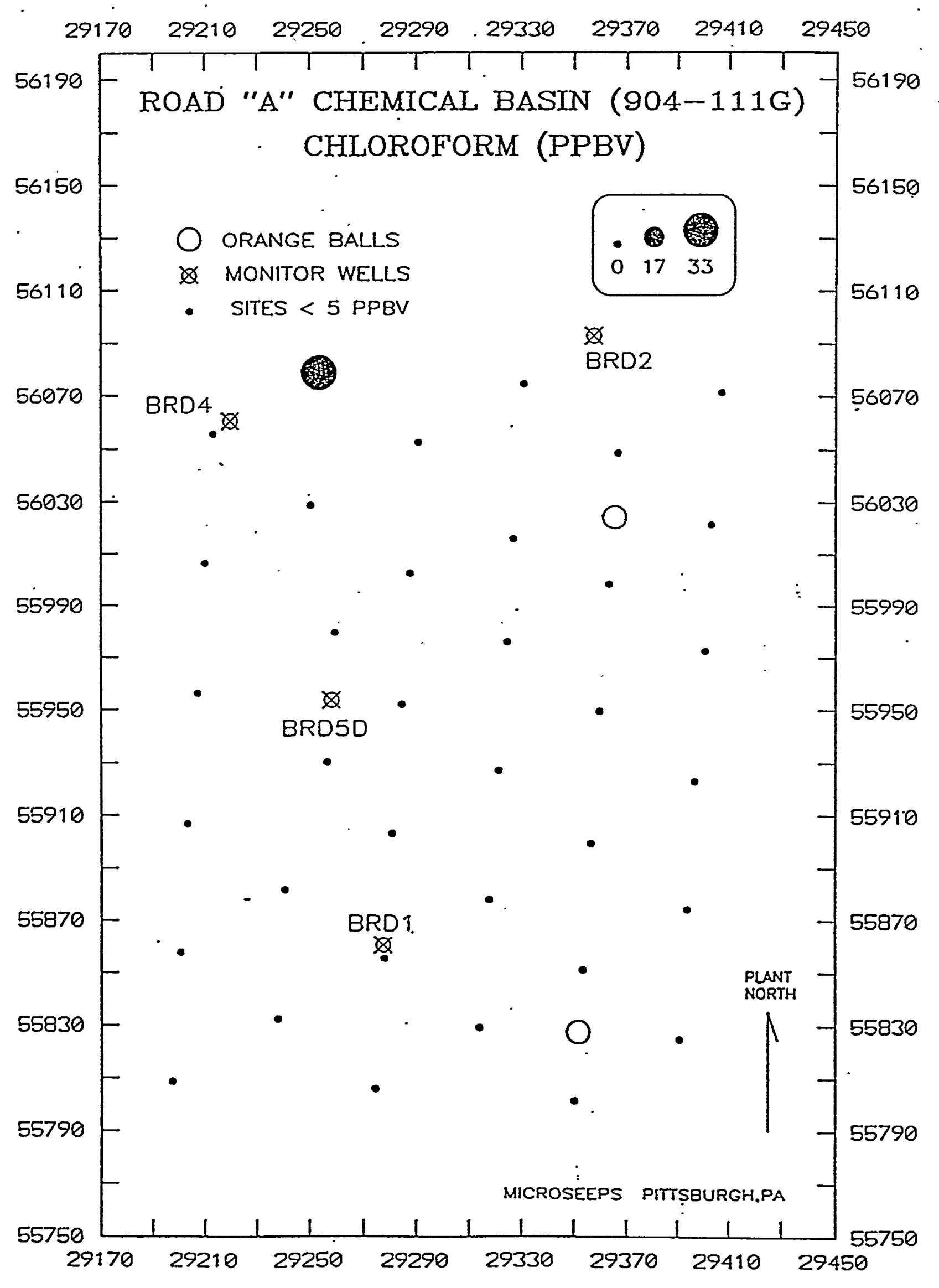




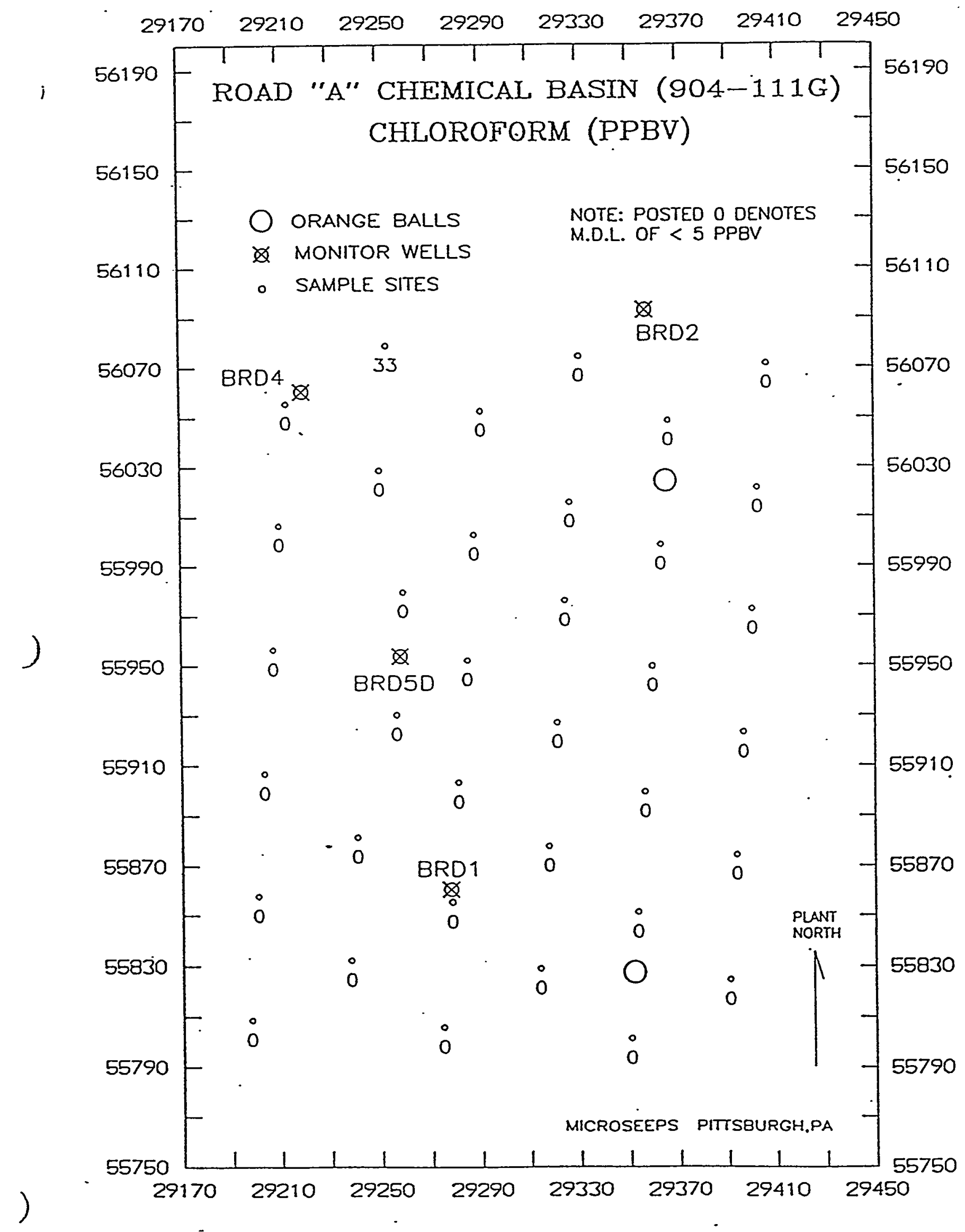

Figure 25. Chloroform (ppbv) Map 


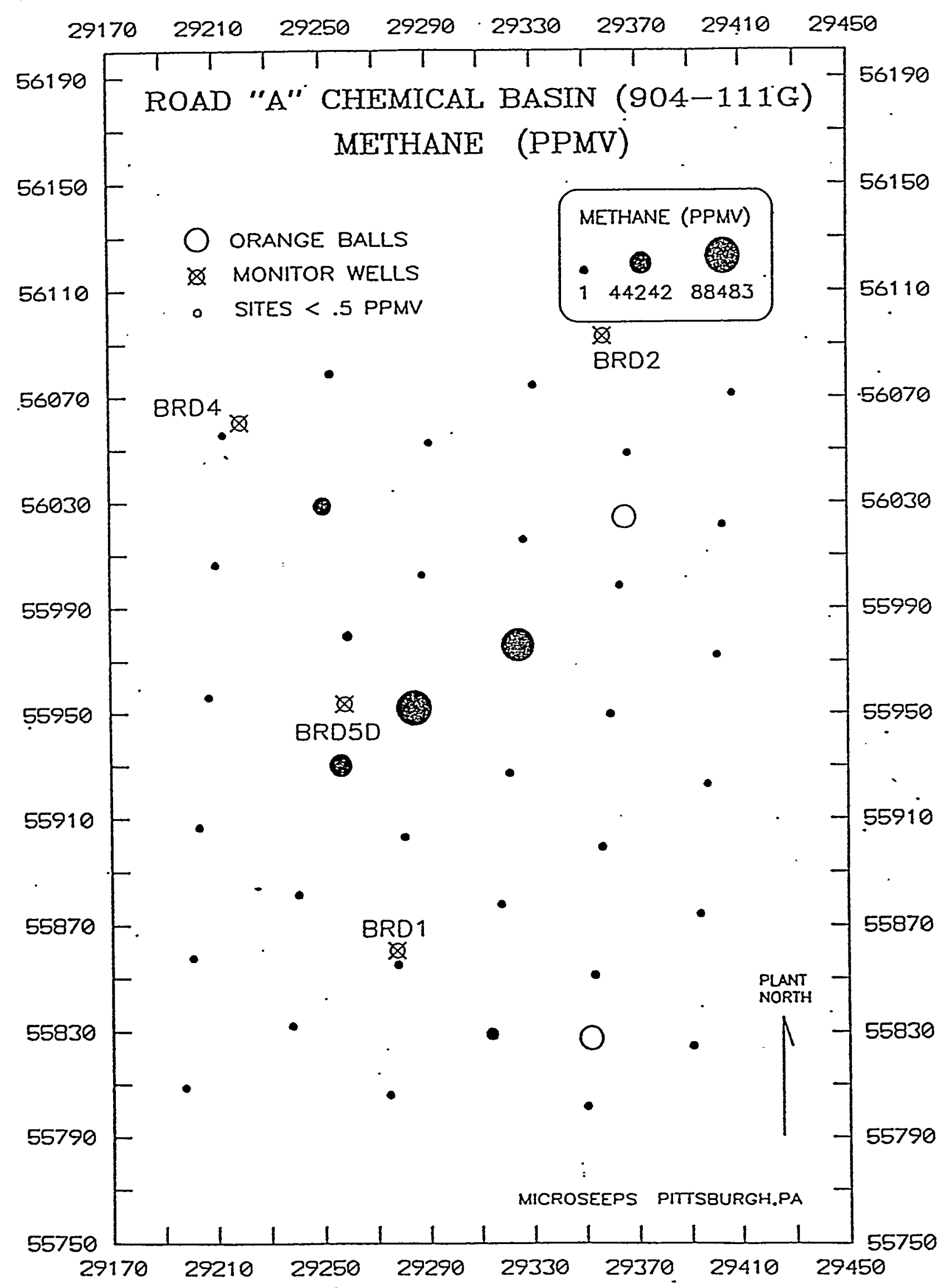

Fiqure 26. Methane Sumbor Man 


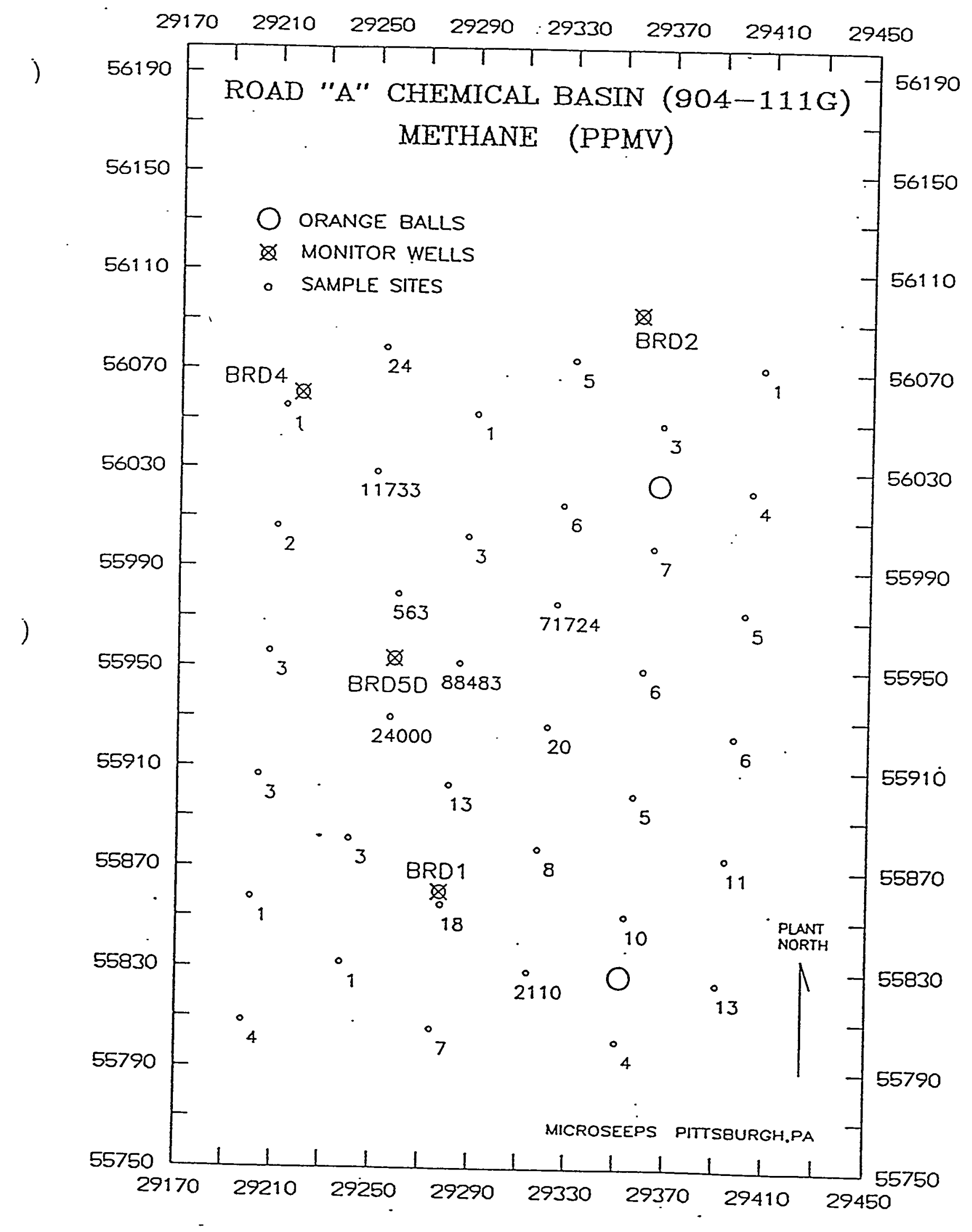

Figure 27. Methane (ppmv) Map 
SAVAKKAH RIVER SITE -...-

ROAD A CHEKICAL BASIY (904-111G) -....

SOIL GAS CONCEKTRATIONS (PPHV)

SAMPLE

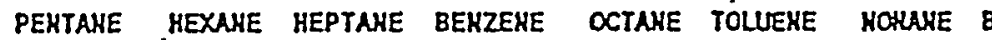

\begin{tabular}{|c|c|c|c|c|c|c|c|c|c|c|c|}
\hline $904-111 G-1$ & 0.30 & 0.10 & $<.07$ & $<.07$ & $<.07$ & $<.07$ & $<.07$ & $<.07$ & $<.07$ & $<.07$ & $<.07$ \\
\hline $904-1116-2$ & 0.36 & 0.13 & $<.07$ & $<.07$ & $<.07$ & $<.07$ & $<.07$ & $<.07$ & $<.07$ & $<.07$ & $<.07$ \\
\hline $904-111 G-3$ & 0.42 & 0.14 & $<.07$ & $<.07$ & $<.07$ & $<.07$ & $<.07$ & $<.07$ & $<.07$ & $<.07$ & $<.07$ \\
\hline $904-111 G-4$ & 0.10 & $<.07$ & $<.07$ & $<.07$ & $<.07$ & $<.07$ & $<.07$ & $<.07$ & $<.07$ & $<.07$ & $<.07$ \\
\hline $904-1116-5$ & 0.15 & $<.07$ & $<.07$ & $<.07$ & $<.07$ & $<.07$ & $<.07$ & $<.07$ & $<.07$ & $<.07$ & $<.07$ \\
\hline $906-1119-6$ & 0.15 & $<.07$ & $<.07$ & $<.07$ & $<.07$ & $<.07$ & $<.07$ & $<.07$ & $<.07$ & $<.07$ & $<.07$ \\
\hline $904-111 G-7$ & 0.08 & $<.07$ & $<.07$ & $<.07$ & $<.07$ & $<.07$ & $<.07$ & $<.07$ & $<.07$ & $<.07$ & $<.07$ \\
\hline $904-1116-8$ & $<.07$ & $<.07$ & $<.07$ & $<.07$ & $<.07$ & $<.07$ & $<.07$ & $<.07$ & $<.07$ & $<.07$ & $<.07$ \\
\hline $904-1116-9$ & 0.24 & 0.08 & $<.07$ & $<.07$ & $<.07$ & $<.07$ & $<.07$ & $<.07$ & $<.07$ & $<.07$ & $<.07$ \\
\hline $904-111 G-10$ & 0.16 & $<.07$ & $<.07$ & $<.07$ & $<.07$ & $<.07$ & $<.07$ & $<.07$ & $<.07$ & $<.07$ & $<.07$ \\
\hline $904-111 G-10 A$ & $<.07$ & $<.07$ & $<.07$ & $<.07$ & $<.07$ & $<.07$ & $<.07$ & $<.07$ & $<.07$ & $<.07$ & $<.07$ \\
\hline $904-111 G-11$ & $<.07$ & $<.07$ & $<.07$ & $<.07$ & $<.07$ & $<.07$ & $<.07$ & $<.07$ & $<.07$ & $<.07$ & $<.07$ \\
\hline $904-111 G-12$ & $<.07$ & $<.07$ & $<.07$ & $<.07$ & $<.07$ & $<.07$ & $<.07$ & $<.07$ & $<.07$ & $<.07$ & $<.07$ \\
\hline $904-111 G-13$ & 0.08 & $<.07$ & $<.07$ & $<.07$ & $<.07$ & $<.07$ & $<.07$ & $<.07$ & $<.07$ & $<.07$ & $<.07$ \\
\hline $904-1116-14$ & 0.12 & $<.07$ & $<.07$ & $<.07$ & $<.07$ & $<.07$ & $<.07$ & $<.07$ & $<.07$ & $<.07$ & $<.07$ \\
\hline $904-111 G-15$ & 0.28 & 0.09 & $<.07$ & $<.07$ & $<.07$ & $<.07$ & $<.07$ & $<.07$ & $<.07$ & $<.07$ & $<.07$ \\
\hline $904-911 G-16$ & 0.20 & $<.07$ & $<.07$ & $<.07$ & $<.07$ & $<.07$ & $<.07$ & $<.07$ & $<.07$ & $<.07$ & $<.07$ \\
\hline $24-1116-17$ & 0.14 & $<.07$ & $<.07$ & $<.07$ & $<.07$ & $<.07$ & $<.07$ & $<.07$ & $<.07$ & $<.07$ & $<.07$ \\
\hline$>04-911 G-18$ & 0.03 & $<.07$ & $<.07$. & $<.07$ & $<.07$ & $<.07$ & $<.07$ & $<.07$ & $<.07$ & $<.07$ & $<.07$ \\
\hline $904-911 G-19$ & $<.07$ & $<.07$ & $<.07$ & $<.07$ & $<.07$ & $<.07$ & $<.07$ & $<.07$ & $<.07$ & $<.07$ & $<.07$ \\
\hline $904-1116-20$ & 0.19 & 0.09 & $<.07$ & 0.11 & $<.07$ & $<.07$ & $<.07$ & $<.07$ & $<.07$ & $<.07$ & $<.07$ \\
\hline $904-111 G-20 A$ & 0.19 & $<.07$ & $<.07$ & $<.07$ & $<.07$ & $<.07$ & $<.07$ & $<.07$ & $<.07$ & $<.07$ & $<.07$ \\
\hline $904-1116-21$ & 0.08 & $<.07$ & $<.07$ & $<.07$ & $<.07$ & $<.07$ & $<.07$ & $<.07$ & $<.07$ & $<.07$ & $<.07$ \\
\hline $904-111 G-22$ & $<.07$ & $<.07$ & $<.07$ & $<.07$ & $<.07$ & $<.07$ & $<.07$ & $<.07$ & $<.07$ & $<.07$ & $<.07$ \\
\hline $904-111 G-23$ & 0.13 & $<.07$ & $<.07$ & $<.07$. & $<.07$ & $<.07$ & $<.07$ & $<.07$ & $<.07$ & $<.07$ & $<.07$ \\
\hline $904-1116-24$ & 0.08 & $<.07$ & $<.07$ & $<.07$ & $<.07$ & $<.07$ & $<.07$ & $<.07$ & $<.07$ & $<.07$ & $<.07$ \\
\hline $904-111 G-25$ & $<.07$ & $<.07$ & $<.07$ & $<.07$ & 0.15 & $<.07$ & $<.07$ & $<.07$ & $<.07$ & $<.07$ & - $<.07$ \\
\hline $904-111 G-26$ & 0.10 & $<.07$ & $<.07$ & $<.07$ & $<.07$ & $<.07$ & $<.07$ & $<.07$ & $<.07$ & $<.07$ & $<.07$ \\
\hline $904-111 G-27$ & 0.10 & $<.07$ & $<.07$ & $<.07$ & $<.07$ & $<.07$ & $<.07$ & $<.07$ & $<.07$ & $<.07$ & $<.07$ \\
\hline $904-111 G-28$ & 0.09 & $<.07$ & $<.07$ & $<.07$ & $<.07$ & $<.07$ & $<.07$ & $<.07$ & $<.07$ & $<.07$ & $<.07$ \\
\hline $904-1116-29$ & 0.26 & $<.07$ & $<.07$ & $<.07$ & $<.07$ & 1.19 & $<.07$ & $<.07$ & 0.39 & 0.35 & $<.07$ \\
\hline $904-111 G-30$ & $<.07$ & $<.07$ & $<.07$ & $<.07$ & $<.07$ & $<.07$ & $<.07$ & $<.07$ & $<.07$ & $<.07$ & $<.07$ \\
\hline $904-1116-30 A$ & $<.07$ & $<.07$ & $<.07$ & $<.07$ & $<.07$ & $<.07$ & $<.07$ & $<.07$ & $<.07$ & $<.07$ & $<.07$ \\
\hline $904-1116-31$ & $<.07$ & $<.07$ & $<.07$ & $<.07$ & $<.07$ & $<.07$ & $<.07$ & $<.07$ & $<.07$ & $<.07$ & $<.07$ \\
\hline $904-1116-32$ & $<.07$ & $<.07$ & $<.07$ & $<.07$ & $<.07$ & $<.07$ & $<.07$ & $<.07$ & $<.07$ & $<.07$ & $<.07$ \\
\hline $904-1116-33$ & $<.07$ & $<.07$ & $<.07$ & $<.07$ & $<.07$ & $<.07$ & $<.07$ & $<.07$ & $<.07$ & $<.07$ & $<.07$ \\
\hline $904-111 G-34$ & 0.16 & $<.07$ & $<.07$ & $<.07$ & 0.07 & $<.07$ & $<.07$ & $<.07$ & $<.07$ & 4.21 & $<.07$ \\
\hline $904-1116-35$ & $<.07$ & $<.07$ & $<.07$ & $<.07$ & $<.07$ & $<.07$ & $<.07$ & $<.07$ & $<.07$ & $<.07$ & $<.07$ \\
\hline $904-811 G-36$ & $<.07$ & $<.07$ & $<.07$ & $<.07$ & $<.07$ & $<.07$ & $<.07$ & $<.07$ & $<.07$ & $<.07$ & $<.07$ \\
\hline $904-911 \sigma^{*}$ SB1 & $<.07$ & $<.07$ & $<.07$ & $<.07$ & $<.07$ & $<.07$ & $<.07$ & $<.07$ & $<.07$ & $<.07$ & $<.07$ \\
\hline $904-111 G^{*} 582$ & $<.07$ & $<.07$ & $<.07$ & $<.07$ & $<.07$ & $<.07$ & $<.07$ & $<.07$ & $<.07$ & $<.07$ & $<.07$ \\
\hline $904-111 G^{*} 583$ & $<.07$ & $<.07$ & $<.07$ & $<.07$ & $<.07$ & $<.07$ & $<.07$ & $<.07$ & $<.07$ & $<.07$ & $<.07$ \\
\hline $904-1116 * 584$ & $<.07$ & $<.07$ & $<.07$ & $<.07$ & $<.07$ & $<.07$ & $<.07$ & $<.07$ & $<.07$ & $<.07$ & $<.07$ \\
\hline
\end{tabular}


HICROSEEPS

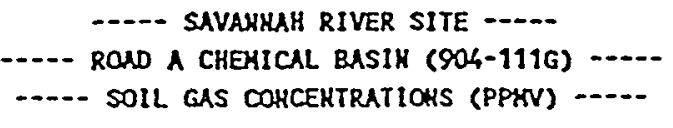

\begin{tabular}{|c|c|c|c|c|c|c|c|c|c|}
\hline $\begin{array}{l}\text { SAYPLE } \\
\text { HAYE }\end{array}$ & $\begin{array}{l}\text { VIKYL } \\
\text { CHLORIDE . }\end{array}$ & $\begin{array}{r}\text { HETHYLEHE } \\
\text { CHLORIOE }\end{array}$ & $\begin{array}{l}\text { TRAKS } 1,2 \\
\text { DICHLORO } \\
\text { ETHYLEKE }\end{array}$ & $\begin{array}{r}\text { CHLORO } \\
\text { FORH }\end{array}$ & $\begin{array}{l}111 \text { TRI } \\
\text { CHLORO } \\
\text { ETHUHE }\end{array}$ & $\begin{array}{r}\text { CARBOH } \\
\text { TETRA } \\
\text { CKLORIDE }\end{array}$ & $\begin{array}{r}\text { TRI } \\
\text { CHLORO } \\
\text { ETHYLEKE }\end{array}$ & $\begin{array}{r}\text { TETRA } \\
\text { CHLORO } \\
\text { ETHYLEKE }\end{array}$ & $\begin{array}{r}\text { FILE } \\
\end{array}$ \\
\hline $904-111 G-1$ & $<3$ & $<2$ & $<.10$ & $<.005$ & $<.005$ & $<.005$ & $<.005$ & $<.005$ & 123 155 \\
\hline $904-1116-2$ & 3 & $<2$ & $<.10$ & $<.005$ & $<.005$ & $<.005$ & $<.005$ & $<.005$ & V23 156 \\
\hline $904-111 G-3$ & $<$ & $<2$ & $<.10$ & $<.005$ & $<.005$ & $<.005$ & $<.005$ & $<.005$ & $\sqrt{23} 157$ \\
\hline $904-111 G-4$ & $<3$ & $<2$ & $<.10$ & $<.005$. & $<.005$ & $<.005$ & $<.005$ & $<.005$ & V23 158 \\
\hline $904-111 G-5$ & 3 & $<2$ & $<.10$ & $<.005$ & $<.005$ & $<.005$ & $<.005$ & $<.005$ & N23 159 \\
\hline $904-111 G-6$ & 3 & $<2$ & $<.10$ & $<.005$ & $<.005$ & $<.005$ & $<.005$ & $<.005$ & 123160 \\
\hline $90 \xi-111 G-7$ & $<3$ & $<2$ & $<.10$ & $<.005$ & $<.005$ & $<.005$ & $<.005$ & $<.005$ & 123161 \\
\hline $904-111 G-8$ & $<$ & $<2$ & $<.10$ & $<.005$ & $<.005$ & $<.005$ & $<.005$ & $<.005$ & U23 162 \\
\hline $904-111 G-9$ & $<3$ & $<2$ & $<.10$ & $<.005$ & $<.005$ & $<.005$ & $<.005$ & $<.005$ & 123163 \\
\hline $904-111 G-10$ & $<$ & $<2$ & $<.10$ & $<.005$ & $<.005$ & $<.005$ & $<.005$ & $<.005$ & 123164 \\
\hline $904-111 G-101$ & $<3$ & $<2$ & $<.10$ & $<.005$ & $<.005$ & $<.005$ & $<.005$ & $<.005$ & 423165 \\
\hline $904-111 G-11$ & $<3$ & $<2$ & $<.10$ & $<.005$ & $<.005$ & $<.005$ & $<.005$ & $<.005$ & 123168 \\
\hline $904-111 G-12$ & $<3$ & $<2$ & $<.10$ & $<.005$ & $<.005$ & $<.005$ & $<.005$ & $<.005$ & 123169 \\
\hline $904-111 G-13$ & $<3$ & $<2$ & $<.10$ & $<.005$ & $<.005$ & $<.005$ & $<.005$ & $<.005$ & 423170 \\
\hline $904-111 G-14$ & $<$ & $<2$ & $<.10$ & $<.005$ & $<.005$ & $<.005$ & $<.005$ & $<.005$ & 123171 \\
\hline $904-111 G-15$ & $<3$ & $<2$ & $<.10$ & $<.005$ & $<.005$ & $<.005$ & $<.005$ & $<.005$ & 123172 \\
\hline $904-111 G-16$ & $<$ & $<2$ & $<.10$ & $<.005$ & $<.005$ & $<.005$ & $<.005$ & $<.005$ & 423173 \\
\hline $904-111 G-17$ & 3 & $<2$ & $<.10$ & $<.005$ & $<.005$ & $<.005$ & $<.005$ & $<.005$ & 1523174 \\
\hline $904-111 G-18$ & $<3$ & $<2$ & $<.10$ & $<.005$ & $<.005$ & $<.005$ & $<.005$ & $<.005$ & 123175 \\
\hline $904-111 G-18$ & $<3$ & $<2$ & $<.10$ & $<.005$ & $<.005$ & $<.005$ & $<.005$ & $<.005$ & प्र23 176 \\
\hline $904-111 G-20$ & $<3$ & $<2$ & $<.90$ & $<.005$ & $<.005$ & $<.005$ & $<.005$ & $<.005$ & 12317. \\
\hline $904-111 G-20 R$ & $<3$ & $<2$ & $<.10$ & $<.005$ & $<.005$ & $<.005$ & $<.005$ & $<.005$ & 123178 \\
\hline $904-111 G-21$ & $<3$ & $<2$ & $<.10$ & $<.005$ & $<.005$ & $<.005$ & $<.005$ & $<.005$ & IR3 181 \\
\hline $904-1116-22$ & $<$ & $<2$ & $<.10$ & $<.005$ & $<.005$ & $<.005$ & $<.005$ & $<.005$ & 123182 \\
\hline $904-111 G-23$ & 3 & $<2$ & $<.10$ & $<.005$ & $<.005$ & $<.005$ & $<.005$ & $<.005$ & 123183 \\
\hline $906-1116-24$ & $<$ & $<2$ & $<.10$ & $<.005$ & $<.005$ & $<.005$ & $<.005$ & $<.005$ & प्र23 184 \\
\hline $904-111 G-25$ & 3 & $<2$ & $<.10$ & $<.005$ & $<.005$ & $<.005$ & $<.005$ & $<.005$ & 423185 \\
\hline $904-1116-26$ & $<$ & $<2$ & $<.10$ & $<.005$ & $<.005$ & $<.005$ & $<.005$ & $<.005$ & 123186 \\
\hline $904-111 G-27$ & $e$ & $<2$ & $<.10$ & $<.005$ & $<.005$ & $<.005$ & $<.005$ & $<.005$ & Y23 187 \\
\hline $904-111 G-28$ & 3 & $-<2$ & $<.10$ & $<.005$ & $<.005$ & $<.005$ & $<.005$ & $<.005$ & Yर23 188 \\
\hline $904-111 G-29$ & $<3$ & $<2$ & $<.10$ & $<.005$ & $<.005$ & $<.005$ & $<.005$ & $<.005$ & U23 189 \\
\hline $904-1111 G-30$ & $<$ & $<2$ & $<.10$ & 0.033 & $<.005$ & $<.005$ & $<.005$ & $<.005$ & 123990 \\
\hline $904-111 G-30 A$ & $<$ & $<2$ & $<.10$ & 0.035 & $<.005$ & $<.005$ & $<.005$ & $<.005$ & 123191 \\
\hline $904-111 G-31$ & 3 & $<2$ & $<.10$ & $<.005$ & $<.005$ & $<.005$ & $<.005$ & $<.005$ & प्र23 194 \\
\hline $904-111 G-32$ & $<3$ & $<2$ & $<.10$ & $<.005$ & $<.005$ & $<.005$ & $<.005$ & $<.005$ & प्रत3 195. \\
\hline $904-1116-33$ & $<3$ & $<2$ & $<.10$ & $<.005$ & $<.005$ & $<.005$ & $<.005$ & $<.005$ & प्र23 196 \\
\hline $904-111 G-34$ & $<3$ & $<2$ & $<.10$ & $<.005$ & $<.005$ & $<.005$ & $<.005$ & $<.005$ & Y23 197 \\
\hline $904-111 G-35$ & $<3$ & 2 & $<.10$ & $<.005$ & $<.005$ & $<.005$ & $<.005$ & $<.005$ & $\sqrt[4]{23} 198$ \\
\hline $904-111 G-36$ & $<$ & $<2$ & $<.10$ & $<.005$ & $<.005$ & $<.005$ & $<.005$ & $<.005$ & Y23 199 \\
\hline $904-111 G^{*} S 81$ & $<$ & $<2$ & $<.10$ & $<.005$ & $<.005$ & $<.005$ & $<.005$ & $<.005$ & Y23 153 \\
\hline $904-111 G^{\star}$ SB2 & $<3$ & $<2$ & $<.10$ & $<.005$ & $<.005$ & $<.005$ & $<.005$ & $<.005$ & 123166 \\
\hline $904-1116 * 583$ & $<3$ & $<2$ & $<.10$ & $<.005$ & $<.005$ & $<.005$ & $<.005$ & $<.005$ & $1 / 23179$ \\
\hline $904-111 G^{\star} S B 4$ & 3 & $<2$ & $<.10$ & $<.005$ & $<.005$ & $<.005$ & $<.005$ & $<.005$ & Y्र23 192 \\
\hline
\end{tabular}


MICROSEEPS

-..- SAVAHKAH RIVER SITE -...-

ROND A CHEHICAL BASIN (SO4-111G) -....

-...- SOIL GAS COHCEHTRATIOHS (PPHV)

\begin{tabular}{|c|c|c|c|c|c|c|c|}
\hline $\begin{array}{l}\text { SNHPLE } \\
\text { HAME }\end{array}$ & $\begin{array}{r}\text { HETHAHE } \\
\text { (PPHV) }\end{array}$ & $\begin{array}{l}\text { ETHAHE } \\
\text { (PPBV) }\end{array}$ & $\begin{array}{r}\text { PROPAHE } \\
\text { (PPBV) }\end{array}$ & $\begin{array}{r}\text { I-ВUTАKE } \\
\text { (PP्BV) }\end{array}$ & $\begin{array}{r}\text { X-BUTANE } \\
\text { (PPBV) }\end{array}$ & $\begin{array}{r}\text { ETHYLEHE } \\
\text { (PPBV) }\end{array}$ & $\begin{array}{r}\text { PROPYLEKE } \\
\text { (PPBY) }\end{array}$ \\
\hline & & $=--$ & $\cdots$ & $=-$ & - & $\ldots$ & - - \\
\hline $904-111 G-1$ & 13.132 & 1363 & 561 & 197 & 207 & 802 & 878 \\
\hline $904-111 \mathrm{G}-2$ & 4.443 & 393 & 171 & 71 & 72 & 251 & 577 \\
\hline $904-111 G-3$ & 9.589 & 487 & 180 & 127 & $<5$ & 325 & 346 \\
\hline $904-11116-4$ & 11.332 & 734 & 263 & 194 & 122 & 50.5 & 585 \\
\hline $904-1110-5$ & 5.080 & 303 & 143 & 109 & $<5$ & 217 & 268 \\
\hline $904-1116-6$ & 5.579 & 309 & 120 & 34 & $<5$ & 165 & 196 \\
\hline $904-111 G-7$ & 5.531 & 356 & 92 & 20 & $<5$ & 199 & 192 \\
\hline $904-1116-8$ & 4.615 & 111 & 39 & 49 & $<5$ & 52 & 61 \\
\hline $904-1116-9$ & 6.780 & 116 & 48 & $<5$ & $<5$ & $\pi$ & 81 \\
\hline $904-1116-10$ & 3.737 & 183 & 79 & 17 & $<5$ & 154 & 155 \\
\hline $904-111 G-101$ & $3.82,1$ & 136 & 52 & 40 & $<5$ & 113 & 106 \\
\hline $904-111 G-11$ & 3.167 & 166 & 62 & 29 & $<5$ & 122 & 118 \\
\hline $904-1116-12$ & 1.422 & 37 & 14 & 6 & $<5$ & 29 & 25 \\
\hline $904-1110-13$ & 4.596 & 237 & 88 & 124 & $<5$ & 188 & 209 \\
\hline $904-1116-14$ & 1.319 & 134 & 61 & 23 & $<5$ & 91 & 113 \\
\hline $904-1116-15$ & 5.744 & 390 & 147 & 91 & $<5$ & 279 & 287 \\
\hline $904-1116-16$ & 3.383 & 312 & 122 & 26 & 24 & 204 & 199 \\
\hline $904-1116-17$ & 71724.000 & HO & 395 & 262 & 143 & 480 & 580 \\
\hline $904-1116-18$ & 88483.000 & KD & 1097 & 216 & 1664 & $<5$ & 221 \\
\hline $906-1116-19$ & 20.353 & 129 & 73 & $<5$ & 87 & 88 & 90 \\
\hline $904-111 G-20$ & 12.687 & 400 & 156 & $379^{\circ}$ & $<5$ & 341 & 352 \\
\hline $904-1190-204$ & 50.438 & 688 & 191 & 147 & $<5$ & 386 & 378 \\
\hline $904-111 G-21$ & 7.803 & 102 & 42 & 22 & $<5$ & 82 & 85 \\
\hline $904-1116-22$ & 17.942 & 65 & 26 & $<5$ & $<5$ & 63 & 61 \\
\hline $904-1119-23$ & 2109.900 & 162 & 109 & 113 & $<5$ & 198 & 198 \\
\hline $906-1116-24$ & 6.642 & 291 & 221 & $<5$ & 445 & 226 & 188 \\
\hline $904-1116-25$ & 0.723 & 36 & 47 & $<5$. & 103 & 15 & $<5$ \\
\hline $904-1116-26$ & 2.940 & 181 & 75 & $<5$ & 19 & 135 & 137 \\
\hline $904-1116-27$ & 24000.000 & HO & 169 & 25 & $<5$ & 156 & 198 \\
\hline $904-111 G-28$ & 563.010 & 98 & 52 & $<5$ & $<5$ & 107 & 101 \\
\hline $904-1116-29$ & 11733.333 & KO & 238 & $<5$ & $<5$ & 145 & 201 \\
\hline $904-1119-50$ & 24.017 & 22 & 12 & $<5$ & $<5$ & 17 & 21 \\
\hline $904-1116-301$ & 2.585 & 19 & 7 & $<5$ & $<5$ & 16 & 16 \\
\hline $904-1196-31$ & 1.230 & 10 & 5 & $<5$ & $<5$ & 11 & 13 \\
\hline $904-111 G-32$ & 2.395 & 15 & 9 & $<5$ & $<5$ & 5 & $<5$ \\
\hline $904-1116-33$ & 3.345 & 51 & 19 & $<5$ & $<5$ & 40 & 46 \\
\hline $904-1116-34$ & 3.460 & 262 & 118 & 102 & $<5$ & 190 & 215 \\
\hline $904-1116-35$ & 0.660 & 53 & 21 & $\$$ & $<$ & 38 & 40 \\
\hline $904-9116-36$ & 4.294 & 86 & 21 & 39 & $<5$ & 81 & 57 \\
\hline $904-111 G * 581$ & 1.772 & $<5$ & $<5$ & $<5$ & $<5$ & 5 & $<5$ \\
\hline $904-1116=582$ & 1.791 & 6 & $<5$ & -5 & $<5$ & $<5$ & $<5$ \\
\hline $904-1111 G^{*} 583$. & 3.439 & 5 & $<5$ & $<5$ & $<5$ & $<5$ & $<5$ \\
\hline $904-1111 G^{*} 584$ & 1.900 & $<5$ & $<5$ & $<5$ & $<5$ & $<5$ & $<5$ \\
\hline
\end{tabular}

Table 3.- Iight Hydrocarbon Soil Gas Concentrations and System Blanks at the Road A Chemical Basin (904-111G) 
- VOC STANDARD CONCENTRATIONS (ppmv) -

\begin{tabular}{|c|c|c|c|c|c|c|}
\hline COMPOUND & $\begin{array}{r}\text { RANGE } \\
1\end{array}$ & $\begin{array}{r}\text { RANGE } \\
2\end{array}$ & $\begin{array}{r}\text { RANGE } \\
3\end{array}$ & $\begin{array}{r}\text { RANGE } \\
4\end{array}$ & $\begin{array}{r}\text { RANGE } \\
5\end{array}$ & $\begin{array}{r}\text { RANGE } \\
6\end{array}$ \\
\hline PENTANE & 942.19 & 91.52 & 9.13 & 0.91 & 0.091 & 0.0091 \\
\hline 11 OICHLOROETHYLENE & 1358.80 & 131.99 & 13.16 & 1.32 & 0.132 & 0.0132 \\
\hline METHYLENE CHLORIDE & 1694.16 & 164.57 & 16.41 & 1.64 & 0.164 & 0.0164 \\
\hline TRANS 1,2 DICHLOROETHYLENE & 1408.09 & 136.78 & 13.64 & 1.36 & 0.136 & 0.0136 \\
\hline 11 DICHLOROETHANE & 1291.56 & 125.46 & 1251 & 1.25 & 0.125 & 0.012 \\
\hline CHLOROFORM & 1356.81 & 131.80 & 13.14 & 1.31 & 0.131 & 0.013 \\
\hline 111 TRICHLOROETHANE & 1089.10 & 105.79 & 10.55 & 1.05 & 0.105 & 0.0105 \\
\hline CARBON TEIRACHLORIDE & 1125.32 & 109.31 & 10.90 & 1.09 & 0.109 & 0.0109 \\
\hline HEPTANE & 741.22 & 72.00 & 7.18 & 0.72 & 0.072 & 0.0072 \\
\hline BENZENE & 1214.92 & 118.02 & 11.77 & 1.18 & 0.118 & 0.0118 \\
\hline TRICHLOROETHYLENE & 1208.33 & 117.38 & 11.70 & 1.17 & 0.117 & 0.0117 \\
\hline OCTANE & 668.30 & 64.92 & 6.47 & 0.65 & 0.065 & 0.0065 \\
\hline TOLUENE & 1021.92 & 99.27 & 9.90 & 0.99 & 0.099 & 0.0099 \\
\hline TETRACHLOROETHYLENE & 1062.81 & 103.24 & 10.29 & 1.03 & 0.103 & 0.0103 \\
\hline NONANE & 607.90 & 59.05 & 5.89 & 0.59 & 0.059 & 0.0059 \\
\hline ETHYL BENZENE & 886.78 & 86.14 & 8.59 & 0.86 & 0.086 & 0.0086 \\
\hline M-XYLENE & 883.71 & 85.84 & 8.56 & 0.86 & 0.086 & 0.0086 \\
\hline P-XYLENE & 880.64 & 85.54 & 8.53 & 0.85 & 0.085 & 0.0085 \\
\hline O-XYLENE & 888.83 & 86.34 & 8.61 & 0.86 & 0.086 & 0.0086 \\
\hline DECANE & 557.12 & 54.12 & 5.40 & 0.54 & 0.054 & 0.0054 \\
\hline
\end{tabular}




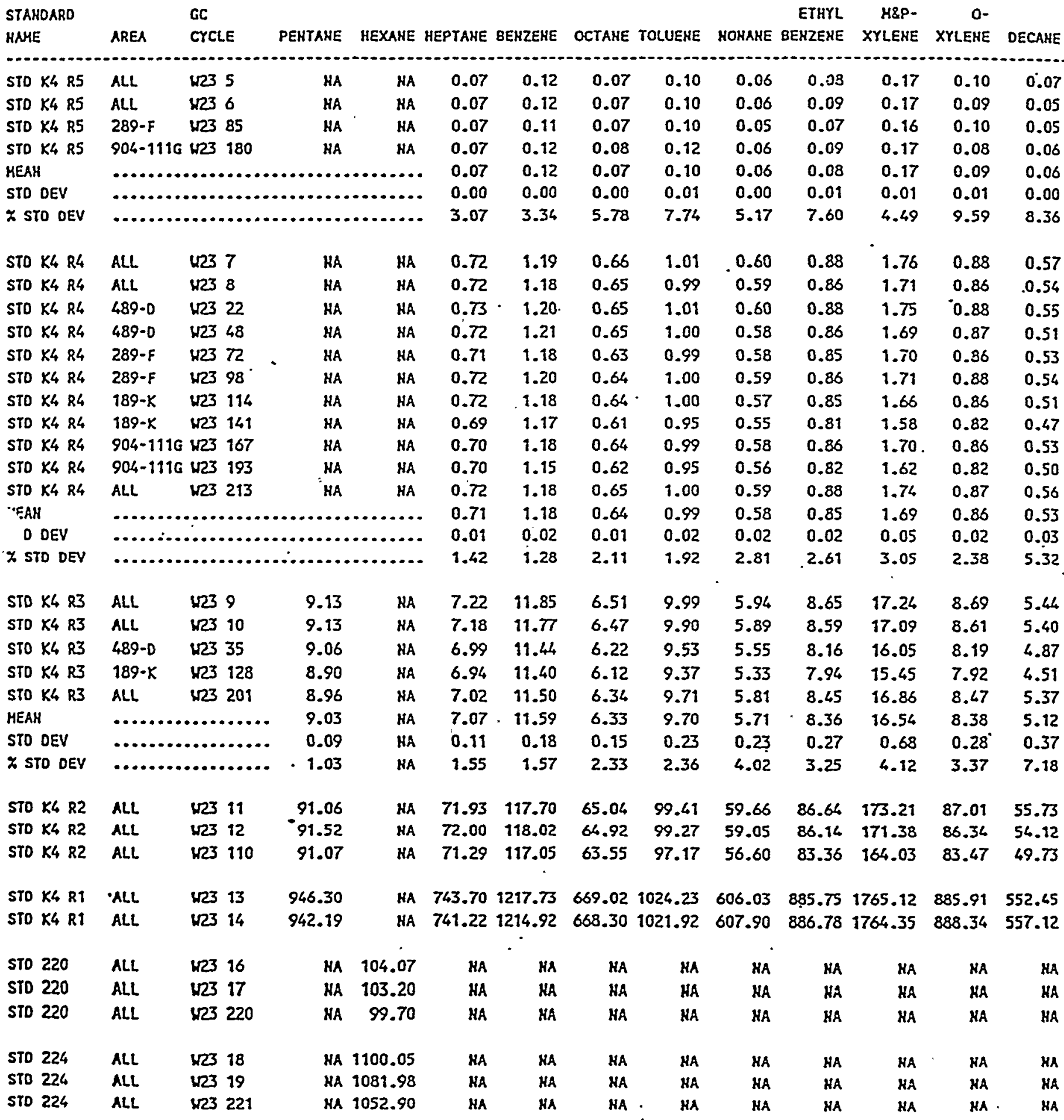


-...- OCTOBER, 1992 (D23) STAMDAROS -...-

-.... GAS COHCEHTRATIOKS IK (PPHV) .....

\begin{tabular}{|c|c|c|c|c|c|c|c|c|c|c|}
\hline $\begin{array}{l}\text { STANDARD } \\
\text { WAHE }\end{array}$ & AREA & $\begin{array}{l}\text { GC } \\
\text { CYCLE }\end{array}$ & $\begin{array}{r}\text { VINYL } \\
\text { CHLORIOE }\end{array}$ & $\begin{array}{r}\text { METHYLEHE } \\
\text { CHLORIDE }\end{array}$ & $\begin{array}{l}\text { TRAHS } 1,2 \\
\text { DICHLORO } \\
\text { ETHYLEHE }\end{array}$ & $\begin{array}{r}\text { CHLORO } \\
\text { FORH }\end{array}$ & $\begin{array}{l}111 \text { TRI } \\
\text { CHLORO } \\
\text { ETHAHE }\end{array}$ & $\begin{array}{r}\text { CARBOH } \\
\text { TETRA } \\
\text { CHLORIDE }\end{array}$ & $\begin{array}{r}\text { TRI } \\
\text { CHLORO } \\
\text { ETHYLEHE }\end{array}$ & $\begin{array}{r}\text { TETRA } \\
\text { CHLORO } \\
\text { ETHYLENE }\end{array}$ \\
\hline STD KG RG & ALL & 1233 & HA & NA & $\mathrm{HA}$ & 0.013 & 0.011 & 0.011 & 0.012 & 0.010 \\
\hline STO K4 R6 & ALL & H23 4 & HA & NA & $H A$ & 0.013 & 0.011 & 0.011 & 0.012 & 0.010 \\
\hline STO K4 R6 & $080-24 G$ & Y23 60 & HA & HA & HA & 0.016 & 0.014 & 0.012 & 0.013 & 0.011 \\
\hline STO K4 R6 & $904-1116$ & 123154 & HA & KA & NA & 0.013 & 0.009 & 0.011 & 0.012 & 0.011 \\
\hline HEAH & & $\cdots \ldots$ & & & 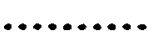 & 0.014 & 0.011 & 0.011 & 0.012 & 0.011 \\
\hline STO DEY & ......... & ......... & $\ldots$ & & ..... & 0.001 & 0.002 & 0.000 & 0.000 & 0.000 \\
\hline$\approx$ STD DEV & ....... & ......... & $\ldots$ & ....... & $\ldots \ldots$ & 9.448 & 15.870 & 3.849 & 3.535 & 4.762 \\
\hline STO K4 R5 & ALL & 1235 & HA & HA & 0.16 & 0.133 & 0.105 & 0.110 & 0.120 & 0.106 \\
\hline STO K4 R5 & ALL & W23 6 & HA & MA & 0.14 & 0.131 & 0.105 & 0.109 & 0.117 & 0.103 \\
\hline STO K4 R5 & $289-8$ & W23 85 & MA & MA & 0.14 & 0.131 & 0.105 & 0.108 & 0.117 & 0.103 \\
\hline STO KL R5 & $904-1116$ & W23 180 & HA & MA & 0.13 & 0.130 & 0.106 & 0.111 & 0.117 & 0.103 \\
\hline MEAH & $\ldots \ldots \ldots$ & $\cdots \cdots \cdots$ & $\bullet$ & $\cdots$ & 0.14 & 0.131 & 0.105 & 0.110 & 0.118 & 0.104 \\
\hline STO DEV & ........ & ......... & & $\ldots$ & 0.00 & 0.001 & 0.000 & 0.001 & 0.001 & 0.001 \\
\hline ₹ STD DEV & ....... & ......... & & $\ldots$ & 1.04 & 0.830 & 0.411 & 0.755 & 1.103 & 1.252 \\
\hline STO K4 R4 & ALL & LR3 7 & HA & 1.69 & 1.36 & 1.328 & 1.054 & 1.094 & 1.191 & 1.053 \\
\hline STO $\times 4 R 4$ & ALL & W23 8 & HA & 1.64 & 1.36 & 1.310 & 1.050 & 1.090 & 1.170 & 1.030 \\
\hline STD K4 R4 & 489-D & y23 22 & MA & 1.67 & 1.54 & 1.559 & 1.186 & 1.190 & 1.304 & 1.121 \\
\hline STO K4 R4 & $489-0$ & 42348 & HA & 1.68 & 1.56 & 1.554 & 1.202 & 1.206 & 1.293 & 1.099 \\
\hline STO K4 R4 & $289-F$ & 12372 & MA & 1.64 & 1.36 & 1.295 & 1.039 & 1.079 & 1.158 & 1.019 \\
\hline STO K4 R4 & $289-F$ & 42398 & HA & 1.77 & 1.36 & 1.302 & 1.050 & 1.095 & 1.162 & 1.025 \\
\hline STO KL R4 & $189-K$ & 123114 & NA & 1.67 & 1.35 & 1.304 & 1.045 & 1.085 & 1.146 & 1.000 \\
\hline STO K4 R4 & $189-K$ & W23 141 & HA & 1.69 & 1.33 & 1.297 & 1.045 & 1.082 & 1.128 & 0.971 \\
\hline STO $K 4 R 4$ & $904-1116$ & W23 167 & NA & 1.70 & 1.34 & 1.293 & 1.041 & 1.087 & 1.149 & 1.018 \\
\hline STD K4 R4 & $904-111 G$ & W23 193 & HA & 1.62 & 1.32 & 1.268 & 1.026 & 1.075 & 1.118 & 0.984 \\
\hline STO K4 R4 & ALL & W23 213 & NA & 1.63 & 1.35 & 1.315 & 1.148 & 1.099 & 1.164 & 1.043 \\
\hline MEAK & ........ & .......... & $\ldots$ & 1.67 & 1.38 & 1.348 & 1.081 & 1.107 & 1.180 & 1.033 \\
\hline STO DEY & ...... & $\cdots$ & & 0.04 & 0.08 & 0.099 & 0.062 & 0.043 & 0.059 & 0.043 \\
\hline$\approx$ STD DEV & & $\ldots$ & & 2.30 & 5.64 & 7.379 & 5.704 & 3.914 & 4.986 & 4.172 \\
\hline STO K4 R3 & ALL & 1239 & MA & 16.49 & 13.81 & 13.146 & 10.613 & 11.016 & 11.806 & 10.432 \\
\hline STO KL R3 & ALL & W23 10 & HA & 16.41 & 13.64 & 13.100 & 10.550 & 10.900 & 11.700 & 10.290 \\
\hline STO $\times 4 R 3$ & $489-0$ & 12335 & MA & 16.08 & 14.56 & 14.183 & 11.144 & 10.604 & 12.034 & 9.783 \\
\hline STO K4 R3 & $189-K$ & Y23 128 & NA & 15.94 & 13.71 & 13.343 & 10.821 & 10.377 & 11.670 & 9.467 \\
\hline STO KK R3 & ALL & 123201 & HA & 15.93 & 13.69 & 13.196 & 10.738 & 10.903 & 11.894 & 10.119 \\
\hline MEAH & ......... & .......... & ........... & 16.17 & 13.88 & 13.394 & 10.773 & 10.760 & 11.821 & 10.018 \\
\hline STO DEY & ........ & $\cdots \cdots$ & & 0.24 & 0.34 & 0.403 & 0.208 & 0.235 & 0.133 & 0.351 \\
\hline Z STO DEY & $\ldots \ldots$ & 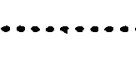 & $\cdots$ & 1.46 & 2.47 & 3.009 & 1.932 & 2.186 & 1.125 & 3.499 \\
\hline STO K4 R2 & ALL & 12311 & NA & 163.78 & 136.68 & 131.060 & 105.291 & 107.879 & 117.666 & 104.111 \\
\hline STO KL R2 & ALL & $4 \sqrt{23} 12$ & HA & 164.57 & 136.78 & 131.800 & 105.790 & 109.310 & 117.380 & 103.200 \\
\hline STO K4 R2 & ALL & 123110 & HA & 164.56 & 136.78 & 131.723 & 106.042 & 106.481 & 115.161 & 100.004 \\
\hline STO KL R1 & ALL & 12313 & HA & 1701.07 & 2615.52 & 1361.363 & 1092.136 & 1117.806 & 1214.405 & 1068.049 \\
\hline STO K4 R1 & $A L L$ & W23 14 & HA & 1694.16 & 2625.02 & 1356.810 & 1089.100 & 1125.320 & 1208.530 & 1063.000 \\
\hline
\end{tabular}

STO YC-99.6 ALL V23 $308 \quad 2409.7$ STO VC-99.6 ALL WZ3 $309 \quad 2428.7$

$\begin{array}{lllllll}\text { HA } & \text { HA } & \text { HA } & \text { HA } & \text { HA } & \text { HA } & \text { KA } \\ \text { HA } & \text { HA } & \text { HA } & \text { HA } & \text { HA } & \text { HA } & \text { HA }\end{array}$




\section{- SAVANNAH RIVER SITE - \\ - LIGHT HYDROCARBON STANDARD ANALYSIS - \\ - 904-111G ROAD A CHEMICAL BASIN -}

\begin{tabular}{|c|c|c|c|c|c|c|c|c|c|}
\hline $\begin{array}{r}\text { STANDARD } \\
\text { TYPE } \\
\end{array}$ & RUN\# & $\begin{array}{r}\text { DATE } \\
\text { ANALYZED } \\
\end{array}$ & $\begin{array}{r}\text { METHANE } \\
\text { PPBV } \\
\end{array}$ & $\begin{array}{r}\text { ETHANE } \\
\text { PPBY } \\
\end{array}$ & $\begin{array}{r}\text { PROPANE } \\
\text { PPBV } \\
\end{array}$ & $\begin{array}{r}\text { 1-BUTANE } \\
\text { PPBV } \\
\end{array}$ & $\begin{array}{r}\text { N-BUTANE } \\
\text { PPBV } \\
\end{array}$ & $\begin{array}{r}\text { ETHYLENE } \\
\text { PPQV } \\
\end{array}$ & $\begin{array}{r}\text { PROPYLENE } \\
-\quad \text { PPBV } \\
\end{array}$ \\
\hline STD M & 191 & $10-20-92$ & 10101 & 1007 & 1005 & 1011 & 1044 & 1009 & 1000 \\
\hline STDM & 202 - & $10-20-92$ & 10123 & 1010 & 1005 & 1020 & 1056 & 1010 & 988 \\
\hline STOM & 229 & $10-21-92$ & 10274 & 1030 & 1029 & 1048 & 1105 & 1028 & 1025 \\
\hline STOM & 230 & $10-21-92$ & 10231 & 1024 & 1024 & 1042 & 1100 & 1022 & 1022 \\
\hline \multirow[t]{4}{*}{ STOM } & 244 & $\begin{array}{c}10-21-92 \\
.\end{array}$ & 10599 & 1003 & 1003 & 1007 & 1018 & 1003 & 998 \\
\hline & & MEAN & 10266 & 1015 & 1013 & 1026 & 1065 & 1014 & 1007 \\
\hline & & STD DEV & 179 & 10 & . 11 & 16 & . 33 & 9 & 14 \\
\hline & & \% STD DEV & 1.74 & 1.02 & 1.09 & 1.61 & 3.13 & 0.90 & 1.43 \\
\hline$\cdot$ & & & & . & & & & & \\
\hline STO 224 & 216 & $10-20-92$ & 1011600 & 1050400 & 1013000 & & 1052300 & & \\
\hline STD 224 & 227 & $10-20-92$ & 1007300 & 1042400 & 1005700 & & 1031100 & & \\
\hline STO 224 & 232 & $10-21-92$ & 980860 & 1029800 & 1014600 & & 1014600 & & \\
\hline \multirow[t]{4}{*}{ STO 224} & 233 & $10-21-92$ & 1004600 & 1047000 & 1012500 & & 1080200 & & \\
\hline & & MEAN & 1001090 & 1042400 & 1011450 & & 1044550 & & \\
\hline & & STO DEV & 11944 & 7809 & 3409 & & 24540 & . & \\
\hline & & \% STO DEV & 1.19 & 0.75 & 0.34 & & 2.35 & & $\cdot$ \\
\hline
\end{tabular}

Table 7. Light Hydrocarbon Analyses of Standards " $M$ " and "224" 
- SAVANNAH RIVER SITE -

- MINIMUM DETECTION LEVELS for 904-111G ROAD A CHEMICAL BASIN - AREA REJECT $=40$, CONCENTRATIONS IN PPMV --

\begin{tabular}{|r|r|r|}
\hline COMPOUND & IDEAL & ACTUAL \\
NAME & M.D.L. & M.D.L. \\
\hline VINYL CHLORIDE & 0.10 & 3.0 \\
PENTANE & 0.040 & 0.070 \\
HEXANE & 0.033 & 0.070 \\
METHYLENE CHLORIDE & 0.03 & 2.0 \\
TRANS 1,2 DICHLOROETHYLE & 0.011 & 0.1 \\
CHLOROFORM & 0.00019 & 0.005 \\
111 TRICHLOROETHANE & 0.00007 & 0.005 \\
CARBON TETRACHLORIDE & 0.00004 & 0.005 \\
HEPTANE & 0.026 & 0.070 \\
BENZENE & 0.032 & 0.070 \\
TRICHLOROETHYLENE & 0.00015 & 0.005 \\
OCTANE & 0.023 & 0.070 \\
TOLUENE & 0.028 & 0.070 \\
TETRACHLOROETHYLENE & 0.00005 & 0.005 \\
NONANE & 0.021 & 0.070 \\
ETHYL BENZENE & 0.024 & 0.070 \\
M\&P-XYLENE & 0.025 & 0.070 \\
O-XYLENE & 0.024 & 0.070 \\
DECANE & 0.020 & 0.070 \\
\hline
\end{tabular}

Table 8. Minimum Detection Levels 
SAVAHHAH RIVER SITE -...-.

SOIL GAS SYSTEH BLANKS -- DATA DIRECTORIES D21 THRU D25 -....

-.... SOIL GAS COHCENTRATIONS (PPHY) -....

SAMPLE

ETHYL H\&P-

$0-$

FILE

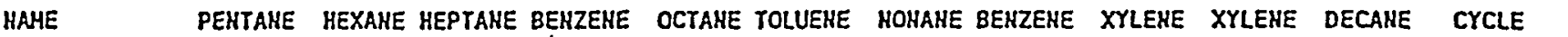

\begin{tabular}{|c|c|c|c|c|c|c|c|c|c|c|c|c|}
\hline $631-4 G-581$ & HO & No & KO & HO & HD & ND & צס & HD & HO & KD & ND & H21 41 \\
\hline $631-4 G-582$ & HO & HO & Ho & HO & ко & HO & no & HO & HD & HD & SD & H21 54 \\
\hline $731-5 A-581$ & 0.096 & Ho & HO & HD & NO & HD & No & HD & HO & HD & HO & W21 85 \\
\hline $731-5 A-5 B 2$ & No & Ho & ND & Ho & HO & HO & HD & HD & HD & ND & HO & 421 98 \\
\hline $731-5 A-5 B 3$ & No & ND & ND & NO & ND & HD & No & ND & Ho & HO & NO & H21 111 \\
\hline $731-5 A-5 B 4$ & HO & No & NO & No & KD & HD & ND & พD & HO & KD & ND & 421.124 \\
\hline $731-5 A-585$ & HO & 0.197 & HO & HO & No & HO & No & 0.033 & 0.111 & 0.070 & ND & 221137 \\
\hline $484-100-581$ & HO & ND & NO & No & NO & NO & No & ND & NO & ผ0 & No & H21 149 \\
\hline $731-5 A-586$ & Ho & HO & HO & HD & ND & HO & No & HD & но & Ho & NO & H21 192 \\
\hline $731-5 A-5 B 7$ & Ho & но & ND & HO & HD & ND & พ0 & HO & so & HD & ND & प्र21 200 \\
\hline $731-5 A-588$ & Ho & Ho & No & NO & HO & HO & พD & No & YO & ND & HO & H21 217 \\
\hline $731-5 A-589$ & Ho & No & HD & No & ND & No & No & \&NO & No & No & HO & 421230 \\
\hline $731-5 A-5810$ & HO & HO & NO & No & HO & ND & HO & ND & HO & HO & NO & 121243 \\
\hline $731-5 A-5819$ & MD & HO & HD & No & HO & HO & WD & Ho & No & No & NO & 421 256 \\
\hline $731-5 A-5812$ & พO & No & HO & No & ND & HD & HO ${ }^{\circ}$ & No & HO & KD & ND & 421269 \\
\hline $731-5 A-5813$ & Ho & No & ND & พо & NO & No & HO & NO & MO & No & NO & प्र22 18 \\
\hline $731-5 A-5814$ & no & No & Mo & Ho & HD & no & No & No & ND & หo & MO & U22 27 \\
\hline $731-5 A-5 B 15$ & No & No & No & พо & No & No & ND & HO & ND & No & No & W22 40 \\
\hline $31-5 A-5 B 16$ & Yo & No & HD & No & WD & No & ND & ND & NO & Ho & NO & प्र22 53 \\
\hline $21-5 A-5817$ & No & No & NO & Ho & Ho & No & ND & No & No & но & No & H22 66 \\
\hline $731-5 A-5818$ & 'so & No & ND & HO & ND & no & Ho & MO & HD & . HO & No & 12279 \\
\hline $731-5 A-5 B 19$ & No & NO & HD & ND & Ho & HO & Ho & ND & но & ND & ko & Y222 92 \\
\hline $731-5 A \cdot 5820$ & NO & NO & HO & HO & HO & Ho & so & NO & HO & SO & 0.017 & 422900 \\
\hline $731-5 A-5821$ & HO & Ho & ND & HD & HD & Ho & No & No & HD & No & No & 122107 \\
\hline $731-5 A=5822$ & No & no & No & No & No & HO & HO & SD & ND & HO & No & 422. 120 \\
\hline $731-5 A-5823$ & No & No & Ho & No & ND & HD & но & No & หо & ผB & HO & $\sqrt{22} 133$ \\
\hline $731-5 A-5824$ & HO & No & No & No & YO & no & MO & ND & No & No & HO & 122146 \\
\hline $731-5 A-5825$ & ND & HO & ND & No & หо & HD & SO & พо & HO & ND & HD & 422159 \\
\hline $731-5 A-5826$ & HO & NO & HD & No & ND & HD & ND & ND & No & Ho & HO & 1222172 \\
\hline $731-5 A-5827$ & HO & No & HO & No & NO & No & HO & NO & No & No & ND & 422243 \\
\hline $080-24 G-S B 1$ & SO & No & HO & No & Ho & kD & NO & No & No & Ho & HO & પ222 193 \\
\hline $080-24 G-532$ & NO & Kо & ND & No & Hо & Ho & No & No & No & Ho & No & 122 206 \\
\hline $080-246-583$ & ND & HO & NO & HO & NO & No & No & No & NO & มо & No & प्र22 219 \\
\hline $080-24 G-584$ & No & No & HO & HO & HD & ND & אס & NO & ND & มо & ND & 1222 232 \\
\hline $080-24 G-535$ & - Ho & MO & HO & Ho & No & No & NO & NB & NO & No & HO & 122236 \\
\hline $643-11 G-581$ & No & HO & HO & NO & HO & No & NO. & ко & NO & No & No & 122246 \\
\hline $643-11 G-582$ & NO & HD & HO & No & พо & HO & No & Ho & No & No & No & 122258 \\
\hline $643-11 G-583$ & Ho & No & No & HD & HO & HO & No & No & HO & HO & so & 122271 \\
\hline $484-100-5 B 2$ & NO & NO & HO & HO & Ho & No & HD & HO & HO & wo & NO & 422367 \\
\hline $484-100-583$ & HO & HO & Ho & HO & KO & HO & KO & พ0 & HO & Ho & No & L22 380 \\
\hline $484-100-584$ & HO & No & KD & No & HO & HO & ND & no & No & so & ko & V22 394 \\
\hline 489-0-581 & No & HO & Ho & Ho & HO & HO & HO & No & No & No & ND & 12321 \\
\hline $489-0-582$ & 'No & HO & HO & Ho & Ho & HD & KO & Ho & KO & но & NO & 12334 \\
\hline 489-D-S83 & so & Ho & No & so & No & No & No & HD & No & so & HO & 42347 \\
\hline $289-F-581$ & No & No & HO & No & No & no & NO & Ho & No & Ho & No & प्र23 71 \\
\hline $289-F-582$ & MO & No & HO & Ho & No & so & ND & No & No & มо & so & Y23 84 \\
\hline $7-F-S B 3$ & NO & No & No & NO & No & HO & но & MD & พо & HO & HO & 42397 \\
\hline $89-x-581$ & Ho & No & Hо & so & Ho & HO & NO & NO & HD & มอ & No & 423115 \\
\hline $189-K-S 82$ & พ० & No & No & yo & no & No & No & No & 0.043 & ND & No & $423 \quad 127$ \\
\hline $189-x-583$ & NO & No & HD & ND & HD & ND & HD & Ho & No & No & HO & 423140 \\
\hline $904-111 G-5 B 1$ & Ho & ผо & No & .80 & ND & No & HD & HD & - NO & พ0 & No & 423153 \\
\hline $904-1116-582$ & มD & NO & MO & No & มо & NO & พ0 & HO & HO & Ho & No & 423166 \\
\hline
\end{tabular}

Tahto o 
SAVAMKAH RIVER SITE -...-

SOIL GAS SYSTEM BLANKS -- DATA DIRECTORIES O21 THRU D25 -.......- SOIL GAS COHCEHTRATIOHS (PPMV) .....

\begin{tabular}{|c|c|c|c|c|c|c|c|c|c|c|c|c|}
\hline $\begin{array}{l}\text { SAMPLE } \\
\text { WAME } \quad \cdot .\end{array}$ & PEUTAME & HEXAHE & HEPTANE & BENZEHE & OCTAHE T & TOLUENE & HONANE & $\begin{array}{r}\text { ETHYL } \\
\text { BEHZENE }\end{array}$ & $\begin{array}{r}\text { H\&P- } \\
\text { XYLENE }\end{array}$ & $\begin{array}{r}0- \\
\text { XYLENE }\end{array}$ & DECANE & $\begin{array}{l}\text { FILE } \\
\text { CYCLE }\end{array}$ \\
\hline $904-111 G-S B 3$ & HO & KO & HD & HO & HD & WD & ND & No & ND & No & HO & 1023179 \\
\hline $904-111 G-584$ & HO & HO & MD & NO & NO & No & HO & yo & HO & NO & Ho & U23 192 \\
\hline 289-H-S81: & KD & HO & No & NO & NO & wo & HO & KO & HO & NO & HO & 42485 \\
\hline $289-H-582$ & HOे & HO & YD & No & ND & YO & NO & No & NO & HO & Ho & W24 97 \\
\hline 289-H-583. & ND & NO & ND & HO & HO & No & Wo & אס & HO & NO & HD & प्र24 110 \\
\hline $231-4 F-5813$ & HO & No & NO & No & NO & HD & NO & No & HO & NO & HO & $124 \quad 176$ \\
\hline $231-4 F-5814$ & ND & SO & KD & ND & ND & No & HO & No & HO & NO & Ho & W24 188 \\
\hline $231-4 F-5815$ & พO & No & HO & No & HO & SD & NO & Ho & HO & HO & YD & W24 201 \\
\hline $231-4 F-5816$ & NO & YNO & No & ND & HO & MO & WD & No & HO & NO & NO & - प्र24 216 \\
\hline $231-48-5817$ & ND & ס א & NO & 0.053 & MO & No ${ }^{\circ}$ & No & No & HO & No & Ho & Y24 236 \\
\hline $231-6 F-5 B 18$ & No & YND & No & NO & No & No & No & NO & HO & NO & พס & W24 261 \\
\hline $231-4 F-5819$ & HO & 40 & 40 & NO & HO & พอ & No & No & No & Ho & No & प्र24 278 \\
\hline $231-4 F-5820$ & HO & No & NO & NO & No & No & NO & NO & No & ND & no & W24 287 \\
\hline HPSL-SB1 & NO & KD & No & No & No & no & NO & NO & HO & HD & NO & Y24 300 \\
\hline $131-1 L-S B 2$ & HO & No & WO & HO & HO & Ho & NO & NO & HD & No & HO & 424302 \\
\hline $131-1 L-S B 3$ & No & No & No & NO & wo & no & ND & No & HO & no & no & 424315 \\
\hline $131-1 L-S B 4$ & NO & No & No & Ko & No & HO & No & No & YO & KO & No & 424 328 \\
\hline $131-1 L-5 B 5$ & ND & HD & มูO & ND & No & ND & ND & No & Ho & NO & พo & 124351 \\
\hline $131-1 L-586$ & NO & HO & NO & ND & ND & No & ND & No & HO & ND & HO & W24 364 \\
\hline MAPL-SB1 & No & NO & HO & NO & NO & ND & HO & NO & HO & NO & HD & प124 368 \\
\hline HAPL-SE2 & NO & HO & No & NO & No & No & NO & NO & Ho & HO & HO & प्W24 382 \\
\hline MAPL-SB3 & ND & NO & NO & No & Ho & No & NO & No & NO & Ho & NO & 424395 \\
\hline UTRC-S83 & HD & ND & NO & ND & NO & HO & MD & ND & HO & Ho & No & प्र24 413 \\
\hline UTRC-SB4 & NO & Ho & HO & NO & HO & No & No & No & HO & no & Ho & $W 24 \quad 426$ \\
\hline UTRC-\$85 & NO & HO & No & YNo & HD & HO & No & No & Ho & HO & Ho & $124 \quad 439$ \\
\hline UTRC-SB6 & No & KO & NO & HO & Ho & NO & NO & No & Ho & NO & YD & प्र24 452 \\
\hline UTRC-SB7 & ND & NO & KD & NO & No & ผ0 & NO & NO & HD & NO & YO & W24 465 \\
\hline $189-9-581$ & No & No & HO & NO & no & HO & NO & No & HO & HO & Ho & प्र25 35 \\
\hline $189-8-582$ & NO & Ho & NO & NO & No & HD & HO & No & Wo & HD & ND & W25 $4 \dot{8}$ \\
\hline $189-P-583$ & Ho & NO & NO & No & No & ND & NO & No & WO & ND & HO & W25 61 \\
\hline $189-C-581$ & MD & HO & ND & HO & NO & No & no & KD & Hо & No & yo & W25 106 \\
\hline $189-c-582$ & Ho & no & HO & No & HO & NO & HO & No & но & HO & HO & प्र25 119 \\
\hline $189-c-583$ & NO & NO & NO & HD & No & ND & NO & NO & MO & HD & No & प्र25 132 \\
\hline $788-3 A-5 B 1$ & Yo & ND & NO & MO & YO & 0.084 & No & No & צूo & NO & พo & Y्र25 157 \\
\hline $788-3 A-582$ & HO & HO & Yo & YO & ผอ & KD & HD & HO & HO & HO & No & 125173 \\
\hline $788-3 A-583^{\circ}$ & No & ND & หo & HD & wo & ND & NO & Ho & HO & NO & No & W25 187 \\
\hline MS8-76-S81 & HO & KO & NO & ND & พD & NO & No & No & Ho & HO & HO & W2S 201 \\
\hline HSB-76-SB2 & HO & NO & ко & No & No & KO & NO & No & HO & HO & HO & प्र25 220 \\
\hline OHS-SBI & YO & HO & MD & Ho & но & NO & NO & No & HO & Ko & No & 125227 \\
\hline OHS-SB2 & NO & NO & No & NO & HO & KD & KO & KD & พั & SD & HO & U25 240 \\
\hline $131-4 L-583$ & HO & HO & HO & WD & ND & ND & NO & No & ND & HD & Ho & 125290 \\
\hline $131-4 L-584$ & HO & HO & HD & HO & No & NO & ผO & HO & סאו & Ho & Ho & 125297 \\
\hline $484-100-585$ & yo & No & Ho & Mo & No & HO & NO & NO & No & So & NO & $\lcm{25308}$ \\
\hline AVERAGE & 0.049 & 0.035 & 0.026 & 0.032 & 0.023 & 0.029 & 0.021 & 0.024 & 0.026 & 0.024 & 0.020 & \\
\hline STO OEV & 0.006 & 0.017 & 0.000 & 0.002 & 0.000. & 0.006 & 0.000 & 0.001 . & 0.009 & 0.005 & 0.000 & \\
\hline AVG+2STD DEV & 0.052 & 0.068 & 0.026 & 0.037 & 0.023 & 0.040 & 0.021 & 0.026 & 0.044 & 0.034 & 0.021 & \\
\hline
\end{tabular}


SAVAHHAH RIVER SITE -..--

SOIL GAS SYSTEH BLAMKS -- DATA DIRECTORIES D21 THRU D25 -.... ..... SOIL GAS COHCEHTRATIONS (PPHY) -....

\begin{tabular}{|c|c|c|c|c|c|c|c|c|c|}
\hline $\begin{array}{l}\text { SAMPLE } \\
\text { HAME }\end{array}$ & $\begin{array}{r}\text { VIHYL } \\
\text { CHLORIOE }\end{array}$ & $\begin{array}{l}\text { HETHYLEHE } \\
\text { CHLORIOE }\end{array}$ & $\begin{array}{r}\text { TRAHS } 1,2 \\
\text { DICHLORO } \\
\text { ETHYLEHE }\end{array}$ & $\begin{array}{l}\text { CHLORO } \\
\cdot \text { FORH }\end{array}$ & $\begin{array}{l}111 \text { TRI } \\
\text { CHLORO } \\
\text { ETHAHE }\end{array}$ & $\begin{array}{r}\text { CARBOH } \\
\text { TETRA } \\
\text { CHLORIOE }\end{array}$ & $\begin{array}{r}\text { TRI } \\
\text { CHLORO } \\
\text { ETHYLEHE }\end{array}$ & $\begin{array}{r}\text { TETRA } \\
\text { CHLORO } \\
\text { ETHYLENE }\end{array}$ & $\begin{array}{l}\text { FILE } \\
\text { CYCLE }\end{array}$ \\
\hline $831-40-581$ & Ho & MD & HO & HO & NO & Ho & KO & Ho & W21 41 \\
\hline $631-4 G-582$ & HD & NO & HO & HD & NO & HO & HO & HO & W21 54 \\
\hline $731-5 A-581$ & HO & ND & 0.012 & HO & KO & No & HO & No & 12185 \\
\hline $731-5 A-5 B 2$ & No & No & HO & Wo & NO & so & 0.00100 & 0.01400 & प्र2198 \\
\hline $731-5 A-5 B 3$ & Ho & Ho & HO & HD & HO & HO & HD & 0.01000 & H21 111 \\
\hline $731-5 A-584$ & HO & HO & HD & ND & NO & HO & 0.00100 & 0.01700 & H21 124 \\
\hline $731-5 A-585$ & 1.2 & .0 .45 & 0.088 & 0.00100 & HO & 0.00100 & 0.24700 & 0.00500 & W21 137 \\
\hline $484-100-5 B 1$ & 0.7 & No & No & HO & HO & HD & 0.01000 & 0.00500 & प्र21 149 \\
\hline $731-5 A-586$ & HO & HO & HD & HO & HO & KD & HD & HO & H21 192 \\
\hline $731-5 A-587$ & 0.3 & HO & NO & Ho & HO & YO & HD & HO & H21 200. \\
\hline $731-5 A-588$ & 0.2 & NO & no & No & NO & Ho & Ho & NO & H21 217 \\
\hline $731-5 A-539$ & 0.2 & No & หo & . NO & NO & ND & NO & 0.00400 & 1421 230 \\
\hline $731-5 A-5810$ & 0.2 & ND & No & Ho & No & MO & HO & 0.00100 & प्र21 243 \\
\hline $731-5 A-5811$ & 0.2 & HO & HO & NO & MO & No & 0.00100 & 0.00900 & W21 256 \\
\hline $731-5 A-5812$ & 0.1 & NO & Ho & พอ & HO & No & $0.00200^{\circ}$ & 0.01200 & 42? 269 \\
\hline $731-5 A-5813$ & 0.2 & NO & Ho & NO & 0.00100 & HO & HO & NO & 42218 \\
\hline $731-5 A-5814$ & 0.3 & No & Ho & No & No & Ho & so & 0.00100 & H22 27 \\
\hline $731-5 A-5815$ & 0.2 & NO & 0.005 & ผо & ND & HO & HO & HO & 42240 \\
\hline $71-5 A-5816$ & Ho & HO & 0.006 & No & HO & NO & x๐o & HO & 142253 \\
\hline$-5 A-5817$ & NO & HO & 0.007 & HO & HO & HD & MO & NO & 42266 \\
\hline . $21-5 A-5818$ & 0.4 & HO & HO & ND & HO & ND & Ko & ND - & 4:2279 \\
\hline $731-5 A-5319$ & 0.2 & No & 0.007 & No & HO & ND & no & HO & 12292 \\
\hline $731-5 A-5820$ & 0.3 & NO & 0.011 & NO & 0.00100 & MD & HD & HO & Y22 100 \\
\hline $731-5 A-5821$ & 0.4 & No & HO & NO & No & HO & 0.00300 & 0.00100 & N22 107 \\
\hline $731-5 A-5822$ & HO & NO & Nס & NO & No & HO & 0.10100 & 0.00100 & W22 120 \\
\hline $731-5 A-5823$ & มо & NO & No & HO & No & но & 0.01400 & HO & 422133 \\
\hline $731-5 A-S B 24$ & 0.2 & HO & No & NO & 4ס & No & 0.01400 & 0.00100 & 122146 \\
\hline $731-5 A-5825$ & no & NO & NO & 0.00100 & So & 0.00100 & 0.20200 & 0.00200 & W22 159 \\
\hline $731-5 A-5826$. & 0.1 & NO & 0.009 & NO & ND & Ho & 0.00800 & หอ & 422 172 \\
\hline $731-5 A-5827$ & พо & HO & NO & Ho & HO & มо & HO & HO & 122243 \\
\hline $080-24 G-S B 1$ & HO & HO & KO & HO & NO & HO & No & HO & W22 193 \\
\hline $080-24 G-582$ & 0.2 & Ho & Ho & Ho & No & HD & wo & ND & प्र22 206 \\
\hline $080-24 G-S 83$ & มо & HO & KD & No & No & no & YO & אט & 122219 \\
\hline $080-24 G-584$ & Ho & HO & HO & WO & NO & HO & HO & HO & W22 232 \\
\hline $080-24 G-S 85$ & SO & HO & No & HO & NO & HO & 4о & Ho & 522236 \\
\hline $643-11 G-581$ & No & HO & NO & HO & No & มо & HO & No & प्र22 246 \\
\hline $643-11 G=582$ & HO & HO & No & Ho & No & Ho & หo & HO & 122258 \\
\hline $643-11 G-583$ & 0.1 & HO & HO & HO & NO & No & พ0 & NO & प्र22 271 \\
\hline $484-100-582$ & HO & HO & NO & HO & HO & Ho & HO & HO & W22 367 \\
\hline $484-100-583$ & NO & no & No & No & HO & No & so & NO & W22 380 \\
\hline $484-100-584$ & HO & NO & No & NO & 0.00700 & но & HO & 0.00400 & 122394 \\
\hline $489-0-581$ & Ho & HO & MO & HO & NO & но & 0.00100 & 0.00100 & 12321 \\
\hline $489-0-582$ & No & No & HO & KO & HO & NO & ko & NO & 42334 \\
\hline $489-0-\$ 83$ & Ho & No & HO & No & Ko & Ho & HO & Ho & 12347 \\
\hline $289-F-581$ & No & Ho & Ho & Ho & HD & No & no & KD & 12371 \\
\hline $289-8-582$ & HO & No & NO & HO & Ho & \&o & so & Ho & 152384 \\
\hline$P-8-S B 3$ & No & so & HO & NO & NO & พO & HD & NO & प्र23 97 \\
\hline $3-x-581$ & HO & Ho & NO & No & no & Ho & มо & No & $123 \quad 115$ \\
\hline $189-k-582$ & HO & Ho & No & NO & HO & No & no & HO & प्र23 127 \\
\hline $189-K \cdot S 83$ & MO & NO & No & Ho & No & no & Ho & HO & 123140 \\
\hline $904-111 G-581$ & - HO & HO & HO & HO & Ho & Ho & - HO & KO & 423153 \\
\hline $904-1116-582$ & - HO & HO & ino & ND & NO & Ho & no & HO & 623166 \\
\hline
\end{tabular}

Table 10. System Blanks (ECD) for Data Directories "D21 $\div$ D25" 
SAVAHHAH RIVER SITE -...-

-..-- SOIL GAS SYSTEH BLAKKS -- DATA DIRECTORIES O21 IHRU 025 -.......- SOIL GAS COHCENTRATIOHS (PPHV) -....

\begin{tabular}{|c|c|c|c|c|c|c|c|c|c|}
\hline $\begin{array}{l}\text { SAMPLE } \\
\text { HAME }\end{array}$ & $\begin{array}{r}\text { VIHYL } \\
\text { CHLORIDE }\end{array}$ & $\begin{array}{l}\text { METHYLENE } \\
\text { CHLORIDE }\end{array}$ & $\begin{array}{r}\text { TRAHS } 1,2 \\
\text { DICHLORO } \\
\text { ETHYLENE }\end{array}$ & $\begin{array}{r}\text { CHLORO } \\
\text { FORH }\end{array}$ & $\begin{array}{r}111 \text { TRI } \\
\text { CHLORO } \\
\text { ETHANE }\end{array}$ & $\begin{array}{r}\text { CARBON } \\
\text { TETRA } \\
\text { CHLORIDE }\end{array}$ & $\begin{array}{r}\text { TRI } \\
\text { CHLORO } \\
\text { ETHYLENE }\end{array}$ & $\begin{array}{r}\text { TETRA } \\
\text { CHLORO } \\
\text { ETHYLENE }\end{array}$ & $\begin{array}{l}\text { FILE } \\
\text { CYCLE }\end{array}$ \\
\hline $904-111 G-583$ & NO & ND & No & No & NO & No & ND & HO & 423179 \\
\hline $904-1116-584$ & NO & ND & MO & No & HO & NO & NO & HO & H23 192 \\
\hline $289-8-581$ & Ho & KO & MO & HO & NO & No & ND & KD & 12485 \\
\hline $289-H-582$ & 0.2 & No & WO & HO & 0.00100 & HO & NO & NO & 12497 \\
\hline $289-H-583$ & 0.1 & ND & NO & พo & HO & WD & HO & NO & $W 24110$ \\
\hline $231-4 F-5813$ & No & HD & 0.011 & ND & 0.00100 & HO & NO & 0.00500 & 124176 \\
\hline $231-4 F-5814$ & 0.2 & No & 0.012 & NO & KD & ND & NO & 0.00100 & 124188 \\
\hline $231-4 F-5 B 15$ & 0.2 & ND & 0.013 & 0.00400 & HO & ND & WD & ND & Y्र24 201 \\
\hline $231-4 F-5816$ & 0.1 & NO & 0.016 & WO & 0.00100 & NO & No & 0.00100 & 124214 \\
\hline $231-48-5817$ & 0.1 & ND & 0.015 & ND & KD & No & No & 0.00100 & 424236 \\
\hline $231-6 F-5818$ & 0.1 & ND & 0.010 & ND & 0.00100 & NO & NO & 0.00100 & 124261 \\
\hline $231-45-5819$ & 0.3 & - NO & 0.015 & Ho & 0.00100 & พO & NO & HO & 124278 \\
\hline $231-4 F-5820$ & 0.2 & HO & 0.014 & No & No & No & No & HO & W24 287 \\
\hline HPSL-SBI & 0.2 & No & 0.014 & HO & 0.00200 & No & WO & 0.00100 & W24 300 \\
\hline $131-1 L-582$ & 0.2 & HO & 0.008 & Ho & 0.00100 & MO & ND & Ho & 424302 \\
\hline $131-1 L-583$ & HO & HO & ND & No & HO & No & MO & HO & W24 315 \\
\hline $131-1 L-584$ & 0.1 & HD & 0.010 & NO & HD & WD & NO & No & W24 328 \\
\hline $131-1 L-585$ & 0.2 & HD & 0.012 & Ho & No & NO & NO & ND & W24 351 \\
\hline $131-1 L-586$ & 0.3 & Ho & 0.025 & No & 0.00100 & No & No & NO & 104364 \\
\hline MAPL-SB1 & 0.2 & No & 0.011 & ND & 0.00100 & No & ND & Ho & 124368 \\
\hline KAPL-SBZ & 0.4 & No & .0 .016 & Ho & 0.00100 & HO & No & HO & W24 382 \\
\hline MAPL-SB3 & 0.2 & No & 0.012 & NO & 0.00100 & No & NO & 0.25500 & 424395 \\
\hline UTRC-SB3 & HO & Mo & 0.009 & No & HO & NO & No & No & 124413 \\
\hline UTRC-SB4 & 0.1 & Ho & 0.009 & No & Ho & No & No & NO & 124426 \\
\hline UTRC-SBS & 0.1 & NO & 0.008 & No & NO & ND & NO & Ho & $124 \quad 439$ \\
\hline UTRC-\$86 & 0.2 & No & 0.015 & No & ND & No & No & HO & tיW24 452 \\
\hline UTRC-537 & 0.3 & 0.36 & 0.030 & NO & No & NO & NO & NO & W24 465 \\
\hline $189-p-581$ & 0.0 & No & 0.009 & ND & 0.00100 & No & HO & HO & 12535 \\
\hline $189-p-582$ & 0.0 & No & 0.010 & No & 0.00100 & NO & No & No & W2S 48 \\
\hline $189-9-583$ & 0.0 & HO & 0.011 & Ho & 0.00100 & NO & HO & NO & W25 61 \\
\hline $189-c-581$ & 0.0 & ND & 0.015 & HO & 0.00300 & HO & ND & HD & W25 106 \\
\hline $189-C-582$ & 0.0 & MQD & 0.009 & HO & HO & No & NO & No & प्र25 119 \\
\hline $189-c-583$ & 0.0 & No & 0.009 & Ho & No & No & HO & NO & W25 132 \\
\hline $788-3 A-581$ & 0.0 & HO & 0.016 & - HD & 0.00100 & HO & HO & No & W25 157 \\
\hline $788-3 A-582$ & 0.0 & No & 0.009 & HO & Ko & HO & NO & NO & W25 173 \\
\hline $788-3 A-583$ & 0.0 & NO & 0.007 & HO & HO & No & KD & KD & W25 187 \\
\hline HS8-76-581 & 0.0 & ND & 0.012 & HO & No & NO & HO & No & W25 201 \\
\hline HS8-76-SB2 & 0.0 & NO & 0.018 & KD & 0.00100 & No & ND & NO & W2S 220 \\
\hline OHS-SBI & 0.0 & ND & 0.018 & NO & 0.00100 & NO & No & ND & प्र25 227 \\
\hline OHS-S82 & 0.0 & NO & 0.027 & HO & 0.00300 & No & HO & KD & 25240 \\
\hline $131-4 l-583$ & Ho & No & HO & HO & 0.00100 & HO & no & Ho & Y25 290 \\
\hline $131-4 L-584$ & 0.0 & No & No & NO & 0.00100 & NO & no & HO & W25 297 \\
\hline $484-900-585$ & HO & No & NO & HO & 0.00100 & HO & HO & HO & 125308 \\
\hline AVERAGE & 0.1 & 0.04 & 0.012 & 0.00025 & 0.00112 & 0.00006 & 0.00650 & 0.00375 & \\
\hline STO DEV & 0.2 & 0.05 & 0.008 & 0.00040 & 0.00068 & 0.00014 & 0.03381 & 0.02608 & \\
\hline AVG+2STD DEV & 0.5 & 0.15 & 0.030 & 0.00106 & 0.00247 & 0.00034 & $0.0741 i$ & 0.05591 & \\
\hline
\end{tabular}


APPENDIX I

SAMPIING METHODS 
SAMPIING METHOD SMI

SOIL GAS PROBE SAKIPIING

i. 0 Scope and Application

1.1 Soil gas probe samples are collected with Microseeps unique, portable soil gas sampling probe which permits access to any area. In addition, the probe allows unlimited purging between sample sites and incorporates the capability to discard the volume of air in the sample probe before the soil gas sample at each site is taken.

\subsection{Apparatus}

2. I Soil Gas Probe: The soil gas probe consists of a $1 / 2$ inch diameter steel tube equipped with a rubber packer and a $1 / 8$ " $0 . d$. ss sample tube inserted concentrically to the bottom of the $1 / 2$ " diameter tube to minimize dead space in the sample volume. The $1 / 8 " 0 . d$. sample tube is connected through a three way valve to a $250 \mathrm{cc}$ gas tight syringe mounted as an integral part of the sample probe. The third port of the three-way valve is terminated with a syringe needle and serves two functions: first a small amount of gas equal to or larger than the dead space volume of the $1 / 8$ " $0 . d$. sample tube is discarded through this port before each soil gas sample is taken; second, the syringe needle serves to facilitate transfer of the soil gas sample through a rubber septum into a previously evacuated sample vial, minimizing the possibility of contamination of any sample.

2.2 Slide Hammer Plunger Bar: The slide hammer plunger bar contains a 5.5 ft. $x .5$ in rod with a $9 / 16$ inch ball. Fitted over one end of the rod is a weighted slide hammer. (Heath consultants caて 478$)$.

2.3 Sample vials: The sample vials used are determined by the analytical method that is required for analysis. All vials should be free of interferences and meet the specifications described in the analytical method to be used.

\subsection{Procedure}

3.1 Prior to any sampling, the soil gas sampling probe should be purged clean of interferences, the syringe needle should be removed, and the three way valve should be in the stop flow
position. 
3.2 A 9/16 inch diameter hole is created to the desired depth using the slide hammer plunger bar.

3.3 The plunger bar is removed and the sample probe is inserted into the hole. A seal should be obtained to prevent ambient air from entering the hole when the soil gas sample is removed. position.

3.4 The three way valve is turned to the probe/syringe

3.5 A $10 \mathrm{cc}$ volume of gas is drawn into the syringe.

3.6 The three way valve is turned to the syringe/needle position (needle removed as described in section 3.1 ) and the $10 \mathrm{cc}$ sample is discarded.

3.7 The three way valve is turned to the probe/syringe position and the appropriate amount of soil gas is drawn into the syringe.

3.8 The three. way valve is turned to the stop flow position

3.9 The needle is attached to the probe needle fitting.

3.10 An evacuated sample vial is attached by inserting the sample vial septum onto the needle.

3.11 The three way valve is turned to the syringe/needle position. The volume of the evacuated vial will be drawn into the sample vial. Additional volume (positive pressure) can then be added by depressing the plunger and displacing the remaining volume in the syringe.

3.12 The sample vial should be quickly removed once desired volume is displaced.

$3.13 \mathrm{~A}$ volume of approximately $50 \mathrm{cc}$ of ambient air should be drawn back through the needle.

3.14 Remove the needle.

3.15 Remove the sample probe from the hole.

3.16 Purge the sample probe clean of interferences by filling and exhausting the syringe five times before taking the next sample: 


\subsection{Sample Documentation}

4.1 All samples should be labeled immediately after collection with the following information:

1. Site number

2. Daily sequence number

3. Date and time

4. Samplers initials

5. Project

4.2 All samples taken in the field by Microseeps, Ita. should be entered onto a Field Iog sheet. For each sample, the following entries will be made:

1. Site number

2. Daily sequence number

3. Date and time

4. Samplers initials

5. Project

6. Iocation

7. Sample description

8. Miscellaneous comments

4.3 When appropriate, samples will be security sealed and chain of custody records will be maintained.

\subsection{Safety Precautions}

5.1 Do not use a mechanical device to depress the sampling syringe plunger:

5.2 Do not attempt to collect soil gas probe samples without prior knowledge of the location of underground utilities and other possible environmental hazaras.

5.3 Always cap or remove the soil gas probe syringe needle when transporting or handiing the soil gas probe.

\subsection{Preventive Maintenance}

6.0 The soil gas sample probe should be cleaned when necessary or at the end of each day with soap and organic free water. It is especially important to keep the gas sampling syringe clean from fine soil particles as the particles will quickly deteriorate the teflon/glass plunger seal.

6.1 The glass wool filter plug (located in the probe tip) should be changed often and the probe tip should be kept clear of
soil. 
APPENDIX.I

ANALYTICAT METHODS 
ANALYTICAL METHOD AM1

ANAIYSIS OF $\mathrm{C}_{1}-\mathrm{C}_{4}$ HYDROCARBONS, HYDROGEN, HELIUM, IN SOIL GAS

\subsection{Scope and Application}

I.I Method AMI is used to determine the concentration of $C_{1}-C_{4}$ hydrocarbons, helium and hydrogen in soil gas samples. Specifically, Method AMI may be used to detect the following substances:

methane

ethane

ethylene

propane

propylene

i-butane

n-butane

helium

hydrogen

1.2 This method is recommended for use by, or under the supervision of, analysts experienced in the operation of gas chromatographs and in

the interpretation of chromatograms.

\subsection{Summary of Method}

2.1 Analysis of the above constituents of free soil gas is accomplished with a custom chromatograph, built by Microseeps. The custom, dual detector gas chromatograph provides a seguential output from two detectors. First, the $c_{1}-C_{4}$ hydrocarbons are detected with a flame ionization detector (FID), next helium and hydrogen are detected with a thermal conductivity detector (TCD). The sample (and standard calibration gas) is flowed through the gas chromatograph and introduced into the columns by the mechanical injection of two sample loops.

\subsection{Interferences}

3.1 Contamination by carryover can occur whenever high-level and low-level samples are sequentially analyzed. A non-restricted flow of pure nitrogen from a $10 \mathrm{psig}$ source should be purged for 30 seconds through the sample loops prior to all analyses.

3.2 The analyst should demonstrate the absence of contamination by carryover by analysis of the contents of the sample loops when purged with nitrogen. This demonstration should be performed prior to the 
analysis of a sample set and when carryover contamination is suspected (after high samples). In the event that 'ghost peaks' (peaks similar to previous sample) appear when a pure nitrogen sample is analyzed, measures should be taken to eliminate the carryover contamination.

3.3 Extra peaks in a chromatogram can be actual peaks from a previous run. Contamination from late eluting peaks can occur when injection to injection time is too short. The dual gas chromatograph is set up in the backflush pre-column valve arrangement to minimize this interference.

3.4 The analyst should be certain that all peaks have eluted from the previous analysis prior to analyzing any sample or standard. If samples or standard chromatograms contain suspected 'extra 'peaks' the sample should again be analyzed after a clean baseline is established.

\subsection{Apparatus and Materials}

4.1 Sample vials: $125 \mathrm{ml}$ glass vials (Wheaton equivalent). Vials should be free of hydrocarbons, helium, and hydrogen prior to use. This can be accomplished by heating to 100 degrees $C$ followed by purging with pure nitrogen.

4.2 Septums: Butyl rubber septums (Wheaton \#224154 or equivalent) may be used provided vials are capped within two weeks prior to use. other septums may be used, provided they are gas tight and do not produce interferences.

. 4.3 Gas Chromatograph: The chromatograph is equipped with two sets of the following: column oven, pre-column, analytical column, detector, injection port, sample valve and sample loop. The colum and detector for determination of $c_{1}-c_{4}$ hydrocarbons are a granular 3 ft. $x 3 / 16$. in. alumina analytical column and a flame ionization detector. The alumina column is protected against contamination by heavy organics by a 3 in. $x 3 / 16$ in. pre-column which is back-flushed after butanes have entered the analytical colum. This arrangement allows rapid turn-around for consecutive analyses and a clean baseline for accurate, reproducible results. The flame ionization detector is of a special design which allows considerably more sensitivity than commercialiy available models. In a laboratory setting, noise levels are comonly at the 500 ppt level. Although, these sensitivities are rarely realized in the field, 1 to 2 $\mathrm{ppb}$ is achievable and $5 \mathrm{ppb}$ is routine. Hydrogen and helium, are simultaneously determined using a 3 ft. $x 3 / 16$ in. molecular sieve 5A (80/100 mesh) pre-column and 10 ft. $x 3 / 16$ in. analytical column connected to a thermal conductivity detector. Injection times and the signal output are sequenced so that the output of the two detectors is displayed in a single continuous chromatogram.

4.4 Data Collection: The output of the chromatograph is directed to a chart recorder and a Hewlett Packard (HP-3392A) Networking Integrator 
which passes the processed data to a microcomputer for data storage and/or further processing.

5.0 Sample preparation and Analysis

5.1 Sample vial preparation: All sample vials should meet specifications as noted in sections 4.1 and 4.2 above. Vials should be tightly capped and evacuated to a pressure of less than 100 millitorr. The vial septum should be punctured with needles of 22 gauge or smaller.

5.2. The evacuated sample vials should be filled with sample gas to a pressure of 9 psig. A positive pressure capable of delivering at least $25^{\circ} \mathrm{Cc}$ of sample must be available per each injection.

5.3 The pressurized sample vial is connected to the sample loops through a needle fitting and flow control valve. The flow is monitored by a flow meter connected to the out port on the gas chromatograph.

5.4 After the appropriate volume of sample (minimum $25 \mathrm{cc}$ ) has been flushed through the sample loops of the gas chromatograph, the injection valves may be activated. This is accomplished by switching on the cycle timer.

\subsection{Calibration}

6. I The standard calibration gas should be introduced in the same manner as described in section 5.4 above. Measured peak areas are converted to concentrations in parts per miliion by volume using certified comercial gas standards traceable to NBs standards. (Matheson Gas Products Inc., or Scott Specialty Gases). The sample concentrations are calculated from calibration points near the concentration level of the sample.

6.2 - At the beginning of a project or sample.set, standards of appropriate calibration ranges wili be run at least three times or until the results agree with a percent standard deviation no greater than $10 \%$.

6.3 The instrument response (for any one subsequent standard in section 6.5 above) must not vary by more than $20 \%$; or any two consecutive standards must not vary by more than $15 \%$ from the mean of the three previous standards. 


\subsection{Quality Control}

7.1 If the parameters set forth in section 6.3 are not met, the analytical program will be terminated until the cause is determined and a solution is effected. The cause and the solution will be recorded in the Laboratory Notebook and signed by the operater, before the analytical program is resumed.

7.2 Before and during sample analysis, instrument blanks (sample loops filled with flush nitrogen) should be analyzed to assure the absence of interferences as described in section 3.0 above.

7.3 Standards analyzed during the course of analyzing samples are averaged into the calibration table as well as being used for. peak identification. All chromatograms should be examined by an experienced analyst.

7.4 . Throughout analysis the soil gas samples are injected mechanically to achieve a uniform sample size from a flow directly from the soil gas sample vial which has been pressured at the time of sampling. This pressuring preserves sample integrity since any leakage is out of the vial and does not result in contamination or sample
ution.

7.5 Calibration records are generated and stored. All such records will be maintained in the laboratory during the course of the project.

\subsection{Instrument conditions}

8.1 Gas Chromatograph:

Injection Temp. ambient

Flame Ionization Detector Temp. ambient

Thermal Conductivity Detector Temp. $45 \mathrm{deg} . \mathrm{c}$.

C1-C4 Oven Temp. $100 \mathrm{deg}$. C. isothermal

Helium/Hydrogen Oven Temp. $45 \mathrm{deg}$. C. isothermal

Initial T.C.D. Signal Range 10

Initial F.I.D. Signal Range l0E9

Carrier Gas Regulator Pressures:

T.C.D. 40 psig.

F.I.D. 17 psig.

Hydrogen Pressure 22 psig.

- Flame Air Pressure 30 psig. (1.0 scfh). 
ANALYTICAL METHOD AM4

ANALYSIS OF VOIATILE ORGANIC COMPOUNDS IN SOIL GAS

\subsection{Scope and Application}

:.1 Method AM4 is used to determine the concentration of volatile organic compounds in soil gas samples. Specifically, Method AM4 may be used to detect the volatile organics including but not limited to the following compounds:

pentane
hexane
heptane
octane
nonane
methane
vinyl chloride
$1,1-d i c h l o r o e t h y l e n e$
methylene chloride
$1,1-$ dichloroethane
$1,2-$ dichloroethane
trans 1,2-dichloroethylene
chloroform
$1,1,1-$ trichloroethane
carbon tetrachloride
trichloroethylene
tetrachloroethylene
1,1,2,2-tetrachloroethane
$1,3-d i c h l o r o b e n z e n e$

\author{
benzene \\ toluene \\ m \& p-xylene \\ o-xylene \\ ethyl benzene \\ chloromethane. \\ bromomethane \\ chloroethane \\ fluorotrichloromethane \\ 1,2-dichloropropane \\ bromodichloromethane \\ cis 1,3-dichloropropylene \\ trans 1,3-dichloropropylene \\ $1,1,2$-trichloroethane \\ chlorodibromomethane \\ chlorobenzene \\ bromoform \\ 1,2-dichlorobenzene \\ I,4-dichlorobenzene
}

1.2 This method is recommended for use by, or under the supervision of, analysts experienced in the operation of a gas chromatograph and in the interpretation of a chromatogram.

\subsection{Summary of Method}

$\because$ The volatile organic compounds are analyzed using a Hewlett Packard Model 5890A Gas Chromatograph in conjunction with a Hewlett Packard Model 19395A Automated Headspace Sampler and an H.P. 3396A Networking Integrator. A Supelco, $60 \mathrm{M} \times 0.75 \mathrm{~mm}$ i.d. Vocol, wide bore capillary column is used in conjunction with an output splitter connected to an electron capture detector and a flame ionization detector. The integrator is interfaced to an IBM microcomputer for data storage and processing. Data transfer and analyses are facilitated using a chromatography data system (Chrom Perfect, Justice Innovations). 


\subsection{Interferences}

3.1 Contamination by carryover can occur whenever high-level and low-level samples are sequentially analyzed. . While in the standby mode, the HP $19395 \mathrm{~A}$ provides continuous flushing of the sample loop and sample valve between sample analyses. This flush flow should be maintained and the sample valve and loop should be kept heated.

3.2 The analyst should demonstrate the absence of carryover contamination by analysis of the contents of the sample loop when purged with pure nitrogen. This demonstration should be performed prior to the analysis of a sample set and when carryover contamination is suspected (after high samples). In the event that 'ghost peaks' (peaks similar to previous sample) appear when a 'pure nitrogen sample is analyzed measures should be taken to eliminate the carryover contamination.

3.3 Extra peaks in a chromatogram can be actual peaks from a previous run. Contamination from compounds eluting late in the chromatogram can occur when injection to injection time is too short. The HP 5890A is equipped with a temperature programmable oven which can be utilized to minimize this interference.

3.4 The analyst should be certain that all peaks have eluted from the previous analysis prior to analyzing any sample or standard. This can be accomplished by elevating the oven temperature after an analysis until such time that a clean stable baseline is obtained. If samples or standard chromatograms contain suspected 'extra peaks' the sample should be reanalyzed after a clean baseline is established.

\subsection{Materials and Equipment}

4.I Sample vials: $22 \mathrm{ml}$ glass vials (Hewlett Packard \#93010716 or equivalent). Vials should be free of chlorinated hyarocarbons prior to use. This can be accomplished by washing and rinsing with hyorocarbon free water then heating to 100 degrees $C$ for 1 hour followed by purging with pure nitrogen.

4.2 Septums: Teflon lined septums (Wheaton equivalent) may be used provided vials are capped within two weeks prior to use. Other septums may be used provided they are gas tight and do not produce interferences.

4.3 Gas Chromatograph: The Hewlett Packard 5890A Gas Chromatograph is equipped with a supelco, $60 \mathrm{M} \times 0.75 \mathrm{~mm}$ i.d. Vocol, wide bore capillary colum connected to an electron capture detector and flame ionization detector. 
4.4 Headspace Sampler: A Hewlett Packard Model 19395A Automated Headspace Sampler is used which contains a heated bath with 24 slots for headspace vials, a heated sample valve, a heated sample loop and a heated transfer line to facilitate transfer of the sample onto the column in the gas chromatograph.

4.5 Data collection: The output of the chromatograph is directed to a chart recorder and a Hewlett Packard (HP-3396A) Networking Integrator which passes the processed data to a microcomputer for data storage and/or further processing.

\subsection{Sample Preparation and Analysis}

5.1 Sample vial preparation: AII sample vials should meet specifications as noted in sections 4.1 and 4.2 above. Vials should be tightly capped and evacuated to a pressure of less than 100 millitorr. The vial septum should be punctured only with needles of 22 gauge or smaller.

5.2 The evacuated sample vials should be filled with sample or standard gas to a positive gauge pressure. Sample vials should be used (filled with sample) within two weeks of preparation.

5.3 The 22 cc sample vials are placed directly into the heated headspace sampling unit for a minimum of 90 minutes prior to injection.

5.4 The headspace sampling unit is programmed to mechanically puncture the septum, transfer the sample to the heated sample loop, and mechanically inject the sample into the column flow stream via the heated transfer line.

\section{0 standards and Calibrations}

6.1 Gas standards or Iiquid standards may by used to achieve calibrations. In some-situations it may be necessary to use both types of. standards. Certified commercial gas standards are most desirable, but may not always be available for all the compounds or for the concentration levels of the compounds of interest.

6.2 Commercial gas standards are introduced by filling a $22 \mathrm{ml}$ headspace vial with standard gas. The gas standards are placed in the vials and analyzed in the same manner as samples (as described in section 5.0 ). The concentrations are those certified by the manufacturer.

6.3 Iiquid standard solutions are injected directly into a capped.vial and allowed to vaporize. These standards are produced from high purity compounds as described in standard Preparation Method SP1. The liquid standard solutions are placed in vials that meet specifications described in sections 4.1 and 4.2 . The vials 
used must be capped and be at atmospheric pressure when the liquid standard is injected. The vial is then analyzed in the same manner as a sample as described in section 5.3 .

6.4 At the beginning of a project or sample set, standards of appropriate calibration ranges will be run at least three times or until the results agree with a percent standard deviation no greater than $10 \%$.

6.5 Thereafter, at least one standard will be run for every 10 samples.

6.6 The instrument response (for any one subsequent standard in section 6.5 above) must not vary by more than $20 \%$; or any two consecutive standards must not vary by more than $15 \%$ from the mean of the three previous standards.

\subsection{Quality control}

7.1 If the parameters set forth in section 6.6 are not met the analytical program will be terminated until the cause is determined and a solution is effected. The cause and the solution will be recorded in the Laboratory Notebook and signed by the operator, before the analytical program is resumed.

7.2 Before and during sample analysis, instrument blanks (sample loops filled with flush nitrogen) should be analyzed to assure the absence of interferences as described in section 3.0 above.

7.3 Prior to the analysis of a sample set, multiple standards, at different concentration levels, should be analyzed to establish an initial calibration table. During sample analysis, standards should be run at a rate of 1 for each 10 samples.

7.4 Standards analyzed during the course of analyzing samples are compared to the calibration table as well as being used for peak identification. All chromatograms should be examined by an experienced analyst.

7.5 The soil gas sample vial is pressurized at the time of sampling. This pressure preserves sample integrity since any leakage is out of the vial and does not result in contamination or sample dilution.

7.6 The headspace sampling unit contains a heated bath as well as a heated sampling loop and transfer line. The latter two zones are continually flushed with nitrogen between sample analyses to minimize the chance of instrumental carry over. This nitrogen in the sample loop is injected periodically to check for instrument contamination. 
7.7 Once the headspace vials are punctured in the headspace unit, the sample loop is allowed to equilibrate to atmospheric pressure just prior to injection (see section 8.2 , vent time). This insures that an accurate, equal volume will be injected each time. Each vial is analyzed one time only.

7.8 Calibration records are generated and stored in the computer. All such records will be maintained in the laboratory during the course of the project.

\subsection{Instrument Conditions}

8.1. Gas Chromatograph:

Injection Temp. 220 deg. C.

Flame Ionization Detector Temp. 220 deg. $C$.

Electron Capture Detector Temp. 375 deg. C.

Oven Temp. program:

Initial temp. $30 \mathrm{deg} . \mathrm{c}$.

Hold 10 min.

Rate 4 deg. min. to $110 \mathrm{deg} . \mathrm{c}$.

Hold .01 min.

Rate $20 \mathrm{deg}$. min. to $200 \mathrm{deg}$. C. .

Hold 15 min.

Equilibration Time 1 min.

Initial E.C.D. Signal Range 5

Initial F.I.D. Signal Range 4

Carrier Flow Rates: (output of column split)

Packed Injection Port $2 \mathrm{cc} / \mathrm{min}$.

Head Space Sampler $10 \mathrm{cc} / \mathrm{min}$.

Make up gas to E.C.D. $76 \mathrm{cc} / \mathrm{min}$.

Make up gas to F.I.D. $34 \mathrm{cc} / \mathrm{min}$.

Total column $12 \mathrm{cc} / \mathrm{min}$.

Hydrogen Pressure 22 psig.

Flame Air Pressure 30 psig.

8.2 Headspacẻ Sampler: .

Bath Temp. 75 deg. C.

Valve/Loop Temp. $140 \mathrm{deg}$. C.

Headspace Method 1

Equilibration time 0 min.

Sampling interval $90 \mathrm{~min}$ (remote)

Valve Timing:

Probe down I sec.

Vent/fill loop $3 \mathrm{sec}$.

Vent/fill loop off $13 \mathrm{sec}$.

Inject to G.C. $15 \mathrm{sec}$.

Inject return 1:15 sec.

Probe up 1:17 sec.

Aux pressure (flush) .5 bar

Valve Air pressure 3.5 bar

Carrier Flow $10 \mathrm{cc} / \mathrm{min}$. 
STANDARD PREPARATION METHOD SP3

GAS STANDARD RREPARATION FOR VOC'S

\subsection{Scope and Application}

1.1 Gas standards may be prepared from pure Iiquid compounds when commercial gas standards are not available. Known weights of pure compounds are placed in a 22ml vial under known conditions. The ideal gas law is used to calculate gas volumes for each compound. Concentrations may be calculated in parts per million volume (ppmv) or micrograms per liter air (ug/l air).

\subsection{Summary}

2.1 Equal volumes of pure liquid compounds are combined. A uI amount of the pure blend is injected into a $22 \mathrm{ml}$ headspace vial (at atmos. pressure) to produce a known concentration gas (Ievel 1 standard). The pure compound blend is diluted in solvent so that when $u I$ amounts of the diluted blend are injected into a $22 \mathrm{ml}$ Headspace vial (at atmos. pressure) a known concentration of gas (level 2) is produced. The pure blend is again diluted in solvent to produce other gas standards (level 3 and 4 ). Level 5 and level 6 gas standard may be produced by further diluting level 2 and level 3 blends 1000:1. For each level number increase, the weight amount of compound ( $\mathrm{g} / \mathrm{ul}$ blend) decreases by a factor of 10 .

\subsection{Apparatus and Materials}

3.1 Solvent: The solvent normally used is high purity (99+\%) chromatographic grade methyl alcohol. It must be determined if the solvent will interfere with or mask compounds of interest.

3.2 Pure compounds of interest: AII compounds used must meet required specifications and be approved on the supplies and Materials List.

3.3 Storage of Prepared Standards: Vials (Alltech \$72716 or equivalent), Caps (Ailtech $\$ 25246$, mininert valves), septa (AlItech \#548).

$3.4 \mathrm{ml}$ disposable pipettes: corning or equivalent.

$3.522 \mathrm{ml}$ Headspace Vial: Hewlett Packard \#9301-0716.

3.610 ul liquid syringe: Hamilton 701 or equivalent.

3.7 Pipette Dispenser, Micro-Pipex: Fisher Scientific. 


\subsection{Procedure}

4.1 Add Iml of each compound to a pre-cleaned $22 \mathrm{ml}$ vial using a new disposable $1 \mathrm{ml}$ pipette for each compound. The total volume of the pure blend should be greater than $9 . \mathrm{ml}$. If less than 9 compounds are used then $2 \mathrm{ml}$ of each compound should be combined.

4.2 Using a disposable $1.0 \mathrm{ml}$ glass pipette, fill at least two $4.5 \mathrm{ml}$ vials with the pure blend. Immediately cap the vials with mininert valve caps. Label the vials "Pure BIend standard [I.D.]

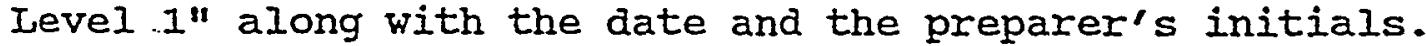

4.3 Using a disposable $1.0 \mathrm{ml}$ glass pipete, fill each of three new pre-labeled $4.5 \mathrm{ml}$ vials with the following ml amounts of solvent; 3.960 (level 2), 4.355 (level 3), and 4.395 (level 4). The labels should reflect the appropriate standard I.D. and level.- Cap all vials with mininert valve caps.

4.4 Using a clean IOuI syringe add 4.4 ul of pure blend to the vial containing $4.395 \mathrm{ml}$ of solvent and labeled level 4 .

4.5 Using the same $10 \mathrm{ul}$ syringe as in step 4.4 add 44 ul of pure blend to the vial containing 4.355 and labeled level 3 .

4.6 Using a clean $1 \mathrm{ml}$ pipette add $.44 \mathrm{ml}$ of pure blend to the vial containing $3.960 \mathrm{ml}$ of solvent and labeled level 2 .

4.7 To produce level 5 and level 6 dilute blends add $4.395 \mathrm{ml}$ of solvent to two clean prelabeled $4.5 \mathrm{ml}$ vials. For level 5 add $4.4 \mathrm{ul}$ of level 2 blend and for level 6 add 4.4 ul of level 3 blend.

4.8 Gas standards are produced by injecting ul amounts of blend (levels $1-6$ ) into $22 \mathrm{ml}$ headspace vials containing clean air and capped with TFE lined septums. Refer to the appropriate Standard Calculations Table for actual amounts to inject into the headspace vials and resulting concentrations of each compound. .

4.9 The standard calculations table is produced in spreadsheet format and contains at least the following information; solvent used, compound density and molecular weight, ul compound/Iul blend, compound weight/volume of blend, gas volume of compound, weight of compound per liter of air, and the parts per million of compound by volume for each concentration level of standard. 


\subsection{Calculations}

5.1 The following formulas are used to calculate the gas concentration (vol/vol) originating from liquid (weight).

CONCENTRATION in PPMV $=\cdot($ COMPOUND VOL/TOTAL VOL $) * 1000000$

$P=1 \mathrm{ATM}$

$V=1$ MOLE (IDEAI GAS) 22.4 IITER

$T=$ TEMP. $273 \mathrm{~K}$

$\mathrm{R}=\mathrm{IDEAI}$ GAS CONSTANT $(.082) \quad \mathrm{R}=\mathrm{PV} / \mathrm{NT} \quad \mathrm{R}=(1 * 22.4) /(1 * 273)$

$N=$ COMPOUND WEIGHT/MOL. WEIGHT

$W=$ WEIGHT OF COMPOUND USED (IN ug)

$M=$ MOL. WEIGHT OF THE COMPOUND

$\mathrm{D}=\mathrm{DENSITY}$ (GRAMS/mL)

$I=$ IIQUID VOI. USED (IN UI)

$t=$ TEMP $.25 \mathrm{C}+273 \mathrm{~K}=298 \mathrm{~K}$

$\mathrm{V}=$ UNKNOWN VOTUME

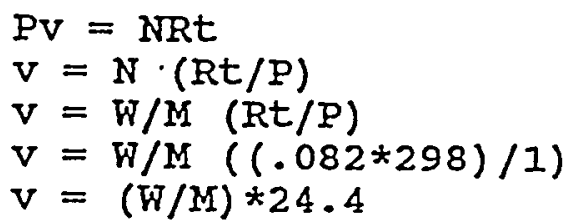

$D=W / L * 1000$

$\mathrm{W}=\mathrm{DL} * 1000$

5.2 To calculate the standard gas concentrations in ug/I air the above ideal gas law formula must be used to calculate the volume of gas of the compound when added to the headspace vial. This volume is then added to the volume of the headspace vial to determine the total volume. The following formula can then be used:

CONCENTRATION (ug/I air) =

(I Iiter air/total vol) (compound weight/total volume).

\subsection{Safety Precautions}

6.1 General laboratory safety precautions should be followed when preparing standards: The safety precautions should include, but not be limited to, the following safeguards; Eye and face protection, proper clothing (gloves, shoes, etc.), proper ventilation, spill protection, and an emergency response plan.

$6.2 \mathrm{All}$ safety precautions as stated on the material data sheets should be followed when handling hazardous materials. 
: APPENDIX II

SOIL GAS SAMPLE COLLECTION IOGS 
XICROSEEPS 110.

alext: $\frac{\text { SRS / Kelly Waid }}{\text { Road A Chemical Basin }}$ PROJECT(1): $904-111 G$ PAEE: ___ O\&:

18322832282 SAXPLE COLECTIOA LOG 1118328281

SAXPLER xaxE(S): Kab/Cds

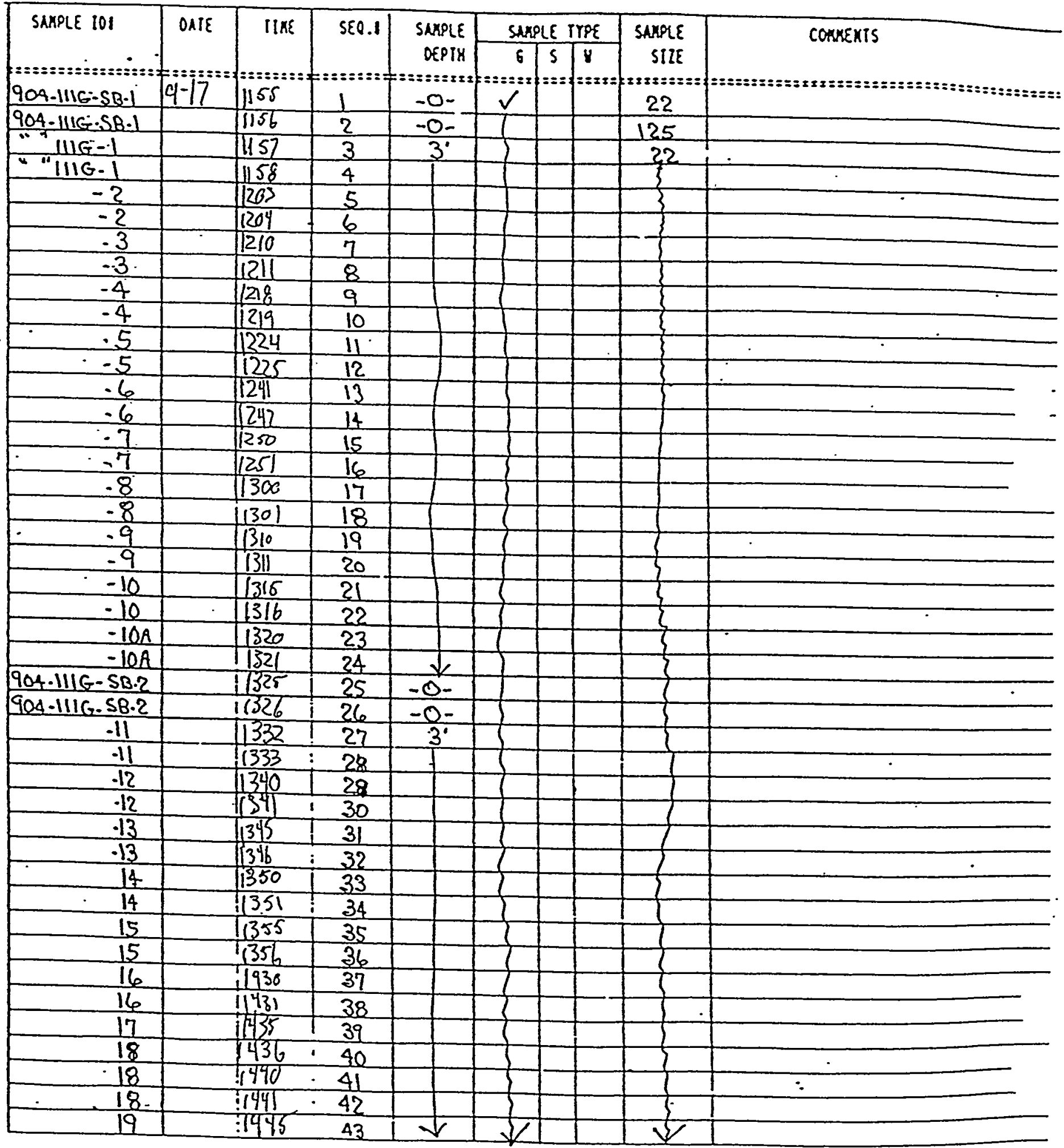


)

\section{APPENDIX II}

WASTE MANAGEMENT UNIT WORKSHEETS

) 
MICROSEEPS 110.

AIEx: SRS / Kelly Waird Locarlax: Baod A Chem Basin PAGE: ——_ of:

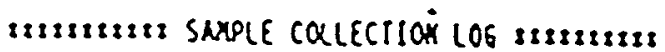

SARP(ER XAXE(S): Ka\&/CdS

\begin{tabular}{|c|c|c|c|c|c|c|c|c|c|}
\hline SAMPLE IOI & OAIE & IIKE. & SEO.1 & SAXPLE & & LE T & & SAAPRE & comrexis \\
\hline & & & & DEPIY & 6 & $s$ & $y$ & SILE & \\
\hline 904.1116 .19 & $9-17$ & 1486 & $\begin{array}{ll}:=::= \\
44\end{array}$ & $\begin{array}{l}3: 3: 8 z= \\
3\end{array}$ & $:=:: 3$ & $x=3$ & $:=: 32$ & $\begin{array}{c}x 23 x=: 3= \\
125\end{array}$ & 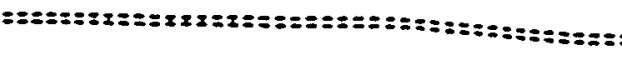 \\
\hline .20 & & 1455 & 45 & $\xi$ & 1 & & & 22 & \\
\hline-20 & & 466 & 46 & 3 & & & & 7 & \\
\hline $20 A$ & & 500 & 47 & & & & & 3 & \\
\hline $20 A$ & & 1501 & 48 & $\$$ & & & & 3 & \\
\hline $904-111 \mathrm{G}-5 B-3$ & & 1505 & 49 & -0 - & & & & \} & \\
\hline $904-1116 \cdot S B-3$ & & 1506 & So & -0 & & & & & \\
\hline 21 & & 507 & SI & $3^{\prime}$ & I & & & $\xi$ & \\
\hline 21 & & $150^{\circ}$ & 52 & 3 & 3 & & & & \\
\hline 22 & & 1513 & 53 & 3 & $T$ & & & ל & \\
\hline 22 & & 1514 & 54 & $\xi$ & & & & & \\
\hline 23 & & 1518 & 55 & & 5 & & & 5 & \\
\hline 23 & & 1519 & 56 & 1 & & & & & - \\
\hline 24 & & 1525 & 57 & I & T & & & & \\
\hline 24 & & 1526 & 58 & 3 & & & & & \\
\hline 25 & & 1530 & 59 & 3 & & & & & \\
\hline 25 & & $|53|$ & 60 & $\xi$ & & & & & - \\
\hline 26 & & 11535 & (4) & 5 & & & & & \\
\hline 20 & & 1536 & 62 & T & & & & & \\
\hline 27 & & 1540 & 63 & 1 & & & & & \\
\hline 27. & & 1541 & 64 & t & & & & $\zeta$ & \\
\hline 28 & & 1645 & 65 & 3 & & & & & \\
\hline 28 & & 1546 & 66 & 3 & & & & & \\
\hline 29 & & 1550 & 67 & I & & & & & \\
\hline 29 & & 1559 & 68 & 3 & & & & & \\
\hline 30 & & $1 / 553$ & 69 & 3 & & & & & \\
\hline 30 & & 1556 & 70 & f & f & & & & \\
\hline $30 A$ & & 1800 & 21 & 5 & & 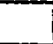 & & & \\
\hline $30 \mathrm{~A}$ & & 1801 & 72 & $v$ & T & 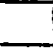 & & & \\
\hline $90 r-111 G=58-4$ & & 11605 & 73 & -0 & & & & & \\
\hline $904 \cdot 111 G \cdot S B A$ & & 1606 & 74 & -0 & & & & 7 & \\
\hline 31 & & 4608 & 75 & 3 & & & . & & - \\
\hline 31 & & 1609 & 36 & 3 & & & & 1 & \\
\hline 32 & & 11625 & 77 & 3 & 5 & & & & \\
\hline$\frac{32}{12}$ & & 11626 & 78 & 3 & 1 & - & & $\xi$ & \\
\hline 33 & & 1639 & 79 & & & & & & \\
\hline 33 & & 1640 & 80 & 3 & 1 & 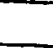 & & $\zeta$ & \\
\hline 34 & & 11645 & 81 & 3 & 2 & & & & \\
\hline 34 & & 1642 & 82 & 2 & 1 & 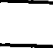 & & 3 & \\
\hline 35 & & 11655 & 83 & 3 & $\zeta$ & & & & \\
\hline$\frac{35}{21}$ & & 1656 & 84 & 3 & 3 & $E_{0}$ & & 7 & $\because$ \\
\hline 36 & & inao & 85 & 3 & 5 & & & $\zeta$ & \\
\hline 36 & & $:(70 \mid$ & 86 & $\xi$ & $V$ & & & 5 & \\
\hline
\end{tabular}


University of Pittsburgh Applied Research Center

220 William Pitt Way, Pittsburgh, PA 15238

(412) 826-5245

FAX (412) 826-3433

February 4, 1999

\author{
Mr. Tom McAdams \\ Westinghouse Savannah River Company \\ Building 730-2B \# 3137 \\ Aiken, SC 29808
}

\title{
Dear Tom:
}

We have examined the raw data for the soil vapor samples collected at the Road A Chemical Basin in 1992 and have found no evidence of the presence of chlorobenzene.

Even though the SRS request did not include chlorobenzene as a compound of interest, the samples were analyzed on an instrument that was calibrated for that compound. When samples are analyzed the detector responses are digitized and recorded as "raw" data files. The chromatography software processes the raw data using a calibration file with retention times and detector response factors for known amounts of compounds in the calibration mix. We were able to reload the raw data files for the Road A samples and reprocess them with a calibration file which included chlorobenzene. None of the sample chromatograms showed a peak at the known retention time. I have enclosed copies of the reports showing the chromatograms processed with the calibration file that includes chlorobenzene and a copy of a continuing calibration verification showing a chlorobenzene peak. Even though the calibration verification was analyzed two days after the last Road A sample, you can see on the reports that the initial calibration was performed prior to beginning the Road A analyses.

If you have any further questions, please contact me at the above telephone number.

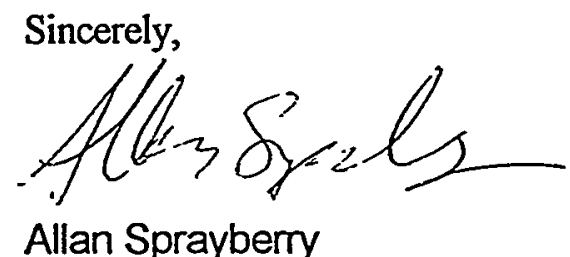

Allan Sprayberry 
File=C: \CP \D23 \U23A1.53R Date printed=01-27-1999 Time= 15:12:15

Sample Name $=904-111 G^{\star} \mathrm{SB} 1$

2.0 to $36.0 \mathrm{~min}$. LoH $Y=0.388$ High $Y=0.503 \mathrm{mV}$ Span=0.115

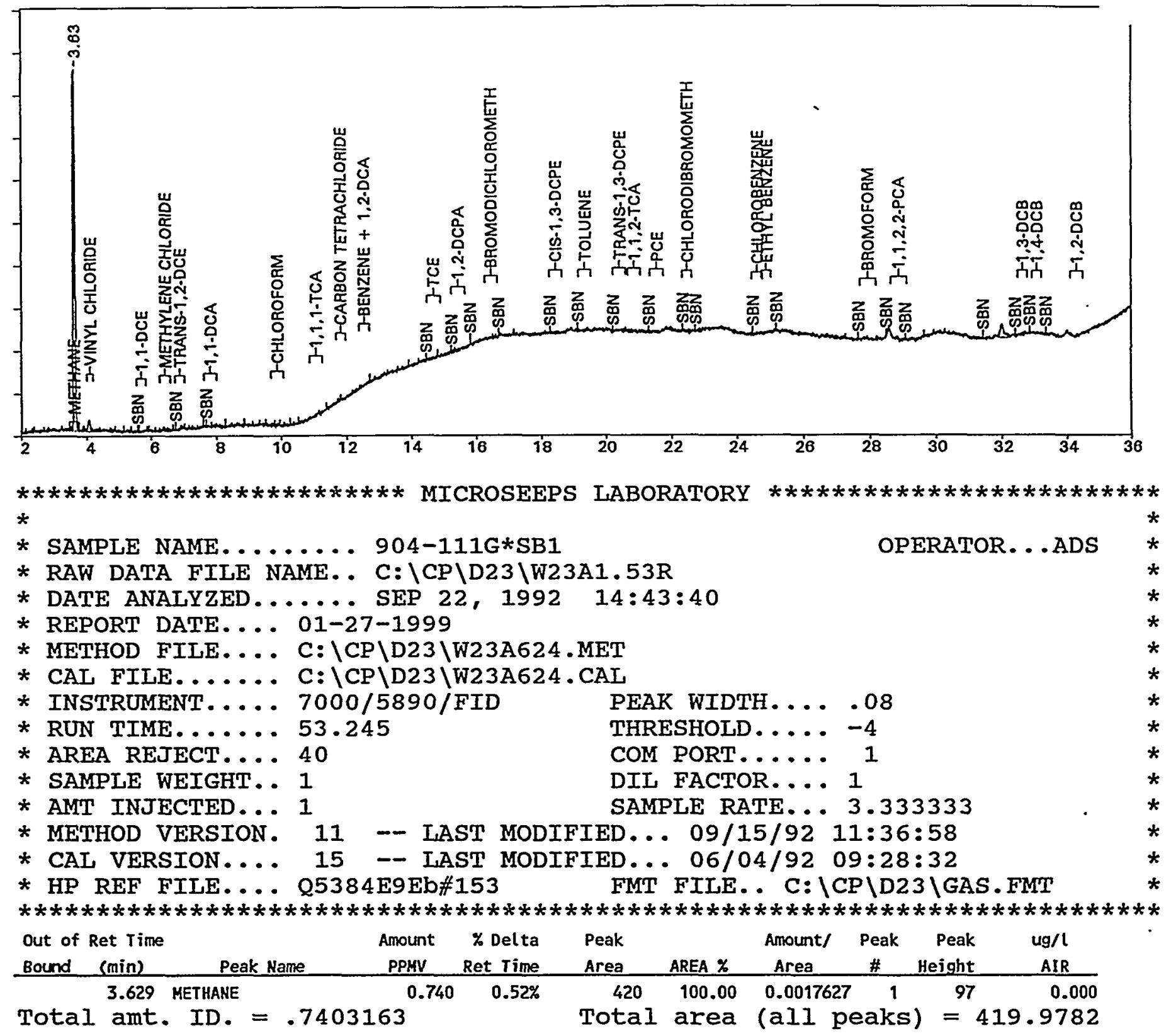




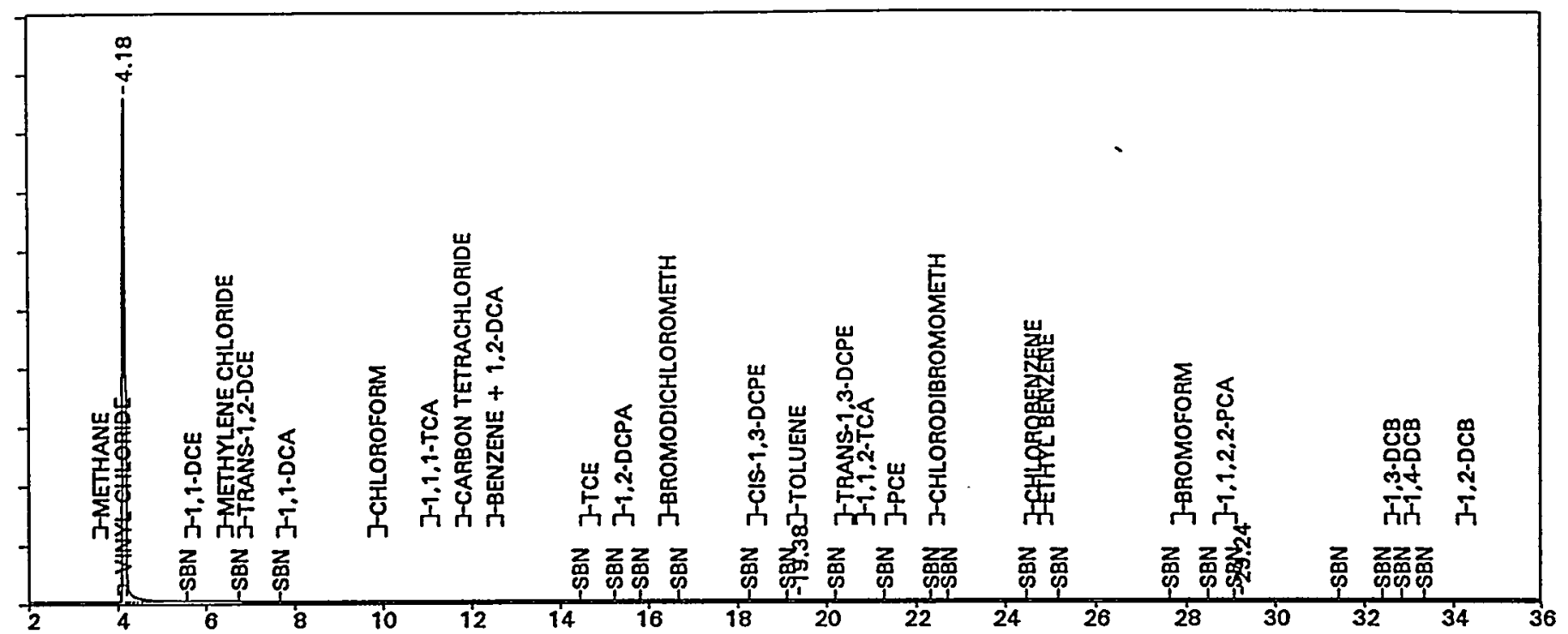

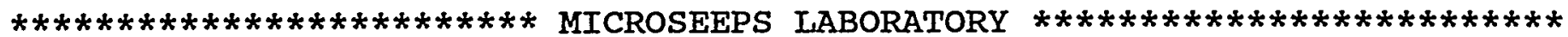
$*$

* SAMPLE NAME........ STD K4 R6

* RAW DATA FIIE NAME.. C: \CP\D23\W23A1.54R

* DATE ANALYZED....... SEP 22, 1992 15:50:50

* REPORT DATE... 01-27-1999

* METHOD FILE... C: \CP\D23\W23A624.MET

* CAL FILE...... C: \CP\D23\W23A624.CAL

* INSTRUMENT.... 7000/5890/FID PEAK WIDTH.... 08

* RUN TIME...... 53.245 THRESHOLD .... -4

* AREA REJECT.... 40

* SAMPIE WEIGHT. . 1

COM PORT...... 1

* AMT INJECTED... 1

DIL FACTOR.... 1

* METHOD VERSION. 11 - LAST MODIFIED .. 0 09/15/92 11:36:58

* CAL VERSION ... 15 - LAST MODIFIED... 06/04/92 09:28:32

* HP REF FILE.... Q5385E5Bb\#154 FMT FILE.. C: ICP\D23 IGAS.FMT

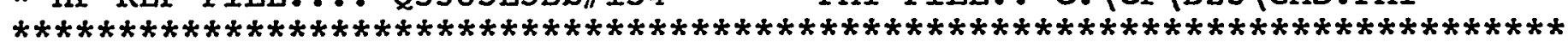

\begin{tabular}{|c|c|c|c|c|c|c|c|c|c|c|}
\hline $\begin{array}{l}\text { Out of } \\
\text { Bound }\end{array}$ & $\begin{array}{l}\text { Ret Time } \\
\text { (min) }\end{array}$ & Peak Hame & $\begin{array}{c}\text { Amount } \\
\text { PPHV }\end{array}$ & $\begin{array}{l}\text { \% Delta } \\
\text { Ret Time }\end{array}$ & $\begin{array}{l}\text { Peak } \\
\text { Area }\end{array}$ & AREA $\%$ & $\begin{array}{l}\text { Amount/ } \\
\text { Area }\end{array}$ & $\begin{array}{c}\text { Peak } \\
\#\end{array}$ & $\begin{array}{r}\text { Peak } \\
\text { Height }\end{array}$ & $\begin{array}{r}\text { ug/l } \\
\text { AIR }\end{array}$ \\
\hline & 4.180 & VIHYL CHLORIDE & 44146.730 & $1.71 \%$ & 6939147 & 100.00 & 0.0063620 & & 1448522 & 0.000 \\
\hline & 19.379 & TOLUENE & 0.077 & $0.20 \%$ & 104 & 0.00 & 0.0007390 & 3 & 10 & 0.000 \\
\hline
\end{tabular}

Total amt. ID. $=44146.81$

Total area (all peaks) $=6939318$ 
File=C: \CP \D23 \U23A1.55R Date printed=01-27-1999 Time= 15:14:58

Sample Name $=904-1116-1$

2.0 to $36.0 \mathrm{~min}$. Low $Y=0.382 \mathrm{High} Y=1.622 \mathrm{mv}$ Span=1.24

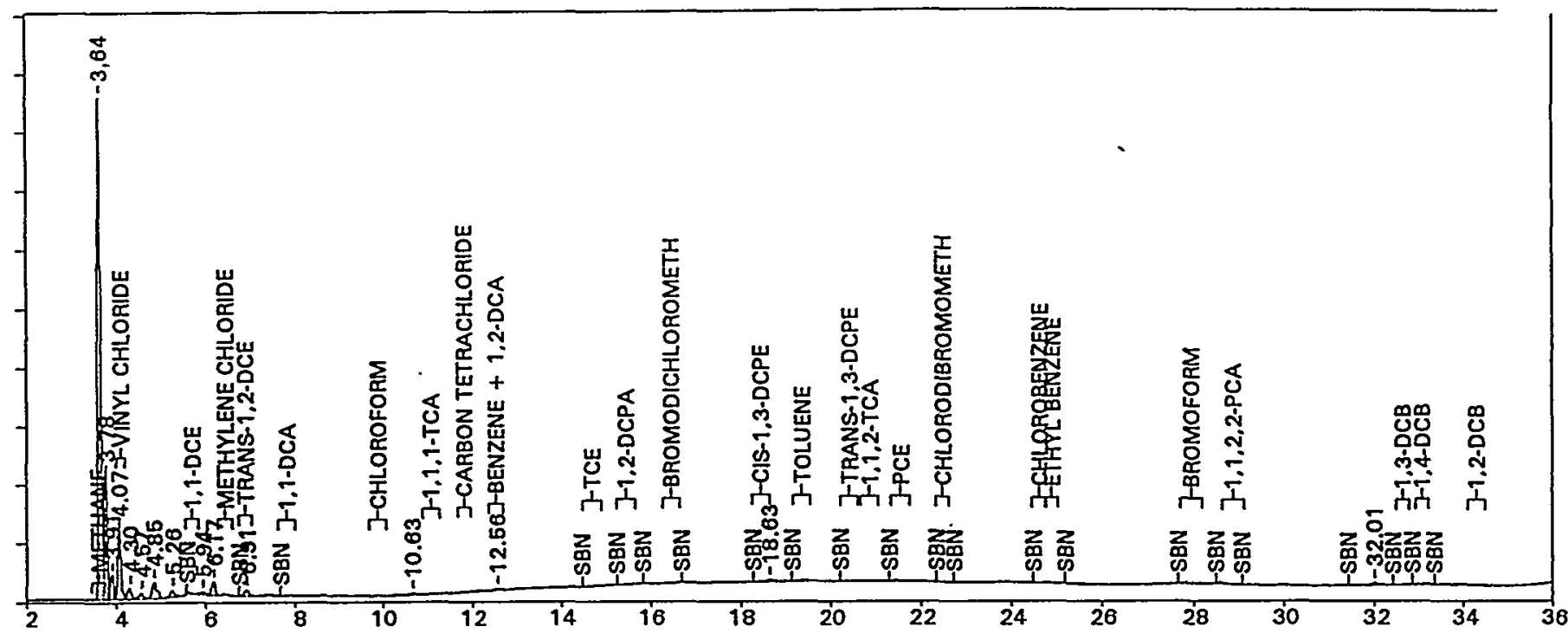

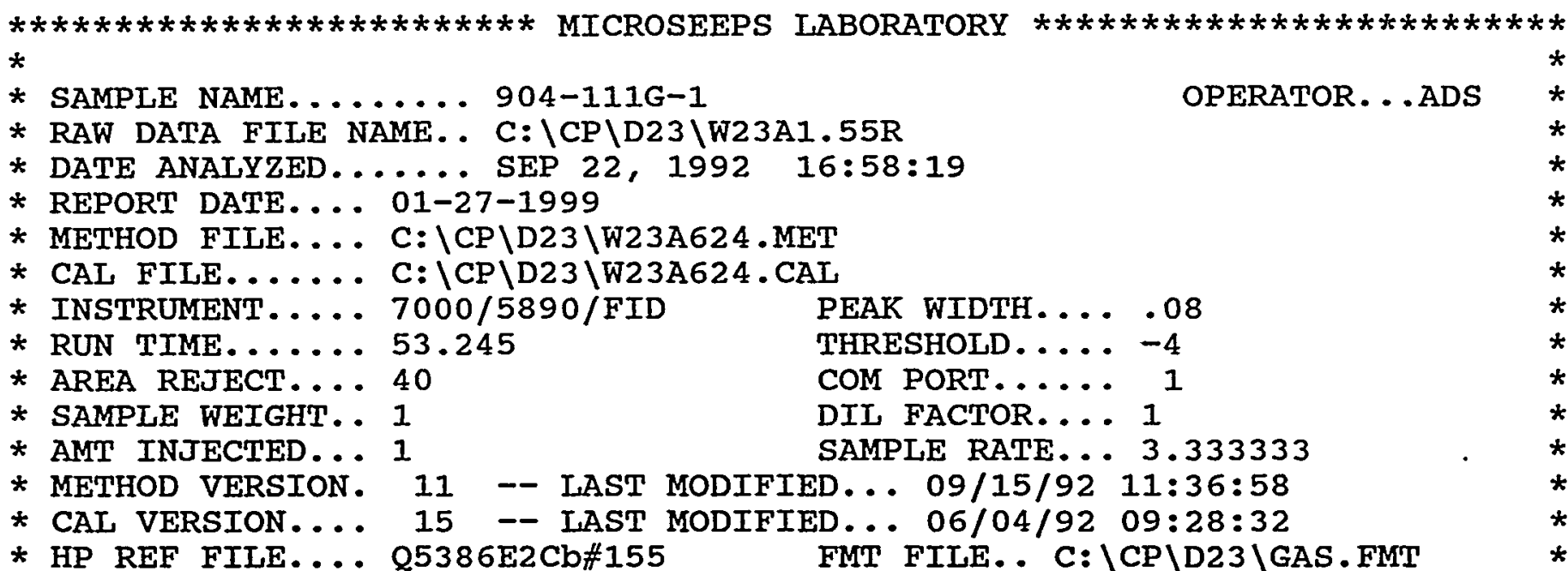

$\star * * * * * * * * * * * * * * * * * * * * * * * * * * * * * * * * * * * * * * * * * * * * * * * * * * * * * * * * * * * * * * * * * * * * * * * *$

\begin{tabular}{|c|c|c|c|c|c|c|c|c|c|c|}
\hline $\begin{array}{l}\text { Out of } \\
\text { Bound }\end{array}$ & $\begin{array}{l}\text { Ret Time } \\
\text { (min) }\end{array}$ & Peak Name & $\begin{array}{c}\text { Amount } \\
\text { PPHV }\end{array}$ & $\begin{array}{r}\text { X Delta } \\
\text { Ret Time }\end{array}$ & $\begin{array}{l}\text { Peak } \\
\text { Area }\end{array}$ & AREA $\%$ & $\begin{array}{l}\text { Amount/ } \\
\text { Area }\end{array}$ & $\begin{array}{c}\text { Peak } \\
\#\end{array}$ & $\begin{array}{r}\text { Peak } \\
\text { Height } \\
\end{array}$ & $\begin{array}{r}u g / l \\
\text { AIR } \\
\end{array}$ \\
\hline & 3.642 & METHANE & 7.987 & $0.90 \%$ & 4820 & 60.53 & 0.0016569 & 1 & 1059 & 0.000 \\
\hline & 4.068 & VINYL CHLORIDE & 4.537 & $-1.01 \%$ & 712 & 8.94 & 0.0063709 & 4 & 140 & 0.000 \\
\hline & 6.911 & TRANS-1,2-DCE & 1.766 & $0.44 \%$ & 97 & 1.22 & 0.0181932 & 12 & 13 & 0.000 \\
\hline & 12.563 & BENZENE + 1,2-DCA & 0.049 & $0.31 \%$ & 40 & 0.51 & 0.0012136 & 17 & 4 & 0.000 \\
\hline & 18.634 & CIS-1,3-DCPE & 0.077 & $1.05 \%$ & 43 & 0.54 & 0.0018091 & 18 & 4 & 0.000 \\
\hline
\end{tabular}

Total amt. ID. $=14.41567$

Total area (all peaks) $=7963.615$ 
File=C: \CP \D23 \W23A1.56R Date printed $=01-27-1999$ Time= 15:16:23

Sample Hame $=904-1116-2$

2.0 *n 36.0 min. LoH $Y=0.381$ High $Y=1.461 \mathrm{mv}$ Span=1.08

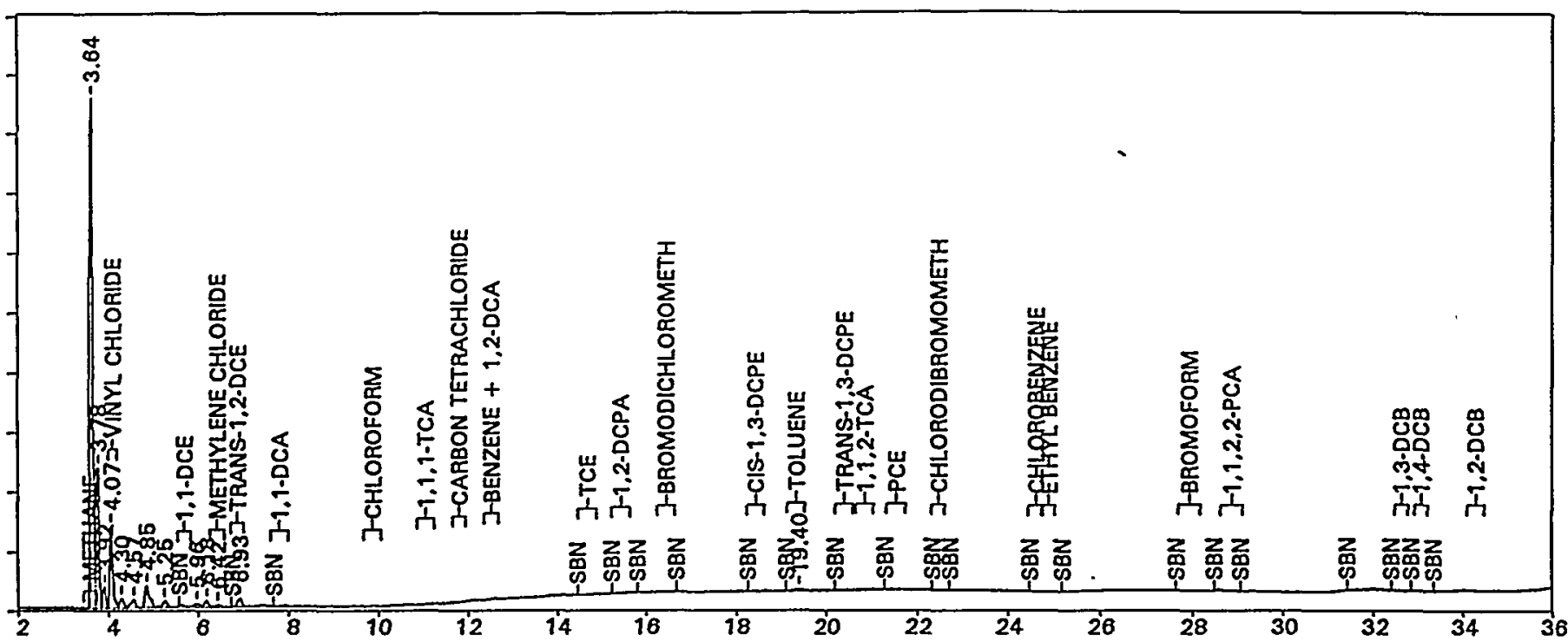

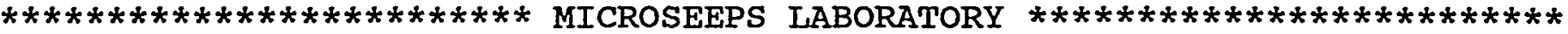
$*$

* SAMPLE NAME........ 904-111G-2

* RAW DATA FIIE NAME.. C: \CP\D23\W23A1.56R

* DATE ANATYZED........ SEP 22, 1992 18:05:40

* REPORT DATE... 01-27-1999

* METHOD FIIE.... C: \CP\D23\W23A624.MET

* CAL FILE...... C: $\backslash$ CP $\backslash D 23 \backslash W 23 A 624 . C A L$

* INSTRUMENT.....7000/5890/FID PEAK WIDTH.....08

* RUN TIME..... 53.245 53 THRESHOID.... -4

* AREA REJECT.... 40 COM PORT..... 1

* SAMPLE WEIGHT.. 1 DIL FACTOR... 1

* AMT INJECTED... 1 SAMPIE RATE...3.333333

* METHOD VERSION. 11 - LAST MODIFIED... 09/15/92 11:36:58

* CAI VERSION.... 15 - LAST MODIFIED... 06/04/92 09:28:32

* HP REF FILE.... Q5387DF5b\#156 FMT FILE.. C: ICP\D23 GAS.FMT

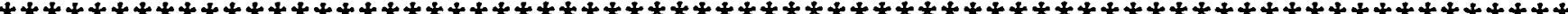

\begin{tabular}{|c|c|c|c|c|c|c|c|c|c|c|}
\hline $\begin{array}{l}\text { Out of } \\
\text { Bound }\end{array}$ & $\begin{array}{l}\text { Ret Time } \\
\text { (min) }\end{array}$ & Peak Name & $\begin{array}{c}\text { Amount } \\
\text { PPMV }\end{array}$ & $\begin{array}{l}\text { \% Delta } \\
\text { Ret Time }\end{array}$ & $\begin{array}{l}\text { Peak } \\
\text { Area }\end{array}$ & AREA $x$ & $\begin{array}{c}\text { Amount/ } \\
\text { Area }\end{array}$ & $\begin{array}{c}\text { Peak } \\
\# \\
\end{array}$ & $\begin{array}{r}\text { Peak } \\
\text { Height } \\
\end{array}$ & $\begin{array}{r}\text { ug/l } \\
\text { AIR }\end{array}$ \\
\hline & 3.644 & METHANE & 6.944 & $0.93 \%$ & 4118 & 57.20 & 0.0016860 & 1 & 921 & 0.000 \\
\hline & 4.074 & VIHYL CHLORIDE & 4.762 & $-0.88 \%$ & 748 & 10.38 & 0.0063705 & 4 & 149 & 0.000 \\
\hline & 6.424 & METHYLENE CHLORIDE & 0.311 & $-0.02 \%$ & 51 & 0.71 & 0.0060595 & 12 & 5 & 0.000 \\
\hline & 6.929 & TRANS-1,2-DCE & 2.218 & $0.72 \%$ & 123 & 1.70 & 0.0181022 & 13 & 16 & 0.000 \\
\hline & 19.400 & TOLUENE & 0.032 & $0.31 \%$ & 43 & 0.59 & 0.0007390 & 16 & 4 & 0.000 \\
\hline
\end{tabular}

Total amt. ID. $=14.26668$

Total area (all peaks) $=7199.902$ 
File $=$ C: $\backslash$ CP \O23\W23A1.57R Date printed $=01-27-1999$ Time= 15:17:49

Sample Name $=904-111 \mathrm{G}-3$

2.0 to 36.0 min. Low $Y=0.379$ High $Y=3.013 \mathrm{mr}$ Span=2.634

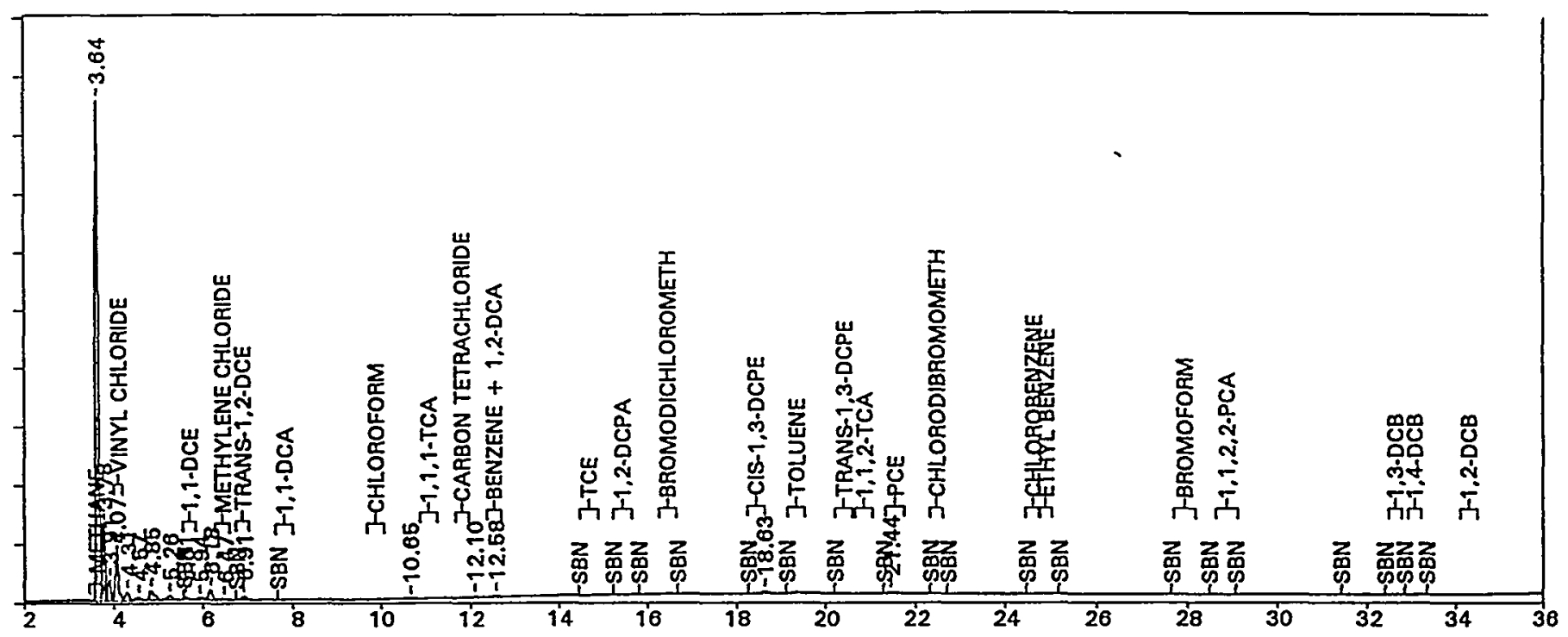

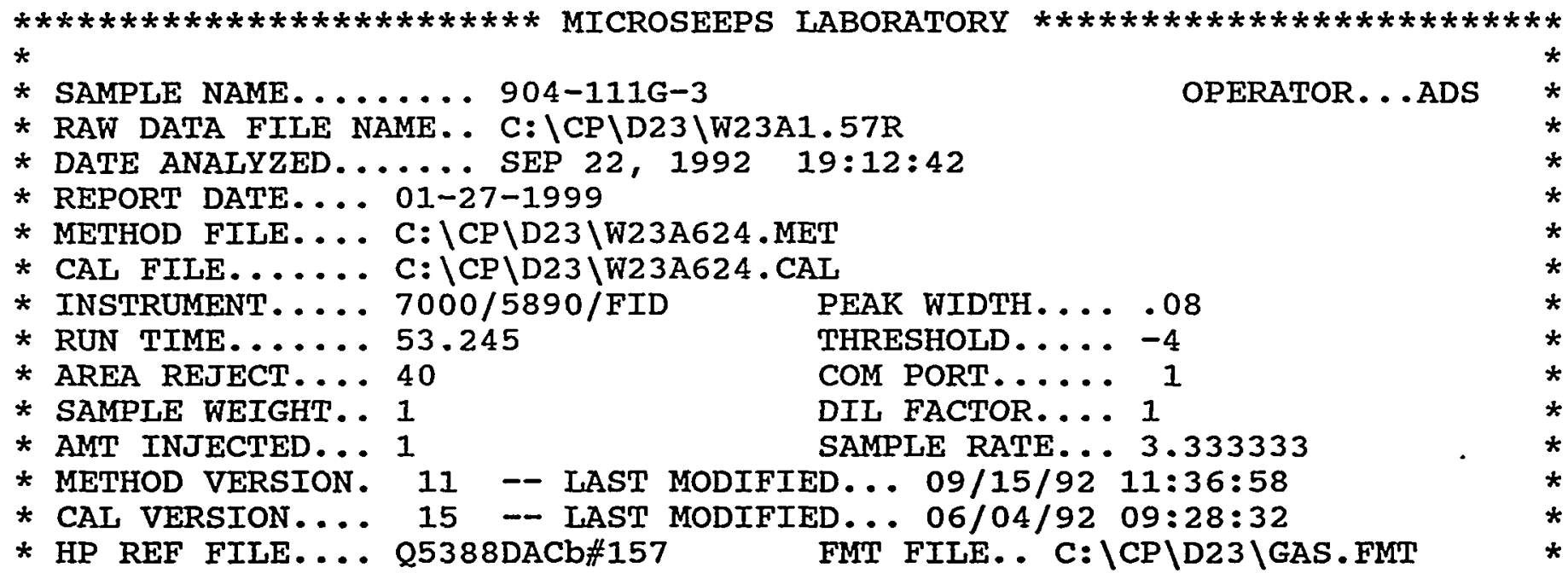

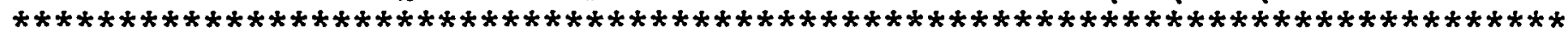

\begin{tabular}{|c|c|c|c|c|c|c|c|c|c|c|}
\hline $\begin{array}{l}\text { Out of } \\
\text { Bound }\end{array}$ & $\begin{array}{l}\text { Ret Time } \\
\text { (min) }\end{array}$ & Peak Name & $\begin{array}{l}\text { Amount } \\
\text { PPHV }\end{array}$ & $\begin{array}{l}\text { \% Delta } \\
\text { Ret Time }\end{array}$ & $\begin{array}{l}\text { Peak } \\
\text { Area }\end{array}$ & AREA $\%$ & $\begin{array}{c}\text { Amount/ } \\
\text { Area }\end{array}$ & $\begin{array}{c}\text { Peak } \\
\#\end{array}$ & $\begin{array}{r}\text { Peak } \\
\text { Height }\end{array}$ & $\begin{array}{r}\mathrm{ug} / \mathrm{l} \\
\mathrm{AIR}\end{array}$ \\
\hline & 3.641 & METHANE & 16.905 & $0.86 \%$ & 10114 & 67.61 & 0.0016715 & 1 & 2243 & 0.000 \\
\hline & 4.070 & VINYL CHLORIDE & 6.276 & $-0.97 \%$ & 985 & 6.59 & 0.0063684 & 4 & 182 & 0.000 \\
\hline & 5.606 & $1,1-D C E$ & 0.009 & $-1.56 \%$ & 43 & 0.29 & 0.0002046 & 9 & 8 & 0.000 \\
\hline & 6.473 & METHYLENE CHLORIDE & 0.458 & $0.74 \%$ & 76 & 0.51 & 0.0060595 & 12 & 7 & 0.000 \\
\hline & 6.906 & TRANS-1,2-DCE & 2.326 & $0.37 \%$ & 130 & 0.87 & 0.0179167 & 13 & 17 & 0.000 \\
\hline & 12.578 & BENZENE + 1,2-DCA & 0.095 & $0.43 \%$ & 78 & 0.52 & 0.0012136 & 20 & 8 & 0.000 \\
\hline & 18.631 & CIS-1,3-DCPE & 0.173 & $1.03 \%$ & 96 & 0.64 & 0.0018091 & 21 & 10 & 0.000 \\
\hline & 21.436 & PCE & 0.146 & $-0.44 \%$ & 74 & 0.50 & 0.0019709 & 23 & 5 & 0.000 \\
\hline
\end{tabular}


File=c: \CP \D23 IW23A1.58R Date printed $=01-27-1999$ Time= 15:19:14

Sample Hame $=904-111 \mathrm{G}-4$

2.0 to $36.0 \mathrm{~min}$. Low $Y=0.392 \mathrm{High} Y=0.83 \mathrm{mv}$ Span=0.438

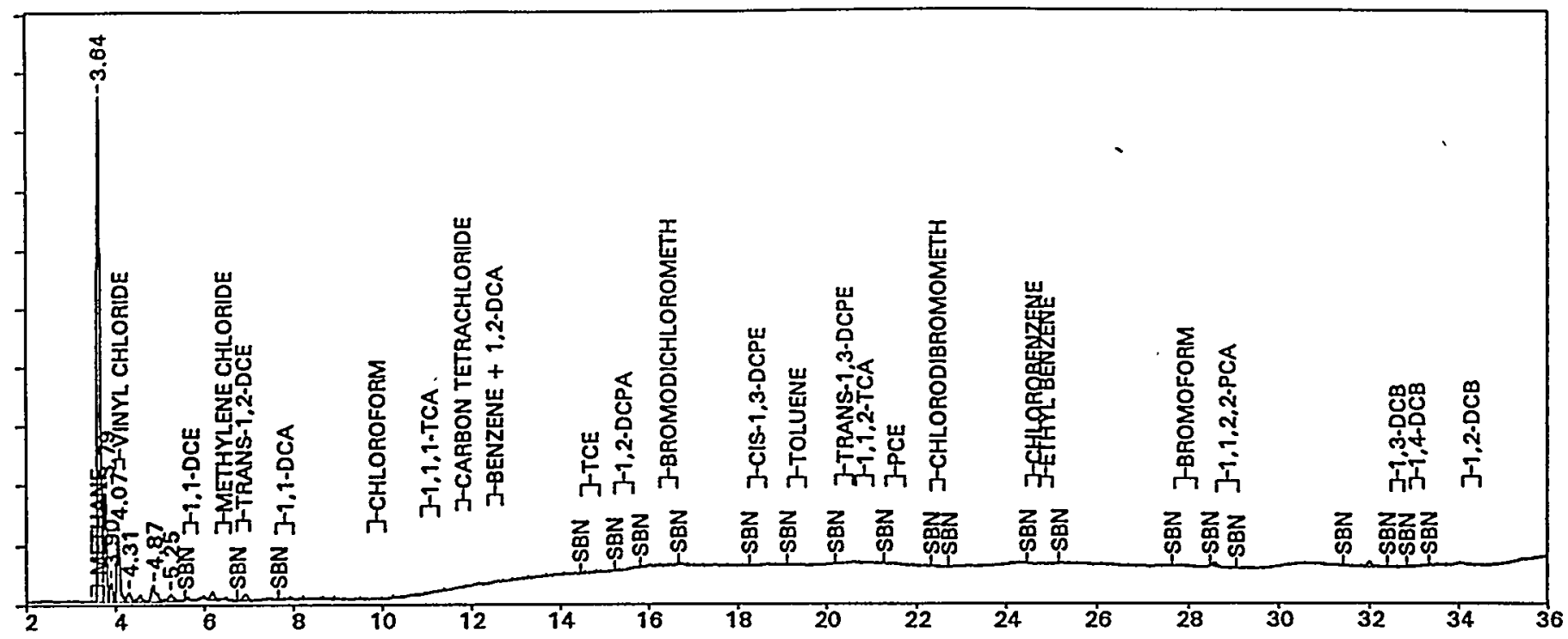

$* * * * * * * * * * * * * * * * * * * * * * * * *$ MICROSERPS LABORATORY $* * * * * * * * * * * * * * * * * * * * * * * * *$ *

* SAMPle NAME....... 904-111G-4

* RAW DATa FILE NAME. C C: \CP\D23\W23A1.58R

* DATE ANALYZED...... SEP 22, 1992 20:19:46

* REPORT DATE... 01-27-1999

* METHOD FILE.... C: \CP\D23\W23A624.MET

* CAL FILE....... C: \CP\D23\W23A624. CAI

* INSTRUMENT.... 7000/5890/FID PEAK WIDTH.... .08

* RUN TIME...... 53.245 THRESHOLD..... -4

* AREA REJECT. . . 40

* SAMPLE WEIGHT.. 1

COM PORT..... 1

* AMT INJECTED... 1

DIL FACTOR.... 1

TAST MODIFTED

* CAL VERSION.... 15 -- LAST MODIFIED... 06/04/92 09:28:32

* HP REF FILE.... Q5389D63b\#158 FMT FILE.. C:\CP\D23\GAS.FMT

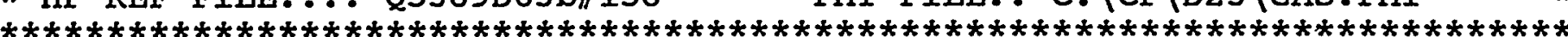

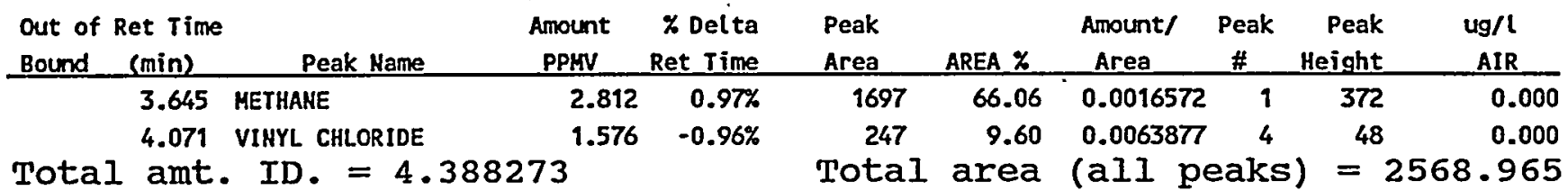




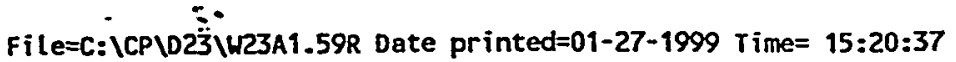

Sample Hane $=904-1116-5$

2.0 to $36.0 \mathrm{~min}$. Low $Y=0.395$ High $Y=0.856 \mathrm{mV}$ Span=0.461

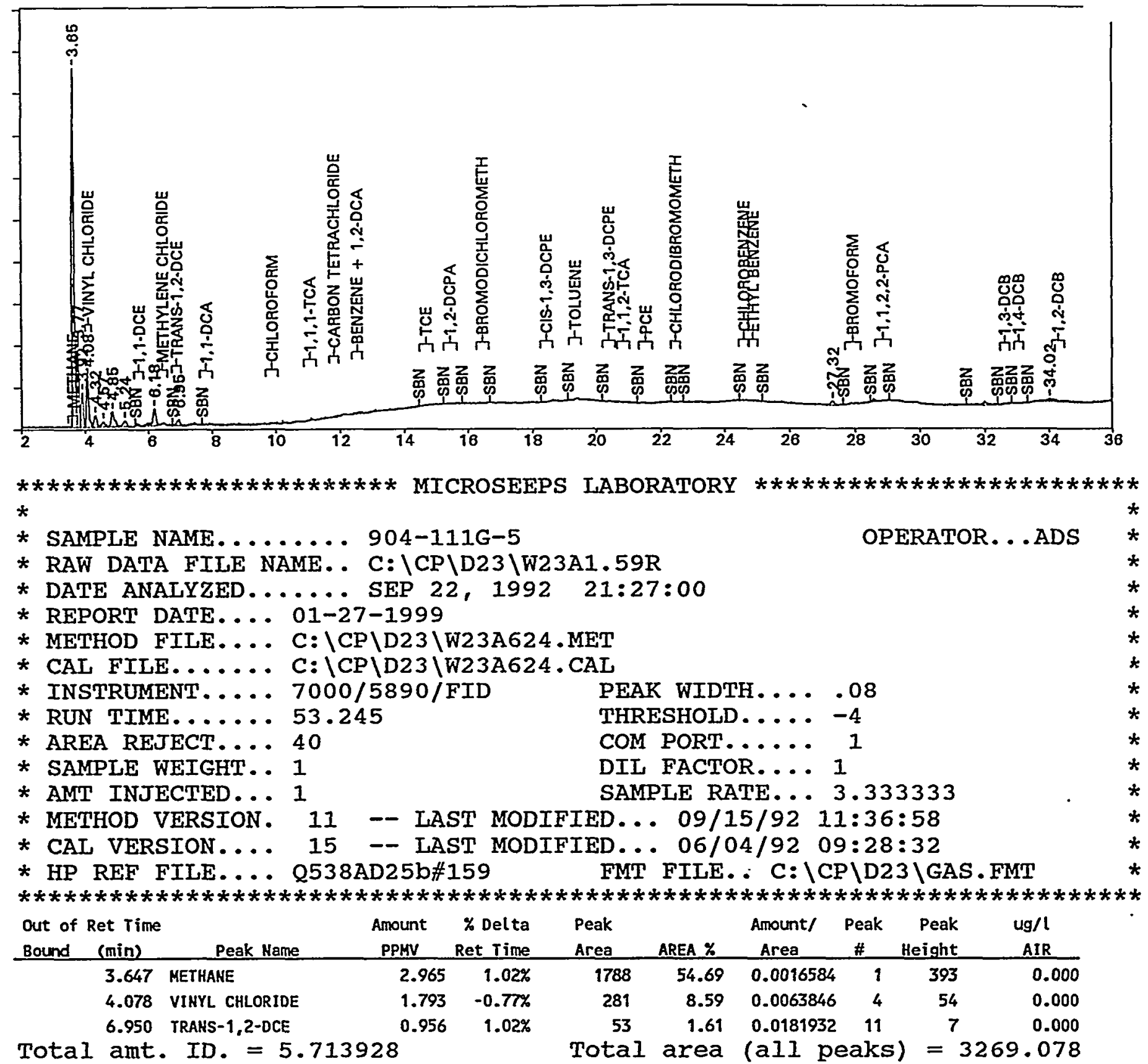




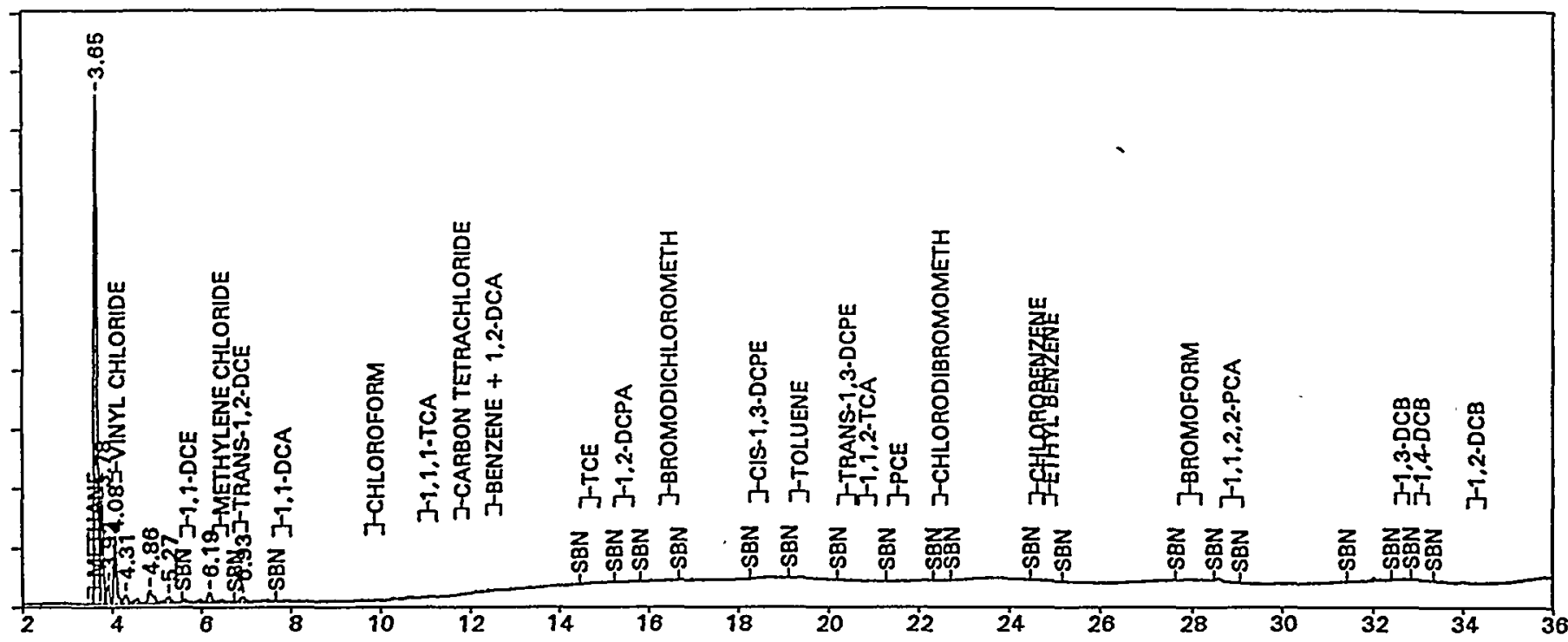

$* * * * * * * * * * * * * * * * * * * * * * * * *$ MICROSEEPS LABORATORY $* * * * * * * * * * * * * * * * * * * * * * * * *$ $\star$

* SAMPLE NAME....... 904-111G-6

* RAW DATA FIIE NAME. C: C: CP\D23\W23A1.60R

* DATE ANALYZED ....... SEP 22, 1992 22:34:09

* REPORT DATE... 01-27-1999

* METHOD FILE.... C: \CP\D23\W23A624.MET

* CAL FILE...... C: \CP\D23\W23A624.CAI

* INSTRUMENT.... 7000/5890/FID PEAK WIDTH.....08

* RUN TIME...... 53.245

* arEa REJECT... 40

* SAMPLE WEIGHT. . 1

* AMT INJECTED ... 1

* METHOD VERSION. 11 - IAST MODIFIED... 09/15/92 11:36:58

* CAL VERSION... 15 - LAST MODIFIED... 06/04/92 09:28:32

* HP REF FILE.... Q538BCE2b\#160 FMT FILE.. C: ICP ID23 \GAS.FMT

$* * * * * * * * * * * * * * * * * * * * * * * * * * * * * * * * * * * * * * * * * * * * * * * * * * * * * * * * * * * * * * * * * * * * * * * * *$

\begin{tabular}{|c|c|c|c|c|c|c|c|c|c|c|}
\hline $\begin{array}{l}\text { Out of } \\
\text { Bound }\end{array}$ & $\begin{array}{l}\text { Ret Time } \\
\text { (min) }\end{array}$ & Peak Name & $\begin{array}{l}\text { Amount } \\
\text { PPHV }\end{array}$ & $\begin{array}{l}\text { \% Delta } \\
\text { Ret Time }\end{array}$ & $\begin{array}{l}\text { Peak } \\
\text { Area }\end{array}$ & AREA $x$ & $\begin{array}{l}\text { Amount/ } \\
\text { Area }\end{array}$ & $\begin{array}{c}\text { Peak } \\
\#\end{array}$ & $\begin{array}{r}\text { Peak } \\
\text { Height }\end{array}$ & $\begin{array}{l}\text { ug/l } \\
\text { AIR }\end{array}$ \\
\hline & 3.649 & METHAKE & 4.274 & $1.09 \%$ & 2581 & 66.64 & 0.0016562 & 1 & 566 & 0.000 \\
\hline & 4.076 & VIHYL CHLORIDE & 2.053 & $-0.84 \%$ & 322 & 8.31 & 0.0063817 & 4 & 63 & 0.000 \\
\hline & 6.933 & TRANS-1,2-DCE & 0.813 & $0.77 \%$ & 45 & 1.15 & 0.0181932 & 13 & 5 & 0.000 \\
\hline
\end{tabular}

Total amt. ID. $=7.140236$

Total area (all peaks) $=3873.055$


File=C: ICP \D23 IH23A1.61R Date printed $=01-27-1999$ Time $=15: 23: 24$

Sample Nane $=904-1116-7$

2.0 to 36.0 min. Low $Y=0.396$ High $Y=0.906 \mathrm{mV}$ Span=0.509
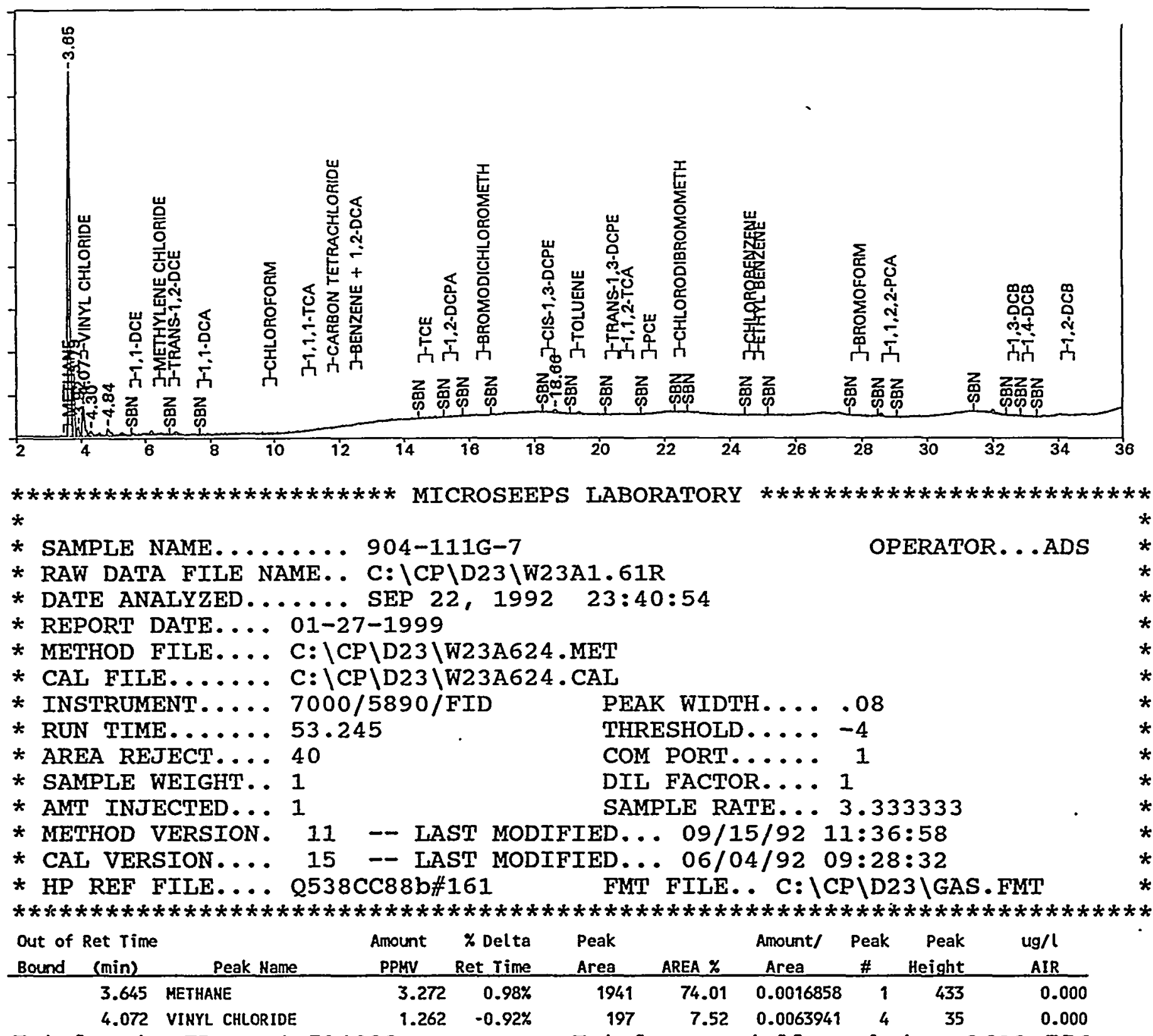

Total amt. ID. $=4.534022$ Total area $($ all peaks $)=2622.756$ 


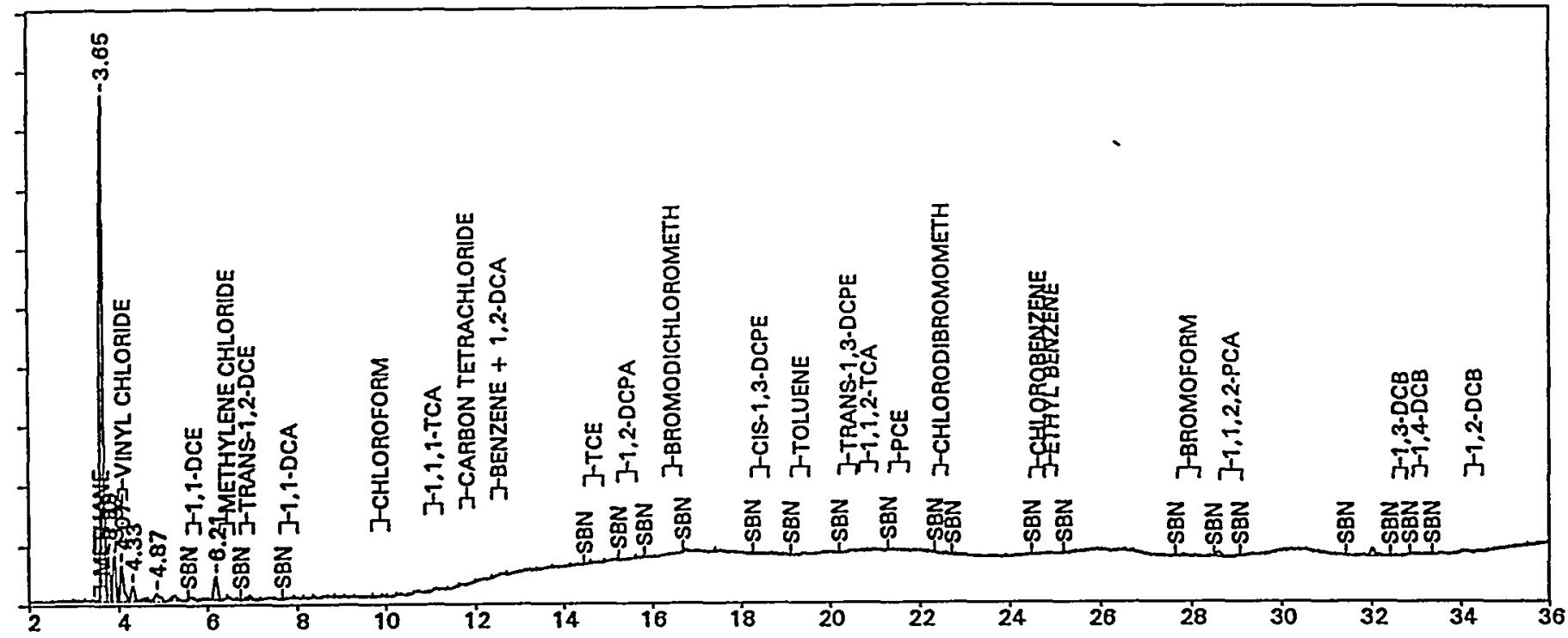

$\star * * * * * * * * * * * * * * * * * * * * * * * *$ MICROSERPS LABORATORY $* * * * * * * * * * * * * * * * * * * * * * * * *$ $\star$

* SAMPle Name....... 904-111G-8 OPERATOR...ADS

* RAW DATA FILE NAME. . C: \CP\D23\W23A1.62R

* DATE ANALYZED...... SEP 23, 1992 00:47:52

* REPORT DATE... 01-27-1999

* METHOD FILE.... C: CCP\D23\W23A624.MET

* cal file....... C: \CP\D23\W23A624.CAL

* INSTRUMENT.... 7000/5890/FID PEAK WIDTH.... .08

* RUN TIME...... 53.245

* area REJECT.... 40

* SAMPLE WEIGHT. . 1

* AMT INJECTED... 1 THRESHOLD.....-4

* METHOD VERSION. 11 -- LAST MODIFIED... 09/15/92 11:36:58

*. CAL VERSION.... 15 -- LAST MODIFIED... 06/04/92 09:28:32

* HP REF FILE. . . Q538DC3Ab\#162

COM PORT...... 1

DII FACTOR.... I 1

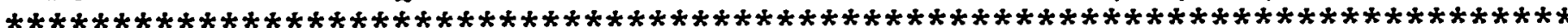

\begin{tabular}{|c|c|c|c|c|c|c|c|c|c|c|}
\hline $\begin{array}{l}\text { Out of } \\
\text { Bound }\end{array}$ & $\begin{array}{l}\text { Ret Time } \\
\text { (min) }\end{array}$ & Peak Name & $\begin{array}{l}\text { Amount } \\
\text { PPHV }\end{array}$ & $\begin{array}{l}\text { \% Delta } \\
\text { Ret Time }\end{array}$ & $\begin{array}{l}\text { Peak } \\
\text { Area }\end{array}$ & AREA $\%$ & $\begin{array}{l}\text { Amount/ } \\
\text { Area }\end{array}$ & $\begin{array}{c}\text { Peak } \\
\#\end{array}$ & $\begin{array}{r}\text { Peak } \\
\text { Height }\end{array}$ & $\begin{array}{l}u g / l \\
\text { AIR }\end{array}$ \\
\hline & 3.648 & METHANE & 2.129 & $1.04 \%$ & 1257 & 70.81 & 0.0016931 & 1 & 282 & 0.000 \\
\hline & 4.075 & VIHYL CHLORIDE & 0.734 & $-0.86 \%$ & 114 & 6.44 & 0.0064175 & 4 & 20 & 0.000 \\
\hline
\end{tabular}

Total amt. ID. $=2.862413$

Total area $($ all peaks $)=1775.765$ 


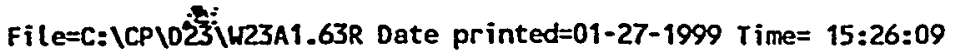

Sample Name $=904-1116-9$

2.0 to $36.0 \mathrm{~min}$. Low $Y=0.392$ High $Y=2.089 \mathrm{mv}$ Span=1.697

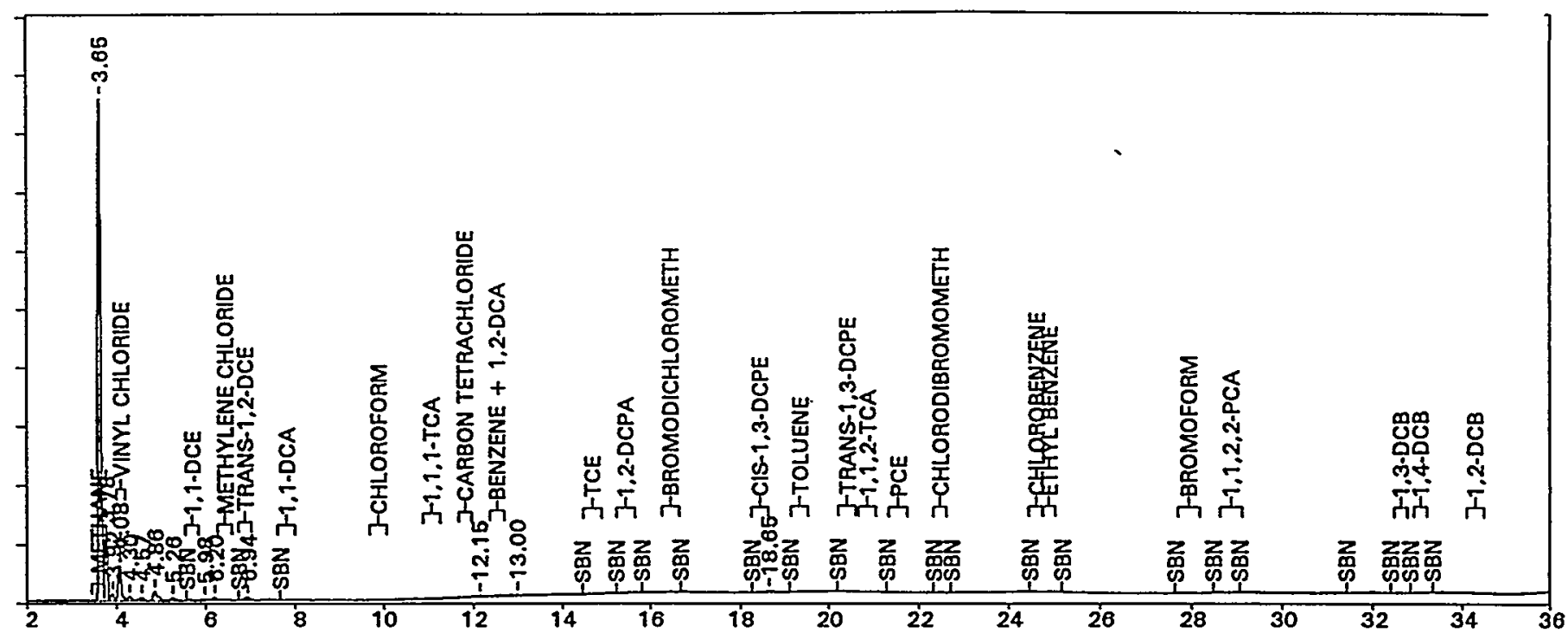

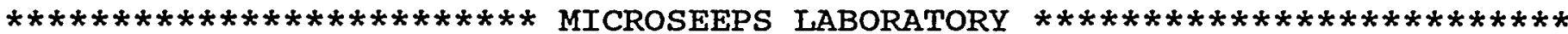
$\dot{x}$

* SAMPLE NAME....... 904-111G-9

OPERATOR...ADS

* RAW DATA FILE NAME.. C: \CP\D23\W23A1.63R

* DATE ANALYZED....... SEP 23, 1992 01:54:53

* REPORT DATE... 01-27-1999

* METHOD FILE.... C: \CP\D23\W23A624.MET

* CAI FIIE...... C: \CP\D23\W23A624.CAL

* INSTRUMENT.....7000/5890/FID PEAK WIDTH.....08

* RUN TIME...... 53.245

* AREA REJECT.... 40

* SAMPLE WEIGHT.. 1

* AMT INJECTED... 1

* METHOD VERSION. 11

* CAI VERSION.... 1

* HP REF FILE.... Q538EBEFb\#163

THRESHOLD..... -4

COM PORT...... 1

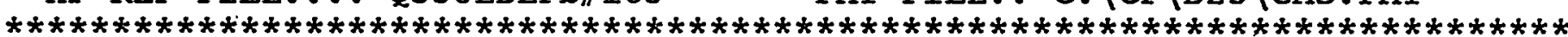

\begin{tabular}{|c|c|c|c|c|c|c|c|c|c|c|}
\hline $\begin{array}{l}\text { Out of } \\
\text { Bound }\end{array}$ & $\begin{array}{l}\text { Ret Time } \\
\text { (min) }\end{array}$ & Peak Name & $\begin{array}{l}\text { Amount } \\
\text { PPMV }\end{array}$ & $\begin{array}{l}\text { \% Del ta } \\
\text { Ret Time }\end{array}$ & $\begin{array}{l}\text { Peak } \\
\text { Area }\end{array}$ & AREA $\boldsymbol{x}$ & $\begin{array}{c}\text { Amount/ } \\
\text { Area }\end{array}$ & $\begin{array}{c}\text { Peak } \\
\#\end{array}$ & $\begin{array}{r}\text { Peak } \\
\text { Height }\end{array}$ & $\begin{array}{l}\text { ug/l } \\
\text { AIR }\end{array}$ \\
\hline & 3.648 & METHANE & 10.926 & $1.04 \%$ & 6423 & 74.76 & 0.0017011 & 1 & 1449 & 0.000 \\
\hline & 4.079 & VINYL CHLORIDE & 3.313 & $-0.75 \%$ & 520 & 6.05 & 0.0063742 & 4 & 102 & 0.000 \\
\hline & 6.943 & TRANS-1,2-DCE & 1.432 & $0.91 \%$ & 79 & 0.92 & 0.0181932 & 12 & 9 & 0.000 \\
\hline
\end{tabular}

Total amt. ID. $=15.67158$

DII FACTOR.... 1

SAMPLE RATE... 3.333333

Total area (all peaks) $=8591.569$ 
File=C:ICPYO23IW23A1.64R Date printed $=01-27-1999$ Time= $15: 27: 34$

Sample Hame $=904-111 \mathrm{G}-10$

2.n to $36.0 \mathrm{~min}$. LoH $Y=0.399$ High $Y=0.834 \mathrm{mv}$ Span=0.435

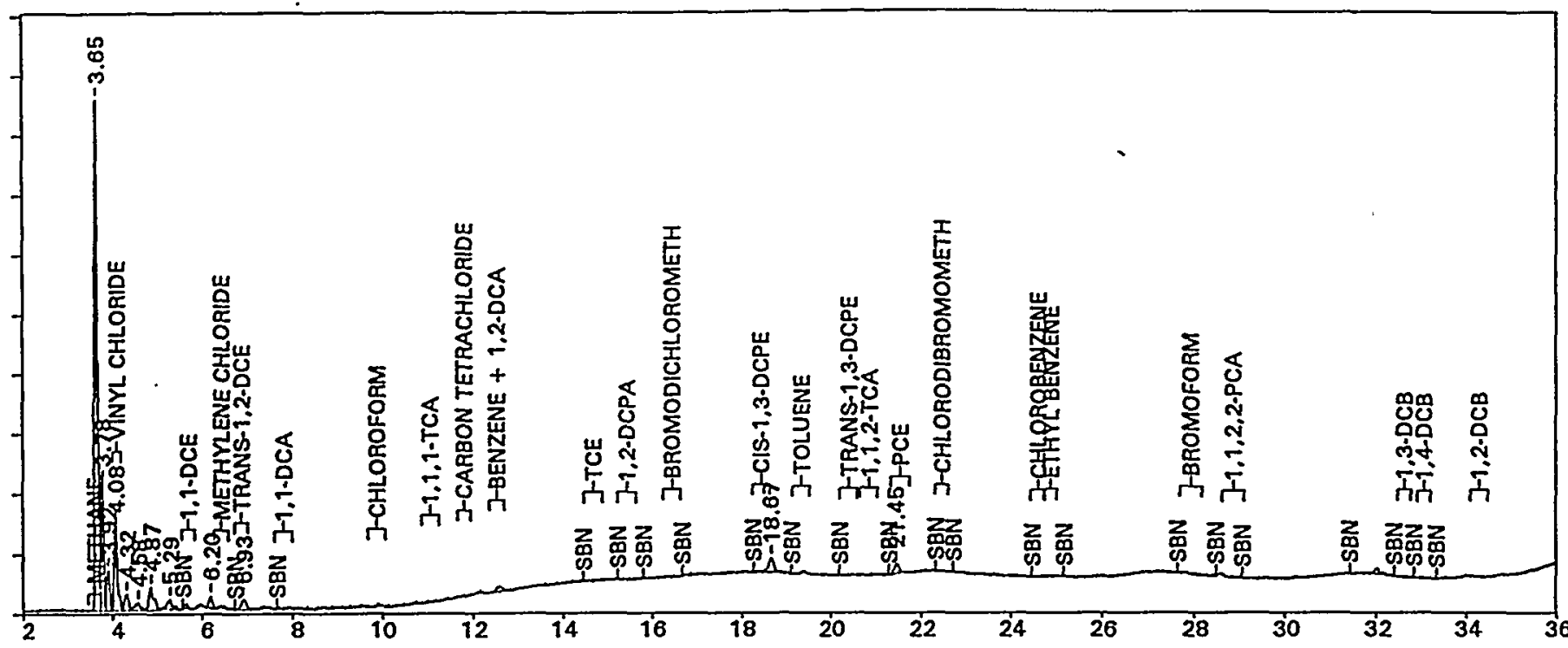

$* * * * * * * * * * * * * * * * * * * * * * * * *$ MICROSEEPS IJABORATORY $* * * * * * * * * * * * * * * * * * * * * * * * *$ $*$

* SAMPLE NAME....... 904-111G-10

* RAW DATA FILE NAME.. C: |CP\D23\W23A1.64R

* DATE ANATYZED....... SEP 23, 1992 03:01:38

* REPORT DATE... 01-27-1999

* METHOD FILE.... C: \CP\D23\W23A624.MET

* CAL FILE...... C: \CP\D23\W23A624.CAL

* INSTRUMENT.... 7000/5890/FID

* RUN TIME...... 53.245

* AREA REJECT....40

* SAMPLE WEIGHT. 1

* AMT INJECTED... 1

PEAK WIDTH.....08

OPERATOR ...ADS

* METHOD VERSION. 11

* CAI VERSION.... 15

* HP REF FIIE.... Q538FB94b\#164

THRESHOLD..... -4

COM PORT....... 1

DIL FACTOR ... 1

SAMPIE RATE... 3.333333

$\star * * * * * * * * * * * * * * * * * * * * * * * * * * * * * * * * * * * * * * * * * * * * * * * * * * * * * * * * * * * * * * * * * * * * * * * *$

\begin{tabular}{|c|c|c|c|c|c|c|c|c|c|c|}
\hline $\begin{array}{l}\text { Out of } \\
\text { Bound }\end{array}$ & $\begin{array}{l}\text { Ret Time } \\
\text { (min) }\end{array}$ & Peak Name & $\begin{array}{c}\text { Amount } \\
\text { PPNV }\end{array}$ & $\begin{array}{r}\text { \% Delta } \\
\text { Ret Time }\end{array}$ & $\begin{array}{l}\text { Peak } \\
\text { Area } \\
\end{array}$ & AREA $\%$ & $\begin{array}{l}\text { Amount/ } \\
\text { Area }\end{array}$ & $\begin{array}{c}\text { Peak } \\
\#\end{array}$ & $\begin{array}{r}\text { Peak } \\
\text { Height } \\
\end{array}$ & $\begin{array}{r}u g / l \\
\text { AIR } \\
\end{array}$ \\
\hline & 3.652 & METHANE & 2.803 & $1.17 \%$ & 1703 & 54.24 & 0.0016462 & .1 & 371 & 0.000 \\
\hline & 4.081 & VINYL CHLORIDE & 2.078 & $-0.79 \%$ & 326 & 10.37 & 0.0063815 & 4 & 59 & 0.000 \\
\hline & 6.934 & TRANS-1,2-DCE & 1.114 & $0.78 \%$ & 61 & 1.95 & 0.0181932 & 11 & 8 & 0.000 \\
\hline & 21.446 & PCE & 0.107 & $-0.39 \%$ & 54 & 1.73 & 0.0019709 & 14 & 8 & 0.000 \\
\hline
\end{tabular}




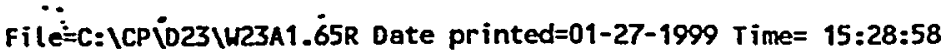

Sample Name $=904-111 \mathrm{G}-10 \mathrm{~A}$

2.0 to $36.0 \mathrm{~min}$. LoH $Y=0.401 \mathrm{High} Y=0.713 \mathrm{mv}$ Span=0.312

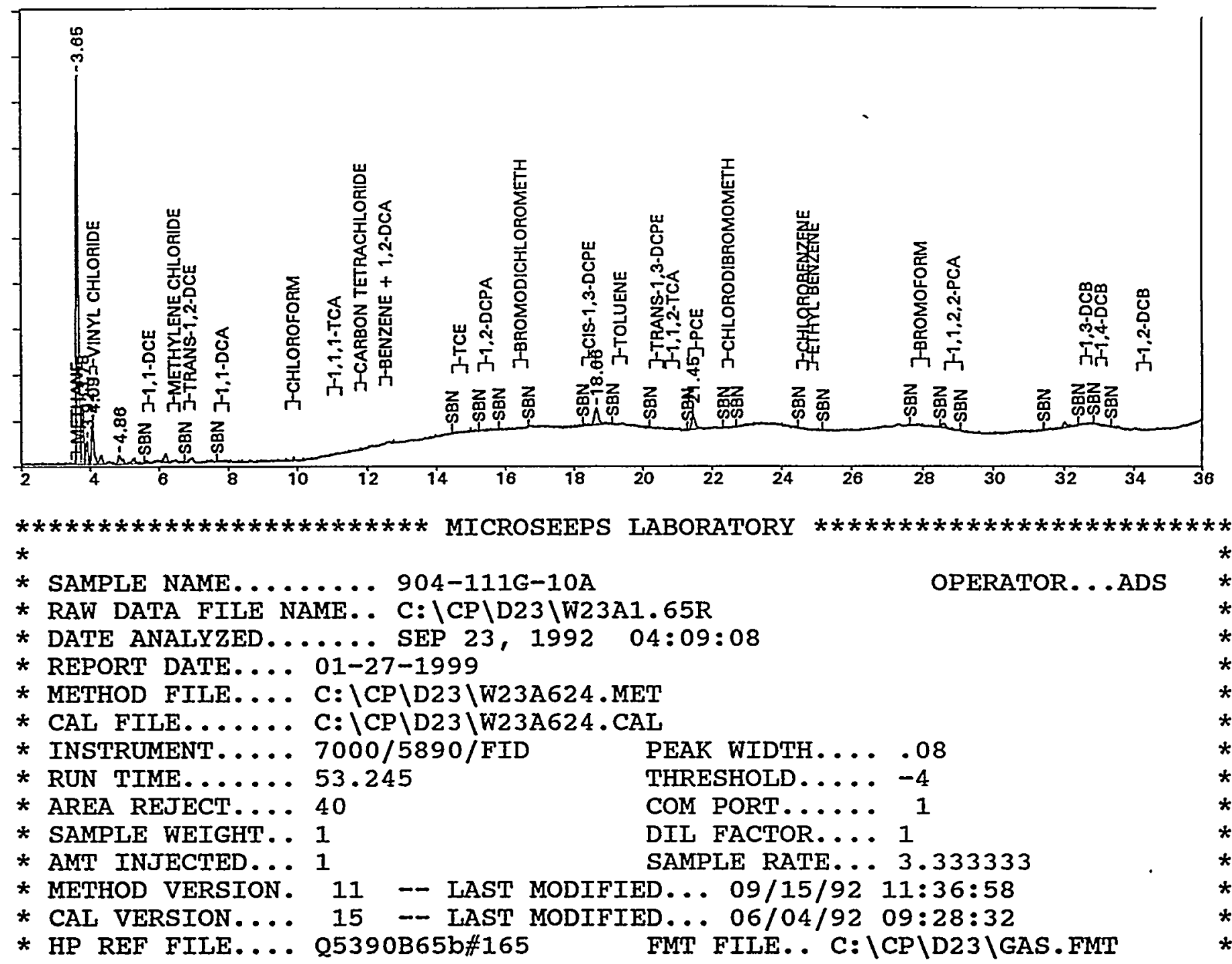

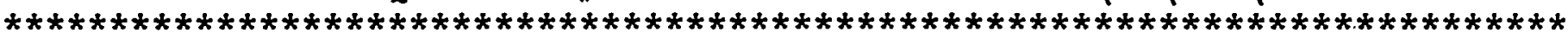

\begin{tabular}{|c|c|c|c|c|c|c|c|c|c|c|}
\hline $\begin{array}{l}\text { Out of } \\
\text { Bound }\end{array}$ & $\begin{array}{l}\text { Ret Time } \\
\text { (min) }\end{array}$ & Peak Name & $\begin{array}{l}\text { Amount } \\
\text { PPHY }\end{array}$ & $\begin{array}{r}\text { * Delta } \\
\text { Ret Time }\end{array}$ & $\begin{array}{l}\text { Peak } \\
\text { Area } \\
\end{array}$ & AREA $\%$ & $\begin{array}{l}\text { Amount/ } \\
\text { Area }\end{array}$ & $\begin{array}{c}\text { Peak } \\
\# \\
\end{array}$ & $\begin{array}{r}\text { Peak } \\
\text { Height } \\
\end{array}$ & $\begin{array}{r}\text { ug/l } \\
\text { AIR } \\
\end{array}$ \\
\hline & 3.653 & METHANE & 2.013 & $1.19 \%$ & 1198 & 66.03 & 0.0016811 & 1 & 266 & 0.000 \\
\hline & 4.088 & VIKYL CHLORIDE & 0.936 & $-0.54 \%$ & 146 & 8.06 & 0.0064054 & 4 & 27 & 0.000 \\
\hline & 21.446 & PCE & 0.130 & $-0.39 \%$ & 66 & 3.63 & 0.0019709 & 11 & 9 & 0.000 \\
\hline
\end{tabular}


File=c:ICP DDล̇3iWL23AT.66R Date printed=01-27-1999 Time= 15:30:21

Sample Name $=904-111 \mathrm{G}^{\star} \mathrm{SB2}$

2.0 to $36.0 \mathrm{~min}$. LOH $Y=0.402$ High $Y=0.521 \mathrm{mv}$ Span=0.119

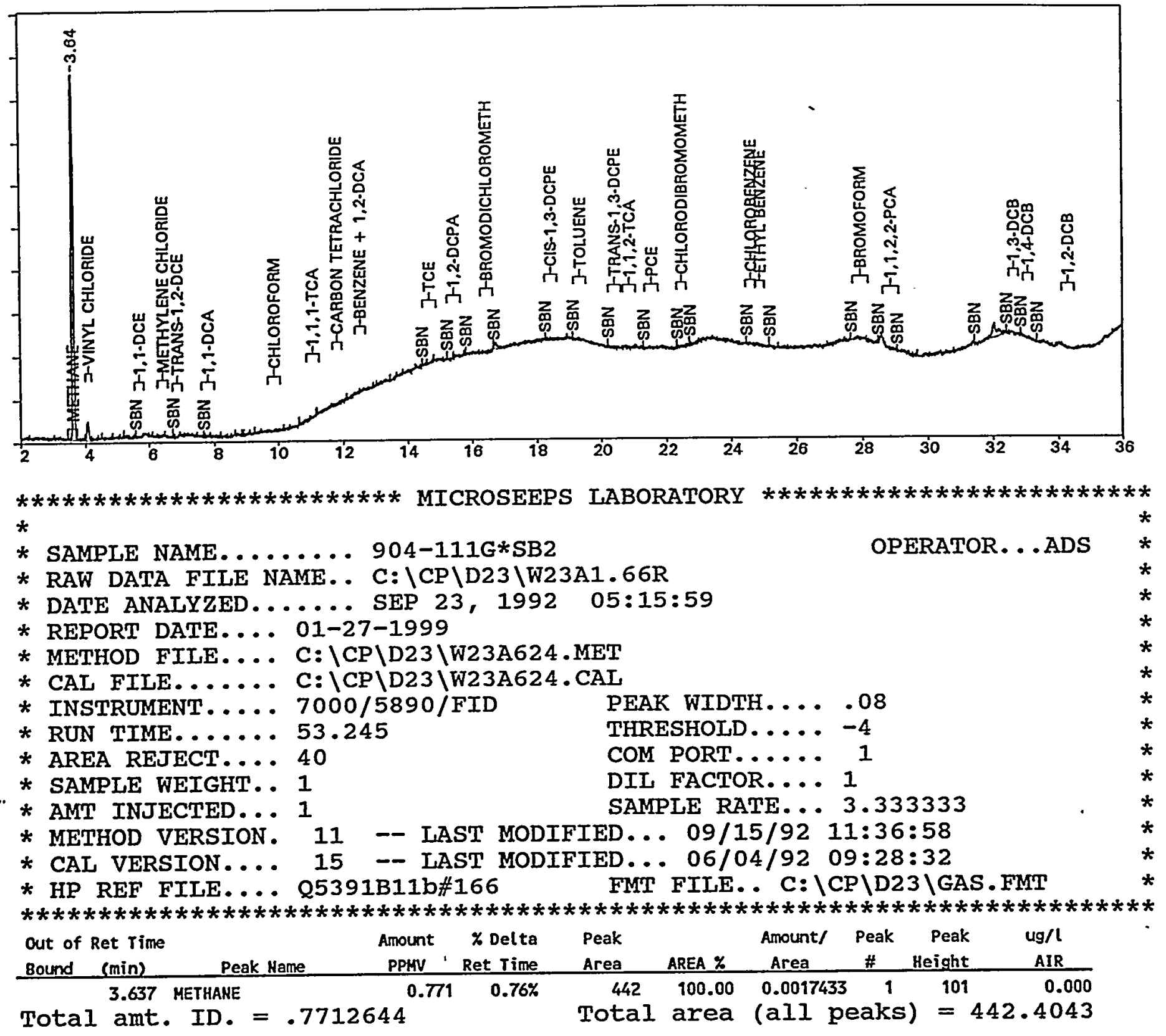


File=G: \CP \D23 \W23A1.67R. Date printed=01-27-1999 Time= 15:31:44 Sample Name=STD $K 4$ R4

2.0 to 36.0 min. Lor $Y=-7.727$ High $Y=1686.362 \mathrm{mv}$ Span=1694.089

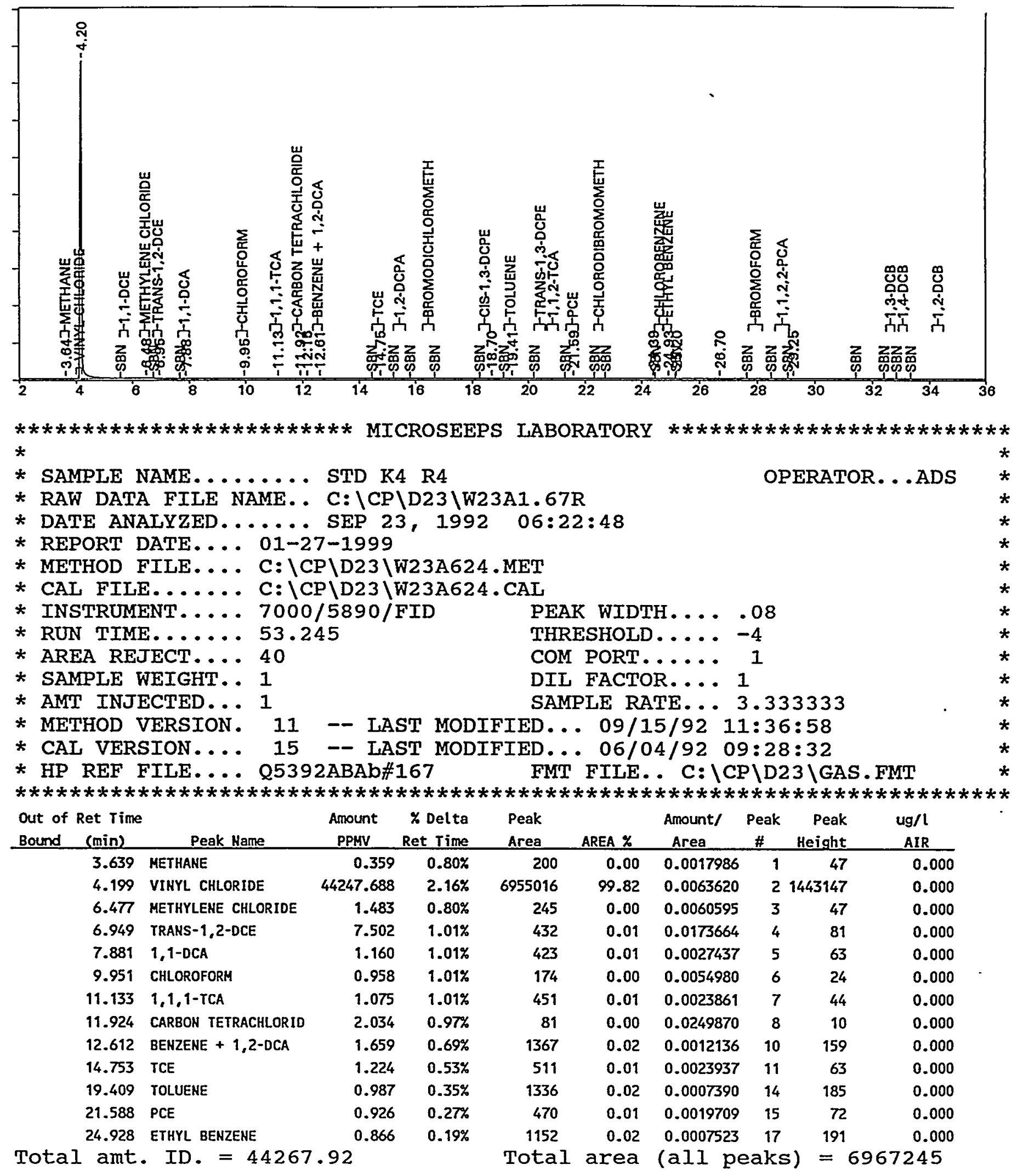


File=C:iCP1023IW23A1.68R Date printed=01-27-1999 $\mathrm{Time}=15: 33: 10$

Sample Nảme $=904-1116-11^{\circ}$

2.0 to $36.0 \mathrm{~min}$. Low $Y=0.394$ High $Y=0.672 \mathrm{mv}$ Span=0.277

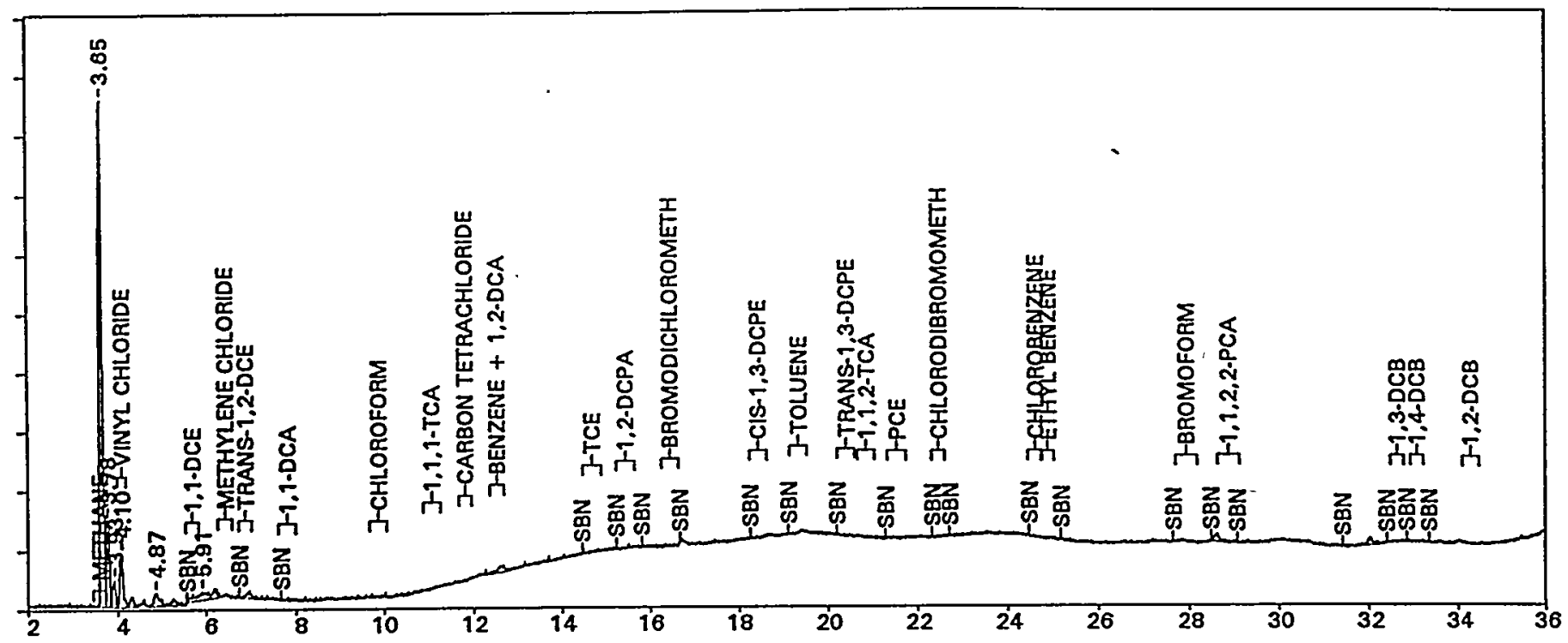

$* * * * * * * * * * * * * * * * * * * * * * * * *$ MICROSEEPS IABORATORY $* * * * * * * * * * * * * * * * * * * * * * * * *$ *

* SAMPLE NAME........ 904-111G-11

* RAW DATA FILE NAME.. C: \CP\D23\W23A1.68R

* DATE ANALYZED....... SEP 23, 1992 07:29:39

* REPORT DATE. . . 01-27-1999

* METHOD FILE.... C: \CP\D23\W23A624.MET

* CAL FILE....... C: \CP\D23\W23A624.CAL

* INSTRUMENT.... 7000/5890/FID PEAK WIDTH.....08

* RUN TIME...... 53.245

* AREA REJECT.... 40

* SAMPLE WEIGHT. . 1

* AMT INJECTED... 1

* METHOD VERSION. 11 - LAST MODIFIED... 09/15/92 11:36:58

* CAI VERSION.... 15 -- LAST MODIFIED... 06/04/92 09:28:32

* HP REF FILE.... Q5393A65b\#168 FMT FILE.. C: \CP\D23\GAS.FMT

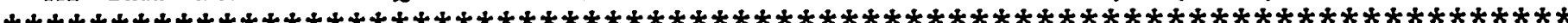

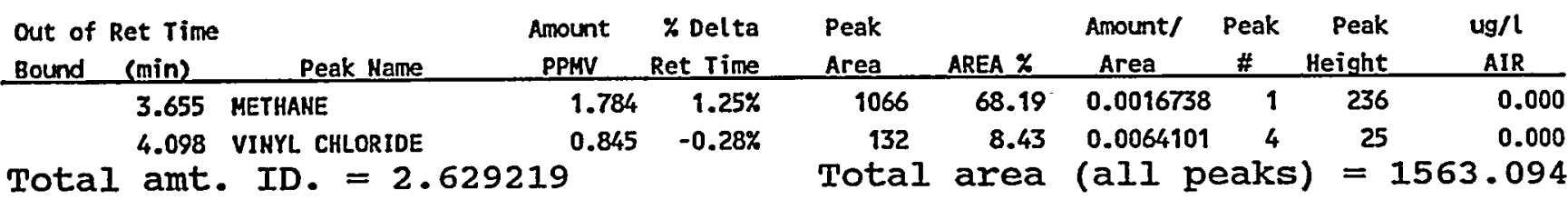


File $=$ C: \CP \D23 $1 H 23 A 1.698$ Date printed $=01-27-1999$ Time $=15: 34: 32$

Sample Hame $=904-111 \mathrm{G}-12$

2.0 to $36.0 \mathrm{~min}$. LoH $Y=0.398$ High $Y=0.627 \mathrm{mv}$ Span=0.228

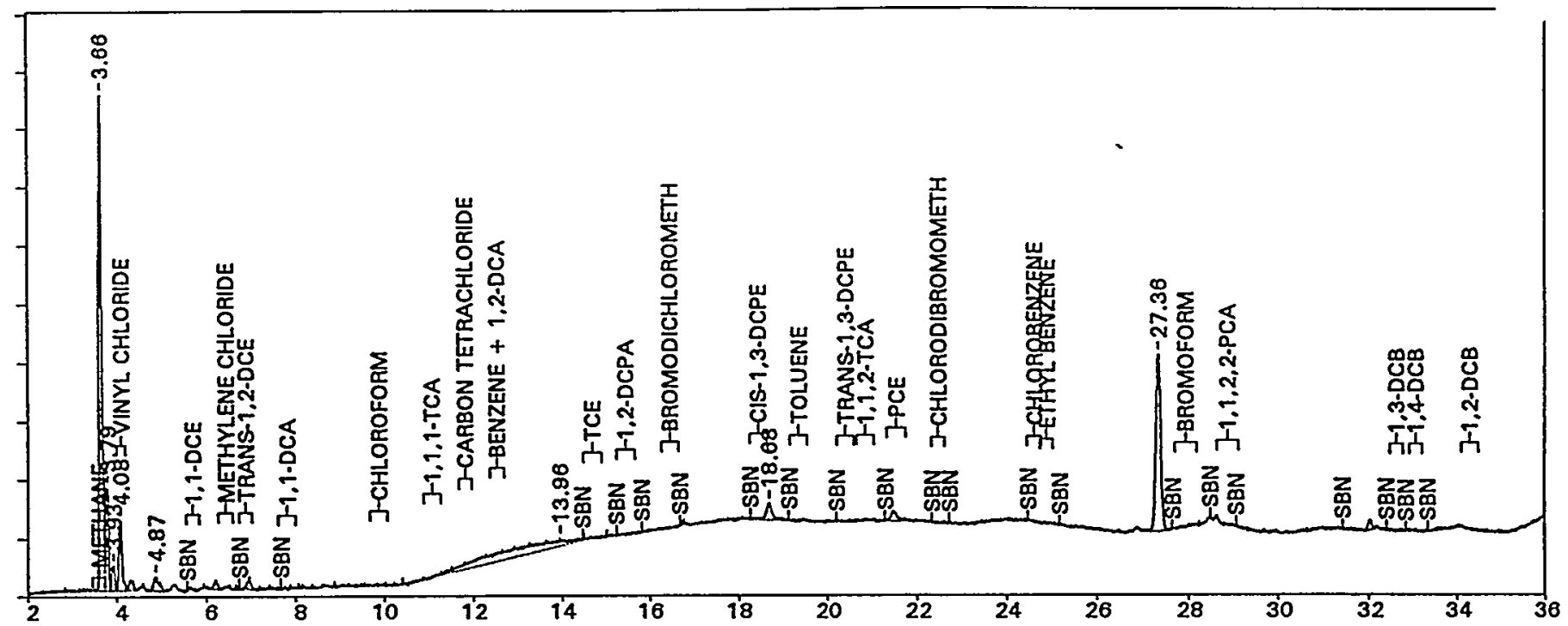

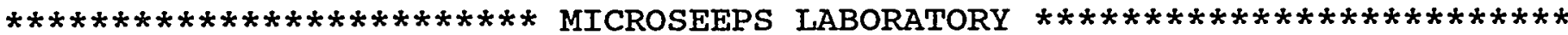
$\star$

* SAMPLE NAME........ 904-111G-12

* RAW DATA FIIE NAME. C C: \CP\D23\W23A1.69R

* DATE ANALYZED....... SEP 23, 1992 08:38:29

* REPORT DATE... 01-27-1999

* METHOD FIIE.... C: $\backslash$ CP \D23\W23A624.MET

* CAL FIIE...... C: \CP\D23\W23A624.CAI

* INSTRUMENT.... 7000/5890/FID PEAK WIDTH....08

* RUN TIME...... 53.245 THRESHOLD.... -4

* AREA REJECT... 40 COM PORT..... 1

* SAMPLE WEIGHT. 1 DIL FACTOR.... 1

* AMT INJECTED... 1 SAMPLE RATE.. 3.333333

* METHOD VERSION. 11 - LAST MODIFIED. . 0 09/15/92 11:36:58

* CAI VERSION.... 15 -- LAST MODIFIED... 06/04/92 09:28:32

* HP REF FIIE.... Q5394A87b\#169 FMT FILE.. C: ICP \D23 \GAS.FMT

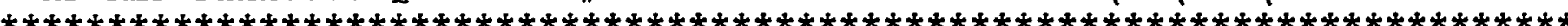

\begin{tabular}{|c|c|c|c|c|c|c|c|c|c|c|}
\hline $\begin{array}{l}\text { Out of } \\
\text { Bound }\end{array}$ & $\begin{array}{l}\text { Ret Time } \\
\text { (min) }\end{array}$ & Peak Name & $\begin{array}{l}\text { Amount } \\
\text { PPKV }\end{array}$ & $\begin{array}{l}\text { \% Delta } \\
\text { Ret Time } \\
\end{array}$ & $\begin{array}{l}\text { Peak } \\
\text { Area } \\
\end{array}$ & AREA $x$ & $\begin{array}{l}\text { Amount/ } \\
\text { Area }\end{array}$ & $\begin{array}{c}\text { Peak } \\
\# \\
\end{array}$ & $\begin{array}{r}\text { Peak } \\
\text { Height }\end{array}$ & $\begin{array}{r}\text { ug/l } \\
\text { AIR }\end{array}$ \\
\hline & 3.659 & METHANE & 1.463 & $1.35 \%$ & 885 & 38.76 & 0.0016534 & 1 & 193 & 0.000 \\
\hline & 4.080 & VINYL CHLORIDE & 0.898 & $-0.72 \%$ & 140 & 6.14 & 0.0064072 & 4 & 27 & 0.000 \\
\hline
\end{tabular}

Total amt. ID. $=2.361759 \quad$ Total area $($ all peaks $)=2283.139$ 
file=C: ICPID23 \U23A1.70R Date printed=01-27-1999 Time= 15:35:55

Sample Hame $=904-111 \mathrm{G}-13$

2.0 to $36.0 \mathrm{~min}$. LoH $Y=0.396 \mathrm{High} Y=0.907 \mathrm{mV}$ Span=0.51

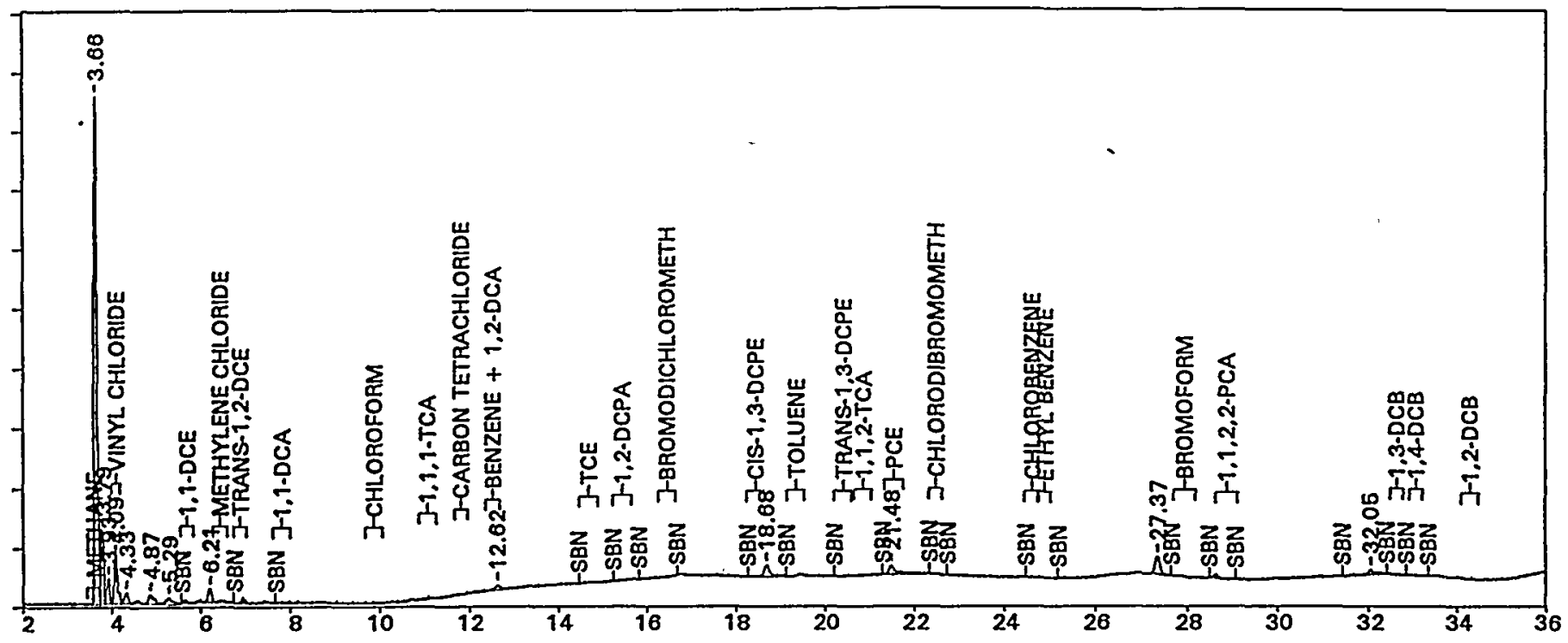

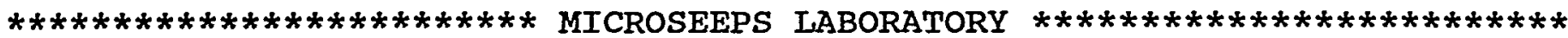
$\star$

* SAMPle NAME....... 904-111G-13

* RAW DATa FILE NAME.. C: \CP\D23\W23A1.70R

* DATE ANALYZED...... SeP 23, 1992 09:46:21

* REPORT DATE.... 01-27-1999

* METHOD FILE.... C: \CP\D23\W23A624.MET

* CAL FILE....... C: \CP\D23\W23A624. CAL

* INSTRUMENT.... 7000/5890/FID PEAK WIDTH.... .08

* RUN TIME...... 53.245

* aREA REJECT. . . 40

* SAMPLE WEIGHT. . 1

THRESHOLD..... -4

* AMT INJECTED... 1

COM PORT...... 1

* METHOD VERSION. 11

DII FACTOR.... 1

* CAL VERSION.... 15 -- LAST MODIFIED... 06/04/92 09:28:32

* HP REF FILE.... Q5395A6Eb\#170 FMT FILE.. C: ICP\D23 \GAS.FMT

OPERATOR...ADS

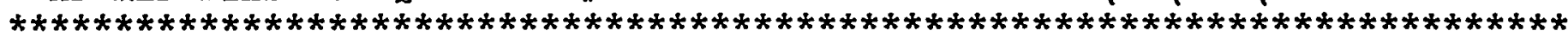

\begin{tabular}{|c|c|c|c|c|c|c|c|c|c|}
\hline $\begin{array}{l}\text { Out of Ret Time } \\
\text { Bound (min) }\end{array}$ & Peak Name & $\begin{array}{l}\text { Amount } \\
\text { PPMV }\end{array}$ & $\begin{array}{l}\text { * Delta } \\
\text { Ret Time }\end{array}$ & $\begin{array}{l}\text { Peak } \\
\text { Area }\end{array}$ & AREA $\%$ & $\begin{array}{l}\text { Amount/ } \\
\text { Area }\end{array}$ & $\begin{array}{c}\text { Peak } \\
\#\end{array}$ & $\begin{array}{r}\text { Peak } \\
\text { Height }\end{array}$ & $\begin{array}{r}u g / l \\
\text { AIR }\end{array}$ \\
\hline 3.661 & METHAME & 3.281 & $1.40 \%$ & 1966 & 60.16 & 0.0016690 & 1 & 434 & 0.000 \\
\hline 4.090 & VIHYL, CHLORIDE & 1.408 & $-0.48 \%$ & 220 & 6.74 & 0.0063908 & 4 & 38 & 0.000 \\
\hline 12.622 & BENZENE $+1,2-D C A$ & 0.086 & $0.77 \%$ & 71 & 2.18 & 0.0012136 & 11 & 5 & 0.000 \\
\hline 21.485 & PCE & 0.201 & $-0.21 \%$ & 102 & 3.13 & 0.0019709 & 13 & 8 & 0.000 \\
\hline
\end{tabular}


File=c: ICP ID23 IW23A1.71R Date printed=01-27-1999 Time= 15:37:20

Sample Name $=904-111 \mathrm{G}-14$

2.0 to $36.0 \mathrm{~min}$. LOH $Y=0.393$ High $Y=0.748 \mathrm{mv}$ Span $=0.354$

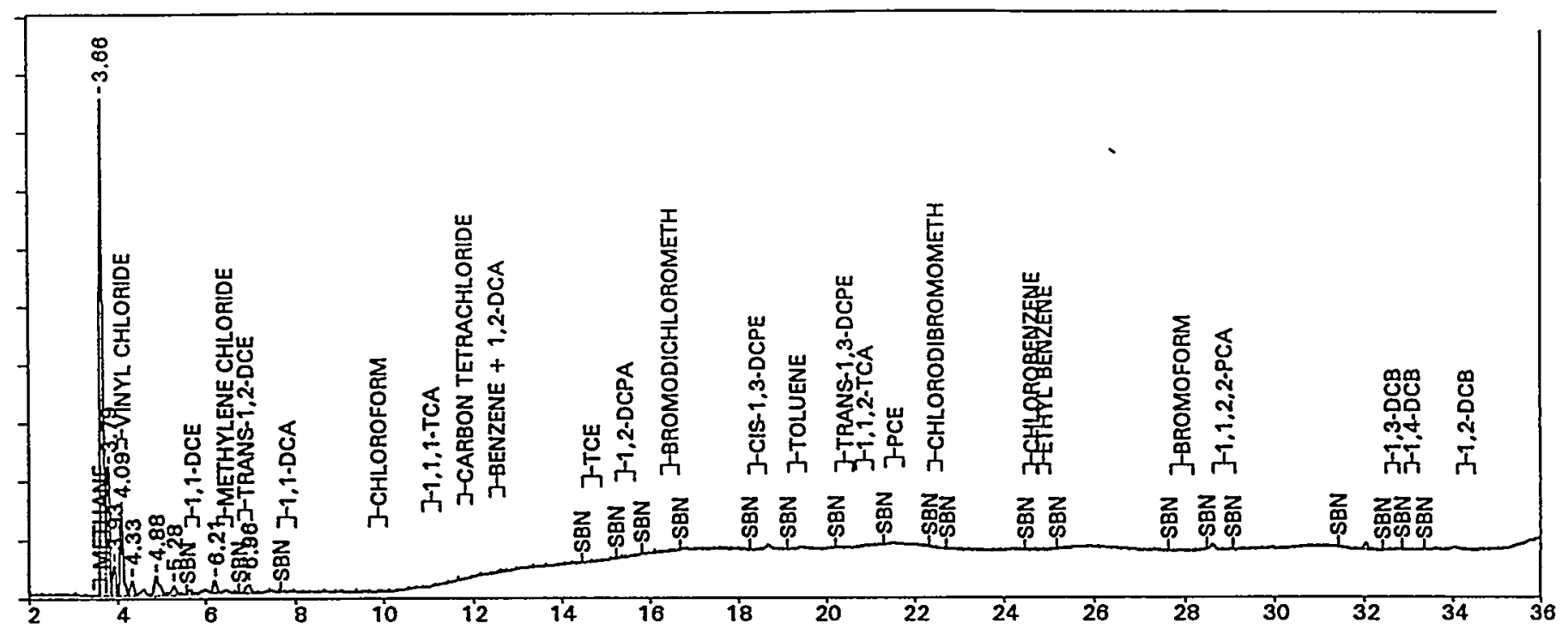

$\star * \star * * * * * * * * * * * * * * * * * * * * * *$ MICROSEEPS ILABORATORY $* * * * * * * * * * * * * * * * * * * * * * * * *$ *

* SAMPLE NAME........ 904-111G-14

* RAW DATA FILE NAME.. C: ICP\D23\W23A1.71R

* DATE ANALYZED....... SEP 23, 1992 10:54:09

* REPORT DATE... 01-27-1999

* METHOD FILE.... C: \CP \D23\W23A624.MET

* CAI FILE...... C: \CP\D23\W23A624.CAL

* INSTRUMENT.... 7000/5890/FID

* RUN TIME...... 53.245

* arEa REJECT... 40

* SAMPIE WETGHT.. 1

* AMT INJECTED... 1

* METHOD VERSION. 11 - LAST MODIFIED .. 09/15/92 11:36:58

* CAL VERSION.... 15 - - LAST MODIFIED... 06/04/92 09:28:32

* HP REF FILE... Q5396A52b\#171

FMT FILE.. C: \CP\D23\GAS.FMT

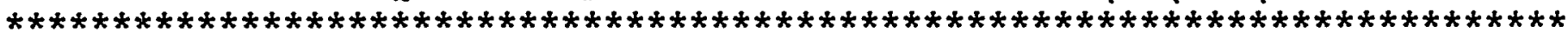

\begin{tabular}{|c|c|c|c|c|c|c|c|c|c|c|}
\hline $\begin{array}{l}\text { Out of } \\
\text { Bound }\end{array}$ & $\begin{array}{l}\text { Ret Time } \\
\text { (min) }\end{array}$ & Peak Name & $\begin{array}{l}\text { Amount } \\
\text { PPHV }\end{array}$ & $\begin{array}{l}\text { \% Delta } \\
\text { Ret Time }\end{array}$ & $\begin{array}{l}\text { Peak } \\
\text { Area }\end{array}$ & AREA $\%$ & $\begin{array}{l}\text { Amount/ } \\
\text { Area }\end{array}$ & $\begin{array}{c}\text { Peak } \\
\#\end{array}$ & $\begin{array}{r}\text { Peak } \\
\text { Height }\end{array}$ & $\begin{array}{r}\text { ug/l } \\
\text { AIR }\end{array}$ \\
\hline & 3.660 & METHANE & 2.279 & $1.37 \%$ & 1351 & 57.59 & 0.0016870 & 1 & 301 & 0.000 \\
\hline & 4.090 & VINYL CHLORIDE & 1.632 & $-0.48 \%$ & 256 & 10.89 & 0.0063868 & 4 & 49 & 0.000 \\
\hline & 6.958 & TRANS-1,2-DCE & 0.904 & $1.14 \%$ & 50 & 2.12 & 0.0181932 & 10 & 5 & 0.000 \\
\hline
\end{tabular}

Total amt. ID. $=4.814771$

Total area (all peaks) $=2345.69$ 
Fíle=C: \CP\D23 IL23A1 $-72 R$ Date printed=01-27-1999 Time= 15:38:44

Sample Hame $=904-1116-15$

2.0 to $36.0 \mathrm{~min}$. LoH $Y=0.389$ High $Y=1.892 \mathrm{mv}$ Span=1.503

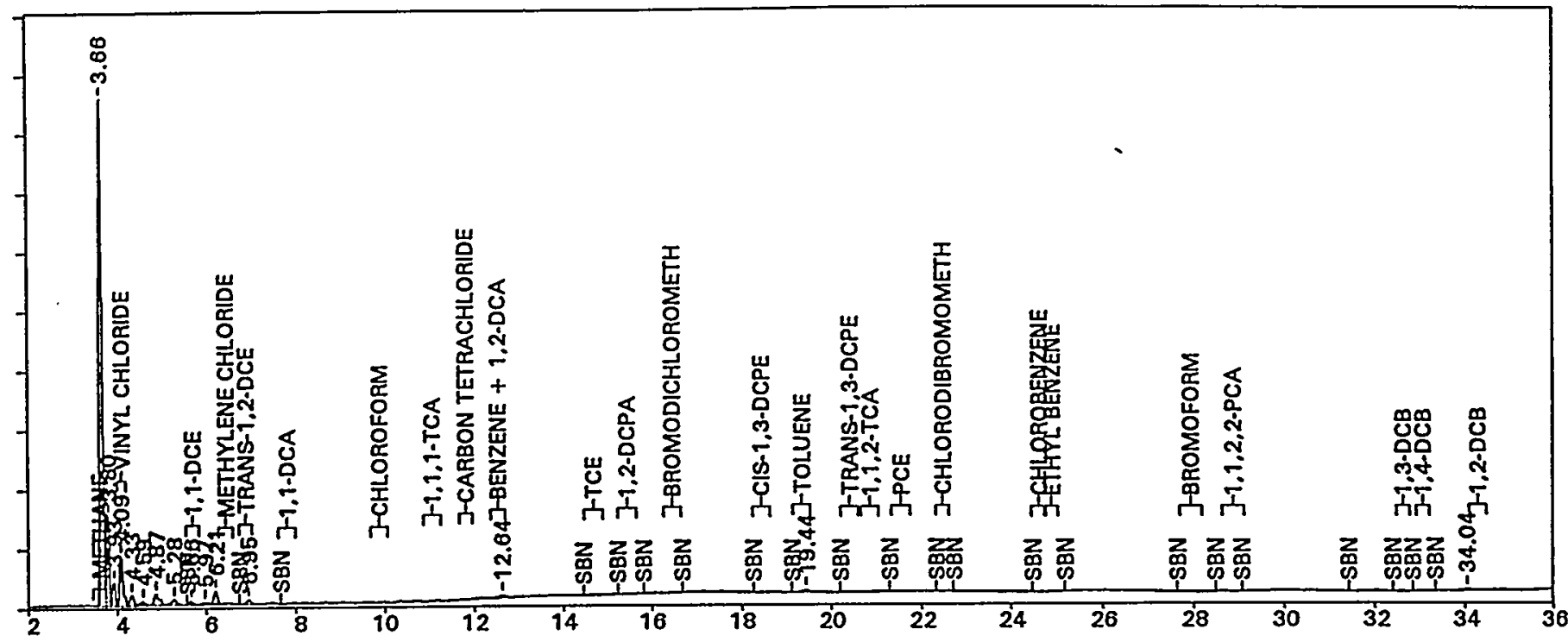

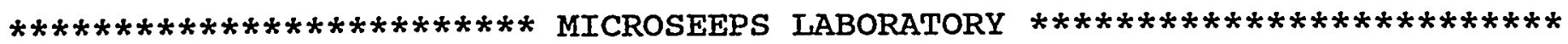
$*$

* SAMPLE NAME. . . . . . 904-111G-15

* RAW DATA FIIE NAME.. C: \CP\D23\W23A1.72R

* DATE ANALYZED....... SEP 23, 1992 12:01:55

* REPORT DATE... 0 01-27-1999

* METHOD FILE.... C: \CP\D23\W23A624.MET

* CAL FILE....... C: \CP\D23\W23A624.CAL

* INSTRUMENT.... 7000/5890/FID

* RUN TIME...... 53.245

* AREA REJECT.... 40

* SAMPLE WEIGHT. . 1

* AMT INJECTED... 1

* METHOD VERSION. 11 -- IAST MODIFIED... 09/15/92 11:36:58

* CAL VERSION.... 15 -- IAST MODIFIED... 06/04/92 09:28:32

* HP REF FILE.... Q5397A34b\#172 FMT FILE.. C: \CP\D23 \GAS.FMT

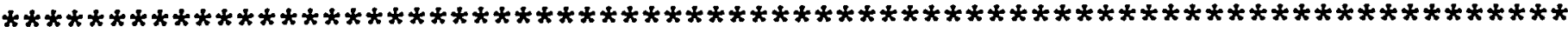

\begin{tabular}{|c|c|c|c|c|c|c|c|c|c|}
\hline $\begin{array}{l}\text { Out of Ret Time } \\
\text { Bound (min) }\end{array}$ & Peak Name & $\begin{array}{l}\text { Amount } \\
\text { PPMV }\end{array}$ & $\begin{array}{r}\text { \% Delta } \\
\text { Ret Time }\end{array}$ & $\begin{array}{l}\text { Peak } \\
\text { Area }\end{array}$ & AREA $x$ & $\begin{array}{l}\text { Amount/ } \\
\text { Area }\end{array}$ & $\begin{array}{l}\text { Peak } \\
\#\end{array}$ & $\begin{array}{r}\text { Peak } \\
\text { Height }\end{array}$ & $\begin{array}{r}\text { ug/t } \\
\text { AIR }\end{array}$ \\
\hline 3.660 & METHANE & 9.641 & 1.39\% & 5800 & 64.78 & 0.0016624 & 1 & 1279 & 0.000 \\
\hline 4.088 & VIHYL CHLORIDE & 4.312 & $-0.53 \%$ & 677 & 7.56 & 0.0063714 & 4 & 122 & 0.000 \\
\hline 5.659 & $1,1-D C E$ & 0.011 & $-0.63 \%$ & 56 & 0.62 & 0.0002046 & 9 & 10 & 0.000 \\
\hline 6.950 & TRANS-1,2-DCE & 1.562 & $1.02 \%$ & 86 & 0.96 & 0.0181932 & 12 & 11 & 0.000 \\
\hline 12.637 & BENZENE + 1,2-DCA & 0.080 & $0.89 \%$ & 66 & 0.74 & 0.0012136 & 15 & 7 & 0.000 \\
\hline 19.441 & TOLUENE & 0.052 & $0.52 \%$ & 70 & 0.78 & 0.0007390 & 16 & 5 & 0.000 \\
\hline
\end{tabular}

Total amt. ID. $=15.6589$

Total area (all peaks) $=8952.604$ 
File=C: \CP \D23\U23A1.73R Date printed $=01-27-1999$ Time= 15:40:09

Sample Name $=904-111 \mathrm{G}-16$

2.0 to $36.0 \mathrm{~min}$. Low $Y=0.387 \mathrm{High} Y=1.554 \mathrm{mv}$ Span=1.167
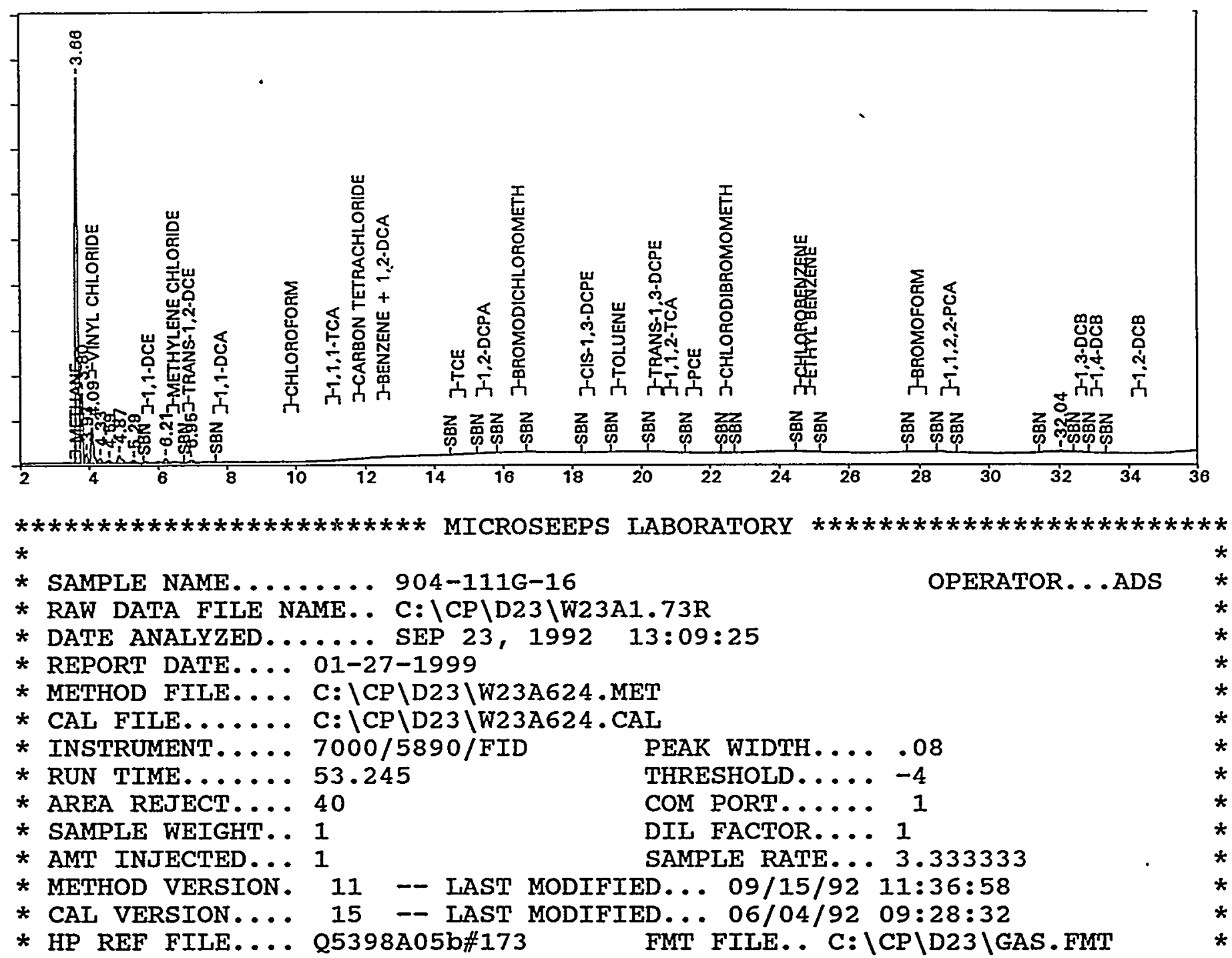
$* * * * * * * * * * * * * * * * * * * * * * * * * * * * * * * * * * * * * * * * * * * * * * * * * * * * * * * * * * * * * * * * * * * * * * * * *$

\begin{tabular}{|c|c|c|c|c|c|c|c|c|c|c|}
\hline $\begin{array}{l}\text { Out of } \\
\text { Bound }\end{array}$ & $\begin{array}{l}\text { Ret Time } \\
\text { (min) }\end{array}$ & Peak Name & $\begin{array}{l}\text { Amount } \\
\text { PPHV }\end{array}$ & $\begin{array}{l}\text { \% Delta } \\
\text { Ret Time }\end{array}$ & $\begin{array}{l}\text { Peak } \\
\text { Area }\end{array}$ & AREA $\%$ & $\begin{array}{l}\text { Amount/ } \\
\text { Area }\end{array}$ & $\begin{array}{c}\text { Peak } \\
\#\end{array}$ & $\begin{array}{r}\text { Peak } \\
\text { Height }\end{array}$ & $\begin{array}{r}\text { ug/l } \\
\text { AIR }\end{array}$ \\
\hline & 3.661 & METHANE & 7.484 & $1.41 \%$ & 4469 & 69.01 & 0.0016746 & 1 & .992 & 0.000 \\
\hline & 4.093 & VINYL CHLORIDE & 3.151 & $-0.41 \%$ & 494 & 7.63 & 0.0063748 & 4 & 92 & 0.000 \\
\hline & 6.948 & TRANS-1,2-DCE & 1.132 & $0.99 \%$ & 62 & 0.96 & 0.0181932 & 12 & 7 & 0.000 \\
\hline
\end{tabular}




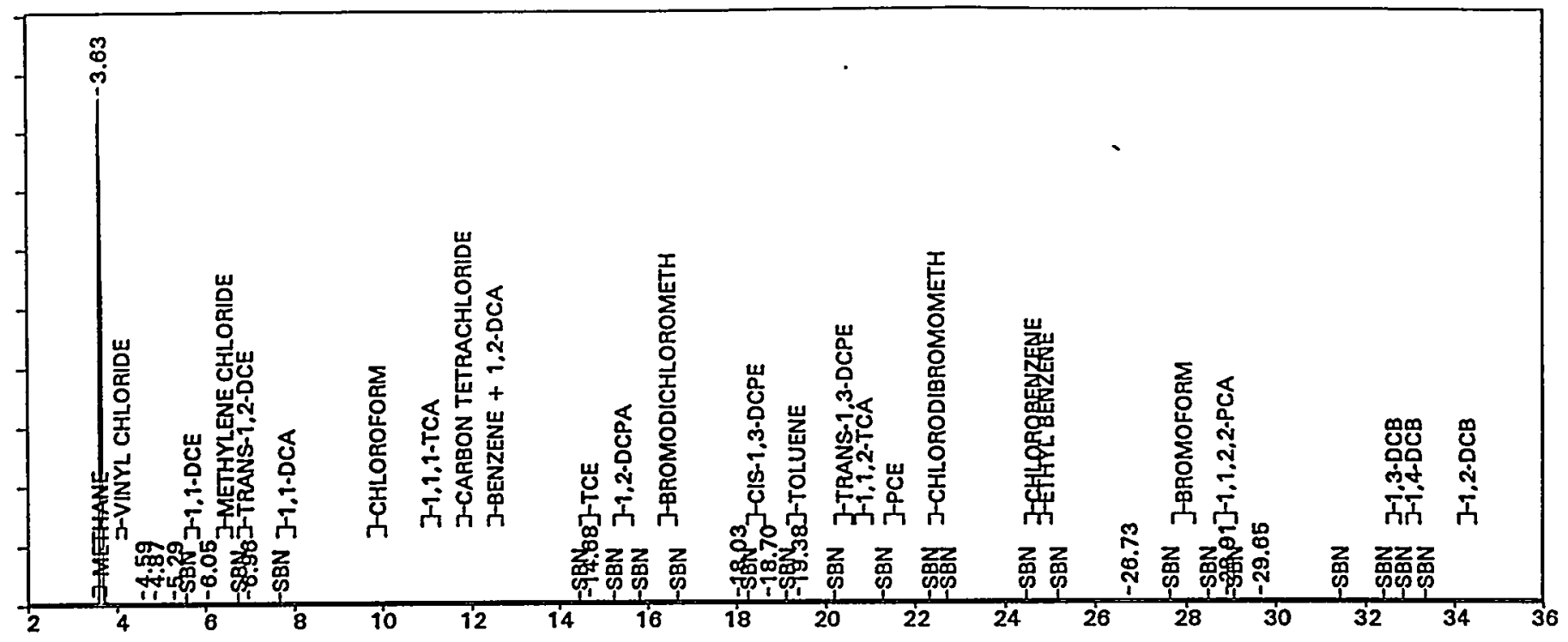

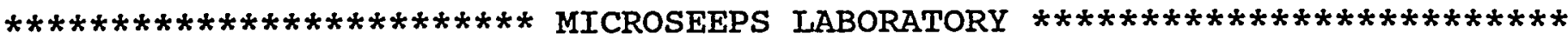
*

* SAMPLE NAME....... 904-111G-17

* RAW DATA FILE NAME.. C: |CP\D23 |W23A1.74R

* DATE ANALYZED........ SEP 23, 1992 14:30:41

* REPORT DATE... 01-27-1999

* METHOD FILE... C: C \CP\D23\W23A624.MET

* CAL FILE....... C: \CP $\mid D 23 \backslash W 23 A 624 . C A L$

* INSTRUMENT.... 7000/5890/FID PEAK WIDTH....08

* RUN TIME...... 53.245

* AREA REJECT... 40

* SAMPIE WEIGHT. . 1

* AMT INJECTED... 1 THRESHOLD .... -4

COM PORT....... 1

* METHOD VERSION. 11 - LAST MODIFIED... 09/15/92 11:36:58

* CAL VERSION.... 15 - LAST MODIFIED... 06/04/92 09:28:32

* HP REF FILE.... Q5399D12b\#174 FMT FILE.. C: ICP ID23 IGAS.FMT

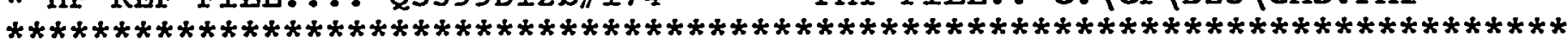

\begin{tabular}{|c|c|c|c|c|c|c|c|c|c|c|}
\hline $\begin{array}{l}\text { Out of } \\
\text { Bound }\end{array}$ & $\begin{array}{l}\text { Ret Time } \\
\text { (min) }\end{array}$ & Peak Hame & $\begin{array}{l}\text { Amount } \\
\text { PPHV }\end{array}$ & $\begin{array}{r}\text { \% Delta } \\
\text { Ret Time }\end{array}$ & $\begin{array}{l}\text { Peak } \\
\text { Area } \\
\end{array}$ & AREA $\%$ & $\begin{array}{l}\text { Amount/ } \\
\text { Area }\end{array}$ & $\begin{array}{c}\text { Peak } \\
\#\end{array}$ & $\begin{array}{r}\text { Peak } \\
\text { Height }\end{array}$ & $\begin{array}{r}u g / l \\
\text { AIR } \\
\end{array}$ \\
\hline & 3.625 & METHANE & 310481.844 & $0.42 \%$ & 43277348 & 100.00 & 0.0071742 & \multicolumn{2}{|c|}{$1 \times 125424$} & 0.000 \\
\hline & 6.955 & TRANS-1,2-DCE & 1.072 & $1.09 \%$ & 59 & 0.00 & 0.0181932 & 6 & 6 & 0.000 \\
\hline & 14.677 & TCE & 0.139 & $0.02 \%$ & 58 & 0.00 & 0.0023937 & 8 & 6 & 0.000 \\
\hline & 19.381 & TOLUEKE & 0.035 & $0.21 \%$ & 47 & 0.00 & 0.0007390 & 11 & 5 & .0 .000 \\
\hline & 28.907 & $1,1,2,2-P C A$ & 0.146 & $0.11 \%$ & 70 & 0.00 & 0.0020817 & 16 & 13 & 0.000 \\
\hline
\end{tabular}

Total amt. ID. $=310483.2$

Total area (all peaks) $=4.327908 \mathrm{E}+07$ 
File $=$ = $=\backslash C P \backslash D 23 \backslash W 23 A 1.75 R$ Date printed $=01-27-1999$ Time $=15: 42: 56$

Semple Name $=904-111 \mathrm{G}-18$

2.0 to $36.0 \mathrm{~min}$. LOH $Y=-48.888 \mathrm{High} Y=10220.735 \mathrm{mV}$ Span=10269.623

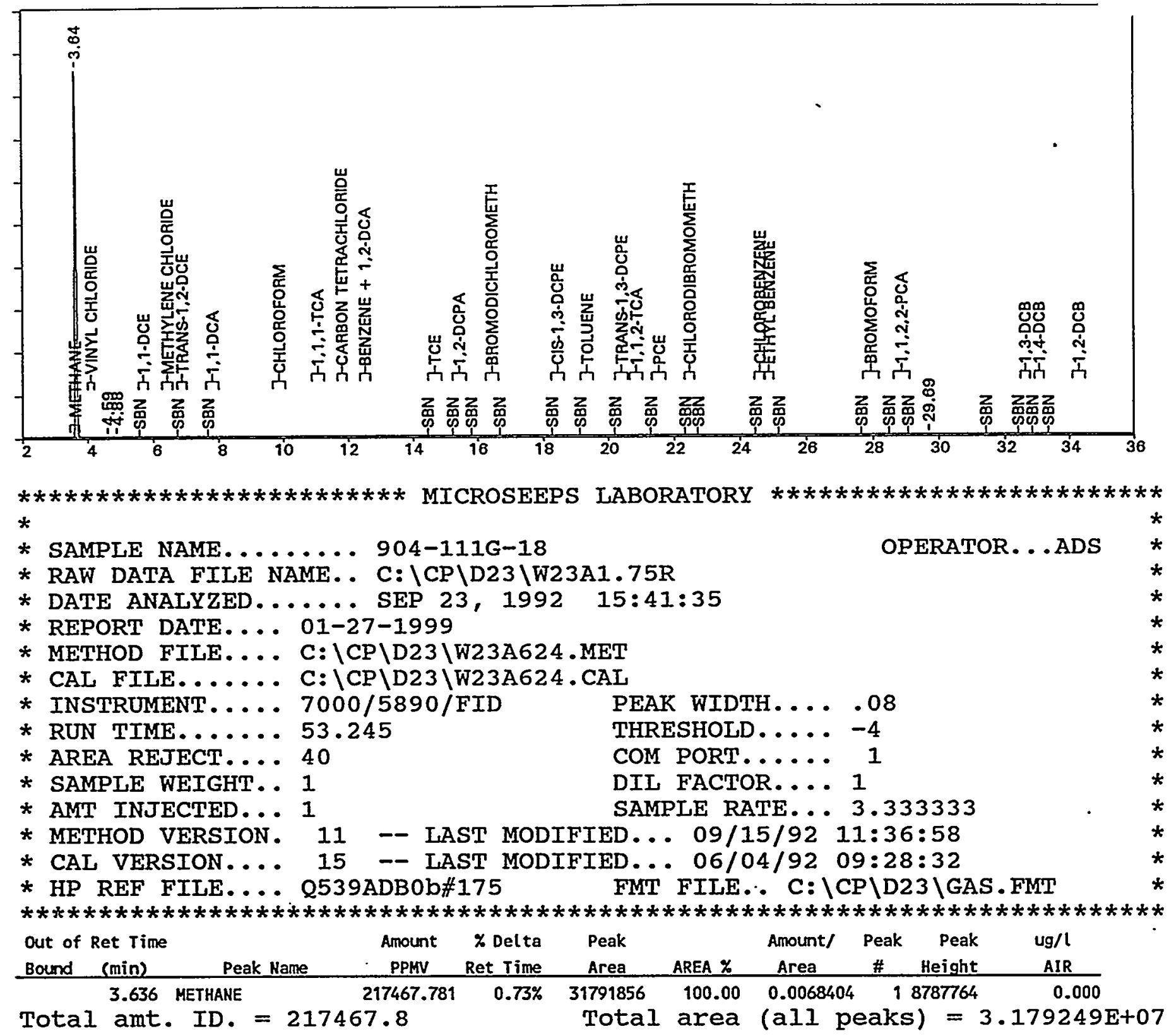




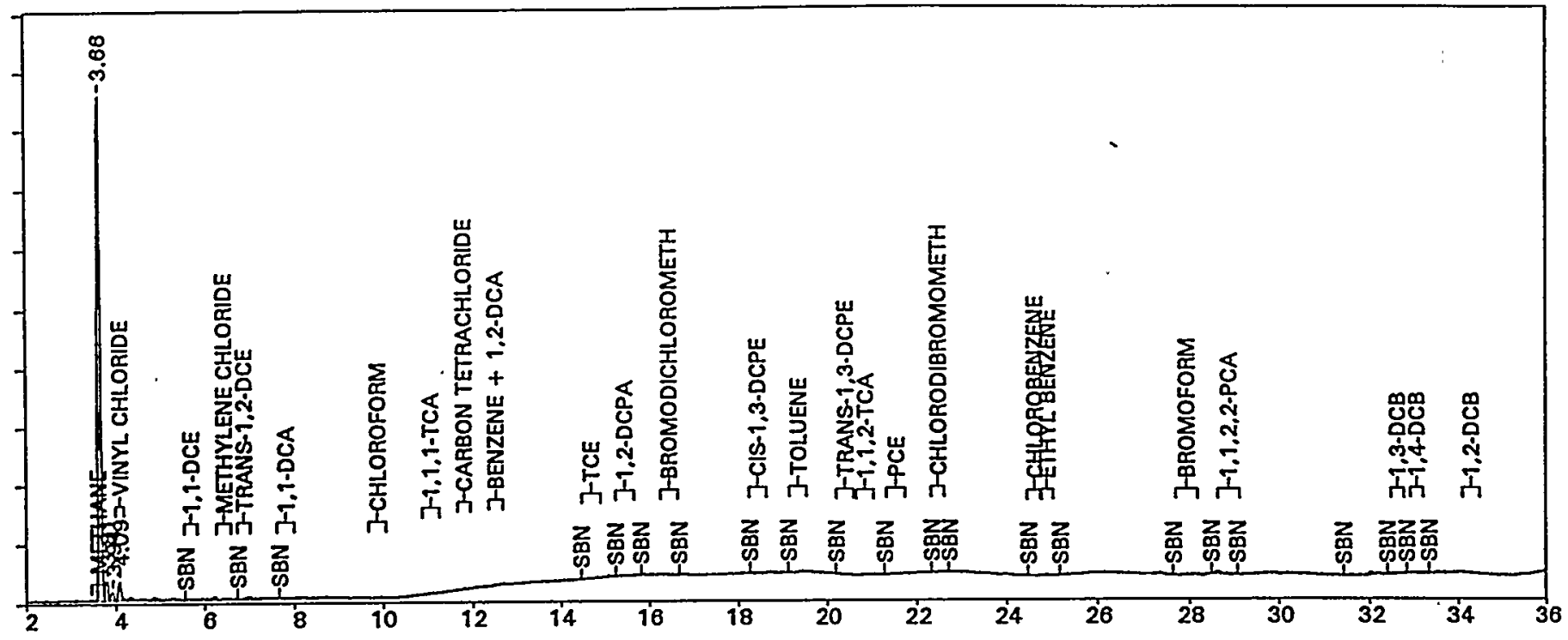

$* * * * * * * * * * * * * * * * * * * * * * * * *$ MICROSEEPS LABORATORY $* * * * * * * * * * * * * * * * * * * * * * * * *$ *

* SAMPLE NAME....... 904-111G-19

* RAW DATA FIIE NAME. C: CPP\D23\W23A1.76R

* DATE ANALYZED ....... SEP 23, 1992 16:48:45

* REPORT DATE... 01-27-1999

* METHOD FIIE.... C: \CP\D23\W23A624.MET

* CAL FILE....... C: \CP\D23\W23A624.CAL

* INSTRUMENT.... 7000/5890/FID PEAK WIDTH....08

* RUN TIME..... 53.245

* AREA REJECT... 40

* SAMPLE WEIGHT. 1

THRESHOLD .... -4

* AMT INJECTED... 1

COM PORT ...... 1

* METHOD VERSTON. 11

SAMPLE RATE... 3.333333

* CAI VERSION.... 15 - LAST MODIFIED... 06/04/92 09:28:32

* HP REF FILE... Q539BD6Eb\#176

FMT FILE.. C: $\backslash \mathrm{CP} \backslash \mathrm{D} 23 \backslash \mathrm{GAS} . \mathrm{FMT}$

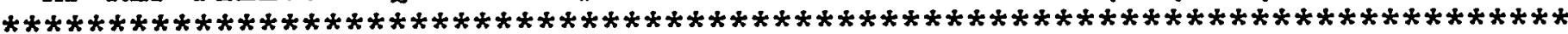

\begin{tabular}{|c|c|c|c|c|c|c|c|c|c|c|}
\hline $\begin{array}{l}\text { Out of } \\
\text { Bound }\end{array}$ & $\begin{array}{l}\text { Ret Time } \\
\text { (min) }\end{array}$ & Peak Hame & $\begin{array}{l}\text { Amount } \\
\text { PPHY }\end{array}$ & $\begin{array}{r}\text { \% Delta } \\
\text { Ret Time }\end{array}$ & $\begin{array}{l}\text { Peak } \\
\text { Area }\end{array}$ & AREA $\%$ & $\begin{array}{l}\text { Amount/ } \\
\text { Area }\end{array}$ & $\begin{array}{c}\text { Peak } \\
\# \\
\end{array}$ & $\begin{array}{r}\text { Peak } \\
\text { Height }\end{array}$ & $\begin{array}{r}u g / t \\
\text { AIR } \\
\end{array}$ \\
\hline & 3.661 & METHAHE & 4.389 & $1.40 \%$ & 2610 & 90.99 & 0.0016814 & 1 & 581 & 0.000 \\
\hline rot & $\begin{array}{l}4.094 \\
\text { amt. }\end{array}$ & $\begin{array}{l}\text { VIHYL CHLORIDE } \\
\text { ID. }=5 .\end{array}$ & $31^{0.696}$ & $-0.38 \%$ & $\begin{array}{r}108 \\
\text { Tota }\end{array}$ & $\begin{array}{r}3.78 \\
\text { area }\end{array}$ & $\begin{array}{l}0.0064205 \\
(\mathrm{a} 11 \mathrm{p}\end{array}$ & $\begin{array}{r}4 \\
\text { aks }\end{array}$ & $=21$ & $\begin{array}{r}0.000 \\
3.616\end{array}$ \\
\hline
\end{tabular}


File=C:ICP ID23 IHZ3A1.77R Date printed $=01-27-1999$ Time $=15: 45: 41$

Sample Name $=904-111 \mathrm{G}-20$

2.0 to $36.0 \mathrm{~min}$. Low $Y=0.39$ High $Y=1.639 \mathrm{mv}$ Span=1.25

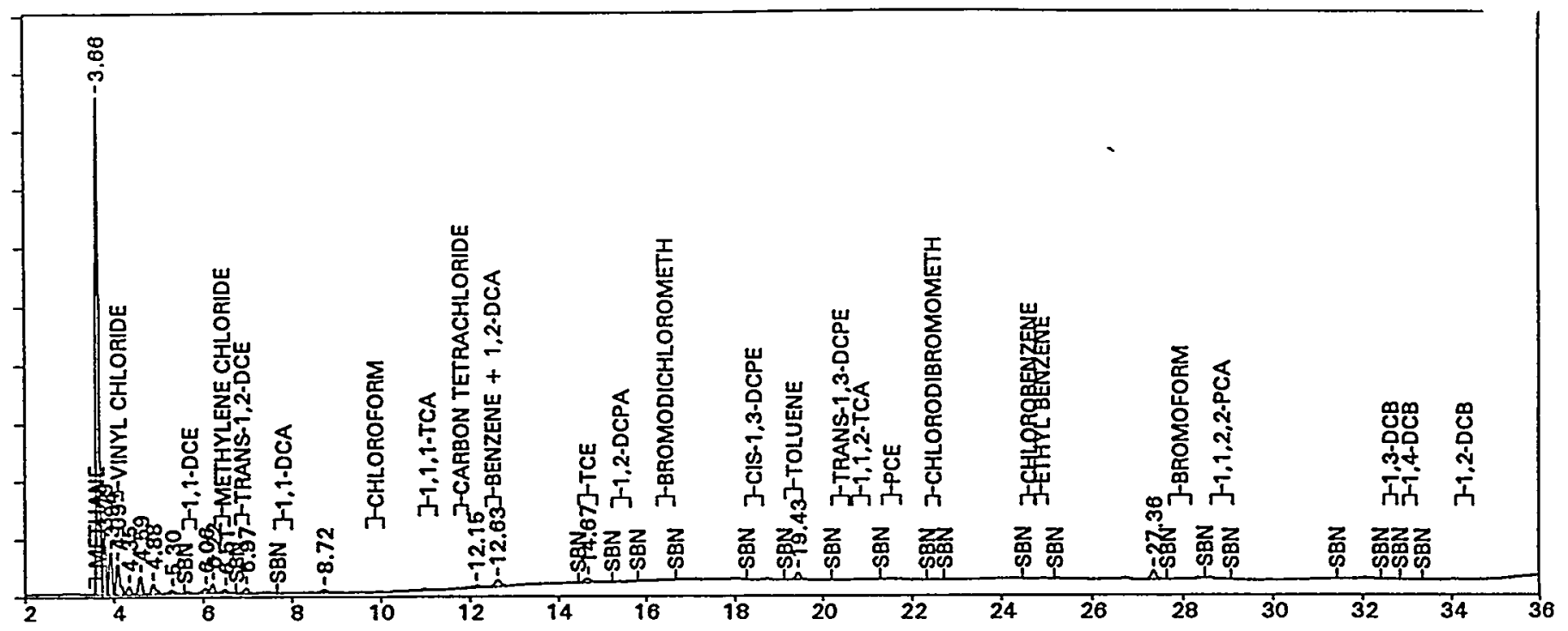

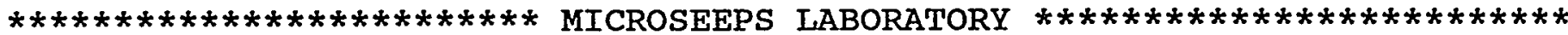
$*$

* SAMPLE NAME........ 904-111G-20

* RAW DATA FIIE NAME.. C: \CP\D23\W23A1.77R

* DATE ANAIYZED....... SEP 23, 1992 17:55:21

* REPORT DATE... 01-27-1999

* METHOD FILE.... C: $\backslash$ CP \D23\W23A624 .MET

* CAL FILE...... C: $\backslash C P \backslash D 23 \backslash W 23 A 624 . C A L$

* INSTRUMENT.... 7000/5890/FID PEAK WIDTH.....08

* RUN TIME..... 53.245 THRESHOLD.... -4

* AREA REJECT.... 40 COM PORT..... 1

* SAMPIE WEIGHT. . 1 DIL FACTOR... 1

* AMT INJECTED... 1 SAMPLE RATE... 3.333333

* METHOD VERSION. 11 - LAST MODIFIED... 09/15/92 11:36:58

* CAI VERSION.... 15 - LAST MODIFIED... 06/04/92 09:28:32

* HP REF FILE.... Q539CDOBb\#177 FMT FILE.. C: ICP\D23 IGAS.FMT

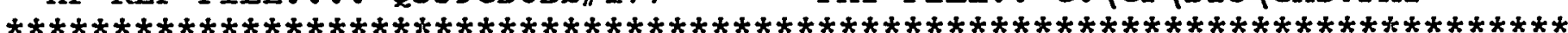

\begin{tabular}{|c|c|c|c|c|c|c|c|c|c|c|}
\hline $\begin{array}{l}\text { Out of } \\
\text { Bound }\end{array}$ & $\begin{array}{l}\text { Ret Time } \\
\text { (min) }\end{array}$ & Peak Name & $\begin{array}{c}\text { Amount } \\
\text { PPHV }\end{array}$ & $\begin{array}{l}\text { \% Delta } \\
\text { Ret Time }\end{array}$ & $\begin{array}{l}\text { Peak } \\
\text { Area }\end{array}$ & AREA $\%$ & $\begin{array}{l}\text { Amount/ } \\
\text { Area }\end{array}$ & $\begin{array}{c}\text { Peak } \\
\# \\
\end{array}$ & $\begin{array}{r}\text { Peak } \\
\text { Height }\end{array}$ & $\begin{array}{r}\text { ug/l } \\
\text { AIR } \\
\end{array}$ \\
\hline & 3.660 & METHANE & 8.018 & $1.39 \%$ & 4759 & 62.04 & 0.0016847 & 1 & 1063 & 0.000 \\
\hline & 4.091 & VINYL CHLORIDE & 2.468 & $-0.46 \%$ & 387 & 5.04 & 0.0063784 & 4 & 65 & 0.000 \\
\hline & 6.594 & METHYLENE CHLORIDE & 0.427 & $1.38 \%$ & 70 & 0.92 & 0.0060595 & 12 & 9 & 0.000 \\
\hline & 6.974 & TRANS-1,2-DCE & 1.534 & $1.36 \%$ & 84 & 1.10 & 0.0181932 & 13 & 11 & 0.000 \\
\hline & 12.631 & BENZENE + 1,2-DCA & 0.167 & $0.84 \%$ & 138 & 1.80 & 0.0012136 & 18 & 14 & 0.000 \\
\hline & 14.673 & TCE & 0.228 & $-0.01 \%$ & 95 & 1.24 & 0.0023937 & 19 & 9 & 0.000 \\
\hline & 19.430 & TOLUENE & 0.093 & $0.46 \%$ & 125 & 1.63 & 0.0007390 & 20 & 15 & 0.000 \\
\hline
\end{tabular}


File $=$ C: $\backslash C P \backslash D 23 \backslash$ W23A1.78R Date printed=01-27-1999 Time= 15:47:06

Sample Name $=904-1116-20 \mathrm{~A}$

2.0 to $36.0 \mathrm{~min}$. LoH $Y=0.371$ High $Y=6.382 \mathrm{mv}$ Span=6.011

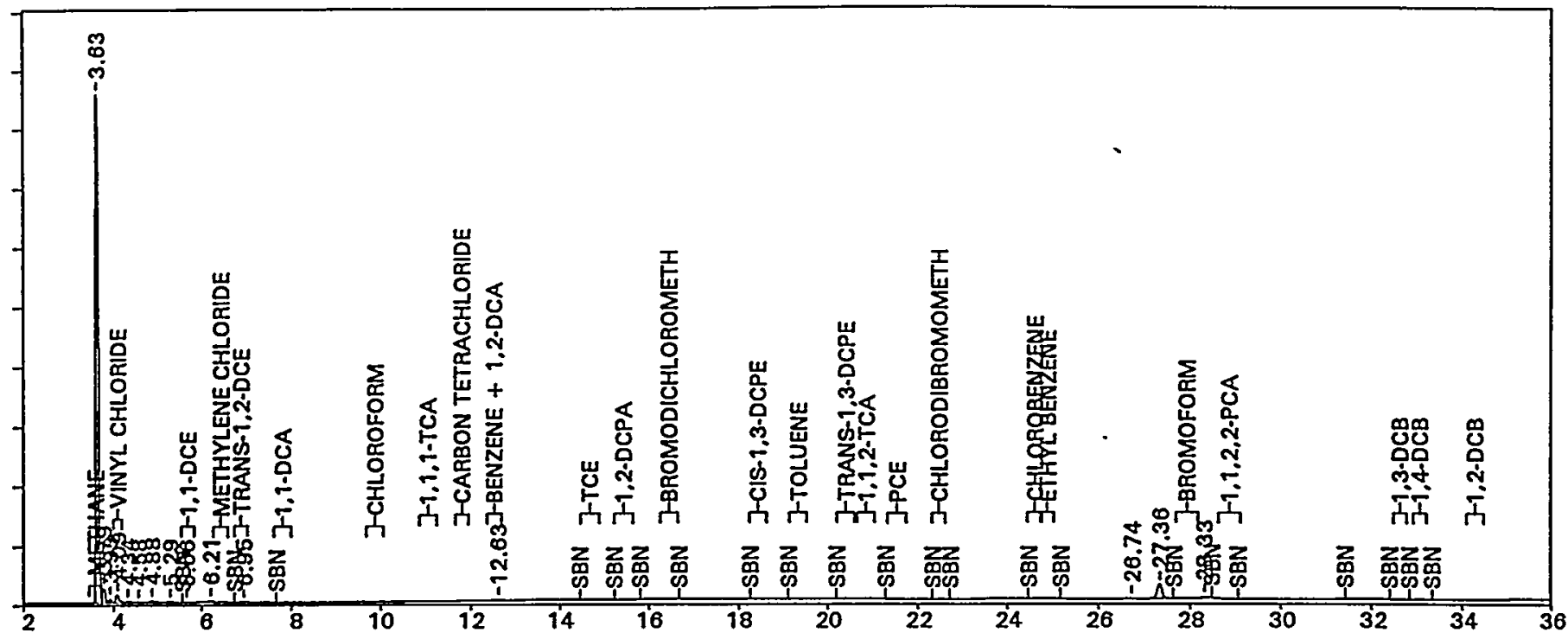

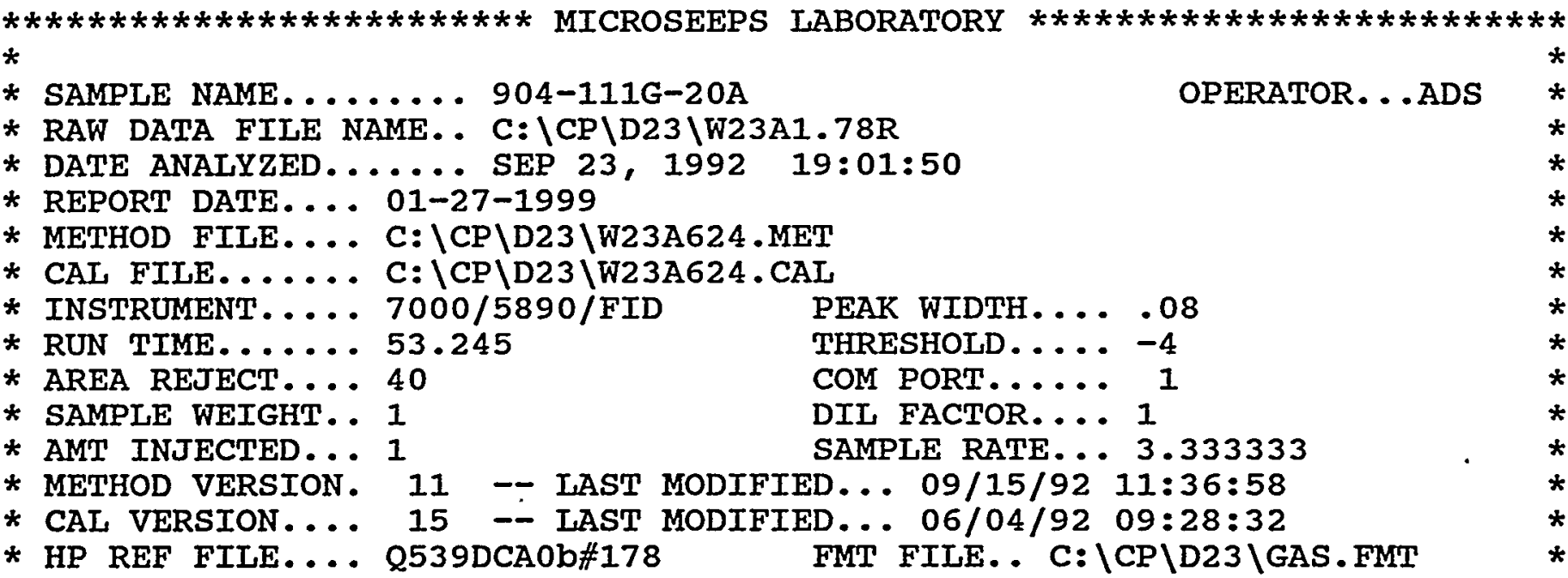

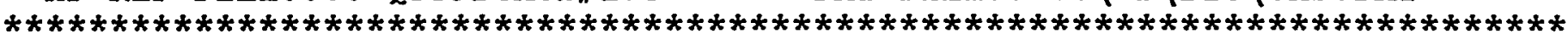

\begin{tabular}{|c|c|c|c|c|c|c|c|c|c|c|}
\hline $\begin{array}{l}\text { Out of } \\
\text { Bound }\end{array}$ & $\begin{array}{l}\text { Ret Time } \\
\text { (min) }\end{array}$ & Peak Name & $\begin{array}{l}\text { Amount } \\
\text { PPKV } \\
\end{array}$ & $\begin{array}{r}\% \text { Delta } \\
\text { Ret Time }\end{array}$ & $\begin{array}{l}\text { Peak } \\
\text { Area }\end{array}$ & AREA $\%$ & $\begin{array}{l}\text { Amount/ } \\
\text { Area }\end{array}$ & $\begin{array}{c}\text { Peak } \\
\#\end{array}$ & $\begin{array}{r}\text { Peak } \\
\text { Height }\end{array}$ & $\begin{array}{r}u g / l \\
\text { AIR }\end{array}$ \\
\hline & 3.634 & METHANE & 38.580 & $0.66 \%$ & 22101 & 87.26 & 0.0017456 & 1 & 5119 & 0.000 \\
\hline & 4.094 & VIKYL CHLORIDE & 2.947 & $-0.39 \%$ & 462 & 1.82 & 0.0063757 & 4 & 78 & 0.000 \\
\hline & 5.659 & $1,1-D C E$ & 0.009 & $-0.63 \%$ & 43 & 0.17 & 0.0002046 & 9 & 7 & 0.000 \\
\hline & 6.949 & TRAMS-1,2-DCE & 1.030 & $1.01 \%$ & 57 & 0.22 & 0.0181932 & 11 & 7 & 0.000 \\
\hline & 12.631 & BENZENE + 1,2-DCA & 0.102 & $0.85 \%$ & 84 & 0.33 & 0.0012136 & 15 & 7 & 0.000 \\
\hline
\end{tabular}

Total amt. ID. $=42.66712$

Total area (all peaks) $=25328.19$ 
File $=$ : $: \backslash C P \backslash D 23 \backslash H i 23 A 2.44 R$ Date printed $=01-27-1999$ Time $=16: 17: 45$

Sample Hame=STD 624-4

2.0 to $36.0 \mathrm{~min}$. LoH $Y=-11.584$ High $Y=2480.9 \mathrm{mv}$ Span=2492.484

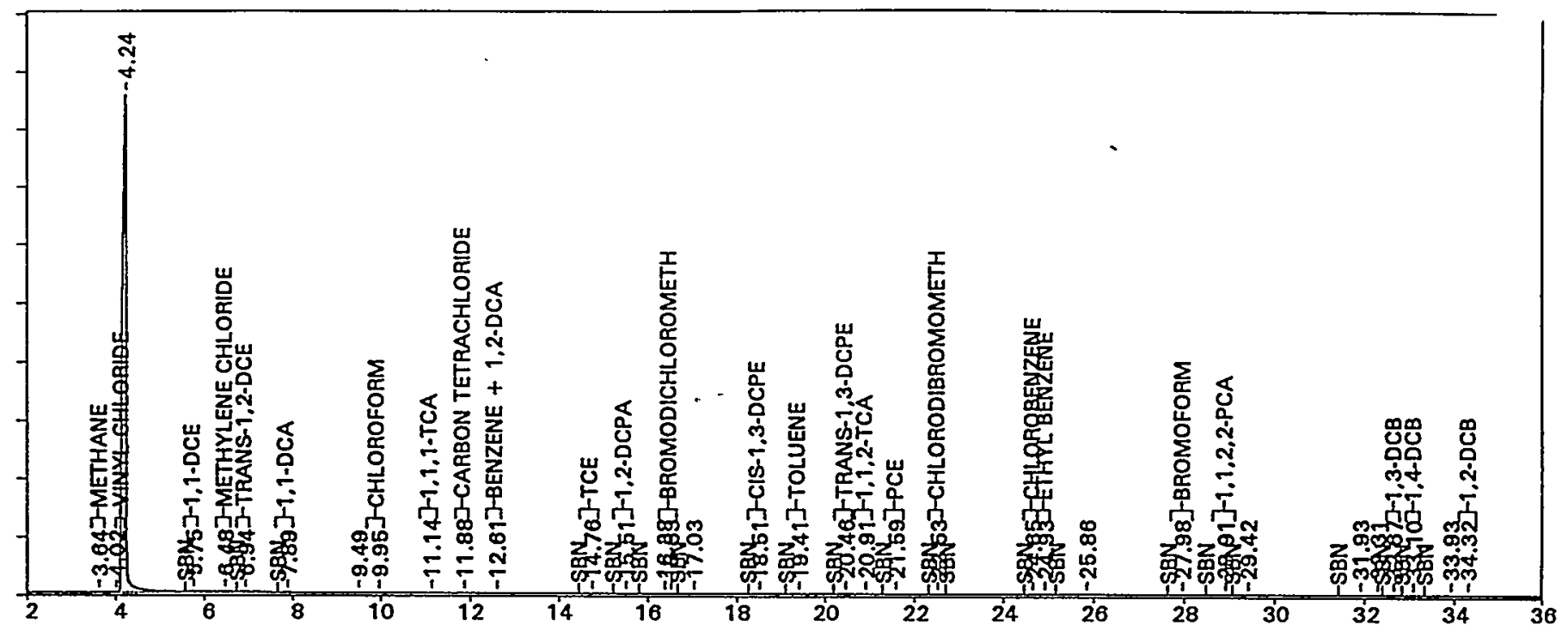

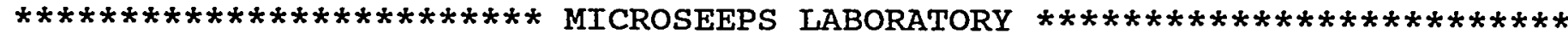
*

* SAMPle NAME........ STD 624-4

* RAW DATA FILE NAME. . C: \CP\D23\W23A2.44R

* DATE ANALYZED....... SEP 26, 1992 20:48:25

* REPORT DATE.... 01-27-1999

* METHOD FILE.... C: $\backslash C P \backslash D 23 \backslash W 23 A 624 . M E T$

* CAL FILE....... C: $\backslash C P \backslash D 23 \backslash W 23 A 624 . C A L$

* INSTRUMENT.... 7000/5890/FID PEAK WIDTH... .08

* RUN TIME...... 53.245

* AREA REJECT. ... 40

* SAMPLE WEIGHT.. 1

THRESHOLD..... -4

* AMT INJECTED... 1

COM PORT..... 1

* METHOD VERSION. 11

DIL FACTOR.... 1

SAMPLE RATE... 3.333333

OPERATOR...ADS

CAL VERSION.... 15 - L LAST MODIFIED... 06/04/92 09:28:32

* HP REF FILE. . . Q Q53DEA1Ab\#244 FMT FILE.. C: \CP\D23 IGAS. FMT

\begin{tabular}{|c|c|c|c|c|c|c|c|c|c|c|}
\hline $\begin{array}{l}\text { Out of } \\
\text { Bound }\end{array}$ & $\begin{array}{l}\text { Ret Time } \\
\text { (min) }\end{array}$ & Peak Name & $\begin{array}{l}\text { Amount } \\
\text { PPHV }\end{array}$ & $\begin{array}{r}\% \text { Delta } \\
\text { Ret Time }\end{array}$ & $\begin{array}{l}\text { Peak } \\
\text { Area } \\
\end{array}$ & AREA $\%$ & $\begin{array}{l}\text { Amount/ } \\
\text { Area }\end{array}$ & $\begin{array}{c}\text { Peak } \\
\# \\
\end{array}$ & $\begin{array}{r}\text { Peak } \\
\text { Height } \\
\end{array}$ & $\begin{array}{r}\text { ug/l } \\
\text { AIR } \\
\end{array}$ \\
\hline & 3.636 & METHANE & 0.152 & $0.73 \%$ & 77 & 0.00 & 0.0019827 & 1 & 19 & 0.000 \\
\hline & 4.025 & VIKYL CHLORIDE & 3.985 & $-2.08 \%$ & 625 & 0.00 & 0.0063721 & 2 & 142 & 0.000 \\
\hline & 5.750 & 1,1-DCE & 3.891 & $0.96 \%$ & 18753 & 0.15 & 0.0002075 & 4 & 3545 & 0.000 \\
\hline & 6.485 & METHYLENE CHLORIDE & 4.055 & $0.93 \%$ & 694 & 0.01 & 0.0058439 & 5 & 140 & 0.000 \\
\hline & 6.940 & TRAHS-1,2-DCE & 3.841 & $0.87 \%$ & 232 & 0.00 & 0.0165346 & 6 & 43 & 0.000 \\
\hline & 7.890 & $1,1-D C A$ & 3.783 & $0.87 \%$ & 1334 & 0.01 & 0.0028357 & 7 & 197 & 0.000 \\
\hline & 9.955 & CHLOROFORH & 3.069 & $0.87 \%$ & 531 & 0.00 & 0.0057798 & 9 & 68 & 0.000 \\
\hline & 11.140 & $1,1,1-\mathrm{TCA}$ & 2.856 & $0.87 \%$ & 1153 & 0.01 & 0.0024772 & 10 & 114 & 0.000 \\
\hline & 11.876 & CARBON TETRACHLORID & 2.106 & $0.56 \%$ & 103 & 0.00 & 0.0203802 & 11 & 11 & 0.000 \\
\hline & 12.615 & BENZENE + 1,2-DCA & 8.794 & $0.72 \%$ & 7029 & 0.05 & 0.0012511 & 12 & 646 & 0.000 \\
\hline & 14.756 & TCE & 2.919 & $0.55 \%$ & 1158 & 0.01 & 0.0025204 & 13 & 152 & 0.000 \\
\hline & 15.514 & $1,2-D C P A$ & 3.436 & $0.51 \%$ & 2093 & 0.02 & 0.0016416 & 14 & 265 & 0.000 \\
\hline & 16.380 & BROMOO I CHLOROMETH & 4.680 & $-0.42 \%$ & 245 & 0.00 & 0.0191242 & 15 & 36 & 0.000 \\
\hline & 18.513 & CIS-1,3-DCPE & 3.490 & $0.39 \%$ & 1872 & 0.01 & 0.0018641 & 18 & 269 & 0.000 \\
\hline & 19.411 & TOLUENE & 4.164 & $0.37 \%$ & 5513 & 0.04 & 0.0007553 & 19 & 790 & 0.000 \\
\hline & 20.464 & TRANS-1,3-DCPE & 3.442 & $0.32 \%$ & 1483 & 0.01 & 0.0023207 & 20 & 234 & 0.000 \\
\hline & 20.913 & $1,1,2-T C A$ & 2.854 & $0.30 \%$ & 1279 & 0.01 & 0.0022313 & 21 & 198 & 0.000 \\
\hline & 21.590 & PCE & 2.236 & $0.28 \%$ & 1093 & 0.01 & 0.0020458 & 22 & 165 & 0.000 \\
\hline & 22.534 & CHLOROOIBROMOMETH & 1.843 & $0.28 \%$ & 129 & 0.00 & 0.0142855 & 23 & 22 & 0.000 \\
\hline
\end{tabular}


File=C: ICPID23 IL23A1.79R Date printed=01-27-1999 Time= 15:48:30

Sample Hane $=904-111 \mathrm{G}^{\star} \mathrm{SB3}$

2.0 to $36.0 \mathrm{~min}$. LOH $Y=0.397$ High $Y=0.555 \mathrm{mv}$ Span=0.157

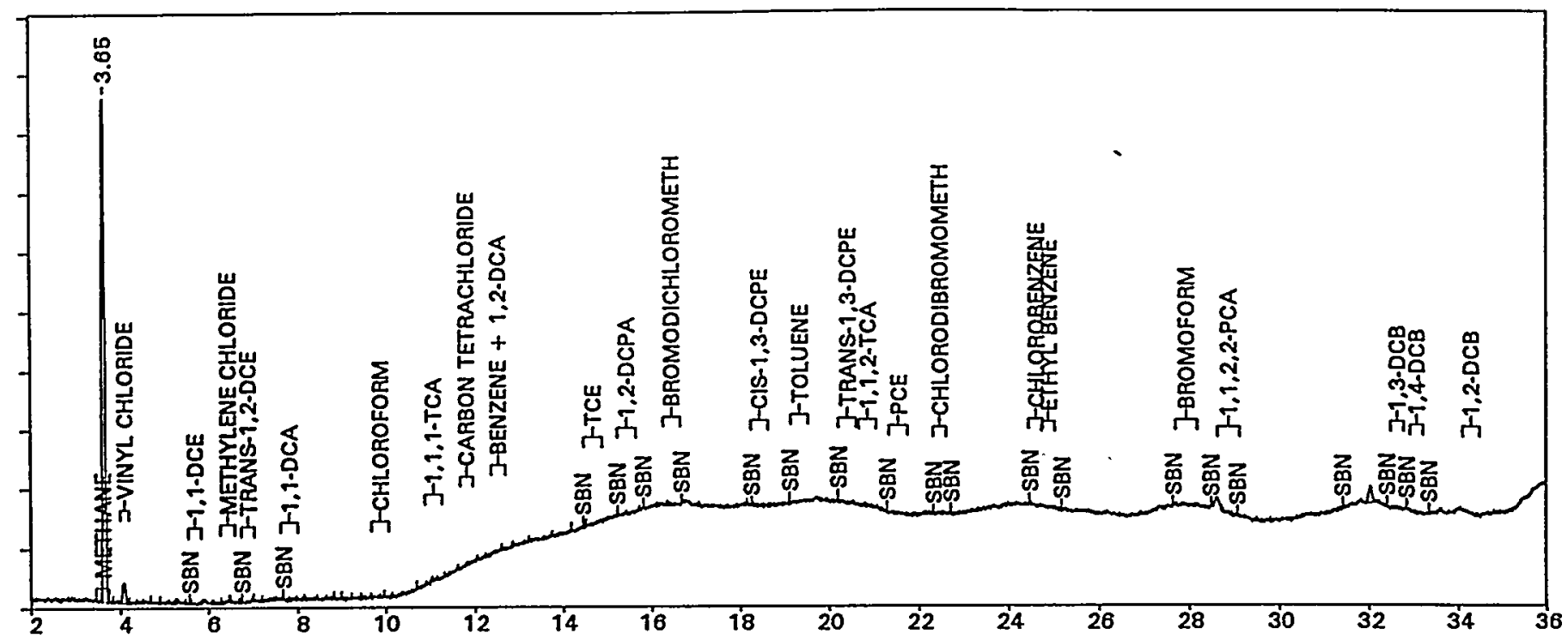

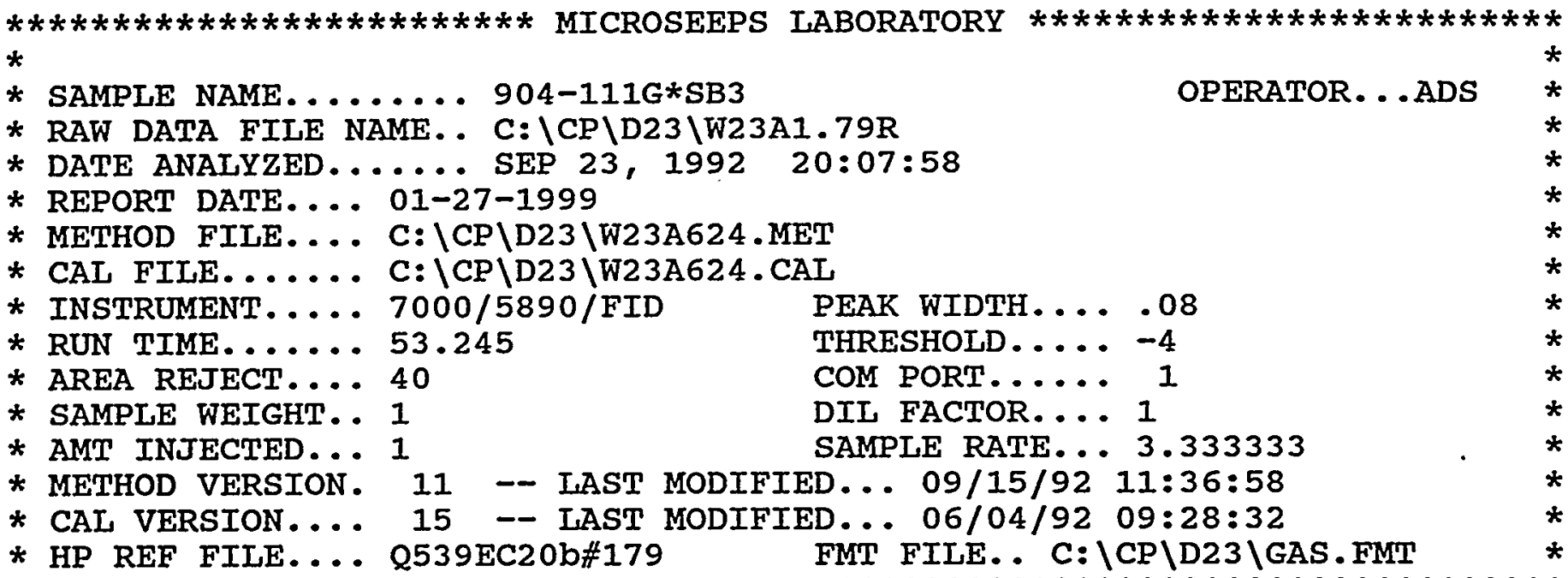
$* * * * * * * * * * * * * * * * * * * * * * * * * * * * * * * * * * * * * * * * * * * * * * * * * * * * * * * * * * * * * * * * * * * * * * * * *$

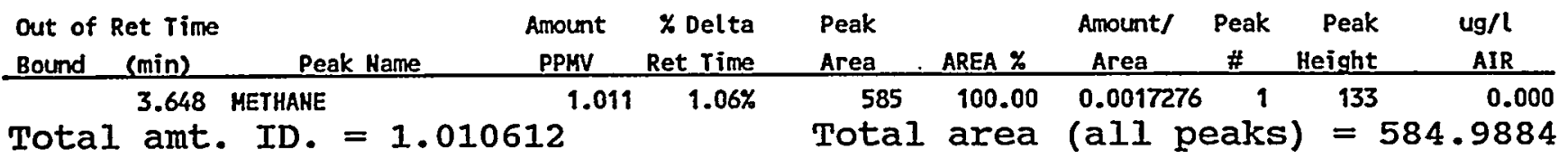


File=C: \CP \D23 \W23A1.80R Date printed $=01-27-1999$ Time $=15: 49: 51$

Sample Name $=$ STD K4 R5

2.0 to 36.0 min. Low $Y=-7.839$ High $Y=1708.664$ mv Span=1716.502

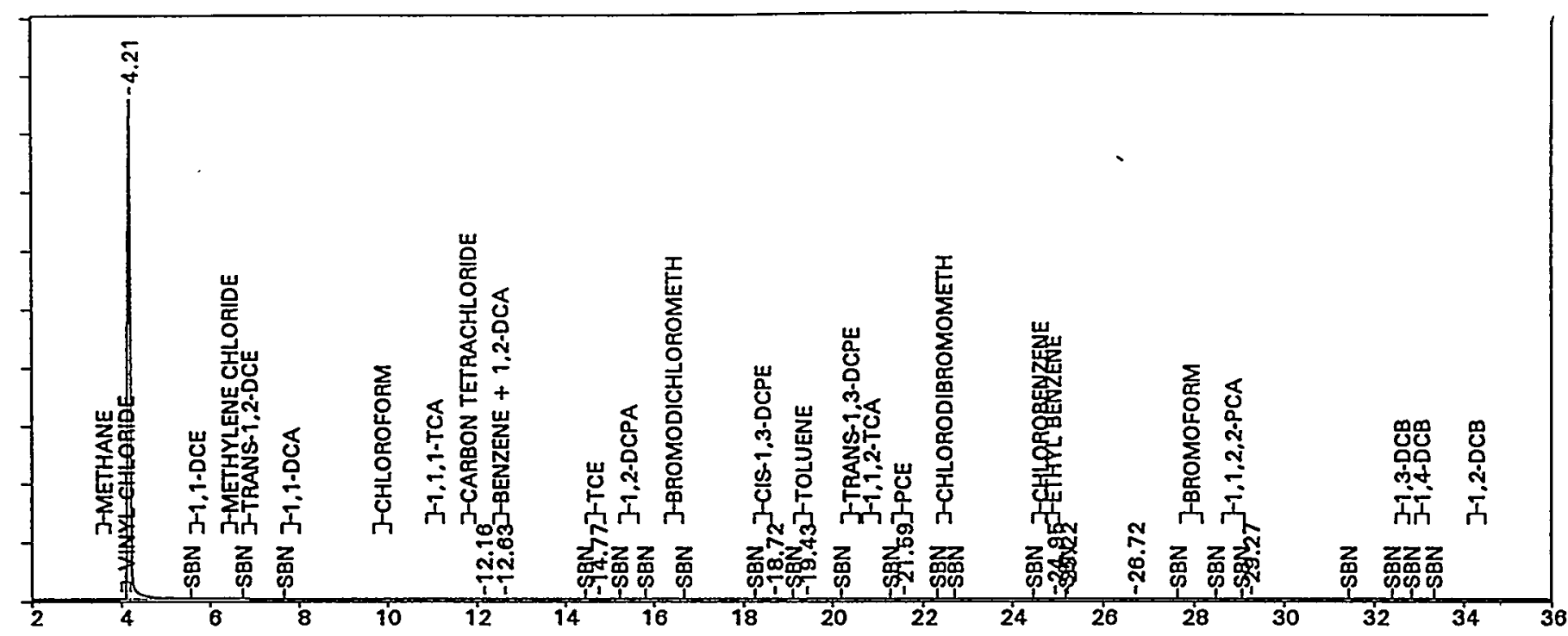

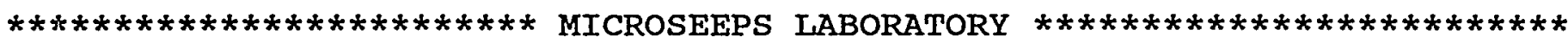

*

* SAMPLE NAME........ STD K4 R5

* RAW DATA FILE NAME.. C: \CP\D23\W23A1.80R

* DATE ANALYZED...... SEP 23, 1992 21:14:05

* REPORT DATE... 01-27-1999

* METHOD FILE.... C: CCP\D23\W23A624.MET

* CAL FILE...... C: \CP\D23\W23A624.CAL

* INSTRUMENT. ....77000/5890/FID PEAK WIDTH.... .08

* RUN TIME...... 53.245

* AREA REJECT.... 40

* SAMPLE WEIGHT. 1

* AMT INJECTED... 1

* METHOD VERSION. 11 - LAST MODIFIED... 09/15/92 11:36:58

* CAL VERSION.... 15 -- IAAST MODIFIED... 06/04/92 09:28:32

* HP REF FIIE.... Q539FB9Fb\#180

THRESHOLD..... -4

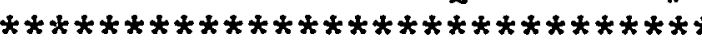

\begin{tabular}{|c|c|c|c|c|c|c|c|c|c|c|}
\hline $\begin{array}{l}\text { Out of } \\
\text { Bound }\end{array}$ & $\begin{array}{l}\text { Ret Time } \\
\text { (min) }\end{array}$ & Peak Name & $\begin{array}{l}\text { Amount } \\
\text { PPHV }\end{array}$ & $\begin{array}{l}\text { \% Del ta } \\
\text { Ret Time }\end{array}$ & $\begin{array}{l}\text { Peak } \\
\text { Area }\end{array}$ & AREA $\%$ & $\begin{array}{l}\text { Amount/ } \\
\text { Area }\end{array}$ & $\begin{array}{c}\text { Peak } \\
\#\end{array}$ & $\begin{array}{r}\text { Peak } \\
\text { Height }\end{array}$ & $\begin{array}{r}\mathrm{ug} / \mathrm{l} \\
\mathrm{AIR}\end{array}$ \\
\hline & 4.210 & VINYL CHLORIDE & 45338.594 & $2.42 \%$ & 7126489 & 99.98 & 0.0063620 & \multicolumn{2}{|c|}{21461086} & 0.000 \\
\hline & 12.630 & BENZENE $+1,2-D C A$ & 0.172 & $0.84 \%$ & 141 & 0.00 & 0.0012136 & 4 & 17 & 0.000 \\
\hline & 14.771 & TCE & 0.135 & $0.65 \%$ & 57 & 0.00 & 0.0023937 & 5 & 7 & 0.000 \\
\hline & 19.430 & TOLUENE & 0.167 & $0.46 \%$ & 227 & 0.00 & 0.0007390 & 7 & 27 & 0.000 \\
\hline & 21.588 & PCE & 0.090 & $0.27 \%$ & 46 & 0.00 & 0.0019709 & 8 & 7 & 0.000 \\
\hline & 24.946 & ETHYL BENZENE & 0.089 & $0.26 \%$ & 119 & 0.00 & 0.0007523 & 9 & 19 & 0.000 \\
\hline
\end{tabular}

Total amt. ID. $=45339.25$

Total area (all peaks) $=7127704$ 
File $=$ : $i c \dot{P} \backslash 023 \backslash W 23 A 1.81 R$ Date printed=01-27-1999 Time= 15:51:15

Sample Hame $=904-111 \mathrm{G}-21$

2.0 to $36.0 \mathrm{~min}$. Low $Y=0.393$ High $Y=1.49 \mathrm{mr}$ Span=1.097

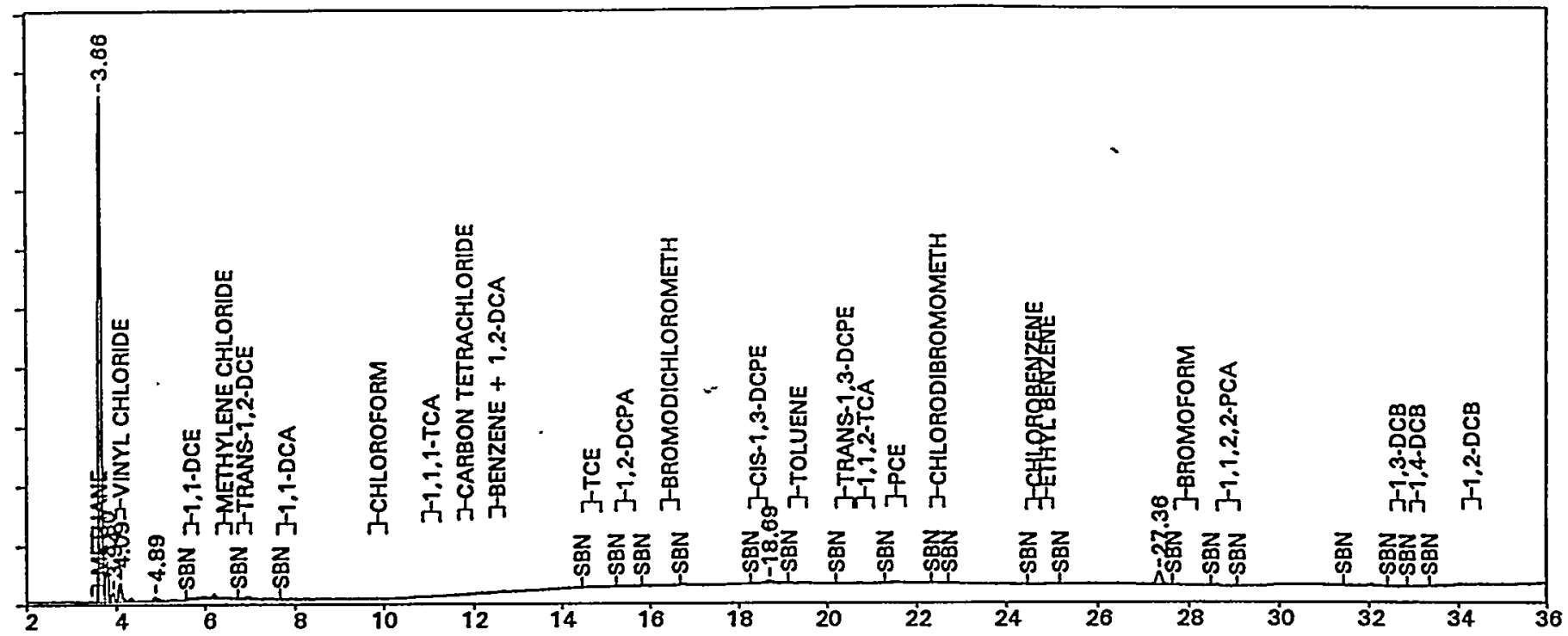

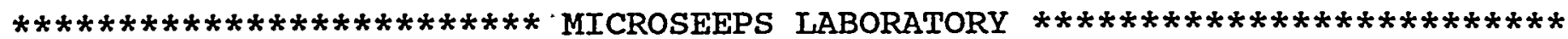
$*$

* SAMPLE NAME........ 904-111G-21

* RAW DATA FILE NAME.. C: CPP\D23 WW23A1.81R

* DATE ANALYZED ........SEP 23, 1992 22:20:16

* REPORT DATE... 01-27-1999

* METHOD FILE.... C: \CP\D23\W23A624.MET

* CAL FIIE...... C: \CP\D23\W23A624.CAL

* INSTRUMENT.... 7000/5890/FID PEAK WIDTH....08

* RUN TIME...... 53.245 THRESHOLD .... -4

* AREA REJECT.... 40

* SAMPLE WEIGHT. 1

COM PORT..... 1

* AMT INJECTED... 1

DIL FACTOR.... 1

* METHOD VERSION. 11 - IAST MODIFIED. . 0 09/15/92 11:36:58

* CAL VERSION.... 15 - LAST MODIFIED... 06/04/92 09:28:32

* HP REF FILE... Q53A0B22b\#181 FMT FILE.. C: ICPID23 IGAS.FMT

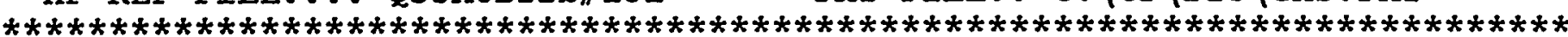

Out of Ret Time

Bound (min)

Peak Name

3.661 METHANE

4.093 VIKYL CHLORIDE

Total amt. ID. $=8.203704$
Amount $\%$ Delta Peak PPHV Ret Time

$7.046 \quad 1.42 \%$

$1.158-0.42 \%$

$-0.42 \%$ Area 4153

181
AREA $\%$

83.87

3.66

Amount/

peak

Peak

ug/l

Total area (all peaks) $=4952.029$ 
File=C: \CP \D23 \W23A1.82R Date printed $=01-27-1999$ rime $=15: 52: 37$

Sample Name $=904-111 \mathrm{G}-22$

2.0 to $36.0 \mathrm{~min}$. Low $Y=0.388$ High $Y=2.47 \mathrm{mv}$ Span=2.082

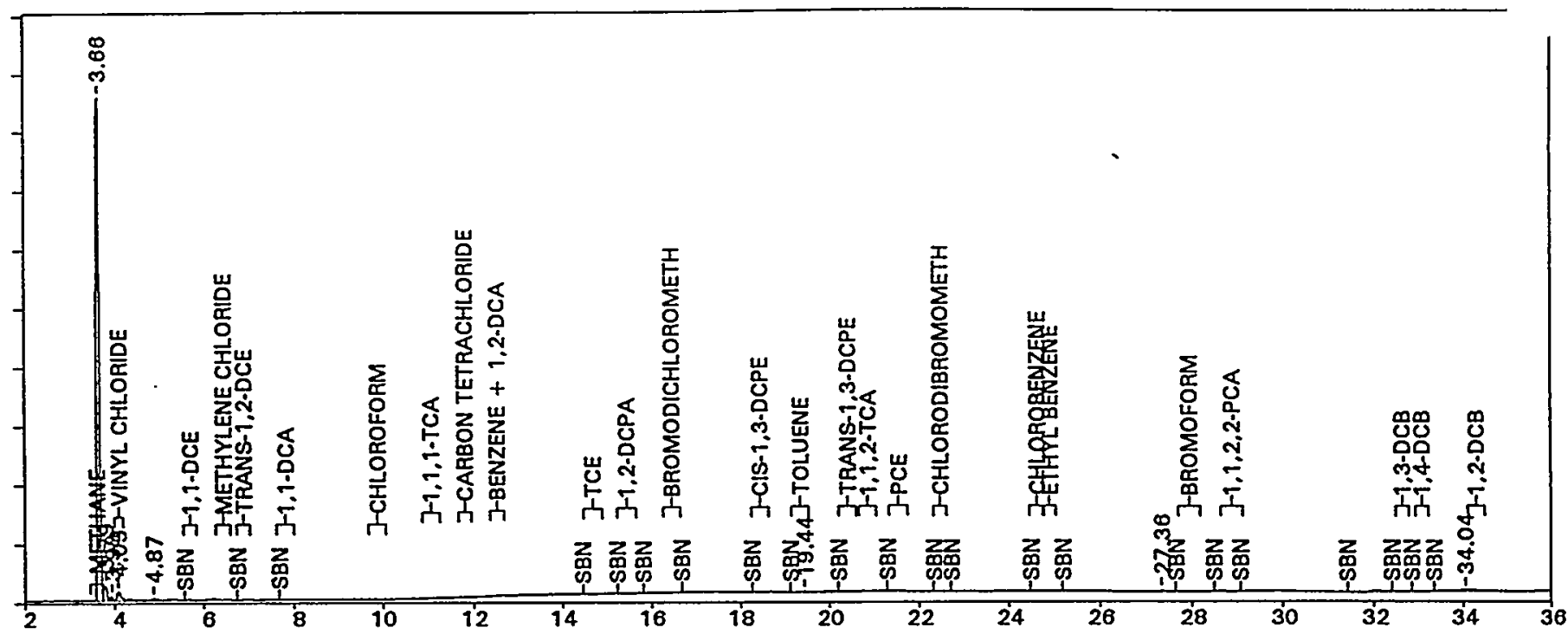

$* * * * * * * * * * * * * * * * * * * * * * * * *$ MICROSEEPS LABORATORY $* * * * * * * * * * * * * * * * * * * * * * * * *$ $*$

* SAMPLE NAME....... 904-111G-22

* RAW DATA FILE NAME.. C: CPP\D23\W23A1.82R

* DATE ANALYZED...... SEP 23, 1992 23:26:15

* REPORT DATE... 01-27-1999

* METHOD FILE.... C: CCP\D23\W23A624.MET

* CAL FILE...... C: ICP\D23\W23A624.CAL

* INSTRUMENT.... 7000/5890/FID PEAK WIDTH.... .08

* RUN TIME...... 53.245 THRESHOLD.... -4

* aREa REJECT. . . 40

* SAMPLE WEIGHT. . 1 COM PORT..... 1

* AMT INJECTED... 1 DIL FACTOR.... 1

* METHOD VERSION. 11 -- LAST MODIFIED... 09/15/92 11:36:58

* CAL VERSION.... 15 - - LAST MODIFIED... 06/04/92 09:28:32

* HP REF FILE.... Q53A1A99b\#182 FMT FILE.. C: \CP\D23\GAS. FMT

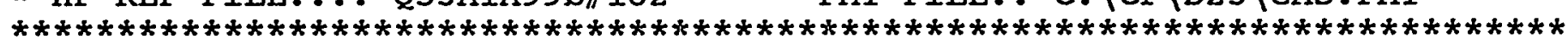

\begin{tabular}{|c|c|c|c|c|c|c|c|c|c|c|}
\hline $\begin{array}{l}\text { Out of } \\
\text { Bound }\end{array}$ & $\begin{array}{l}\text { Ret rime } \\
\text { (min) }\end{array}$ & Peak Name & $\begin{array}{l}\text { Amount } \\
\text { PPMV }\end{array}$ & $\begin{array}{r}\% \text { Delta } \\
\text { Ret Time }\end{array}$ & $\begin{array}{l}\text { Peak } \\
\text { Area }\end{array}$ & AREA $\%$ & $\begin{array}{l}\text { Amount/ } \\
\text { Area }\end{array}$ & $\begin{array}{c}\text { Peak } \\
\# \\
\end{array}$ & $\begin{array}{r}\text { Peak } \\
\text { Height }\end{array}$ & $\begin{array}{l}u g / l \\
\text { AIR }\end{array}$ \\
\hline & 3.659 & METHANE & 13.356 & $1.36 \%$ & 7808 & 90.84 & 0.0017105 & 1 & 1772 & 0.000 \\
\hline & 4.092 & VIHYL CHLORIDE & 1.236 & $-0.44 \%$ & 193 & 2.25 & 0.0063948 & 4 & 31 & 0.000 \\
\hline & 19.440 & TOLUENE & 0.032 & $0.52 \%$ & 43 & 0.50 & 0.0007390 & 12 & 3 & 0.000 \\
\hline
\end{tabular}

Total amt. ID. $=14.62317$ 


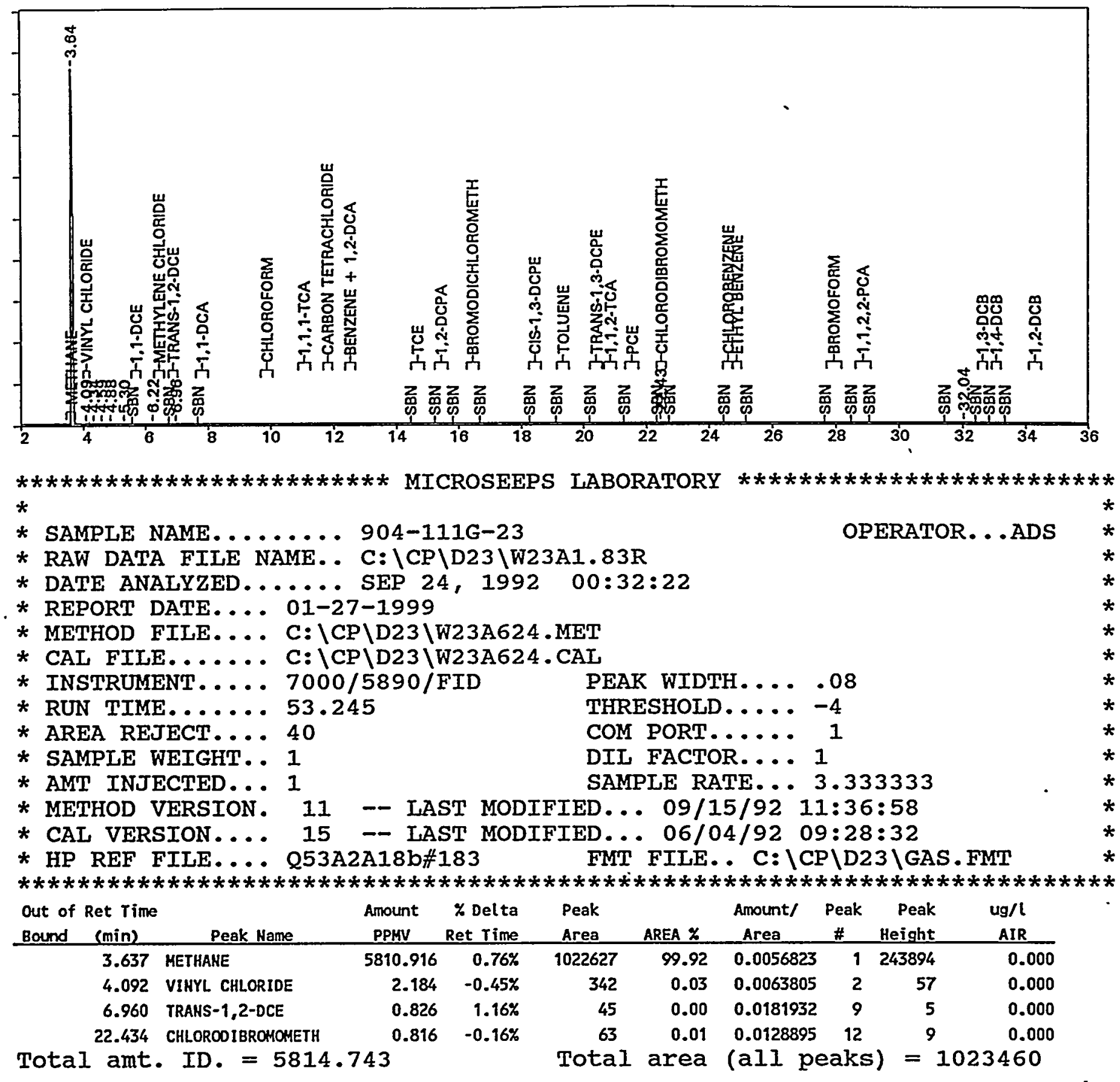


File:=C: \CP \D23IW23A1.84R Date printed $=01-27-1999$ Time $=15: 55: 25$

Sample Name $=904-111 \mathrm{G}-24$

2.0 to 36.0 min. Low $Y=0.388$ High $Y=2.581 \mathrm{mV}$ Span=2.193

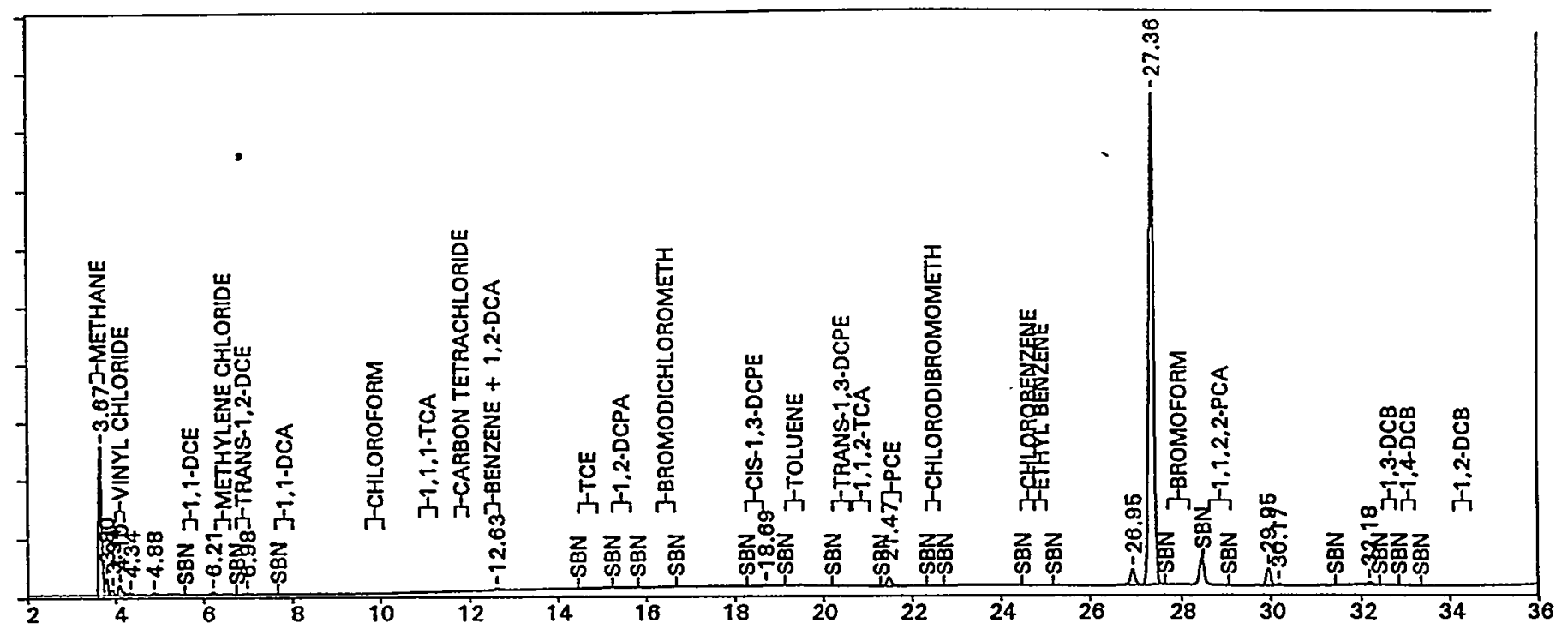

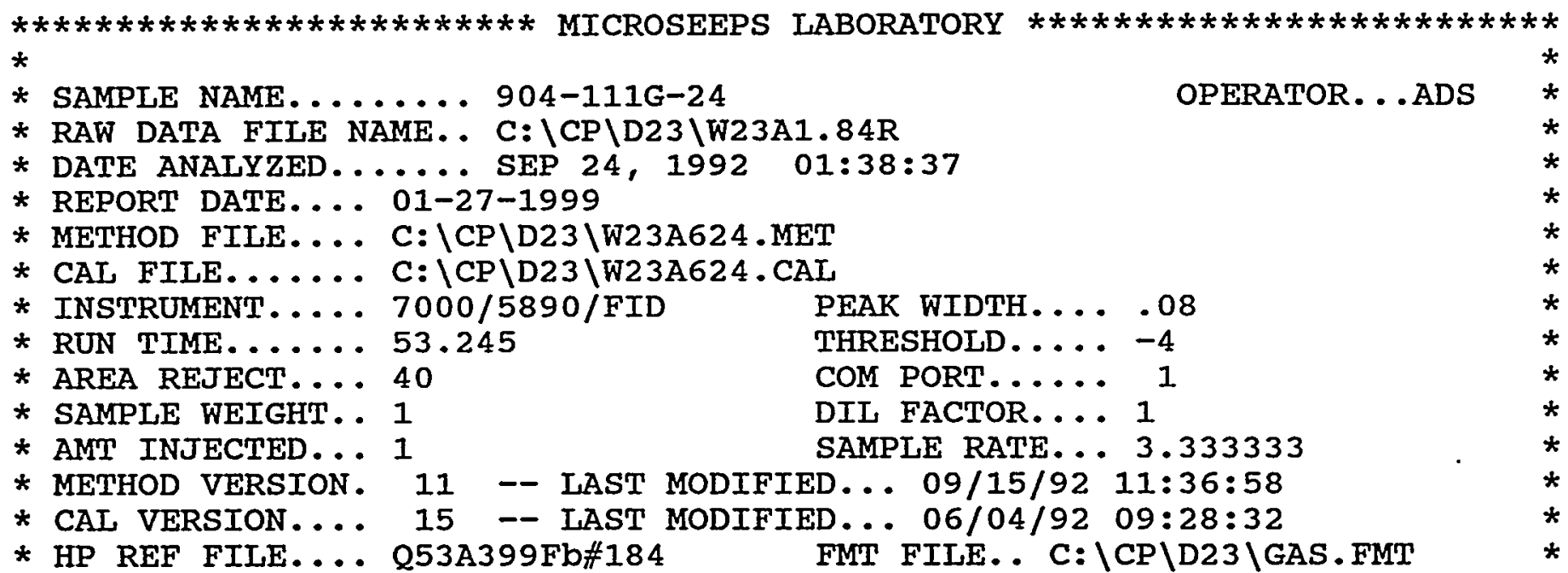

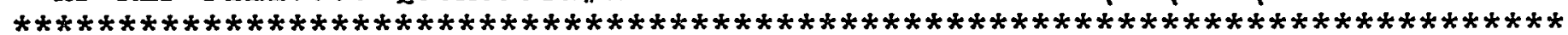

\begin{tabular}{|c|c|c|c|c|c|c|c|c|c|c|}
\hline $\begin{array}{l}\text { Out of } \\
\text { Bound }\end{array}$ & $\begin{array}{l}\text { Ret Time } \\
\text { (min) }\end{array}$ & Peak Name & $\begin{array}{l}\text { Amount } \\
\text { PPHV }\end{array}$ & $\begin{array}{r}\text { \% Delta } \\
\text { Ret Time }\end{array}$ & $\begin{array}{l}\text { Peak } \\
\text { Area }\end{array}$ & AREA $\%$ & $\begin{array}{l}\text { Amount/ } \\
\text { Area }\end{array}$ & $\begin{array}{c}\text { Peak } \\
\# \\
\end{array}$ & $\begin{array}{r}\text { Peak } \\
\text { Height }\end{array}$ & $\begin{array}{r}\text { ug/l } \\
\text { AIR } \\
\end{array}$ \\
\hline & 3.665 & METHANE & 4.184 & $1.53 \%$ & 2522 & 13.87 & 0.0016591 & 1 & 554 & 0.000 \\
\hline & 4.103 & VINYL CHLORIDE & 1.429 & $-0.18 \%$ & 224 & 1.23 & 0.0063904 & 4 & 35 & 0.000 \\
\hline & 6.980 & TRANS-1,2-DCE & 0.818 & $1.45 \%$ & 45 & 0.25 & 0.0181932 & 10 & 7 & 0.000 \\
\hline & 12.625 & BENZENE + 1,2-DCA & 0.085 & $0.80 \%$ & 70 & 0.38 & 0.0012136 & 11 & 8 & 0.000 \\
\hline & 21.474 & PCE & 0.508 & $-0.26 \%$ & 258 & 1.42 & 0.0019709 & 14 & 33 & 0.000 \\
\hline
\end{tabular}




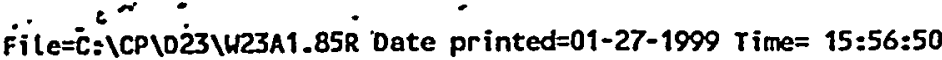

Sample Hame $=904-1116-25$

2.0 to $36.0 \mathrm{~min}$. Low $Y=0.394 \mathrm{High} Y=1.363 \mathrm{mv}$ Span=0.968

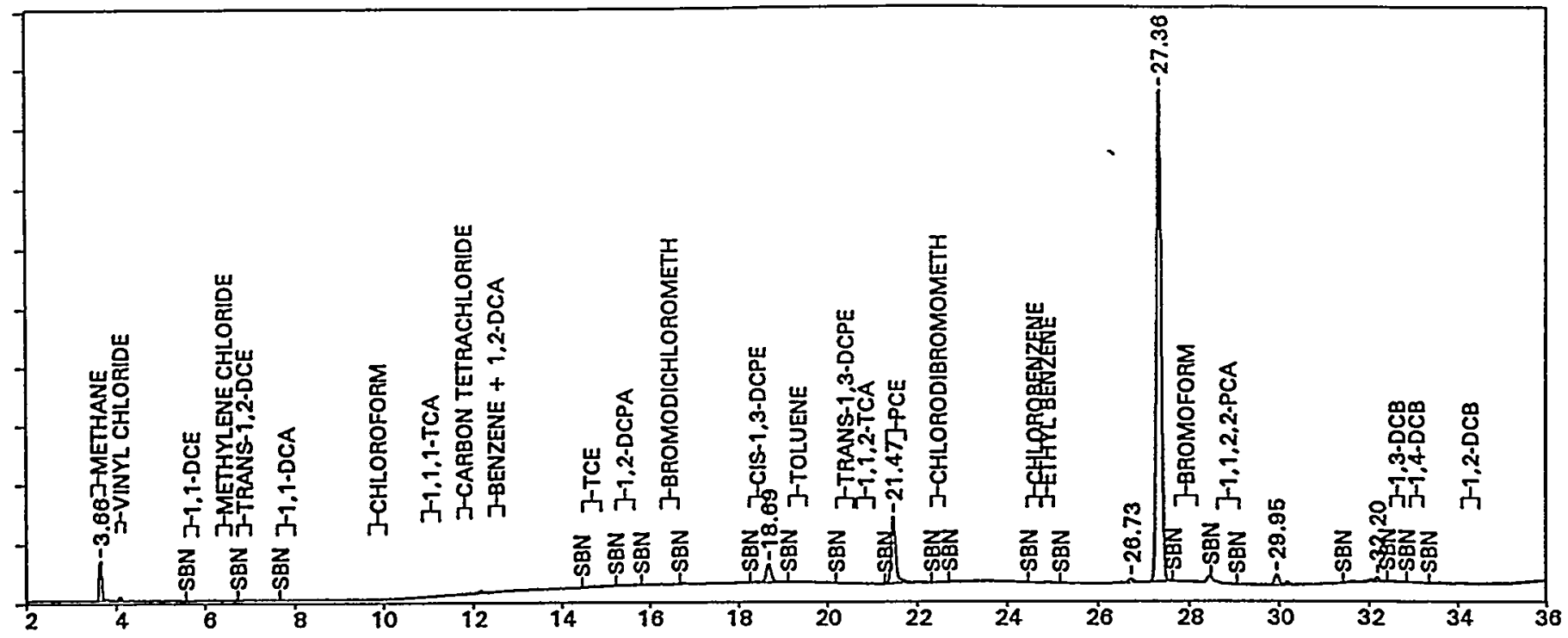

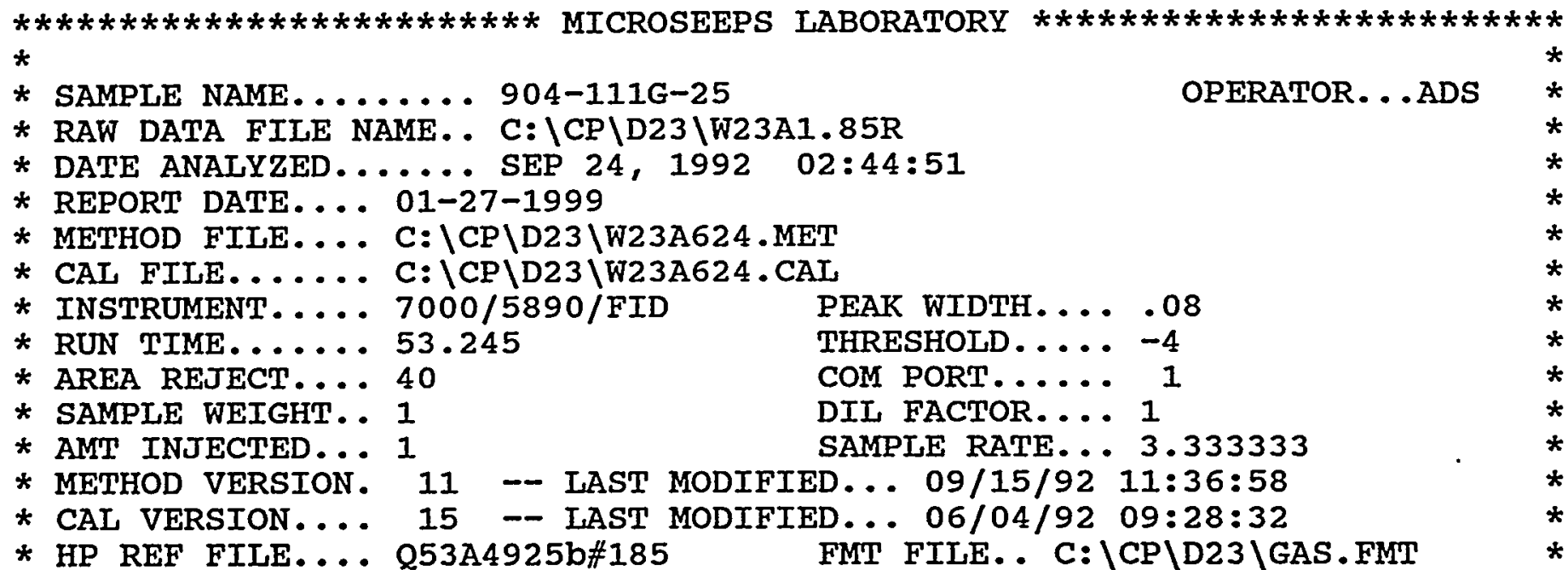

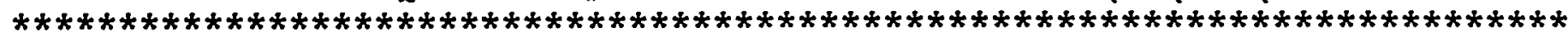

\begin{tabular}{|c|c|c|c|c|c|c|c|c|c|c|}
\hline $\begin{array}{l}\text { Out of } \\
\text { Bound }\end{array}$ & $\begin{array}{l}\text { Ret Time } \\
\text { (min) }\end{array}$ & Peak Name & $\begin{array}{c}\text { Amount } \\
\text { PPHV }\end{array}$ & $\begin{array}{r}\text { \% Delta } \\
\text { Ret Time }\end{array}$ & $\begin{array}{l}\text { Peak } \\
\text { Area } \\
\end{array}$ & AREA $\%$ & $\begin{array}{l}\text { Amount/ } \\
\text { Area }\end{array}$ & $\begin{array}{l}\text { Peak } \\
. \# \\
\end{array}$ & $\begin{array}{r}\text { Peak } \\
\text { Height }\end{array}$ & $\begin{array}{r}\text { Ug/l } \\
\text { AIR } \\
\end{array}$ \\
\hline & 3.661 & METHANE & 0.500 & $1.42 \%$ & 290 & 3.94 & 0.0017201 & 1 & 65 & 0.000 \\
\hline & 21.472 & PCE & 1.565 & $-0.27 \%$ & 782 & 10.61 & 0.0020016 & 5 & 109 & 0.000 \\
\hline
\end{tabular}


File $=C: \backslash C P \backslash D 23 \backslash$ W23A1.86R Date printed $=01-27-1999$ Time $=15: 58: 12$

Sample Name $=904-111 \mathrm{G}-26$

2.0 to $36.0 \mathrm{~min}$. Low $Y=0.384$ High $Y=3.402 \mathrm{mv}$ Span=3.017

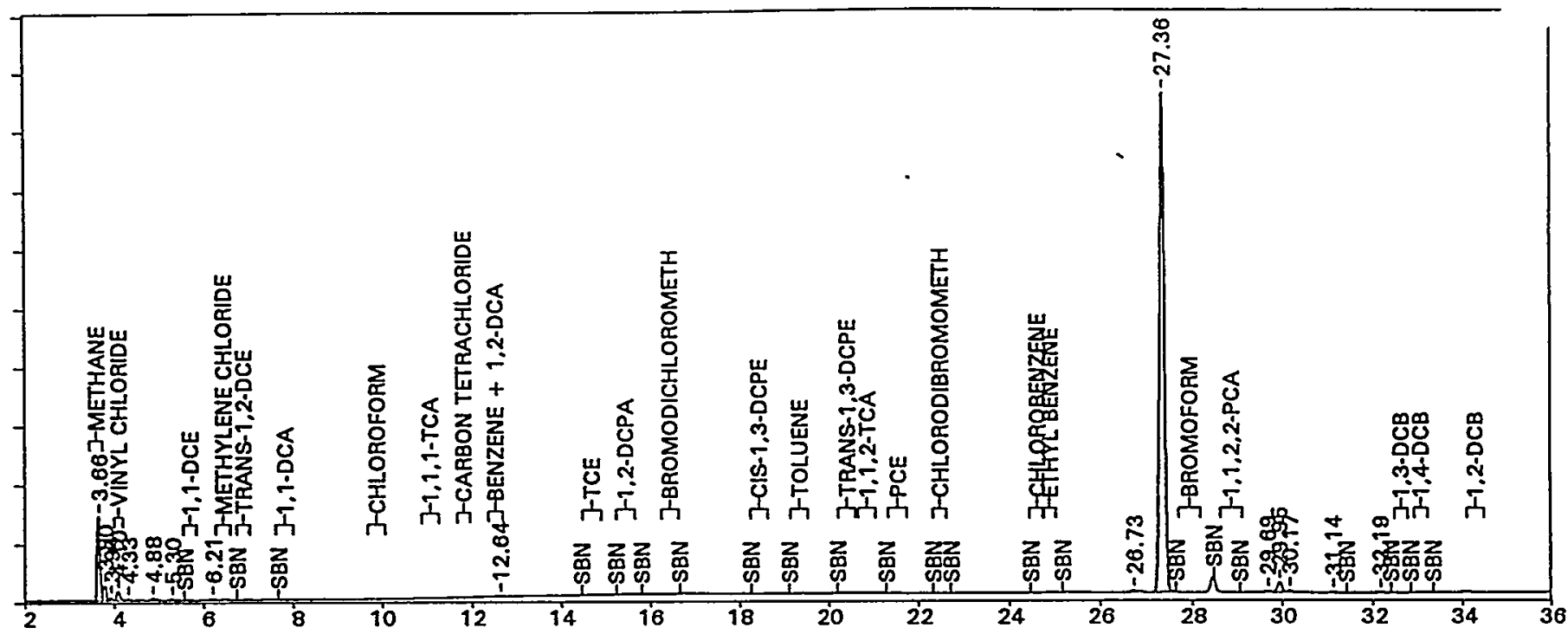

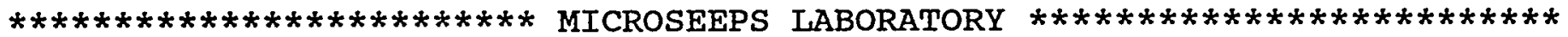
$*$

* SAMPLE NAME....... 904-111G-26

* RAW DATA FILE NAME.. C: \CP\D23\W23A1.86R

* DATE ANALYZED....... SEP 24, 1992 03:51:02

* REPORT DATE... 01-27-1999

* METHOD FILE.... C: CCP\D23\W23A624.MET

* CAI FILE...... C: \CP\D23\W23A624.CAL

* INSTRUMENT.... 7000/5890/FID PEAK WIDTH.....08

* RUN TIME...... 53.245 THRESHOLD..... -4

* AREA REJECT... 40

* SAMPLE WEIGHT. . 1 COM PORT...... 1

* AMT INJECTED... 1 DII FACTOR.... 1

* METHOD VERSION. 11 -- LAST MODIFIED... 09/15/92 11:36:58

* CAL VERSION.... 15 - LAST MODIFIED... 06/04/92 09:28:32

* HP REF FILE. . . Q53A58A8b\#186 FMT FILE.. C: \CP\D23\GAS.FMT

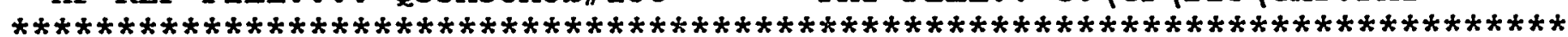

\begin{tabular}{|c|c|c|c|c|c|c|c|c|c|c|}
\hline $\begin{array}{l}\text { Out of } \\
\text { Bound }\end{array}$ & $\begin{array}{l}\text { Ret Time } \\
\text { (min) }\end{array}$ & Peak Name & $\begin{array}{l}\text { Amount } \\
\text { PPHV }\end{array}$ & $\begin{array}{r}\text { \% Delta } \\
\text { Ret Time }\end{array}$ & $\begin{array}{l}\text { Peak } \\
\text { Area } \\
\end{array}$ & AREA $\%$ & $\begin{array}{l}\text { Amount/ } \\
\text { Area }\end{array}$ & $\begin{array}{c}\text { Peak } \\
\# \\
\end{array}$ & $\begin{array}{r}\text { Peak } \\
\text { Height } \\
\end{array}$ & $\begin{array}{r}u g / l \\
\text { AIR } \\
\end{array}$ \\
\hline & 3.663 & METHANE & 3.259 & $1.46 \%$ & 1943 & 8.75 & 0.0016774 & 1 & 432 & 0.000 \\
\hline & 4.098 & VINYL CHLORIDE & 1.587 & $-0.29 \%$ & 248 & 1.12 & 0.0063875 & 4 & 43 & 0.000 \\
\hline & 12.639 & BENZENE + 1,2-DCA & 0.056 & $0.91 \%$ & 46 & 0.21 & 0.0012136 & 12 & 5 & 0.000 \\
\hline
\end{tabular}

Total amt. ID. $=4.902425$ Total area (all peaks) $=22209.55$ 


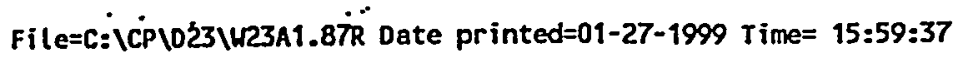

Sample Hame $=904-111 \mathrm{G}-27$

2.0 to 36.0 min. LoH $Y=-17.863$ High $Y=3788.006 \mathrm{mV}$ Span=3805.869

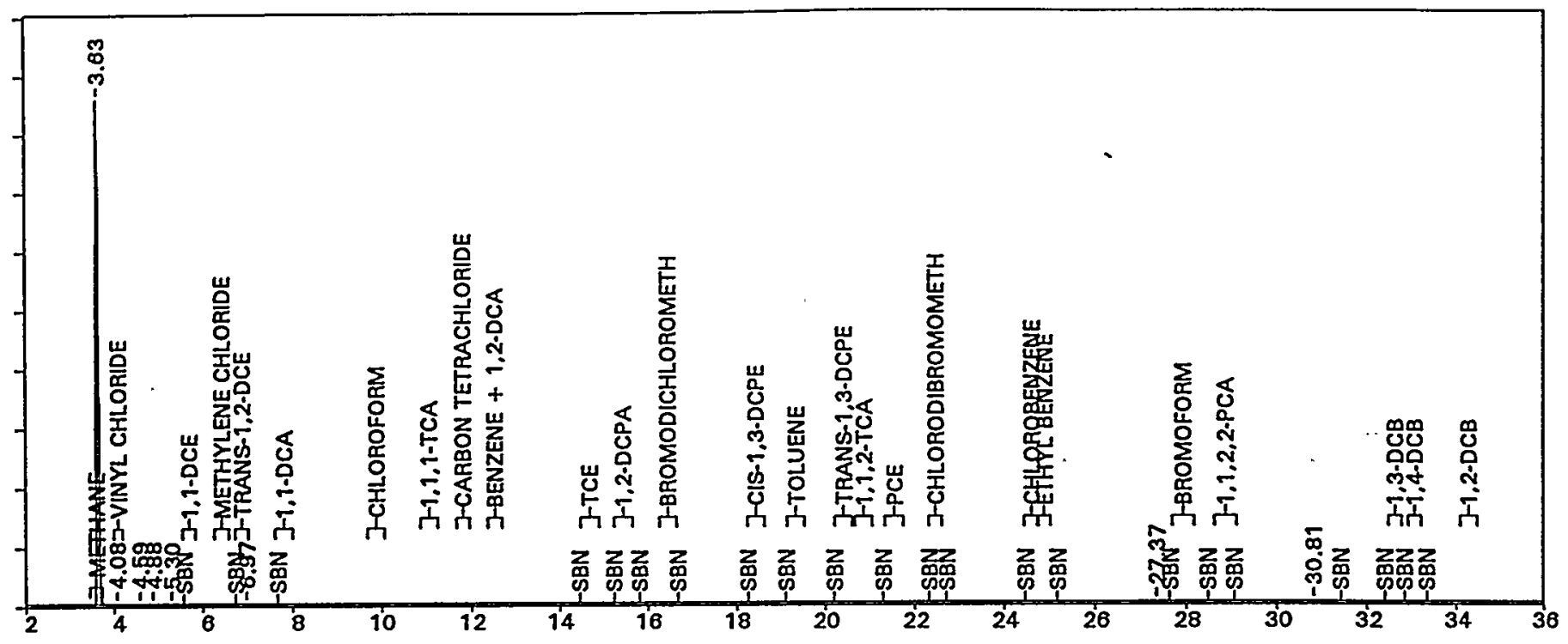

$* * * * * * * * * * * * * * * * * * * * * * * * *$ MICROSEEPS LABORATORY $* * * * * * * * * * * * * * * * * * * * * * * * *$ *

* SAMPLE NAME........ 904-111G-27

OPERATOR...ADS

* RAW DATA FILE NAME. C C: ICP\D23\W23A1.87R

* DATE ANALYZED ....... SEP 24, 1992 04:57:18

* REPORT DATE... 01-27-1999

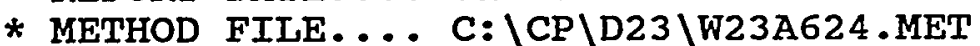

* CAL FILE...... C: \CP\D23\W23A624.CAL

* INSTRUMENT.... 7000/5890/FID PEAK WIDTH....08

* RUN TIME...... 53.245 THRESHOID.... -4

* AREA REJECT... 40

* SAMPLE WEIGHT. 1

COM PORT...... 1

* AMT INJECTED... 1

DII FACTOR .... 1

* METHOD VERSION. 11 - IAAST MODIFIED . . 09/15/92 11:36:58

* CAI VERSION.... 15 - LAST MODIFIED... 06/04/92 09:28:32

* HP REF FILE.... Q53A6830b\#187 . FMT FIIE.. C: ICPID23 IGAS.FMT

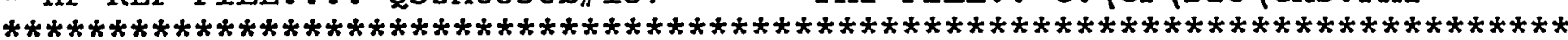

\begin{tabular}{|c|c|c|c|c|c|c|c|c|c|c|}
\hline $\begin{array}{l}\text { Out of } \\
\text { Bound }\end{array}$ & $\begin{array}{l}\text { Ret Time } \\
\text { (min) }\end{array}$ & Peak Name & $\begin{array}{l}\text { Amount } \\
\text { PPHV }\end{array}$ & $\begin{array}{r}\text { \% Delta } \\
\text { Ret Time }\end{array}$ & $\begin{array}{l}\text { Peak } \\
\text { Area }\end{array}$ & AREA $\%$ & $\begin{array}{l}\text { Amount/ } \\
\text { Area }\end{array}$ & $\begin{array}{c}\text { Peak } \\
\#\end{array}$ & $\begin{array}{r}\text { Peak } \\
\text { Height }\end{array}$ & $\begin{array}{r}u g / l \\
\text { AIR } \\
\end{array}$ \\
\hline & 3.632 & METHANE & 81249.039 & $0.62 \%$ & 12448470 & 99.99 & 0.0065268 & & 3289075 & 0.000 \\
\hline & 4.077 & VINYL CHLORIDE & 4.457 & $-0.81 \%$ & 700 & 0.01 & 0.0063711 & 2 & 89 & 0.000 \\
\hline & 6.970 & TRANS-1,2-DCE & 0.804 & $1.31 \%$ & 44 & 0.00 & 0.0181932 & 8 & 6 & 0.000 \\
\hline
\end{tabular}

Total amt. ID. $=81254.3$

Total area (all peaks) $=1.244979 \mathrm{E}+07$ 
Fi-le=c: $\backslash C P \backslash \ddot{D} 23 \backslash$ U23A1 $-88 R$ Date printed $=01-27-1999$ Time= 16:00:59

Sample Hame $=904-111 \mathrm{G}-28$

2.0 to $36.0 \mathrm{~min}$. Low $Y=-0.717 \mathrm{High} Y=231.783 \mathrm{mv}$ Span=232.5

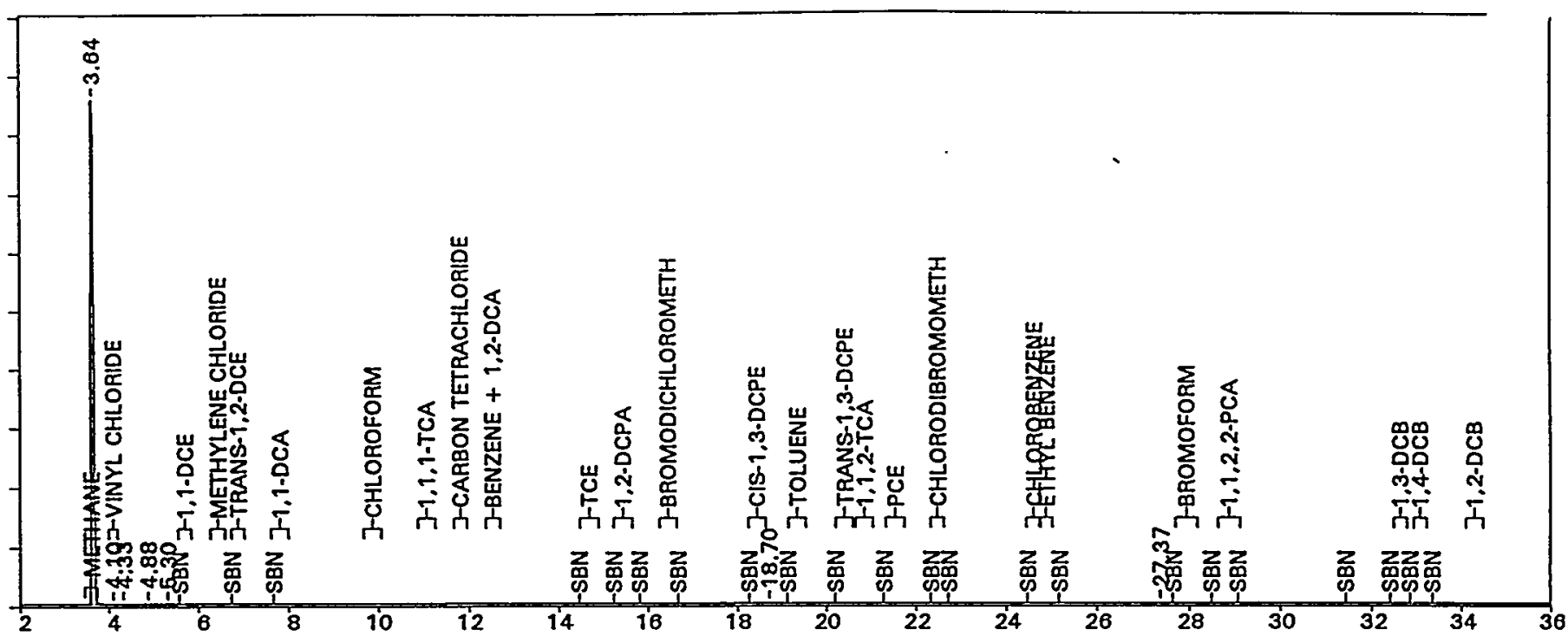

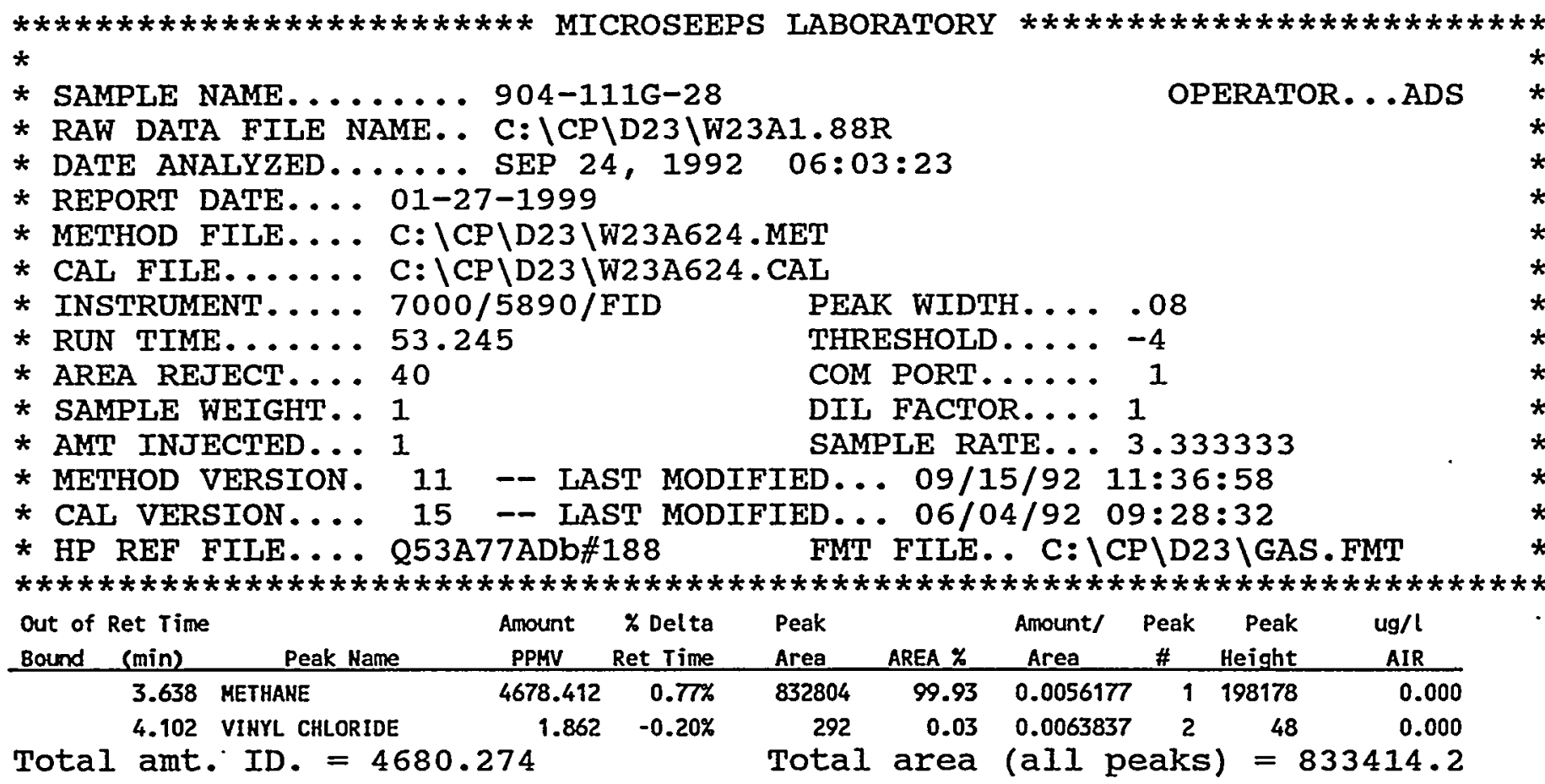


File=C:ICPID23IW23A1.89R Date printed=01-27-1999 Time= 16:02:21

Sample Name $=904-111 \mathrm{G}-29$

2.0 to $36.0 \mathrm{~min}$. Low $Y=-6.731 \mathrm{High} Y=1479.246 \mathrm{mv}$ Span=1485.977

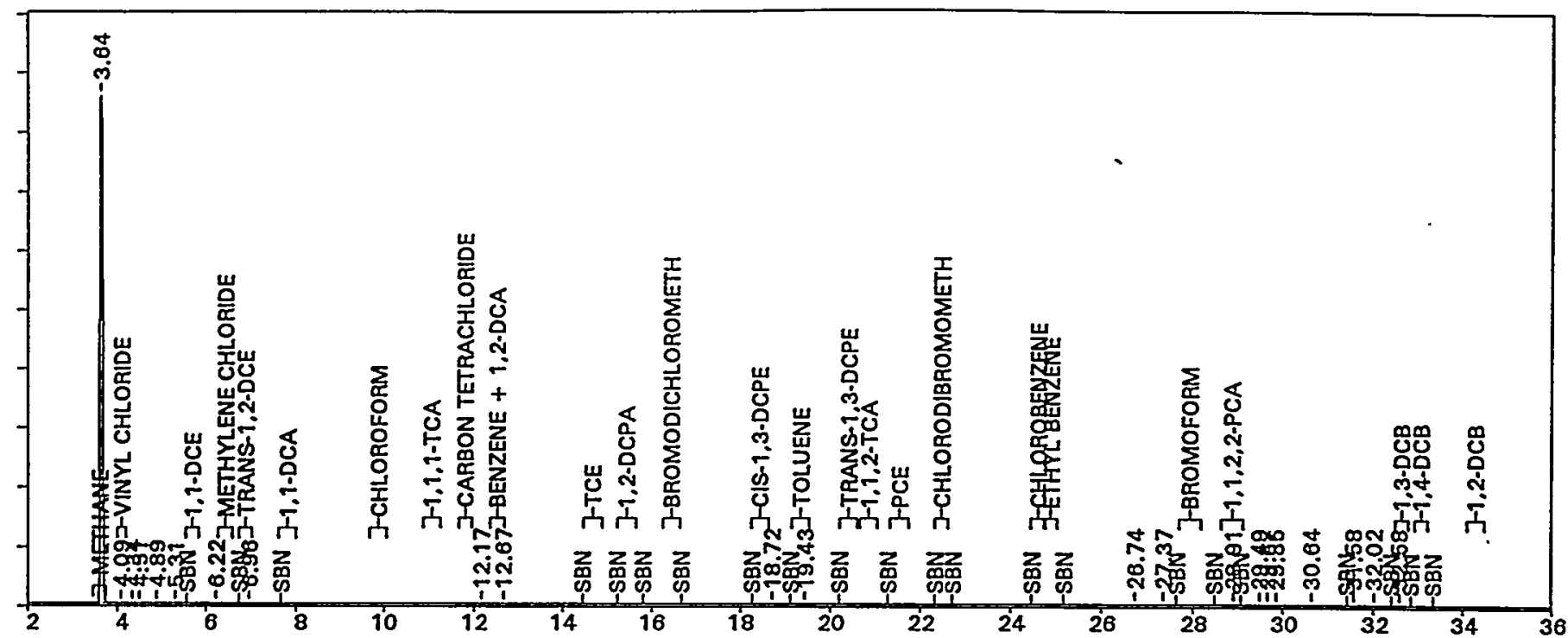

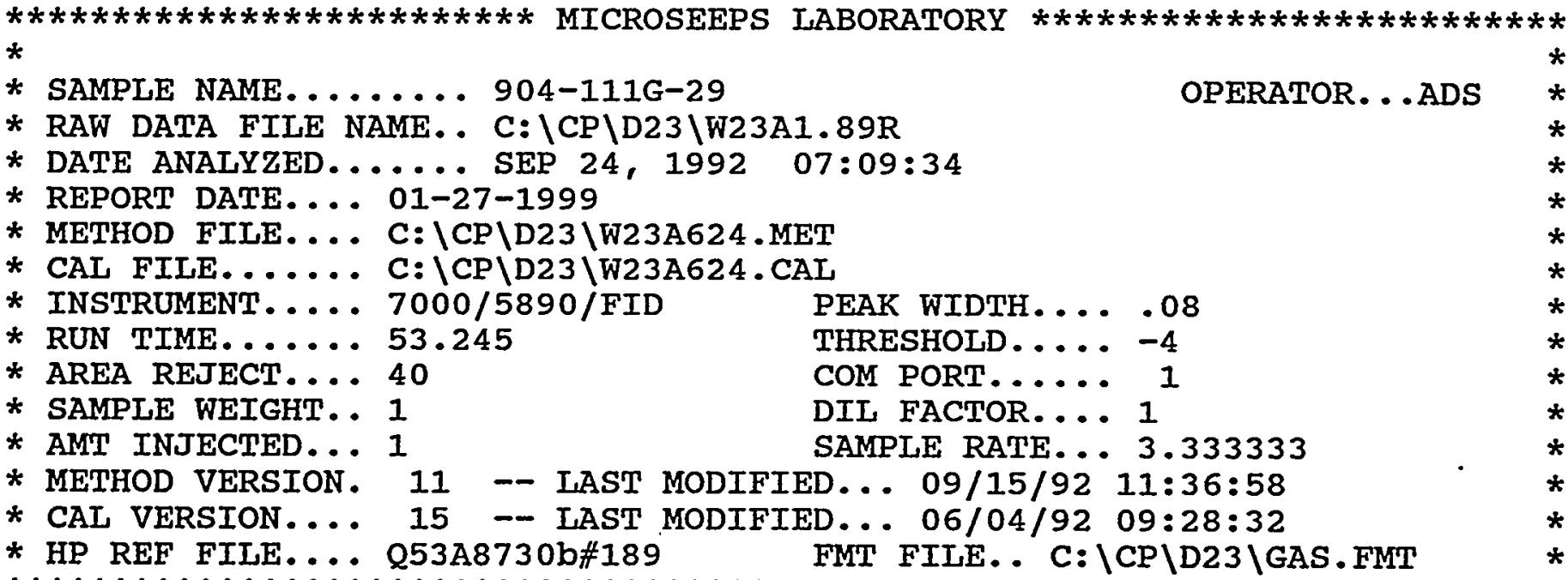

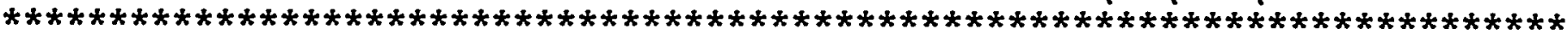

\begin{tabular}{|c|c|c|c|c|c|c|c|c|c|c|}
\hline $\begin{array}{l}\text { Out of } \\
\text { Bound }\end{array}$ & $\begin{array}{l}\text { Ret Time } \\
\text { (min) }\end{array}$ & Peak Hame & $\begin{array}{l}\text { Amount } \\
\text { PPHV }\end{array}$ & $\begin{array}{r}\text { \% Delta } \\
\text { Ret Time }\end{array}$ & $\begin{array}{l}\text { Peak } \\
\text { Area }\end{array}$ & AREA $\%$ & $\begin{array}{c}\text { Arrount/ } \\
\text { Area }\end{array}$ & $\begin{array}{c}\text { Peak } \\
\# \\
\end{array}$ & $\begin{array}{r}\text { Peak } \\
\text { Height }\end{array}$ & $\begin{array}{r}\text { ug/l } \\
\text { AIR }\end{array}$ \\
\hline & 3.641 & METHANE & 31116.195 & $0.86 \%$ & 5364405 & 99.81 & 0.0058005 & & 1265382 & 0.000 \\
\hline & 4.086 & VINYL CHLORIDE & 3.110 & $-0.59 \%$ & 488 & 0.01 & 0.0063750 & 2 & 67 & 0.000 \\
\hline & 6.960 & TRANS-1,2-DCE & 1.053 & $1.17 \%$ & 58 & 0.00 & 0.0181932 & 10 & 8 & 0.000 \\
\hline & 12.674 & BENZENE + 1,2-DCA & 0.051 & $1.19 \%$ & 42 & 0.00 & 0.0012136 & 12 & 5 & 0.000 \\
\hline & 19.432 & TOLUENE & 1.185 & $0.48 \%$ & 1604 & 0.03 & 0.0007390 & 15 & 218 & 0.000 \\
\hline & 28.912 & $1,1,2,2-P C A$ & 2.011 & $0.13 \%$ & 937 & 0.02 & 0.0021449 & 18 & 146 & 0.000 \\
\hline & 32.578 & 1,3-DCB & 3.588 & $0.13 \%$ & 3943 & 0.07 & 0.0009101 & 27 & 678 & 0.000 \\
\hline
\end{tabular}


File $=C: \backslash C P i D 23 \backslash W 23 A 1.90 R$ Date printed $=01-27-1999$ Time= 16:03:47

Sample Name $=904-1116-30$

2.0 to $36.0 \mathrm{~min}$. . Low $Y=0.398$ High $Y=0.552 \mathrm{mv}$ Span=0.154

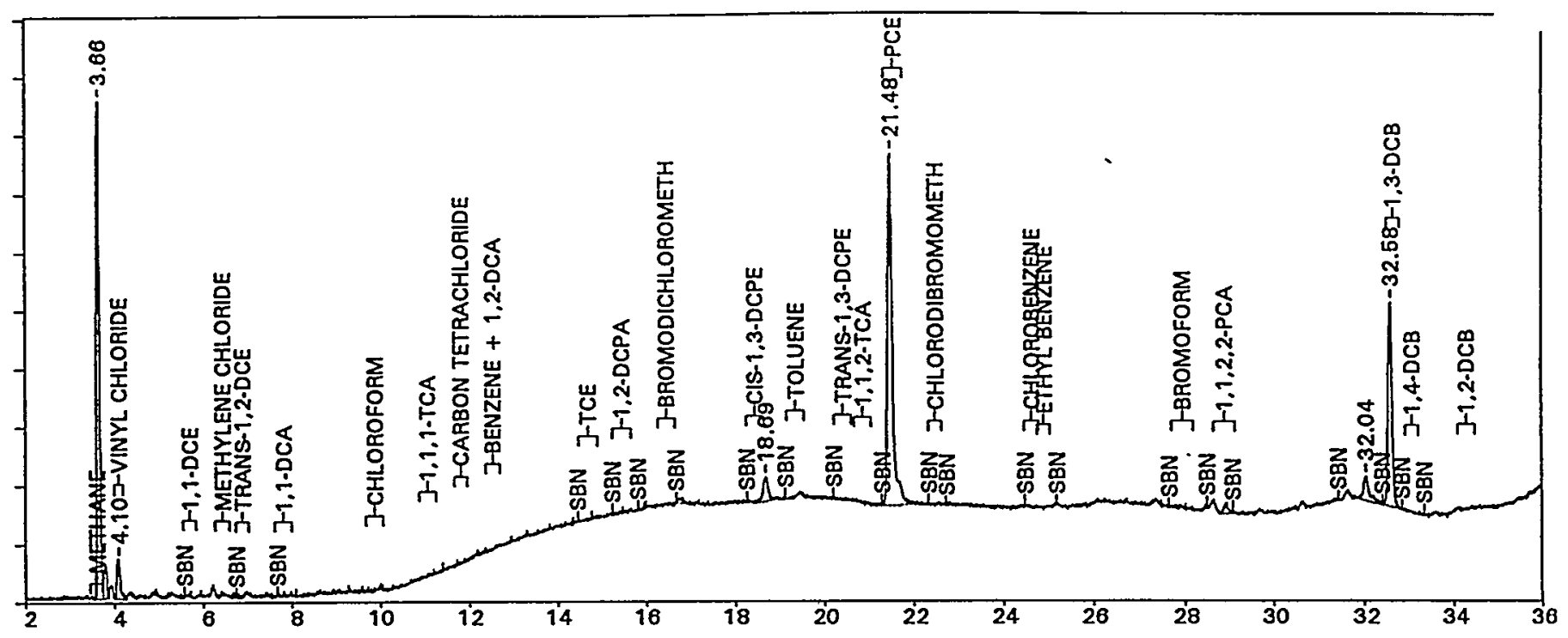

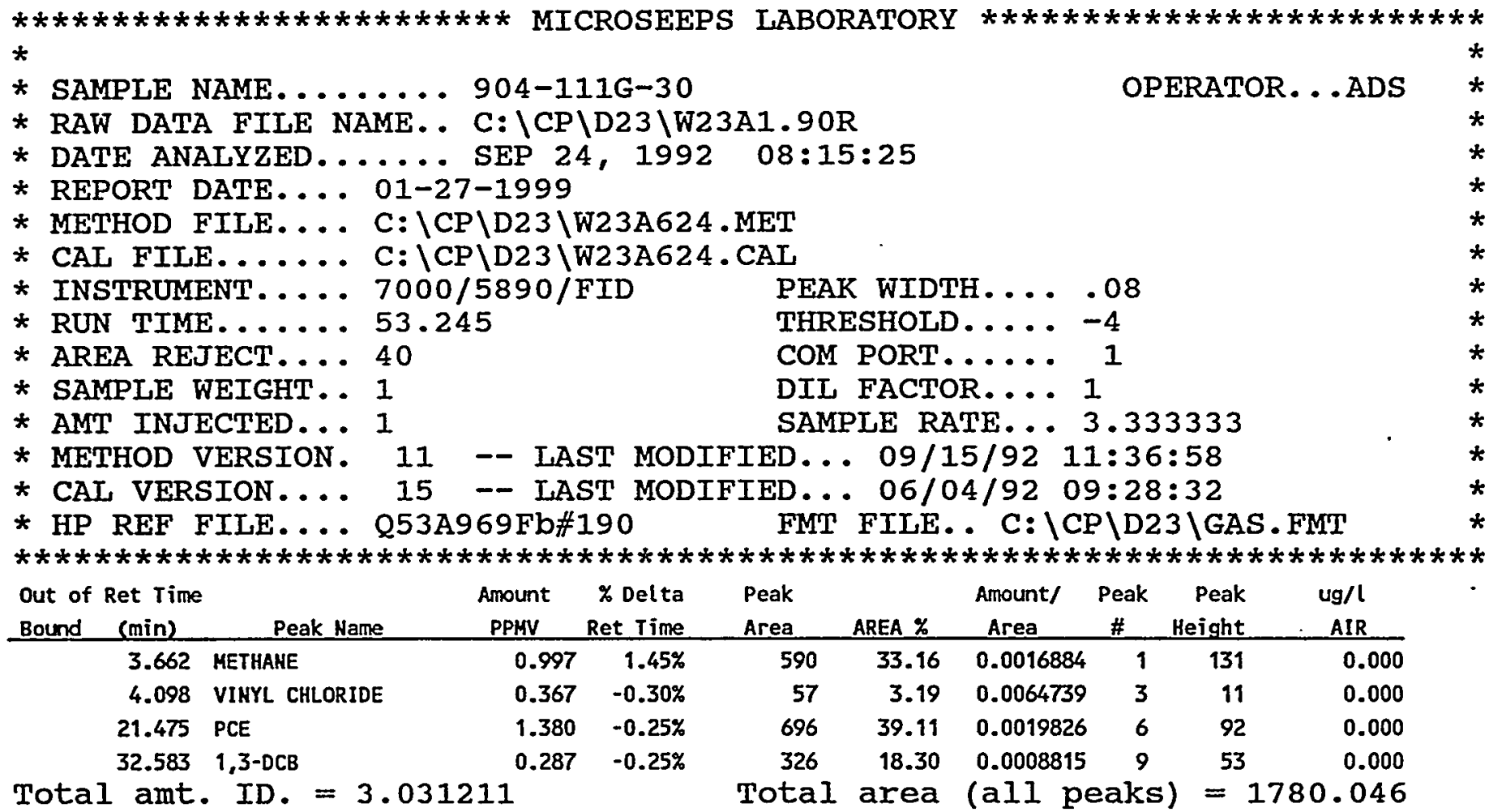


File=C: \CP\ס̈23 $\backslash$ H23A1.91R Date printed=01-27-1999 $\mathrm{Time}=16: 05: 10$

Sample Hame $=904-111 \mathrm{G}-30 \mathrm{~A}$

2.0 to $36.0 \mathrm{~min}$. Low $Y=0.397$ High $Y=0.52 \mathrm{mv}$ Span=0.123

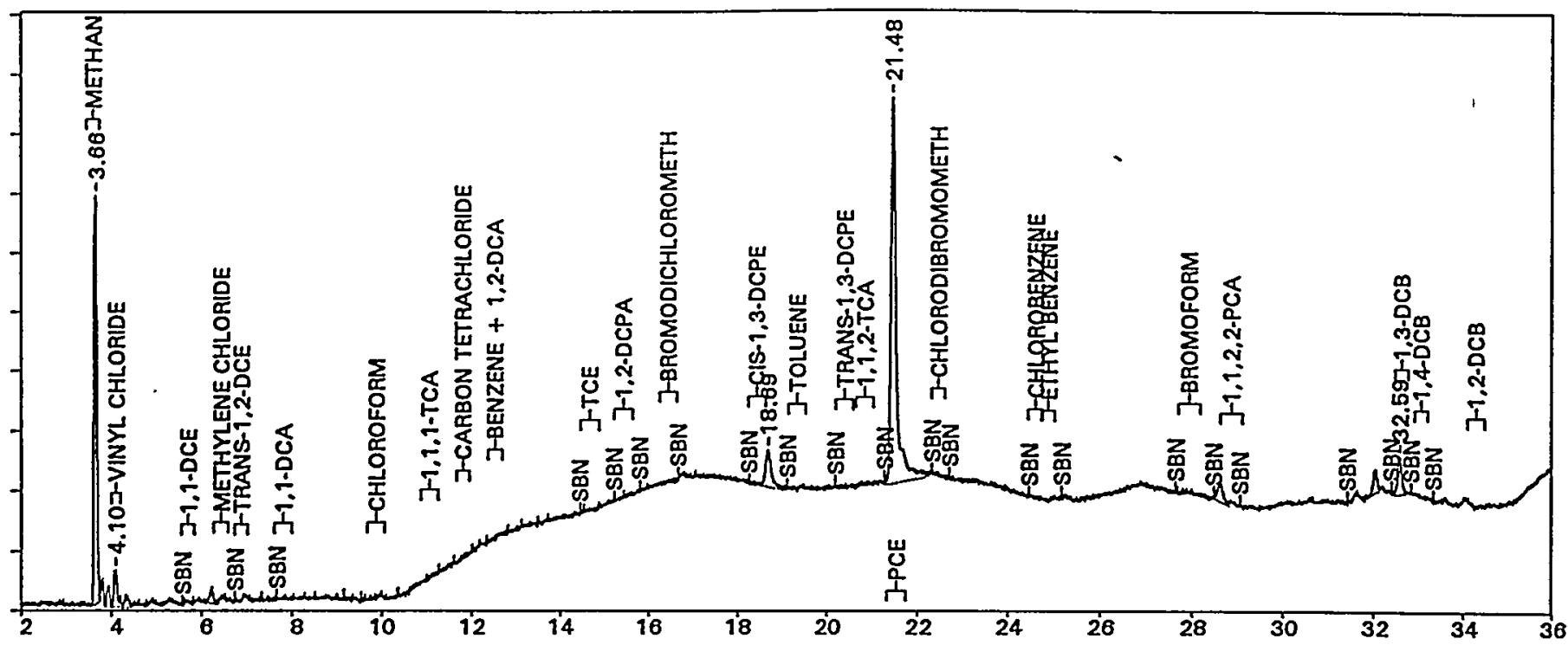

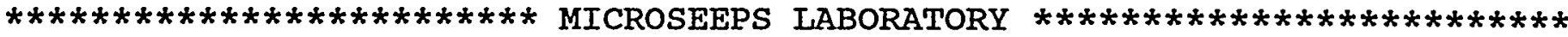
*

* SAMPLE NAME....... 904-111G-30A

* RAW DATA FILE NAME.. C: \CP\D23\W23A1.91R

* DATE ANALYZED...... SEP 24, 1992 09:21:43

* REPORT DATE... 01-27-1999

* METHOD FILE.... C: \CP\D23\W23A624.MET

* CAI FILE....... C: \CP\D23\W23A624.CAL

* INSTRUMENT.... 7000/5890/FID PEAK WIDTH.....08

* RUN TIME...... 53.245 THRESHOLD..... -4

* AREA REJECT... 40

* SAMPLE WEIGHT. . 1

COM PORT...... 1

* AMT INJECTED... 1

DII FACTOR.... 1

* METHOD VERSION. 11 - LAST MODIFIED... 09/15/92 11:36:58

* CAL VERSION.... 15 -- LAST MODIFIED... 06/04/92 09:28:32

* HP REF FILE.... Q53AA629b\#191

FMT FILE.. C: \CP\D23 \GAS.FMT

$* * * * * * * * * * * * * * * * * * * * * * * * * * * * * * * * * * * * * * * * * * * * * * * * * * * * * * * * * * * * * * * * * * * * * * * * * 4)$

\begin{tabular}{|c|c|c|c|c|c|c|c|c|c|}
\hline $\begin{array}{l}\text { Out of Ret Time } \\
\text { Bound (min) }\end{array}$ & Peak Name & $\begin{array}{l}\text { Amount } \\
\text { PPHV }\end{array}$ & $\begin{array}{r}* \text { Delta } \\
\text { Ret Time }\end{array}$ & $\begin{array}{l}\text { Peak } \\
\text { Area } \\
\end{array}$ & AREA $x$ & $\begin{array}{l}\text { Amount/ } \\
\text { Area }\end{array}$ & $\begin{array}{c}\text { Peak } \\
\#\end{array}$ & $\begin{array}{r}\text { Peak } \\
\text { Height }\end{array}$ & $\begin{array}{r}\text { ug/l } \\
\text { AIR }\end{array}$ \\
\hline 3.664 & METHANE & 0.637 & $1.51 \%$ & 372 & 31.05 & 0.0017130 & 1 & 84 & 0.000 \\
\hline 4.099 & VIHYL CHLORIDE & 0.380 & $-0.28 \%$ & 59 & 4.90 & 0.0064702 & 3 & 8 & 0.000 \\
\hline 21.480 & PCE & 1.280 & $-0.23 \%$ & 649 & 54.19 & 0.0019709 & 6 & 79 & 0.000 \\
\hline 32.592 & 1,3-DCB & 0.043 & $-0.23 \%$ & 48 & 4.03 & 0.0008815 & 9 & 8 & 0.000 \\
\hline
\end{tabular}


File=CF $1 C P \backslash 023 \backslash$ L23A1.

Sample Hame $=904-111 \mathrm{G}^{\star} \mathrm{SB} 4$

2.0 to $36.0 \mathrm{~min}$. Lor $Y=0.391 \mathrm{High} Y=0.53 \mathrm{mv}$ Span=0.139

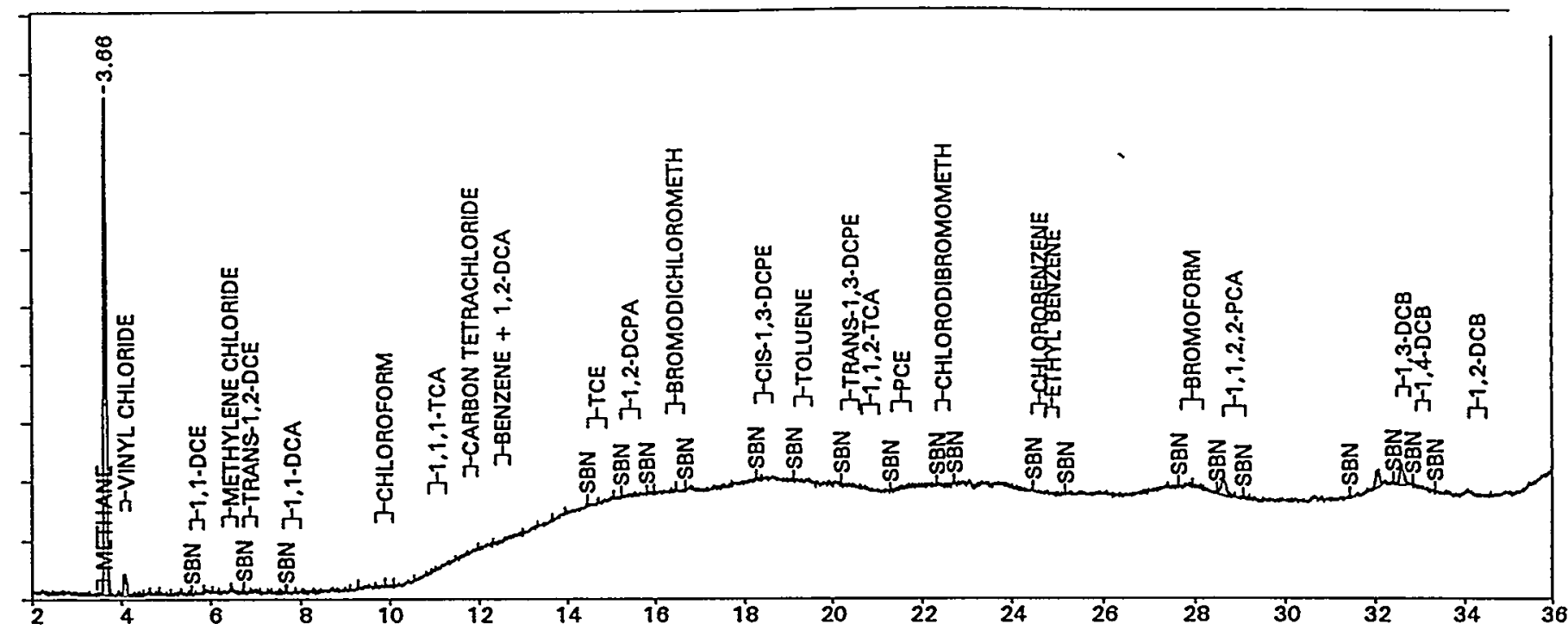

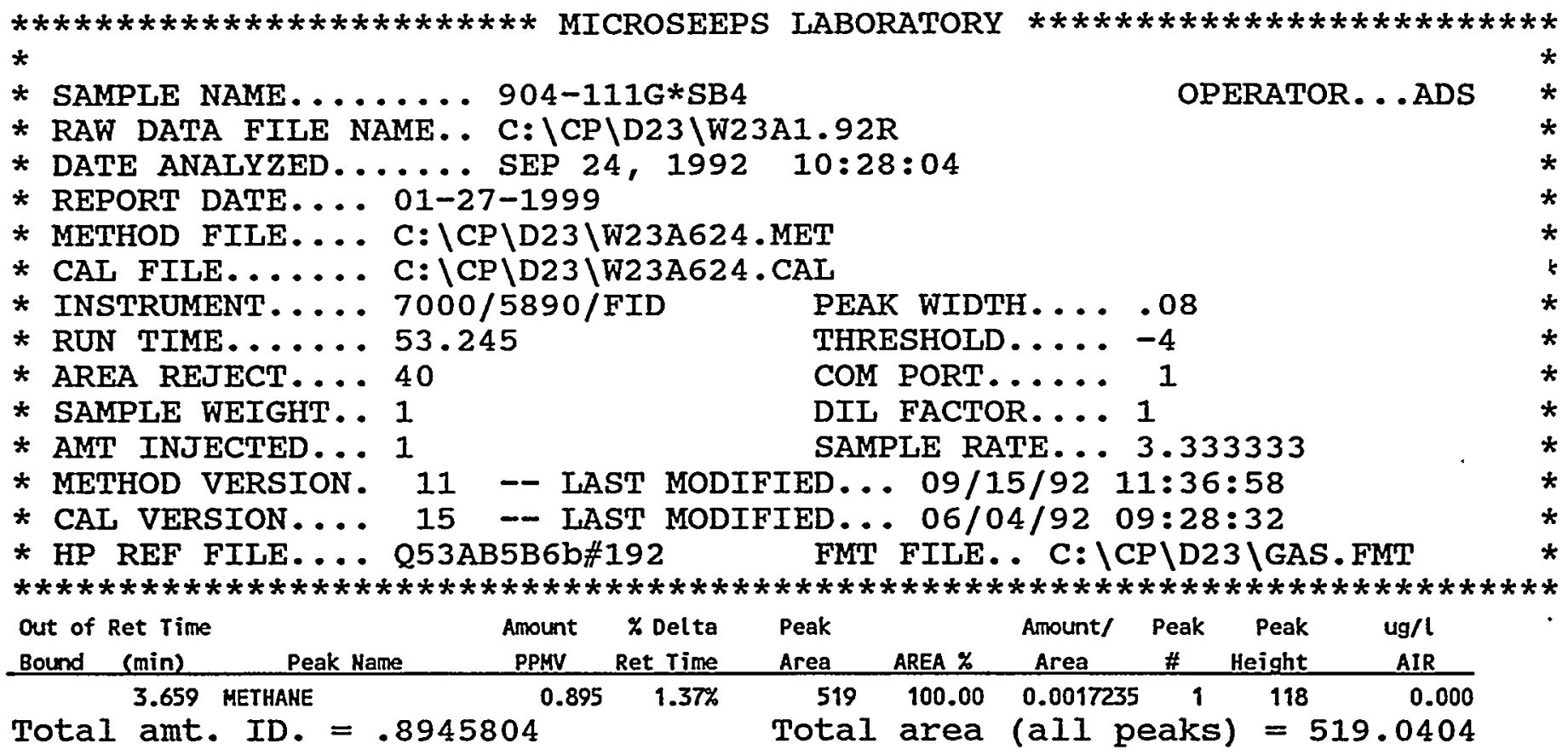


Fíle=c: \CPID23in23A1.93R Date printed=01-27-1999 Time= 16:07:56

Sample Name $=5 T 0$ K4 R4

2.0 to $36.0 \mathrm{~min}$. Lok $Y=-7.427$ High $Y=1621.712 \mathrm{mV}$ Span=1629.139

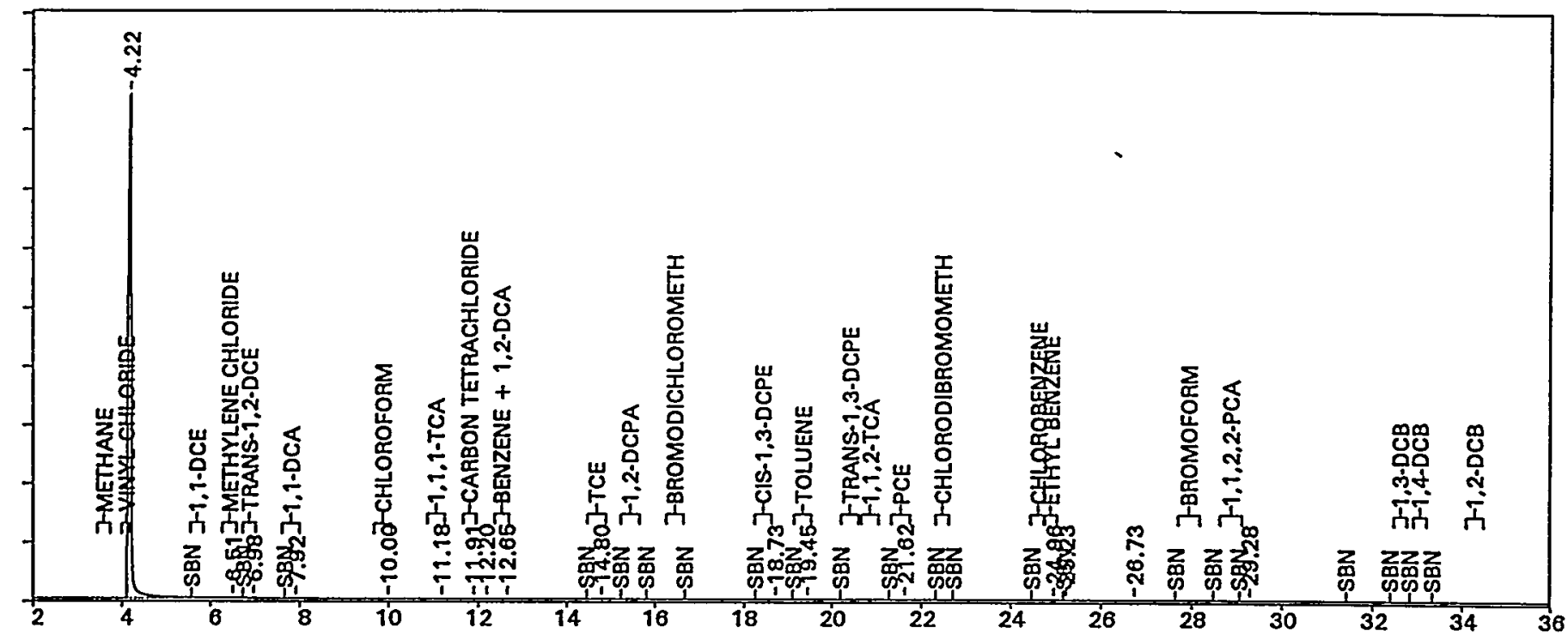

$* * * * * * * * * * * * * * * * * * * * * * * * *$ MICROSEEPS IABORATORY $* * * * * * * * * * * * * * * * * * * * * * * * *$ *

* SAMPLE NAME........ STD K4 R4

* RAW DATA FILE NAME.. C: \CP\D23\W23A1.93R

* DATE ANAIYZED....... SEP 24, 1992 11:34:34

* REPORT DATE... 01-27-1999

* METHOD FILE.... C: \CP\D23\W23A624.MET

* CAI FILE. . . . . C: \CP\D23\W23A624.CAI

* INSTRUMENT..... 7000/5890/FID PEAK WIDTH.... .08

* RUN TIME...... 53.245

* AREA REJECT.... 40

* SAMPLE WEIGHT.. 1

* AMT INJECTED... 1

THRESHOLD..... -4

* METHOD VERSION. 11

COM PORT...... 1

OPERATOR...ADS

* CAL VERSION.... 15 - LAST MODIFIED... 06/04/92 09:28:32

* HP REF FILE.... Q53AC54Cb\#193

FMT FILE.. C: $\backslash C P \backslash D 23 \backslash G A S . F M T$

$* * * * * * * * * * * * * * * * * * * * * * * * * * * * * * * * * * * * * * * * * * * * * * * * * * * * * * * * * * * * * * * * * * * * * * * * *$

\begin{tabular}{|c|c|c|c|c|c|c|c|c|c|}
\hline $\begin{array}{l}\text { Out of Ret Time } \\
\text { Bound (min) }\end{array}$ & Peak Name & $\begin{array}{l}\text { Amount } \\
\text { PPHV }\end{array}$ & $\begin{array}{l}\text { \% Delta } \\
\text { Ret Time }\end{array}$ & $\begin{array}{l}\text { Peak } \\
\text { Area } \\
\end{array}$ & AREA $\%$ & $\begin{array}{c}\text { Amount/ } \\
\text { Area }\end{array}$ & $\begin{array}{c}\text { Peak } \\
\#\end{array}$ & $\begin{array}{r}\text { Peak } \\
\text { Height }\end{array}$ & $\begin{array}{r}\text { ug/l } \\
\text { AIR }\end{array}$ \\
\hline 6.506 & METHYLENE CHLORIDE & 1.394 & $1.26 \%$ & 230 & 0.00 & 0.0060595 & 3 & 45 & 0.000 \\
\hline 6.981 & TRANS-1,2-DCE & 7.412 & $1.47 \%$ & 427 & 0.01 & 0.0173513 & 4 & 78 & 0.000 \\
\hline 7.919 & $1,1-D C A$ & 1.151 & $1.47 \%$ & 420 & 0.01 & 0.0027437 & 5 & 62 & 0.000 \\
\hline 9.999 & CHLOROFORM & 0.890 & $1.47 \%$ & 162 & 0.00 & 0.0054980 & 6 & 22 & 0.000 \\
\hline 11.179 & 1,1,1-TCA & 1.026 & $1.47 \%$ & 430 & 0.01 & 0.0023861 & 7 & 43 & 0.000 \\
\hline 11.905 & CARBON TETRACHLORID & 2.061 & $0.81 \%$ & 82 & 0.00 & 0.0250274 & 8 & 10 & 0.000 \\
\hline 12.655 & BEHZEHE + 1,2-DCA & 1.610 & $1.04 \%$ & 1327 & 0.02 & 0.0012136 & 10 & 157 & 0.000 \\
\hline 14.798 & TCE & 1.158 & $0.84 \%$ & 484 & 0.01 & 0.0023937 & 11 & 61 & 0.000 \\
\hline 19.446 & TOLUENE & 0.961 & $0.55 \%$ & 1301 & 0.02 & 0.0007390 & 14 & 179 & 0.000 \\
\hline 21.624 & PCE & 0.889 & $0.44 \%$ & 451 & 0.01 & 0.0019709 & 15 & 69 & 0.000 \\
\hline 24.960 & ETHYL BEHZENE & 0.831 & $0.32 \%$ & 1105 & 0.02 & 0.0007523 & 16 & 184 & 0.000 \\
\hline
\end{tabular}

Total amt. ID. $=19.38369$ 
File=C: VPPID23iW23A1.94R Date printed $=01-27-1999$ Time= 16:09:22

Sample Name $=904-111 \mathrm{G}-31$

2.0 to $36.0 \mathrm{~min}$. Low $Y=0.387$ High $Y=0.517 \mathrm{mV}$ Span=0.13

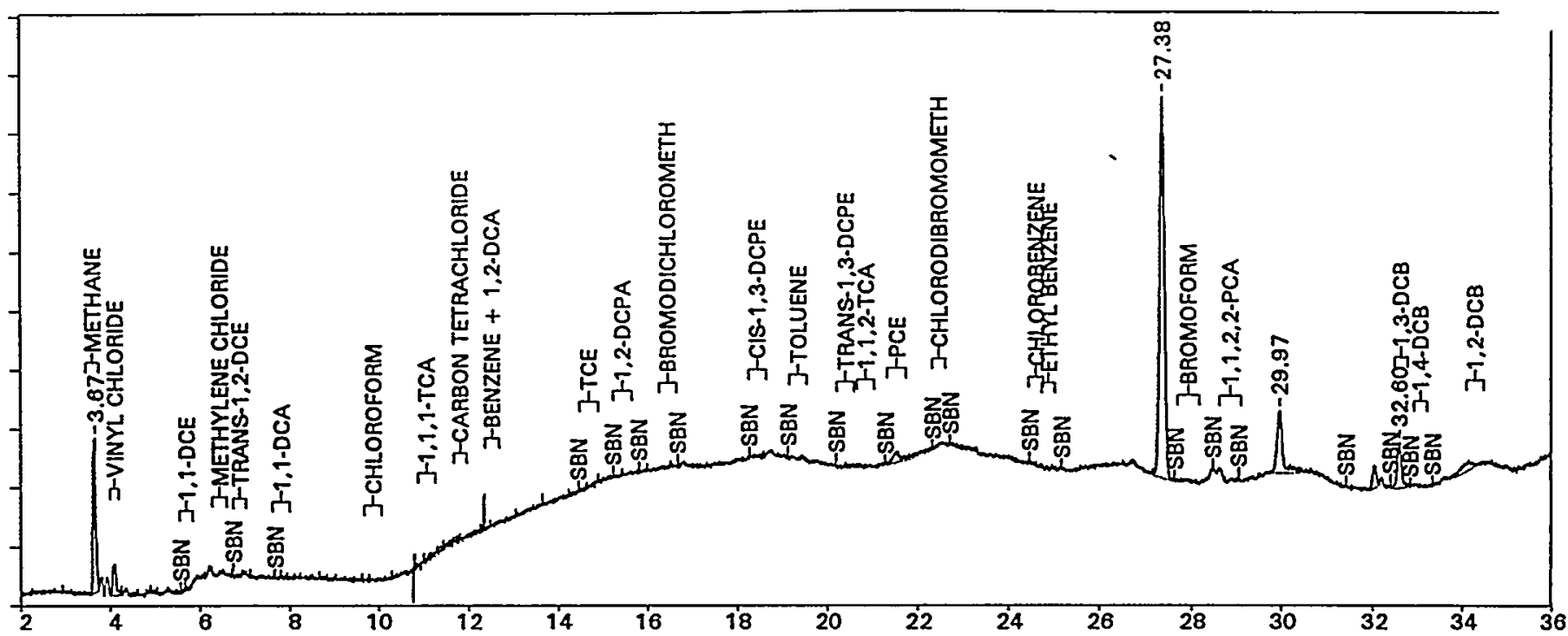

$\star * * * * * * * * * * * * * * * * * * * * * * * *$ MICROSEEPS LABORATORY $* * * * * * * * * * * * * * * * * * * * * * * * *$ *

* SAMPIE NAME........ 904-111G-31

* RAW DATA FIIE NAME.. C: \CP\D23\W23A1.94R

* DATE ANALYZED....... SEP 24, 1992 12:41:03

* REPORT DATE... 01-27-1999

* METHOD FILE.... C: \CP\D23\W23A624.MET

* CAL FILE...... C: \CP\D23\W23A624.CAL

* INSTRUMENT.... 7000/5890/FID PEAK WIDTH....08

* RUN TIME...... 53.245 THRESHOLD.... -4

* AREA REJECT.... 40 COM PORT..... 1

* SAMPLE WEIGHT. 1 DIL FACTOR.... 1

* AMT INJECTED... 1 SAMPLE RATE...3.333333

* METHOD VERSION. 11 - LAST MODIFIED... 09/15/92 11:36:58

* CAL VERSION.... 15 - LAST MODIFIED... 06/04/92 09:28:32

* HP REF FILE.... Q53AD4E1b\#194 FMT FILE.. C: ICP\D23 IGAS.FMT

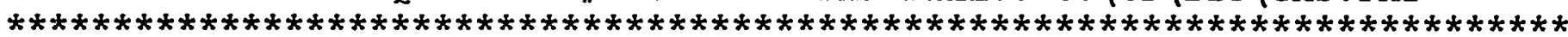

\begin{tabular}{|c|c|c|c|c|c|c|c|c|c|}
\hline $\begin{array}{l}\text { Out of Ret Time } \\
\text { Bound (min) }\end{array}$ & Peak Name & $\begin{array}{l}\text { Amount } \\
\text { PPHV }\end{array}$ & $\begin{array}{l}\text { \% Delta } \\
\text { Ret Time }\end{array}$ & $\begin{array}{l}\text { Peak } \\
\text { Area } \\
\end{array}$ & AREA $\%$ & $\begin{array}{l}\text { Amount/ } \\
\text { Area }\end{array}$ & $\begin{array}{c}\text { Peak } \\
\#\end{array}$ & $\begin{array}{r}\text { Peak } \\
\text { Height } \\
\end{array}$ & $\begin{array}{r}\text { ug/l } \\
\text { AIR }\end{array}$ \\
\hline 3.669 & METHANE & 0.264 & $1.63 \%$ & 152 & 15.94 & 0.0017419 & $i$ & 34 & 0.000 \\
\hline 32.602 & $1,3-O C B$ & 0.057 & $1.63 \%$ & 64 & 6.76 & 0.0008815 & 7 & 10 & 0.000 \\
\hline
\end{tabular}

Total amt. ID. $=.3209273 \quad$ Total area (all peaks) $=951.6958$ 
Fité=C:ICPIDŻ3iH23AT.95R Date printed=01-27-1999 Time= 16:10:44

Saimple Mame $=904-111 \mathrm{G}-32$

2.0 to $36.0 \mathrm{~min}$. LoH $Y=0.387$ High $Y=0.516 \mathrm{mv}$ Span=0.13

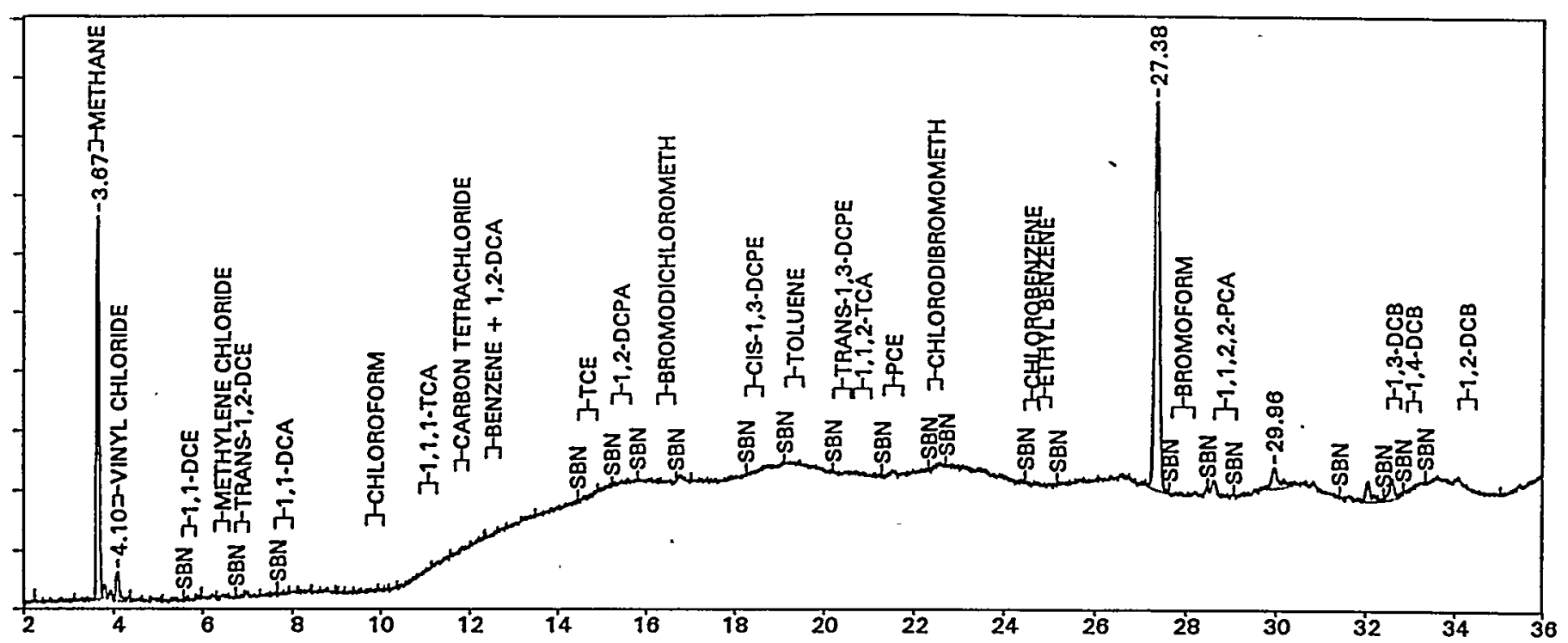

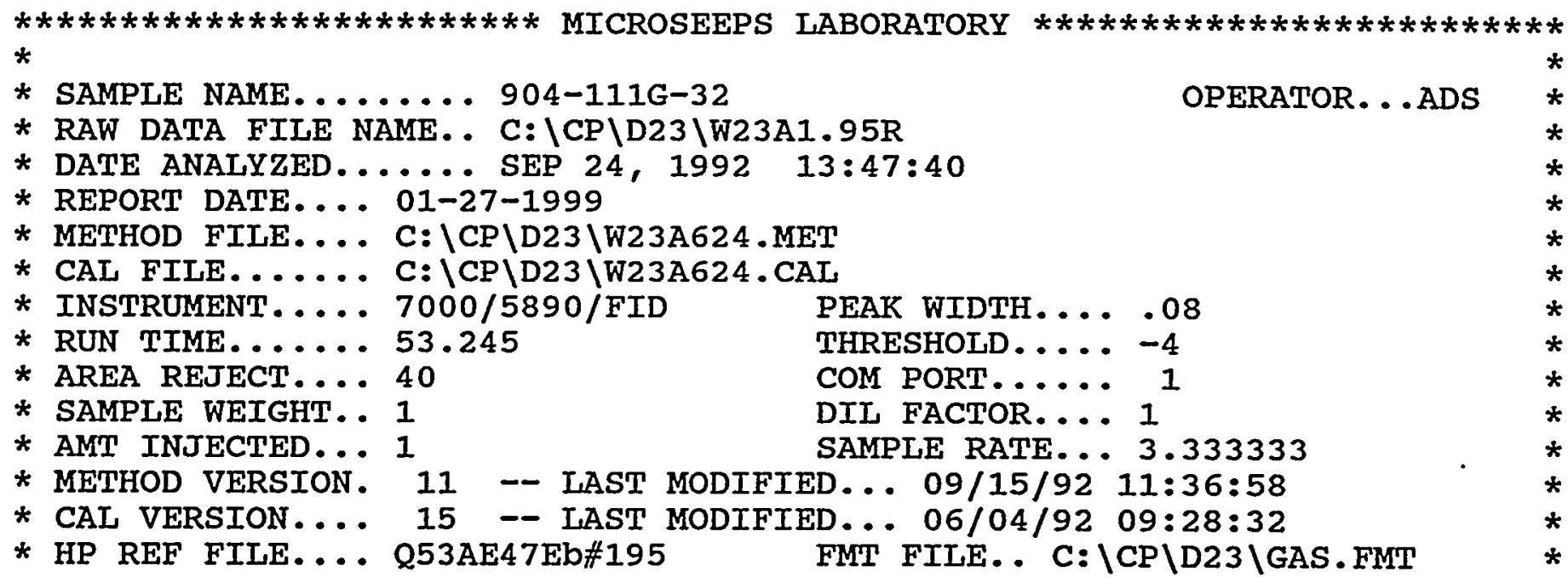

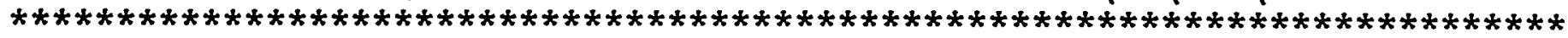

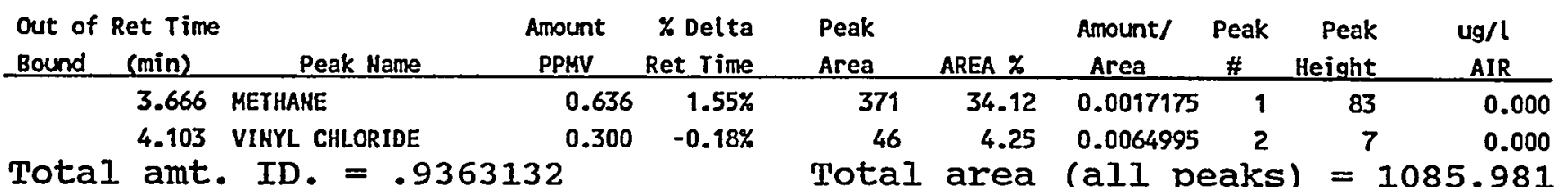


Fi $\because$ ex:C: \CP\D23)H23A1.96R Date printed=01-27-1999 Time= 16:12:06

Sample Name $=904-1116-33$

2.0 to $36.0 \mathrm{~min}$. Low $Y=0.385$ High $Y=0.829 \mathrm{mv}$ Span $=0.445$

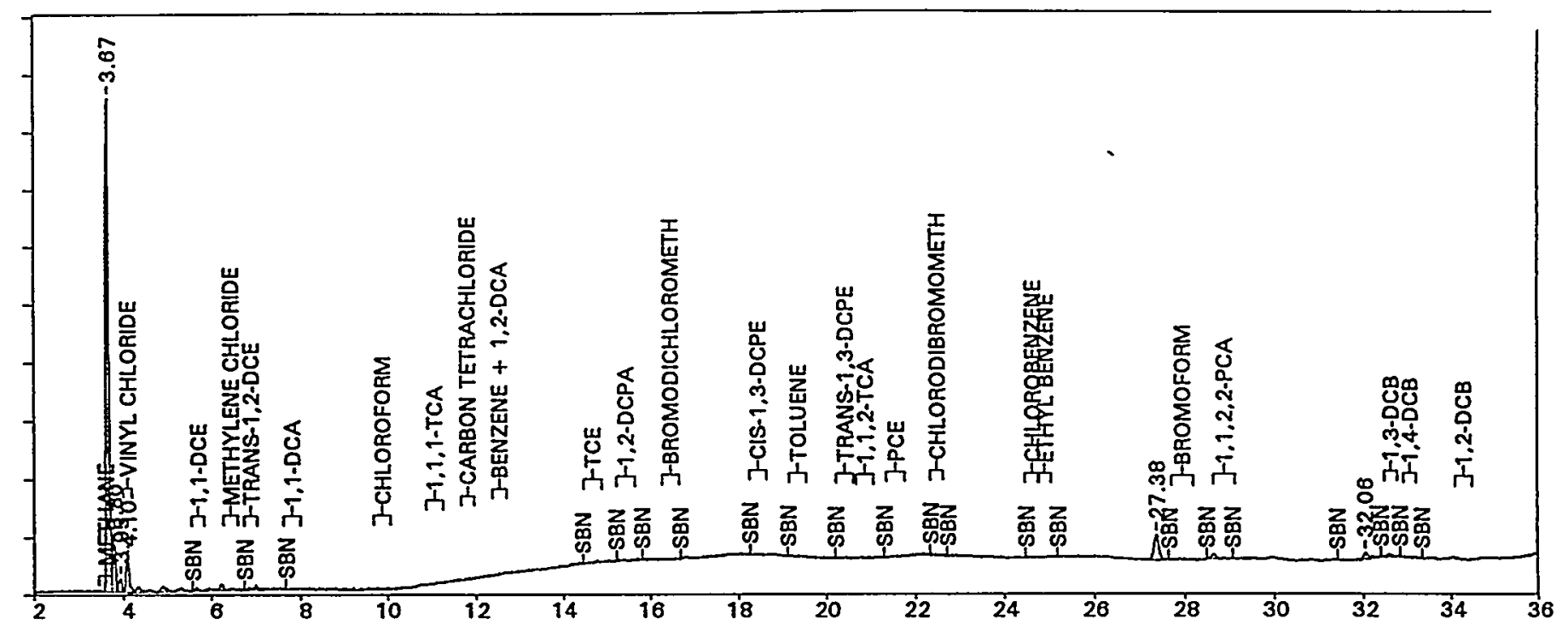

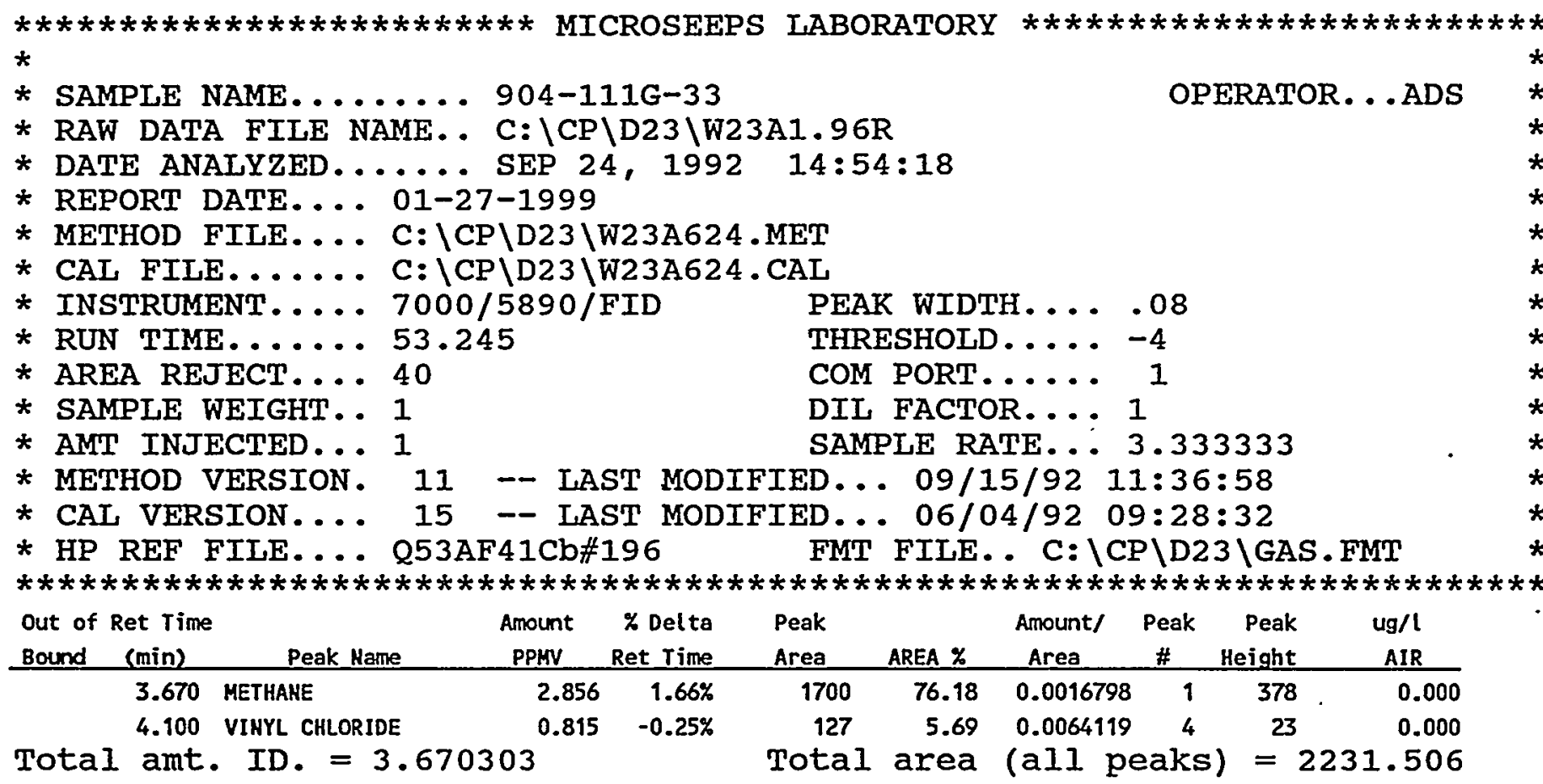




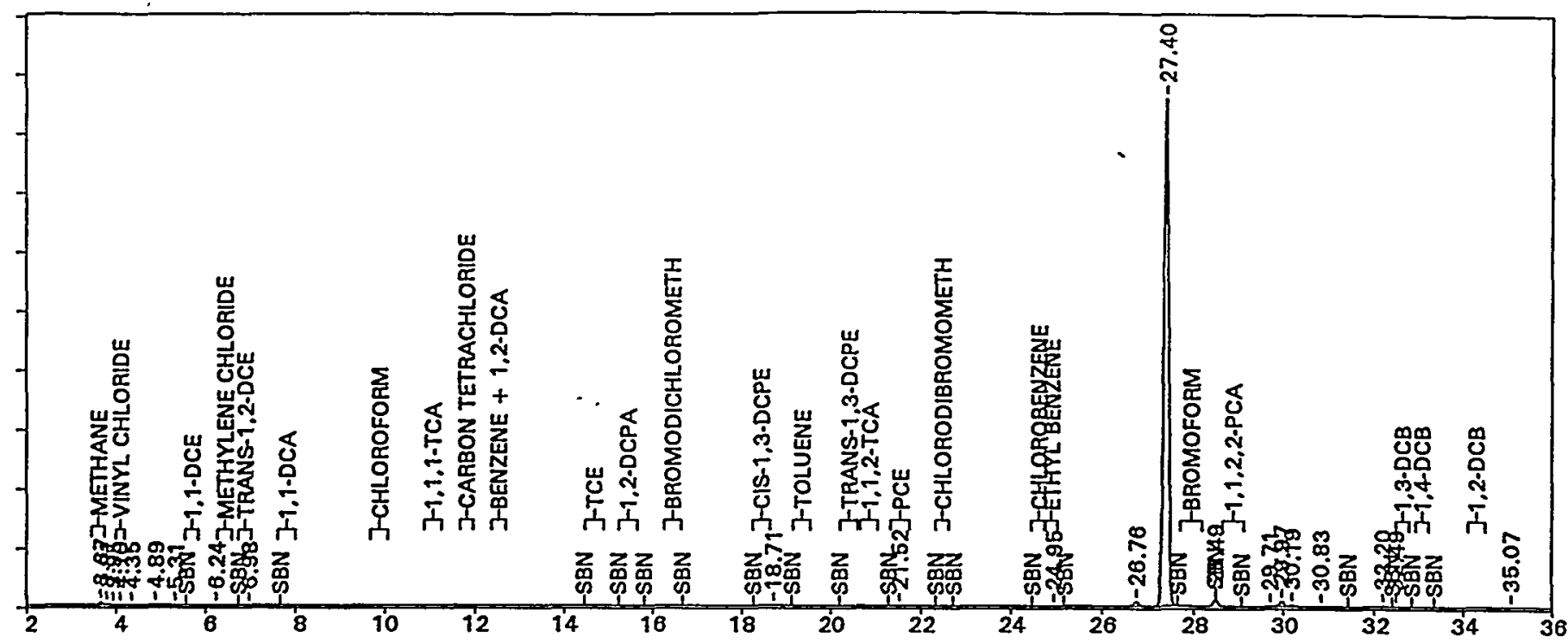

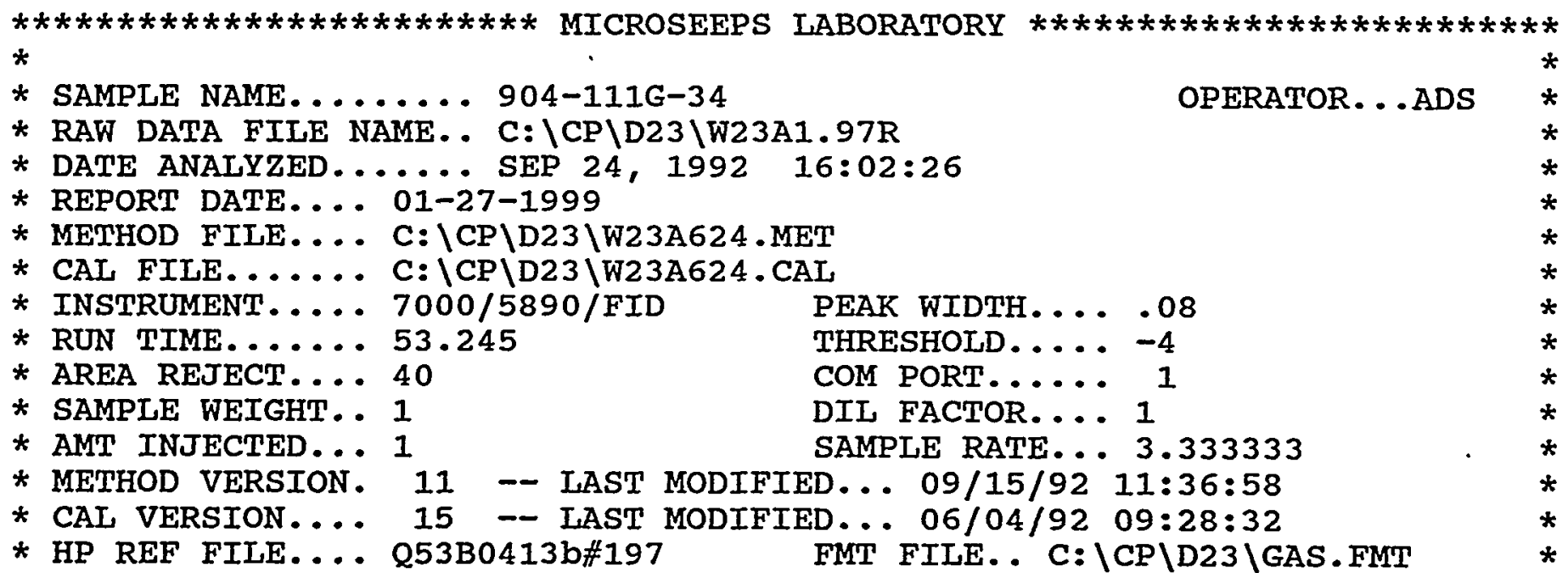

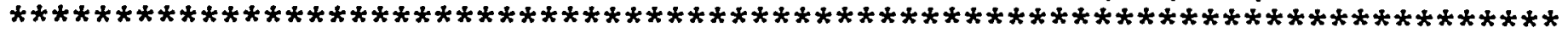

\begin{tabular}{|c|c|c|c|c|c|c|c|c|c|c|}
\hline $\begin{array}{l}\text { Out of } \\
\text { Bound }\end{array}$ & $\begin{array}{l}\text { Ret Time } \\
\text { (min) }\end{array}$ & Peak Name & $\begin{array}{c}\text { Amount } \\
\text { PPHV }\end{array}$ & $\begin{array}{l}\text { \% Delta } \\
\text { Ret Time }\end{array}$ & $\begin{array}{l}\text { Peak } \\
\text { Area } \\
\end{array}$ & AREA $\%$ & $\begin{array}{c}\text { Amount/ } \\
\text { Area }\end{array}$ & $\begin{array}{c}\text { Peak } \\
\# \\
\end{array}$ & $\begin{array}{r}\text { Peak } \\
\text { Height }\end{array}$ & $\begin{array}{r}\text { ug/l } \\
\text { AIR } \\
\end{array}$ \\
\hline & 3.673 & METHANE & 4.310 & $1.75 \%$ & 2616 & 0.32 & 0.0016477 & 1 & 571 & 0.000 \\
\hline & 4.101 & VINYL CHLORIDE & 2.532 & $-0.22 \%$ & 397 & 0.05 & 0.0063780 & 4 & 73 & 0.000 \\
\hline & 6.976 & TRANS-1,2-DCE & 0.886 & $1.39 \%$ & 49 & 0.01 & 0.0181932 & 10 & 6 & 0.000 \\
\hline & 21.525 & PCE & 0.168 & $-0.02 \%$ & 85 & 0.01 & 0.0019709 & 13 & 7 & 0.000 \\
\hline & 24.947 & ETHYL BENZENE & 0.039 & $0.27 \%$ & 52 & 0.01 & 0.0007523 & 15 & 7 & 0.000 \\
\hline rot & $\begin{array}{r}32.489 \\
\text { amt }\end{array}$ & $\begin{array}{l}\text { 1,3-DCB } \\
\text { ID. }=8\end{array}$ & $63^{0.109}$ & $0.27 \%$ & $\begin{array}{r}123 \\
\text { Tota }\end{array}$ & $\begin{array}{r}0.01 \\
\text { area }\end{array}$ & $\begin{array}{l}0.0008815 \\
\text { (a11 pe }\end{array}$ & $\begin{array}{l}26 \\
\text { eaks }\end{array}$ & $\begin{array}{l}23 \\
=8\end{array}$ & $\begin{array}{r}0.000 \\
683.5\end{array}$ \\
\hline
\end{tabular}


2.0 to $36.0 \mathrm{~min}$. Low $Y=0.379$ High $Y=2.041 \mathrm{mV}$ Span=1.663

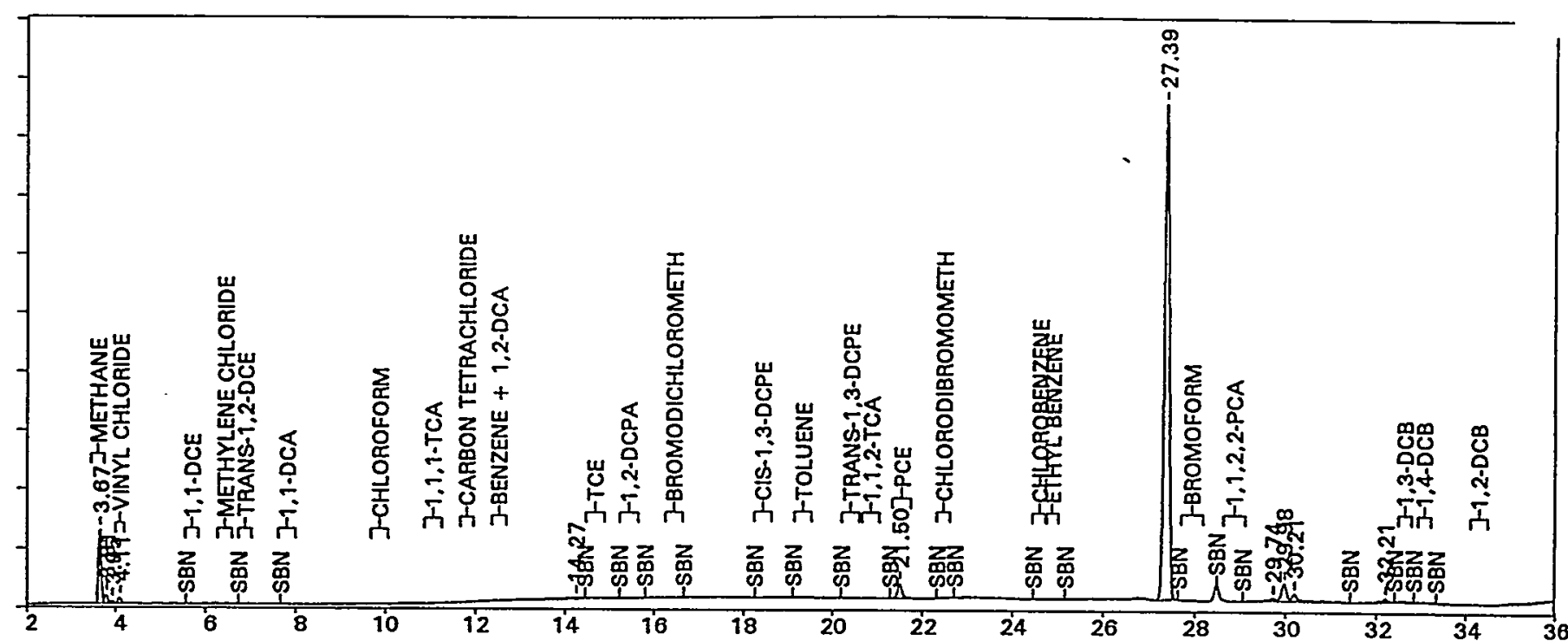

$\star * * * * * * * * * * * * * * * * * * * * * * * *$ MICROSEEPS IABORATORY $* * * * * * * * * * * * * * * * * * * * * * * * *$ $\star$

* SAMPLE NAME....... 909-111G-35

* RAW DATA FILE NAME. C C: \CP\D23\W23A1.98R

* DATE ANAIYZED....... SEP 24, 1992 17:10:15

* REPORT DATE... 01-27-1999

* METHOD FILE.... C: \CP \D23\W23A624.MET

* CAI FILE....... C: \CP\D23\W23A624.CAI

* INSTRUMENT.... 7000/5890/FID PEAK WIDTH....08

* RUN TIME...... 53.245

* AREA REJECT... 40

* SAMPIE WEIGHT. . 1

* AMT INJECTED... 1

* METHOD VERSION. 11 - LAST MODIFIED . . 09/15/92 11:36:58

* CAL VERSION.... 15 - LAST MODIFIED... 06/04/92 09:28:32

* HP REF FILE.... Q53B13F8b\#198 FMT FILE.. C: ICP\D23 GAS.FMT OPERATOR...ADS

THRESHOLD ..... -4

COM PORT...... 1

DIL FACTOR.... 1

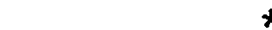
Out of Ret Time

Bound (min)

Amount $\%$ Delta

Peak PPHV Ret Time

Area.

AREA

4.115 VINYL CHLORIDE

1.578

$1.71 \%$

21.501 PCE

0.578

$0.11 \%$

0.595

$-0.13 \%$

Total amt. ID. $=2.751949$

7.47

90

302

0.71

0.71
2.37

Amount/

Peak

Peak

ug/l

Total area (a11 peaks) $=12715.91$ 
File=C: (CP YD23 \W23A1.99R Date printed $=01-27-1999$ Time= 16:16:20

Sample Hame $=904-111 \mathrm{G}-36$

2.0 to $36.0 \mathrm{~min}$. Low $Y=0.389 \mathrm{High} Y=0.851 \mathrm{mv}$ Span $=0.462$

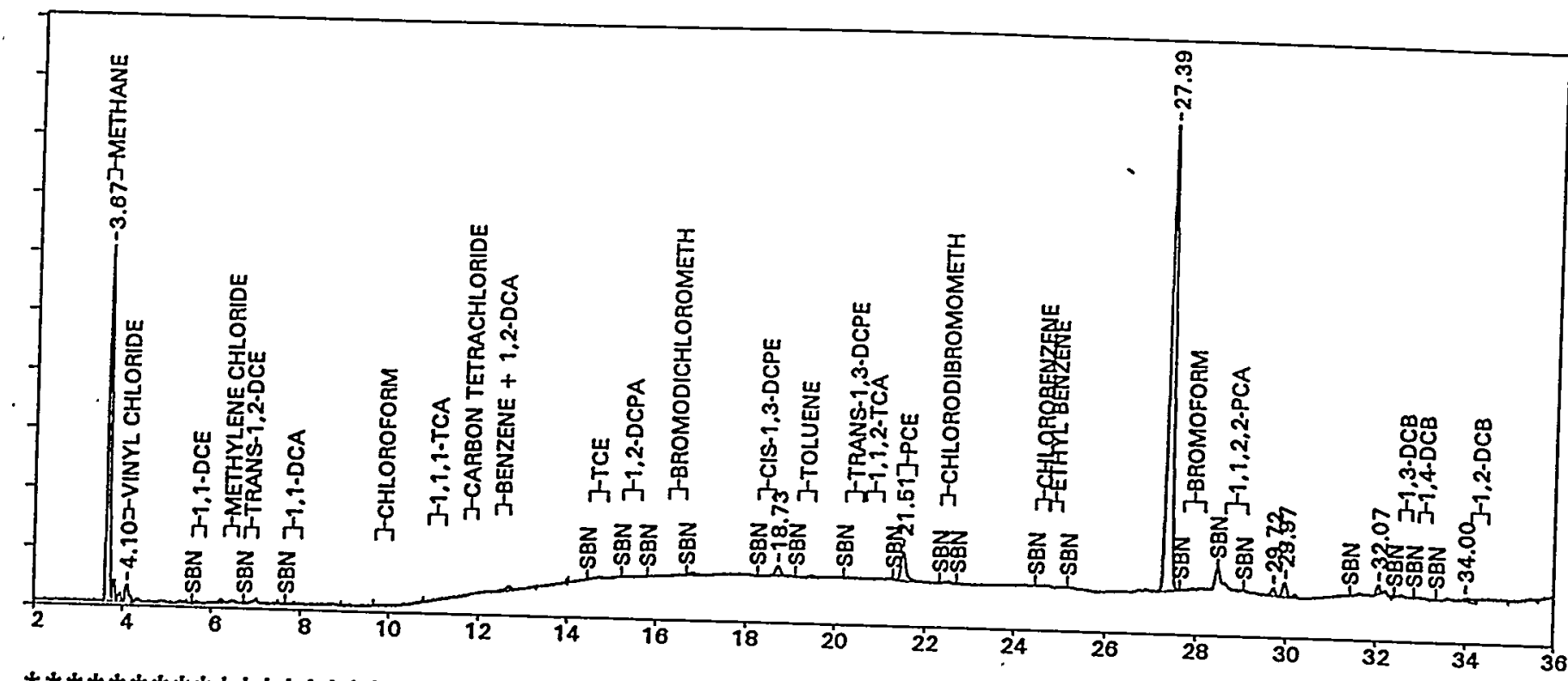

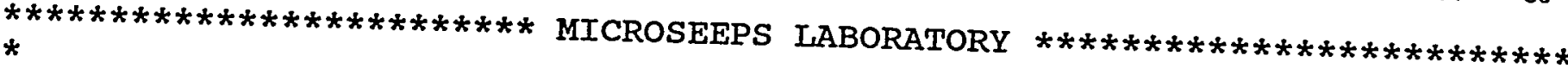

* sample name....... 904-111G-36

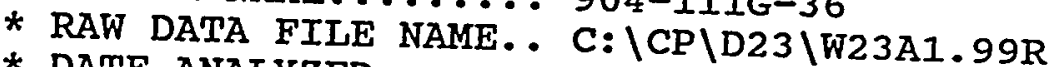

* DATE ANALYZED...... SEP 24, 1992 18:30:19

* REPORT DATE... 01-27-1999

* METHOD FILE.... C: \CP\D23\W23A624.MET

* CAL FILE....... C: \CP\D23\W23A624.CAL

* INSTRUMENT....7 7000/5890/FID

* RUN TIME..... 53.245

* AREA REJECT... 40

* SAMPLE WEIGHT. 1

* AMT INJECTED... 1

* METHOD VERSION

* CAL VERSION . - LAST MODIFIED... 09/15/92 11:36:58

* HP REF FILE.... 15 - L53BST MODIFIED... 06/04/92 09:28:32

$* * * * * * * * * * * * * * * *$ Q53B26BDb\#199

PEAK WIDTH.... .08

OPERATOR...ADS

out of Ret Time

Bound (min)

3.673 METHAME
4.096 VIHYL

4.096 VIHYL CHLORIDE

21.510 PCE

Peak Name

FMT FILE.

THRESHOLD.... -4

COM PORT...... 1

DIL FACTOR..... 1

otal amt. ID. $=3.023804$

\begin{tabular}{|c|c|c|c|c|c|c|c|}
\hline $\begin{array}{l}\text { Amount } \\
\text { PPMV }\end{array}$ & $\begin{array}{r}\text { \% Delta } \\
\text { Ret Time }\end{array}$ & $\begin{array}{l}\text { Peak } \\
\text { Area } \\
\end{array}$ & AREA $\%$ & $\begin{array}{l}\text { Amount/ } \\
\text { Area }\end{array}$ & $\begin{array}{c}\text { Peak } \\
\# \\
\end{array}$ & $\begin{array}{r}\text { Peak } \\
\text { Height }\end{array}$ & $\begin{array}{r}\text { ug/l } \\
\text { AIR }\end{array}$ \\
\hline 2.098 & $1.76 \%$ & 1256 & 28.19 & 0.0016704 & 1 & 277 & 0.000 \\
\hline 0.565 & $-0.33 \%$ & 88 & 1.97 & 0.0064342 & 3 & 14 & 0.000 \\
\hline $4^{0.361}$ & $-0.09 \%$ & 183 & 4.11 & 0.0019709 & 10 & 23 & 0.000 \\
\hline
\end{tabular}

Total area (all peaks) $=4455.209$ 


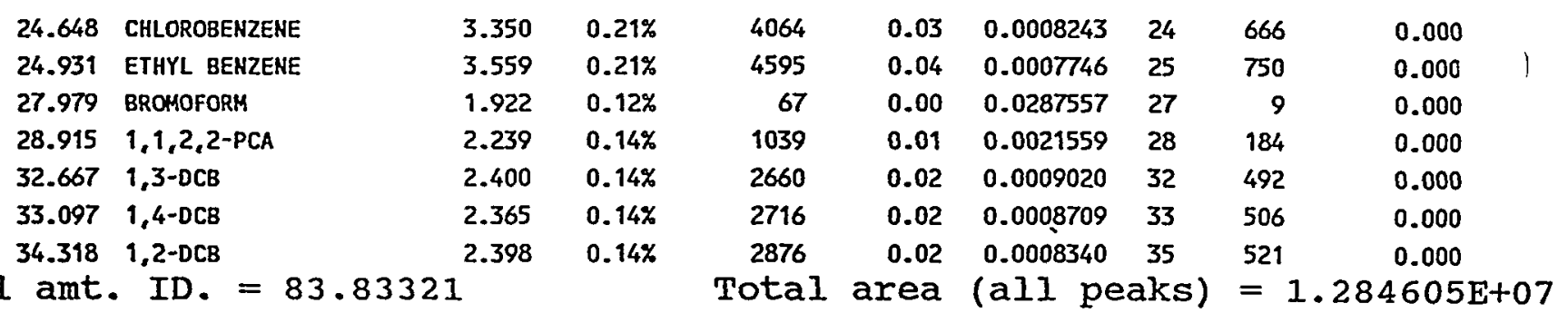

Total amt. ID. $=83.83321$ 
Appendix F

Radiological Survey 
This page intentionally left blank. 


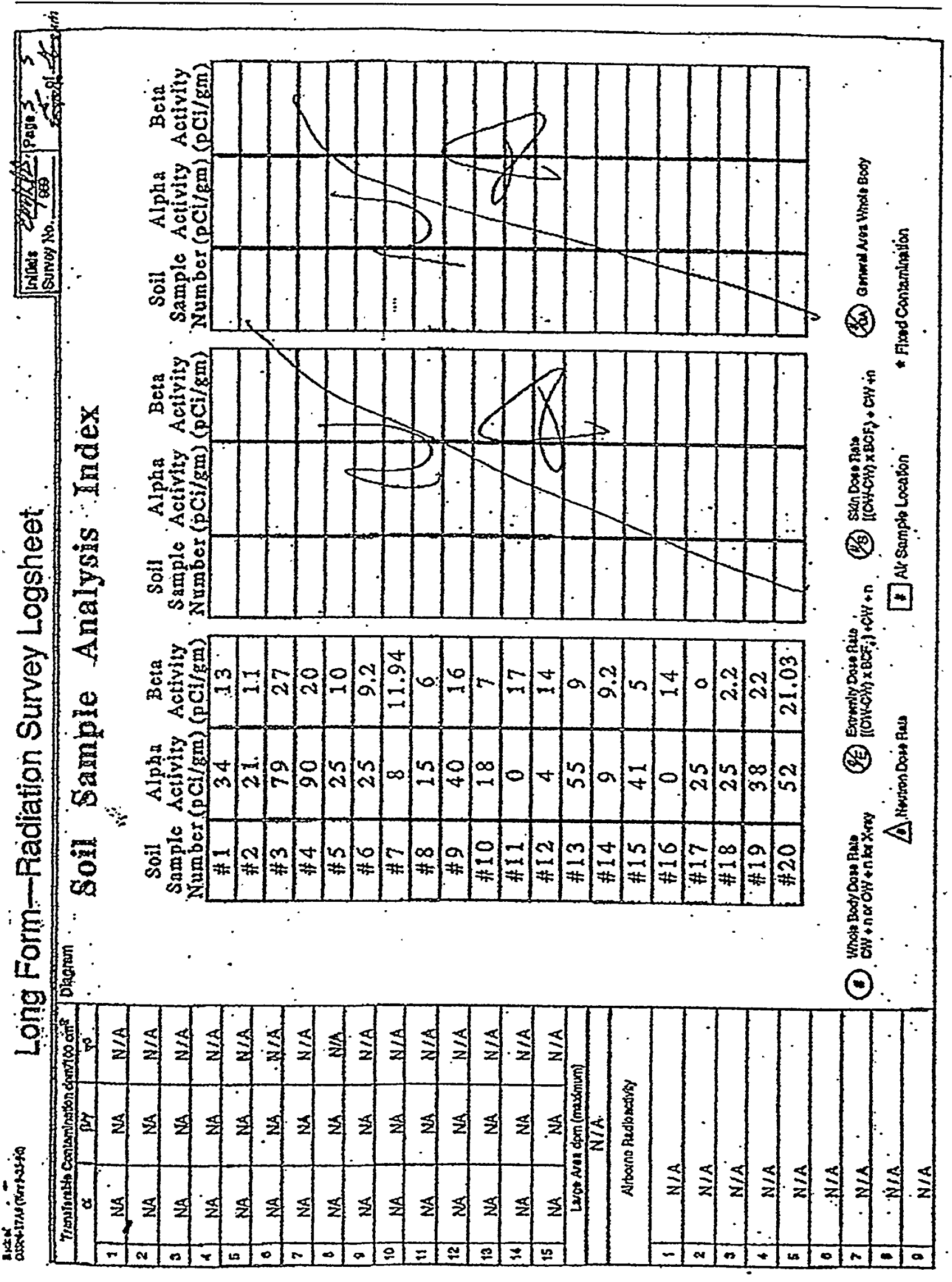




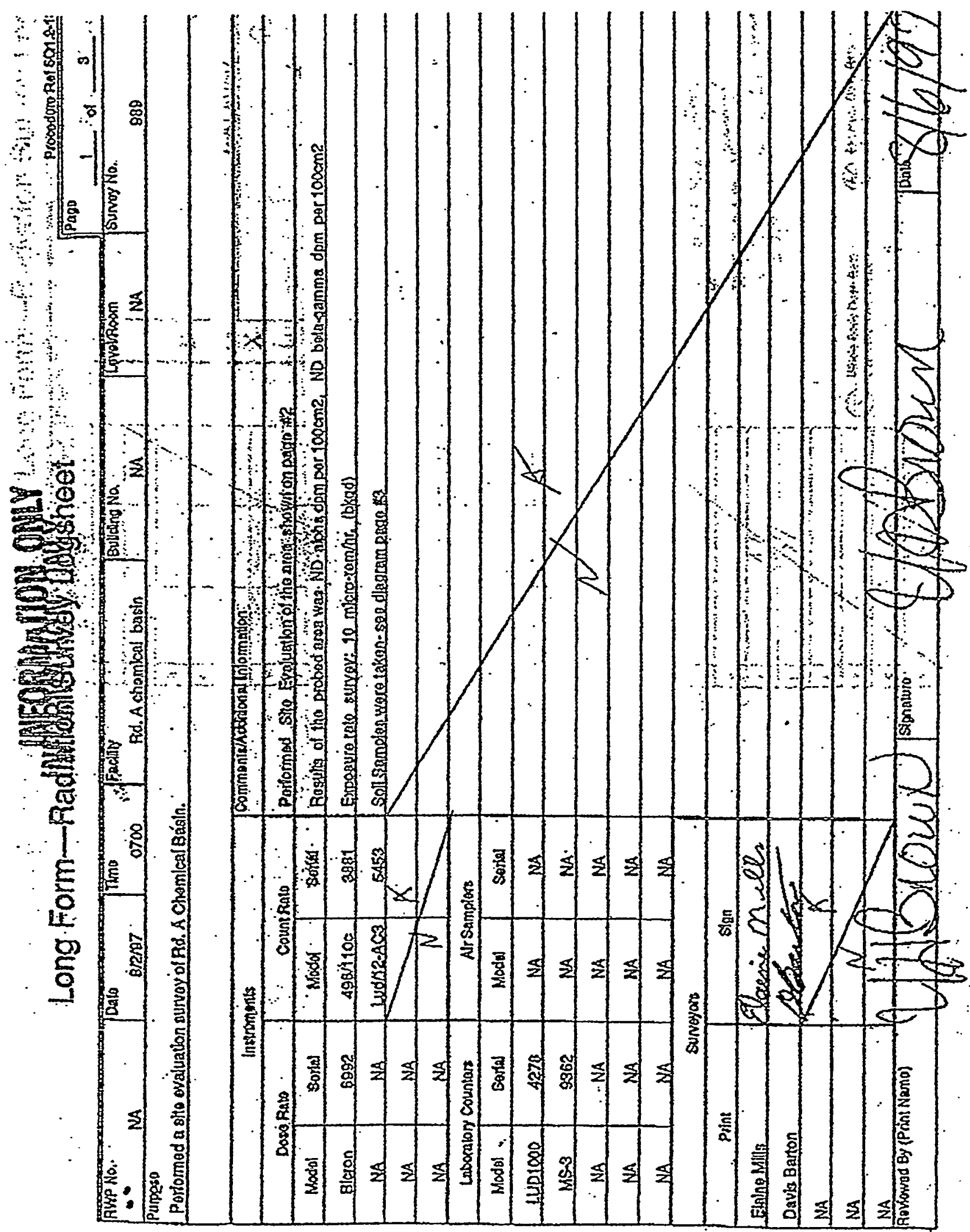

